

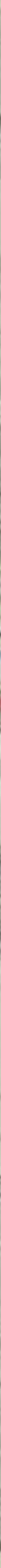


Федеральное государственное бюджетное учреждение науки

Калмыцкий институт гуманитарных исследований

Российской академии наук

Федеральное государственное бюджетное образовательное учреждение

высшего профессионального образования

«Калмыцкий государственный университет»

\author{
B. Т. Тепкеев
}

КАЛМЫКИ

В СЕВЕРНОМ ПРИКАСПИИ

ВО ВТОРОЙ ТРЕТИ ХVII ВЕКА:

ПРОБЛЕМЫ ПОЛИТИЧЕСКИХ

ВЗАИМООТНОШЕНИЙ 


\section{Научное издание}

Утверждено к печати Ученым советом

Федерального государственного бюджетного учреждения науки Калмыцкого института гуманитарных исследований РАН

\section{Ответственный редактор:}

доктор исторических наук, профессор А. Н. Команджаев

\section{Рецензенты:}

доктор исторических наук, доцент У. Б. Очиров

кандидат исторических наук В. П. Санчиров

\section{Тепкеев B. T.}

T 341 Калмыки в Северном Прикаспии во второй трети XVII века: проблемы политических взаимоотношений. - Элиста: ЗАОр «НПП «Джангар», 2014. - 448 с

Книга посвящена политической истории калмыков со времени их появления в степях Северного Прикаспия во второй трети XVII в. Подробно рассматриваются события внутриполитической жизни калмыщкого общества Немаловажную роль имеет и исследование русско-калмьщких отношений, во многом определявших политическую историю Восточной Европы.

Подробно рассматриваются военно-политические связи калмыков с соседними народами и государствами, в том числе с ногаями, бапткирами. донскими и янцкими казаками, народами Северного Кавказа, Лжунгарией, Тибетом, среднеазиатскими ханствами, Персией, Крымским ханством, Украиной и Польшей.

Исследование выполнено на основе архивных материалов, большинство из которых впервые вводятся в научный оборот. Публикуются письма калмыцких тайшей, составленных на старописьменном калмьщком, монгольском и татарском языках.

Книга рассчитана на историков и всех, кто интересуется историей России и калмыцкого народа.

ISBN 978-5-94587-626-2

$$
\begin{aligned}
& \text { (c) Федеральное государственное бюджетное } \\
& \text { учреждение науки Калмыцкий институт } \\
& \text { гуманитарных исследований } \\
& \text { Российской академии наук, } 2014 \\
& \text { (c) В. Т.Тепкеев, } 2014
\end{aligned}
$$

\section{ГЛАва 1. ИСТОРИЧЕСКИЕ ПРЕДПОСЫЛКИ ПОЯВЛЕНИЯ}

КАЛМЫКОВ В СЕВЕРНОМ ПРИКАСПИИ

1.1. Установление русско-калмыцких отношений в Сибири . . . 34

1.2. Калмыцко-ногайские отношения в начале XVII века . . . . 48

1.3. Внутриполитический кризис в ойратском обществе в $1625-$ 1630 гг.

1.4. Территориальный вопрос в русско-калмыцких переговорах

\section{ГЛава 2. НАЧАЛЬНЫЙ ПЕРИОД РАССЕЛЕНИЯ КАЛМЫКОВ} В СЕВЕРНОМ ПРИКАСПИИ

2.1. Политическая ситуация в 1630-1635-х гг. . . . . . . . . . . 75

2.2. Политическая ситуация во второй половине 1630-х гг.

2.3. Джунгарский съезд 1640 г. и его политическое значение

\section{Глава 3. ПОЛИТИЧЕСКИЙ КРИЗИС В КАЛМЫЦКОМ}

\section{ОБЩЕСТВЕ}

3.1. Взаимоотношения калмыков с соседними народами в начале 1640-х гг.

3.2. Ситуация в калмыцком обществе в 1642-1643 гг. . . . . . . . 128

3.3. Военно-политические контакты калмыков с народами Северного Кавказа . . . . . . . . . . . . . . . . . . . . . . . . 143

3.4. Политический кризис в калмыщком обществе . . . . . . . . . 156

3.5. Русско-калмыцкие переговоры в 1645 г. . . . . . . . . . . . . . 167

3.6. Политическое влияние буддийского духовенства . . . . . . 175

3.7. Калмыцкие кочевья в $1645-1647$ гг. . . . . . . . . . . . . . . 181

\section{ГЛава 4. ПОЛИТИЧЕСКАЯ СИТУАЦИЯ В СЕВЕРНОМ}

ПРИКАСПИИ В 1648-1655 гГ.

4.1. Политическое возвышение Дайчина . . . . . . . . . . . . . 191

4.2. Крымский поход калмыков . . . . . . . . . . . . . . . . . 195

4.3. Русско-калмыцкие переговоры и шерть 1649 г. . . . . . . . . . 202 
4.4. Калмыцко-башкирские отношения в 1648-1649 гг. . . . . . . 207

4.5. Миграция хошутских улусов на запад . . . . . . . . 213

4.6. Конфликт под Астраханью и русско-калмыцкие переговоры . 218

4.7. Укрепление политической власти Дайчина . . . . . . . . . . . 235

4.8. Крымский поход калмыков в 1651 г. . . . . . . . . . . . . . . . . 240

4.9. Русско-калмыцкие переговоры 1651-1654 гг. . . . . . . . . . 246

4.10. Второй приезд Зая-пандиты . . . . . . . . . . . . . . . . . . . . 256

\section{ГЛава 5. ПОЛИТИЧЕСКАЯ СИТУАЦИЯ В СЕВЕРНОМ}

\section{ПРИКАСПИИ В 1655-1661 гГ.}

5.1. Русско-калмыцкие переговоры и шерти 1655, 1656 и 1657 гг. 260

5.2. Калмыщко-крымские и калмыщко-башкирские отношения в 1658-1661 гг. . . . . . . . . . . . . . . . . . . . . . . . . . 282

5.3. Русско-калмыцкие переговоры и шерти 1661 г. . . . . . . . . . 305

\section{Глава 6. ПОЛИТИЧЕСКАЯ СИТУАЦИЯ В СЕВЕРНОМ}

\section{ПРИКАСПИИ В 1662-1672 ГГ.}

6.1. Укрепление власти Мончака . . . . . . . . . . . . . . . . . . 328

6.2. Калмыки и Башкирское восстание 1662-1664 гг. . . . . . . . . 340

6.3. Участие калмыков в русско-польской войне . . . . . . . . . 347

6.4. Мончак и русско-калмыцкие переговоры . . . . . . . . . . . . 361

6.5. Калмыцко-донские отношения в период Разинского

восстания . . . . . . . . . . . . . . . . . . . . 376

6.6. Политический кризис в калмыцком обществе. Приход к власти

Аюки . . . . . . . . . . . . . . . . . . . . . . . . . 381

Заключение . . . . . . . . . . . . . . . . . . 395

Приложение . . . . . . . . . . . . . . . . . . . . . 411

Указатель имен . . . . . . . . . . . . . . . . . . . . . . . . . 418

Указатель географических названий . . . . . . . . . . . . . . . . . . 431

Источники и литература . . . . . . . . . . . . . . . . . . . . . 438

\section{ВВЕДЕНИЕ}

Проблема истории политических взаимоотношений в многонациональных регионах Российского государства всегда была объектом внимания научной общественности. На новом этапе исторического развития в начале XXI столетия проблема межнациональных отношений не только не теряет своей важности, но и в связи с резким обострением политической ситуации в таких регионах как Северный Кавказ, Крым и Украина неизбежно приобретает качественно новое значение. Особая актуальность темы заключается в том, что на новом витке истории межнациональная проблема приобретает еще более сложный характер, постепенно перерастая в глобальное противоречие. Освещение этой проблемы в историческом контексте также имеет значение для более глубокого осмысления процессов, происходящих в современном обществе.

Несмотря на неплохую степень изученности истории XVII столетия, всестороннее исследование внешних и внутренних политических отношений калмыков в этот период были исследованы недостаточно глубоко. Известно, что кочевые народы в различные эпохи играли важную роль в истории ряда стран Евразии. Это дает возможность поставить вопрос о степени политического влияния в регионе калмыцких тайшей и степени их самостоятельности во взаимоотношениях с Московским государством. С учетом международной ситуации определенная автономия давала возможность проведения собственных внешнеполитических шагов.

XVII столетие представляет наибольший интерес в изучении исторического прошлого калмыцкого народа, предками которого были ойраты (западные монголы). Именно в эту эпоху ойратские кочевья занимали огромные территории, простиравшиеся почти от Волго-Донского междуречья до Великой Китайской стены. На таком значительном пространстве евразийского континента ойраты основали четыре большие группировки улусов, на основе которых затем 
образовались три кочевых государства - Калмыцкое, Джунгарское и Кукунорское ханства.

Процесс политической интеграции волжских калмыков в российское общество в XVII в. был весьма длительным и сложным. Появление калмыков у сибирских границ Московского государства и продвижение их на Волгу невольно заставляют искать исторические параллели с событиями прошлого, когда кочевые народы так же из степных глубин Азии стремительно продвигались на запад. Однако история прихода калмыков в степи Северного Прикаспия еще недостаточно исследована, а в исторической литературе с XVIII в. по этому вопросу имеются противоречивые концепции. И только богатый фактический материал, извлеченный из архивных данных XVII в., позволит приблизиться к истине, даст возможность составить более достоверную историческую картину.

Основной целью работы является изучение всего комплекса политических отношений калмыков в Северном Прикаспии во второй трети XVII в. Исходя из цели работы и учитывая слабую изученность темы, а также ее многоплановый характер, автор поставил перед собой следующие задачи:

- показать причины появления калмыков в Северном Прикаспии, а также политику России в отношении кочевого народа во второй трети XVII в.;

- осветить политические события калмыцкой истории, особенно те, которые еще не нашли достаточного отражения, или же связанные с ними проблемы, которые до сих пор остаются дискуссионными;

- дать представление о конкретной международной политической обстановке в Северном Прикаспии и соседних регионах.

История волжских калмыков второй трети XVII в. связана с их расселением в Северном Прикаспии, который рассматривается как целостное историко-географическое пространство ${ }^{1}$. Ценность владения этими землями заключалась в особой геополитической роли региона на евразийском материке. Черноморско-Каспийский регион

${ }^{1}$ Впервые в историографии этот регион как самостоятельный объект изучения был рассмотрен в работе Ж. Б. Кундакбаевой «Знаком милости Е.И.В. ...». Россия и народы Северного Прикаспия в XVIII веке». М.-СПб., 2005 . и его население представляли важный стратегический узел в борьбе между Россией и Османской империей, а наличие здесь исторически сложившихся транзитных торговых путей имело весьма существенное значение ${ }^{2}$. Необходимо учитывать, что волжские калмыки имели тесные связи с другими ойратскими группировками в Юго-Западной Сибири и Центральной Азии, с государствами и народами Восточной Европы и Средней Азии.

История взаимоотношений России с кочевыми народами всегда интересовала как отечественных, так и зарубежных исследователей. Хотя история волжских калмыков рассматриваемого нами периода рассматривалась в работах отдельных ученых, но она еще не становилась предметом глубокого исследования. История миграции части ойратского этноса на запад и его расселение в Северном Прикаспии изучается уже более трех столетий. За это время был выявлен и введен в научный оборот огромный массив источников, отражающих это событие.

Самые первые попытки исследования по истории калмыков XVII в., сопровождавшиеся публикацией документов, были предприняты в трудах выдающегося археографа и историка Г.Ф. Миллера. Во время поездки по Сибири (1734-1742 гг.) Миллером было собрано большое количество документов и на их основе написана монументальная «История Сибири», увидевшая свет в 1750 г. и 1764 г. Она была переиздана в 1937 г. и 1941 г., но в этой работе использовано последнее издание ${ }^{3}$. Для нас наибольший интерес представляет третий том сочинения, изданный впервые в 2005 г., и куда вошла ранее неопубликованная десятая глава под названием «Калмыцкие великие князья джунгарского поколения. Кучумовы царевичи и малые калмыцкие князья $)^{4}$. Здесь автор осветил отдельные эпизоды истории ойратов и русско-ойратские отношения на раннем этапе. Поскольку Миллер в своей работе использовал материал из сибирских архивов, то из его поля зрения выпала та ветвь калмыков, которая выдвинулась в степи Северного Прикаспия. Но в качестве предыстории и выяснения истинных причин миграции части ойратов из южной части За-

\footnotetext{
${ }^{2}$ Кундакбаева Ж.Б. Указ. соч. С. 20-21.

${ }^{3}$ Миллер Г.Ф. История Сибири. Т. ІІ. М., 2000; Т. ІІІ. М., 2005

${ }^{4}$ Миллер Г.Ф. Указ. соч. Т. ІІІ. С. 8-38.
} 
падной Сибири на запад этот материал позволяет ответить на многие вопросы

В 1761 г. переводчиком Коллегии иностранных дел В.М. Бакуниным была подготовлена работа «Описание калмыцких народов и особливо из них торгоутского и поступков их ханов и владельцев $)^{5}$. Рукопись долгое время оставалась неопубликованной, и только в 1939 г. она в неполном виде была напечатана в журнале «Красный архив». В работе достаточно подробно описывается история взаимоотношений России с калмыцкими правителями в первой половине XVIII в., в то время как события XVII в. отражены весьма поверхностно. Более того, датировка некоторых событий не соответствует действительности. Например, приход дербетского улуса Солом-Церена на Волгу из Джунгарии автор почему-то относит к 1673-1674 гг. ${ }^{6}$, хотя русские документы достаточно ясно свидетельствуют, что это событие произошло намного раньше - в 40-е годы XVII в. В целом работа Бакунина содержит несколько больше информации о XVII столетии, чем работы его предшественников. Но автор часто пользовался непроверенной информацией, которую многие исследователи, взяв у него без должного ее сравнения с архивными источниками, до сих пор используют в своих трудах.

Большой вклад в монголоведение сделал известный путешественник, академик П.С. Паллас. В составе Второй академической экспедиции он объездил весь юг России, собрав богатый материал по истории, культуре и религии калмыцкого народа. Итогом проделанной работы стал выход в свет двухтомного труда на немецком языке «Собрание исторических известий о монгольских народах». В первом томе книги Паллас дает краткий экскурс в историю калмыков и подробные родословные тайшей, составленные на основе русских и калмыцких источников?

В XIX столетии количество исследований, посвященных истории калмыков, резко возросло, но в основном их авторы опирались на уже

${ }^{5}$ Бакунин В.М. Описание калмыцких народов, а особливо из них торгоутского, и поступков их ханов и владельцев. 2-е изд. Элиста, 1995.

${ }^{6}$ Бакунин В.M. Указ. соч. С. 26.

${ }^{7}$ Pallas P.S. Sammlungen historischer Nachrichten uber die mangolischen Volkerschaften. T. 1. SPb., 1776. опубликованные материалы. В историографии этого времени существовали различные точки зрения в оценке характера политических отношений России и калмыков

Приход калмыков в степи Северного Прикаспия большинство авторов рассматривали в рамках концепции «нашествия кочевников» в пределы России с целью «восстановления империи Чингисхана». В русле этой концепции лежит исследование Н.Я. Бичурина (Иакинфа) ${ }^{8}$, основанное на китайских источниках и опубликованных российских законодательных материалах. Истории калмыков XVII в. в этой работе отведено очень мало места, и сведения носят общий характер. По мнению Бичурина, к западу от Урала калмыки появились только в 1636 г., а временем принятия ими русского подданства он считает 1655 г., когда была дана первая письменная шерть. Рассматривая причины прикочевки к русским границам, автор указывает на завоевательные устремления ойратов, подчеркивая, что это движение совершилось якобы с ведома и согласия остальных ойратских владетелей, с которыми волжские калмыки и в дальнейшем не прерывали связей. Всю вину за негативные моменты в русско-калмыцких отношениях он возлагает на калмыков, объясняя их действия сплошным неподчинением и постоянным односторонним нарушением обязательств 9 . Ошибочность многих из этих суждений можно объяснить отсутствием серьезного архивного исследования русских документов того времени. Несмотря на очевидные недостатки, его работа представляет собой первое систематическое изложение истории ойратов и калмыков со времени падения Юаньской династии в Китае и до начала XIX в.

К проблеме определения характера русско-калмыцких отношений в XVII в. обращались многие дореволюционные авторы. Так, исследователь Ф.А. Бюлер полагал, что калмыки «были скорее плохие союзники, чем беспокойные подданные ${ }^{10}$. Весьма интересную оцен-

${ }^{8}$ Бичурин Н.Я. (Иакинф). Историческое обозрение ойратов, или калмыков, с XV столетия до настоящего времени. 2-е изд. Элиста, 1991.

${ }^{9}$ Бичурин Н.Я. Указ. соч. С. 81.

10 Бюлер $\Phi . A$. Кочующие и оседло-живущие в Астраханской губернии инородцы. Их история и настоящий быт // Отечественные записки. СПб., 1846. T. 47. № 7. C. 15-16. 
ку дал А. Попов, который считал, что все договоры царского правительства с тайшами имели силу только на бумаге, а на деле не выполнялись, так как калмыки «подданство свое России считали не более, как союзничеством. Исходя из такого взгляда, нарушение своих шертей тайши не считали преступлением ${ }^{11}$. В том же духе выразился и Г.И. Перетяткович, который сравнивал подданство калмыцких тайшей с присягой ногайских мирз в XVI в., указывая, что она «имела для России более формальное значение, чем по существу дела; она, по всей вероятности, давалась ими лишь для того, чтобы получать от русского правительства разные подарки, до которых всегда охочи были начальники кочевых народов» ${ }^{12}$.

Особо стоит отметить точку зрения Н.А. Фирсова, который справедливо отметил, что политика правительства по отношению к нерусскому населению, в том числе и калмыкам, характеризовалась стремлением по преимуществу мирными средствами привести их в подданство, прекратить взаимные набеги, помешать использованию их другими государствами. На первых порах правительство не требовало никаких знаков холопства кроме шертей, не вмешивалось в их внутренние дела, представляло им известную свободу во внешних сношениях. «Сами калмыки, - замечает Н.А. Фирсов, - смотрели на свои отношения с Русским государством, как на договор между равноправными сторонами или как на меру к достижению определенной цели) ${ }^{13}$

Одному из немногих авторов XIX в., кому все-таки удалось привлечь архивные материалы по истории калмыков в рассматриваемый период, был известный российский историк С.М. Соловьев. В своем монументальном труде «История России с древнейших времен» ${ }^{14} \mathrm{OH}$ отмечает, что калмыки являлись последними представителями «движения среднеазиатских кочевых орд на запад, в европейские преде-

${ }^{11}$ Попов A. Краткие замечания о приволжских калмыках // Журнал Министерства народного просвещения. СПб., 1886. Ч. ХХІІ. Отд.2. С. 19-20.

${ }^{12}$ Перетяткович Г.И. Поволжье в XVII и начале XVIII века (Очерки из истории колонизации края). Одесса, 1882. С. 181.

${ }^{13}$ Фирсов Н.А. Положение инородцев северо-восточной России в Московском государстве. Казань, 1866.

${ }_{14}$ Соловьев С.М. История России с древнейших времен / Отв. ред. И.Д. Ковальченко, С.С. Дмитриев. Кн. VI. Т. 11-12. М., 1991. лы». Но, по мнению автора, это движение запоздало, так как оно натолкнулось на сильную Россию, и калмыки вынуждены были волеюневолею подчиниться власти последней. При этом подчиненность их была довольно шаткой.

Первую попытку периодизации калмыцкой истории предпринял М.Г. Новолетов ${ }^{15}$, проработавший долгое время в Главном управлении калмыцкого народа. Относительно времени исследования он пребывание калмыков в России разделил на два периода. Первый период, который характеризовался полной свободой от царского правительства, по его мнению, продолжался до 1655 г. Второй начинается временем принятии Дайчином русского подданства. Автор считал, что приход калмыков на Волгу относится к 1630 г., и до 70-х годов XVII в. территория их кочевий не носила постоянного характера. При этом калмыки продолжали поддерживать постоянные связи с покинутой ими родиной и вынашивали планы возвращения.

В 1886 г. появилась статья известного монголоведа А.М. Позднеева, которая представляет собой критический отклик на исторический очерк Новолетова ${ }^{16}$. Отметим, что сам Позднеев по истории калмыков XVII в. с точки зрения пополнения новых фактических данных не сказал ничего нового. Прикочевку калмыков к границам Русского государства он объяснял не слабостью «ойратского союза», а напротив - значительным его усилением. Почувствовав свою силу в объединении, ойраты, по его мнению, стали расширять свои владения и двинулись на новые территории, а само расселение происходило с ведома и согласия «ойратского союза». Царское правительство XVII в. он обвиняет в отсутствии какой-либо определенной политики по отношению к калмыкам. Заключенным многочисленным шертям, как он считает, кочевники никогда не придавали значения, «потому что содержание этих шертей осталось им неизвестным», поскольку они «писались на плоском или татарском языках, одинаково непонятных калмыкам ${ }^{17}$

${ }^{15}$ Новолетов М.Г. Калмыки. Исторический очерк. СПб., 1834.

${ }^{16}$ Позднеев A.M. Астраханские калмыки и их отношения к России до начала нынешнего столетия // Журнал Министерства народного просвещения. Ч. CCXLIV. Отд. 2. 1886. C. 140-170.

${ }^{17}$ Позднеев А.М. Указ. соч. С. 167 
Новые данные о кочевьях калмыков в начале XVII в. были опубликованы в статье Н.И. Веселовского ${ }^{18}$. На основе новых архивных данных автор делает вывод о том, что калмыки на Волге появились значительно раньше 1630-1632 гг., как единогласно утверждалось предшественниками. Можно согласиться с другим его выводом о том, что калмыки в тот период представляли собой значительную силу, так как сумели сохранить свою независимость в условиях враждебного окружения.

Первым фундаментальным исследованием по истории Крымского ханства были труды выдающегося русского историка-востоковеда В.Д. Смирнова ${ }^{19}$. Его работы посвящены в основном внутренней истории Крыма, лишь попутно касаясь внешней политики, в том числе калмыцко-крымских отношений. Огромная ценность исторических трудов Смирнова состоит в том, что он первым в русской исторической литературе ввел в научный оборот турецкие и татарские источники. К сожалению, им недостаточным образом использовались русские архивные материалы, что, несомненно, повлекло за собой неполный анализ внешней политики Крымского ханства. Однако впоследствии никто из советских и российских историков так и не смог написать полную и всеобъемлющую историю Крымского ханства с использованием в комплексе отечественных и зарубежных источников.

Рассмотрение работ дореволюционных авторов показывает, что большинство из них весьма мало внимания уделяло вопросам внутриполитических взаимоотношений калмыков и связей с соседними народами и государствами. Политические события XVII в. нашли в них весьма краткое и поверхностное освещение.

С началом советского периода и получением национальной автономии в калмыцком обществе резко возрос интерес к историческому прошлому, особенно к периоду становления и развития государственности в XVII-XVIII вв. В 1921 г. по приглашению руководства

${ }^{18}$ Веселовский Н.И. Передовые калмыки на пути к Волге // Записки Восточного отделения Императорского Русского археологического общества. Т. 3. СПб., 1888. С. 365-370.

${ }^{19}$ Смирнов В.Д. Крымское ханство под верховенством Оттоманской Порты до начала XVIII века. СПб., 1887. архивно-музейную секцию Калмыцкой автономной области возглавил Н.Н. Пальмов, который в ходе систематизации и описании архивных документов XVIII в. приступил к разработке истории Калмыцкого ханства. Одна за одной вышли его работы: в 1922 г. он издал в первом номере «Ойратских известий» краткий «Очерк истории калмыцкого народа за время его пребывания в пределах России» ${ }^{20}$, а в 1926-1932 гг. - «Этюды по истории приволжских калмыков» в пяти частях, из которых нашему периоду посвящена первая часть ${ }^{21}$.

Но ввиду того, что материалы по истории калмыков XVII в. в основном хранились в архивах Москвы и Санкт-Петербурга (Ленинграда) и были малодоступны, по интересующему нас периоду труды проф. Пальмова дали очень немного новых сведений. Особняком стоит только его статья «Абулгази в калмыцких кочевьях» 22 , изданная в наши дни и повествующая о связях калмыков с правителями и народами Средней Азии. В силу ограниченности источниковой базы при изучении истории калмыков XVII в. он в основном опирался на немногие калмыцкие летописи, такие как «История калмыцких ханов», и работы авторов XIX века. В силу этого он, как и предшествующие авторы, в своей работе воспроизвел ряд фактических ошибок: утверждал о смерти Хо-Урлюка под стенами Астрахани в 1645 г., завоевательных настроениях калмыков после съезда 1640 г. и т.д., что не подтверждается документами. Однако Пальмов критически отнесся к взглядам А.М. Позднеева и Н.Я. Бичурина на причины появления калмыков у сибирских границ Московского государства. Так, он высказывает мысль о том, что калмыцкая миграция из Джунгарии была вызвана естественными причинами, такими как стремлением обособиться друг от друга, возросшей численностью населения и необходимостью расширить пастбиша для скота ${ }^{23}$.

${ }^{20}$ Пальмов Н.Н. Очерк истории калмыцкого народа за время его пребывания в пределах России. 2-е изд. Элиста, 1992.

${ }^{21}$ Пальмов Н.Н. Этюды по истории волжских калмыков XVII и XVIII века. Ч. І. Астрахань, 1926

${ }^{22}$ Пальмов Н.Н. Материалы по истории калмыцкого народа за период пребывания в пределах России / Сост. А.М. Джалаева. Элиста, 2007. С. $397-$ 409.

${ }^{23}$ Пальмов Н.Н. Очерк... С. 31. 
По поводу времени появления калмыков на берегах Волги Пальмов отметил, что «не так важно искать годы, когда калмыки увидели Волгу в первый раз - они могли увидеть ее вскоре после того как стали производить свои налеты на ногайцев в начале XVII века - но гораздо важнее определить тот политический момент, которым воспользовались калмыки и, подойдя к Волге, почувствовали себя господами положения в такой степени, что перестали опасаться за свою дальнейшую судьбу и порешили остаться здесь) ${ }^{24}$. Рассматривая в целом территориальный вопрос, Пальмов справедливо отмечает, «что между моментом, когда калмыки познакомились с Волгой, и временем, когда они получили фактическую возможность пользоваться кочевьями на Ногайской стороне Волги, прошло несколько десятилетий, и что наличные источники позволяют считать калмыков более или менее прочно прикрепившимися к левобережным кочевьям на Волге с 1655 г.» ${ }^{25}$.

Также без его внимания не остался и вопрос о времени принятия калмыцкими тайшами русского подданства и анализ текстов шертей. Он приходит к весьма интересному выводу, что калмыки стали подданными русского государства с 1661 г. В распоряжении Пальмова, как уже отмечалось, был сравнительно небольшой круг архивных источников по XVII столетию, но его работы стали заметной вехой в изучении истории калмыцкого народа

В 1929 - начале 1930 года по просьбе Н.Н. Пальмова к изучению истории калмыков XVII в. приступил один из серьезных знатоков архивного дела, специалист по истории Москвы, представитель «школы Ключевского» - Сергей Константинович Богоявленский. Именно его можно отнести к «пионерам» историографии калмыков XVII столетия, поскольку ему впервые удалось ввести в научный оборот огромный массив архивных материалов за указанный период. Результатом этой работы стала рукопись «Материалы по истории торгоутов» ${ }^{26}$, которая, к сожалению, так и не была опубликована целиком и судьба

${ }^{24}$ Пальмов Н.Н. Этюды... Ч. І. С. 4.

${ }^{25}$ Пальмов Н.Н. Этюды... Ч. 5. С. 1, 2

${ }^{26}$ Название этой рукописи фигурирует в списке «Работы С.К. Богоявленского» (от 6 января 1944 г.) в разделе «Архивоведение и археография». которая хранится в Архиве РАН. которой до сих пор неизвестна. В 1930 г. С.К. Богоявленский по так называемому «академическому делу» подвергся аресту и до 1933 г. находился в ссылке в Новосибирске. Однако сокращенное содержание этого исследования стало широко известно благодаря вышедшей в свет в 1939 г. статье под названием «Материалы по истории калмыков в первой половине XVII века) ${ }^{27}$.

Именно ему на основе многочисленных архивных документов впервые удалось осветить в подробностях малоизвестный до этого времени процесс движения калмыцких улусов на запад и опровергнуть ряд ошибочных утверждений своих предшественников. Опираясь на фонды Государственного архива феодально-крепостнической эпохи (ныне - Российский государственный архив древних актов). Богоявленский в четкой хронологической последовательности изложил сведения по истории калмыков до 1645 г. включительно, а также составил ценную историческую справку о калмыцких тайшах того времени. Неслучайно работа им названа «материалами», ибо она представляет собой добросовестную сводку фактических данных. Естественно, что статья С.К. Богоявленского не ставила целью исследовательскую разработку затронутых в ней вопросов, хотя в ряде случаев автор и пытался соответствующим подбором источников выявить свое отношение к тем или иным сторонам жизни калмыков XVII в. Кроме того, Богоявленский внес существенные фактические поправки к существовавшим до него представлениям. Так, он опроверг господствовавшее долгое время в исторической литературе утверждение о гибели Хо-Урлюка под стенами Астрахани во время осады и по архивным данным выяснил, что на самом деле он погиб в Кабарде в $1644 \Gamma^{28}$.

Вкратце о взаимоотношениях калмыков с донскими казаками в своей работе пишет Н.Л. Янчевский ${ }^{29}$. Автор ошибочно полагает, что уже в 30-х годах XVII в. калмыки якобы появляются на Дону. Видимо, основанием для такого утверждения стало то, что в 1638 г. казаки

${ }^{27}$ Богоявленский С.К. Материалы по истории калмыков в первой половине XVII века // Исторические записки. М., 1939. № 5. С. 48-102.

28 Богоявленский С.К. Указ. соч. С. 82.

29 Янчевский Н.Л. Колониальная политика на Дону торгового капитала Московского государства в XV-XVII вв. Ростов-на-Дону, 1930. 
хотели заключить союз с калмыками для защиты Азова. Автор, правда, не пользовался архивными документами и свои суждения строил на основании описей ногайских, турецких и крымских дел Новочеркасского архива.

На состояние исторических исследований по истории калмыкам в последующие годы бесспорно отрицательное влияние оказали начавшаяся Великая Отечественная война и депортация калмыцкого народа. Долгое время изучение истории калмыков находилось под строгим запретом, не появилось ни одной специальной работы. Лишь отдельные авторы, изучая историю других народов, попутно говорили о калмыках

К таким работам, например, можно отнести вышедшую в 1947 г. статью Н.В. Устюгова ${ }^{30}$, весьма подробно раскрывающую непростую историю калмыцко-башкирских взаимоотношений в 20-60-е годы XVII века. На основе новых архивных материалов автор подробно рассматривает политику царского правительства к взаимоотношениям двух народов, которые в этот период он называет «сложными и, в основном, враждебными», что было обусловлено борьбой за кочевья. Московское правительство, по мнению Устюгова, до 1661 г. неизменно поддерживало интересы башкир и добивалось откочевки калмыков от границ Башкирии. Но политика калмыков, продолжает автор, заключалась в обратном - завладеть не только кочевьями, но и подчинить себе башкир ${ }^{31}$.

В капитальном труде А.А. Новосельского «Борьба Московского государства с татарами в первой половине XVII века $)^{32}$ нашли довольно полное отражение калмыцко-ногайские взаимоотношения в первой половине XVII века. Другая работа Новосельского в виде незаконченной рукописи, основанная исключительно на архивных материалах, увидела свет только в 1994 г., после смерти автора ${ }^{33}$. Она

30 Устюгов Н.В. Башкирское восстание 1662-1664 гг. // Исторические записки. № 24. 1947. С. 30-110.

31 Устюгов Н.В. Указ. соч. С. 56

${ }^{32}$ Новосельский А.А. Борьба Московского государства с татарами в первой половине XVII века. М.-Л., 1948.

${ }^{33}$ Новосельский A.A. Исследования по истории эпохи феодализма (научное наследие). М., 1994. также имеет большое значение для исследуемой темы, так как в ней подробно изложены события, связанные с набегами калмыцких отрядов на Крым и участием калмыков в Русско-польской войне 16541667 гг.

С восстановлением калмыцкой автономии в 1957 г. и официальным празднованием 350-летия вхождения калмыцкого народа в состав России в 1959 г. интерес к истории калмыков возрос с новой силой. Особенно актуальным стало изучение истории русско-калмыцких отношений в XVII столетии. В 1960-х гг. этой тематике были посвящены сразу две диссертационные работы ученых - П.С. Преображенской и М.Л. Кичикова. Работа с архивными материалами позволила этим исследователям ввести в научный оборот ранее неизвестные факты по истории калмыков XVII в., определить предпосылки вхождения калмыков в состав Российского государства и установить время образования Калмыцкого ханства.

Первой серьезной работой по истории калмыков XVII в. в этот период можно считать статью московской исследовательницы П.С. Преображенской «Из истории русско-калмыцких отношений в 50-60-х годах XVII в.) ${ }^{34}$. На основе архивных материалов автор в ней достаточно подробно рассматривает историю русско-калмыцких отношений за указанные годы. В дальнейшем этот материал стал частью диссертационного исследования Преображенской, успешно защищенной ею в 1963 году ${ }^{35}$.

Анализируя архивные документы, Преображенская приходит к главному выводу, что присоединение калмыков к России представлял собой «сложный и длительный процесс, растянувшийся почти на полстолетия). Начальный этап присоединения она относит к 16061608 гг., а фактическое подданство только с 1657 г. При этом автор делает существенную оговорку, говоря, что и после окончательного вхождения калмыцкие тайши надолго сохранили полную свободу

34 Преображенская П.С. Из истории русско-калмыцких отношений в 50-60-х годах XVII в. // Записки Калмыцкого НИИЯЛИ. Элиста, 1960. Вып. 1. С. 49-83.

35 Преображенская П.С. Калмыки в первой половине XVII века. Принятие калмыками (торгоутами и дербетами) русского подданства. Автореф канд. дис. М., 1963. 
в вопросах внутренней жизни улусов, а также известную свободу внешних сношений. Вполне верно Преображенская указывает и на исторические условия, способствовавшие вхождению калмыков в состав Российского государства в конце 50-х - начале 60-х гг. XVII в.: территориальный вопрос, безопасность кочевий, экономические связи, начало войны России с Крымом и Польшей. В целом автор положительно оценивает для калмыков присоединение к России, что отразилось на усилении Калмыцкого ханства. Доказательством этому служит факт присоединения к нему новых групп калмыцких улусов в 60-70-х гг. XVII века ${ }^{36}$.

М.Л. Кичиков, подводя итоги своего диссертационного исследования ${ }^{37}$, приходит к выводу, что приход калмыков на Волгу не был результатом (ннашествия или экспансии», а являлся результатом «объективного исторического процесса». «Вхождение»автор также называет не одномоментным событием, а результатом «сложного процесса», получившему начало в 1608-1609 гг. и завершившемуся соглашениями 1655 и 1657 гг. Именно этот процесс, по мнению Кичикова, обеспечил фактическое образование Калмыцкого ханства в составе России в 1664 г. Последующее наделение тайши Мончака атрибутами власти и полномочиями правителя, продолжает автор, преследовало цель усилить русское влияние на калмыков, укрепить политическое и юридическое положение нового правителя ${ }^{38}$. Основное содержание диссертации Кичикова было изложено в его монографии ${ }^{39}$, вышедшей в 1966 г., и последующем переиздании ${ }^{40}$.

К сожалению, в дальнейшем П.С. Преображенская и М.Л. Кичиков отказались от продолжения исследования этого периода, но их материалы вошли в третью и четвертую главы первого тома «Очер15.

${ }^{36}$ Преображенская П.С. Калмыки в первой половине XVII века... С. 14

${ }^{37}$ Кичиков M J. Образование Калмыщкого ханства в составе России (1607-1664): автореф. дис. ... канд. ист. наук / АН СССР, Ин-т народов Азии, КНИИЯЛИ. М.-Элиста, 1963.

${ }^{38}$ Кичиков М.Л. Указ. соч. С. 13, 14.

${ }^{39}$ Кичиков М.Л. Исторические корни дружбы русского и калмыцкого народов. Элиста, 1966.

${ }^{40}$ Кичиков М.Л. Образование Калмыщкого ханства. Элиста, 1994. ков истории Калмыцкой $\mathrm{ACCP})^{41}$. Также к написанию этого коллективного труда были привлечены и другие известные советские историки: Н.В. Устюгов, И.Я. Златкин, Е.Н. Кушева. Выход в свет «Очерков» стали большим событием в общественной жизни Калмыкии и на многие годы являлись единственной обобщающей работой по истории калмыков.

В 1964 г. вышло в свет фундаментальное исследование И.Я. Златкина, посвященное истории Джунгарского ханства и выдержавшее два издания ${ }^{42}$. Данный труд, основанный на богатой источниковой базе, подводит итог изучению истории ойратов более чем за двухсотлетний период. В своей работе Златкин опирался преимущественно на русские архивные материалы, но он также впервые широко использовал и монголо-ойратские источники, что, несомненно, положительно сказалось в целом на его исследовании. Особенно это видно при освещении им религиозной и политической роли в ойратском обществе XVII в. буддийского просветителя Зая-пандиты ${ }^{43}$. По мнению Златкина, принятие буддизма ойратами в качестве официальной религии имело важное значение и серьезные последствия, так как в основе этого лежали военно-политические интересы ханов и князей ${ }^{44}$.

Труды военных историков Т.И. Беликова и К.П. Шовунова ${ }^{45}$ продолжают исследования по военной истории калмыков. Если первый автор осветил значение участия калмыков в войнах России с точки зрения защиты южных рубежей, то Шовунов создал объемный труд по военной истории калмыков. Он тщательно разработал положение о позиции Калмыцкого ханства как верного союзника России в борьбе против Османской империи и ее вассала - Крымского ханства в XVII в.

${ }^{41}$ Очерки истории Калмыцкой АССР: Дооктябрьский период / Под ред. Н.В. Устюгова. М., 1967. 1983.

42 Златкин И.Я. История Джунгарского ханства. 1635-1758. 2-е изд. М.,

43 Златкин И.Я. Зая-Пандита - как политический деятель // 320 лет старокалмыцкой письменности. Материалы научной сессии. Элиста, 1970. C. 21-39.

44 Златкии И.Я. История... С. 105.

${ }^{45}$ Беликов Т.И. Участие калмыков в войнах России в XVII, XVIII и первой четверти XIX вв. Элиста, 1960; Шовунов К.П. Очерки военной истории калмыков (XVIII-XIX вв.). Элиста, 1991. 
К сожалению, в дальнейшем в историографии уже не отмечалось новых серьезных попыток провести тщательное исследование истории калмыков XVII столетия с привлечением широкого круга архивных материалов. Как часть основной темы сведения о калмыках во второй трети XVII в. прослеживаются в трудах многих известных и малоизвестных исследователей.

Первым крупным исследованием на рубеже XX-XXI вв. по социально-политической истории калмыков стали работы М.М. Батмаева, венцом которых стала вышедшая в 2002 г. монография ${ }^{46}$. Правда, исследованию архивных документов XVII в. автор уделил свое внимание в основном эпохе правления Аюки-хана, в то время как по нашему периоду им использовались только опубликованные материалы.

Большой интерес для нас представляет его аналитический обзор периода складывания калмыцкой государственности. По мнению Батмаева, Калмыцкое ханство складывалось не как самостоятельное образование, а в составе Российского государства, которое выступало своего рода «повивальной бабкой при рождении не слишком желанного ребенка). В дальнейшем, продолжает автор, оно (пристально следило за каждым шагом своего подопечного, направляя его в нужную сторону: переводя на язык политики - Калмыцкое ханство было вассальным по отношению к России ${ }^{47}$. Несмотря на сложную историческую обстановку, в которой происходило становление ханства, Батмаев верно указывает на благоприятные факторы, способствовавших завершению «строительства здания калмыцкой государственности»: планы правительства по привлечению военных сил калмыков, положительное решение территориальной проблемы и стабилизация населения улусов. Консолидации калмыков также способствовали вытеснение или подчинение ногайцев, организация безопасности улусов, единый подход тайшей в переговорах с царским правительством, чтобы успешнее добиваться выгодных условий $^{48}$. Батмаев также выделил в несколько этапов складывание Калмыцкого ханства: создание предпосылок образования ханства в пе-

${ }^{46}$ Батмаев M.M. Социально-политический строй и хозяйство калмыков в XVII-XVIII вв. Элиста, 2002.

${ }^{47}$ Батмаев M.M. Указ. соч. С. 90

${ }^{48}$ Батмаев М.М. Указ. соч. С. 91. риод перекочевки калмыков в Россию, поселение на Нижней Волге и принятие подданства; складывание общекалмыцкой государственности и оформление ханства в период правления Мончака и Дайчина в 50-60-е гг. XVII в.; окончательное их становление в период правления Аюки-хана ${ }^{49}$.

Вопросам политических взаимоотношений калмыков с Россией, в т. ч. и в XVII столетии, а также становлению национально-государственного статуса Калмыцкого ханства, посвящены работы К.Н. Максимова $^{50}$. По мнению автора, Россия до середины XVII в. стремилась строить взаимоотношения с калмыками на добровольных договорных началах, основанных на «вассально-сеньориальных отношениях». В то же время калмыки желали установить «иммунитетные политические отношения», не исключая принципы «сюзеренитета-вассалитета», где обе стороны должны были выступать «носителями суверенитета). Со второй половины XVII в. калмыки, «юридически оформив и закрепив государственное подданство», добровольно вошли в состав Российского государства, признавшего Калмыцкое ханство «этнополитическим образованием $)^{51}$.

Две главы нашему периоду посвятил в своей монографии В.И. Колесник ${ }^{52}$. Основываясь в основном на опубликованных материалах он рассматривает не только русско-калмыцкие связи, но и некоторые моменты внутриполитических отношений калмыцкого общества XVII в. Внимание автора уделено калмыцко-донским контактам и отношению калмыков к Разинскому восстанию. Оценивая непростой характер русско-калмыцких отношений, Колесник делает существенное объяснение, что «царское правительство не распола-

${ }^{49}$ Батмаев $M$ М Указ. соч. С. 93.

${ }_{50}$ Максимов К.Н. Калмыкия в национальной политике, системе власти и управления России (XVII-XX). М., 2002; Он же. Роль шерти в правовой инкорпорации калмыков в российское подданство // Калмыки в многонациональной России: опыт четырех столетий. Элиста, 2008. С. 71-90; Oн же. Калмыки в геостратегических планах России XVII века // Вестник Калмыцкого института гуманитарных исследований РАН. Элиста, 2013. С. 5-10

${ }^{51}$ Максимов К.Н. Калмыкия в национальной политике... С. 509.

${ }^{52}$ Колесник В.И. Последнее великое кочевье: Переход калмыков из Центральной Азии в Восточную Европу и обратно в XVII и XVIII веках. М., 2003. 
гало в регионе достаточным военным и административным потенциалом для того, чтобы надежно оборонять его от внешних врагов и контролировать здесь своих собственных подданных〉. В то же время Мончак также контролировал ситуацию не во всех калмыцких улу$\operatorname{cax}^{53}$.

Проблемы политических взаимоотношений Калмыцкого ханства в составе России рассмотрел в своей монографии А.В. Цюрюмов ${ }^{54}$ Появление калмыков в Поволжье, как отмечает автор, упрочило экономические и политические позиции России в регионе, так как они превратили южныс границы государства в «надежный кордон на пути турецко-крымских войск в центральную часть страны». Приобретение столь важного звена в системе внешней политики России упрочило ее позиции и на международной арене ${ }^{55}$.

В рамках празднования 400-летия вхождения калмыцкого народа в 2009 г. в свет вышел первый том 3-томной «Истории Калмыкии с древнейших времен до наших дней» ${ }^{56}$. Третий раздел «Истории» в авторстве В.П. Санчирова и М.М. Батмаева полностью посвящен нашему периоду. В своей части раздела Санчиров впервые ввел в научный оборот ранее неизвестные для российской историографии выдержки в русском переводе из материалов ойратских письменных памятников XVIII-XIX вв.

Теме калмыцко-ногайских отношений XVII в. в своих работах уделили внимание В.В. Трепавлов ${ }^{57}$ и Е.В. Кусаинова ${ }^{58}$. Включив в научный оборот большой массив архивных документов «Калмыцких》 и «Ногайских дел», Трепавлов вполне верно замечает, что вытеснение ногаев не являлось целью калмыцких владельцев, так

${ }^{53}$ Колесник В.И. Указ. соч. С. 94.

${ }^{54}$ Цюорюмов A.B. Калмыцкое ханство в составе России: проблемы политических взаимоотношений. Элиста, 2007.

${ }_{55}^{5}$ Цюрюмов А.В. Калмыщкое ханство... С. 366, 367.

${ }^{56}$ История Калмыкии с древнейших времен до наших дней: в 3-х т. Элиста, 2009

57 Трепавлов В.В. История Ногайской Орды. М., 2002; Он же. Алтыулы: остатки Ногайской орды в казахских степях // Вестник Евразии. М., 2001. № 2. C. $33-53$

${ }_{58}$ Кусаинова E.B. Русско-ногайские отношения и казачество в конце XV-XVII веке. Волгоград, 2005. как им нужны были «пространство для кочевания и покорные подданные». Попытки калмыков вернуть к себе ногайских беженцев русским правительством всячески пресекались. В целом, как отмечает автор, «калмыцкое нашествие имело роковые последствия для исторических судеб Большой Ногайской Орды», а ногаи, лишившись привычной территории, рассеялись по причерноморским степям ${ }^{59}$.

Трепавлов в своих работах также уделил внимание и вопросам трактовки калмыками российского подданства, их представлениями о русском монархе, о пределах подчиненности ему, как и пребывание в составе Московского государства ${ }^{60}$. По мнению автора, после шертей 1655 и 1657 гг. начались постепенная интеграция калмыков в структуру Российского государства и юридическое оформление подданства. Тайши, как справедливо считает Трепавлов, рассматривали соглашения 1650-х гг. прежде всего как «мирный договор с военнополитическим партнером и союзником, пусть и «старшим» по иерархическому рангу $)^{61}$.

Истории калмыцко-башкирских отношений посвящено немало работ, но среди них хотелось бы выделить третий том 7-томной «Истории башкирского народа» ${ }^{62}$ и работу Б.А. Азнабаева ${ }^{63}$. На основе документальных источников и литературы авторы освещает сложный исторический процесс в отношениях двух народов в рассматриваемый нами период.

Зарубежная историография также не отличается привлечением новых архивных материалов, а ее авторы ограничиваются лишь аналитикой уже известных опубликованных материалов.

${ }^{59}$ трепавлов В.В. История... С. 414, 415.

${ }^{60}$ Трепавлов B.B. «Белый царь»: образ монарха и представление о подданстве у народов России XV-XVIII вв. М., 2007; Он же. Калмыки и Россия в XVII-XVIII вв.: подданные, вассалы или союзники? // Калмыки в многонациональной России: опыт четырех столетий. Элиста, 2008. С. 58-70.

${ }^{61}$ Трепавлов B.B. «Белый царь»... С. $158,159$.

${ }^{62}$ История башкирского народа: в 7 т. / гл. ред. М.М. Кушарипов. Уфа, 2011. T. III.

${ }^{63}$ Азнабаев Б.А. Статус пленных в башкирских общинах XVII в. // Известия Алтайского государственного университета. Барнаул, 2012. № 4-1. C. 12-16. 
В 1966 г. впервые в американской историографии вышел «Калмыцко-ойратский сборник〉 под редакцией А. Э. Борманжинова и И. Крюгера. Наибольший интерес для нас представляет вышедшая в нем статья русского историка Г.В. Вернадского ${ }^{64}$. На основе опубликованных материалов он дает краткий обзор русско-калмыцким отношениям с начала XVII в. и до 1655 г. Проанализировав текст шерти 1655 г., Вернадский отметил существенную разницу в определении положения калмыков и ногаев. Ногаи, замечает он, определяются в шерти как «вечные холопы», а калмыки - состоящие в «вечном послушании» у царя, что можно определить как разницу между подданством и вассалитетом ${ }^{65}$.

В зарубежных востоковедных изданиях появился целый ряд работ, в которых оспариваются многие выводы советского историка И.Я. Златкина и подвергаются ревизии его изложения ойратской истории и трактовка конкретных событий. К ним можно причислить японскую исследовательницу Джунко Мияваки, которая опубликовала ряд статей по истории ойратов XVII в. ${ }^{6}$, применив сравнительносопоставительный анализ всех видов источников на разных языках. Подобный источниковедческий подход позволил ей расширить фактологическую базу исследований и прибблизиться к пониманию их подлинного смысла. Так, Мияваки внесла существенные коррективы в работу Златкина и правильно интерпретировала события междоусобонй войны ойратов $1625-1630$ гг. $^{67}$, которая имела судьбоносное значение для всей ойратской истории и стала главной причиной появления калмыков в Северном Прикаспии.

${ }^{64}$ Вернадский Г.В. Историческая основа русско-калмыщких отношений // Калмыцко-ойратский сборник / Под ред. А.Э. Борманжинова, И. Крюгера. Филадельфия, 1966. С. 11-50.

${ }^{65}$ Вернадский Г.В. Указ. соч. С. 33.

${ }^{66}$ Miyowaki, Junko. A Volga-Kalmyk family tree in the Ramstedt collection // Journal de la Societe Finno-Ougrienne. Helsinki, 1991. Vol. 83; Она же. Internal Rivalries in the Four Oyirad Tribal Federation // Ethnohistorische Wege und Lehrjahre eines Philosophen: Festschrift für Lawrence Krader zum 75. Geburtstag. Frankfurt am Main u.a.: Lang, 1995. P. 228-260.

${ }^{67}$ Мияваки-Окада Дж. Калмыцкие тайши в начале XVII века / Пер. с англ. В. Санчирова // Altaika IV. М., 2000. С. 70-77.
Проблеме южных границ России и истории русско-калмыцких отношений XVII-XVIII вв. посвящены работы американского историка М. Ходарковского ${ }^{68}$. Основываясь на опуббликованных русских и турецких источниках, автор дает глубокий исторический анализ политическим отношениям Российского государства и кочевников. Он, в частности, отмечает, что приход калмыков на Волгу и их масштабные набеги нарушили существующий баланс сил в регионе и стали заметным толчком в обороне южных российских границ ${ }^{69}$.

Несмотря на столь длительное и в целом плодотворное изучение истории калмыков XVII столетия, в современной историографии нет единого мнения даже в отношении хронологии событий. В этом издании многие страницы истории калмыцкого народа в XVII в. подвергаются новому прочтению и серьезному переосмыслению.

Источниковую базу исследования составляет широкий круг архивных документов, в большинстве своем неопубликованных. Несмотря на то, что название работы обозначено географическими рамками Северного Прикаспия, события, излагаемые в нем, связаны также с такими регионами, как Северный Кавказ, Причерноморье, Украина, Приуралье, Сибирь, Средняя Азия и Тибет, где калмыки активно контактировали с местными народами. Письменные источники последних довольно слабо представлены в данной работе, поэтому основу источниковой базы составляют официальные документы центральных и местных органов власти России XVII в.

История калмыцкого народа XVII в. довольно полно отражена в документальных материалах Российского государственного архива древних актов. В фондах государственных учреждений, ведавших связями с калмыками, отложилось большое количество документов делопроизводственного характера, составляющих документальную основу в нашей работе. С прикочевкой калмыцких улусов в начале столетия к сибирским границам Московского государства связи с калмыками поддерживались через приказ Казанского дворца, Сибирский приказ или Посольский приказ. Если материалы Сибирского

${ }^{68}$ Khodarkovsky M. Where Two Worlds Met: The Russian State and The Kalmyk Nomad, 1600-1771. Ythaka, N.Y., 1992; Он же. Russia's Steppe Frontier. The Making of a Colonian Empire, 1500-1800. Bloomington, 2002.

${ }^{69}$ Khodarkovsky $M$ Where Two Worlds Met... P. 236. 
приказа в достаточной мере отражают начальный этап миграции калмыков и русско-калмыцких отношений, то материалы приказа Казанского дворца интересующего нас периода таких больших сведений нам не дают, так как архив этого приказа неоднократно горел.

При подготовке данной работы особое внимание уделялось комплексному изучению еще неопубликованных материалов Посольского приказа, состоящий из нескольких фондов: 111 (《Донские дела»), 112 («Дела едиссанских, ембулуцких, буджацких и едичкульских татар»), 113 («Зюнгорские (контайшинские) дела»), 115 («Кабардинские, черкесские и другие дела» или «Кабардинские дела»), 119 («Калмыцкие дела»), 123 («Сношения России с Крымом» или «Крымские дела»), 127 («Сношения России с ногайскими татарами»или «Ногайские дела»).

Документы «Калмыцких дел», которые ведут отсчет с 1616 г., достаточно в полной мере отражают историю заселения калмыками степей Северного Прикаспия, взаимоотношения их с соседними народами и государствами и интеграции в политическое поле Московского государства. Характер русско-калмыцких отношений в полной мере раскрывают шертные записи тайшей, жалованные и дипломатические царские грамоты, дела о калмыцких и русских посольствах. Особый научный интерес вызывают «листы» (письма) тайшей центральным и региональным властям, составленных на старописьменном татарском, калмыцком и монгольском языках.

«Ногайские дела» подробно освещают взаимоотношения калмыков с различными ногайскими группами, кочевавших в Нижнем Поволжье, Северном Кавказе и Северном Причерноморье. Особое внимание автором уделялось изучению многочисленных отписок астраханских воевод в Посольский приказ, где среди различных сведений о положении ногайцев затрагивалась и калмыцкая тематика.

В ходе рассмотрения материалов «Донских дел» наше внимание в первую очередь было приковано к переписке Посольского приказа с атаманами Войска Донского, а также к расспросам приехавших в Москву донских казаков. Именно эти сведения подробно освещают не только отношения калмыков с казачеством, но и калмыцко-крымские и калмыцко-ногайские контакты в Северном Причерноморье и на Северном Кавказе.
Весьма скромную информацию о калмыцко-кабардинских связях дают нам документы «Кабардинских дел». Большой интерес вызывают подробные сведения о вторжении калмыков на Северный Кавказ в 1643-1644 гг, нападении их на Терский городок, большом сражении в Кабарде и гибели Хо-Урлюка

Выборочно на предмет калмыцко-крымских отношений были просмотрены и документы «Крымских дел». В первую очередь это касается сведений о калмыках из переписки Посольского приказа с русскими послами в Крыму, показаний гонцов, пленников, донесений воевод и запорожских гетманов и атаманов. Наибольший всплеск подобной информации, конечно, приходится на период Русско-польской войны 1654-1667 гг.

Материалы по истории калмыков XVII в. также широко представлены в фонде 178 («Астраханская приказная изба») научного архива Санкт-Петербургского института истории РАН. Кроме отписок астраханских воевод и правительственных указов, часто дублирующихся в фонде Посольского приказа, этот фонд содержит большое количество первичных материалов по сношениям с калмыками. Это, в первую очередь, записи или «памяти» о приездах калмыцких посланцев в Астрахань, выдаче им и приславшим их тайшам жалованья. Подобного рода записи характеризуют развитие дипломатических связей воевод с калмыками.

Все эти архивные материалы можно классифицировать следующим образом: отчеты царских воевод различных городов Сибири, Приуралья, Поволжья, Северного Кавказа и Украины; грамоты Посольского Приказа и Приказа Казанского дворца; отчеты и доклады русских послов и посланцев, служилых людей, посещавших калмыцкие улусы для ведения переговоров; показания пленных, беженцев и торговых людей; записи приема калмыцких послов в различных русских городах и Москве; договоры и шертные записи, а также грамоты царей; переписка калмыцких тайшей и ногайских мирз с различными органами власти России.

Наиболее многочисленной группой документов из всех перечисленных нами фондов являются отписки в центральные приказы от воевод различных городов. В них воеводы достаточно подробно из- 
лагали события за определенные отрезки времени, иногда за целый год. Особой обстоятельностью и тщательностью изложения были отписки астраханских воевод, в связи с чем они и составили значительный объем материала данной работы. Отписки довольно насышенно описывают связи местной администрации с тайшами, районы калмыцких кочевий, взаимоотношения их с соседями и т.д. В ответ на отписки воеводы получали грамоты из центральных приказов, в которых царское правительство давало подробные указания о порядке сношений с калмыками. Государевы грамоты являются прекрасными источниками для характеристики политики правительства по всем вопросам взаимоотношений с калмыками: попытки привести их в русское подданство, развитие торговых связей, решение территориального вопроса и т.д.

Дополнительные данные можно получить из расспросных речей выходцев из калмыцких улусов, взятых в плен калмыков и ногайцев, из челобитных самого разнообразного содержания, записей о выдаче жалованья посланцам и самим тайшам. Эти категории документов образовывались как в центральных органах власти, т.е. приказах, так и на местах.

Особо отметим группу документов, именуемых иертями или иертными записями. Сведения о принесении калмыками шертей встречаются в документах с начала XVII века. Но шерти тайшей в сибирский период носили исключительно устный характер. В сношениях же с волжскими калмыками появляются уже шертные записи, скрепленные подписями калмыцких тайшей или их доверенных лиц. Правда, тексты шертей подготавливались заранее царскими властями по определенной кальке с дополнениями для новой политической ситуации. Шертные записи являются чрезвычайно важными источниками, отражающими юридическую сторону вопроса о российском подданстве.

В архивных фондах сохранилось большое количество документов, отражающих дипломатические связи центральных органов власти с калмыцкими тайшами. Среди них упомянем прежде всего нака$36 l$ посланцам, отправлявшимся в калмыцкие улусы из Москвы или из сибирских и поволжских городов. В наказах обстоятельно излагалось то, что следовало сказать тайшам, предусматривались даже ответы на возможные вопросы с калмыцкой стороны. К этой же группе источников относятся записи в Посольском приказе приема калмыцких послов, выписки о предыдущих приездах послов и т.д.

Важными по содержанию являются и статейные списки русских послов, побывавших в калмыцких улусах. Они представляют собой своеобразные отчеты послов, весьма подробно отражающие ход переговоров с тайшами. В них можно найти много интересных сведений о жизни в калмыцких улусах, взаимоотношениях калмыков с соседями и т.д.

Следующую группу документов составляют письма тайшей на имя русских царей или адресованные воеводам пограничных городов. По данным В.Л. Котвича, наиболее раннее упоминание об отправке ойратами письма относится к 1636 г. ${ }^{70}$ За изучаемый нами период сохранилось немалое количество документов этого вида.

Краткий обзор всех названных выше групп источников свидетельствует о чрезвычайном их богатстве и разнообразии. Значение русских архивных документов трудно переоценить, поскольку они содержат сведения о внутреннем положении и внешней политике калмыков, данные об экономической, общественно-политической и культурной жизни калмыков в XVII столетии. Но при работе с такими материалами необходимо принимать во внимание характер тех или иных сведений, их достоверность, поскольку в них запечатлены вольные или невольные следы политической конъюнктуры. В особенности это касается официальных донесений воевод, стремившихся представить свою деятельность перед Москвой в более выгодном свете, и приводимых в этих донесениях показаний различных агентов, побывавших в калмыцких улусах, которые могли выдавать свои предположения за факты, слухи - за действительные происшествия, а иногда и намеренно вводить местные власти в заблуждение ${ }^{71}$.

При рассмотрении сборников материалов, относящихся к истории калмыцкого народа и изданных в дореволюционное время, прежде всего бросается в глаза их бессистемность и большие хронологические разрывы между опубликованными документами. Надо отметить, что до революции не было ни одного специального издания до-

\footnotetext{
${ }^{70}$ Котвич В. Л. Указ. соч. С. 1199-1214.

${ }^{71}$ Богоявленский С. К. Указ. соч. С. 50.
} 
кументов по истории калмыков. Весьма значительное их количество было опубликовано Археографической комиссией в отдельных томах «Русской исторической библиотеки» ${ }^{72}$, «Актов исторических $\rangle^{73}$ и «Дополнениях к Актам историческим» ${ }^{74}$.

В «Актах Московского государства» ${ }^{75}$ представлены документы из дел Московского стола Разрядного приказа, благодаря чему в оборот вошли документы, отражающие историю взаимоотношений калмыков с южнорусскими городами.

Основная масса материалов о калмыках встречается в сборниках документов, посвященных истории других народов России. Взаимоотношения калмыков с донскими казаками отражены в актах материалов «Донские дела», изданных в серии «Русская историческая библиотека», и «Крестьянская война под предводительством Степана Разина» ${ }^{76}$. В «Актах, относящиеся к истории Южной и Западной России» $)^{77}$ мы встречаем сведения о контактах калмыков с украинским населением в период русско-польской войны. Материалы, опубликованные в таких изданиях, как «Кабардино-русские отношения в XVI-XVIII вв.) ${ }^{78}$

${ }^{72}$ Русская историческая библиотека, издаваемая Императорскою Археографическою коммиссиею. Т. 2. СПб., 1875; Т. 26. Донские дела. Кн. 3. СПб., 1909; Т. 29. Донские дела. Кн. 4. СПб., 1913; Русская историческая библиотека Министерства Народного Просвещения. Т. 34. Донские дела. Кн. 5. Петроград, 1917.

${ }^{73}$ Акты исторические, собранные и изданные Археографическою коммиссиею. Т. 3. 1613-1645. СПб., 1841; Т. 4. 1645-1676. СПб.. 1842.

${ }^{74}$ Дополнения к Актам историческим, собранные и изданные Археографическою коммиссиею. Т. 2. СПб., 1846; Т. 3. СПб., 1848; Т. 6. СПб., 1857.

75 Акты Московского государства, изданные Императорскою Академиею Наук / Под ред. Н.А. Попова. Т. 2. Разрядный приказ. Московский стол. 1635-1639 гг. СПб., 1894; Т. 3. 1660-1664 гг. СПб., 1901.

${ }^{76}$ Крестьянская война под предводительством Степана Разина. Сборник документов. Т. 1. 1666 - июнь 1670 гг. / Сост. Е.А. Швецова. М., 1954; Т. 2. M., 1957; T. 3. М., 1962; T. 4. M., 1976.

${ }^{77}$ Акты, относящиеся к истории Южной и Западной России, собранные и изданные Археографической комиссией. Т. 5. 1659-1665. СПб., 1867; Т. 6. 1665-1668. СПб., 1869; Т. 7. 1659-1665. СПб., 1872; Т. 8. 1668-1669. СПб., 1875; Т. 9. 1668-1672. СПб., 1877.

${ }^{78}$ Кабардино-русские отношения в XVI-XVIII вв. Документы и материалы. М., 1957. Т. 2. и «Материалы по истории Башкирской АССР) ${ }^{79}$ проливают свет на отношения кочевников с народами Северного Кавказа и Приуралья. Специальные издания источников, включая переводы из сочинений восточных авторов, такие как «Материалы по истории Туркменской, Таджикской и Узбекской ССР» ${ }^{80}$ и «Материалы по истории туркмен и Туркмении» ${ }^{81}$ освещают лишь отдельные эпизоды взаимоотношений волжских калмыков с народами и государствами Средней Азией.

Особую группу документов составляют историко-юридические памятники. Среди них, конечно, на первом месте стоит «Полное собрание законов Российской империи ${ }^{82}$. Наибольший интерес для нас представляет опубликованный полный текст шерти 1655 г. В решении территориального вопроса этот документ сыграл большую роль в русско-калмыцких отношениях.

На втором месте уникальный источник - монголо-ойратские законы 1640 г. Составленные на съезде ойратских и монгольских владельцев, законы очень ярко отражают общественное устройство этих народов того времени, дают возможность охарактеризовать различные слои общества, выявить их экономическое и политическое положение. Этот законодательный источник стал известен русским властям в 20-е годы XVIII в. Законы были переведены со старописьменного калмыцкого языка на русский советником Коллегии иностранных дел В. Бакуниным. Перевод до сих пор хранится в фонде «Калмыцких дел» ${ }^{83}$. В XIX в. появилось два издания этих законов: изданы Ф.И. Леонтовичем в $1879-1880$ гг. ${ }^{84}$ и К.Ф. Голстунским в

${ }^{79}$ Материалы по истории Башкирской АССР. Ч. 1: Башкирские восстания в XVII и первой половине XVIII в. М.-Л., 1936.

${ }^{80}$ Материалы по истории Узбекской, Таджикской и Туркменской ССР. Вып.3. Ч. 1. Л., 1933.

${ }^{81}$ Материалы по истории туркмен и Туркмении. Т. II. XVI-XIX вв. Иранские, бухарские и хивинские источники / Под ред. В.В. Струве, А.К. Боровкова, А.А. Ромаскевича и П.П. Иванова. М.-Л., 1938.

82 Полное собрание законов Российской империи, повелением Государя Императора Николая Павловича составленное. Собрание Первое. Т. 1, 5. С 1649 по 1675. СПб., 1830

${ }^{83}$ РГАДА. Ф. 119. Оп. 1. Д. 2

${ }^{84}$ Леонтович Ф.И. К истории права русских инородщев. Древний монголо-калмыцкий или ойратский устав взысканий. Одесса, 1879. 
$1880 \Gamma{ }^{85}$ В.Л. Котвичем дана подробная характеристика всех переводов и разных изданий монголо-ойратских законов ${ }^{86}$.

К наиболее полным и достоверным источникам по истории ойратов XVII в. можно отнести биографию виднейшего ойратского религиозного и политического деятеля, просветителя и составителя ойратско-калмыцкого алфавита Зая-пандиту (1599-1662), написанную его учеником Раднабхадрой. В этом произведении подробно освещены исторические даты, места и персонажи, что вкупе с русскими архивными материалами значительно помогает восстановить события того времени. С качественным переводом и историческими комментариями этого источника можно ознакомиться в нескольких изданиях ${ }^{87}$.

Существенным дополнением к данным русских архивных документов могут служить и калмыцкие историко-генеалогические сочинения XVIII-XIX вв.: 《История дурбэн-ойратов» Габан Шараба, «История дурбэн-ойратов» Батур-Убаши Тюменя, «Краткая история калмыцких ханов» и «История Хо-Урлюка» анонимных авторов. Первые два сочинения сходны по структуре и содержанию, содержат родословные ойратских князей и рассказы об их поступках. В «Истории калмыцких ханов» в хронологической последовательности повествуется об основных вехах истории калмыков со времени их поселения на Волге. Выдержки из анонимной летописи «История ХоУрлюка» в переводе В.П. Санчирова дают нам несколько ранее неизвестных фактов о событиях XVII в., правда, без указания на даты, что, конечно, значительно затрудняет трактовку указанных исторических событий.

Изучая историю калмыков в Северном Прикаспии, невозможно обойти вниманием и сочинения среднеазиатские авторов, которые в

${ }^{85}$ Голстунский К.Ф. Монголо-ойратские законы 1640 г., дополнительные указы Галдан-хун-тайджия и законы, составленные для волжских калмыков при калмыцком хане Дондук-Даши. СПб., 1880.

${ }^{86}$ Котьич В.Л. Указ. соч. С. 795-797.

${ }^{87}$ Раднабхадра. «Лунный свет»: История рабджам Зая-пандиты / Пер. с ойрат. Г.Н. Румынцева и А.Г. Сазыкина. СПб., 1999; Норбо III. Зая-Пандита (Материалы к биографии) / Пер. со старомонг. Д.Н. Музраевой, К.В. Орловой, В.П. Санчирова. Элиста, 1999. большинстве своем опубликованы в русском переводе 88 . Значительная часть из них опубликована на русском языке в извлечениях, вошедших в различные тематические сборники документов и материалов ${ }^{89}$. Сведения о калмыках в них имеют случайный характер, но использование этих источников вкупе с русскими и калмыцкими материалами расширяет наши возможности в изучении этого периода.

В условиях неравномерного освещения в документах истории исследуемого периода приходится привлекать и материалы неофициального происхождения, существующие в разнообразных жанрах (летописи, хроники, фольклор, предания, биографии и т.п.). А поскольку данные русских, калмыцких и тюркских источников довольно часто противоречат друг другу, составлена хронология исторических событий в данном издании на основе сведений, совпадающих во всех или в большинстве источников. В рассмотрении исторических событий, надо полагать, это позволяет избежать односторонности и приблизиться к большей достоверности и полноте.

${ }^{88}$ Абуль-Гази. История монголов и татар / Пер. с перс. Г.С. Саблукова // Известия Казанского университета. Казань, 1905. Т. 21.

${ }^{89}$ Материалы по истории туркмен и Туркмении. Том. II. XVI-XIX вв. Иранские, бухарские и хивинские источники / Под ред. В.В. Струве, А.К. Боровкова, А.А. Ромаскевича и П.П. Иванова. М.-Л., 1938; Материалы по истории Узбекской, Таджикской и Туркменской ССР. Вып.3. Ч. 1. Л., 1933. 


\section{Глава 1.}

\section{ИСТОРИЧЕСКИЕ ПРЕДПОСЫЛКИ ПОЯВ.ЛЕИЯ} КАЛМЫКОВ В СЕВЕРНОМ ПРИКАСПИИ

\section{1. Установление русско-калмыцких отношений в Сибири}

В исторической литературе существуют различные точки зрения на причины откочевки из Центральной Азии ойратов в конце XVI начале XVII вв. Не углубляясь в специальное рассмотрение этого вопроса, ограничимся только некоторыми замечаниями.

На территории современной Западной Монголии и Джунгарии (северной части нынешнего Синьцзян-Уйгурского автономного района Китая) в XV-XVI вв. существовал так называемый военно-политический союз ойратских племен, именовавшийся «дурбэн ойрат». В него входили наиболее крупные субэтносы: торгуты, хошуты, дербеты, хойты и цоросы (чоросы). К началу XVII в. этот союз трансформировался в отдельные группировки, каждая из которых в зависимости от конкретной политической ситуации пыталась действовать совместно с другими или автономно. Но угроза потери самостоятельности в борьбе с внешними силами побуждала ойратских правителей координировать свои действия перед лицом общей опасности. В этих условиях возрастали роли такого политического института, как съезды князей («чулганы» или «хуралы»), и лиц, возглавлявших работу этого совещательного органа ${ }^{1}$.

Опираясь на различные источники, можно сделать вывод, что у миграции ойратов на запад было четыре главных причин:

Экологическая. Природно-климатические явления играли в жизни кочевых народов Востока огромную роль. Ухудшение климатических условий, например, аридизация (иссушение) или зна-

${ }^{1}$ История Калмыкии с древнейших времен до наших дней: в 3-х т. Элиста, 2009. Т. 1. С.250-251. чительное похолодание, вызывающее сокращение кормовой базы скота, вели к угрозе голода и вынуждали кочевников мигрировать в более благоприятные районы на границе с оседлым миром, где происходили вооруженные столкновения. Если в такой исторический момент в степи оказывался сильный и удачливый лидер, способный сплотить кочевников и направить их на путь завоевания, начиналась глубокая военная экспансия² ${ }^{2}$ Русские и ойратские источники неоднократно свидетельствуют о периодах резкого похолодания в Центральной Азии в начале XVII в., что, скорее всего, и приводило к массовому падежу скота и лошадей, а также поиску кочевниками новых пастб́ищных земель с более умеренными климатическими условиями.

Внешнеполитическая. В рассматриваемый период причиной откочевки была и внешняя угроза. Ойраты были вытеснены из восточных районов Алтая современной Западной Монголии в результате военных поражений, нанесенных им войсками Алтын-хана во второй половине XVI - начале XVII в. Хотогойтское княжество Алтын-ханов занимало территорию в северо-западной части современной Монголии между озерами Убсу-Нур и Хубсугул. На рубеже XVI-XVII вв. первым Алтын-ханом и основателем этого кочевого государства был Шолой Убаши-хунтайджи, который одновременно претендовал и на роль всеойратского хана ${ }^{3}$. Растянувшаяся почти на столетие вооруженная борьба Алтын-ханов против ойратов вышла за рамки пограничных инцидентов и превратилась в большую войну, в которую постепенно были втянуты все ойратские владения ${ }^{4}$.

Экономическая. Открытое вооруженное противостояние с монгольскими и казахскими феодалами лишало ойратов свободных выходов к китайским и среднеазиатским рынкам. Торговля играло большую роль в хозяйственной жизни кочевников, особенно в период роста поголовья скота. Поэтому в дальнейшем, когда ойраты вступили в непосредственные сношения с царскими властями, они добивались

${ }^{2}$ Дробыпиев Ю.И. Человек и природа в кочевых обществах Центральной Азии (ІІІ в. до н.э. - XVI в. н.э.). М., 2014. С. 63, 64.

${ }^{3}$ История Калмыкии... Т. 1. С. 252-253.

4 Златкин И.Я. История Джунгарского ханства (1635-1758). М., 1964 C. 70 . 
права продавать скот, лошадей и скотоводческое сырье на русских рынках ${ }^{5}$.

Внутриполитическая. По мнению И.Я. Златкина, тайша ХараХула пытался объединить ойратов под главенством именно цоросского дома, как это было в XV в. - во времена гегемонии их правителей Тогона и Эсена. Но другие тайши, не желая подчиняться власти цоросов, со своими улусами откочевали в районы Юго-Западной Сибири Главным оппонентом Хара-Хулы внутри цоросского дома были дербетские тайши во главе с Далай-Батуром. Именно они стали главными инициаторами откочевки в пределы Юго-Западной Сибири, чтобы там совместно с торгутскими тайшами основать собственный центр кочевий, как политический противовес джунгарским тайшам. Позже к ним присоединились и хошутские тайши, что значительно укрепило позиции Далай-Батура. Только во второй половине XVII в. в результате политических интриг и военных действий джунгарам удалось окончательно подчинить своей власти большую часть ойратов в границах созданного ими Джунгарского ханства.

На рубеже столетий ойратские кочевья простирались: на востоке - до окрестностей озера Баркуль, на западе включали территорию Семиречья, гранича с казахскими владениями, на юге хошутские кочевья граничили с Восточным Туркестаном, а на севере, в районе Черного Иртыша и озера Зайсан, располагались кочевья дербетов. Рядом с ними, у южных и западных отрогов Тарбагатая, кочевали торгуты ${ }^{7}$ Существует мнение, что Алтын-хан стремился оттеснить ойратские кочевья как можно дальше на запад, за линию Алтайских гор ${ }^{8}$. Но главной целью Алтын-хана все-таки было подчинение всех ойратских племен и включение их в состав своего княжества.

Объективно территория Джунгарии не в состоянии была вместить многочисленных ойратских беженцев с имуществом и скотом из Восточного Алтая. Небольшие группы ойратов были подчинены Алтын-ханом, другая их часть впоследствии направилась в запад-

\footnotetext{
5 Златкин И.Я. Указ. соч. С. 66.

6 Златкин И.Я. Указ. соч. С. 139.

${ }^{7}$ История Калмыкин... Т. 1. С. 252.

${ }^{8}$ Бембеев В.ШІ. Ойраты и калмыки на евразийском пространстве (XIII 60-е гг. XVII века). Элиста, 2007. С. 195.
}

ном направлении и заняла территорию Семиречья. Хойты, например, позднее мигрировали в южном направлении, войдя в контакт с мусульманским населением Восточного Туркестана (Кашгара). Но основная масса ойратов, представленная преимущественно дербетами и торгутами, двинулась на северо-запад, вниз по Иртышу в пределы Юго-Западной Сибири. В определении путей миграции действия ойратских тайшей носили согласованный характер.

Массовые переселения кочевников из Центральной Азии на запад отмечались издавна, поскольку, будучи скотоводами, охотниками и воинами, они в силу господствовавшего у них способа производства нуждались в обширных пространствах. Демографический рост, увеличение численности поголовья скота, закончившиеся неудачей войны и как результат - сокращение пастбищных территорий вынуждали кочевое население пускаться в дальние странствия, одно из которых ойраты и совершили в XVII в.

Еще до времени своего появления у сибирских границ Московского государства на рубеже XVI-XVII вв. ойраты в русских документах именуются «калмыками». В 50-х гг. XVI в. об этом свидетельствует Р. Джонсон, спутник английского посла Дженкинсона, узнавший от русских купцов о неких «желтых» и «черных» калмыках 9 . Еще В. Котвич обратил внимание на то, что в русских документах 1574, 1583 и последующих годов встречаются упоминания о калмы$\operatorname{kax}^{10}$. К этому можно добавить и то, что в посольских делах России с европейскими государствами за 80-90-е гг. XVI в. также имеются прямые указания на калмыков, «колмацкую орду», «пегих калмыков». На рубеже XVI-XVII вв. отдельные группы калмыков входили в состав Казахской орды, калмыцкие отряды находились в войсках кучумовичей ${ }^{11}$. Впоследствии в русских документах появляется тер-

${ }^{9}$ Каиин В.Н. Крестьянская железоделательная промышленность Кузнецкого края XVII-XVIII вв. // Проблемы истории докапиталистических обществ. № 7-8. М., 1934. С. 21.

${ }^{10}$ Котьич В.Л. Русские архивные документы по сношениям с ойратами в XVII-XVIII веках // Известия Российской академии наук. № 12-15. 1919. C. $1082-1083$.

${ }^{11}$ Путешествия русских послов XVI-XVII вв. Статейные списки. М.-Л., 1954. С. 174; Богоявленский С.К. Указ. соч. С. 51-52. 
мин «(чакарские калмыки» ${ }^{12}$ как название группировки ойратов, кочевавших в степях Западной Сибири

Калмыцкие улусы, откочевавшие из Западной Монголии, расположились в верховьях рек Иртыша, Ишима, по Камышлову, Оми и у Соленых озер. Это были малонаселенные и почти никем не обороняемые степные пространства Юго-Западной Сибири. Калмыки стали ближайшими соседями Тарского, Тобольского и Томского уездов Московского государства. На реке Оби они объявились еще в 1598 г. $^{13}$

В наказе тобольскому воеводе от 11 февраля 1601 г. московское правительство предписывало внимательно наблюдать за передвижениями калмыков. Но первый официальный контакт в русских документах зафиксирован только в сентябре 1606 г., когда в Таре появляется посланец торгутского тайши Хо-Урлюка - Катачей Бурундуев. Тайша просил разрешения кочевать по Камышлову, Ишиму и приезжать для торговли в Тару. Однако первые переговоры не увенчались успехом, поскольку калмыцкие набеги причиняли серьезный ущерб ясачному населению приграничных районов. Попытки воеводы С.И. Гагарина продолжить переговорный процесс закончились исчезновением его посланников во владении Хо-Урлюка ${ }^{14}$

По мнению К.Н. Максимова, Московское государство в отношении местных народов использовало гибкую мирную дипломатию, предлагая взаимовыгодные условия, свое покровительство, а калмыцкие тайши не отрицали установления верховного права российского царя по отношению к ним ${ }^{15} .30$ марта 1607 г. из Приказа Казанского

12 Этноним чакар можно трактовать, во-первых, как чахар (перс.) - «четыре народа». Отсюда невольно возникает аналогия с термином дурбэн-ойpam (четыре ойрата). Во-вторых, существует и монгольское значение слова чахар (цахар. цахр) - «слуга». «свита при хане». «телохранитель». «обслуга хана», «население, живущее при ханской ставке либо монастыре» (Народы и религии мира. Энциклопедия. М., 1998). Этноним «чакарские калмыки» встречается только в русских источниках XVII в.

13 Златкин И.Я. Указ. соч. С. 123.

${ }^{14}$ Материалы по истории русско-монгольских отношений (далее-МИРМО). 1607-1636: Сб. документов / Сост. Л.М. Гатауллина, М.И. Гольман, Г.И. Слесарчук; отв. ред. И.Я. Златкин, Н.В. Устюгов. М., 1959 С. 28-29

${ }^{15}$ Максимов K.H. Калмыкия в национальной политике, системе власти и управления России (XVII-XX). М., 2002. С. 13. дворца, который в это время заведовал и «Сибирскими делами», была послана, от имени Василия Ивановича Шуйского, грамота Гагарину, в которой предписывалось ему отправить к калмыкам посольство. Велено было говорить, «чтоб колмацкие князи и мурзы и всякие улусные люди были под нашею царскою рукою и шерть и утверждение и заклады дали, что им бытии вперед под нашею царскою высокою рукою неотступным, и нам ясак с себя платить по вся годы безпереводно... нашим ясачным людем тесноты не чинили и не побивали, а мы их (калмыков. - B.T.) также велим беречи и от недругов оберегати» ${ }^{16}$

Вызывает сомнение в готовности тайшей выплачивать ясак. Как справедливо отмечает Г.В. Вернадский, из вышеизложенной грамоты видно, что «в Москве не разобрались в сущности калмыцкого вопроса и недооценили силу калмыков, так как указали тарскому воеводе, чтоб он не только принял калмыков под царскую руку, но потреб́овал, чтобы калмыки платили русскому царю ясак, т. е. потребовали не вассалитета, а подданства с платежом ясака (дани), от которого даже высшие слои сибирских татар были освобождены» ${ }^{17}$.

Но в 16 июня 1607 г. в Тару прибыл дербетский тайша Кугонай Тубеев. От себя и от имени других четырех старших тайшей - Изенея, Далай-Батура, Ужена и Юрикты Конаевых - Кугонай шертовал в том, что калмыцкие тайши принимают русское подданство, в знак чего готовы платить ясак скотом. В указанной ойратской группировке насчитывалось 45 владельцев под предводительством 5 старших тайшей. Общая численность их улусных людей составляла примерно 120 тыс. человек. У русских властей тайши просили разрешения кочевать вверх по Иртышу и у Соленых озер. Но Кугонай не шертовал за торгутских Хо-Урлюка и Кирсана, которые три года назад отошли от них и расположились с улусами вверх по Иртышу ${ }^{18}$.

Из воеводского донесения видно, что данная ойратская группировка кочевала отдельно от основной массы ойратов и на тот момент действовала самостоятельно в отношении царского правительства

${ }^{16}$ МИРМО. М., 1959. С. 21.

${ }^{17}$ Вернадский Г.В. Историческая основа русско-калмыцких отношений // Калмыцко-ойратский сборник / Под ред. А.Э. Борманжинова, И. Крюгера. Филадельфия. 1966. С. 27

${ }^{18}$ МИРМО. М., 1959. С. 22. 
По мнению С.К. Богоявленского, торгуты в это время также не представляли собой единого общества, будучи разделенными на две группы $^{19}$. Основываясь на данных родословных торгутских князей, можно с уверенностью говорить, что под Изенеем здесь подразумевается ни кто иной, как Езене-тайджи, двоюродный дядя Хо-Урлюка. Езенетайджи стоял во главе той группы торгутов, от которой действовал обособленно Хо-Урлюк.

Из донесения видно, что калмыки готовы были доставлять русским коней и верблюдов, хотя воевода не упомянул слово «ясак». Но в грамоте Приказа Казанского дворца воеводам снова был употреблен этот термин. Отсюда, как делает вывод Г.В. Вернадский, в дальнейшем происходили недоразумения, но ясак калмыки, конечно, так и не согласились платить, при этом лошадей охотно продавали русским ${ }^{20}$ Не только калмыки, но и русские были крайне заинтересованы в торговле, поскольку нуждались в средствах для освоения Сибири ${ }^{21}$

Вести о переговорах сибирских воевод с калмыками получили поддержку в Москве. Тарскому воеводе предписывалось командировать к тайшам послов с объявлением, что Московское государство берет их под свое покровительство, обещает защиту от воинственных соседей и разрешает кочевать вверх по Иртышу. Царская грамота воеводе также содержала очень важный пункт - о разрешении калмыкам свободно приезжать в Тару для ведения торговли. На первых порах Москва решила сосредоточить в своих руках дела по осуществлению связей с калмыками, не передоверяя их сибирским воеводам. Для окончательного оформления присяги на подданство настоятельно рекомендовалось приглашать тайшей непосредственно в столицу. Правительство не удовлетворилось несколько пассивными действиями тарского воеводы к призванию «под государеву высокую руку» Хо-Урлюка и Кирсана и поставило перед ним конкретную задачу - проявить инициативу и направить послов к указанным тайшам и добиться принятия ими русского подданства ${ }^{22}$.

${ }^{19}$ Богоявленский С.К. Указ. соч. С. 53.
${ }^{20}$ Вернадский Г.В. Указ. соч. С. 28.

${ }^{21}$ Любимов Ю.В. Миграция западных ойратов в Поволжье и русско-калмыцкие отношения // Восток. Афро-азиатские общества: история и современность. № 2. М., 2008. С. 46-47.

${ }^{22}$ МИРМО. М., 1959. С. 23.
Очевидно, что действия тайшей из данной группировки были не совсем скоординированными. В мае 1607 г. тайши Изеней, Абакай и Узеней прислали в Томск своих послов с просьбой о принятии в подданство и разрешении торговли. Из Москвы поступили указания во многом сходные с теми, которые были получены в Таре. Ответное посольство из Томска в составе конных казаков во главе с Б. Константиновым, отправленное в октябре 1608 г, не достигло калмыцких улусов, получив по дороге известие об уходе тайшей на войну с Алтын-ханом и казахами ${ }^{23}$. Тем временем калмыцкие улусы постепенно продвигались в западном направлении вдоль сибирских границ Московского государства.

В сентябре 1607 г. калмыцкие тайши Далай-Батур, Кугонай Тубеев, Юрикты Конаев и Шевгей Урлюков прислали в Тару посланцев Баучина, Девлета Тахабакшеева, Арлая Алакова и Кесенчака Чиганова. Тайши вновь просили защитить их от Алтын-хана и казахов и разрешить кочевать им вверх по Иртышу, у Соленых озер и Камышлову. Калмыцким торговцам было разрешено беспошлинно продать лошадей в Таре, что официально и положило начало русско-калмыцкой торговле ${ }^{24}$.

Тарский воевода, следуя наказам правительства, отправил калмыцких послов в Москву. Это было первое калмыцкое посольство, посетившее столицу Московского государства. 14 февраля 1608 г. послы присутствовали на приеме у царя Василия Ивановича Шуйского. В Москве были поражены простотой одежды калмыцких послов, для чего им были выданы в качестве жалованья нарядные одежды из Посольского приказа ${ }^{25}$. Отсюда Г.В. Вернадский делает предположение, что калмыцкие тайши не возлагали больших надежд на это посольство и не придавали ему особого значения, а потому отправили в Москву не знатных, а «худых» людей ${ }^{26}$.

От имени тайшей они просили о принятии их в подданство и защите от неприятелей, которое могло обеспечить строительство рус-

\footnotetext{
${ }^{23}$ МИРМО. М., 1959. С. 32-33.

${ }^{24}$ МИРМО. М., 1959. С. 24, 25.

${ }^{25}$ МИРМО. М., 1959. С. 75.

${ }^{26}$ Вернадский Г.В. Указ. соч. С. 28.
} 
ской крепости на реке Омь. Послы подняли также вопросы о дозволении калмыкам кочевать по Иртышу, Оми и Камышлову и возвращении пленных. Московское правительство пообещало выполнить все пожелания тайшей ${ }^{27}$. Изенею и Далай-Батуру было разрешено с улусами кочевать в сибирских пределах по Иртышу, Оми и Камышлову и обещано обеспечение защиты от ногаев, казахов и монголов. При этом центральная власть подчеркивала обязательность приезда старших тайшей в Москву для переговоров. В качестве непременного условия выдвигалось требование о выдаче калмыцких аманатов (заложников) - привычный для царского правительства способ держать в повиновении подданных, особенно на национальных окраинах. По мнению М. Ходарковского, если власти рассматривали подобную процедуру как знак безусловного и исключительного подчинения, то «иноверцы» - как неприятный, но необходимый акт, сопутствующий договору с русскими о военном союзе, взаимном ненападении и покровительстве ${ }^{28}$. Институт аманатов был заимствован русскими из ордынской политической практики ${ }^{29}$.

Узнав об активных переговорах других тайшей с русскими властями, Хо-Урлюк также включился в этот процесс, прислав в июне 1608 г. в Тару своего представителя - Шапкулу Татугуева. Торгутский тайша также выразил желание быть «под царскою рукою» и отправить своих посланцев в Москву. Эту группу улусов численностью около 4 тыс. человек возглавляли пятеро торгутских тайшей: Хо-Урлюк, Улчечи (возможно, Илю-Цензе, дядя Хо-Урлюка. - B.T.), Тогачи Тохтораев, Буяран У лчиев и Дубеней ${ }^{30}$.

На начальном этапе становления русско-калмыцких отношений правительство было заинтересовано и в покупке калмыцкого скота и лошадей. Пунктами торговли с калмыками были определены: Тара, Тобольск, Тюмень, Пермь (Чердынь), Уфа, Казань и Москва. Калмыцких торговых представителей, едущих с «конскими базарами» в

${ }^{27}$ МИРМО. М., 1959. С. 24-27, 37, 74.

${ }^{28}$ Khodarkovsky $M$. Russia's Steppe Frontier. The Making of a Colonian Empire, 1500 - 1800. Bloomington, 2002. P. 59.

${ }^{29}$ Трепавлов B.B. «Белый царь»: образ монарха и представление о подданстве у народов России XV-XVIII вв. М., 2007. С. 140.

${ }^{30}$ МИРМО. М., 1959. С. 36. русские города, предписывалось пропускать без задержек и обеспечивать подводами и провожатыми ${ }^{31}$.

Но успешно начавшиеся русско-калмыцкие переговоры вскоре зашли в тупик. Поездка в калмыцкие улусы посольства П. Голубина летом 1609 г. не имела успеха. Вдова Изенея - Абай, а также тайши Кошевчей, Хо-Урлюк и другие отказались приехать в Тару и прислать своих торговых людей. Объяснили они это сборами в поход против казахов, в тот момент охваченных междоусобной войной. Тайши также отказались платить ясак, заметив, что сами собирают ясак с «белых калмыков» и впредь никому платить его не намерены. Пределы кочевий тайши определяли самостоятельно, поскольку считали себя людьми вольными. Столь резкая перемена в их настроении объяснялась успешными действиями калмыков против войск Алтын-хана и казахов. Они почувствовали уверенность в своих силах. Возможно, до тайшей дошли слухи и о тяжелом внутреннем положении в Московском государстве. Несмотря на это, правительство предписывало воеводе И. Мосальскому придерживаться прежнего политического курса по отношению к калмыкам ${ }^{32}$.

Воодушевленные военными победами над Алтын-ханом, калмыки усилили свои набеги на ясачных татар Тарского уезда. В 1613 г. местный воевода трижды отправлял против калмыков ратных людей. Потерпев ряд поражений в столкновениях с русскими отрядами, в ноябре Далай-Батур и Тургень отправили в Тару своих послов. Тайши обещали не нападать на русские земли и вернуть пленных, в чем послы и учинили шерть. В мае 1615 г. представители Далай-Батура, Тургеня и Хо-Урлюка в очередной раз появляются в Таре. В конце года шертовали уже тайши Тургень, Бутак и Малдышеря. Ответное посольство этих калмыцких владельцев посетило Тару, где калмыцкие послы выразили желание торговать в русских городах ${ }^{33}$.

Некоторое затишье и мирный характер в отношениях царских властей с калмыками отмечались до 1620-х годов. В начале 1616 г. в калмыцкие улусы прибыло русское посольство Т. Петрова и И. Куницына, отправленное главой русской администрации в Сибири - то-

\footnotetext{
${ }^{31}$ МИРМО. М., 1959. с. 34-37.

${ }^{32}$ МИРМО. М., 1959. С. 37-40.

${ }^{33}$ МИРМО. М., 1959. С. 41-43.
} 
больским воеводой И.С. Куракиным. Калмыки проявили радушие к гостям, здесь послы провели переговоры с Далай-Батуром, его братом Исентурой и другими тайшами. Последние подтвердили свое согласие стать царскими подданными, вновь подняв вопрос о беспрепятственном пропуске своих послов и торговых людей в сибирские города. Решение по вопросу о кочевьях тайши представили на усмотрение русских властей, не выражая каких-либо претензий. В распоряжении этой группировки имелось постоянное 40-тысячное войско под командованием четырех тайшей. Первенствующим тайшой здесь выступал дербетский Далай-Батур ${ }^{34}$.

Иначе в это время складывались отношения калмыков с Алтынханом, который объективно на тот момент был сильнее ойратов и стремился обложить их ясаком. Последние же искали поддержки у Московского государства ${ }^{35}$. По-видимому, при заключении шертей калмыцкие тайши рассчитывали на вполне конкретную военную помощь русских, а не просто на предоставление им рынков сбыта своей продукции. Но правительство, не располагая достаточными силами для ведения активных военных действий в Сибири, стремилось к мирному разрешению пограничных споров и охотно принимало калмыцких послов ${ }^{36}$.

В Тобольске воевода И. Куракин прилагал немало усилий, чтобы склонить калмыцких правителей к осознанию необходимости отправить в Москву авторитетное калмыцкое посольство для переговоров о подданстве. Правительство Михаила Федоровича не желало довольствоваться внешнеполитическими результатами, достигнутыми при правлении Василия Шуйского. Новая династия Романовых всячески стремилась утвердить свое положение и добивалась пересмотра заключенных ранее договоренностей. В ходе переговоров русского посланника Савельева с Далай-Батуром в августе 1617 г. было достигнуто соглашение о поездке его представителей в Москву. В ноябре 1617 г. дербетские послы Буга и Коомдан прибыли в Тобольск, откуда и были отправлены в Москву. 20 марта 1618 г. их принял дьяк По-

${ }^{34}$ МИРМО. М., 1959. С. 52.

${ }^{35}$ РГАДА. Ф. 119. Оп. 1. 1616 г. Д. 1. Л. 8.

${ }^{36}$ МИРМО. М., 1959. С. 52, 53; Очерки истории Калмыцкой АССР: Дооктябрьский период / Под ред. Н.В. Устюгова. М., 1967. С. 85, 87. сольского приказа С. Романчуков. От имени Далай-Батура и его сына послы выразили готовность быть под «царскою рукою» и просили защиты от врагов. Большое впечатление на них оказало сообщение Романчукова о приезде в Москву и послов Алтын-хана с челобитьем о подданстве. После аудиенции в Посольском приказе калмыцкие послы были приняты царем. 14 апреля 1618 г. на имя Далай-Батура была пожалована грамота, извещавшая о согласии царя принять тайшей в русское подданство. Сибирским воеводам строго предписывалось не причинять вреда калмыкам, а последние получили право торговать в сибирских городах ${ }^{37}$

Очевидно, что Далай-Батур действовал вполне самостоятельно, и его авторитет в ойратской среде позволял ему единолично вести переговоры с Москвой, в том числе и по вопросу о принятии подданства. Однако в его группировку входили далеко не все ойратские тайши. Например, Хара-Хула, Тургень, Бутак, Табутай и Малдышеря действовали самостоятельно. Все они, кроме Хара-Хулы, автономно сносились с Тарой, шертовали и просили разрешения посылать своих торговых людей ${ }^{38}$. Но была еще и третья группа, состоявшая из мелких молодых владельцев и кочевавшая отдельно, о которых Далай-Батур в разговоре с посланником И. Савельевым сообщал следующее: «а царевич и с ними мелкие тайши от них кочюют далече, а бегают от них от ясака тому третей год, а государевы волости воюют воровством без их ведома $\rangle^{39}$. Именно они вместе с сибирским царевичем Ишимом, сыном Кучума, в 1616 г. и последующие годы совершали нападения на уфимские волости, что в целом противоречило политике Далай-Батура и других старших тайшей, всячески стремившихся стабилизировать отношения с русскими властями ${ }^{40}$. Например, в начале 1616 г. тайша Тургень в разговоре с посланцем В. Калашниковым предупреждал русскую сторону о готовящемся набеге летом этого года кучумовича Ишима с калмыками под сибирские города и ${ }^{37}+79$

${ }^{37}$ РГАДА. Ф. 119. Оп. 1. 1618 г. Д. 1. Л. 8-10; МИРМО. М., 1959. С. 53.

${ }^{38}$ Русская историческая библиотека, издаваемая Императорскою Археографическою комиссиею (далее- РИБ). Т. 2. СПб., 1875. С. 338-339.

${ }^{39}$ РГАДА. Ф. 119. Оп. 1. 1618 г. Д. 1. Л. 15.

${ }^{40}$ РГАДА. Ф. 119. Оп. 1. 1618 г. Д. 1. Л. 13. 
уфимские волости ${ }^{41}$. Вместе с тем Далай-Батур заверил русскую сторону, «что они царевича за то ограбят», но при этом отказался выдать его царским властям: «и того у них в мысли нет» ${ }^{42}$.

Как видим, у ойратов в это время не было единой жесткой организации в обычном понимании, поскольку каждый улус был независим в принятии решении, но при этом только по вопросам не касавшимся всех или нескольких улусов. Лишь общая проблема или угроза объединяли эти автономные образования и способствовали временной консолидации ${ }^{43}$.

О начале образования отдельной группировки ойратских улусов свидетельствуют и показания русских посланцев - Т. Петрова и И. Куницына, побывавших в улусах в 1616 г. Обращает на себя внимание тот факт, что Далай-Батура калмыки называли «всею Колмацкою землею царем, а сам он себя царем не пишет... а думчие ближние тайши - Чюгур да Урлук-тайша» ${ }^{44}$. Общее признание формальной власти дербетского тайши со стороны его соратников - торгутского Хо-Урлюка и хошутского Чокура - можно рассматривать как признание Далай-Батура «первым среди равных». Такой роли, как известно, ранее удостаивался хошутский тайша Байбагас. Обычно такие союзы скреплялись династическими браками между старшими правителями улусов. Так, например, сестра Хо-У рлюка была выдана замуж за Далай-Батура, дочь хошутского Чокура - за Шукур-Дайчина, старшего сына Хо-Урлюка ${ }^{45}$

Власть дербетского Далай-Батура распространялась и на определенную часть Казахской орды и киргизских племен. Однако его взаимоотношения с Алтын-ханом продолжали оставаться напряженными, и положение дел складывалось не в пользу ойратов. Известно об уплате дани тайшами Алтын-хану, что, скорее всего, относится к правителям юго-восточной группировки, обитавшей в Джунгарии. Тогда же некоторые хошутские владельцы со своими улусами откочевали в Сибирь, как это сделал хошутский Чокур ${ }^{46}$.

${ }^{41}$ РГАДА. Ф. 119. Оп. 1. 1616 г. Д. 1. Л. 25.

${ }^{42}$ РГАДА. Ф. 119. Оп. 1. 1618 г. Д. 1. Л. 15.

43 Любимов Ю.В. Указ. соч. С. 48.

${ }^{44}$ МИРМО. М., 1959. С. 52.

${ }^{45}$ История Калмыкии... Т. 1. С. 272

${ }^{46}$ История Калмыкии... Т. 1. С. 273.
Необходимо внести ясность в вопросе об идентификации личности Чокура (Чогура, Чуукэра или Шукера). Начиная с работ С.К. Богоявленского и И.Я. Златкина, он долгое время ошибочно считался цоросским тайшой, сыном Хара-Хулы и братом Батура-хунтайджи. Действительно, у цоросов, судя по генеалогическому древу, были одноименные братья - Чокур и Байбагас. Но они были намного моложе и в русских источниках впервые упоминаются примерно с конца 1630-х гг. В данном случае речь идет о хошутском тайше Чокуре из рода Гурван эикэ Галгас, выделявшемся своей предприимчивостью и энергией, что давало ему возможность играть заметную роль в ойратских делах. Впервые эту ошибку в работах советских историков

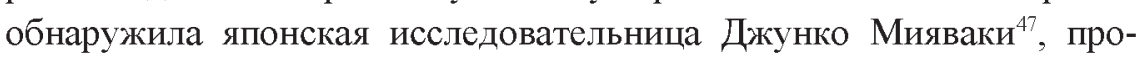
ведя тщательное изучение монгольских родословных, что подтверждается уже новыми материалами из русских источников. Согласно Габан Шарабу, именно хошутскому Чокуру долгое время удавалось захватывать чужие улусы, что вызывало резко негативное отношение к нему у большинства ойратских тайшей ${ }^{48}$.

Со временем центральная власть расширила компетенцию тобольского воеводы. Фактически Тобольск становился центром, осуществлявшим связи с калмыками. Например, в 1616 г. без санкции тобольского воеводы И. Куракина тюменский воевода уже не мог отправить вооруженные отряды против калмыков. Такая позиция правительства, возможно, отчасти объяснялась большим влиянием Куракина в придворной среде, где его ценили как умного и дальновидного администратора. В 1619 г. царская грамота рекомендовала тобольским воеводам не пропускать калмыцких послов в Москву, а все возникавшие вопросы решать на месте ${ }^{49}$.

Таким образом, первые сношения с калмыками ознаменовались заключением тайшами шерти (договоров) с Московским государством, посещением калмыцкими послами Москвы и отправлением

${ }^{47}$ Мияваки-Окада Дж. Калмыцкие тайши в начале XVII века / Пер. с англ. В. Санчирова // Altaica IV. M., 2000. С. 70-77.

${ }^{48}$ Габан ЦІараб. Сказание об ойратах (Калмыцкая летопись) // Лунный свет: Калмыцкие историко-литературные памятники / сост., ред., предисл., коммент. А.В. Бадмаева. Элиста, 2003. С. 96.

${ }^{49}$ МИРМО. М., 1959. С. 43-44, 77-78. 
ответных посольств от правительства в калмыцкие улусы. По мнению К.Н. Максимова, подписанные в августе 1609 г. Василием Шуйским две грамоты положили «начала официальному вхождению калмыцкого народа в состав России ${ }^{50}$. Но, как показывают дальнейшие события, период в 1607-1609 гг. можно рассматривать все-таки как начало установлению русско-калмыцких отношений. Заинтересованность в обеспечении кочевьями, развитии экономических связей с Московским государством и укреплении обороны от соседей заставляли калмыков искать поддержки у русских властей. Калмыцкие тайши обращались к правительству с просьбой о защите тогда, когда до предела осложнялись их отношения со степными соседями. Однако, как уже отмечалось, царское правительство не располагало в Сибири достаточными ресурсами для оказания вооруженного отпора, поэтому всячески стремилось к мирному разрешению пограничных конфликтов и охотно принимало миролюбивые инициативы калмыков. Но прежде чем говорить о дальнейшем развитии русско-калмыцких связей, необходимо рассмотреть взаимоотношения калмыков с другими государствами и народами.

\section{2. Калмыцко-ногайские отношения в начале XVII века}

Столкнувшись с укрепленными пунктами сибирских городов Московского государства, миграция калмыков, начиная со второго десятилетия XVII в., получила уже западное направление. Обойдя с севера казахские кочевья, калмыцкие улусы проследовали по маршруту вдоль рек Иртыш, Ишим и Тобол, достигли степной части Тургайской ложбины, откуда двинулись на юго-запад, добравшись почти до Приаральских Каракумов. После этого движение их снова получило западное направление, теперь уже вдоль рек Эмба, Яик и Волга. В ходе продвижения калмыки сталкивались с новыми для себя соседями - ногаями и башкирами. По мнению В.В. Трепавлова, первоначально этот процесс носил «пульсирующий» характер миграций, до-

${ }_{50}$ Максимов К.Н. Калмыки в геостратегических планах России XVII века // Вестник Калмыщкого института гуманитарных исследований РАН. Элиста, 2013. С. 8. казательством чему служат свидетельства об эпизодическом появлении калмыков в степях Северного Прикаспия еще во второй половине XVI в., когда в 1556 и 1560 гг. восточное крыло ногаев совместно с астраханскими стрельцами успешно отбило нападение калмыков ${ }^{51}$. Если учесть, что ойраты в то время проживали далеко на востоке - в Западной Монголии и Джунгарии, трудно предположить, кто были эти люди. Можно допустить, что это была группа калмыков, подчинявшаяся казахскому хану.

В начале XVII в. восточные границы Большой Ногайской Орды начинались в районе Эмбы. Именно здесь весной 1607 г. ногайцы князя Иштерека неожиданно обнаружили калмыков ${ }^{52}$. Среди ногайских мирз пронесся тревожный слух о поездке калмыцких послов в Москву и получении ими разрешения подчинить ногайцев власти тайшей ${ }^{53}$. Во втором десятилетии XVII в. огромное пространство между Самарской Лукой и Аралом почти ежегодно становилось ареной постоянных стычек калмыков с ногайцами ${ }^{54}$.

Об опасности появления калмыков в районе Яика был предупрежден и московский царь Михаил Федорович, планировавший в 1613 г. отправить своих послов к персидскому шаху Аббасу. В силу невозможности проезда в Персию морем через Астрахань, занятую в то время мятежным атаманом И. Заруцким, посольство вынуждено было ехать окружным путем по Ногайской степи к Яику, а оттуда через Ургенч. По сообщению среднеазиатских купцов, обстановка в Ногайской степи была неспокойной: «А как де только, государь, на реках лед вскроется и снеги последние сойдут, и конский корм будет, тогды де, государь, Колмыки и Нагаи лошеди откормят, и без людей в степи не будет, потому меж собя Колмыки и Нагаи учнут подъезды чинить (т. е. совершать друг на друга набеги. - B.T.), тогда ды, государь, дорогою будет не проехать $){ }^{55}$.

${ }^{51}$ Трепавлов В.В. История Ногайской Орды. М., 2002. С. 371-372.

${ }_{52}^{52}$ Трепавлов В.В. История... С. 412.

${ }^{53}$ Богоявленский С.К. Указ. соч. С. 56

${ }_{54}$ Златкин И.Я. Указ. соч. С. 83.

${ }^{55}$ Цит. по: Веселовский Н.И. Передовые калмыки на пути к Волге // Записки Восточного отделения Императорского Русского археологического общества. Т. 3. СПб., 1888. С. 366-367. 
Такие опасения не были беспочвенными, так как в том же году был отмечен переход через Яик 4-тысячного отряда калмыков и внезапное его нападение на ногайский улус мирзы Кель-Мухаммеда ${ }^{56}$. В ноябре в Уфе стало известно от башкир, что объединенный отряд, состоящий из ногайцев, астраханских стрельцов, крымцев, казыевцев и черкесов, под началом Иштерека и Кель-Мухаммеда двинулся против калмыков. Местом предполагаемого сражения была назначена «великая гора Урук) стал известен из сообщения в Москве ногайского посланца Кары Богатыря, согласно которому, Иштереку якобы удалось разгромить калмыков и «с юртов согнать $)^{58}$.

По всей видимости, калмыкам были необходимы новые охотничьи угодья, поскольку в степях южной части Западной Сибири таковые уже были заняты ясачными народами, находившимися под защитой русских военных отрядов. Движение калмыков в яицком направлении не встретило сильного сопротивления. Первоначально это были всего лишь разведывательные отряды калмыков, искавших в том числе и пути для возможной миграции на запад в случае неудачных военных действий на восточном направлении против Алтын-хана. «История калмыцких ханов) во многом это подтверждает, повествуя, что в 1618 г. Хо-Урлюк «послал добрых людей высмотреть берега Каспийского моря» с целью возможного дальнейшего продвижения на запад ${ }^{59}$.

Другой причиной, заставившей калмыков устремиться в западном направлении, как отмечал С.К. Богоявленский, было и то, что вследствие больших снегов скот не находил себе подножного корма и практически весь вымер ${ }^{60}$. Действительно, осенью 1615 г. и последующей зимой отмечаются в регионе сильные заморозки, и, как отмечали очевидцы, «(многие с стужи помирают и лошади падут» ${ }^{61}$.

${ }^{56}$ Богояеленский С.К. Указ. соч. С. 57.

${ }^{57}$ РГАДА. Ф. 127. Оп. 1. 1613 г. Д. 1. Л. 1-3.

${ }^{58}$ РГАДА. Ф. 127. Оп. 1. 1614 г. Д. 2. Л. 2.

${ }^{59}$ История калмыцких ханов // Лунный свет: Калмыщкие историко-литературные памятники / Сост., ред., предисл., коммент. А.В. Бадмаева. Элиста, 2003. C. 113

${ }^{60}$ Богоявленский С.К. Указ. соч. С. 57

${ }^{61}$ РГАДА. Ф. 119. Оп. 1. 1616 г. Д. 1. Л. 6.
Известно, что экстенсивное скотоводческое хозяйство кочевников постоянно терпело большой урон при наступлении неблагоприятных погодных условий. Такие чрезвычайные обстоятельства, как дзуты (гололед зимой), бескормицы из-за засух в летнюю пору, эпизоотии и др. приводили к массовому падежу скота, что могло побудить обнищавших и терпящих голод скотоводов искать новые источники для своего пропитания ${ }^{62}$. Например, в калмыцкой летописи «История Хо-Урлюка) встречается упоминание о том, что торгутам во время массового падежа скота и лошадей приходилось даже заниматься земледелием, и тем самым они сумели спастись от голодной смерти. Вместе с тем столь предприимчивый выход из сложной ситуации, найденный Хо-Урлюком, способствовал значительному притоку к нему людей из других улусов ${ }^{63}$.

В 1617 г. ногайский мирза Иштерек жаловался в Москву о разорении его людей калмыками ${ }^{64} .1619$ г. был отмечен новым нападением калмыков на ногайцев, кочевавших по рекам Узень и Камыш-Самара в Волго-Яицком междуречье. Улусы двух враждующих ногайских родов - Урмаметевых и Тинмаметевых - находились в постоянных столкновениях. Напуганные усилением Урмаметевых, Тинмаметевы увели свои улусы к Яику и стали там в укрепленном месте. Но здесь они подверглись нападению калмыков, страх перед которыми был сильнее внутренней вражды и сильнее недоверия к русской власти. Это в конечном итоге привело к тому, что дети Иштерека и ДинМухаммеда вновь были вынуждены прикочевать к Астрахани ${ }^{65}$.

Причиной тому послужило тяжелое положение калмыков: разгорелась очередная война с казахами и Алтын-ханом. Под давлением неприятелей калмыцкие улусы отступили к Ишиму и уфимским волостям. Вновь встал вопрос о восстановлении отношений с русскими властями. Чтобы найти выход из создавшегося положения хошутский тайша Байбагас созвал съезд старших тайшей, среди которых были

${ }^{62}$ Санчиров В.П. К изучению топонимики ойратов и калмыков (XVII XVIII вв.) // Новый исторический вестник. М., 2011. № 29. С. 68 .

${ }^{63}$ История Калмыкии... Т. 1. С. 225.

${ }^{64}$ Трепавлов В.В. История ... С. 412.

${ }^{65}$ Кусаинова E.B. Русско-ногайские отношения и казачество в конще XV-XVII веке. Волгоград, 2005. С. 158. 
Далай-Батур, Хо-Урлюк и Чокур. Как видим, в период военной опасности во главе данной группировки снова встал Байбагас, шертовавший за всех тайшей перед послом из Уфы. Собрание, состоявшееся в улусе Чокура, приняло решение «быть под царской рукой», вернуть в Уфу всех пленных башкир и в дальнейшем не нападать на их волости. Позже в Уфе калмыцкие послы «шертовали» в подданстве за всех тайшей и сибирского царевича Ишима, просили разрешения в будущем посылать в Уфу торговых людей со скотом. Посол Байбагаса отправился в Москву, где заявил, что его тайша бьет челом за всех калмыцких людей о принятии «под высокую царскую руку» ${ }^{66}$.

Наступление войск Алтын-хана вынуждало тайшей не только поддерживать мирные отношения с Московским государством, но и искать жизненное пространство в западном направлении, особенно в случае возможного поражения и отступления. В мае 1622 г. ногаец Ишббердей сообщил в Астрахани, что в районе развалин городка Сарайчика на Яике объявился отряд в 800 калмыков под началом Ишима, сына Кучума, и хошутского тайши Тлеченбая - брата Байбагаса. Они разгромили кочевавших здесь татар-тумаков. Сам Ишбердей в числе 32 человек был взят в плен, но через 3 дня ему удалось сбежать и объявится в улусе Каная. Калмыки перешли в Волго-Яицкое междуречье и кочевали в урочище Насыр Хабырге. Главной целью Тлеченбая и Ишима были алтыульские татары мирзы Султаная, но, узнав, что те приняли царское подданство и кочуют под защитой Астрахани, отменили свой набег и ушли за Яик, на урочище Кайнар Сагызу. Астраханские власти так и не решились отправить посланцев к калмыкам, тем более, что они быстро исчезли из зоны видимости ${ }^{67}$.

Набеги калмыков вызвали такую волну паники у ногайских мирз, что для их успокоения царской администрации пришлось расставить в улусах стрелецкую охрану ${ }^{68}$. Подобные свои действия в степях Северного Прикаспия калмыки считали оправданными, поскольку этот регион представлялся им вполне безопасным, так как находился на весьма отдаленном расстоянии от неприятельских сил.

${ }^{66}$ Богоявленский С.К. Указ. соч. С. 60-61.

${ }^{67}$ РГАДА. Ф. 127. Оп. 1. 1622 г. Д. 1. Л. 11-13.

${ }^{68}$ Богоявленский С.К. Указ. соч. С. 61.
Новый фронт калмыками был открыт и в Средней Азии. Еще в 1615 г. у них возник конфликт с бухарцами, когда были разгромлены и ограблены два торговых каравана. Практически дорога между Бухарой и сибирскими городами, которая занимала 4 недели пути, была полностью перекрыта калмыками ${ }^{69}$. Поскольку для бухарцев торговля имела жизненное значение, то они предъявили калмыкам ультиматум - прекратить бесчинства, а в случае отказа начать против них военные действия ${ }^{70}$. Казахский правитель г. Саврана Аблахан предлагал русским властям совместно очистить степь от калмыков, а сибирские воеводы советовали государю построить на реке Ишим крепость или острог, чтобы таким образом сократить до двух недель расстояние пути до Саврана, увеличить пошлину и вынудить калмыков уйти с окрестных степей ${ }^{71}$. По мнению А. Чулошникова, полное отсутствие сведений о всяких посольствах из Средней Азии в Московское государство после 1622-1623 гг. было связано с ситуацией, сложившейся на старых вековых путях с приходом в зауральские степи калмыков, которые в 1620 г. появились на берегах рек Орь и Эмба ${ }^{72}$

Отношения с соседями, как отмечалось выше, ухудшало и то обстоятельство, что ряд молодых тайшей без разрешения на то старших тайшей совершали набеги на московских подданных. Именно они своими необдуманными действиями вызывали ответную силовую реакцию царских властей. В условиях постоянного военного давления со стороны восточных и южных соседей старшие тайши пытались сохранить хрупкий мир с Москвой. Войска Алтын-хана все активнее теснили калмыков, и Далай-Батур вынужден был искать новые кочевья вблизи сибирских городов. Зимой 1622 г. он кочевал в четырех днях пути от Тюмени, а некоторые улусы уже приблизились к Уфе. Следует отметить, что калмыки проявляли сдержанность по отношению к башкирам. Один из тайшей, например, упрекал башкир за вторжение на занятые калмыками территории и сетовал, что они

\footnotetext{
${ }^{69}$ РГАДА. Ф. 119. Оп. 1. 1616 г. Д. 1. Л. 6.

${ }^{70}$ Богоявленский С.К. Указ. соч. С. 62.

${ }^{71}$ РГАДА. Ф. 119. Оп. 1. 1616 г. Д. 1. Л. 7.

72 Чулошников А. Торговля Московского государства со Средней Азией в XVI-XVII вв. // Материалы по истории Узбекской, Таджикской и Туркменской ССР. Вып.3. Ч. 1. Л., 1933. С. 75-76.
} 
ничего не могут поделать, поскольку их старшие тайши решительно запрещают им трогать башкир ${ }^{73}$.

Весной 1623 г. к Далай-Батуру, Хо-Урлюку, Чокуру и Байбагасу был отправлен Василий Волков для передачи выговора тайшам о том, что они не соблюдают шерти и нападают на уфимские волости. Но в улусах оказались только младшие тайши, поскольку старшие тайши в это время воевали с Алтын-ханом. Младший брат Далай-Батура, Мангыт, шертовал за 30 дербетских тайшей и торгутского ХоУрлюка. Как позже выяснилось, нападение на уфимские волости совершил цоросский тайша Исенгул в отместку за разгром башкирами его посольства, направлявшегося в Уфу, и убийство его брата ${ }^{74}$.

Военные дела на этот раз складывались для калмыков благоприятно: продвижение войск Алтын-хана вглубь кочевий по Иртышу было остановлено в результате победы в генеральном сражении 1623 г. Именно эти события описаны в «Повести о том, как дурбэнойраты нанесли поражение монголам», когда объединенные ойратские войска разбили халха-монголов и убили Шолой-Убаши-хунтайджи или Алтын-хана, как он называется в русских источниках, и вернули себе независимость ${ }^{75}$.

В сентябре 1625 г. ногайский бий Канай сообщал в Астрахани, что был инициатором отправки Алей-мирзы к калмыцким тайшам. Подобная самостоятельность ногайского князя не вызвала одобрения у астраханских властей и ему впредь было запрещено без ведома администрации ссылаться с калмыками. Канай же попытался договориться с тайшами, предложив им заключить мирное соглашение и установить торговые отношения. Дорога в калмыцкие улусы, располагавшиеся в это время на Иртыше, у Алея заняла около 14 недель, а пробыл он там в общей сложности 2 месяца. Согласно данным Алея, «начальными людьми» у калмыков были хошутский Чокур, дербетский Далай-Батур, торгутский Мерген-Темене и Батур. Тайши довольно приветливо встретили приезд мирзы, который, по указанию

${ }^{73}$ Богоявленский С.К. Указ. соч. С. 61-62.

${ }^{74}$ РГАДА. Ф. 119. Оп. 1. 1633 г. Д. 1. Л. 10-11, 18-21.

${ }^{75}$ Miyawaki J. A Volga-Kalmyk family tree in the Ramstedt collection // Journal de la Societe Finno-Ougrienne. Helsinki, 1991. Vol. 83. Р. 207; История... Т. 1. С. 283.
Каная, предлагал, чтобы они «со всеми калмыцкими людьми были под... царского величества высокою рукою в прямом холопстве навеки неотступны». Калмыцкие владельцы подтвердили свое желание поддерживать с Канаем мирные отношения и выразили желание отправить в Астрахань на продажу 3 тыс. лошадей ${ }^{76}$. С городами Московского государства тайши поддерживали мирные отношения, например, Алей был свидетелем возвращения из Уфы 40 калмыцких посланцев, успешно там продавших лошадей. Калмыки также помирились с Казахской ордой, а с ургенцами и бухарцами находились в состоянии перманентного мира. Хивинский хан Исфендиар прислал к тайшам своих послов с предложением выкупить своих людей, захваченных калмыками в ходе их набега на Ургенч весной 1625 г. ${ }^{77}$

Калмыки попытались договориться с ногайцами, обеспечив безопасность своих кочевий на юго-западном участке. Но единственным из тайшей, кто вступил в непосредственные переговоры с ногайской стороной, был Батур. Он подарил Алею 3 калмыцких коней, а вместе с ним к Канаю отправил своего посланца Алатая, послав «в поминках〉 одного коня. Канай подарок принял и уже с калмыцким представителем отправил к тайшам Кулука, чтобы тот проведал: «калмыцкие тайши к нему, к Канаю князю, послов своих прислали с правдою и не чают ли они какова дурна?». В ноябре 1625 г. Кулук благополучно вернулся с новым калмыцким посольством и заверением калмыцкой стороны в мирных намерениях. Ближайшие к ногайским кочевьям калмыцкие улусы кочевали на урочищах Иргиз и Сауке, в 25 днях пути от Астрахани. Калмыцкому послу удалось заключить мир с Канаем, но вскоре 700 улусных людей под командой Тордугала из ногайского клана Тинмаметевых угнали лошадей из близлежащих калмыцких улусов. Спустя месяц в повторный набег направились люди Хан-мирзы Тинмаметева. Все это обеспокоило русские власти, так как из-за ответных действий калмыков могло начаться бегство ногаев на правый берег Волги. Правительство строго предупредило мирз, чтобы они своими необдуманными действиями не раздражали калмыков, а инициатора угона калмыцких лошадей посадили в тюрьму ${ }^{78}$.

\footnotetext{
${ }^{76}$ РГАДА. Ф. 127. Оп. 1. 1625 г. Д. 1. Л. 47-51.

${ }_{77}$ РГАДА. Ф. 127. ОП. 1. 1625 г. Д. 1. Л. 49, 50.

${ }^{78}$ РГАДА. Ф. 127. Оп. 1. 1625 г. Д. 1. Л. 79-81.
} 
Как видно из свидетельств мирз, первыми мирное соглашение все-таки нарушила ногайская сторона. Ради справедливости отметим, что клан Тинмаметевых не имел договоренностей с калмыцкой стороной. Но именно их действия подорвали в целом доверие тайшей к мирзам, что в впоследствии не могло не отразиться на калмыцконогайских отношениях

\section{3. Внутриполитический кризис в ойратском обществе в $1625-1630$ гг.}

Одержанная победа ойратов над Алтын-ханом в 1623 г. не принесла им долгожданного мира, поскольку в дальнейшем обострила уже внутренние противоречия. По мнению И.Я. Златкина, ойратские феодалы часто то образовывали союзы, то расторгали их, становясь врагами свои вчерашним союзникам, «что говорит о том, что эти союзы были весьма кратковременны, а их состав крайне текуч» ${ }^{79}$. С.К. Богоявленский также считает, что союз ойратов не охватывал всех тайшей, но при этом никогда отношения между ними не доходили до крупных вооруженных столкновений ${ }^{80}$. Дальнейшие события, произошедшие в 1625 г., оказались не только трагическими для ойратской истории, расколов общество на два враждебных лагеря, но и послужили новым импульсом миграции кочевников в западном направлении

В историографии превалирует мнение, что в авангарде продвигавшихся на запад вдоль сибирских границ Московского государства калмыков находились торгуты Хо-Урлюка, вслед за которыми со своими улусами двигались и другие тайши. Но при изучении новых материалов подобное утверждение не находит соответствующего подтверждения. Например, известно, что хошутские улусы братьев Чокура, Байбагаса и Чин-тайши в первой половине 1625 г. кочевали в урочищах Улен Кабала и Чюдете, располагавшихся от Уфы в 10 днях, а от верховьев Эмбы - в 20 днях пути. Общая численность в

\footnotetext{
79 Златкин И.Я. Указ. соч. С. 159.

${ }^{80}$ Богоявленский С.К. Указ. соч. С. 60-61, 63.
}

этих улусах составляла свыше 30 тыс. человек ${ }^{81}$. Это дает основание предположить, что передовой частью ойратской миграции на запад в 1620-х гг. были именно хошутские улусы. Стоит также отметить, что к началу XVII в. хошуты представляли собой наиболее сплоченное и многочисленное объединение среди ойратов ${ }^{82}$.

Первопричиной междоусобных конфликтов, возникавших время от времени в ойратской среде, в основном являлись внутрисемейные разборки. Не стала исключением и ситуация, сложившаяся в хошутском доме, когда в июне 1625 г. умер Чин-тайша, не оставив после себя наследника. Чокур на правах родного брата самовольно присоединил к себе его улус численностью в тысячу кибиток, и, как отмечали очевидцы, «брату своему Байбагишу воли не дал». Но последний, собрав значительное войско, силой присоединил к себе улус Чин-тайши ${ }^{83}$.

Судя по родословным хошутских князей, содержащимся в ойратских и монгольских источниках, Чокур и Чин были полнородными братьями, рожденными от одних отца и матери. Байбагас приходился им троюродным братом по отцу, а по матери все трое были единоутробными братьями. Их мать, Ахай-хатун, после смерти своего мужа (отца Чокура и Чин-тайши) вторично вышла замуж за его двоюродного брата по имени Ханай-нойон Хонгор и родила ему пятерых сыновей, в ойратской истории известных как «пять барсов», старшим из которых был Байбагас ${ }^{84}$. Борьба за улус умершего брата обернулась ожесточенным столкновением между Чокуром и Байбагасом, которое впоследствии привело к расколу не только среди хошутов, но и всего ойратского общества.

Конфликт между братьями стал набирать обороты, что не могло не встревожить остальных тайшей. По сведениям, полученным от казака Я. Сарбашова в августе 1625 г. в Тобольске, для разрешения хошутского конфликта свое посредничество предложили дербет-

${ }^{81}$ История Казахстана в русских источниках (далее - ИКРИ). Алматы, 2005. T. 1. C. 312

${ }^{82}$ История Калмыкии... Элиста, 2009. Т. 1. С. 251

${ }^{83}$ МИРМО. М., 1959. С. 139.

${ }^{84}$ Мияваки-Окада Дж. Указ. соч. С. 75-76; История Калмыкии... Т. 1. 
ские тайши - братья Далай-Батур и Эрке-Елден. В сопровождении тысячного отряда они направились к хошутам, представив как вполне компромиссный вариант разрешения спора - поровну разделить улус покойного Чин-тайши между Чокуром и Байбагасом (по 500 кибиток). Стремление примирить хошутов было вызвано еще и тем, что сохранялась весьма сложная внешнеполитическая ситуация: они опасались, «чтобы услыша то, мугальские люди, что меж колмыцкими тайшами война, не пришли на них войной». Этот конфликт даже приостановил переговорный процесс тайшей с русской администрацией. Дербетские тайши предложили Байбагасу вернуть 500 кибиток Чокуру. Байбагас уже было склонялся к такому варианту и намеревался отправить брату половину улуса Чин-тайши, но Чокур наотрез отказался, посчитав себя обманутым. Он срочно собрал вокруг себя своих верных сторонников (Мерген-Темене, Куяна, Табытая и др.) и с 30-тысячным войском неожиданно атаковал позиции Байбагаса. Поняв, к чему все это может привести, Далай-Батур «ночью с вестью» предупредил Байбагаса о готовящемся нападении. Как отмечали очевидцы, в районе левого берега Иртыша, ниже Ямыш-озера, происходило вооруженное столкновение между противниками, в результате которого Байбагас потерял большое количество своих людей и имущества. Он, видимо, не ожидал вероломного нападения своего брата в разгар переговорного процесса и не успел подготовиться, а в наличии у него «людей было мало, все были в разъезде». Но на помощь своему старому соратнику Байбагасу пришел цоросский тайша Хара-Хула с 10-тысячным войском. Мелкие тайши также разбились на два враждебных лагеря. В этой непростой ситуации Далай-Батур с дербетами занял выжидательную позицию: «хто из них, Чокур ли или Байбагиш, будет силен, х тому хочет и пристати». Многие очевидцы тех событий склонялись к общему мнению: «меж колмацкими тайши быть войне великой, и миру меж ими не бывать» ${ }^{85}$. За стремлением Чокура полностью завладеть наследством своего родного брата Чинтайши, не выделяя какой бы то ни было доли Байбагасу, скрывалась борьб̆а за власть, имевшая место в хошутском доме ${ }^{86}$

\footnotetext{
${ }^{85}$ МИРМО. М., 1959. С. 138-140.
}

${ }^{86}$ История Калмыкии... Т. 1. С. 286.
Многочисленные свидетели того времени, побывавшие в калмыцких улусах, по-разному интерпретировали результаты сражения. Например, в ноябре 1625 г. в Астрахани объявился бежавший из калмыцкого плена русский полоняник М. Родионов. 9 лет назад он был взят в плен ногайцами, но спустя год оказался у калмыков в результате их набега на ногайский улус. С его слов, в сражении 1625 г. на стороне Чокура выступили тайши Батур, Хо-Урлюк, Далай-Батур и Мерген-Темене, а за Байбагаса - Хара-Хула и некий (контайша). Байбагас и его сторонники были разбиты и бежали за Иртыш, при этом экстренную переправу через реку им обеспечили сибирские казаки, направлявшиеся на лодках за солью. Чокур со своими союзниками не стал дальше преследовать Байбагаса и откочевал прочь от Иртыша к верховьям Эмбы, где была запланирована зимовка улусов с целью дальнейшего наступления на ногайские улусы ${ }^{87}$.

Согласно другим свидетельствам, в том сражении победили Хара-Хула и Байбагас, а Чокур бежал за Каракумы, где был разбит казахами, после чего удалился под уфимские волости. Русский пленник, бежавший из улуса Хо-Урлюка, сообщал иное: «Бьются Урлюк с Чокуром, идут великие бои». Основываясь на сообщениях мирзы Алея о том, что Чокур осенью 1625 г. кочевал совместно с Далай-Батуром и входил в число старших тайшей, а Хо-Урлюк удалился на север, где искал себе места для кочевок и вошел с этой целью в сношения с русскими властями, можно сделать вывод, что «партия» Чокура вышла из кровавой распри победительницей, но во время борьбы возникли недоразумения уже между Чокуром и Хо-Урлюком, что последний был разбит и удалился на север под Тару ${ }^{88}$

После столкновения сторонники Чокура перекочевали к верховьям реки Эмбы. Здесь они встретили улусы алтыульских татар, принадлежавших мирзам Салтанаю и Шайнеку, которые, не желая быть у русских в подданстве, удалились из-под Астрахани. По сообщению ногайского Султаная-мирзы Шихмамаева, в начале 1626 г. в улус алтыульского мирзы Шайнека на Эмбу прибыли послы от тайшей Далай-Батура, Мангыта и Батура с предложением о заключении мира и ведении совместных военных действий против общих недругов. Улу-

\footnotetext{
${ }^{87}$ РГАДА. Ф. 127. Оп. 1. 1626 г. Д. 1. Л. 28, 29.

${ }^{88}$ Богоявленский С.К. Указ. соч. С. 63-64.
} 
сы указанных тайшей в это время кочевали в Приаральских Каракумах и Барсучьих песках, примерно в 15 днях пути от улуса Шайнека ${ }^{89}$. По всей видимости, здесь находились их зимние кочевья, а весной они вновь поднимались вверх по Тургайской ложбине на летние пастбища, поближе к сибирским городам.

Во время междоусобной войны отношения калмыков с соседями складывались в целом благоприятно. С Казахской ордой у них был заключен мир, а с Ургенчем и Бухарой открытой войны не было. Наконец, есть основание предполагать, что войска Алтын-хана не сильно проникли вглубь калмыцких кочевий, по крайней мере, калмыки могли передвигаться и по Иртышу и за Иртыш. В Таре было получено известие, что между Табытаем, Далай-Батуром и Хо-Урлюком идет бой, тарские воеводы всерьез стали опасаться такого близкого соседства ${ }^{90}$. По мнению С.К. Богоявленского, все это свидетельствовало о том, как быстро росла сила калмыков, несмотря на их столкновения с соседями и внутренние распри ${ }^{91}$.

Но у группировки Чокура отношения с казахами в дальнейшем сложились не совсем благополучно. В начале 1627 г. один из ближайших сторонников Чокура, торгутский тайша Мерген-Темене, с улусом в 10 тыс. человек ${ }^{92}$ расположился рядом с кочевьями казахского хана Ишима (Есима) и с ним «учинился в миру». Приехавший с Эмбы в Астрахань татарин сообщал, что летом 1627 г. казахский хан Ишим совместно с ташкентским правителем Турсуном во главе 10-тысячного войска внезапно напал на калмыков и «многих калмыцких людей побил и в полон поймал». Во время этих событий Ишим казнил Турсуна, который пытался избежать кровопролития и для этого вступил в переговоры с калмыками, а голову его отправил к бухарскому хану Имам-кули, что стало сигналом для последнего, и он двинулся

${ }^{89}$ РГАДА. Ф. 127. Оп. 1. 1626 г. Д. 1. Л. 221, 222; ИКРИ. Алматы, 2005. T. 1. C. 294.

${ }^{90}$ ИКРИ. Алматы, 2005. Т. 1. С. 301.

${ }^{91}$ Богоявленский С.К. Указ. соч. С. 64

92 Здесь, по всей вероятности, имеется в виду количество воинов, поскольку в «Биографии Нейджи-тойна» есть упоминание о наличии у торгутского тайши Мерген-Темене 10-тысячного войска (Пурбуева Ц.П. Указ. соч. C. 49). на Ташкент. Мерген-Темене с остатками своих улусных людей, испытывая острый недостаток в лошадях и скоте, бежал к реке Сырт (Сырдарья) $^{93}$

Согласно сведениям из русских источников, можно прийти к выводу, что появление калмыков на Эмбе было связано с поражением группировки Чокура от казахов. По сообщению стрельцов в Астрахани, побывавших в плену у алтыульцев, осенью 1627 г. объединенные силы сторонников Чокура численностью до 40 тыс. воинов, в ответ на вероломное нападение казахского хана Ишима на улус МергенТемене летом этого года, ходили на него войною, но снова потерпели от казахов сокрушительное поражение. Силы Чокура и его соратников рассеялись, а около 2 тыс. калмыков, таким образом, оказались в верховьях Эмбы. Отсюда они отправили пятерых посланцев к алтыульским мирзам Султанаю и Шейх-Мухаммеду с предложением объединиться и совершить совместный набег на ногайские улусы под Астраханью. Но мирзы отказались, сославшись на малочисленность и желание уйти кочевать в Туркестан или под Ургенч 94

Военные неудачи, как правило, сопровождавшиеся значительными потерями скота и имущества, требовали от кочевников искать новые возможности поживиться за счет более слабого соседа. Часть калмыков выступала за то, «чтоб идти войною на нагайские улусы, а другая де половина их говорят, чтоб им на нагайские улусы войною не ходить». Алтыульские мирзы в это время окончательно рассорились с русскими властями, поскольку в конце 1627 г. ограбили отправленного к ним из Астрахани посланца Якова Бухарова, а часть сопровождавших его людей убили ${ }^{95}$. Именно этот случай стал причиной отправки весной 1628 г. из Астрахани стрелецкого карательного отряда на Эмбу, в ходе которого были разбиты улусы Султаная и Шейх-Мухаммеда. Согласно союзническим договоренностям, алтыульцы обратились за военной помощью к тайше Дайчину, сыну Батура $^{96}$.

${ }^{93}$ РГАДА. Ф. 127. Оп. 1. 1627 г. Д. 1. Л. 442; ИКРИ. Алматы, 2005. Т. 1. C. 309 .

${ }^{94}$ РГАДА. Ф. 127. Оп. 1. 1628 г. Д. 2. Л. 342, 343.

${ }_{95}^{5}$ Богоявленский С.К. Указ. соч. С. 64-65.

${ }^{96}$ РГАДА. Ф. 127. Оп. 1. 1627 г. Д. 1. Л. 354-358. 
После разгрома своих становищ царскими войсками алтыульские мирзы задумались о пути дальнейшей миграции. Султанай предлагал откочевать под защиту хивинских или казахских ханов; ШейхМухаммеду и его брату Кулаю более подходящим направлением миграции казались бухарские владения. Кроме того, была возможность присоединиться к туркменам или калмыкам. Во время этих споров произошла даже ссора между Султанаем и Шейх-Мухаммедом, которые стали кочевать порознь. Однако выбора ориентации им не оставило вмешательство калмыков, которые подошли вплотную к алтыульским становищам ${ }^{97}$.

O первых контактах калмыков с астраханской администрацией становится известно, когда зимой 1627/28 года в Астрахань для переговоров приехали алтыульский Алей-мирза с двумя калмыцкими посланцами. Как оказалось, инициатором их отправки была супруга тайши Батура, которая с детьми кочевала по Эмбе в 5 днях пути от устья реки. Вверх по реке от них также кочевали небольшие разрозненные группы калмыков, а в 12 днях пути от Эмбы располагался улус торгутского тайши Мерген-Темене. Всего их в общей сложности насчитывалось около 3 тыс. улусных людей, и они испытывали серьезные материальные трудности: «животиною и лошадми скудны», так как в течение 1627 г. дважды подверглись разгрому со стороны казахского хана Ишима. Супруга тайши Батура призывала алтыульских мирз кочевать с ней совместно, чтобы сообща противостоять «недругам» или совершать на них набеги. Но мирзы предпочли все-таки кочевать отдельно от калмыков, сославшись на зимнюю непогоду ${ }^{98}$.

Значительно дополнили сведения об этих событиях и сообщения вышедшего из калмыцкого плена русского человека по имени Антон, полученные от него в Астрахани в ноябре 1628 г. Он сообщал, что проживал в хошутском улусе и невольно оказался свидетелем событий 1625 г. По его данным, у Байбагаса на момент конфликта насчитывалось более 20 тыс. улусных людей, а у Чокура - менее 20 тыс. человек. Оба брата до ссоры долгое время кочевали «меж себя неподалеку и были в совете». Неизвестно, в чью пользу закончилось

${ }_{97}^{7 p}$ Трпавлов B.B. Алтыулы: остатки Ногайской орды в казахских степях // Вестник Евразии. М., 2001. № 2. С. 43.

${ }^{98}$ РГАДА. Ф. 127. Оп. 1. 1628 г. Д. 1. Л. 137, 138. сражение в 1625 г., но Чокур со своими сторонниками отошел к башкирам, в У фимский уезд. В 1626 г. Байбагас в результате военного похода разбил Чокура, и тот был вынужден бежать на юг - в Среднюю Азию, к низовьям реки Сырт. Весной 1628 г. в семье Чокура произошла ссора, приведшая к уходу тайши от своей старшей супруги Мазики. Женщина вместе с сыном Доржи и другими мелкими тайшами, в том числе и Бай-Батуром, с более тысячью своих людей откочевали на Эмбу. Летом того же года младший брат Доржи, тайша Данашир, в сопровождении 20 человек отправился на Иртыш с целью выяснения обстановки в ойратском обществе, а точнее - отношение других тайшей к Чокуру: «нет ли на отца ево от ково войны». А уже перед осенним набегом на ногайские улусы тайши Ухандыр, Дай-Батур и 10 других молодых тайшей с Султанаем и 5 мирзами «учинили меж себя клятву и пошли на ногайские улусы войною заодин $)^{99}$.

Возможно, что Чокур и его соратники в условиях постоянной внешней военной угрозы сознательно дистанцировались от общеойратских дел. Более того, именно они часто были виновниками нападений на ясачных людей Московского государства, с которым другие тайши в условиях продолжающейся войны с монголами пытались построить мирные отношения. По мнению С.К. Богоявленского, так называемые союзные тайши преследовали тех своих собратьев, которые всячески отказывались принимать участие в общих предприятиях, направленных на обеспечение безопасности всего ойратского общества ${ }^{100}$. Ситуацию усугубила и смерть Байбагаса, которая произошла примерно в 1628 г. и в которой, скорее всего, был повинен именно Чокур.

Как следствие всех этих действий образовалась так называемая «античокуровская) коалиция, союзные тайши начинают повсеместно преследовать Чокура и его людей, «чтоб ево однолично, где ни сойти да убить». Некоторые из тайшей, первоначально входившие в состав группировки Чокура, постепенно стали его покидать, как, например, торгутский Дайчин. Под давлением отца Хо-Урлюка и нависшей над ним угрозы он в 1628 г. откочевал от Чокура, доводившегося ему те-

\footnotetext{
${ }^{99}$ ИКРИ. Алматы, 2005. Т. 1. С. $315,316$.

${ }^{100}$ Богоявленский С.К. Указ. соч. С. 66.
} 
стем. Летом этого же года группировка Чокура бежит за реку Ишим, к верховьям Тобола (в 5 днях пути от Тюмени), где совершает нападение на ясачных татар. Осенью они перебираются на Эмбу. По свидетельствам очевидцев, у Чокура и его соратников в общей сложности насчитывалось примерно 3-4 тыс. улусных людей. Непосредственно вместе с Чокуром кочевало 400 человек. По другим данным, воинов у данной группировки насчитывалось 6 тыс., в том числе 800 с огнестрельным оружием ${ }^{101}$. Цифры о численности калмыков, как видно из показаний различных свидетелей того времени, сильно разнятся. Это можно объяснить стремительными передвижениями ойратских улусов по огромной территории, постоянными их столкновениями с соседями и людскими потерями

Осенью 1628 г. вспыхнул новый конфликт между ногайцами. Воспользовавшись ситуацией, алтыульские мирзы срочно отправили калмыкам на Эмбу предложение о совершении совместного набега против ногайцев. В ноябре в Астрахань прибыл раненный конный стрелец М. Яковлев, со слов которого стало известно, что 31 октября, ночью на заре, ногайский улус Мамбет-Сеина (сына Кары Кель-Мухаммеда) подвергся внезапному нападению калмыков. Большинство ногайцев не смогло организовать должного сопротивления и просто разбежалось, а М. Яковлев был ранен в плечо из лука. Улус Кель-Мухаммеда срочно прикочевал к переправе на реку Бузан. Астраханские власти сформировали отряд под началом стрелецкого сотника М. Шабликина для преследования калмыков. По сведениям стрелецкого головы С. Осичкова, ногайцы в момент сражения бросили стрельцов и сбежали, а самим служивым людям пришлось в окружении отсидеться в тележном городке, захватив в плен двух татар ${ }^{102}$.

По показаниям пленников, данные ими в ходе допроса в Астрахани, становятся известны отдельные эпизоды последних событий. Пленник Зулейхан сообщил, что последний набег на ногайцев совершили люди хошутского тайши Доржи, сына Чокура. Кроме того стало известно, что еще до усобицы Чокур с братом Байбагасом и зятем Дайчином кочевали в урочищах Улек Кабале и Чюдете, что в 10 днях

${ }^{101}$ MUРМО. М., 1959. С. 145.

${ }^{102}$ РГАДА. Ф. 127. Оп. 1. 1629 г. Д. 1. Л. 18, 19. от Уфы и 20 днях от верховьев Эмбы. Всего у трех тайшей насчитывалось до 30 тыс. улусных людей. После вооруженного столкновения с Байбагасом в 1625 г. Чокур с 10 тыс. своих людей бежал за «Черные пески» (Каракумы) в Туркестан, к местному хану, а его сын Доржи со своими людьми остановился в верховьях Эмбы. Позже казахи внезапным ударом разбили улус Чокура, который, потеряв 400 человек убитыми и 1000 пленными, бежал на север, в Сибирь, в урочище Карачав (в месяце пути от Уфы), а затем и в урочище Каракул (в 10 днях пути от Уфы). Отсюда в 1627 г. Чокур пытался войти в контакт со своим братом Байбагасом, «чтоб им быть меж себя в дружбе и в совете». Байбагас пошел навстречу Чокуру и приказал брату присоединиться к нему. Но летом 1628 г. Чокур неожиданно прикочевал к своему сыну в урочище Урачин, в 15 днях пути от Эмбы. Доржи объединял вокруг себя таких же молодых тайшей, у которых общая численность улусных людей составляла примерно 4 тыс. человек. Здесь они установили отношения с алтыульскими мирзами, уступившими калмыкам «угожие кочевные места и сайгачьи ловли». В ходе переговоров Султанай предложил Доржи совершить совместный набег на едисан, так как у него имелась информация, что после междоусобного столкновения с другими ногайцами едисанские улусы во главе с Канаем отошли к Яику и были плохо защищены ${ }^{103}$.

Другой пленник, алтыулец Мурзыгелдей, дополнил, что с Доржи в последнем набеге принимали участие 2 тыс. калмыков под началом Мерген-Темене, Батура, Куена, а также 250 алтыулов мирз Султаная, Мамая, Урака, Шамамета и Юсупа. Сбор их отрядов произошел в междуречье Яика и Эмбы. На Эмбе с Чокуром осталось примерно 3-4 тыс. калмыков, и он в указанное время не предпринимал активных действий, поскольку боялся «приходу на себя мунгальских калмык» $\rangle^{104}$

Как видим, в этих событиях не участвовал Чокур, который со своим улусом откочевал к северу. Уфимский толмач Ф. Кондратьев сообщал в Самаре, что в 1628 г. видел торговых калмыков Чокура под

${ }^{103}$ РГАДА. Ф. 127. Оп. 1. 1629 Г. Д. 1. Л. 20-24.

${ }^{104}$ РГАДА. Ф. 127. Оп. 1. 1629 г. Д. 1. Л. 27-30; ИКРИ. Алматы, 2005 T. 1. C. $312-314$. 
Уфой. По его словам, в группировке Чокура состояли четверо тайшей, и у них в общей сложности насчитывалось более 10 тыс. улусных людей ${ }^{105}$. По сообщению тюменского воеводы П. Пушкина, осенью 1628 г. Чокур кочевал по Тоболу, в пяти днях от Тюмени, а его улусные люди самовольно заняли охотничьи угодья местных сибирских татар. Здесь калмыцкий тайша искал места для кочевья, чтобы провести зимовку, и даже по этому вопросу советовался с пленными ясачными татарами. В декабре П. Пушкину удалось организовать против калмыков экспедиционный отряд, состоящий из 272 боярских детей и служилых татар, под командой Б. Внукова и Н. Молчанова. Однако, Чокур, не приняв боя, своевременно с улусом откочевал вверх по Тоболу к верховьям реки Ик ${ }^{106}$.

Слухи о намерении калмыков перейти в Волго-Яицкое междуречье вызвали среди ногайцев новую волну паники. В октябре в Астрахани объявился выходец из калмыцкого плена ногаец Белек, со слов которого стало известно, что калмыки и алтыулы кочуют в низовьях Эмбы и готовят очередной набег на ногайские улусы. После погрома ногайцев калмыцкие тайши планировали кочевать примерно в 70 верстах от Астрахани - в урочище Кондаки, как они сами объясняли, «потому что те кандаковские места изстари были их калмыцкие кочевные места $\rangle^{107}$. Алтыулы угрожали остальным ногайцам выгнать их всех на правый берег Волги, а самим с калмыками кочевать в междуречье ${ }^{108}$.

Астраханские власти не могли согласиться с подобными планами тайшей, но противопоставить им значительные военные силы не имели возможности, ограничившись лишь дополнительным усилением охраны ногайских улусов ${ }^{109}$. Очередная вспышка междоусобицы в ногайской среде и усиливавшееся давление калмыков вынудили правящую верхушку ногайцев в 1629 г. обратиться к Москве с прошением взять на себя управление ордой ${ }^{10}$.

${ }^{105}$ РГАДА. Ф. 119. Оп. 1. 1630 г. Д. 1. Л. 45.

${ }^{106}$ РГАДА. Ф. 214. Оп. 4. 1628 г. Д. 8. Л. 1-5.

${ }^{107}$ РГАДА. Ф. 127. Оп. 1. 1629 г. Д. 1. Л. 285, 286.

${ }^{108}$ РГАДА. Ф. 127. Оп. 1. 1629 г. Д. 1. Л. 37, 38.

${ }^{109}$ РГАДА. Ф. 127. Оп. 1. 1629 г. Д. 1. Л. 287.

${ }^{110}$ Трепавлов В.В. История... С. 407.
В марте 1629 г. Канай располагал сведениями, что алтыулы численностью в 500 человек кочуют за Эмбой в урочище Шам, калмыки на правобережье Эмбы, у реки Оил. По словам едисанского перебежчика Бердыгула, всего калмыков насчитывалось около 5 тыс. человек. Весной они планировали очередной набег на владения Каная ${ }^{111}$. Но ни весной, ни летом этого года набегов со стороны калмыков не наблюдалось. В сентябре ногайские перебежчики вновь предупреждали Каная о готовящемся набеге, но уже со стороны Мерген-Темене, кочевавшего около Яика и у которого в наличии имелось до 2 тыс. человек. Канай, не дожидаясь очередного набега, просил астраханские власти подкрепления для упреждающего удара по калмыцким улусам, тем более что численность их была весьма мала. Но воеводы, не владея точной информацией о численности калмыков, не решались без царского указа отправить своих служилых людей в столь далекий поход и ограничились лишь охраной ногайских улусов ${ }^{112}$.

Осенью 1629 г. 30 едисан-ногайцев ходили под калмыцкие улусы на Эмбу и отогнали 130 лошадей. Отряд в 50 калмыков сумел их нагнать, и в ходе боя они взяли в плен ногайца Беша Бегемышева. Через две недели ногайца отпустили в Астрахань, чтобы тот передал воеводам следующие слова: «Они, калмыцкие тайши, преж сево были в холопстве под твоею государскою высокою рукою и кочевали блиско Сибири на реке Иртышу. И тому де государь ныне другой год, учиняя они с своею братею с калмыки меж себя рознь и войну, пришли с улусы своими кочевать на реку на Емму, а ныне кочуют блиско Яика. И их бы калмыцких тайшей со всеми их улусными людьми принять... под твою царского величества высокую руку в холопство и велети б им с улусы своими кочевать по реке Ембе и по Яику». Всего у этой группы улусов насчитывалось 5 тыс. калмыков и 1 тыс. алтыулов, в том числе 800 человек с «огненным боем». Улусные люди Чокура серьезно опасались прихода хошутских тайшей Гуши и Дургучи (Кунделена-Убаши), братьев Байбагаса, у которых в общей сложности насчитывалось 20 тыс. воинов, а также их союзника - казахского Кучука Салтана, имевшего в распоряжении 10 тыс. воинов ${ }^{113}$.

${ }^{111}$ РГАДА. Ф. 127. Оп. 1. 1629 г. Д. 1. Л. 205.

112 РГАДА. Ф. 127. Оп. 1. 1629 г. Д. 1. Л. 43-47, 260.

${ }^{113}$ РГАДА. Ф. 127. Оп. 1. 1629 г. Д. 1. Л. 289-293; Богояеленский С.К Указ. соч. С. 65. 
Астраханские власти положительно отреагировали на просьбу Чокура и его сторонников и отправили к ним того же ногайца Беша и 5 юртовских татар с уведомлением прислать в Астрахань для переговоров послов и аманатов. Калмыкам указывалось кочевать за Эмбой и не приходить войной на астраханских ногайцев. Алтыульским мирзам предлагали отойти от калмыков и вернуться под Астрахань ${ }^{114}$.

Чокур и его сторонники всерьез опасались удара с востока, и эти опасения были не беспочвенны. Еще летом 1629 г. 300 человек из улуса Чокура совершили набег на Каратабынскую волость Уфимского уезда. В Уфе местные власти ошибочно посчитали, что набег совершили люди Далай-Батура. Воевода И. Желябовский отправил в дербетские улусы, кочевавшие в это время на Иртыше, посольство во главе с А. Гладышевым. Но в районе реки Ишим посольство было ограблено все теми же людьми Чокура ${ }^{115}$. Неизвестно, был ли в курсе событий сам Чокур, по его ли заданию были совершены эти акции, но ограбление русского посольства, направлявшегося к Далай-Батуру, считалось ничем иным, как оскорблением самого дербетского предводителя. Жесткий его ответ не заставил себя долго ждать. Выяснив на месте, что улусные люди Далай-Батура не имели никакого отношения к нападению на башкир, русские послы получили подарки и заверение в виде шерти от союзных тайшей: «быти под государевою высокою рукою $)^{116}$

Осенью 1629 г. Далай-Батур и Гуши организовали карательную экспедицию против группировки Чокура и Мерген-Темене, обитавшую в степях Северного Прикаспия. Численность данного войска, по сообшению послов, доходила до 40 тыс. человек. Цифру эту можно считать вполне реальной, если учитывать, что у самого Далай-Батура имелось в наличии 16 тыс., а у его детей в общей сложности - 20 тыс. воинов. В коалицию также входили хошуты Гуши, занявшего место брата Байбагаса, и торгуты Хо-Урлюка. Участвовать в походе против Чокура выразили желание и цоросы, но Далай-Батур им от-

${ }^{114}$ РГАДА. Ф. 127. Оп. 1. 1629 г. Д. 1. Л. 293-295.

115 MИРМО. М., 1959. С. 151

${ }^{116}$ МИРМО. М., 1959. С. 149. казал, заявив, что справится своими силами. Исключение было сделано только цоросскому тайше Сунгулу, свату Далай-Батура, чей улус располагался по соседству с Чокуром, с которым он также находился во враждебных отношениях. Союзники заранее уведомили русскую сторону о своем намерении зимовать с войсками на реке Оил в 10 днях пути от Уфы, заверив, что возвратят весь башкирский полон, захваченный Чокуром ${ }^{117}$.

Слухи о готовящемся нападении, видимо, дошли до Чокура и его сторонников, так как в начале 1630 г. их группировка, опасаясь прихода «больших калмыков», предусмотрительно перекочевала с Эмбы на Яик, где приняла участие в нападении на местных казаков. В мае 1630 г. самарский воевода Борис Салтыков сообщал в Москву, что яицкие казаки с семьями просятся на житье в Самару из-за массового наплыва калмыков на Яик. В небольших казацких городках, разбросанных по Яику, проживало в общей сложности всего лишь 300 казаков. Зимой 1629/1630 года люди Чокура атаковали казачьи городки. На приступе многие из числа нападавших калмыков были убиты и ранены. Взятые во время боя раненые калмыки сообщали, что у них война с «большими калмыками», а они пришли кочевать по Яику вплоть до Волги с прицелом захватить улусы Большой Ногайской орды. Позже все калмыцкие пленники скончались от ран.

22 апреля, во время осады калмыками Чокура казачьих городков, неожиданно с тыла им совершили нападение союзные калмыки, практически полностью разгромив их. Большинство улусных людей Чокура и его соратников были уничтожены или пленены. Уцелевшие сторонники Чокура бежали вниз по Яику к морю, где в районе Соленого городка вновь вступили в бой с местными казаками. Калмыки при штурме использовали деревянные щиты и огнестрельное оружие, но снова были разбиты. Казакам в этих условиях стало довольно трудно жить на Яике, поскольку пришедшие калмыки расположились по обоим берегам реки, заняв дороги и разбив все принадлежавшие им учуги. Часть яицких казаков, не выдержав калмыцкого вторжения, вынуждена была по воде мигрировать на Волгу и Дон ${ }^{118}$.

${ }_{117}^{11}$ МИРМО. М., 1959. С. 151, 152.

${ }^{118}$ РГАДА. Ф. 119. Оп. 1. 1630 г. Д. 1. Л. 36-39. 
Довольно интересные сведения об этих событиях сохранились и в показаниях ногайцев, попавших в плен к казакам. Первый из них, Ештей, в Самаре сообщал, что попал в плен к калмыкам на Эмбе и жил в улусе тайши Хандера, соратника Чокура. Союзные тайши из-за Эмбы, с района урочища Барсучьи Копани, двинулись против Чокура, располагавшегося в урочище Карадуван на Яике. Союзники Чокура, алтыульские татары во главе с Султанаем, бежали в район Ургенча. Другой ногаец, Денай Девлетев, попал в калмыцкий плен примерно в 1624-1625 гг. во время набега калмыков на Яик под командованием Зоройкту. Он также жил в улусе Хандера и стал невольным свидетелем войны между Чокуром и Байбагасом. По сведениям Деная, ближайшими сторонниками Чокура выступали тайши Мерген-Темене и Хандер, причем каждый из них самостоятельно управлял своим улусом. Всего у них насчитывалось более 4 тыс. улусных людей. С осени 1629 г. и до весны 1630 г. указанные трое тайшей кочевали по Яику, пока здесь не разгромили их ДалайБатур и Гуши с 10-тысячным войском. Денай слышал от пленных калмыков, что у захваченного в плен Хандера «союзные» калмыки выкроили ремни со спины и казнили, Чокур был убит в бою, а судьба Мерген-Темене так и осталась неизвестной. Уцелевшие сторонники Чокура затаились на время в северной прибрежной части Каспия. Улусы Далай-Батура и Гуши расположились в это время в Приаральских Каракумах ${ }^{119}$.

Таким образом, впервые калмыцкие улусы появились в степях Северного Прикаспия с целью поселения здесь в 1628 г. Это был хошутский улус супруги и сына Чокура - Мазики и Доржи. Приход их на реку Эмба в этом же году можно считать началом отсчета пребывания калмыков в данном регионе. Позже, потерпев поражение от казахов, сюда со своими соратниками прибудет Чокур, тем самым численно увеличив присутствие калмыков в Прикаспии. Период с 1628 по 1630 гг. можно рассматривать как начало поселения калмыков в степях Северного Прикаспия.

${ }^{119}$ РГАДА. Ф. 119. Оп. 1. 1630 г. Д. 1. Л. 39-44.

\section{4. Территориальный вопрос в русско-калмыцких переговорах}

После разгрома группировки Чокура дербетские улусы расположились кочевьем в районе, охватывавшем территорию от верховьев Эмбы до Приаральских Каракумов. Далай-Батур по достоинству оценил новые для себя земли: торговые пути, близость крупных российских и среднеазиатских рынков, обилие рек и богатых пастбищ, относительно теплый климат в зимнее время. Немаловажное значение имели территориальная удаленность от неприятельских сил в лице Алтын-хана, а таюже соседство слабых в военном отношении кочевых народов. Все эти преимущества и привлекли дербетских тайшей к этим землям. Оставалось только согласовать с Москвой вопрос о предоставлении возможности безопасного для себя кочевания здесь. Как показали дальнейшие события, предводитель дербетов решил самостоятельно форсировать решение вопроса о кочевьях.

Еще осенью 1629 г. Далай-Батур отправил в Уфу старшего сына, в русских документах фигурирующего под именем Доржи, с просьбой принять дербетов в подданство. Доржи шертовал в Уфе за отца, за братьев и всех своих людей в том, «что им быть под царскою высокою рукою в прямом холопстве навеки неотступным». Кроме того, в Москву Далай-Батур отправил послов Балту и Баучина с аналогичной просьбой и всячески добивался разрешения перекочевать дербетским улусам с Приаральских Каракумов под уфимские волости. Дербетские послы также сообщали, что их глава с семью сыновьями (ЧовоМерген, Майдар, Дайчин, Омбо, Доржи, Токчу, Кокун) кочует в верховьях Эмбы. Рядом с ними кочевал сват Далай-Батура - хошутский тайша Дургучи (Кунделен-Убаши) с братом Гуши ${ }^{120}$ С.К. Богоявленский просьбу Далай-Батура связывал с опасностью, исходившей от Алтын-хана ${ }^{121}$.

10 мая 1630 г. дербетские послы были на аудиенции у царя, и в русских архивных документах сохранились сведения о том, как проходил этот официальный прием. Из государевой конюшни послам

${ }^{120}$ МИРМО. М., 1959. С. 148-149, 153-154.

${ }^{121}$ Богоявленский С.К. Указ. соч. С. 66. 
предоставили лошадей для проезда в Посольскую палату, возле которой на площади стояли вооруженные стрельцы всех приказов. Там их уже ждали царь, бояре и окольничьи в позолоченных платьях, а само помещение было расписано золотом. Послов царю представил думный дьяк Е. Телепнев, начавший свою речь следующими словами: «Великий государь и великий князь Михаил Федорович Всея Руси самодержец и многих государств обладатель, калмыцких Далай-тайши да Доржи-тайши послы, Балта да Баучи, Вам, великому государю, челом ударили». После того как послы передали государю пожелания и просьбы своих тайшей, им подали «государево жалованье». Царский ответ, полученный позже от дьяка Телепнева, заключался в перечислении обязательств дербетских тайшей, которые после заключения ими шерти, должны были находиться под «царскою высокою рукою в прямом холопстве навеки неотступно», и «великому государю служили». Послам было обещано их народ «держать в царском милостивом жалованье и в призренье и от недругов в обороне и в защищенье» ${ }^{122}$.

Переговоры в Москве по вопросу получения дербетами разрешения кочевать в степях Северного Прикаспия проходили довольно сложно. Не получив дозволения кочевать на Яике, вблизи Уфимского уезда, дербетские послы предложили царским властям другой вариант. Теперь речь шла уже о районе Эмбы, находившемся в удалении как от Астрахани, так и от Уфы. Послы клятвенно обещали, что дербеты не будут обижать царских подданных ногаев и башкир, напомнив, что за время их 6-летнего пребывания под «государевою высокою рукою» «дурна от них никакова не бывало и вперед не будет», поскольку они «прямые холопи государевы» ${ }^{123}$.

В историографии уже неоднократно высказывалось мнение о принципиальных различиях в интерпретации подданства как российскими властями, так и степными правителями. Если первые, начиная со второй половины XVI в., видели в договорных соглашениях начало безусловного подчинения и покорности царю со всеми вытекающими из этого обстоятельствами, то вторые трактовали их как заключение военного союза, который вовсе не подразумевал их вечного соблю-

122 РГАДА. Ф. 119. Оп. 1. 1630 г. Д. 1. Л. 17-19.

${ }^{123}$ МИРМО. М., 1959. С. 154-155. дения $^{124}$. В качестве доказательства можно привести пример: спустя два года, в 1632 г., в Москву прибыли калмыцкие послы во главе с Мурзеем, им напомнили, что глава предыдущего посольства тайша Дорджи шертовал в Уфе о том, чтобы всем дербетам «быть под царского величества высокою рукою в прямом холопстве навеки». Однако Мурзей передал, что их тайши наказывали им вести переговоры с царскими властями только о мире и взаимном ненападении, «... а под царскою рукою в холопстве тайши их быти хотят ли или нет, того они (послы. - В.T.) не ведают $)^{125}$.

Дербетские тайши небезосновательно надеялись, что Москва в благодарность за разгром «царских недругов» - Чокура и его соратников разрешит им кочевать в северо-восточной части Прикаспия. Однако царская администрация, формально приняв дербетов в подданство, потребовала от их тайшей отвести свои улусы из района Эмбы и Яика на старые кочевья в Юго-Западной Сибири ${ }^{126}$.

Отказ царского правительства был вполне мотивирован. Дело в том, что те земли, которые дербеты просили для кочевки, были традиционными охотничьими угодьями «ясачных» башкир и ногаев, подданных Московского государства. Калмыки, как известно, ясак в казну не платили. Поэтому передача им этих земель означала потерю угодий и как следствие - сокращение поступлений ясака в царскую казну. Пушной промысел обеспечивал государственную казну самой надежной и стабильной на тот момент «конвертируемой валютой» в мире. Между тем конфликты между кочевниками из-за охотничьих угодий в южной части Приуралья продолжались, что приводило к сокращению доходов в казну от этого экспортного товара. Так, дербетские послы в Посольском приказе жаловались на уфимских башкир, которые на Яике убили зятя Далай-Батура, сына тайши Голугеня. В ответ Далай-Батур во время похода на Чокура захватил 10 башкир в заложники, которых впоследствии и обменял ${ }^{127}$.

В переговорный процесс с Москвой включились и другие тайши. В январе 1632 г. в российскую столицу прибыло большое посольство, состоявшее из представителей хошутских и торгутских тайшей.

\footnotetext{
${ }^{124}$ Трепавлов В.В. «Белый царь»... С. 143-144

${ }^{125}$ MИPMO. М., 1959. С. 172.

${ }^{126}$ МИРМО. М., 1959. С. 158-159.

${ }^{127}$ MИРМО. M., 1959. C. 154.
} 
В русских документах сохранились имена всех калмыцких послов: Мурзей и Девлет представляли интересы хошутского Гуши, Болда хошутского Кунделена-Убаши, Мандраш - хошутского Очирту-тайджи (сына Байбагаса), Чингил и Бойма - представители торгутского Сюнкея (сына Хо-Урлюка), Тургай - хошутского Аблая (сына Байбагаса). 12 января они были приняты в Посольском приказе думными дьяками Федором Лихачевым и Максимом Матюшкиным. Переговоры шли по вопросу о военном сотрудничестве. Когда хошутским послам предложили лично шертовать за тайшей, чтобы «быть им под государскою рукою в холопстве навеки», то они отказались, сославшись на отсутствие у них полномочий решать подобные вопросы: «здесь им шертовать в том не наказано) 128 .

Таким образом, вышеизложенные события ясно показывают, что на рубеже 20-30-х годов XVII в. Далай-Батур вполне серьезно рассматривал прикаспийские степи как основное место пребывания своих улусов. Однако ему так и не удалось получить от царской администрации разрешения кочевать на данной территории. Несмотря на то, что переговоры закончились провалом, дербетский предводитель не стал обострять отношения с русскими, подчинился требованиям Москвы и принял решение вернуться на прежние места кочевок. ДалайБатур оставался последовательным в своих поступках по отношению к русским властям, являясь, таким образом, одним из немногих ойратских политиков, которые вели вполне конструктивную дипломатию и придерживались заключенных ранее договоренностей. Но его примеру не следовали другие ойратские тайши, стремившиеся приобрести для себя новые, более удобные и безопасные кочевья. Только после возвращения Далай-Батура в южные степи Западной Сибири в конце 1630 г. уже в степи Северного Прикаспия пришли торгуты ХоУрлюка, положившие начало образованию отдельной группировки улусов, а впоследствии - нового Калмыцкого государства.

${ }^{128}$ РГАДА. Ф. 119. Оп 1. 1632 г. Д. 1. Л. 1-2, 12-13, 15-16; МИРМО. М., 1959. C. $171-172$.

\section{Глава 2. \\ НАЧАЛЬНЫЙ ПЕРИОД РАССЕЛЕНИЯ КАЛМЫКОВ В СЕВЕРНОМ ПРИКАСПИИ}

\section{1. Политическая ситуация в 1630-1635-х гг.}

Территория эмбо-яицкого междуречья после разгрома группировки Чокура и его союзников недолго оставалась пустующей. На смену ей пришли сюда кочевать улусы торгутских князей. Вопрос о дате появления торгутов Хо-Урлюка на Волге в историографии является дискуссионным. Если обратиться к калмыцким источникам XVIII в., то Габан Шараб сообщает нам о времени этого движения и его инициаторах следующее: В 1630-м году Лузан перешел Яик и Волгу, завоевал татар. В том же году Хо-Урлюк и Дайчин пришли к Яику, в 1631 году пришли к Волге ${ }^{1}$

Но русские источники вполне конкретно свидетельствуют о времени их прихода в степи Северного Прикаспия. С большой долей вероятности можно утверждать, что Хо-Урлюк с сыновьями появился в этом регионе, участвуя в составе коалиционных сил тайшей, разгромивших группировку Чокура в начале 1630 г. Но возникает вопрос: при каких обстоятельствах Хо-Урлюк решился увести свой улус от основной массы ойратов? Возможно, отчасти ответить на этот вопрос нам помогут сведения из ойратской летописи «История Хо-Урлюка». Его анонимный автор, описывая отдельные события из истории торгутов, правда, без указания на время, отмечал, что Хо-Урлюк известил Батура-хунтайджи об откочевке своих 15 тыс. кибиток в местность Орын гани модон ${ }^{2}$. Под личностью «Батура-хунтайджи» здесь, скорее всего, имеется в виду не кто иной, как дербетский предводитель Далай-Батур, который, возможно, в это время имел титул «хунтайд-

\footnotetext{
${ }^{1}$ Габан Шараб. Сказание об ойратах... С. 106.

${ }^{2}$ История Калмыкии... Т. 1. С. 225.
} 
жи», поскольку в русских документах еще в 1616 г. именовался «царем калмыков $)^{3}$. Но большинство исследователей склоняются к тому, что это был цоросский Батур-хунтайджи, и здесь, вероятней всего, кроется ошибка. Батур-хунтайджи был намного моложе Хо-Урлюка и доводился ему зятем. Большинство торгутских тайшей в это время во многом политически зависели именно от дербетского Далай-Батура.

Вопрос о численности торгутских улусов, пришедших с ХоУрлюком в степи Северного Прикаспия, в историографии остается также дискуссионным. Немалая часть исследователей ссылается на сведения анонимной «Истории калмыцких ханов», согласно которой с Хо-Урлюком прибыло 50 тыс. кибиток ${ }^{4}$. Но при сравнении с данными из различных русских источников первой половины XVII в. эта цифра получается завышенной почти в несколько раз. Если учесть, что в данной калмыцкой летописи, помимо торгутов, представлены дербеты и хошуты, то, возможно, в ней указана общая численность ойратских улусов на тот период. Это косвенно подтверждает и С.К. Богоявленский, по оценке которого «общее число калмыков определялось приблизительно в 80 тыс. воинов и 200 тыс. черных людей и ясыря» ${ }^{5}$.

В нашем случае предпочтительнее будет довериться историческим сведениям хивинского хана Абу-л-Гази (1603-1663), около года (с декабря 1640 г. по декабрь 1641 г.) прожившего в улусе торгутского тайши Сюнке. Согласно им, примерно на рубеже 1630-1631 гг. с северной стороны (т. е. с Сибири по Тургайской ложбине) с ХоУрлюком прибыли около 10 тыс. кибиток и «поселились в юрте мангытов» (ногайцев - B.T.) ${ }^{6}$. Во многом это подтверждают и сведения из летописи «История Хо-Урлюка», в которой указывается, что из Джунгарии с Хо-Урлюком откочевали 15 тыс. кибиток?. Таким образом, цифра примерно в 10-15 тыс. кибиток, находившихся под началом Хо-Урлюка в 1630 г., является наиболее правдоподобной

\footnotetext{
${ }^{3}$ МИРМО. М., 1959. С. 53.

${ }^{4}$ История калмыцких ханов... С. 113

${ }^{5}$ Богольленский С.К. Указ. соч. С. 87.

${ }^{6}$ Родословная туркмен. Сочинение Абу-л-гази, хана хивинского. М.: AH CCCP, 1958. C. 335.
}

${ }^{7}$ История Калмыкии... Т. 1. С. 225.
Осенью 1630 г. Хо-Урлюк со своими улусами перекочевал на зимовку от сибирских городов сначала в Приаральские Каракумы, а затем на Эмбу. Здесь он вошел в тесный контакт с алтыульским Султанаем, который предложил ему совершить совместный набег на ногайские улусы под Астраханью ${ }^{8}$. Султанай продолжал оставаться непримиримым противником астраханских властей и промосковски настроенных ногайских мирз, и появление калмыков на Эмбе он расценил для себя как еще одну возможность навредить своим оппонентам. По мнению В.П. Санчирова, междуречье Эмбы и Яика служило своего рода плацдармом для продвижения калмыков к берегам Волгия. Теперь соседями ногайцев были уже не слабые отряды Чокура и молодых тайшей, а многочисленные торгутские улусы.

При организации набега на ногайские кочевья Хо-Урлюка, повидимому, тревожила защищенность собственных улусов с восточного направления, так как в качестве заслона на Эмб́е он оставил значительную часть своего войска, а в набег при поддержке сотни алтыульцев отправил только 2 тыс. калмыков. Поскольку отряд был небольшой и действовал двумя группами, упор делался на фактор внезапности, и алтыульцы в конечном итоге смогли незаметно в обход застав провести калмыков к окрестностям Астрахани. 27 декабря 1630 г. (по новому стилю - 6 января 1631 г.) ногайские улусы были неожиданно для себя атакованы калмыками. Наибольшие людские и материальные потери понесли улусы Каная, Кель-Мухаммеда Урмаметева, Алея и Шейдяка ${ }^{10}$.

После внезапного удара по ногайским улусам калмыки так же неожиданно скрылись, как и появились. Стрелецкий голова И. Болтин с отрядом из стрельцов и ногайцев в двух днях пути от Астрахани сумел настигнуть калмыков в урочище Саразман, где бился с ними целый день, в результате чего отбил только часть захваченного скота

\footnotetext{
${ }^{8}$ Богоявленский С.К. Указ. соч. С. 67.

${ }^{9}$ Санчиров В. П. На пути к Волге: ойратские этнополитические объединения 20-30-х гг. XVII в. // Вестник Калмыщкого института гуманитарных исследований РАН. Элиста, 2008. № 2. С. 12.

${ }^{10}$ РГАДА. Ф. 127. Оп. 1. 1631 г. Д. 3. Л. 11, 12; Новосельский А.А. Борьба Московского государства с татарами в первой половине XVII века. М.-Л., 1948. C. 224.
} 
и пленных. В ходе боя стрельцы захватили в плен трех калмыков, сообщивших на допросе, что набег совершили улусные люди ХоУрлюка. Ногайские мирзы открыто признались астраханским воеводам, что против калмыков они бессильны, и просили воевод срочно отправить к калмыкам посланцев с требованием не нападать на их улусы и вернуть полон ${ }^{11}$.

Очередной калмыцкий набег вызвал панику, и масса ногайских семей начала срочно переправляться на «крымскую сторону» Волги. На попытки астраханских властей вернуть к городу ушедших ногайцев Канай и Янмамет упрекнули власти за недостаточное обеспечение безопасности своих улусов. Возле Астрахани оставались в основном только юртовские татары и едисаны, жившие под охраной астраханского гарнизона. В тот же момент из Астрахани срочно была отправлена грамота Хо-Урлюку, где сообщалось, что подобные действия против царских подданных и дружба с царскими изменниками (алтыульцами) не допустимы ${ }^{12}$.

В мае 1631 г. к ногайским мирзам Хо-Урлюк прислал своих послов Хара-Мергена и Мейдалу. Тайша предложил мирзам приехать к нему для выкупа своих людей. Астраханский воевода Ф.С. Куракин отправил к Хо-Урлюку посланцев с напоминанием о том, что ногайцы являются подданными Русского государства и нападать на них нельзя. Он требовал от калмыков немедленно отпустить пленных в Астрахань без всяких условий, а самим отойти за Яик и Эмбу. Посланцы прибыли первоначально в улус Дайчина на Эмбе, а затем отправились в улус его отца Хо-Урлюка. Выяснилось, что в последнем набеге на ногайцев участвовали люди Дайчина. Тайши признались в содеянном, сказав, что поступили так, «не ведая» о том, что ногайцы «холопи твоего царского величества». Четверо дней у тайшей проходил съезд, на котором они решили вернуть ногайский ясырь в Астрахань ${ }^{13}$.

${ }^{11}$ РГАДА. Ф. 127. Оп. 1. 1631 г. Д. 3. Л. 12; Новосельский А.А. Указ. соч. С. $224 ;$ Богоявленский С.К. Указ. соч. С. 67. C. 67.

${ }^{12}$ Новосельский А.А. Указ. соч. С. 224; Богоявленский С.К. Указ. соч.

${ }^{13}$ РГАДА. Ф. 119. Оп. 1. 1640 г. Д. 3. Л. 1-9.
В августе от тайшей в Астрахань прибыли калмыцкие послы, правда, без писем, объясняя это тем, что «они кочевные люди, грамоте никакой не умеют». Астраханцы обратились через них к тайшам с просьбой не трогать на контролируемой калмыками территории купеческие караваны, направляющиеся сухопутным маршрутом из Бухары и Ургенча в русские города и обратно. Тайши через послов обещали вернуть захваченных в плен ногайцев и впредь на них войной не ходить ${ }^{14}$.

Обращает на себя тот факт, что Хара-Мерген 12 (22) сентября 1631 г. принес шерть.

Урлюк тайие да сыну ево, Дайчи тайие, и Урлюк тайииным братьям и детем, и племянником, и улусным калмыцким людем тебе, великому государю, царю и великому князю Михаилу Федоровичу Всея Руси самодержиу и твоим иарским детем служсти и прямити и во всем добра хотети и быть под твоею царскою рукою в холопстве вовеки неотступным. И кочевать им, где ты великий государь укажешь. И твоих государевых русских людей нигде ни в которых местах не побивать, и на нагайские улусы, которые кочуют твоего царского величества у отчины Астрахань или в ыных местах учнут кочевать под твоею царскою высокою рукою, войною не приходить и не побивать, и не грабить, и в полон не имати, и у собя не держать, и ни в которые государства не продовати.

От твоей царские высокие руки Урлюк тайще з братею и з детьми и з племянники не отступить, и тебе, великому государю, не изменити. В Крым и в Казыев улус, и в Азов, и в горские черкасы, и в Юргенч, и в Бухары, и в Казачью орду, и в выные ни в которые государстьа, и за Яик, и на Эмбук алтыулльским мурзам не отьехати. Ис твоими государевыми непослуиники и с ызменники ни скем ни о чем не ссылатия.

А как торговые люди из Бухар или из Юргенч пойдут с товары с своими в твою государеву отчину в Астрахань и к Караганской бусной пристани, и им их не побивать и не громити, а от сторонних воинских людей оберегати и дорогу очистить по своей вере и утверженью 15 .

\footnotetext{
${ }^{14}$ РГАДА. Ф. 119. ОП. 1. 1640 г. Д. 3. Л. 10, 14.

${ }^{15}$ РГАДА. Ф. 119. Оп. 1. 1640 г. Д. 3. Л. 15-18.
} 
Послам зачитали текст шерти, и они дали клятву по своей вере: «секли сабаку жолтую, да прошли меж сабли и пищали, и ножовое острие лизали». Им вернули ранее захваченных в плен калмыков и выдали жалованье. Обратно в улусы с ними отправили боярского сына Г. Русакова и толмача К. Артемьева ${ }^{16}$.

Несмотря на шаблонность текста шерти и его ограничительный характер, нельзя быть уверенным в том, что посол был уполномочен от тайшей давать подобные обязательства. Правда, неизвестно, смог ли Хара-Мерген, не владевший русским языком, понять смысл шерти, особенно в той части, где говорится об обязательстве «быть под царскою рукою в холопстве вовеки неотступным». Впоследствии на переговорах с царскими представителями торгутские тайши неустанно подчеркивали, что никогда не принимали обязательств быть «царскими холопами». Можно предположить, что это было всего лишь дипломатическим прикрытием истинных намерений тайшей, поскольку в реальности условия этой шерти не соблюдались.

Калмыки продолжали наносить удар за ударом по ногайским улусам, которые все чаще откатывались за Волгу. Московское правительство, понимая, что с уходом ногайцев приграничные уезды лишатся заслона от агрессии соседних кочевых народов, всячески пыталось вернуть их на левобережье Волги. К тому же в преддверии войны с Речью Посполитой оно не было заинтересовано в увеличении численности войск Малого Ногая и Крымского ханства за счет мигрировавших туда ногайских кочевников из Большой орды. Поэтому астраханские воеводы делали все от них зависящее, чтобы вернуть ногайцев под Астрахань. Отчасти решению этой задачи способствовало то, что ушедшие ногайцы на «крымской стороне» оказались втянутыми в политические интриги, вылившиеся в кровавые междоусобицы. Некоторые мирзы, потерпев поражение в междоусобной войне и опасаясь окончательного разгрома, уже осенью 1631 г. вынуждены были вернуться на Волгу.

Готовясь к войне с Речью Посполитой московское правительство в 1631 г. попыталось мобилизовать астраханских ногайцев и татар в русскую армию, но эта инициатива встретила резкий отпор.

${ }^{16}$ РГАДА. Ф. 119. Оп. 1. 1640 г. Д. 3. Л. 18, 22.
Некоторые подкупные мирзы даже были побиты своими улусными людьми за обещание царским властям выставить на войну большое число вооруженных людей. В условиях постоянной угрозы нападения со стороны калмыков и разоренных хозяйств мобилизация татар и ногайцев была практически не возможна. Это подтвердила мобилизационная кампания 1632 г., когда Москва запросила у мирз 20-30 тыс. воинов. Но фактически к июню удалось собрать только 2201 человека, из которых до пункта назначения дошли лишь 800 человек, поскольку остальные разбежались, по пути приняв участие в грабеже крестьянского населения ${ }^{17}$.

В это время торгутские улусы продолжали занимать довольно обширные кочевья от Яика до Тургайской ложбины. В начале 1632 г. Хо-Урлюк с улусами кочевал в верховьях реки Тургай и междуречье Ишима и Тобола, а Дайчин - в верховьях Яика, в 10 днях пути от своего отца. С.К. Богоявленский предполагал, что под давлением неизвестных обстоятельств Хо-Урлюк откочевал от Яика на северо-восток ${ }^{18}$.

Появление калмыков близ Тюменского уезда и нападения их на ясачных людей серьезно встревожили местные власти. К Хо-Урлюку срочно были отправлены посланцы, которые на месте выяснили положение дел. Торгуты утверждали, что не имеют никакого отношения к нападениям на местных жителей. Всю ответственность за эти действия Хо-У рлюк переложил на улусных людей Далай-Батура и Гуши, кочевавших по реке Тобол и участвовавших в набегах совместно с кучумовичем Аблаем Ишимовым ${ }^{19}$.

По сведениям бухарского посла Казы Казыева, взаимоотношения между ойратскими улусами в 1633 г. носили вполне мирный характер. Тайши заключили своего рода оборонительный договор, согласно которому каждый из главных правителей принял на себя обязанность защищать кочевья от возможной агрессии соседей. Хо-Урлюк с торгутами должен был защищать от ногайцев с запада; Далай-Батур с дербетами - от бухарского хана с юга; Гуши с хошутами - от казахов; цоросский Батур-хунтайджи - от Алтын-хана ${ }^{20}$. Разумеется, при

\footnotetext{
${ }^{17}$ Новосельский А.А. Указ. соч. С. 225

${ }^{18}$ Богоявленский С.К. Указ. соч. С. 67.

${ }^{19}$ МИРМО. М., 1959. С. 189.

${ }^{20}$ Богоявленский С.К. Указ. соч. С. 67-68.
} 
необходимости этот союз из оборонительного мог бы успешно трансформироваться в наступательный, что в дальнейшем и произошло, приведя к значительному расширению ойратских кочевий.

Ситуация под Астраханью в 1633 г. вновь накалилась. Пока большинство ногайцев участвовало в составе русского войска в походе против Малой Ногайской орды и Азова, калмыки вновь разорили их улусы ${ }^{21}$. В начале апреля около 1800 калмыков неожиданно появились на реке Камыш-Самара и двинулись на ногайские улусы с северо-востока. Примерно 13 апреля улусы князя Каная и Урусовых мирз, кочевавших в урочище Тепкире, подверглись нападению, и часть их была захвачена. Для преследования калмыков в Астрахани был срочно сформирован отряд под командованием И. Аристова, куда входили сотня конных стрельцов, дворяне и боярские дети во главе с А. Шушериным и А. Товарыщевым, отряд юртовских татар Я. Бухарова, а также ногайцы князя Каная и Янмамет-мирзы. Несмотря на трудность преследования в условиях ночи, 22 апреля астраханцы и ногайцы нагнали калмыков в степи, возле реки Большая Узень, в 7 днях пути от Астрахани. Перед боем тайши попытались договориться и отправили парламентера-алтыульца в лагерь астраханцев. Но русские убили татарина, что и стало сигналом к началу боя ${ }^{22}$.

По большому счету это было первым значительным военным столкновением русских и калмыков в Северном Прикаспии. Число калмыков доходило до 2 тыс. человек, но к началу боя к ним на помощь подошли еще 3 тыс. воинов, которые стали наступать на русские позиции с правого фланга. Астраханцев было почти вдвое меньше. Местность была открытая, но более грамотно ее ландшафт использовали калмыки - они подожгли камыш. Сильный восточный ветер разносил дым и пепел в сторону стрельцов, и это мешало им эффективно использовать огнестрельное оружие. Калмыки, у которых также было огнестрельное оружие, имели более выгодное положение. Ногайцы в этой ситуации не только не помогали русским, но даже укрывалась за ними либо съезжалась с калмыками, вступая в переговоры и обмениваясь с ними в знак дружбы стрелами, а иные из них открыто

${ }^{21}$ Кусаинова E.B. Русско-ногайские отношения и казачество в конце XV-XVII веке. Волгоград, 2005. С. 165, 166.

${ }^{22}$ РГАДА. Ф. 127. Оп. 1. 1633 г. Д. 1. Л. 106, 112, 139. стреляли в стрельцов. Некоторые астраханские мирзы во время боя отправились непосредственно к тайшам договариваться об условиях выкупа ясыря. Князь Канай прямо заявил русским, что это измена. Лишь с наступлением ночи сражение прекратилось, астраханцы сумели отбить все атаки калмыков, которые, расставив вокруг русского лагеря заставы, отошли на предельное расстояние. Утром стрельцы обнаружили, что полностью окружены калмыками ${ }^{23}$.

Посчитав, что в такой ситуации продолжение борьбы приведет к бессмысленной потере людей, и, не желая напрасно гибнуть из-за ногайцев, стрелецкий голова А. Шушерин вступил с тайшами в переговоры. Русские прислали в калмыцкий лагерь своего представителя И. Шумникова. Тайши охотно пошли на встречу и заявили, что «им до государевых ратных воинских людей дела нет, и с ними биться не хотят, а приходили де войной на улусы по досаде на князя Каная и мурз». Оказалось, что ранее тайши присылали к Канаю своих послов, но князь, отобрав у них лошадей, прогнал обратно. По заключенному соглашению тайши обязались возвратить без выкупа 900 человек ногайского ясыря, а стрелецкие головы поклялись не препятствовать тем ногайцам, кто пожелал бы добровольно кочевать с калмыками. На этих условиях обе стороны присягнули по своей вере. Мирзы также шертовали на Коране в том, что они со своими улусами будут кочевать с калмыками. Позже они привели под Астрахань захваченный калмыками ясырь численностью в 1052 человека ${ }^{24}$.

Бой на Узени, по мнению С.К. Богоявленского, не мог не уронить престижа русской власти и поднять славу калмыцкого оружия, а Дайчин, который и раньше невысоко оценивал силу астраханского гарнизона, теперь считал себя хозяином приволжских степей ${ }^{25}$. И хотя по возвращении в Астрахань стрелецкие командиры не признались воеводам в заключении договора с тайшами на указанных условиях, прецедент был уже создан.

В мае до астраханских властей дошел слух о поездке к Дайчину Борис-мирзы Янарасланова, который дал шерть, что через 1,5-2 меся-

${ }^{23}$ РГАДА. Ф. 127. Оп. 1. 1633 г. Д. 1. Л. 108-109, 116-118.

${ }^{24}$ РГАДА. Ф. 127. Оп. 1. 1633 г. Д. 1. Л. 110, 118; Новосельский А.А. Указ. соч. С. 226; Богоявленский С.К. Указ. соч. С. 69.

${ }^{25}$ Богоявленский С.К. Указ. соч. С. 69. 
ца присоединится к тайше. За это мирзе якобы предоставлялось возможность выкупить у калмыков свой же ясырь «дешевой ценой». В дальнейшем Дайчин предложил ногайским мирзам, «чтоб они с ними (калмыками. - B.T.) помирились и были с ними в миру и в дружбе, кочевали по своим старым кочевным местам, где их нагайских и едисанских мурз отцы и деды по Узени и по Камыш Самаре кочевали». Тайша заверил, что «их (ногайцев. - B.T.) громити не станет и от всяких воинских людей оберегати их учнет и громити их никому не даст». Позже в Астрахани Борис-мирза категорически отрицал эти слухи $^{26}$

Таким образом, торгутские тайши не только начали планомерно осваивать новый для себя регион, но и стали постепенно увеличивать число своих подданных за счет ногайцев. Этот факт опровергает устоявшийся в историографии стереотип о намеренном вытеснении калмыками ногайцев с их исконной территории. Захваченный при набегах ногайский «полон» тайши, как правило, продавали обратно приезжавшим в калмыцкие улусы мирзам, что являлось определенной формой политической зависимости последних от тайшей.

Дайчин на переговорах с царскими представителями всегда подчеркивал главенство своего отца над всеми торгутами, а себя называл его преемником: «Урлюк тайша славен во всех ордах, а отец де ево, Урлюк тайша, в их землях царь, да и он де Дайчин тайша вскоре учинитца царь же». Воинов у Хо-Урлюка, по сведениям татар, в это время насчитывалось примерно 12 тыс., а у Дайчина - 10 тыс. ${ }^{27}$. По мнению С.К. Богоявленского, располагая почти равными силами, Дайчин вел более решительную политику, чем его отец, что в дальнейшем и позволило ему отодвинуть его на второй план ${ }^{28}$. По всей видимости, то, что Дайчин называл своего отца «царем», т. е. ханом, и в дальнейшем планировал принять на себя этот титул, стало началом реализации его плана по образованию ханства в Северном Прикаспии.

Одним из немногих, кто упрямо противился усилению калмыков в регионе, был ногайский князь Канай. В мае 1633 г. он предложил

${ }^{26}$ РГАДА. Ф. 127. Оп. 1. 1633 г. Д. 1. Л. 95-96, 144; Новосельский А.А. Указ. соч. С. 226.

${ }^{27}$ РГАДА. Ф. 127. Оп. 1. 1633 г. Д. 1. Л. 144.

${ }^{28}$ Богоявленский С.К. Указ. соч. С. 94. царским властям проект по созданию коалиции и просил незамедлительно отдать приказ волжским и сибирским воеводам, башкирским мирзам, а также тайшам «дальних калмыков» (чакарцам) одновременно ударить по улусам Хо-Урлюка и его сыновей. Канай располагал информацией о том, что Дайчин и Султанай планируют совершить новый набег под Астрахань уже ближайшей осенью 29.

В ноябре из Москвы в Тюмень действительно поступила инструкция о немедленной отправке военного отряда против Хо-Урлюка, Дайчина, Лузана и Султаная. Поводом для этого послужило сообщение в центр от астраханского воеводы И. Салтыкова о тяжелом положении его гарнизона и невозможности в полной мере обеспечить защиту подвластных ногайцев и татар: «против колмацких людей стояти некем, стали безлюдны и безоружны». А пока астраханскому воеводе оставалось только обнадеживать Каная, что правительство обязательно предпримет меры и по торгутским улусам будет нанесен удар со стороны сибирских городов ${ }^{30}$.

В этом его активно поддерживал и хивинский хан Исфендияр. осенью того же года отправивший царю Михаилу Федоровичу письменное предложение о совместном выступлении против калмыков, кочевавших на Эмбе: «наши торговые люди хаживали с торгом в ваше государство сухим путем, и они (калмыки. - B.T.) ныне дорогу занели, и людей наших не пропущают) ${ }^{31}$. Это подтверждают и слова бухарского посла Казы Казыева, сообщавшего, что ранней весной 1633 г. братья Дайчина - Лузан и Кирсан - напали на бухарский город Савран и захватили 1700 пленных, перебив множество людей и разграбив имушество ${ }^{32}$. Как видим, обширную территорию между реками Сыр-Дарья и Яик занимали со своими улусами Хо-Урлюк и его сыновья.

Набеги и контроль над степными торговыми магистралями, как известно, приносили существенный доход в экономику кочевого общества. Агрессивные действия калмыков на сухопутных маршрутах

${ }^{29}$ Богоявленский С.К. Указ. соч. С. 68.

${ }^{30}$ Миллер Г.Ф. История Сибири. Т. ІІ. М., 2000. С. 475-476.

${ }^{31}$ Материалы по истории Узбекской, Таджикской и Туркменской ССР. Вып.3. Ч. 1. Л., 1933. С. 142.

32 Богоявленский С.К. Указ. соч. С. 70 
стали существенным препятствием в торговле России со среднеазиатскими ханствами, Индией и Персией. Кочевники, используя на первом этапе силовое давление, впоследствии пытались навязать свои экономические и политические условия торгово-земледельческим центрам.

Успешные военные действия калмыков в Северном Прикаспии и Средней Азии заставили даже самых непримиримых ногайских владельцев задуматься о целесообразности дальнейшего сопротивления. Они понимали, что слабый в военном отношении астраханский гарнизон не способен их защитить. Бегство на правобережье Волги также не спасало их, поскольку в свосм продвижении на запад калмыки не планировали ограничиваться волжскими рубежами, да и с Малым Ногаем у астраханских мирз отношения оставались натянутыми. Канай даже отослал от себя небольшой отряд стрельцов, поставленный в его улусе для защиты от калмыков. Однако некоторые мирзы продолжали настойчиво просить об отправке к ним стрельцов ${ }^{33}$.

В Астрахани с тревогой следили за ситуацией в степи. По слухам, дошедшим до астраханских воевод, Дайчин очень образно говорил о военной мощи калмыков: «Такие де у них, калмыков, люди есть, что, пришед под Астрахань среди лета, и заметут ее снегом». С.К. Богоявленский утверждал, что в дальнейшем отношения между калмыками, татарами и русскими Дайчин представлял себе как военный сою3 ${ }^{34}$. Но ногайцев тайша рассматривал не как равноправных союзников, а как потенциальных своих подданных, которые значительно могли бы увеличить численность его войска. Свое политическое видение относительно их будущего Дайчин пытался навязать и русским властям, всячески противившимся развитию подобного сценария.

Формально Дайчин продолжал признавать над собой верховенство отца, но массовый приток представителей тюркских народов в его улусы фактически позволил ему претендовать на главенство не только на правах старшего сына, но и как тайше, обладавшему самым многочисленным улусом и войском. Успех на Узени только подтвер-

\footnotetext{
${ }^{33}$ Богоявленский С.К. Указ. соч. С. 68

${ }^{34}$ Богоявленский С.К. Указ. соч. С. 68-69.
}

дил его претензии на власть, а в мире кочевников это имело большое значение. Желание старшего сына Хо-Урлюка быть самостоятельным подтверждает и тот факт, что в 1632 г. торгутские послы шертовали в Тюмени за Хо-Урлюка, его детей и внучат, за исключением Дайчина, который, как отмечали очевидцы, «кочует себе и отца своего ни в чем не слушает» ${ }^{35}$. Хо-Урлюк в отношении с московскими властями был более осторожен, не всегда одобрял действия старшего сына. К тому же он не желал отрываться от ойратского сообщества, от своих старых соратников - Далай-Батура и Гуши.

Дайчин оставался непреклонным относительно заключенных им «узенских» соглашений. В междуречье Яика и Волги повсюду действовали его разведывательные отряды в поисках еще неприсоединившихся к нему ногайских улусов. Зачастую эти отряды вступали в вооруженные стычки со стрелецкими группами, в свою очередь, пытавшимися разведать обстановку в междуречье и не допустить ухода ногайцев к калмыкам.

9 января 1634 г. калмыки совершили новый набег на ногайцев и с богатой добычей вернулись за Яик. Канай немедленно отправил к Дайчину двух посланцев с сообщением, что калмыки разорили его улус, тем самым лишив возможности оставаться под Астраханью. Отъехать сразу же к калмыкам он не мог, так как за ним повсюду следили стрелецкие заставы. Это стало последним толчком, заставившим ногайские улусы не оставаться далее под Астраханью. По мнению В.В. Трепавлова, фактически с этого времени государственная территория ногаями была утрачена, а левый берег Волги, именовавшийся раньше как «ногайская сторона), ногайцы сами стали называть «(калмыцкой) $)^{36}$.

Однако калмыцкое вторжение не было единственной причиной ногайской откочевки из-под Астрахани. Мирзы припомнили все обиды, нанесенные им воеводами и другими представителями царской власти. Разные должностные лица, прибывавшие в ногайские улусы из Астрахани, отнимали лошадей, овец, некоторые стрелецкие головы на правом берегу Волги даже обзавелись своими отарами, тогда

${ }^{35}$ РИБ. М., 1875. С. 475-478.

${ }^{36}$ Трепавлов B.B. «Белый царь»... С. 105. 
как многие мирзы продолжали находиться в заточении в качестве заложников на Аманатном дворе. Воеводе А.Н. Трубецкому вменяли в вину обидные для ногайцев слова: «пашут де хлеб казанские татаровя, и яз де сделаю вас мурз и черных улусных людей так же, как казанские татаровя, станете и вы хлеб пахать $)^{37}$. Ногайские мирзы говорили, что подобные действия местных царских чиновников просто вынуждали их откочевывать к калмыкам. Историческая литература достаточно долго видела в калмыцком нашествии единственную причину ухода ногайцев с Волги. Однако В.В. Трепавлов отмечает, что подобная односторонняя информация о ногаях поступала от астраханских наместников, а те были заинтересованы называть калмыков виновниками ногайской миграции 1634 г., что впоследствии и устоялось в исторической литературе ${ }^{38}$.

Не получив реальной поддержки у Москвы, ногайцы в конце 1633 - начале 1634 гг. стали уходить из-под Астрахани. Одна их часть пошла к калмыкам, другая - двинулась на запад. Правительство начало расследование, приступив к поискам виновных среди стрелецких командиров, которые были арестованы, а воеводы и дьяки были смещены и вызваны в столицу для объяснений. Однако большинство ногайцев, не веря гарантиям в государевой защите, не желали возвращаться назад ${ }^{39}$. Чтобы сдержать ногайскую миграцию, местные власти прибегли к более жестким мерам. Так, в Астрахани в заложниках насильно удерживались следующие владельцы: князь Канай - за то, что ссылался с калмыками, мирзы Алей Урмаметев и Чубармамет (Джаббар-Мухаммед) Тинмаметев - за связи с Крымом, Ак-мирза Байтереков - за попытку уйти в Крым, мирза Борис Янарасланов - за связи с калмыками. Дополнительно были проведены серьезные оборонительные мероприятия: вокруг мест обитания оставшихся едисан и юртовских татар были вырыты рвы, установлены сторожевые башни, выставлена военная охрана улусов и скота ${ }^{40}$.

Калмыки, по существу, стали полными хозяевами заволжских степей. В январе 1635 г. Дайчин во главе 10-тысячного войска вновь

${ }^{37}$ Новосельский А.А. Указ. соч. С. 227.

${ }^{38}$ Трепавлов В.В. История... С. 408.

${ }^{39}$ Трепавлов В.В. История... С. 409.

${ }^{40}$ Новосельский А.А. Указ. соч. С. 228. появляется под стенами Астрахани. До этого тайша вместе с алтыульцами охотился на сайгаков в районе Карадуванских песков, и к Астрахани он направился уже с урочища Кигач. По пути калмыцкая разведка в камышах захватила двух русских людей, сообщивших Дайчину о расположении едисанских улусов в городских окрестностях. Получив полную информацию и став лагерем за рекой Бузан, Дайчин для отгона скота и захвата ясыря отправил к морским косам отряды «загонщиков», где едисаны, как им казалось, находились со своими стадами в относительной безопасности. С астраханского направления «загонщиков» прикрывал 4-тысячный отборный калмыцкий отряд ${ }^{41}$

Оборону Астрахани возглавляли А. Аристов и С. Горохов. В срочном порядке против калмыков были отправлены конные сотни молодых дворян, стрельцов и ногайцев, которые так и не решились вступить в бой с более многочисленным противником. Первыми дрогнули и побежали к Астрахани едисаны мирзы Янмамета Янаева. Вечером того же дня вернулся в город и отряд А. Тарбеева, который заявил воеводам, что одной конницей против калмыков действовать бесполезно. Тарбеев в помощь просил пехоту и военный обоз в качестве передвижной крепости против более многочисленных кочевников. В ту же ночь в Астрахани срочно был сформирован обоз из телег, верблюдов и быков, дополнительно были выделены два отряда стрельцов и 6 пушек. Поставив обоз против основных сил калмыков, астраханцы не спешили переходить к активным действиям, как они признавались позже, «бояся калмыцких людей». Дайчин спокойно стоял в двух верстах от обоза и наблюдал за русским отрядом. Когда тайша со своими основными силами направился к Бузану, астраханский обоз в виде тележного городка стал постепенно перемещаться за калмыками. Затем Дайчин перешел на учуг Камызяк, приказав на возвышенности развести большие костры, служившие своего рода маяками для возвращающихся калмыцких «загонщиков». Захваченный скот и ясырь Дайчин приказал пропустить вперед, а сам с войском шел сзади, прикрывая отход с тыла. Возвращались калмыки в свои улусы той же дорогой. Астраханский отряд численностью в 500 че-

${ }^{41}$ РГАДА. Ф. 127. Оп. 1. 1635 г. Д. 1. Л. 10-11. 
ловек, державший оборону в тележном городке, просто наблюдал за тем, как калмыки прогоняли мимо них захваченный скот и пленных Отправив трофеи на Яик, калмыки так же организованно и беспрепятственно ушли ${ }^{42}$.

Позже в Астрахани началось расследование по делу стрелецких командиров, не предпринявших должных активных военных действий во время последнего калмыцкого набега. Выяснилось, что только командир Тарбеев пытался переломить ситуацию: собрав добровольцев, он совершил вооруженную вылазку из обоза, навязав бой калмыцкой стороне. Однако во время боя ни Аристов, ни Горохов не пошли к нему на помощь, не отправили людей, хотя Тарбеев просил подкрепление. Впоследствии они объясняли, что хотели избежать потерь «государевых людей», а поскольку отряд их насчитывал всего 500 человек, посчитали, что лучше, если калмыки побьют ногайцев, зато они сохранят своих людей ${ }^{43}$.

Это был очередной удар по политическому престижу астраханских воевод, а в их лице и Московского государства, только недавно потерпевшего поражение в Смоленской войне 1632-1634 гг. Астрахань снова и снова просила у Москвы подкрепления, в особенности конными стрельцами, так как имеющихся у них сил было недостаточно для охраны ногайцев. Воеводы вынуждены были признать свое бессилие против многочисленных, хорошо вооруженных и организованных кочевников, но, как отмечает Н.Н. Пальмов, не «калмыцких шаек» ${ }^{44}$. Эта ситуация наводила на определенные мысли и не присоединившихся еще к калмыкам ногайцев. Москва пригрозила «царской опалой» Аристову и Горохову за бездействие и потребовала немедленно отправить «добрых» послов к Дайчину, чтобы напомнить ему о прежних шертях, данных тайшами в У фе и сибирских городах ${ }^{45}$.

Могущество Дайчина в Северном Прикаспии постепенно росло. Теперь это были не те 170 кибиток, первоначально выделенных ему отцом в качестве наследства, а гораздо больше. Но самое главное -

${ }^{42}$ РГАДА. Ф. 127. Оп. 1. 1635 г. Д. 1. Л. 1-4, 6-7, 12-13; Богоявленский С.К. Указ. соч. С. 71; Новосельский А.А. Указ. соч. С. 227

${ }^{43}$ РГАДА. Ф. 127. Оп. 1. 1635 г. Д. 1. Л. 15.

${ }^{44}$ Пальмов Н.Н. Очерки... С. 33.

${ }^{45}$ РГАДА. Ф. 127. Оп. 1. 1635 г. Д. 1. Л. 16, 33-34. большинство торгутских тайшей признали в нем лидера, обладавшего харизмой и военным талантом. Даже его отец, кочевавший в это время за Эмбой и находившийся в военном походе против Ургенча и Хивы, в помощь старшему сыну для проведения последней военной операции под Астраханью дополнительно выделил 3 тыс. воинов ${ }^{46}$.

Дайчин теперь полностью переключил свое внимание на западный берег Волги, где кочевали еще не подчинившиеся ему ногайские улусы. Калмыцкие тайши, благодаря хорошо организованной военной и дипломатической разведке, были достаточно информированы о состоянии дел среди ногайцев на правобережье Волги. Пока его послы за Волгой предлагали мирзам «мир и совет», он целенаправленно готовился к новой военной акции, запланированной на 1636 г. Но эти намерения пришлось ненадолго отложить в связи с резким изменением международной ситуации в Средней Азии.

\section{2. Политическая ситуация во второй половине 1630-х гг.}

В 1634 г. началась очередная ойрато-казахская война, в которой участвовали практически все старшие ойратские тайши: дербетский Далай-Батур, цоросский Батур-хунтайджи, хошутские Гуши и Кунделен-Убаши, торгутский Хо-Урлюк и другие. Благодаря совместным действиям, ойраты зимой 1634/35 года нанесли сокрушительное поражение казахам ${ }^{47}$. Султан Джахангир, сын казахского хана Ишима, был пленен ойратами, о чем свидетельствуют русские документы $^{48}$

С наибольшей долей вероятности можно предполагать, что Джахангир попал в плен именно к северным ойратам, т. е. чакарским калмыкам. Дербетский предводитель Далай-Батур заключил с Джахангиром союз, выдав за него свою дочь. Этот союз, в первую очередь, был создан в противовес возраставшему политическому влиянию джунгаров и продолжавшимся самостоятельным действиям

${ }^{46}$ РГАДА. Ф. 127. Оп. 1. 1635 г. Д. 1. Л. 13; Боголвленский С.К. Указ. соч. С. 71.

${ }^{47}$ МИРМО. М., 1959. С. 278, 280; Златкин И.Я. Указ. соч. С. 98

${ }^{48}$ МИРМО. М., 1959. С. 278, 280, 281. 
торгутов в Прикаспии, что, конечно, не входило в планы тайшей северной группировки, наиболее крупной по численности.

Практически сразу после победы над казахами у ойратов начался новый виток междоусобной войны. Весной 1635 г. улусы Хо-Урлюка, кочевавшие в степях Юго-Западной Сибири, дважды подверглись нападению казахов. Хо-Урлюк явно не ожидал внезапного нападения на свои улусы. Потеряв много людей и имущества, он вынужден был покинуть свои старые сибирские кочевья и бежать к сыну в прикаспийские степи. Здесь Хо-Урлюк расположился от него в 6-7 днях пути, в районе реки Эмбы. Улус Дайчина в это время кочевал по Яику, в трех днях пути от Астрахани ${ }^{49}$

Причины начавшейся войны между торгутами и чакарцами могли быть разными. Во-первых, Далай-Батур как формальный лидер северной группировки ойратов, наверняка, мог с помощью подчиненных ему казахов султана Джахангира присоединить отколовшуюся и успешно действовавшую в Северном Прикаспии торгутскую группировку. Присоединение торгутов позволило бы чакарским калмыкам численно увеличить свои силы, чтобы в дальнейшем не допустить уже усиления джунгаров и претендовать, таким образом, на гегемонию в ойратском сообществе

Во-вторых, именно в этот период отмечен резкий рост численности людей в торгутских улусах. Например, в Астрахани в 1634 г. озвучивалась цифра в 20 тыс. бойцов, что, возможно, было вызвано массовым бегством рядовых калмыков из улусов Далай-Батура и других ойратских тайшей во владение Хо-Урлюка. Все это также не могло не вызвать негативной реакции со стороны владельцев чакарских калмыков ${ }^{50}$.

В-третьих, по мнению С.К. Богоявленского, «вражда разгорелась, вероятно, на почве властолюбия одного и свободолюбия другого. Далай был, по терминологии русского посла, «царем» калмыков, и враждебное отношение соседей заставило даже свободолюбивых тайшей примириться с подчиненным положением. Но когда отношения с соседями потеряли свою остроту, стремление к независимости

${ }^{49}$ РГАДА. Ф. 119. Оп. 1. 1635 г. Д. 1. Л. 1; Кичиков М.Л. Указ. соч. С. 66.

${ }^{50}$ История Калмыкии... Т. 1. С. 292. могло привести некоторых тайшей к ссоре с Далаем $\rangle^{51}$. Определенно, что Далай-Батур внимательно и ревностно следил за военными успехами Дайчина в Северном Прикаспии. В условиях укрепления им так называемого «ойратского союза» усиление молодого и амбициозного торгутского тайши могло привести к сепаратистским настроениям и среди других таких же молодых тайшей, стремившихся к самостоятельности.

Немаловажное значение имел и тот факт, что в улусе Дайчина после разгрома продолжали скрываться Чокур и его сторонники. На неоднократные требования чакарских тайшей выдать их Дайчин отвечал отказом. Давление на него оказывалось и через его отца. Если Хо-Урлюк склонялся к тому, чтобы подчиниться требованиям ДалайБатура, по крайней мере, в вопросе о выдаче Чокура и Султаная, то Дайчин решительно отказался выдать своего тестя. Даже угрозы отца начать против него военные действия не поколебали мнение сына. Татары в Астрахани говорили, что Дайчин «миритца не хочет и кочевать к нему (Далай-Батуру. - B.T.) не идет) ${ }^{52}$. Дайчин теперь чувствовал себя намного увереннее, чем в 1628 г., когда в условиях реальной угрозы физического истребления он вынужден был бросить своего тестя на произвол судьбы. В целях безопасности Дайчин вместе с алтыульцами откочевывал вверх в горы, в место, что было в полутора днях пути от Яика ${ }^{53}$. Летом 1635 г. на торгутов совершили нападение и башкиры, отогнав у их пограничных улусов небольшое количество скота ${ }^{54}$.

В результате неудачной Смоленской войны 1632-1634 гг. перед Россией снова встала одна из основных проблем - обеспечение надежного прикрытия от набегов кочевников протяженных южных границ. После заключения Поляновского мира с Речью Посполитой (1634 г.) у правительства на повестке дня был не только крымский вопрос, но и ногайский. Массовая миграция ногайцев из Заволжья к Крыму потребовала от правительства проведения масштабных, весьма затратных мероприятий по укреплению южной границы ${ }^{55}$.

\footnotetext{
${ }^{51}$ Богоявленский С.К. Указ. соч. С. 72.

52 РГАДА. Ф. 119. Оп. 1. 1635 г. Д. 1. Л. 11.

53 РГАДА. Ф. 119. ОП. 1. 1635 г. Д. 1. Л. 2.

${ }^{54}$ РГАДА. Ф. 119. ОП. 1. 1635 г. Д. 1. Л. 25.

${ }^{55}$ Малов А.В. Русско-польская война 1654-1667 гг. М., 2006. С. 6.
} 
Напряженной продолжала оставаться и ситуация на границе с калмыками. Москва начала активно перебрасывать вооруженные части с западного на южное направление, которое требовало значительного усиления. Например, в начале 1635 г. в Астрахани насчитывалось всего 573 конных стрельца, поэтому добирать конников пришлось даже из пехоты, а также «из вольных и из гулящих людей»). На здешних ногайцев и татар местная администрация особо не рассчитывала, поскольку большинство мирз перешло на правый берег Волги, а оставшиеся, по заключению властей, «от калмыцкого разоренья разорены и в конец погибли, помирают голодной смертью». Астраханские власти дополнительно выделили мирзам рыбные ловли, 〈(чтобы им и улусным их людем пропитатца) ${ }^{56}$.

Калмыцкие улусы, по сообщению юртовского татарина Асаналея, в это время располагались в Волго-Яицком междуречье, в районе урочища Ачилы-тогай, в 10 днях пути от Астрахани. В конце 1635 г. Дайчин планировал совершить, (ккак реки станут), новый поход на едисанские улусы под Астраханью ${ }^{57}$. Именно в этом году астраханские воеводы в своих донесениях центру фиксировали, что «колмацких людей умножилось, и учали кочевать по Нагайской стороне от Астарахани в ближних местах $3^{58}$. По мнению С.К. Богоявленского, Дайчин планировал перейти на правый берег Волги, где кочевало большинство ногайцев, поскольку оставшиеся на левобережье были настолько разорены, что не представляли сколько-нибудь значительного интереса ${ }^{59}$.

Неожиданно для калмыков в конце 1635 г. к ним в улусы прибыл астраханский толмач А. Борисов с группой юртовских татар и едисан «для ясырского откупу». В условиях постоянной военной угрозы, исходившей с востока от чакарцев и сохранявшейся неопределенности в отношениях с Астраханью, Дайчин был весьма рад приезду Борисова. Тайша воспринял это как добрый знак и сразу же пообещал

56 Дополнения к Актам историческим, собранные и изданные Археографическою комиссиею (далее - ДАИ). Т. 2. СПб., 1846. С. 149-151.

57 ДАИ. СПб., 1846. С. 149-150.

${ }^{58}$ Цит. по: Трепавлов В.В. История... С. 414

${ }^{59}$ Богоявленский С.К. Указ. соч. С. 72 посланцам, что отдаст татарский полон без выкупа, а калмыки, как отмечал Борисов, их «во всем почитали $)^{60}$

Сложная обстановка на востоке вынуждала тайшей корректировать свои планы, и они передали воеводам, что готовы к мирным переговорам, обязуются не нападать на русские города и ногайские улусы. Доказательством этому послужил и тот факт, что, когда калмыцкие улусные люди в ходе стычки убили двух астраханских ногайцев, а одного пленного привели к Дайчину, то он тех калмыков за этот проступок «переграбил и жон их и детей распродал в Юргенч» ${ }^{61}$

В 1636 г. в Большой Ногайской орде обострилась междоусобная рознь: представители клана Тинмаметевых напали на мирз Урмаметевых и подвергли грабежу, что повлекло к бегству 4 тыс. улусных людей Би-мирзы Урмаметева под защиту крымского хана ${ }^{62}$. В разговоре Дайчин поинтересовался у Борисова, насколько верны слухи о том, что будто бы ногайские мирзы изменили государю и откочевали из-под Астрахани на «крымскую сторону» Волги. Он попросил толмача передать воеводам о готовности калмыков оказать военную помощь властям против «государевых непослушников и изменников». В обратный путь с Борисовым Дайчин отправил послом «лутчего своего улусного человека» Карчитая и торговый караван ${ }^{63}$.

В это же время к Дайчину с войсками прибыли его братья. Еще до приезда Борисова Дайчин сообщил Хо-Урлюку, кочевавшему с улусами в верховьях Эмбы, что он планирует военный поход на ногайские улусы по «крымской стороне» Волги. С этой целью он и призвал братьев. В начале 1636 г. Елден возглавил войско, отправившееся на помощь к Дайчину. Переправившись через Яик, войска Елдена и его братьев, не доезжая до реки Бузан, остановились лагерем в районе урочища Берекети. Сюда и прибыли люди от старшего брата, который кочевал в урочище на Нарын-песках, с сообщением, что ситуация изменилась, и Дайчин, хотя и призывал братьев присоединиться к нему, но пока не собирается «без государева указу» идти войной на ногайцев. В это время его послы находились в Астрахани, и тайша

${ }^{60}$ РГАДА. Ф. 119. Оп. 1. 1636 г. Д. 1. Л. 26-27.

${ }^{61}$ РГАДА. Ф. 119. Оп. 1. 1636 г. Д. 1. Л. 13.

${ }^{62}$ Кусаинова Е.В. Указ. соч. С. $168,169$.

${ }^{63}$ РГАДА. Ф. 119. Оп. 1. 1636 г. Д. 1. Л. 29-30. 
ждал реакции местных властей на его предложение об оказании военных услуг. Елден решил, что военные действия начнутся не скоро, и отправил большую часть войска обратно за Яик, а сам с небольшим отрядом остался на прежнем месте ${ }^{64}$

Параллельно с переговорным процессом Дайчин активно концентрировал возле себя людские и материальные ресурсы. Отправляя своих торговых представителей, главным образом, на среднеазиатские рынки для продажи лошадей, он наладил торговлю с яицкими казаками, помирился с бухарцами и ургенцами, возвратив им пленных туркменов. К Дайчину, помимо братьев Елдена и Лузана, присоединился и Хо-Урлюк. Мобилизованы были и алтыульские татары, ногайцы, туркмены, ургенцы, казахи. Участники коалиции, тайши и мирзы, собрались на совещание за рекой Бузан, в урочище Тепкире, на расстоянии дневного перехода от Астрахани, тем самым недвусмысленно давая понять царским властям, кто контролирует территорию Северного Прикаспия. Калмыцкие разведывательные отряды уже действовали и на правобережье Волги. По отношению к тюркским представителям Дайчин проявил себя и как способный идеолог, выбрав известный и всеми почитаемый образ Чингис-хана в качестве объединяющей фигуры для всех кочевников. На требования русских властей удалиться от Астрахани Дайчин заявлял, что калмыцкие тайши - «дети Чингиза», а здешние степи - «древние калмыцкие кочевья) ${ }^{65}$.

Но астраханские власти не желали мириться с подобным ходом событий. Это выразилось и в том, что они не разрешили калмыкам торговать, а посла Карчитая задержали. К тайшам они отправили теперь толмача Л. Степанова с государевой грамотой. По словам Степанова, Дайчин, сняв шапку, принял грамоту, распечатал, посмотрел, а затем вернул обратно, передав, чтобы из Астрахани больше ему не присылали грамот на татарском языке. Тайша не скрывал своего раздражения по поводу задержания в Астрахани своего посла и прямо заявил о своем недоверии Степанову. Дайчин недоумевал, почему астраханские власти не принимают его военных инициатив, направленных

${ }^{64}$ РГАДА. Ф. 119. ОП. 1. 1636 г. Д. 1. Л. 4.

${ }^{65}$ Богоявленский С.К. Указ. соч. С. $73-74$. против ногайцев, ушедших из-под Астрахани. Степанову пришлось объяснять тайше, что ногайцы удалились временно и только из-за калмыцкой угрозы. Воеводы категорически были против перехода калмыков на правобережье Волги. Но Дайчин упорствовал, заявляя, что калмыки могут перейти Волгу и без государева разрешения, что не даст аманатов и придет самовольно кочевать под Астрахань. Если же ногайцы все-таки помирятся с русскими, то и тайша готов был к заключению с ними мира ${ }^{66}$.

В результате стороны договорились о созыве общего русско-калмыцкого съезда с тем, чтобы попытаться решить все накопившиеся проблемы и споры, в частности, вопросы об аманатах и районе кочевий для калмыков. Но заключение договора, по мнению Дайчина. было возможно только при условии возврашения из Астрахани Карчитая. Первоначально стороны условились встретиться в урочище Тепкире, поскольку здесь Дайчин планировал охотиться. По просьбе тайшей на съезд с русской стороны предполагался приезд «добрых боярских и дворянских детей〉, а также авторитетного предводителя юртовских татар - Янмамета Рамазанова. В январе 1636 г. калмыцкие послы были отпущены из Астрахани. Приехавший с ними в улусы Степанов определил с тайшами уже новое место проведения предполагаемого съезда - урочище Берекете у реки Бузан. Из Астрахани на встречу выехали представители русской стороны: А. Тарбеев, Б. Жуков, подъячий А. Путилов, стрелецкий голова Л. Карасашев, толмачи К. Артемьев и Е. Федоров ${ }^{67}$.

На съезде Дайчин вновь предложил русским представителям военную помощь в организации похода против мирз Казыева улуса (Малого Ногая), участвовавших в набегах против южных городов. Тайша даже согласился на определенные уступки: во время похода предоставить аманатов в Астрахань. Но при всей заманчивости калмыцкого предложения местные воеводы даже под страхом смерти не имели права нарушить строгую инструкцию, полученную из Москвы: ни при каких обстоятельствах не допускать калмыков на правый берег Волги, требовать от них отхода от Астрахани в дальние кочевья,

${ }^{66}$ РГАДА. Ф. 119. Оп. 1. 1636 г. Д. 1. Л. 58-60.

${ }^{67}$ РГАДА. Ф. 119. Оп. 1. 1636 г. Д. 1. Л. 60. 
а также выдачи аманатов для обеспечения соблюдения шерти и права беспошлинной торговли. В противном же случае предписывалось выслать против калмыков войска ${ }^{68}$.

Не удивительно, что подобные условия снова завели переговоры в тупик. Калмыцкая сторона категорически отказалась в одностороннем порядке дать аманатов, мотивируя это тем, что тайши «Чингисхана дети». Тайши соглашались прислать в Астрахань аманатов только в том случае, если «на договоре к ним с аманаты приедут и договор учинят лет на 5 или на 6, или на 10 на том, что им калмыкам быть в мире и кочевать меж Волги и Яика блиско Астрахани; и торги б им калмыкам в твоих государевых городах были повольные, а они де калмыки русским людем, ко всяким промышленником и юртовским, и едисанским татаром шкоты никоторые чинити не учнут, а им бы де калмыцким людем потому ж от русских людей шкоты никоторые не было». Дайчин подтверждал, что им «недруги чакарские калмыки Далай тайша с братею», поэтому он просил в случае их военного прихода предоставить в помощь «государевых ратных людей с огненным боем». Тайша также готов был помогать астраханскому гарнизону против «государевых неприятелей〉 ${ }^{69}$. Но стороны так и не пришли к единому мнению, поскольку предъявляемые друг другу условия были неприемлемы.

По просьбе калмыцких представителей для дальнейших переговоров астраханцы отправили за реку Бузан толмачей К. Артемьева и Е. Федорова в сопровождении двух стрельцов. Когда они переплыли реку на лодке, их встретили верхом на лошадях Дурал-дархан с восемью сопровождающими. Прямо на берегу переговорщики «немалое время» вели беседу, а калмыки «по своей вере шертовали», что не причинят толмачам и стрельцам никакого вреда. Стороны стали уже расходиться, как вдруг Дурал-дархан, подозвав к себе толмача Артемьева, схватил его и умчался на лошади прочь. Как позже рассказывал сам Артемьев, калмыки привезли его к Дайчину, причем «ограбя донага, хотели убить, а иные убить не дали». Тайша повелел толмача развязать и вновь выразил готовность предоставить русским

${ }^{68}$ Богояеленский С.К. Указ. соч. С. 73.

${ }^{69}$ РГАДА. Ф. 119. Оп. 1. 1636 г. Д. 1. Л. 66. властям калмыцких аманатов на время похода против «государевых непослушников». В марте К. Артемьев вернулся и привез в Астрахань от тайшей новый вариант договора, условия которого больше носили ультимативный характер. Теперь в случае отказа астраханцев принять новые условия Дайчин грозился заключить союз с мирзами Малого Ногая, с которыми он уже вел переговоры. Но если эти переговоры имели бы отрицательный результат, то калмыки планировали уже ближайшей осенью выступить в поход против Малого Ногая, несмотря на категорический запрет русских властей переходить Волгу. Отходить от Астрахани Дайчин не намеревался, объявляя его окрестности, в частности урочище Кандаки, как «искони вечные природные и калмыцкие места», завоеванные прежде «прадедом» Чингисханом $^{70}$

Также Дайчин передал, что калмыки не боятся русских войск, поскольку ходили на едисан «не по одну зиму, и государевы де ратные люди с ними, калмыки, сходились многижда, а промыслу над ними никакова учинить не могли». Ногайские мирзы говорили Артемьеву: «всем де едисанским татаром, которые кочуют ныне под Астраханью, быть в Калмаках, потому что им в Калмаках кочевья пространные и повольные, где хотят тут и кочуют». В подтверждение этого толмач сообщил о наличии у калмыков примерно 300 ногайцев, более 3 тыс. едисан, а также туркменов, ургенцев и казахов. Он говорил, что ногайские мирзы Дайчина «наводят на всякое дурно», агитируют тайшу кочевать между Волгой и Яиком, ближе к Астрахани, не давать аманатов и в набегах на русские территории «везде бывать в вожах (проводниках. - B.T.) ) ${ }^{71}$.

Воеводы восприняли слова Дайчина как прямую угрозу безопасности Астрахани. Но предпринять действенные меры против нарастающей калмыцкой угрозы они не могли, прося у центральной власти подкрепления и дальнейшие инструкции, указывали, что малочисленный астраханский гарнизон почти целиком занят сторожевой службой. Московские власти, занятые решением проблем на западе и юго-западе страны, продолжали хранить молчание.

\footnotetext{
${ }^{70}$ Богоявленский С.К. Указ. соч. С. 73-74.

${ }^{71}$ РГАДА. Ф. 119. Оп. 1. 1636 г. Д. 1. Л. 67-73
} 
В целом отношения калмыцких тайшей с другими соседями стали уже налаживаться. Артемьев был свидетелем приезда к Дайчину послов от бухарского хана Имам-кули и хивинского правителя Исфендияра. Для торгутов неурегулированным оставался только конфликт с чакарскими калмыками, чьи послы также регулярно к ним приезжали. Далай-Батур для себя решил не начинать военных действий против Дайчина, но предпринял весьма тонкий дипломатический ход, отправив к нему хутугту, - высокое духовное лицо в буддийской иерархии ${ }^{2}$.

Из русских источников известно, что приблизительно в 1630 г. к ойратам из Тибета приезжала большая группа авторитетных буддийских священников с предложением об объединении всех ойратских группировок ${ }^{73}$. Консолидация ойратов, по всей видимости, имела целью борьбу с политическими и религиозными противниками их духовного лидера Далай-Ламы V и «желтошапочной» школы Гелугпа. Начиная со второго десятилетия XVII в., приверженцы школы Гелугпа стали подвергаться серьезным преследованиям со стороны представителей (ккрасношапочной» школы Карма, светского правителя центральной тибетской области Цзан Пунцок Намджала, чахарского Лигдан-хана и халхаского Цогто. В 1634 г. ими было принято решение о полной ликвидации школы Гелугnа ${ }^{74}$. И, очевидно, многие иерархи этой школы эмигрировали из Тибета в ойратские владения и обращались к тайшам за военной помощью.

Известно, что выдающийся ученый и просветитель хутугта ЗаяПандита прибыл к ойратам в 1639 г., на Яике он впервые побывал в 1645 г., а до него у торгутов, согласно «Биографии», с визитом находился только Индзан-хутугта, правда, в этом сочинении нет указания на дату его приезда. О деятельности Индзан-хутугты (Инзанримбочи), как указывает Ш. Норбо, в исторических сочинениях сохранились лишь крайне отрывочные сведения ${ }^{75}$. Таким образом, с большой долей вероятности можно предположить, что к торгутам в 1635-1636 гг. приезжал именно Индзан-хутугта.

${ }^{72}$ РГАДА. Ф. 119. Оп. 1. 1636 г. Д. 1. Л. 72; Богоявленский С.К. Указ. соч. С. 72

${ }^{73}$ МИРМО. М., 1959. С. 152.

${ }^{74}$ История Калмыкии... Т. 1. С. 295.

${ }^{75}$ Норбо ШІ. Зая-Пандита (Материалы к биографии) / Пер. со старомонг. Д.Н. Музраевой, К.В. Орловой, В.П. Санчирова. Элиста, 1999. С. 169-170.
Это косвенно подтверждают и русские источники. В фонде «Ногайских дел» за 1636 г. сохранились сведения о приезде весной к Дайчину большого представительного посольства (200 человек) некоего «кутукты» (хутугты). Миссия имела целью не только религиозную направленность. Анализ этой информации показывает, что посредническая роль хутугты заключалась в том, чтобы убедить торгутских тайшей вернуться на старые кочевья в Юго-Западной Сибири и вновь присоединиться к чакарским тайшам. Хутугта передал Дайчину требование Далай-Батура о совместном с ним кочевании, прекращении самостоятельных сношений с соседями и выдаче чакарцам Чокура и Султаная ${ }^{76}$.

Далай-Батур стремился не просто консолидировать ойратов, а и централизовать внешнеполитические отношения, в первую очередь, с Московским государством. По всей видимости, Далай-Батур считал, что эта практика, когда едва ли не каждый ойратский владелец пытался войти в контакт с царским правительством, мешала полноценной политической консолидации. Выдача союзникам Чокура и его соратников также имела немаловажное значение. Дайчин в своих политических взглядах, скорее всего, в какой-то степени находился под влиянием своего тестя, и чакарские тайши, понимая это, проявляли в этом вопросе твердую решимость

Приезд хутугты в торгутских улусах получил большой общественный резонанс, и Дайчину пришлось даже выступить с пламенной речью перед своими улусными людьми. Он разъяснил народу сложившуюся ситуацию и рассказал об истинной цели миссии хутугты: агитировать торгутов присоединиться к чакарцам. Дайчин всерьез опасался попасть под контроль Далай-Батура, поэтому и предложил своим улусным людям собрать «добрых» лошадей, чтобы таким образом «задобрить» хутугту. Также он пообещал урегулировать отношения с Астраханью и отпустить астраханских татар. В дар хутугте было собрано богатое подношение, состоявшее из 20 тыс. жеребят двух окрасов (вороных и карих) и 10 тыс. отборных овец ${ }^{77}$.

${ }^{76}$ РГАДА. Ф. 127. Оп. 1. 1636 г. Д. 1. Л. 133, 196; Богоявленский С.К. Указ. соч. С. 72.

${ }^{77}$ РГАДА. Ф. 127. Оп. 1. 1636 г. Д. 1. Л. 131, 133, 196. 
Авторитет хутугты среди ойратов был настолько высок, что Дайчин, несмотря на свою твердую убежденность, все-таки не решился ответить ему открытым отказом. Поддавшись уговорам хутугты, он согласился откочевать к Далай-Батуру. Но, как показали дальнейшие события, Дайчин с братьями решили инсценировать откочевку к чакарцам, чтобы тем самым побудить хутугту покинуть пределы торгутских кочевий вместе с многочисленной его свитой. Летом 1636 г. с урочища реки Орь началось мнимое движение торгутских улусов на восток, при этом тайши предусмотрительно оставили скот и имущество на прежнем месте. Отъехав на довольно приличное расстояние, торгутские тайши неожиданно повернули назад, к Яику. Хутугта при виде этого стал выговаривать Дайчину и его братьям, «что они на своей правде не устояли». Тайшам пришлось заверить Индзан-хутугту, что после зимовки они обязательно приедут к Далай-Батуру ${ }^{78}$.

На чем же основывалась столь неуступчивая позиция торгутских тайшей? Ответ, видимо, кроется в том, что Дайчин был в курсе событий, развернувшихся в степях Юго-Западной Сибири. В это время у чакарских калмыков вспыхнул конфликт с жителями сибирских городов. Еще в 1633-1634 гг. новая волна набегов чакарских калмыков накрыла Кулебинскую и Барабинскую волости. Совместно с кучумовичами калмыки хошутского тайши Гуши подступили к Таре и Тюмени, заняли подступы к Ямыш-озеру и всячески срывали снабжение населения сибирских уездов солью ${ }^{79}$.

Военная агрессия со стороны Гуши была вызвана задержкой в Таре бухарского посла Казыя, отправленного туда тайшой. Гуши неоднократно требовал от воеводы отпустить бухарца, но каждый раз получал отказ. Далай-Батур, не заинтересованный в резком обострении русско-калмыцких отношений, в этом конфликте выступил в роли посредника. В 1635 г. он отправил своих послов в Тобольск с предложением отпустить Казыя к Гуши, что прекратило бы столкновения между калмыками и русскими. Далай-Батур обещал вернуть в Тобольск весь русский и татарский полон, находившийся в калмыцких улусах. Ходатайство Далай-Батура было удовлетворено: Казый из Тары был отпущен. Но пленных так и не удалось заполучить от

${ }^{78}$ РГАДА. Ф. 127. Оп. 1. 1636 г. Д. 1. Л. 188.

${ }^{79}$ МИРМО. М., 1959. С. 238. калмыков, поскольку Гуши выдвинул новое требование - вернуть в степи взятых в плен под Уфой кучумовичей, а в противном случае он обещал разорить Тарский уезд ${ }^{80}$. Далай-Батуру, сохранявшему лояльное отношение к царским властям в Сибири, не удавалось прекратить набеги на русскую границу не только не подчиненных ему тайшей, но и тех, которые его «слушали». Все это приводило к продолжению вооруженных стычек на границе. Известно, что дербеты в это время совершили очередной набег на тюменские волости, в ответ тюменцы разгромили один из дербетских улусов ${ }^{81}$.

Так и не сумев окончательно разрешить противоречия между калмыками и русскими, примерно в конце 1636 или начале 1637 гг. умирает Далай-Батур. В калмыцких и русских источниках последние годы его жизни отражены весьма скупо и противоречиво. Согласно Габан Шарабу, незадолго до смерти Далай-Батур распорядился оставить двум старшим сыновьям наследство меньшее, чем третьему сыну - Дайчин-Хошучи. Встречается и упоминание о том, что еще при живом Далай-Батуре одна из старших его жен попыталась взять под контроль все дербетские улусы ${ }^{82}$. По всей вероятности, каждая из жен дербетского тайши хотела отхватить для своих детей саму большую часть наследства, и борьба внутри многочисленной семьи, видимо, разгорелась настолько, что привела даже к убийству ДалайБатуром одного из сыновей по имени Манзу ${ }^{83}$.

После смерти Далай-Батура внутрисемейные интриги переросли уже в открытое противостояние между его старшими сыновьями. В отписке тюменского воеводы И. Львова сообщалось, что в дербетских улусах, кочевавших по Иртышу, после смерти Далай-Батура вспыхнула борьба за отцовские улусы между двумя старшими его сыновьями $^{84}$. В донесении Б. Аршинского говорилось, что братья

${ }^{80}$ Пузанов В.Д. Военные факторы русской колонизации Западной Сибири (конец XVI-XVII вв.). СПб., 2010. С. 91.

${ }^{81}$ РИБ. СПб., 1875. С. 547.

${ }^{82}$ Габан Шараб. Указ. соч. С. 96

${ }^{83}$ Габан Шараб. Указ. соч. С. 98.

84 Материалы по истории русско-монгольских отношений (далее МИРМО). 1636-1654: Сб. документов / Сост. М.И. Гольман, Г.И. Слесарчук; отв. ред. И.Я. Златкин, Н.В. Устюгов. М., 1974. С. 102. 
Дайчин-Хошучи и Гумба конфликтуют со старшим своим братом Даян-Омбо ${ }^{85}$. Все эти события привели к тому, что некогда могущественное и централизованное владение, являвшееся одной из главных сил в составе старого союза дурбэн-ойратов, заметно ослабло, уступив лидирующие позиции хошутам в северной группировке ойратских улусов ${ }^{86}$.

Осложнение отношений между чакарцами и русскими в Сибири, а также смерть Далай-Батура позволяли торгутским тайшам уже не опасаться реальной угрозы с востока. Все свое внимание они теперь переключили на южное направление. Хо-Урлюк, кочевавший рядом с сыном на реке Иргиз, совершил со своими улусными людьми набег под Ургенч, захватив в плен небольшое количество «пахотных людей». С прибывшим из Ургенча послом калмыки заключили мир, вернув ему захваченный полон (19 человек), а летом 1636 г. Дайчин отправил с ним уже своего посла Бокея и крупный торговый караван. В октябре Дайчин начал подготовку к походу на туркменов, подготовив для перехода через безводную пустыню Каракум козлиные меха, в которых запасают воду. Астраханское направление тайше пока виделось бесперспективным, поскольку город за последний год был заметно укреплен и дополнительно усилен ${ }^{87}$

Смерть Далай-Батура повлекла за собой некоторое сближение торгутских и чакарских тайшей. Это выражалось в появлении некоторых торгутских улусов в непосредственной близости от сибирских городов, т. е. на их прежних кочевьях, откуда они бежали после их разгрома в 1635 г. Русские источники свидетельствуют, что в сентябре 1636 г. семеро калмыцких тайшей оказались в урочище Кошкарагае. Вслед за ними на реке Ишим неожиданно появился со своим улусом Хо-Урлюк, незадолго до этого кочевавший на реке Орь. В Тобольск сразу же прибыли торгутские посланцы с просьбой разрешить им торговать в сибирских городах ${ }^{88}$. Местные воеводы никак не могли

${ }^{85}$ Миллер Г.Ф. Указ. соч. С. 129, 528.

${ }^{86}$ История Калмыкии... Т. 1. С. 293.

${ }^{87}$ РГАДА. Ф. 127. Оп. 1. 1636 г. Д. 1. Л. 135, 193, 197.

88 В составе посольства были и представители буддийского духовенства улуса Хо-Урлюка, в частности, от лам Бутурая и Чорти (Курапов A.A. Буддизм и власть в Калмыцком ханстве XVII-XVIII вв. Элиста, 2007. С. 84). понять, зачем же Хо-Урлюку потребовалось так далеко удаляться на север. Предупредив сибирских воевод о возможной опасности, московские власти все же разрешили им направить к нему посланцев для выяснения истинных намерений прикочевавших торгутов ${ }^{89}$.

Отправленный из Тобольска П. Выходцев не застал торгутов на Ишиме, а нашел их уже в Приаральских Каракумах. Хо-Урлюк объяснил ему, что посылал своих людей на Ишим только для рыбной ловли и впредь не собирается кочевать под сибирскими городами. Выходцеву так и не удалось ничего узнать о причинах перекочевок Хо-Урлюка. По его предположению, калмыкам, собравшимся под Астраханью в большом количестве, стало тесно, да и с ногаями у них не было никакой торговли, тогда как с Бухарой велись оживленные торговые сношения. Соображения Выходцева, хотя и не дают исчерпывающих объяснений, все же интересны как признание современником важности для калмыков торговых сношений с соседями. Рядом с Хо-Урлюком кочевал со своим улусом и его сын Елден, женатый на дочери Гуши. Но Хо-Урлюк поддерживал тесные отношения и со старшим сыном - Дайчином, который продолжал кочевать со своим улусом в Северном Прикаспии. По мнению С.К. Богоявленского, ХоУрлюк, опасаясь нежелательных последствий из-за поступка Дайчина по отношению к хутугте, при посредничестве духовенства на Ишиме вел переговоры с Гуши, а когда понял, что они будут иметь благоприятный исход, откочевал на Каракумы, где находился поблизости от кочевий хошутов. Елден же выступал своего рода посредником между отцом и тестем ${ }^{90}$.

Хо-Урлюк был достаточно осведомлен о состоянии дел в сибирских городах. Так, например, задав вопрос Выходцеву: «Сколько из русских городов пришло в сибирские городы людей и для чего посланы?», тайша немало удивил последнего, который стал интересоваться, откуда тайша располагает такими сведениями, на что тот уклончиво ответил: «Как де им про то не ведать!» На сообщение Выходцева о том, что в Тобольск, Тару и Тюмень дополнительно прислано 4 тыс. ратных людей, тайша ответил, что он знает не только об этом факте,

${ }^{89}$ Богоявленский С.К. Указ. соч. С. 74-75.

${ }^{90}$ Богоявленский С.К. Указ. соч. С. 75. 
но даже о том, чем это вызвано. Уже в улусе Хо-Урлюка Выходцев получил известие от дербетского Дайчина-Хошучи о смерти двух соперников - Далай-Батура и Чокура. Последний в конце жизни не играл уже заметной роли и проживал в улусе своего зятя Дайчина. Смерть Далай-Батура давала свободу действиям Хо-Урлюку и его старшему сыну, поскольку Гуши не столь был энергичен и настойчив в вопросе возвращения торгутов на старые кочевья в Сибири ${ }^{91}$.

Дайчин в это время начал новый этап подготовки калмыцкого продвижения на запад, всерьез обеспокоив этим ногайцев на правобережье Волги, причем настолько, что некоторые мирзы предусмотрительно со своими улусами перешли на правобережье Дона. В январе 1637 г. Дайчин вместе с братьями и алтыульскими мирзами направил к Астрахани значительные силы. По сообщению едисан, у тайшей насчитывалось более 10 тыс. воинов, но эта цифра, скорее всего, не совсем точна, поскольку калмыки продвигались несколькими колоннами с разных сторон. Приблизившись к городу на расстояние дневного перехода, Дайчин отправил в разведку за реку Бузан небольшой отряд из «лутчих своих людей» - Дурал-дархана и Калкан-Сарыя во главе отряда из 60 воинов. Сведения, полученные разведкой, для калмыков оказались неутешительными: под городом едисаны расположились в укрепленных местах, повсюду были выкопаны рвы, поставлены бревенчатые ограды и сторожевые башни, на подходах к городу охрану несли многочисленные патрули. Поэтому о внезапном нападении на едисанские улусы не могло быть и речи. Астраханский гарнизон к этому времени получил из центра достаточно сильное подкрепление ${ }^{92}$.

Выяснив положение, Дайчин через пленных едисан передал в Астрахань, что калмыки приходили войной на ногайские улусы, кочевавшие по крымской стороне Волги и ушедшие из-под «государевой руки», но, как оказалось, «итти стало ныне поздно». Действительно, многие ногайцы ушли за Дон и кочевали теперь под Крымом, поэтому тайши решили выступить с инициативой начать мирную торговлю с астраханцами и предложили прислать людей из Астрахани для веде-

\footnotetext{
${ }^{91}$ Богоявленский С.К. Указ. соч. С. 75-76.
}

${ }^{92}$ РГАДА. Ф. 127. Оп. 1. 1637 г. Д. 1. Л. 69; Богояеленский С.К. Указ. соч. С. 76 . ния переговоров. Ответ калмыцкая сторона ожидала за рекой Бузан, в урочище Алгару ${ }^{93}$. Но отправленный воеводами толмач Л. Степанов не застал тайшей в условленном месте. Встретившиеся ему по пути трое калмыков через 10 дней привезли его к Дайчину на Яик. Они же сообщили о внезапном нападении яицких казаков на калмыцкие улусы, кочевавшие по Эмбе, в которых оставались главным образом женщины и дети. Казаки, разгромив улусы, ушли с богатой добычей в укрепленный городок в устье Яика. Дайчин спешно отправился на помощь своим людям и взял в осаду казацкий городок. Толмач стал невольным очевидцем того, как калмыки «жестокими приступами» держали казаков в осаде. Потеряв много людей, да так и не сломив сопротивления казаков, Дайчин приказал отвести войска ${ }^{94}$.

Встретившись с Дайчином, Степанов передал ему все те же требования астраханских воевод о немедленном отводе калмыков на дальние кочевья и покорности. Если бы тайша принял бы эти условия и предоставил в качестве гарантии своей шерти аманатов, то власти готовы были разрешить калмыкам вести торговлю под Астраханью, прислав для этого 30-40 своих торговцев. Но Дайчин категорически пресек все попытки ограничить независимость калмыков, заявив еще раз, что они в «никоторые государства аманат не давали и у добрых царей в холопстве не бывали, а кочевали по своей воле; да и вперед де им, калмыцким тайшам, ни в которые государства аманат не выдавать, да и в холопстве ни у которых царей не бывати». Как альтернативу тайша вновь предложил свои военные услуги против «царских недругов» - малых ногайцев и крымских татар, и только в этом случае он был согласен дать аманатов, да и то лишь на время похода. На следующий после переговоров день Степанов вместе с двумя калмыцкими послами и 60 торговыми людьми, с табунами лошадей и стадами скота отправился в Астрахань ${ }^{95}$.

Но последующие переговоры вращались вокруг все тех же пунктов: об аманатах и пропуске калмыков на правый берег Волги для дальнейшего наступления на ногайцев. Результатом этого непростого

${ }^{93}$ РГАДА. Ф. 127. Оп. 1. 1637 г. Д. 1. Л. 70.

${ }^{94}$ РГАДА. Ф. 127. Оп. 1. 1637 г. Д. 1. Л. 72.

${ }_{95}^{95}$ РГАДА. Ф. 127. Оп. 1. 1637 г. Д. 1. Л. 71, 73; Богоявленский С.К. Указ. соч. С. $76-77$. 
общения стало разрешение, полученное в виде исключения в расчете на будущую покорность калмыков, их торговым людям распродать лошадей и скот за рекой Болдой ${ }^{96}$.

В числе калмыцких торговцев находился и алтыульский татарин, присланный к воеводам от мирзы Арслана, чтобы сообщить о желании мирзы вернуться под Астрахань. Власти передали мирзе, что готовы его простить и в случае возвращения гарантируют ему неприкосновенность ${ }^{97}$. Опасения мирз, кочевавших с калмыками, были небезосновательны. Дербетские и хошутские тайши требовали от ХоУрлюка передать им мирзу Султаная и всех его алтыульских татар. В противном случае чакарцы угрожали торгутам войной. Хо-Урлюк, поддавшись давлению более сильных и многочисленных чакарских тайшей, неоднократно отправлял своих людей к Дайчину с требованием подчиниться и передать алтыульских татар чакарцам. И даже угрозы отца начать против сына военные действия в случае неповиновения не поколебали Дайчина ${ }^{98}$.

Чакарские посланники призывали торгутов к окончательному примирению и предлагали присоединиться к ним для совместного кочевания. Торгутский тайша вполне ясно обрисовал им свое видение политической ситуации: кто хочет с ним мира, тот «к нему, Дайчину тайше, приедет, а ему, Дайчину, к чакарским калмыкам ехать непочто ${ }^{99}$. Это явно говорит о том, что Дайчин чувствовал себя более чем уверенно и предлагал дербетским и хошутским тайшам присоединиться к нему.

Подобная позиция Дайчина основывалась на том, что торгутский тайша был хорошо осведомлен о сложном положении чакарских калмыков в степях Юго-Западной Сибири. Зимой 1636/37 года отряды сибирских городов в отместку за нападения калмыков хошутского Гуши разбили чакарцев. Больше всего пострадали улусы Гуши, Далай-Батура, Кунделен-Убаши, а также их многочисленных братьев и детей. Часть улусов разгромленных чакарских тайшей направилась в сторону торгутских кочевий, что и объясняет активизацию их пере-

${ }^{96}$ РГАДА. Ф. 127. Оп. 1. 1637 г. Д. 1. Л. 74-76.

${ }^{97}$ РГАДА. Ф. 127. Оп. 1. 1637 г. Д. 1. Л. 86-87.

${ }^{98}$ РГАДА. Ф. 127. Оп. 1. 1637 г. Д. 1. Л. 74.

${ }^{99}$ РГАДА. Ф. 127. Оп. 1. 1637 г. Д. 1. Л. 137, 139. говоров о совместном кочевании. Дайчин, в свою очередь, собрал все имеющиеся у него военные силы, включая алтыульцев, и отправился навстречу беженцам, чтобы «кочевать заодно» ${ }^{100}$. В сентябре 1637 г. тюменский воевода И. Львов сообщал тобольскому воеводе М. Темкину-Ростовскому, что «у колмацких де людей ныне меж собою война: Урлюков де сын Тачин Куйшу тайшу повоевал и самого Куйшу в полон взял ${ }^{101}$. Из этого сообщения трудно понять характер взаимоотношений торгутов с чакарцами и действительно ли имели место военные столкновения между ними.

Но в степях Северного Прикаспия продолжали оставаться некоторые торгутские улусы. Например, в сентябре 1637 г. в Астрахань прибыло очередное калмыцкое представительство, возглавляемое Мамутом, а с ними и 40 торговых людей со скотом и лошадьми. Распродав весь скот, в обратный путь калмыки отправились вместе с астраханским представителем - толмачом Д. Аксеновым ${ }^{102}$. Поскольку основная масса калмыков откочевала на дальние кочевья и уже не представляла явной угрозы, в декабре 1637 г. астраханские власти стали призывать ногайцев, кочевавших на правобережье, вернуться на покинутые ими старые кочевья. При этом власти не преминули упрекнуть ногайских мирз и в том, что русские противостоят калмыкам из-за ногайцев, а они «с калмыки не бьютца, лишь съезжая с ними сватаютца и торгуют» ${ }^{103}$.

Осенью 1637 г. из Астрахани к тайшам были отправлен Д.Онученов, но к моменту его приезда Дайчина в улусе не было. В это время при посредничестве буддийского духовенства между торгутскими и чакарскими тайшами активно велись переговоры ${ }^{104}$. Дайчин с Индзан-хутугтой отправились в улус Кунделен-Убаши для «договору об миру», и в результате стороны пришли к единому решению: впредь находиться «на прежних своих кочевьях, где кто кочевал, а вместе им не кочевать» ${ }^{105}$.

\footnotetext{
${ }^{100}$ РГАДА. Ф. 127. Оп. 1. 1637 г. Д. 1. Л. 141.

${ }_{101}$ Миллер Г.Ф. Указ. соч. С. 443; МИРМО. М., 1974. С. 92

102 РГАДА. Ф. 127. Оп. 1. 1637 г. Д. 1. Л. 112.

${ }^{103}$ РГАДА. Ф. 127. Оп. 1. 1637 г. Д. 1. Л. 167.

${ }^{104}$ Kурапов A.A. Указ. соч. С. 85.

${ }^{105}$ РГАДА. Ф. 127. Оп. 1. 1638 г. Д. 1. Л. 35, 37.
} 
В начале 1638 г. Дайчин вернулся в свой улус, и астраханцы вручили ему государеву грамоту и предложили принять русское подданство, предоставив аманатов. Но Дайчин снова отказался от такого предложения, объяснив еще раз: калмыки «искони в государевы городы аманат не давали, люди они степные и в аманатех сидети не привыкли и кочевали по своей воле». Он опять напомнил русской стороне, что готов оказать военные услуги против Крыма и малых ногайцев, и только в этом случае обещал дать в Астрахань аманатов «(сына своего или брата, да и то на время)» ${ }^{106}$.

Отсутствие политического соглашения с царскими властями не мешало тайшам использовать переговорный процесс в своих экономических интересах. В марте 1638 г. Онученов вернулся в Астрахань с четырьмя калмыцкими послами и 30 торговыми людьми, пригнавшими на продажу лошадей и скот. Послы привезли от тайшей предложение о мире, а Дайчин в подтверждение своего намерения с Онученовым отпустил более 40 едисан, обещая отдать «на окуп» весь полон «недорогой ценой», как только соизволит калмыкам «государева милость» ${ }^{107}$. Торговля выступала своего рода стимулом для переговорного процесса, поскольку калмыки были крайне заинтересованы в российском рынке.

Южное направление во внешней политике калмыков также имело немаловажное значение. После долгого противостояния отношения калмыков со среднеазиатскими государствами стали меняться в положительную сторону. В 1637 г. хивинский хан Исфендияр отправил к Дайчину послов с предложением о заключении мира, поскольку в прошлом под Хивой калмыки захватили много пленных. Стороны заключили мир и договорились, чтобы впредь «промеж ими торговать было повольно». Дайчин вернул послам ясырь «без окупу» и отправил с ними уже своих торговых людей ${ }^{108}$.

Онученову удалось узнать о приезде к тайшам послов от бухарского и казахского ханов с предложением о заключении мира и ведении торговли. Это свидетельствует возросшем политическом весе и влиянии калмыцкого тайши в среднеазиатском регионе. К примеру,

${ }^{106}$ РГАДА. Ф. 127. Оп. 1. 1638 г. Д. 1. Л. 35-36.

${ }^{107}$ РГАДА. Ф. 127. Оп. 1. 1638 г. Д. 1. Л. 30-33, 38.

${ }^{108}$ РГАДА. Ф. 127. Оп. 1. 1637 г. Д. 1. Л. 139. бухарский посол передал желание своего хана о личной встрече с Дайчином на реке Сырт (Сырдарья). Дайчин, в свою очередь, передал через послов их правителям, (что он миритца с ними рад) и отправил к ним своих торговых людей с «продажной животиной». Калмыцкий тайша согласился встретиться с «бухарским ханом Букеем»109, но, К сожалению, сама встреча и ее результаты не отражены в документах.

Здесь стоит отметить, что еще с XVI в. часть пленных калмыков, приняв ислам, оседала в Средней Азии. В XVII столетии они составляли уже целое служилое сословие и входили во властную элиту среднеазиатских государств. Среднеазиатские правители охотно использовали калмыков в качестве вооруженной силы в междоусобных войнах. В данном случае под «бухарским ханом Букеем», скорее всего, имеется в виду эмир Мухаммад-Баки-калмок, который еще в 1611 г. возвел на ханский престол в Бухаре Имамкули-хана (16111642 гг. $)^{110}$.

На Мангышлакском полуострове, возле Караганской пристани, находилось около 300 туркменских кибиток, ранее захваченных Дайчином под Ургенчем, а после отпущенных. Периодически небольшими группами по 30-40 человек сюда наведывались калмыцкие представители для ведения торговли с местным населением. А в это время главный калмыцкий посланец собирал здесь пошлину с торговавших на пристани купцов. Бек мангышлакских туркмен к Дайчину регулярно ездил с большими подарками ${ }^{111}$.

Весной 1638 г. чакарцы опять прислали своих послов к торгутам с предложением выдать им алтыульцев. Но Дайчин снова им отказал, заявив, что не согласен заключать соглашение на таких условиях, тем более он состоит уже в мирных отношениях с Астраханью ${ }^{112}$. Но все это было ничем иным, как политическим блефом, поскольку отношения с русскими еще не были урегулированы.

Если Дайчин, найдя компромиссное решение с восточными соседями, оставался со своим улусом на прежних кочевьях в Северном

109 РГАДА. Ф. 127. Оп. 1. 1638 г. Д. 1. Л. 37.

${ }^{110}$ Ахмедов Б.А. История Балха (XVI - первая половина XVIII в.). Ташкент, 1982. С. 105.

111 РГАДА. Ф. 127. ОП. 1. 1638 г. Д. 1. Л. 57-58.

112 РГАДА. Ф. 127. Оп. 1. 1638 г. Д. 1. Л. 112-113. 
Прикаспии, то его отец, Хо-Урлюк, уже активно действовал в русле политики чакарских тайшей. Переместившись со своим улусом ближе к сибирским городам, он вошел в тесный контакт со своими старыми соратниками - хошутскими Гуши и Кунделен-Убаши. По сведениям тобольского воеводы М.М. Темкина-Ростовского, с лета по конец 1638 г. они неоднократно вели переговоры с джунгарским Батуром-хунтайджи о возможности совместного военного выступления против сибирских городов. Причиной столь агрессивному настроению тайшей послужило пленение царскими служилыми людьми двух внуков Кучума - Аблая и Тевки - во время их неудачного набега на Уфимский уезд в 1636 г. Требования Гуши об их выдаче русской стороной были отклонены ${ }^{113}$. Некоторые ойратские тайши с кучумовичами были связаны династическими узами, что и объясняет их заинтересованность в данном вопросе. Например, тайшей не могла оставить равнодушными просьба кучумовича Девлет-Гирея помочь в освобождении плененных братьев, поскольку по материнской линии он приходился внуком Хо-Урлюку.

Сыновья Хо-Урлюка в это время особо не вмешивались в сибирские дела и продолжали кочевать со своими улусами в Прикаспии. Как свидетельствуют русские источники, в конце 1638 г. Дайчин со своим улусом находился в верховьях Эмбы, а Лузан расположился на левом берегу Яика. По сведениям татар, полученным в Астрахани, калмыцкие тайши состояли в довольно мирных отношениях с Бухарой, Ургенчем и казахами, активно вели с ними торговлю. Несмотря на постоянные перекочевки, Дайчин не прекращал переговоров с предводителями чакарских калмыков, и в целом они носили позитивный характер. Алтыульский мирза Шамамет в декабре 1638 г. говорил астраханскому татарину: «Ныне у Дайчин тайши с чекарскими калмыки меж себя бывает без урыву ссылка и мир, а чекарские де калмыки Дайчин тайши с братьею и с детьми и с племянники люднее» ${ }^{114}$.

Но в 1639 г. передвижение части торгутских улусов получило уже восточное направление. В этом же году Дайчин зимовал на

${ }^{113}$ МИРМО. М., 1974. С. 151.

${ }^{114}$ РГАДА. Ф. 127. Оп. 1. 1639 г., Д. 1. Л. 28-33; Богояеленский С.К. Указ. соч. С. $77-78$.
Каракуме, а весной он подошел к сибирским городам. Хо-Урлюк, зимовавший близ Бухары, летом со своими улусами и алтыульцами Султаная оказался на Тоболе. Так, тюменские ясачные татары, выехавшие на «зверовье», наткнулись на калмыцких людей, во главе которых был молодой тайша Дайчи, сын Сюнке. 9 июля в Тобольск от Хо-Урлюка прибыли послы и торговые люди (53 человека). Местные жители явно не доверяли приезжим калмыкам, подозревая их в разведывательной деятельности ${ }^{115}$. Другая часть торгутских улусов оставалась в Северном Прикаспии и, двигаясь вверх по Волге, кочевала по рекам Еруслан и Торгул ${ }^{116}$

Таким образом, в конце 1630-х гг. происходит планомерное разделение торгутских улусов на две группы. Первая группа (улусы Хо-Урлюка, Дайчина, Елдена и Кирсана) входит в тесный контакт с чакарцами и откочевывает на восток, к Аралу, и далее на север по Тургайской ложбине к сибирским городам. Другая группа (улусы Лузана, Сюнке, Санжина и Даян-Эрке) остается на прежних кочевьях в Северном Прикаспии. Именно с ними и сносились астраханские воеводы, сообщая им о пограничных стычках и т. д. Наступило сравнительно мирное время, хотя мелкие конфликты с соседями не прекращались. Подобная расстановка торгутских улусов была связана, в первую очередь, с урегулированием их отношений с чакарскими тайшами и наметившейся консолидацией в ойратском обществе накануне монголо-ойратского съезда 1640 г.

\section{3. Джунгарский съезд 1640 г. и его политическое значение}

К концу 30-х годов XVII века в результате разделения и расселения ойратские кочевья занимали обширное пространство, простиравшееся от эмбо-яицкого междуречья до алтайских хребтов. Между ойратскими группировками установились мирные отношения, и недавние противники собрались на общий съезд в 1640 г., где был принят кодекс монголо-ойратских законов «Великое уложение» («Йэкэ

${ }^{115}$ МИРМО. М., 1974. С. 180-181.

${ }^{116}$ Богоявленский С.К. Указ. соч. С. 77-78. 
цааджин бичиг»). По мнению И.Я. Златкина, «в их основе лежала три цели: урегулировать внутренние взаимоотношения феодалов и исключить возможность междоусобной борьбы; обеспечить объединение сил и взаимную помощь в борьбе против возможной опасности; укрепить феодальные порядки и власть ханов и князей над остальным населением» ${ }^{117}$. В.П. Санчиров считает, что главной причиной, побудившей монгольских и ойратских князей собраться на съезд 1640 г., была не «вполне возможная», а реальная внешняя опасность ${ }^{118}$.

Угроза монгольскому миру возникла на Дальнем Востоке, и политическая обстановка там развивалась следующим образом. В начале XVII в. на востоке Монголии произошло резкое усиление маньчжурской агрессии под властью Нурхаци (1559-1626). Созданное им военно-феодальное государство в течение 20-30-х годов подчинило одно за другим княжества Южной Монголии. Одержав победу над последним номинальным всемонгольским ханом Лигданом, маньчжурский хан Абахай (1626-1643) в 1636 г. провозгласил себя императором и принял для своей династии новое название Цин. Подчинившиеся ему южномонгольские князья собрались на свой съезд и преподнесли ему титул «всемонгольского хана», что позволило в дальнейшем цинским правителям претендовать на остальные независимые княжества Северной Монголии (Халхи)

Несмотря на географическую удаленность кочевий ойратов, они обладали вполне сильной армией, которая могла в случае маньчжурского вторжения в Халху оказать действенную военную помощь монголам. Поэтому монгольские князья, в том числе и самые могущественные правители Северной Монголии: Дзасагту-хан, Тушэту-хан и Цэцэн-хан, не имевшие возможности самостоятельно противостоять маньчжурам, решили пойти на союз с ойратами. Политический компромисс между ними базировался на социально-экономической общности и этнической близости двух родственных народов ${ }^{119}$.

117 Златкин И.Я. Указ. соч. С. 113.

118 Санчиров В.П. Историческое значение Джунгарского съезда монгольских и ойратских князей 1640 года // Вестник Калмыцкого института гуманитарных исследований РАН. Элиста, 2009. № 2. С. 15.

${ }^{119}$ Санчиров В.П. Историческое значение... С. 16.
В исторической литературе существует распространенное мнение, что съезд был созван по инициативе джунгарского Батурахунтайджи в его владениях ${ }^{120}$. По мнению В.П. Санчирова, инициатива проведения съезда исходила от правителей трех самых крупных ханств Северной Монголии, так как имена двух из них, Дзасагту-хана Субуди и Тушэту-хана Гомбодорджи, первыми значатся в списке участников съезда. Очевидно так же и то, что правители Халхи, опасаясь испортить «дружественные) отношения с маньчжурским императором, не рискнули проводить съезд в своих владениях, а провели его на территории Джунгарии ${ }^{121}$. Однако, по нашему мнению, идейным вдохновителем мероприятия являлось все-таки буддийское духовенство во главе с Индзан-хутугтой. Собственно имена буддийских иерархов, таких как Акшоби Манджушири и Амуга-шиди, идут в преамбуле «Великого уложения» перед списком монгольских и ойратских феодалов, а Индзан-хутугта фигурирует как главный гарант съезда ${ }^{122}$. Это подтверждает и автор «Биографии Зая-пандиты», указывая на прибытие на этот съезд Индзан-хутугты. Все это еще раз показывает на рост влияния и вмешательство буддийских лам в политическую жизнь монгольского и ойратского обществ ${ }^{123}$. Как итог проведенной миссионерской работы среди ойратов можно рассматривать и съезд буддийского духовенства, проведенного летом 1639 г. в урочище Усун-Хаджир на реке Буланай. Именно здесь он пожаловал Зая-пандите титул Рабджамбы-хутугты ${ }^{124}$.

5 сентября 1640 г. начал свою работу монголо-ойратский съезд. И.Я. Златкин в своей работе прямо указывает на руководящую роль Батура-хунтайджи в подготовке текста монголо-ойратских законов и созыве съезда, который, по его мнению, мог проходить только в Джунгарии, в кочевьях хунтайджи и его союзника хошутского Очирту ${ }^{125}$. По мнению В.П. Санчирова, который основывается на ана-

120 Златкин И.Я. Указ. соч. С. 113; Их Цааз («Великое уложение»). Памятник монгольского феодального права XVII в. М., 1981. С. 3.

${ }^{121}$ Санчиров В.П. Историческое значение... С. 16.

122 РГАДА. Ф. 119. Оп. 1. 1640 г. Д. 2. Л. $10 б$.

${ }^{123}$ Санчиров В.П. Историческое значение... С. 17.

${ }^{124}$ Норбо ШІ. Указ. соч. С. 42-43, 170-171.

125 Златкин И.Я. Указ. соч. С. 116. 
лизе «статейного списка) посольства М. Ремезова к джунгарам, место проведения съезда находилось все-таки не в улусе Батура-хунтайджи, так как тот отсутствовал у себя в улусе и вернулся домой только в октябре ${ }^{126}$. Основываясь на показаниях этого же источника, японская исследовательница Джунко Мияваки ошибочно считает, что съезд «был созван монгольским правителем Дзасагту-ханом где-то в Халхе» ${ }^{127}$. По мнению монгольского ученого Далая, съезд проходил во владении тайши Очирту, поскольку только хошутские правители по своему происхождению считались выходцами из «золотого рода» Борджигид, возводившими свое происхождение к младшему брату Чингис-хана, Хабуту-Хасару ${ }^{128}$

Что касается конкретного места проведения съезда, то большинство исследователей вслед за Ю. Лыткиным, который основывался на сведениях калмыцкого старца Бебе, полагают, что это было урочище Шибегийн Улан Бура в районе Тарбагатайских гор ${ }^{129}$. Ш. Норбо, ссылаясь на неизвестные «исторические документы», утверждает, что «Великое Уложение» было принято в местности Маниту-гатулган большой переправе через реку Иртыш и к северу от озера Зайсан ${ }^{130}$.

В списке участников съезда, помимо представителей духовенства, фигурировали 28 наиболее влиятельных монгольских и ойратских феодалов. Из Монголии прибыли: Эрдени Дзасагту-хан, Тушетухан, Эрдени хун-тайша и Далай-Хунг (сыновья Шолой Цецен-хана), Хунг-нойон (сын Туменгийна Сайн-нойона) и Мерген-нойон (сын Абугу). Торгутов представляли Цецен-нойон (сын Буры ${ }^{131}$ ), глава си-

${ }^{126}$ Санчиров В.П. Историческое значение... С. 16-17.

${ }^{127}$ Miyawaki, Junko. Internal Rivalries in the Four Oyirad Tribal Federation // Ethnohistorische Wege und Lehrjahre eines Philosophen: Festschrift für Lawrence Krader zum 75. Geburtstag. Frankfurt am Main u.a.: Lang, 1995. P. 228.

${ }_{128}$ Далай Ч. Ойрад Монголын түҮх. ТэргүҮн боть. Хоёрдахь Хэвлэл. Улаанбаатар, 2006. Х. 80; Златкин И.Я. Зая-Пандита как политический деятель // 320 лет старокалмыцкой письменности. Материалы научной сессии. Элиста, 1970. C. 28 .

129 Лыткин Ю.С. Материалы для истории ойратов // Лунный свет: Калмыцкие историко-литературные памятники / сост., ред., предисл., коммент. А.В. Бадмаева. Элиста, 2003. С. 461.

${ }^{130}$ Норбо Ш. Указ. соч. С. 205.

131 Двоюродный брат Хо-Урлюка. бирской группы, западных - Хо-Урлюк, Дайчин и Елден. От хошутов выступали Гуши, Очирту и Кунделен-Убаши. Джунгарскую группировку представляли Батур-хунтайджи с младшими братьями, ЧокурУбаши и Мерген-Дайчином, и старшим сыном Цеценом. От дербетов прибыли сыновья умершего в 1637 г. Далай-Батура, Тенгерийн-Тойн (Даян-Омбо) и Дайчин-Хошучи, а также брат покойного, Бо-Елден ${ }^{132}$. По сообщению автора «Биографии Зая-пандиты», на съезде «первенствовали Дзасагту-хан и два ойратских тайджи» ${ }^{133}$, под которыми, скорее всего, имеются в виду цоросский Батур-хунтайджи и хошутский тайша Очирту

Джунгарский съезд явился одним из наиболее значительных событий в политической жизни монголов и ойратов, а перед его участниками стояло несколько главных задач, требующих скорейшего решения.

Во-первых, официально провозгласить буддизм государственной религией монголов и ойратов, и, как основное его направление, поддержать «желтошапочную» школу Гелугn в религиозной борьбе против «красношапочной» школы Карма Кагью и ее сторонников в лице южных монголов и халхаского Цогту-тайши. Ойратские владельцы, в частности, решили признать Далай-ламу как первосвященника и почитать его тибетский род, а его представителей не удерживать насильно в своих улусах ${ }^{134}$.

Во-вторых, съезд выработал и утвердил общий законодательный кодекс Ике Цааджи («Великое Уложение»). Основная часть законов была направлена на кодифицирование норм обычного права в интересах знати и юридическое закрепление сложившихся у монголов и ойратов общественно-экономических отношений ${ }^{135}$.

B-третьих, юридически закрепить «статус-кво» как между ойратскими группировками, так и в целом между ойратами и восточными монголами. По мнению Н.Н. Поппе, этот исторический документ являлся своего рода «первым в истории не только монголов и калмыков, но вообще в истории народов всего мира пактом о ненападении

132 РГАДА. Ф. 119. Оп. 1. 1640 г. Д. 2. Л. 2; Голстунский К.Ф. Указ. соч. C. $96-102$.

\footnotetext{
${ }^{133}$ Норбо НI. Указ. соч. С. 44.

${ }^{134}$ Габан Шараб. Указ. соч. Элиста, 2003. С. 91.

${ }_{135}$ Санчиров В.П. Историческое значение... С. 18.
} 
и о наказании агрессии ${ }^{136}$. В случае нападения агрессора на одно из монгольских или ойратских владений все князья должны были объединиться и наказать нарушителя мира, а все его имущество подлежало конфискации ${ }^{137}$. Именно этот пункт Уложения в дальнейшем пришлось чаще всего применять на практике, поскольку съезд так и не смог окончательно урегулировать старые конфликты.

Можно предположить, что за период подготовки к съезду буддийское духовенство сумело подготовить и выверить текст «Великого Уложения〉, внеся туда все пожелания и замечания монгольских и ойратских феодалов. Калмыцкий текст «Великого Уложения» впоследствии сохранился только у волжских калмыков ${ }^{138}$.

Для укрепления связей многие ойратские тайши заключили между собой династические браки. Например, Дайчин женил своего третьего сына Мончака (Пунцуга) на дочери от старшей супруги джунгарского Батура-хунтайджи. Молодожены прожили в Джунгарии примерно до конца 1640-х гг, и именно здесь в 1642 г. у них родился первенец - Аюка. Будущий калмыцкий хан воспитывался у родственников по материнской линии до тех пор, пока в 1654 г., возвращаясь из второго своего паломничества в Тибет, Дайчин не привез внука на Волгу.

Как отмечает В.П. Санчиров, мирное объединительное направление деятельности Джунгарского съезда полностью соответствовало национальным интересам обоих монгольских народов, а его решения могли стать прочной основой для укрепления политической стабильности $^{139}$. Однако через несколько лет ойратских феодалов вновь захлестнули внутренние распри, источник которых лежал во внутрисемейных конфликтах. Что касается отношений монгольских и ойратских феодалов, то они также имели печальные последствия. Спустя полвека ожесточенные монголо-ойратские войны привели к потере независимости Северной Монголии (Халхи) и вхождения ее в состав Цинской империи.

${ }^{136}$ Попnе H.Н. Роль Зая-пандиты в культурной истории монгольских народов // Калмыщко-ойратский сборник / Под ред. А.Э. Борманжинова И. Крюгера. Филадельфия, 1966. С. 61

${ }^{137}$ Голстунский К. Ф. Монголо-ойратские законы 1640 г., дополнительные указы Галдан-хун-тайджия и законы, составленные для волжских калмыков при калмыцком хане Дондук-Даши. СПб., 1880. С. 36.

${ }^{138}$ РГАДА. Ф. 119. Оп. 1. 1640 г. Д. 1-2.

${ }^{139}$ Санчиров В.П. Историческое значение... С. 19.
Глава 3.

ПОЛИТИЧЕСКИЙ КРИЗИС

В КАЛМЫЦКОМ ОБЩЕСТВЕ

\section{1. Взаимоотношения калмыков с соседними народами в начале 1640-х гг.}

Консолидация ойратского сообщества, последовавшая после съезда 1640 г., привела к временному отдалению калмыцких улусов от астраханского направления. Но в Астрахани местные власти продолжали следить за перемещениями калмыков в степях Северного Прикаспия. В ноябре 1640 г. в ответ на приезд калмыцкого посланца Бияры астраханский воевода Н.И. Одоевский отправил в калмыцкие улусы боярского сына А. Казанцева и толмача Е. Локтева. Поскольку к декабрю Казанцев не вернулся из калмыцких улусов, то воеводы отправили к Яику разведывательный отряд (4 стрельцов и 20 служилых татар) под началом боярского сына И. Булгакова и едисанского мирзы С. Абдулова. 31 декабря Булгаков вернулся в Астрахань со встретившимися ему по дороге торговыми калмыками, которые пригнали в город на продажу 200 лошадей и 200 голов скота. Местные власти разрешили им торговать в районе реки Болда, обеспечив надежной стрелецкой охраной. После завершения торговли калмыков под охраной стрельцов сопроводили обратно до Яика. В январе 1641 г. некий едисанин, прибывший в Астрахань из калмыцких улусов, сообщал, что улусы Лузана и Сюнке кочуют в междуречье Яика и Эмбы, в районе урочища Оилкарагол, улус Дайчина располагался в 20 днях пути от них по направлению к Бухаре, алтыульцы - за Эмбой на Каракумских песках ${ }^{1}$.

Как выяснилось позже, Казанцев с товарищами после 5-недельного пути в калмыцкие улусы остановились у алтыульских мирз в

${ }^{1}$ РГАДА. Ф. 119. Оп. 1. 1641 г. Д. 1. Л. 1-4. 
верховьях Эмбы. По наблюдениям русского посланца, алтыульцев насчитывалось примерно 600 человек. Казанцев агитировал алтыульских татар вернуться обратно под Астрахань, обещая «государево прощение». Одной из главных причин своего ухода на Эмбу алтыульцы называли притеснение их со стороны едисанского князя Каная Тинбаева. По словам алтыульских мирз, они были не прочь вернуться и расположиться кочевьем где-нибудь за рекой Бузан, но, как сами признавались, «ныне живут у калмыцких людей за большим береженьем» ${ }^{2}$.

На третий день Казанцев отправился вверх по Эмбе уже в улус тайши Сюнке. Посланец передал тайше «государев лист», в котором были представлены старые требования: предоставление аманатов, запрещение калмыкам нападать на царские города и подданных, уход на дальние кочевья и т. д. Сюнке сразу же обозначил Казанцеву свою позицию: калмыки кочуют в степи («п своей воле), а с астраханцами только желают «быть в миру и в совете». Первоначально калмыцкие тайши планировали на зиму откочевать к Яику, но все же опасались, поскольку в том районе они часто подвергались башкирским набегам ${ }^{3}$.

В улусе Сюнке Казанцев узнал, что у тайши в качестве почетного гостя находится беглый султан Абу-л-Гази (в русских источниках упоминается как Абалкасим), впоследствии ставшего хивинским ханом, автор исторических летописей по истории Средней Азии. В начале XVII в. Хивинское ханство было охвачено жестокой борьбой, в которую были вовлечены широкие слои населения - узбеки и туркмены. В результате так называемого «Хорасанского мятежа» у хивинского хана Исфендияра испортились отношения с Персией. Всю вину за этот мятеж - нападение и захват Нисы и Дуруна - хан Исфендияр переложил на своего брата Абу-л-Гази и в 1630 г. отправил его в качестве заложника к персидскому шаху. Персидские власти поселили Абу-л-Гази в Исфагане, в крепости Табарек, где он прожил почти 10 лет. После бегства из ссылки и скитаний в Балхане султан прибыл к

${ }^{2}$ РГАДА. Ф. 119. Оп. 1. 1641 г. Д. 1. Л. 9-12; Пальлов Н.Н. Материалы по истории калмыцкого народа за период пребывания в пределах России. Элиста, 2007. С. 403.

${ }^{3}$ РГАДА. Ф. 119. Оп. 1. 1641 г. Д. 1. Л. 13-15. калмыкам и прожил у них около года 4 . По мнению Н.Н. Пальмова, Абу-л-Гази, благодаря своим лингвистическим способностям, овладел калмыцким языком, и, несомненно, его приезд к тайшам преследовал определенные политические цели ${ }^{5}$.

Не владевший письменной грамотой Сюнке предложил присутствовавшему на переговорах султану прочесть «государев лист» на старописьменном татарском языке. Абу-л-Гази в разговоре с Казанцевым поведал, что прибыл сюда из Персии, а свое решение приехать именно к калмыкам он объяснил тем, что «юргенские цари с ними, калмыцкие тайши, одной природы - Чингиса Хана дети». Сюнке пообещал султану оказать военную помощь в борьбе против его брата Исфендияра, но при этом не преминул подчеркнуть, что без указа отсутствовавшего на тот момент Дайчина не смеет самостоятельно принимать решение, поскольку в это время калмыки официально находились с хивинским ханом «в миру и в совете, и в ссылке) 6 .

В целом ойратские тайши к началу 40-х гг. XVII в. оказывали уже значительное политическое влияние на ход событий в среднеазиатском регионе. Чакарцы и джунгары в полной мере воздействовали на казахов и Туркестан. В Ургенче правил ставленник торгутских тайшей - алтыульский мирза Айтек. Хивинский хан Исфендияр, который был осведомлен о нахождении своего брата у калмыков, регулярно отправлял к торгутским тайшам посольства с богатыми дарами, прося выдачи ему Абу-л-Гази, чтобы, как отмечали русские посланцы, «иво за недружбу убить». Айтек, находившийся в то время в оппозиции хивинскому хану, был также заинтересован в передаче лично ему Абу-л-Гази, но только с иной с целью - поставить его в Ургенче «на царство». Калмыцкие тайши, не заинтересованные в развязывании полномасштабной династической войны в Средней Азии, пытались примирить родных братьев ${ }^{7}$. Более целесообразным для них виделось

\footnotetext{
${ }^{4}$ Каррыев А., Моикова В.Г., Насонов А.Н., Якубовский А.Ю. Очерки из истории туркменского народа и Туркменистана в VIII-XIX вв. Ашхабад, 1954. C. 221-223.

${ }^{5}$ Пальмов Н.Н. Указ. соч. С. 397-398.

${ }^{6}$ РГАДА. Ф. 119. Оп. 1. 1641 г. Д. 1. Л. 16; Пальмов Н.Н. Указ. соч. C. 404.

${ }^{7}$ РГАДА. Ф. 119. Оп. 1. 1641 г. Д. 1. Л. 17; Пальмов Н.Н. Указ. соч C. 404-405.
} 
использование экономических возможностей этого региона, нежели участие в династических войнах. Обращает на себя внимание и то, насколько уважительным было отношение тайшей к среднеазиатским «(чингизидам».

Но Абу-л-Гази, как отмечал Казанцев, упорно продолжал просить Сюнке об оказании ему военной помощи против брата. Тайша в какой-то мере поддался уговорам султана и даже возглавил в так называемом “хивинском походе) небольшой отряд численностью в 550 калмыков и алтыульцев. Русского посла и стрельцов, за исключением толмача, тайша также взял с собой в поход. На просьбы Казанцева отпустить их в Астрахань Сюнке отвечал, что по древней калмыцкой традиции во время войны калмыки во избежание утечки информации о предстоящих военных действиях брали с собой в поход всех иностранных посланников, находившихся в улусах. Но, как показали дальнейшие события, 5-недельный поход носил больше демонстрационный характер, так как столь скромными силами активно действовать против Хивинского ханства было невозможно. Действительно, взяв по дороге ясак с мангышлакских туркменов, Сюнке изменил направление похода с Хивы на Балхинское ханство, в то время находившееся в состоянии войны с калмыками. Но в пустыне отряд «извела безводица», и тайша приказал повернуть обратно в улусы ${ }^{8}$.

В дальнейшем судьба была более благосклонна к Абу-л-Гази. Приаральские узбеки, не признававшие власть хивинского хана Исфендияра, привезли калмыцким тайшам богатые дары и увезли к себе султана9. Поскольку в то время Ургенч представлял собой заброшенный город, то Абу-л-Гази первое время находился в дельте Аму-Дарьи, где еще в 1627 г. собралось до 3 тыс. узбекских шатров. При поддержке узбеков Абу-л-Гази вступает уже в открытую борьбу с туркменской знатью, на которую опирался Исфендияр. Через год после смерти Исфендияра в 1643 г. узбеки провозгласили Абу-л-Гази

8 РГАДА. Ф. 119. Оп. 1. 1641 г. Д. 1. Л. 18-19; Пальмов Н.Н. Указ. соч. C. 404-405.

${ }^{9}$ Материалы по истории туркмен и Туркмении. Т. II. XVI-XIX вв. Иранские, бухарские и хивинские источники / Под ред. В.В. Струве, А.К. Боровкова, А.А. Ромаскевича и П.П. Иванова. М.-Л., 1938. С. 327. ханом, но из-за противодействия туркменской знати хивинским правителем он смог стать только в 1645 г.

После возвращения из похода А. Казанцев в сопровождении Сюнке отправился в улус Лузана. В разговоре с братом Сюнке заявил о своем намерении отправить в Астрахань с русским посланцем своего человека, предложив Лузану последовать его примеру. Но тот отказался, так как уже собирался отправить совместное с Дайчином посольство в Астрахань, когда «конские и животинные стада ожиреют $\rangle^{10}$. Как видим, тайши пытались координировать свои действия в по отношению к русским властям, поскольку ситуация, складывавшаяся в Северном Прикаспии, требовала от них выработки общего плана действий под началом старшего брата. Но так как Дайчина все еще не было в улусах, некоторые из его братьев пытались самостоятельно принять политическое решение по астраханскому направлению.

Весной 1641 г. калмыцкие улусы подверглись нападению войск князя Елантуша из Балха, в результате которого калмыкам был нанесен ощутимый урон. По-видимому, это был ответ балхинцев на поход Сюнке. Тогда же снова напомнили о себе чакарские тайши, прислав очередное посольство к торгутским тайшам. На этот раз дербетский Дайчин-Хошучи и хошутский Гуши требовали выдачи их «недругов» - тайшу Батура и мирзу Салтаная. В случае отказа чакарцы угрожали войной, но торгутские тайши передали им, что их «не боятца», поскольку находятся в «ссылке и в дружбе» с Астраханью, и они «надежны на государеву милость». В доказательство чакарским послам торгуты представили Казанцева ${ }^{11}$. Но все это выглядело блефом, так как отношения торгутских тайшей с Астраханью окончательно еще не были урегулированы.

В то же время с севера калмыки продолжали подвергаться башкирским набегам, которые наносили существенный урон пограничным улусам. Например, один из таких набегов возглавлял некий Елай-ага, чьи люди убили 20 калмыков, в другой раз уже его старший брат на реке Темир убил тайшу Бурвея и 9 калмыков. По улусам про-

${ }^{10}$ РГАДА. Ф. 119. Оп. 1. 1641 г. Д. 1. Л. 19.

${ }^{11}$ РГАДА. Ф. 119. Оп. 1. 1641 г. Д. 1. Л. 20. 
несся тревожный слух о подготовке нового и более массового вторжения - в 5 тыс. башкир. Тайши стали срочно формировать совместные мобильные отряды для отражения набегов северных соседей, а свои улусы отправили в безопасное место к Яику, в урочище Елек. По этой причине Сюнке еще на некоторое время задержал у себя русских посланцев, выговаривая при этом Казанцеву, что, мол, призываете калмыков «быть в послушании», а башкиры, государевы люди, нападают на их улусы: «Дурно и войну почали башкиры, а не мы». Казанцеву ничего не оставалось, кроме как ответить тайше: «Башкиры приходят без государева указа украдом» ${ }^{12}$.

Сложившаяся ситуация заставила Сюнке поскорее отправить Казанцева, а с ним и своего посланца в Астрахань, куда они благополучно прибыли 30 июня 1641 г. В общей сложности миссия Казанцева в калмыцких улусах продлилась около полугода. Калмыцкого посланца астраханские власти поселили за городом, в Вознесеновской слободе. На встрече с воеводами, состоявшейся в «съезжей избе», он предъявил им письмо Сюнке, написанное на фарси (персидском), видимо, оно было составлено с помощью Абу-л-Гази. Тайша просил местные власти предоставить калмыкам возможность торговать под Астраханью, куда он планировал уже осенью пригнать для продажи лошадей и скот. Также он просил прислать к тайшам боярского сына и толмача для продолжения переговорного процесса ${ }^{13}$.

Но самое интересное - это предложение Сюнке астраханским властям по вопросу разграничения русско-калмыцких земель: «Потом писали вы к нам в листу своем, чтоб нам кочевать от Астрахани в дальних кочевьях. И ныне слово то есть: Волга - место ваше, а Яик кочевные места наши. И будет учнут кочевать на ваших местах наши люди у Волги, и вам бы их отгонять; а будет которые ваши люди учнут кочевать по Яику, и мы также отгонять их станем» ${ }^{14}$.

В октябре 1641 г. в Астрахань от Сюнке прибыло торговое представительство (100 человек) во главе с послом Бюрчи, пригнавшее на продажу 1200 лошадей. Местная администрация разрешила калмы-

${ }^{12}$ РГАДА. Ф. 119. Оп. 1. 1641 г. Д. 1. Л. 19, 21-22, 29.

${ }^{13}$ Пальмов Н.Н. Указ. соч. С. 409.

${ }^{14}$ РГАДА. Ф. 119. Оп. 1. 1641 г. Д. 1. Л. 22-25; Богоявленский С.К. Указ. соч. С. 78 . кам торговать за городом, поставив в охранение «калмыцкого базара») 300 стрельцов. В том же месяце большое представительство (300 торговых людей с 3 тыс. лошадей и 10 тыс. коров и овец) прибыло и от тайши Санжина, а его посланник Дарын 31 октября был принят астраханскими властями. В охранение к ним было приставлено 500 стрельцов. Оба посланника привезли подарки царю и просили предоставить им «повольный торг». Власти благосклонно отнеслись к просьбам тайшей, разрешив продажу местному населению калмыцкого скота ${ }^{15}$.

Обратно с калмыками астраханцы отправили к тайшам «для проведыванья〉 боярского сына Д. Пшагина, толмача В. Зиновьева. Им предстояло выяснить примерную численность калмыков и разузнать о планах тайшей относительно астраханского направления на ближайший осенне-весенний период ${ }^{16}$.

Добравшись до калмыцких кочевий, посланцы остановились в улусе Лузана, который довольно приветливо встретил гостей. Он заверил их в том, что «у великого государя в послушанье быти рад и учнет посылати в... государеву отчину в Астарахань послов своих», то есть, несмотря на свою жесткую позицию по вопросу принятия московского подданства, Лузан был не против находиться с русскими «в миру и в совете». Тайша не отпустил Пшагина к братьям, отправив к ним лишь толмача с «государевым листом», это стало для тайшей сигналом к отправке в Астрахань новых своих торговых представителей ${ }^{17}$. Лузан своим поступком ясно дал понять астраханцам, кто на тот момент являлся главным среди тайшей и с кем нужно вести переговоры. Отсутствие в Северном Прикаспии отца Хо-Урлюка и старшего брата Дайчина позволило ему в отношениях с русской властью захватить инициативу в свои руки.

В эти годы русско-калмыцкая торговля заметно активизировалась. Уже в декабре 1641 г. в Астрахань прибыло очередное торговое представительство (400 торговцев с 2 тыс. голов скота и лошадей) от Лузана (представитель Бердыш) и Сюнке (представитель Сенгерчин). В январе 1642 г. прибыли 60 торговых людей от тайши Санжина

\footnotetext{
${ }^{15}$ РГАДА. Ф. 127. Оп. 1. 1641 г. Д. 1. Л. 271-275.

${ }^{16}$ РГАДА. Ф. 127. Оп. 1. 1642 г. Д. 1. Л. 16-17.

${ }^{17}$ РГАДА. Ф. 127. Оп. 1. 1642 г. Д. 1. Л. 107-108.
} 
(представитель Нима-Демчин). Но когда в феврале приехали еще 150 торговых людей от Сюнке (представитель Сыргенчек) и пригнали на продажу 700 лошадей и более 1 тыс. коров и овец, астраханские воеводы уже потребовали у калмыцкого представителя немедленного возвращения русских посланцев из улуса Лузана ${ }^{18}$.

Действительно, в марте русские посланцы, собрав достаточно информации о положении дел в калмыцких улусах, вернулись в Астрахань. Им, в частности, удалось узнать, что тайши планировали совершить зимний поход против ногайцев, кочевавших на правом берегу Волги, но потом они отказались от задуманного, так как астраханский гарнизон был заметно усилен. Там же они узнали о прошлогоднем ответном набеге калмыков на Уфимский уезд, в ходе которого в плен было захвачено 300 человек. Тайши не раз жаловались русским посланцам на башкирские набеги, от которых калмыки терпели большой урон. Они даже планировали направить своих послов в Москву с официальной жалобой на уфимцев. Пшагин также оказался свидетелем приезда к Лузану посланцев от хошутов, тайши которых с улусами кочевали между Бухарой и сибирскими городами. В случае конфликта с русскими хошуты предлагали торгутам проводить совместные военные акции против царских городов ${ }^{19}$. Это указывает на то, что отношения между ойратами действительно улучшились после съезда 1640 г. Очень тесные связи у Лузана налаживались и с хивинским ханом Исфендияром, который прислал к нему туркменских посланцев ${ }^{20}$.

Перед отъездом астраханцев Лузан собственноручно составил письмо, которое передал через них воеводам. Но получив его в Астрахани, местные власти не смогли даже определить, на каком языке оно было написано, не смогли им помочь и приглашенные для его прочтения носители разных языков. Вскоре письмо было отправлено в Москву, но и здесь, несмотря на то, что в Посольском приказе имелись достаточно квалифицированные специалисты, не сумев перевести текст письма, резюмировали: (калмыцкой лист писан мунгальским письмом, а по мунгальски у них никто не умеет, да и наперед сего на

${ }^{18}$ РГАДА. Ф. 127. Оп. 1. 1642 г. Д. 1. Л. 21-23, 64-66, 105-106.

${ }^{19}$ РГАДА. Ф. 127. Оп. 1. 1642 г. Д. 1. Л. 109-110.

${ }^{20}$ РГАДА. Ф. 127. Оп. 1. 1642 г. Д. 1. Л. 202-203. такое письмо переводчиков не бывало» ${ }^{21}$. Сотрудникам приказа уже с начала XVII столетия были известны письма Алтын-хана, написанные на старописьменном монгольском языке.

Ценность этого краткого документа заключается в том, что из известных на сегодня науке калмыцких писем на старописьменном монгольском языке это самое раннее. Обнаружено оно было в Ногайском фонде, вероятно, поэтому монголоведы не могли выявить его раньше. Приводим современный перевод 22 письма Лузана, адресованного царю Михаилу Федоровичу:

Ом сувасти сиддам ${ }^{23}$

Здравы ли Великий бельіи хан князь и бояре со всех земель? Мы здесь во здравии находимся. Мы говорим: «Если держсать мир, то волосы белеют, а если держать железо, то кости белеют». Поэтому посылал я [к вам] торговать беспрерывно и летом и зимой. Говорят, прогнали их со словами: "Так много раз приезжсате для торговли? ». Ты рассуди, что хороио и что плохо - вражда или торговля. Скажи наиу вину. Зачем многословить ${ }^{24}$ ?

Изучая текст данного письма, можно представить, каким был язык калмыков в XVII в. По манере изложения оно схоже с аналогичными калмыцкими письмами XVIII в.: язык документа сжатый, ясный, точный с элементами образности и, несмотря на свою лаконичность, полон правды жизни, динамизма и напряженности ${ }^{25}$. Это подтверждает и приведенная в письме калмыцкая пословица, отражающая суровую действительность, в которой пребывало ойратское обшество в XVII столетии.

Лузан был единственным из шести братьев, кто владел письменной грамотой. Это было связано с событиями начала XVII в., когда ойратские тайши вслед за монгольскими правителями официально приняли буддизм. Первенствующий тайша ойратского союза хошутский Байбагас под влиянием буддийского вероучения решил принять

\footnotetext{
${ }^{21}$ РГАДА. Ф. 127. Оп. 1. 1642 г. Д. 1. Л. 111-113.

22 Перевод выполнил Нацагдорж Цонгоол Батцэнгэлийн.

${ }^{23}$ Популярное буддийское благопожелание.

${ }^{24}$ РГАДА. Ф. 127. Оп. 1. 1641 г. Д. 1. Л. 112.

${ }^{25}$ Сусеева Д.А. Письма хана Аюки и его современников (1714-1724 гг.): опыт лингвосоциологического исследования. Элиста, 2003. С. 15.
} 
монашеский сан, чем вызвал недоумение у своих соратников. Чтобы не допустить ухода в монашество столь уважаемого и авторитетного ойратского лидера, каждый из его близких соратников отдал по одному своему сыну в послушники-банди для принятия духовного звания. Например, дербетский Далай-Батур отдал сына Тойна (Даян-Омбо), цоросский Хара-Хула - сына Чокур-Убаши, торгутский Хо-Урлюк - сына Лузана. Хошутский Байбагас вместо сына отправил учиться в Тибет усыновленного родственника, будущего Зая-пандиту ${ }^{26}$. Так, благодаря буддийским учителям Лузан и овладел старописьменным монгольским языком, хотя буддийским монахом он так и не стал.

Официальная переписка между тайшами и русской администрацией велась в основном на старописьменном татарском, реже - на персидском (фарси) языках. Интересно, что татарский язык в то время был своего рода языком международного общения, на нем, в том числе, общались между собой калмыки и русские. Центральные и местные органы власти России выступали против того, чтобы тайши писали им письма на калмыцком или монгольском языках. Только в 1679 г. Посольский приказ обзавелся собственным штатом специалистов (толмачей) по переводу писем с монгольского и калмыцкого языков $^{27}$. В дальнейшем исследование письменности и истории калмыцкого народа дали в России мощный толчок развитию такой важной области ориенталистики, как научное монголоведение.

\section{2. Ситуация в калмыцком обществе в 1642-1643 гг.}

Перед отъездом в Джунгарию Дайчин неоднократно предостерегал своих братьев и сыновей, «чтоб они под Астарахань войною не ходили и людей своих не посылали и 3 государевыми людьми не ссорилися». Этой же весной тайши Лузан, Санжин и Сюнке планировали совершить поход на Уфимский уезд, поскольку башкиры продолжали угонять лошадей у калмыков. Часть торгутских улусов попрежнему находилась на дальних кочевьях. Известно, например, что

${ }^{26}$ Габан Шараб. Указ. соч. С. 91.

${ }^{27}$ Котвич B.Л. Указ. соч. С. 1206. улусы тайшей Хо-Урлюка и Елдена располагались на реке Тургай ${ }^{28}$. Эта группа торгутских улусов имела контакты с сибирскими городами, правда, не всегда они носили мирный характер. И.Е. Фишер указывает на события, происходившие в 1641 г., когда сводный военный отряд тобольцев и тюменцев предпринял поход против Хо-Урлюка и Елдена. Не обнаружив калмыков, отряд повернул обратно. Но если тюменцы благополучно вернулись домой, то тобольчане на обратном пути подверглись нападению 700 калмыков ${ }^{29}$.

Дайчин находился в Джунгарии у своего свата и одновременно зятя - Батура-хунтайджи, который пока не отпускал его от себя, поскольку владел информацией о готовяшемся на него покушении: «Байбагишевы дети на дороге ево, Дайчин тайшу, хотят убить» ${ }^{30}$. Видимо, это было связано с прошлым торгутского тайши, когда он входил в группировку своего тестя Чокура - главного противника Байбагаса в междоусобной войне. Сыновья Байбагаса - тайша Очирту, союзник джунгарского хунтайджи, по материнской линии приходился Дайчину двоюродным братом, а тайша Аблай - племянником. Но кто из них реально угрожал жизни Дайчина, и существовала ли такая угроза в действительности, остается неизвестным.

В Джунгарии торгутский тайша, по-видимому, остановился после своего участия в совместной военной экспедиции ойратов в Тибете. В 1637 г. объединенное ойратское войско под командованием хошутского Гуши в районе озера Кукунор атаковало лагерь монгольского Цогту и разгромило его. Религиозная война в Тибете закончилась в начале 1642 г. победой объединенных сил ойратов и приходом к власти сторонников «желтошапочной») школы Гелугпа и Далай-Ламы V (Нгаванг Лобсан Гьяцо, 1617-1682 гг.) $)^{31}$.

Где именно в Джунгарии проживал Дайчин со своими людьми, сказать сложно. На этот счет есть только отписка томского воеводы

${ }^{28}$ РГАДА. Ф. 127. Оп. 1. 1642 г. Д. 1. Л. 201.

${ }^{29}$ Фишер И.Е. Сибирская история с самого открытия Сибири до завоевания сей земли российским оружием. СПб., 1774. С. 417.

${ }^{30}$ РГАДА. Ф. 127. Оп. 1. 1642 г. Д. 1. Л. 202.

${ }^{31}$ История Калмыкии... Т. 1. С. 295-299; Китинов Б.У. Священный Тибет и воинственная степь: буддизм у ойратов (XIII-XVII вв.). M., 2004. C. $96-97$. 
С.В. Клубкова-Мосальского в Сибирский приказ о пребывании тарского казака Емели Вершинина в улусе торгутского тайши Дайчина. Согласно его сведениям, Дайчин еще в сентябре 1639 г. отправлял своих посланцев в Томск с просьбой принять его «под высокую царскую руку» и разрешить его людям вести под городом торговлю скотом и пушниной. В ответ томские власти отправили к тайше в Джунгарию казака Е. Вершинина, бухарца Ермомета Шагалакова и казанца Алыбая с уведомлением о необходимости дать новую шерть, гарантирующую государевым людям в Томском уезде безопасность от калмыков. Но вернулся из калмыцкого улуса в Томск только Вершинин, и то через три года, в сентябре 1642 г. Из расспросов казака стало известно, что Дайчин насильно удерживал его в улусе 2 года, после чего отправлял со своими торговыми людьми в пограничный китайский город Синин, Казахскую орду и города Бухарского ханства - Самарканд и Ташкент. Отпуская Вершинина в Томск, Дайчин «по своей вере шертовал, что ему со всем своим улусом великому государю служить и прямить, и добра хотеть, и никакова дурна не думать $)^{32}$.

Можно предположить, что тайша со своими людьми кочевал в местности Хобог-Сайир, расположенной в северной части Джунгарии (нынешнем Синьцзян-Уйгурском автономном районе Китая). Нужно отметить, что этот топоним впервые упоминается в ойратской летописи «История Хо-Урлюка». Его анонимный автор, описывая страницы истории торгутов, правда, без указания на время, отмечал: «В незапамятные времена Хо-Урлюк, извещая Батура-хунтайджи о [предстоящей] откочевке 15 тыс. кибиток из [местностей] Хобог-Сайир и Эмель, доложил [следующее]: «Местность Хобог-Сайир оскудела и обезлюдела. Моим подданным людям (албату) в ней не набраться сил, если не найти себе пропитание, занявшись хлебопашеством» $)^{33}$. Для Дайчина эта местность была связана, в первую очередь, с его детством, по всей видимости, именно здесь он и родился примерно в конце XVI в.

Но Дайчин планировал вскоре вернуться в степи Северного Прикаспия, поскольку, как отмечали очевидцы, «братьям де ево без него,

${ }^{32}$ МИРМО. М., 1974. С. 229-230.

${ }^{33}$ История Калмыкии ... Т. 1. С. 225.
Дайчин тайши, калмыцких улусных ево людей держать не уметь». Тайша через своих доверенных людей передал отцу, братьям и сыновьям о своем скором возвращении в улусы ${ }^{34}$. Но дальнейший ход событий отодвинул его встречу с родными еще на долгих 5 лет.

Как уже отмечалось, междоусобные войны в ойратском обществе коренились в семейных конфликтах. Правящая верхушка ойратов была связана между собой династическими браками, и большинство тайшей приходились друг другу родственниками, если не по отцовской линии, то по материнской непременно. Не стала исключением и очередная междоусобица, начало которой положили распри в дербетском доме. После смерти Далай-Батура между его многочисленными сыновьями разгорелась борьба за отцовское наследство. Не последнюю роль в этом сыграл и сам покойный отец, еще при жизни распределивший между сыновьями кибитки с нарушением принципа старшинства ${ }^{35}$.

Некоторые перипетии внутренних разборок в дербетском доме подробно освещаются в труде немецкого исследователя П.С. Палласа. По сведениям, полученным им от калмыцких информаторов в конце XVIII в., после смерти Далай-Батура в 1637 г. овдовели две его супруги: старшая Ахай и вторая - дочь Хо-Урлюка. Из девяти сыновей, которые были рождены в этих браках, старший был убит отцом. Причины убийства неизвестны. Остальным сыновьям Далай-Батур еще при жизни распределил своих подданных, причем старший из них, Дайчин-Хошучи, в отличие от всех оказался обделенным, получив самую меньшую часть отцовского наследства, а Солом-Церен, младший из них и рожденный от второй жены, - наследовал больше остальных братьев. После смерти отца Дайчин-Хошучи, который уже имел жену Дара-Эке, женился на своей мачехе - матери Солом-Церена, с целью увеличить свои владения. Одновременно с этим вместе с братом Гумбой он попытался оспорить долю отцовского наследства и у другого брата - Даян-Омбоо ${ }^{36}$.

${ }^{34}$ РГАДА. Ф. 127. Оп. 1. 1642 г. Д. 1. Л. 202.

${ }^{35}$ Габан ШІараб. Указ. соч. С. 98.

${ }^{36}$ Pallas P.S. Sammlungen historischer Nachrichten über die mangolischen Völkerschaften. T. 1. SPb., 1776. S. 48. 
Из более поздних русских документов стало известно имя матери Солом-Церена - Сувундай (Субундай). Возможно, ущемление ее с сыном в наследственных правах и послужило главной причиной бегства Сувундай к отцу и братьям в 1642 г. Дайчин-Хошучи организовал погоню за беглецами, и тогда Сувундай обратилась за помощью к отцу Хо-Урлюку и братьям - Елдену и Кирсану, кочевавшим со своими улусами недалеко, где-то в районе Тургайской ложбины, ближе к сибирским городам. По сведениям татарина Карагуша Каигулова, летом 1642 г. Хо-Урлюк с сыновьями кочевал в верховьях реки Тобол, в двух неделях пути от Тюмени ${ }^{37}$. Отец и оба сына приняли решение помочь Сувундай и ее сыну Солом-Церену, выдвинувшись с войском навстречу преследующему их дербетскому войску. Сторонам, видимо, так и не удалось договориться, потому как произошло сражение, в котором погибли Дайчин-Хошучи и пятеро других тайшей. Хо-Урлюк, Елден и Кирсан с улусами покинули свои кочевья в Юго-Западной Сибири и отступили в степи Северного Прикаспия, где предусмотрительно в конце 1630-х гг. на Яике ими были оставлены улусы Лузана, Санжина, Сюнке и Даян-Эрке.

По мнению М.Л. Кичикова, дербето-торгутский конфликт 1642 г. и гибель Дайчин-Хошучи участниками съезда 1640 г. были восприняты как грубое нарушение мира и единства монголо-ойратских феодалов, что согласно «Великому Уложению» каралось полной или частичной конфискацией имущества ${ }^{38}$. В «Биографии Зая-пандиты» упоминается, что в начале 1643 г. по приглашению хошутского Кунделен-Убаши и дербетских тайшей к ним прибыл хутугта для торжественного освящения субургана, построенного в честь погибшего в том бою Дайчина-Хошучи ${ }^{39}$.

Как следствие этих событий вспыхнула новая война между торгутами и чакарцами. Это подтверждает и факт присутствия в это время Дайчина у джунгарского Батура-хунтайджи. Согласно монголо-ойратским законам чакарские тайши рассчитывали на поддержку джунгар в начавшейся против торгутов войне. Но Батур-хунтайджи. по всей видимости, находился под влиянием своей младшей супру-

\footnotetext{
${ }^{37}$ Миллер Г.Ф. Указ. соч. С. 565.

${ }^{38}$ Кичиков М.Л. Исторические... С. 80.

${ }^{39}$ Норбо НІ. Указ. соч. С. 44-45.
}

ги Юм-Агас (дочери Хо-Урлюка) и шурина Дайчина, так как отказал чакарским тайшам в военной помощи против своего тестя, что впоследствии отразилось на политических событиях в ойратском сообществе, поскольку вновь обнажились старые противоречия.

В начале 1643 г. вспыхнула очередная ойрато-казахская война. Причины ее неведомы, но русские источники довольно подробно описывают ход и результаты этой войны. Известно, что коалиционное ойратско-монгольское войско численностью в 50 тыс. воинов возглавлял Батур-хунтайджи. В его состав входили хошуты Очирту, Кунделен-Убаши и Аблая, хойты Солтан-тайши, торгуты Дайчина и монголы Омбо-Эрдени (сына Алтын-хана). Однако вторжение коалиционных сил в казахские пределы внезапным не стало. Как уже отмечалось, еще с 1635 г. между чакарцами и казахами сложились союзнические отношения. Далай-Батур, а после его смерти и КунделенУбаши всячески покровительствовали казахскому султану Джахангиру, считая его своим «названым сыном». Дербетские тайши наотрез отказались от участия в походе против казахов, видимо, в отместку за отказ Батура-хунтайджи в военной поддержке их против торгутов. По всей вероятности, произошла утечка информации, и Джахангир уже знал о готовящемся вторжении. Имея всего 600 воинов, в горах, на заранее подготовленном участке, он сумел навязать бой ойратам и монголам в невыгодных для них условиях и продержаться до подхода основных сил султана Ялантуша с 20-тысячным войском. Коалиционные силы, понеся в горных теснинах под плотным оружейным огнем казахов серьезные потери, отступили. Батур-хунтайджи был зол на дербетов за их отказ от участия в антиказахской коалиции и отправил к Хо-Урлюку 40 торгутов с секретным письмом, в котором предлагал одновременно нанести удар по чакарцам с запада, в то время как джунгары ударили бы по казахам с востока. Но люди Кунделен-Убаши перехватили это письмо ${ }^{40}$. Ясность в эти события внес приехавший в Тобольск в начале 1644 г. посол Аблая - Бахтый. По его словам, Кунделен-Убаши и Аблай, принимая участие в антиказахской коалиции, рассчитывали на поддержку Батура-хунтайджи в их войне против Хо-Урлюка. Когда же стало известно, что хунтайджи

\footnotetext{
${ }^{40}$ МИРМО. М., 1974. С. 234; Златкин И.Я. История... С. 131.
} 
не намерен в ней участвовать, то они перехватили и задержали у себя торгутских посланцев с письмом к Хо-Урлюку ${ }^{41}$.

Конфликт с чакарскими калмыками в Юго-Западной Сибири привел к тому, что торгутские улусы двинулись в западном направлении, а некоторые из них вышли непосредственно к Волге. В январе 1643 г. в Астрахань прибыло очередное калмыцкое посольство во главе с Баимбетом. Посланцы сообщили, что выступают от имени тайшей Даян-Эрке и Санжина и приехали с предложением о взаимной торговле. Но астраханские воеводы приняли их холодно, заявив послам ряд претензий. Одна из них была на то, что прошлой осенью во время охоты под Астраханью калмыки ограбили струг, замерзший на Волге, близ Енотаевского острова. В ответ посланцы заявили, что у калмыков «неведома какие люди» отогнали 101 лошадь, следы которых привели к вышеуказанному стругу, где стрельцы подверглись нападению. Из сообщения послов стало также известно, что ДаянЭрке охотился в урочище у Нарын-песков, в то время как улусы его находились у Яика. Тайша, видимо, был заинтересован в возобновлении торговли с Астраханью, так как с послами отправил 700 лошадей для продажи, но астраханские власти торговать калмыкам не разрешили ${ }^{42}$

В это время Даян-Эрке во главе тысячного отряда находился на калмыцкой заставе, в дневном переходе от Астрахани, и ждал возвращения своих послов. Там его и застал боярский сын Л. Бухаров, который должен был выяснить, с какой целью калмыки оказались в такой близости от Астрахани. Даян-Эрке еще раз заверил Бухарова, что он «великому государю не ослушник», но на обратном пути русские посланцы были ограблены возвращавшимися из Астрахани калмыцкими торговыми людьми (300 человек), которые отняли у стрельцов и татар оружие ${ }^{43}$. По всей вероятности, провал переговоров по торговле вынудил Даян-Эрке перейти к более активным действиям. Неизвестно, как развивались бы события, если астраханские власти все-таки удовлетворили просьбу калмыков о продаже скота.

\footnotetext{
${ }^{41}$ МИРМО 1974. С. 234.

${ }^{42}$ РГАДА. Ф. 119. Оп. 1. 1643 г. Д. 1. Л. 5-7, 10

${ }^{43}$ РГАДА. Ф. 119. Оп. 1. 1643 г. Д. 1. Л. 13-14.
}

С.К. Богоявленский прямо указывает, что Даян-Эрке под видом охоты и ожидания своих торговых людей производил разведку перед запланированным нападением на Астрахань ${ }^{44}$. По другим сведениям, Даян-Эрке пришел под Астрахань (по ссылке) едисанского мирзы Юсупа Тиникеева, который лично шертовал перед тайшей в обязательстве кочевать с ним совместно ${ }^{45}$. «Ногайский» вопрос и в этом случае оказался не последним в нагнетании русско-калмыцких отношений.

В феврале 1643 г. Даян-Эрке повел войско из калмыков и алтыульских татар в наступление на окрестности Астрахани. Встретившаяся им на пути стрелецкая застава была полностью разгромлена. Калмыки захватили в плен стрелецкого сотника Я. Алгамышева с 19 стрельцами, остальных преследовали до реки Большая Болда. Русские источники, основываясь на сведениях очевидцев, указывают, что февральский поход калмыков возглавляли тайши Санжин, ДаянЭрке, Нима-Церен, Церен (сын Елдена), Батур, алтыульский мирза Салтанай и джемболукские мирзы Шамамбет и Арслан ${ }^{46}$. Если говорить о численности участников набега, то, по сведениям едисанских мирз, это были 3 тыс. калмыков и 100 алтыульцев ${ }^{47}$.

Из Астрахани навстречу калмыкам вышел отряд под командованием воеводы И.Н. Траханиотова, и в районе реки Кутум разгорелся ожесточенный бой. В разгар событий, 19 февраля, неожиданно для астраханцев значительная часть едисан, перебив стрелецкую охрану, под прикрытием калмыцкой конницы начала переправляться с семьями и скотом через реку Кутум по направлению к Яику. Переправа происходила в спешке, поэтому многие едисанские женщины и дети утонули. Бой продолжался с четвертого часа после рассвета до заката, т. е. не более 8 часов, и русский отряд потерпел поражение от значительно превосходивших по силам калмыков. Стрельцы не смогли помешать отгону калмыками большого количества лошадей и скота у астраханских жителей. Юртовские татары также намеревались пу-

${ }^{44}$ Богоявленский С.К. Указ. соч. С. 79.

${ }^{45}$ РГАДА. Ф. 127. ОП. 1. 1645 г. Д. 1. Л. 96.

${ }^{46}$ РГАДА. Ф. 119. Оп. 1. 1643 г. Д. 1. Л. 26, 105; Ф. 127. Оп. 1. 1645 г. Д. 1. Л. 96.

${ }^{47}$ РГАДА. Ф. 127. Оп. 1. 1645 г. Д. 1. Л. 96. 
ститься в бегство к калмыкам, но не смогли пробиться сквозь охрану стрельцов $^{48}$.

На первом же привале за рекой Бузан Даян-Эрке приказал передать едисанам весь захваченный под Астраханью ясырь и скот. При этом тайша прилюдно поклялся мирзам и их подвластным, «что от него им... никакова дурна и обид и неволи не будет и деду своему, Урлюку тайше, и иным никому калмыцким тайшам от себя он их не отдаст». Своих же улусных людей Даян-Эрке предупредил «с пристрастием», чтобы самовольно не ездили в едисанские улусы. Кочевьем для присоединенных мирз молодой тайша определил урочище Чегат ${ }^{49}$.

Но вскоре молодому тайше пришлось столкнуться с новой для себя проблемой. В улус Лузана, кочевавший в урочище Еруслан, неожиданно прибыли Хо-Урлюк, Елден и Кирсан во главе 6-тысячного воинского отряда в полном боевом снаряжении. Здесь же и прошел съезд, где обсуждался так называемый «ногайский» вопрос. Деду и дядям Даян-Эрке явно не понравилось то обстоятельство, что молодой тайша захватил едисан и единолично владеет ими. Они были не прочь, чтобы присоединенных ногайцев он разделил между остальными старшими тайшами. На съезде Лузан высказал свою точку зрения. Заключалась она в том, что он не будет против, если Даян-Эрке добровольно разделит между ними едисан. Но в случае отказа молодого тайши, то «он бы Урлюк тайша ево за то не оскорбил, потому, что де он, Урлюк тайша, болшину свою отдал отцу ево Эркину, Дайчину тайше, а отец де ево, Дайчин тайша, болшину отдал ему, Эрке тайше ${ }^{50}$. Таким образом, Лузан бросил упрек отцу по поводу несправедливого, как он считал, раздела своего владения между сыновьями.

В результате Хо-Урлюк, Елден, Лузан и Кирсан договорились отправить к Даян-Эрке 10 посланцев с требованием разделить «по справедливости» присоединенных им едисан и джембойлуков между остальными тайшами. Но Даян-Эрке попросил у прибывших посланцев три дня на обдумывание предложения, решив посоветоваться со

${ }^{48}$ РГАДА. Ф. 119. Оп. 1. 1643 г. Д. 1. Л. 106; Богоявленский С.К. Указ. соч. С. $80 ;$ Кичиков М.Л. Указ. соч. С. 81.

${ }^{49}$ РГАДА. Ф. 127. Оп. 1. 1645 г. Д. 1. Л. 96-97.

${ }^{50}$ РГАДА. Ф. 127. Оп. 1. 1645 г. Д. 1. Л. 99. своей улусной верхушкой. За это время он срочно собрал всю имеющуюся у него в наличии военную силу - примерно в 6 тыс. воинов и созвал «на думу» подвластных ему тайшей и мирз. Даян-Эрке огласил едисанским мирзам требование старших тайшей и поинтересовался их мнением по этому вопросу. Мирзы в присутствии посланцев попросили молодого тайшу сдержать свое обещание - сохранить целостность едисанского улуса. Другого ответа Даян-Эрке от них и не ожидал. Отправив посланцев обратно к деду и дядям ни с чем, Даян-Эрке провел сбор своих войск под предлогом похода на Казыевский улус. К старшим тайшам он отправил четырех свонх «лучших людей», через которых передал им: «будет де Урлюк тайша ево, Эрке тайшу, почтет внуком, а Лаузан тайша з братею почтет ево племянником, и они б едисанцов и енболуков у него не просили, потому что де он, Эрке тайша, взяв едисанцов из-под Астарахани, дал им душу свою на том, что их никому не отдаст, и они б душе вредства ему не учинили». В случае прихода на него войной старших тайшей Даян-Эрке готов был защищать свои интересы и вооруженным путем. Но мирзам с их отрядами на заставу идти Даян-Эрке не велел, однако приказал быть готовыми к худшему и «лошадей держать на арканех» ${ }^{51}$.

Напряженную обстановку в улусе Даян-Эрке разрядило возвращение к нему посланцев на третий день. Именно они сообщили, что Хо-Урлюк был неумолим по вопросу раздела едисанского улуса, выражая даже готовность взять их боем у своего внука. Однако более благоразумным в этой ситуации оказался Лузан, посоветовавший отцу: «им меж собою битца не надобно, а надобно де им битца с сторонними людьми, а не меж собою, а будет де они учнут меж собою битца и улусными де их людьми вперед учнут владеть иные люди, и они б де меж собою не враждовали и войны не вчинали». Хо-Урлюк в итоге согласился с доводами своего сына и отложил военные приготовления против непокорного внука ${ }^{52}$.

В то время как Даян-Эрке действовал под Астраханью, другой молодой тайша Бадма, сын Елдена, с крупным отрядом, состоявшим из калмыков и туркменов, совершил нападение на Яицкий городок.

${ }^{51}$ РГАДА. Ф. 127. Оп. 1. 1645 г. Д. 1. Л. 99-101

${ }_{52}$ РГАДА. Ф. 127. Оп. 1. 1645 г. Д. 1. Л. 101. 
Отогнав 20 лошадей у конных стрельцов и 59 лошадей у жителей городка, калмыки «бились болшим боем», взяли пленных и хотели осадить сам Яицкий городок. Но в эти события сразу же вмешались старшие тайши. Хо-Урлюк, только недавно прибывший в степи Северного Прикаспия, сразу отправил к Бадме лучших своих людей «для сыску лошадей и полона $)^{53}$. По мнению С.К. Богоявленского, старый тайша таким образом пытался сохранить свой авторитет среди внуков и не одобрял их действий по отношению к русским властям ${ }^{54}$. Астраханские власти немедленно отреагировали на последние события на Яике. Несмотря на нехватку воинских ресурсов, астраханцы все же отправили подкрепление к Яицкому городку, состоявшее из более 350 стрельцов, артиллерии и боеприпасов ${ }^{55}$.

Москва теперь серьезно была озабочена ситуацией на астраханском направлении. Воевода Ф. Телятевский, на которого постоянно поступали жалобы из Астрахани, был смещен со своей должности. Большинство мирз были освобождены из крепости и Аманатного двора. Татары и ногайцы на какое-то время успокоились, но их бегство из-под Астрахани усилилось. Часть мирз с улусами удалились на крымскую сторону Волги, ближе к Тереку, другие направились на север, к калмыкам, кочевавшим у Царицына и Саратова. Астраханские власти усилили стрелецкую охрану ногайских улусов ${ }^{56}$.

Вскоре после боя на Кутуме из Астрахани к тайшам были отправлены посланцы во главе со С. Скарятиным. Приехав в улус Лузана, он только здесь узнал, что Лузан не имел никого отношения к февральскому походу калмыков под Астрахань, более того, по словам тайши, он даже не был в курсе событий. Подтвердилось это уже в присутствии Скарятина, когда в улус Лузана приехали люди Даян-Эрке и сообщили о произошедшем с астраханцами сражении ${ }^{57}$.

Новое поколение молодых тайшей все активнее заявляло о себе и таким образом самоутверждалось среди старших тайшей. В отсут-

\footnotetext{
${ }^{53}$ РГАДА. Ф. 119. Оп. 1. 1643 г. Д. 1. Л. 282-283.

${ }^{54}$ Богоявленский С.К. Указ. соч. С. 81

${ }^{55}$ РГАДА. Ф. 119. Оп. 1. 1643 г. Д. 1. Л. 284-285.

${ }^{56}$ РГАДА. Ф. 119. Оп. 1. 1643 г. Д. 1. Л. 381-382; Кичиков М.Л. Указ. соч. С. 82.
}

${ }^{57}$ РГАДА. Ф. 119. Оп. 1. 1643 г. Д. 1. Л. 7. ствие отца Даян-Эрке, видимо, планировал не только сохранить за собой отцовское владение, но и преумножить его за счет ногайских кибиток. Он понимал, что таким образом вступает в конфронтацию с царскими властями и старшими тайшами. Позже молодой тайша отправил письмо астраханским воеводам, объясняя, что приходил под Астрахань по просьбе едисанских мирз ${ }^{58}$.

Скарятину, находившемуся в улусе Лузана, пришлось на себе испытать суровый характер калмыцкого тайши. На его предложение предоставить аманатов в Астрахань и вернуться на дальние кочевья, Лузан не только отругал его за это, но и пригрозил, что продаст как раба на невольничий рынок в Бухару. Тайша говорил, что давать аманатов русским «не для чести», поскольку калмыки кочуют «из давных лет по своей воле, где похотят, а не на указных местах». Летом, например, Лузан планировал кочевать в урочище Иргиз, что находилось между Саратовом и Самарой, т. е. в непосредственной близости от русских городов. Однако русский посланник провел время в калмыцких улусах не без пользы, собрав различную информацию о положении кочевников. По его наблюдениям, Лузан находился в курсе событий, происходящих в Самаре, Саратове и Уфе, регулярно отправляя туда своих представителей. Например, из Уфы к нему прибыли трое стрельцов с просьбой о выдаче русского полона, захваченного калмыками возле города. Лузан пообещал вернуть им пленных, но только за «государево жалованье». Стрельцов же он оставил у себя в отместку за задержанных калмыцких посланцев в Уфе ${ }^{59}$.

Фактически став хозяевами левобережья Нижней Волги, калмыцкие тайши все свое внимание обратили на правобережье. Весной 1643 г. они отправили послов к так называемым (воровским» ногайцам (в русских документах они именуются как «ногайские казаки»), кочевавшим в Мочагах. Ранее эти ногайцы жили под Азовом и охраняли границу Османской империи с Московским государством, но впоследствии самовольно ее оставили. Калмыцкие посланцы их заверили, чтобы они «от них (калмыков. - B.T.) и от едисанских татар ни в чем не боялись и обиды де им ниотково и дурна никакова не будет и жили б де с ними в совете безо всякого опасенья, и старые де

\footnotetext{
${ }^{58}$ Кичиков М.Л. Указ. соч. С. 81-82.
}

${ }^{59}$ РГАДА. Ф. 119. Оп. 1. 1643 г. Д. 1. Л. 250-253. 
их кочевья, где они жили наперед сего, они им очистят, а русских де людей им будет в те поры боятца нечего, потому что они будут все в соединенье». Ногайские казаки, в свою очередь, уверили послов, что в случае выполнения калмыками своих условий, они договорятся «жити в совете ради душами своими и в соединенье к ним пойдут тот час и во всем им будут послушны». Ногайцы к тайшам отправили своего представителя Ярмечена Полевана с 9 сопровождающими лицами, чтобы «учинить договор». После этого предполагалось прислать к ним от калмыков и едисан «добрых и лутчих людей), и они «подлинно договора укрепятца и по своей вере дадут межу собою души и укрепят пойдут к ним в соединенье» ${ }^{60}$.

В то же время отдельные калмыцкие тайши предпринимали самостоятельные попытки установить отношения с ногайскими мирзами. Например, с крымской стороны Волги к Даян-Эрке прибыли посланцы от ногайского мирзы Карашеима с предложением присоединиться к калмыкам. Молодой тайша сразу же отправил к нему «для договору» своего посланца - татарина Бердембета. Весной 1643 г. он вернулся, сообщив об отказе ногайцев от своего предложения. Мотивировали они это тем, что присоединенные к калмыкам едисаны заняли их старые кочевья в урочище Чегат. Но большинство ногайских мирз не исключали возможности присоединения к тайшам, но только при условии, если русские не вернут им их жен и детей, содержавшихся на Аманатном дворе в Астрахани. В результате переговоров ногайские казаки и калмыки договорились о совместном походе на Казыевский улус Малого Ногая. Более того, мирзы заверили тайшей в том, что окажут помощь в случае наступления на торгутов чакарских калмыков. ${ }^{61}$

Присутствие новоприбывших ногайских улусов среди калмыков некоторыми тайшами воспринималось неоднозначно, поскольку вскоре они столкнулись с новой для себя проблемой. В условиях, когда торгуты непрестанно испытывали военное давление со стороны чакарцев, ногайцы стали совершать набеги на русские селения. Весной 1643 г. отряды едисан по 100-300 человек нападали на села, расположенные по Каме и Волге, приводили в свои улусы полон, со-

${ }^{60}$ РГАДА. Ф. 119. Оп. 1. 1643 г. Д. 1. Л. 288-289.

${ }^{61}$ РГАДА. Ф. 127. Оп. 1. 1645 г. Д. 1. Л. 97; Ф. 119. Оп 1. 1643 г. Д. 1. Л. $290,318-319,345$. стоявший из русских, мордвы и казанских татар. Зачастую калмыки насильно отбирали у них захваченных пленников, но иногда и покупали. Например, побывавший в калмыцком плену Д. Ермолин сообщал, что некий тайша отнял у едисан 50 пленных стрельцов за то, что «ходят едисаны в войну на государеву украину воровством украдкою бес калмыцково ведома». Ермолин также был свидетелем того, что едисаны приводили к тайше с целью продажи захваченных в плен 8 астраханских и царицынских стрельцов. Однако тайша не только не купил их, но и своим улусным людям запретил это делать, выговаривая едисанским мирзам, «что они были под государскою рукою, и они де сабаки государю изменили и от Астарахани отошли, а ему да и самому от них какова добра чаят[ь] и готовы де им ему изменит[ь] же». Неизвестный тайша, по словам Ермолина, сам желал быть под «государевой рукою» и выслал этих едисан подальше от своего улуса. Едисаны активно вели торговлю «живым товаром» с башкирами. Своими набегами они тревожили окрестности Саратова и Самары, отгоняли скот и захватывали людей ${ }^{62}$.

Несанкционированные (или санкционированные) набеги калмыцких едисан на русские поселения были не единственной причиной недовольства ими части тайшей. Известно, что большинство старших владельцев выражали свое недоверие лично Даян-Эрке. Как выяснилось, молодой тайша самовольно объявил себя покровителем присоединенных едисан, взяв с них в качестве дани 300 золотых, и при этом он не удосужился поделиться деньгами со старшими тайшами ${ }^{63}$. Фактически едисаны жили одним улусом и подчинялись только Даян-Эрке и никому больше. Позже это обстоятельство привело к трагическим последствиям.

Все эти действия возле русских городов наряду с февральскими событиями под Астраханью значительно испортили репутацию калмыков и не способствовали достижению взаимопонимания с русскими властями. Вместе с тем сохранявшееся серьезное давление с восточного направления, со стороны чакарцев, привело к концентрации торгутских улусов в междуречье Яика и Волги ${ }^{64}$. Летом 1643 г. кал-

${ }^{62}$ РГАДА. Ф. 127. Оп. 1. 1643 г. Д. 1. Л. 102, 402-404.

${ }^{63}$ Богоявленский С.К. Указ. соч. С. 81.

${ }^{64}$ РГАДА. Ф. 119. Оп. 1. 1643 г. Д. 1. Л. 441-443; Богояеленский С.К. Указ. соч. С. 81 ; Кичиков М.Л. Указ. соч. С. 82. 
мыцкие тайши во главе с Хо-Урлюком пять раз пытались вступить в переговоры с самарским воеводой Т. Шушериным по вопросам нормализации отношений с населением приволжских городов и ведения торговли. Но царское правительство жестко отреагировало на эти попытки, выдвинув все те же неприемлемые для тайшей условия: выдача аманатов, возвращение ногайских «изменников) и откочевки за Яик. В Самару так и не были допущены 150 торговых калмыков, и на этой почве вновь возникли вооруженные столкновения ${ }^{65}$.

В 1643 г. в Самару на должность воеводы был назначен Л.А. Плещеев. Главной задачей, поставленной перед ним, была организация похода против калмыков, наводнивших окрестности Самары, из-за чего имели место многочисленные вооруженные стычки. 2 июля поступил указ от царя Михаила Федоровича о начале выступления в поход против калмыков отборного отряда. Когда Плещеев с отрядом находился в степи, в трех днях от реки Сороки, в его лагере появились уфимские татары и стали его всячески торопить, чтобы нанести по калмыкам внезапный удар. Но быстрое продвижение отряда замедляли имевшиеся пушки и большое количество пушечных запасов. Посоветовавшись со своими командирами, воевода Плещеев, как отмечали очевидцы, «пребывал в великом смущении», т. е. им владела определенная нерешительность. Но на следующий день ему с отрядом все-таки удалось настичь один из калмыцких улусов и разбить его, захватить большое количество пленных и трофеев ${ }^{66}$.

Военное давление чакарцев с востока и русских отрядов с запада не только способствовало стесненной расстановке торгутских улусов в междуречье Яика и Волги, но и нагнетало напряженность у правя-

${ }^{65}$ Кичиков М.Л. Указ. соч. С. 82-83.

${ }^{66} \mathrm{~B}$ «Житие Преподобного Сергия Радонежского» в авторстве Епифания Премудрого описывается интересный эпизод, случившийся с Л.А. Плешеевым накануне сражения: «3 июля, когда наступила ночь, он, помолясь перед образом Живоначальной Троицы и великого чудотворца Сергия, задремал и уснул тонким сном. И явился ему великий чудотворец Сергий и сказал: «Не сомневайся, иди, победишь неверных», а потом благословил его крестом и стал невидим. Встав поутру, Лев Афанасьевич рассказал о видении многим людям и, пойдя на калмыков, разбил их, захватил обозы, взял много пленных, множество верблюдов оружие и военную сбрую. И вернулся в Московское государство с великой радостью, благодаря Бога и Преподобного чудотворца Сергия». щей верхушки калмыков. По всей видимости, выход из сложившейся непростой ситуации тайши видели в расширении своих кочевий в западном направлении, на правобережье Волги, где они в течение всего 1643 г. проводили военную и дипломатическую разведку.

\section{3. Военно-политические контакты калмыков с народами Северного Кавказа}

В поисках новых и безопасных мест для кочевий правая сторона Волги или, как еще называли ее в то время «крымская сторона), для торгутов казалась спасительной от ударов как стрелецких отрядов поволжских городов, так и чакарских калмыков. Именно сюда, по всей вероятности, и планировали переселиться тайши, обезопасив таким образом свои кочевья. К тому же вольные просторы на правом берегу Волги давно привлекали калмыцких кочевников обильными травами, реками и озерами, многочисленными стадами сайгаков и теплым климатом. Но какова была военно-политическая ситуация в этом регионе? Насколько были сильны Малая Ногайская Орда, являвшаяся вассалом крымского хана, и кабардинцы (черкесы или адыги), которые в то время практически контролировали большую часть Северного Кавказа? Ответы на эти вопросы мог дать только основательный военно-разведывательный набег.

Северный Кавказ в первой половине XVII в. представлял собой арену борьбы за влияние над местными народами могущественных держав того времени - Московского царства, Османской империи с ее вассалом - Крымским ханством и Персии. Для успешного завоевания Северного Кавказа, в первую очередь, необходимо было покорить свободолюбивых и воинственных кабардинских князей, чьи владения занимали значительные территории, но между которыми постоянно происходили междоусобицы. Именно им подчинялись и платили дань соседние народы. Военно-политическую конкуренцию им составляли только кумыцкие владетели Тарковского шамхальства $^{67}$, которые также претендовали на гегемонию в регионе. Сношения

${ }^{67}$ Шамхал (иавхал или шаухал) - исконно кумыцкая и исторически первичная форма титула верховных кумыцких правителей Дагестана. 
русского правительства с Кабардой и с другими народами Северного Кавказа шли через Терский городок.

Подготовка калмыков к походу на Северный Кавказ практически не находит отражения в документах. В разное время исследователи выдвигали различные версии причин, вызвавших его. По мнению С.К. Богоявленского, пускаясь в столь дальний и опасный поход, такой осторожный политик, как Хо-Урлюк, должен был както уладить отношения с Астраханью: было очень рискованно, уходя на большое расстояние от своих улусов, где оставались семьи и имущество, иметь у себя в тылу враждебный город со значительным гарнизоном. Возможно, с астраханскими воеводами, как предполагает С.К. Богоявленский, было достигнуто какое-то соглашение, и астраханцы не воспользовались случаем отплатить за Кутумовку $^{68}$. По мнению М.М. Батмаева, поход имел несколько конкретных целей: нанести решающий удар по улусам Малого Ногая, упорно сопротивлявшегося натиску калмыков; провести разведку боем политической и военной обстановки на Северном Кавказе; проверить реакцию российского правительства и действенность его контроля над регионами Нижнего Поволжья и Предкавказья ${ }^{69}$. Целью этой акции, утверждает В.В. Трепавлов, было не только расширение кочевого пространства, но и погоня за ногайскими улусами, которых тайши стремились убедить или заставить перейти к себе в подчинение $^{70}$. В.И. Колесник в качестве одной из причин похода видит желание Хо-Урлюка обеспечить первенствующее положение своему младшему сыну Кирсану в случае успешного его исхода ${ }^{71}$.

Н.Н. Пальмов склонялся к другому мнению, считавшим, что в поход калмыки отправились под влиянием донских казаков, возмущенных решением московского правительства относительно переда-

${ }^{68}$ Богоявленский С.К. Указ. соч. С. 83

${ }^{69}$ Батмаев M.M. Калмыки в XVII-XVIII веках. События, люди, быт. В 2-х кн. Элиста, 1993. С. 94.

${ }^{70}$ Трепавлов В.В. История... С. 429.

${ }^{71}$ Колесник В.И. Последнее великое кочевье: Переход калмыков из Центральной Азии в Восточную Европу и обратно в XVII и XVII веках. М., 2003. C. 75. чи туркам Азова ${ }^{72}$. Во многом с ним согласен и А.В. Цюрюмов, который считает, что стремление калмыков и донских казаков выступить единым фронтом против Крыма имело целью подчинить себе казыевских ногайцев ${ }^{73}$.

Первые контакты калмыков с донскими казаками имели место и ранее. Н.Л. Янчевский указывает, что еще в 1638 г. донские казаки в ходе захвата и обороны крепости Азов (1637-1642 гг.) намеревались заключить с калмыками военный сою3 ${ }^{74}$. Но оставление казаками Азова по настоянию московского правительства и пребывание калмыцких улусов на дальних рубежах за Яиком не позволили реализовать этот замысел. Но постепенный переход калмыков в степи Волго-Яицкого междуречья и появление отдельных калмыцких разведывательных отрядов на правобережье Волги, в районе реки Сал, в 1642-1643 гг. вновь возродили в казацком обществе тему о возможном привлечении калмыков к союзу.

Летом 1643 г. донские казаки, ожидая нападения азовцев и крымцев на Раздорный городок, условились на том, «чтоб им послать в Калмыки с подарками с сукнами и с поручными, чтоб их к себе призвать на помочь». При этом внутри казацкого общества существовали и разногласия по вопросу о целесообразности «призвания калмыков». Одни атаманы, например, были против и вполне аргументировано убеждали: «калмык призывать нелзе, только де калмыки придут к ним на помочь будет ли, или не будет, про то им знать не мочно, а от нас де им за то быть в опале, а украиным городам будет разоренье». Тем не менее атаманы решили призвать калмыков на помощь и отправили к тайшам с богатыми подарками своих посланцев - казаков Д. Игнатьева, Я. Солдата и И. Багилдинского с тремя донскими татарами $^{75}$. К сожалению, в документах не находят отражение результаты этих переговоров, но, судя по отсутствию сведений о каких-либо

${ }^{72}$ Пальмов Н.Н. Этюды по истории волжских калмыков XVII и XVIII века. Астрахань, 1926. Ч. І. С. 9.

${ }^{73}$ Цюрюмов А.В. Калмыцкое ханство в составе России: проблемы политических взаимоотношений. Элиста, 2007. С. 72.

74 Янчевский Н.Л. Колониальная политика на Дону торгового капитала Московского государства в XV-XVII вв. Ростов-на-Дону, 1930. С. 104.

${ }^{75}$ АИ. СПб., 1841. Т. 3. С. 476-477. 
серьезных совместных военных выступлениях в дальнейшем, можно догадываться, что они все-таки не имели положительных итогов.

Информация о переговорах донских казаков с калмыками дошла и до Крыма. Еще в 1643 г. крымский хан Мухаммед-Гирей IV (16421644 гг.) доносил царю Михаилу Федоровичу об опасных для себя сношениях донских казаков с калмыками ${ }^{76}$. Например, в «Крымских делах» сохранилось письмо хана от 1 марта 1644 г., где он снова просил царя «унять» казаков, которые продолжали ссылаться с калмыками, в противном случае угрожая направить против них войска ${ }^{77}$

Уже зимой 1643/44 года крымские татары вполне серьезно ожидали прихода калмыков на свои улусы. Крымцы предусмотрительно отогнали скот и табуны в (крепкие и дальние) места и, как отмечали очевидцы, «калмыцково приходу крымские люди добре боятца» ${ }^{78}$. Крымский хан ясно осознавал, что со стороны новых и опасных соседей исходит прямая угроза и всячески старался воспрепятствовать их продвижению на запад. Вторжение калмыков на Северный Кавказ в начале 1644 г. можно рассматривать и как первую серьезную попытку тайшей утвердиться в этом регионе, подчинить себе Малый Ногай и отсюда напрямую угрожать Крыму.

По всей вероятности, у калмыцких тайшей никакого конкретного соглашения с донскими казаками накануне их вторжения на Северный Кавказ не было. Куда больший интерес для них представлял договор 1643 г., заключенный с ногайскими казаками, о совместных походах на Казыевский улус. Именно объединение под своим началом всех ногайских улусов и являлось главной целью тайшей. Часть Большой Ногайской орды уже находилась в подчинении у калмыков, и, видимо, последними на очереди оставались кубанские и терские ногайцы. Если бы такое объединение все-таки состоялось, то калмыцконогайская орда вполне могла бы серьезно доминировать в регионе.

Интересно проследить хронологию событий, разворачивавшихся в этот период. Архивные материалы из Ногайского фонда свидетельствуют, что первой в поход на Северный Кавказ осенью 1643 г. высту-

${ }^{76}$ Смирнов В.Д. Крымское ханство под верховенством Отоманской Порты до начала XVIII века. СПб., 1887. С. 537.

${ }^{77}$ РГАДА. Ф. 123. Оп. 1. 1644 г. Д. 3. Л. 83, 84.

${ }^{78}$ РГАДА. Ф. 115. Оп. 1. 1644 г. Д. 1. Л. 69. пила воинская группа, возглавляемая Лузаном. В нее также входили следующие тайши: Санжин (сын Хо-Урлюка), Мерген (сын Елдена), Ергелды (сын Кирсана); едисанские мирзы: Сююнча Абдулов, Солтанай Рохмангулов, Келимбет Абдулов, Навруз Шигаев и джемболукский мирза Урак. Численность этой группы составляли 2 тыс. калмыков и 500 ногайцев. Перейдя Волгу выше Царицына, они совершили молниеносный набег на Кубань, разгромив Казыевский улус мирзы Карашеима, и захватили большое количество ясыря, скота и лошадей. Лузан также захватил в плен брата Карашеима - Идиля-мирзу, сына Чораш-мирзу, жену и 40 его улусных людей. Возвращаясь с Кубани, отряд Лузана на реке Сарпа вступил в бой с отрядом астраханских стрельцов, закончившийся в пользу калмыков, в плен тогда попало несколько астраханшев ${ }^{79}$.

Успешные действия Лузана на Кубани, в ходе которых были захвачены значительные трофеи, вдохновили и других калмыцких тайшей. Следующей в конце 1643 г. в поход выступила уже группа Даян-Эрке. Она направилась к Тереку. Изучение архивных материалов позволило узнать и причины выступления данной группы. Как оказалось, незадолго до этого ногайский мирза Каспулат Мамаев, направлявшийся с правобережья Волги в улус Лузана, был задержан людьми Даян-Эрке. Молодой тайша объяснил Каспулату, что «у них, у калмыцких людей, ведется так, к кому наперед кто приедет, у того и жить станет $\rangle^{80}$. Подобный поступок племянника, конечно, не мог не раздосадовать его дядю Лузана.

Каспулат Мамаев сообщил Даян-Эрке, что в Мочагах, на правобережье дельты Волги, находятся его улус и улусы некоторых ногайских мирз, и просил перевести их в калмыцкие кочевья. Даян-Эрке с войском перешел Волгу в районе урочища Ичик-боре, в 70 верстах выше Астрахани. Но в Мочагах калмыки не обнаружили указанных ногайских улусов, кроме двух конских “сакм» (следов), одна из которых вела к Сарпе, а другая - на Терек. Узнав от Каспулата, что к Сарпе направился улус мирзы Солтаная Келмаметева, Даян-Эрке отправил за ними 20 человек с требованием присоединиться к тайшам.

${ }^{79}$ РГАДА. Ф. 127. Оп. 1. 1644 г. Д. 1. Л. 13; 1645 г. Д. 1. Л. 107; 1646 г. Д. 2. Л. 104

${ }^{80}$ РГАДА. Ф. 127. Оп. 1. 1645 г. Д. 1. Л. 108 
Основные силы калмыков двинулись дальше на Терек, но и здесь ногайские улусы не были обнаружены. Простояв день около Терского городка, Даян-Эрке направил своих людей «в загон» для поиска ногайцев, которые захватили несколько местных терских ногайцев. Последние сообщили, что ногайские улусы ушли в горы, к кумыцкому князю Казаналпу. Подобное развитие ситуации заставило тайшей призадуматься: стоит ли двигаться вперед, в горы, или вернуться обратно. Простояв на Тереке еще трое суток, калмыки двинулись назад, в улусы. Они были всего в пути полдня, как вдруг Даян-Эрке и Нима-Церен, отъехав в сторону, посоветовались и приняли решение о возвращении на Терек. Обратно в улусы тайши отправили только 1 тыс. калмыков и ногайцев вместе с мирзой Каспулатом. С остальным войском они перешли Терек и двинулись в горы, по направлению к селению Эндери, по дороге захватив всего 100 кибиток ногайского мирзы Чебана Иштерекова ${ }^{81}$.

В фонде «Кабардинских дел» были обнаружены более подробные сведения о действиях этой группы. 3 января 1644 г. в Терский городок пришел бежавший из калмыцкого плена астраханский татарин, который сообщил о передвижении большого количества калмыков в районе между Астраханью и Тереком. Терские воеводы М. Волынский и Е. Самарин срочно отправили в Москву и Астрахань просьбы о подкреплении, поскольку не обладали достаточными силами для обороны крепости. Воеводы сразу же передали информацию об угрозе нападения калмыков в Кабарду, к кумыкам и терским ногайцам, предупредив их о необходимости быть готовыми к принятию боя с неприятелем. Буквально на следующий день, 4 января, около часа дня, калмыцкие отряды появились возле Терского городка, и заречные слободы белопоместных казаков, черкесов и юртовских татар сразу же были атакованы ими. В бою, длившемся до вечера, терцам удалось отстоять слободы князя Муцала Черкасского и Ханмирзы Арсланова. Даян-Эрке, потеряв в сражении значительное количество своих людей, отступил вверх по Тереку и остановился в 30 верстах от городка. По сообщению выходцев из калмыцкого плена, Даян-Эрке ждал подхода основных сил - деда Хо-Урлюка и дядю Лузана с

\footnotetext{
${ }^{81}$ РГАДА. Ф. 127. Оп. 1. 1645 г. Д. 1. Л. 109-111.
}

их войсками для дальнейшего наступления на терские позиции. Но в подкрепление к нему в этот район прибыли только брат Нима-Церен и дядя Сюнке с 2-тысячным отрядом. Общая численность этой калмыцкой группы с учетом ногайцев составила около 10 тыс. воинов. Не сумев с ходу захватить Терский городок, тайши попытались присоединить терских ногайцев, ушедших на территорию кумыцкого владения Барагуны. Для начала ими была захвачена на Тереке застава Кизлярского перевоза. Затем, перейдя по Цареву броду горной реки на кумыцкую сторону, по дороге в горы калмыки захватили небольшой ногайский улус Карасаина Иштерекова. Другие ногайские мирзы, Янмамет и Куденет, укрылись в Эндери. Большие ногайцы Кейкувата-мирзы совместно с эндерийцами вышли навстречу калмыкам и в горах дали им бой, закончившийся безрезультатно для обеих сторон. Калмыки остановились в районе междуречья Терека и Аксая, куда через 5 дней к ним прибыли двое посланцев от терских ногайцев. Неизвестно, чем закончились эти переговоры, но тайши с войском двинулись обратно в улусы ${ }^{82}$.

Воспользовавшись отходом калмыков, терские воеводы решили не отсиживаться в крепости и перешли к наступательным действиям, отправив крупный отряд к Цареву броду, который перекрыл его для отхода кочевников. Бросок калмыков через брод ни к чему не привел, и они, понеся потери, отступили назад. Казаки организовали ночное преследование и навязали калмыкам еще один бой, который также закончился не в пользу последних. Но неожиданно ударили сильные морозы, и Терек встал. Это позволило калмыкам небольшими отрядами перейти через реку на левый берег. Попытки казаков удержать их и не пропустить обратно к Астрахани оказались безуспешными ${ }^{83}$.

По возвращении в улусы этой группе пришлось еще раз вступить в бой, но уже с астраханским отрядом. Во время переправы через Волгу астраханцы разбили передовой отряд калмыков, сопровождавший ногайский улус, и захватили много пленных. Даян-Эрке с основными

82 РГАДА. Ф. 115. Оп. 1. 1644 г. Д. 1. Л. 74-78, 145; Богоявленский С.К. Указ. соч. С. 82; Шмелев А.С. Русско-дагестанско-калмыцкие отношения в XVII в. (По материалам кумыкско-калмыцких контактов) // Кавказ. Балканы. Передняя Азия. Вып.2(9). Махачкала, 2004. С. 228-229.

${ }^{83}$ РГАДА. Ф. 115. Оп. 1. 1644 г. Д. 1. Л. 146-148. 
силами двигался позади примерно в 10 верстах, и, узнав о разгроме авангарда, попытался настичь астраханцев и отбить полон. Но, подойдя к Волге, калмыки обнаружили, что на скованной льдом реке нет снежного покрова. Поскольку лошади были неподкованными, с ходу перейти Волгу и далее преследовать астраханцев было не возможно. Пройдя вверх по реке от урочища Ичик-боре до Енотаевки, калмыки, посыпав лед песком, перешли Волгу и вернулись в улусы на Нарын-песках, в урочище Кизыл-илгын ${ }^{84}$. Таким образом, войско Даян-Эрке, хотя и не было полностью разгромлено терцами и астраханцами, потеряло в боях значительную часть своего состава.

Главные силы были сосредоточены под началом Хо-Урлюка. Возглавляли войска следующие тайши: Елден с сыновьями (Цереном, Бадмой, Тугулом) и Кирсан с сыновьями (Ергелду, Архули, Халду, Чокту). Через несколько дней после ухода на Терек войска Даян-Эрке группа Хо-Урлюка выступила по направлению к Северному Кавказу. Известно, что калмыцкие тайши предварительно вступали в переговоры с малыми ногайцами и кабардинцами, стараясь добровольно привлечь их на свою сторону, но успеха они не имели. Связанные союзническим долгом, кабардинцы выступили на стороне малых ногайцев, и это, по всей видимости, объясняет вторжение калмыков непосредственно на их территорию. Получив информацию о готовящемся нападении калмыков, терские казаки, кабардинцы и малые ногайцы составили план совместных действий, это позволило им избежать больших потерь и в дальнейшем нанести сокрушительное поражение противнику ${ }^{85}$.

В «Книге путешествий» Эвлия Челеби приводится свидетельства очевидцев и участников тех событий, записанные автором во время его пребывания в Кабарде в 60-е гг. XVII в. Они проливают свет на происходившее, в частности, на причины калмыцкого вторжения. Согласно этому источнику, калмыки Хо-Урлюка пришли на Северный Кавказ, преследуя ногайский улус мирзы Арсланбека, сына Каспулат-мирзы и внука Касая, перебравшийся сюда из-под Астрахани. На требование тайшей выдать им ногайский улус кабардинцы ответили

${ }^{84}$ РГАДА. Ф. 127. Оп. 1. 1645 г. Д. 1. Л. 112.

${ }^{85}$ Кабардино-русские отношения в XVI-XVIII вв. Документы и материалы (далее- КРО). М., 1957. Т. 2. С. 242-244. решительным отказом: «Арсланбек - птица, он обрел пристанище, придя на звуки нашего пения. Мы дали ему юрты, сделались братьями. И это племя ногай мы вам не отдадим $)^{86}$.

В «Истории адыхейского народа», опубликованной Ш.Б. Ногмовым в XIX в., посредством народных преданий и песен адыгов представлена фактическая составляющая боевого столкновения кабардинцев с калмыками, которые упоминаются здесь как “(торгуты» ${ }^{87}$. Место последнего сражения, согласно Ш. Ногмову, сохранило название Kau-Kamay, т. е. «беги в горы». С того времени у кабардинцев существует проклятие: «шпорипих уыхо», т. е. «чтобы ты попал туда, где нас режут). Однако в тексте песни (Кашкатау» нет указания на то, что противниками кабардиншев были именно калмыки. По мнению Б.М. Мокова, упоминание имени князя Кази, очевидно, князя Казыя Пшеапшокова, погибшего еще в 1615 г., заставляет полагать, что в этой песне нашло отражение какое-то иное и более раннее событие 88

Согласно османскому летописцу Мустафе Наиму, калмыцкое войско изначально двигалось на Крым, но по пути с целью грабежа совершило набег на Кабарду. Князь Алегуко ${ }^{89}$ с кабардинцами, вооруженными мушкетами, блокировал горный проход, оттянув на себя основные силы калмыков, вооруженных в основном только саблями и пиками. После жестокого и продолжавшегося весь день сражения, когда обе стороны были окончательно вымотаны, крымский отряд ногайцев, отправленный ханом Мухаммед-Гиреем IV в помощь кабардинцам, неожиданно ударил в тыл калмыкам ${ }^{90}$. Ш. Ногмов под-

86 Эвлия Челеби. Книга путешествий (Извлечения из сочинения турецкого путешественника XVII века). Перевод и комментарии. Вып.2. Земли Северного Кавказа, Поволжья и Подонья. М., 1979. С. 87.

${ }^{87}$ Ногмов III.Б. История адыхейского народа, составленная по преданиям кабардинцев. Нальчик, 1958. С. 128-129.

${ }^{88}$ Моков Б.М. Кабарда второй половины XVI-XVII вв. Нальчик, 2001. C. 137

89 Алегуко был сыном Шеганука Пшеапшокова и племянником Казыя Пшеапшокова, после смерти последнего стал владельцем «Казыевой Кабарды».

${ }^{90}$ Khodarkovsky M. Where Two Worlds Met: The Russian State and The Kalmyk Nomad, 1600-1771. Ythaka, N.Y., 1992. P. 86. 
тверждает это, указывая, что к кабардинцам на помощь пришло более 2 тыс. человек, собранных из различных горских племен ${ }^{91}$. Внезапный удар, нанесенный в тыл калмыков вспомогательной группировкой заставил калмыков отступить.

Сведения Эвлия Челеби, полученные им от кабардинцев, во многом подтверждают данные вышеуказанных авторов, если не принимать во внимание завышенную примерно в 10 раз численность противоборствующих сторон. Согласно ему, ногайцы Арсланбека и кабардинцы, оставив в засаде в горных ущельях и на возвышенностях многочисленных стрелков с ружьями, выставили на поле битвы с калмыками до 10 тыс. своих воинов. Едва завидев их, калмыки с боевым кличем «Хо!» ринулись в атаку, преследуя притворно отступавший кабардино-ногайский отряд. Углубившихся в горные теснины калмыков встретил плотный ружейный огонь из засады. Несколько тысяч калмыков были сразу же убиты. Кабардинцы и ногайцы с клинками бросились в контратаку и, охватив калмыков с тыла и флангов, обратили их в бегство. В полной сумятице был убит Хо-Урлюк (Тайшашах), а труп его спрятан. Победителям сражения досталось большое количество калмыцких лошадей. Пытаясь закрепить успех, кабардинцы и ногайцы преследовали отступавших калмыков и в степной местности, вплоть до самой Астрахани, истребляя отставших на загнанных лошадях ${ }^{92}$.

В ходе этого сражения обе стороны понесли серьезные потери. Поименного списка погибших калмыцких тайшей не существует, но из сообщения терского воеводы А.П. Волынского известно, что у калмыков на поле битвы погибли Хо-Урлюк, Кирсан, а также некие 〈Иргентень-тайса да Желдень-тайса $\rangle^{93}$. Ш. Ногмов указывает, что из 10,5 тыс. калмыков спаслись только 1,5-2 тыс., а весь конский состав достался победителям ${ }^{94}$. Русские источники уточняют, что в плен попало больше тысячи калмыцких и едисанских людей, а вместе с ними двое тайшей, одного из которых звали «Илгердей-тайса» ${ }^{95}$ (возмож-

${ }^{91}$ Ногмов ШІ.Б. Указ. соч. С. 129.

${ }_{92}$ Челеби Э. Указ. соч. С. 87.

${ }^{93}$ KPO. M., 1957. T. 1. C. 243.

${ }^{94}$ Ногмов Ш.Б. Указ. соч. С. 129.

${ }^{95}$ KPO. M., 1957. T. 1. C. 243. но, это был Ергелду. - B.T.). Положение калмыков усугубило и то обстоятельство, что еще больше людей погибло от организованной кабардинцами погони и ударов терских казаков на Куме ${ }^{96}$. По сообщениям торгутских послов, прибывших к хошутскому КунделенУбаши в августе 1644 г., в Кабарде погибло 14 тайшей ${ }^{97}$.

При уточнении численности калмыцкого войска под началом ХоУрлюка особое внимание обращают на себя сведения, полученных от едисанских мирз в Астрахани в 1645 г., непосредственно участвовавших в этом походе. Согласно их сообщениям, войско Хо-Урлюка насчитывало 12,5 тыс. человек, включая 2,5 тыс. воинов из улуса Даян-Эрке. Через три дня после возвращения Даян-Эрке из-за Волги, в улусы из разгромленного войска Хо-Урлюка вернулся тайша Сюнке с 300 человек, а спустя два дня и тайша Елден, также с 300 человек. Они и сообщили о гибели в Кабарде Хо-Урлюка, Кирсана, Церена (сына Елдена), Ергелдея (сына Кирсана) и многих других, более мелких и безулусных тайшей. Примерно 2 тыс. человек Даян-Эрке, входивших в войско Хо-Урлюка, также вернулись в улусы. Они понесли наименьшие потери вследствие того, что не входили в горные ущелья, а оставались на равнине ${ }^{98}$. Таким образом, из печального для калмыков кабардинского похода в улусы вернулись примерно 2,5 тыс. человек, а погибло или попало в плен около 10 тыс. человек. Подтверждение этой цифре потерь мы находим и в письме крымского хана Ислам-Гирея на имя царя, отправленного им в Москву в январе 1650 г99.

По мнению С.К. Богоявленского, поражение в Кабарде сломило мощь торгутов, в их жизни наступил поворотный момент. До этого тайши, достигшие высоты могущества и подчинившие себе многочисленные ногайские улусы и пополнившие свои войска новыми подданными, могли разговаривать с царским правительством как с равным. После Кабарды тайши не знали, где бы они могли кочевать в безопасности ${ }^{100}$. Русские источники свидетельствуют, что в середине 40-х гг. XVII в. под влиянием уговоров джунгарского Батура-

\footnotetext{
${ }^{96}$ Богоявленский С.К. Указ. соч. С. 82; КРО. М., 1957. Т. 1. С. 243-244.

${ }^{97}$ МИРМО. М., 1974. С. 245.

${ }^{98}$ РГАДА. Ф. 127. Оп. 1. 1645 г. Д. 1. Л. 113

${ }^{99}$ РГАДА. Ф. 123. Оп. 1. 1650 г. Д. 2. Л. 38.

${ }^{100}$ Богоявленский С.К. Указ. соч. С. 82-83.
} 
хунтайджи и из-за военных поражений торгутские правители всерьез задумывались над возможностью покинуть Поволжье и вернуться в Джунгарию ${ }^{101}$

Но покинуть степи Северного Прикаспия, не решив вопроса о возвращении останков погибших тайшей и пленных, тайши не могли. Поэтому вскоре после поражения в Кабарду приехали калмыцкие послы. Ш. Ногмов указывает на тот факт, что никого из пленных они не нашли, поскольку все были проданы в горы ${ }^{102}$. Это подтверждают и материалы фонда «Кабардинские дела». Согласно сведениям кабардинских узденей в Терском городке, в 1644 г. в Кабарду приезжали 20 калмыцких посланцев, которые просили на выкуп пленных. Князья Алегуко и Ходождуко отправили их искать своих соплеменников в горы и Малый Ногай, но там они никого не смогли найти, поскольку пленники были «распроданы в горы в разные земли». Посланцы в начале 1645 г. ни с чем вернулись обратно ${ }^{103}$.

В «Ногайских делах» за 1644 г. сохранились более подробные сведения о поездке на Кавказ калмыцких послов. В марте тайши отправили к казыевским мирзам калмыцкое посольство (10 человек), которое возглавляли Садашкир, Барын и туркмен Базрек. Калмыки предложили ногайским мирзам присоединиться к тайшам, обменяться пленными и в дальнейшем вместе участвовать в военных акциях против общих недругов. В ответ казыевцы отправили свое посольство (15 человек), привезя к тайшам «для веры» калмыцкого пленника. В результате стороны все-таки договорились об обмене пленными ${ }^{104}$.

Согласно сведениям Эвлия Челеби, калмыцкие тайши, проведя сложные переговоры, связанные с передачей калмыкам останков ХоУрлюка, заплатили казыевским мирзам огромный выкуп, исчисляемый десятками тысяч голов скота и лошадей. При этом кабардинцы получили заверение от калмыков в том, что в дальнейшем они не будут нападать на их земли. Но обещание, по утверждению Челеби, не было сдержано, и с этого времени калмыки с кабардинцами стали непримиримыми и кровными врагами, «вот почему племя кабарты

\footnotetext{
101 Златкин И.Я. История... С. 111.

${ }^{102}$ Ногмов ИІ.Б. Указ. соч. С. 129.

${ }^{103}$ РГАДА. Ф. 115. Оп. 1. 1645 г. Д. 1. Л. 71, 72.

${ }^{104}$ РГАДА. Ф. 127. Оп. 1. 1644 г. Д. 1. Л. 55, 56.
}

уже 20 лет как сидит в горах и не кочует по стране из страха перед калмыками» ${ }^{105}$.

В калмыцкие улусы отправился казыевский мирза Шагин (Шаим) Ельмурзин, взяв с собой выкупленные у кабардинцев останки (сожженные кости) Хо-Урлюка, Кирсана и Церена, в расчете обменять их на свою жену и детей, находившихся в плену у калмыков. Кабардинские князья Алегуко и Ходождуко всячески отговаривали его от этой поездки, но мирза их не послушался и отправился в калмыцкие улусы $^{106}$. Однако Шагин с братом по дороге были перехвачены царским отрядом и посажены в тюрьму в Астрахани. Правительство обвинило их в сговоре с калмыками, и только в 1648 г. они были переведены из тюрьмы в Аманатный двор ${ }^{107}$. По другим сведениям, казыевские мирзы вместе с калмыками направлялись в калмыцкие улусы, но по дороге они совершили нападение на астраханских ногайцев и черноярцев. Астраханцы выслали против них отряд, который и разгромил их в районе Волги ${ }^{108}$. Однако в «Калмыцких делах» сохранилась и другая версия. Когда к калмыкам везли останки тайшей из Казыевского улуса, то по дороге от них сбежал некий татарин, сообщивший властям о передвижении этого отряда. Воеводы срочно выслали против них крупные воинские силы и, устроив засаду, полностью разбили указанный отряд. Многие попали в плен, в том числе и двое казыевских мирз. Захваченные в бою калмыки и татары были повешены в Астрахани ${ }^{109}$.

Получив информацию о нахождении останков Хо-Урлюка в Астрахани, калмыцкие тайши поначалу были обрадованы, поскольку, как говорили очевидцы, они «почитают те кости вместо живых тайшей ${ }^{110}$. Но останки Хо-Урлюка, его сына и внука долгое время являлись предметом политического торга между царскими властями и тайшами, которые требовали их выдачи. Только после подписания шерти в 1657 г. правительство распорядилось выдать «кости Урлю-

\footnotetext{
105 Челеби Э. Указ. соч. С. 88.

${ }^{106}$ РГАДА. Ф. 115. Оп. 1. 1645 г. Д. 1. Л. 72.

${ }^{107}$ КРО. М., 1957. Т. 1. С. 287, 295, 297.

${ }^{108}$ РГАДА. Ф. 127. Оп. 1. 1646 г. Д. 2. Л. 138.

109 РГАДА. Ф. 119. Оп. 1. 1645 г. Д. 1. Л. 60.

${ }^{110}$ РГАДА. Ф. 119. Оп. 1. 1645 г. Д. 1. Л. 55.
} 
ка) Дайчину. Именно на этой почве впоследствии появилась легенда о гибели Хо-Урлюка во время осады Астрахани, которую многие исследователи XVIII - начала XX в. принимали за состоявшийся факт.

Ведя переговоры о передаче останков погибших тайшей, калмыки в то же время рассматривали возможность нового вторжения на Северный Кавказ. При этом тайши искали в этом регионе союзников для совместного выступления. В июле 1644 г. уздени кабардинского князя Будачея Сунчалеевича сообщали терским воеводам, что правитель Эндерийского княжества Казаналп и кабардинский мирза Урусхан Янсохов ведут переговоры с калмыцким посланцем, и якобы Казаналп договорился с мирзами Малой Кабарды Казыем Мударовым, Кельмаметом Ибаковым и Созорукой Анзоровым отправить к тайшам вместе с калмыцким послом У. Янсохова. Целью визита калмыцкого посланца было заключить военный союз с Казаналпом и князьями Малой Кабарды против общих врагов - Терского городка, правителей Большой Кабарды Алегуки Шеганукова и Ходождуки Казыева, а также кабардинских мирз Будачея и Муцала Черкасских и ногайцев Малой орды, которые были виновны в гибели брата Казаналпа - Айдемир-шамхала и калмыцких тайшей. И хотя Казаналп всячески отрицал какие-либо связи с калмыками, царское правительство запретило дагестанским князьям без его дозволения вступать в контакты с тайшами ${ }^{111}$.

\section{4. Политический кризис в калмыцком обществе}

Возмущенные последними действиями тайшей на Северном Кавказе, астраханские воеводы в феврале 1644 г. срочно отправили в калмыцкие улусы боярского сына Б. Голятина и толмача А. Васильева. Прибыв в улус тайши Лузана, они на себе испытали негативные последствия последних событий. С самого начала послы не ждали ничего хорошего от встречи с Лузаном, который выслушал «государев лист» сидя и в шапке, что по правилам русского этикета означало неуважение к царским представителям. Протест астраханцев на недав-

111 РГАДА. Ф. 115. Оп. 1. 1645 г. Д. 1. Л. 44, 45, 193; Шмелев А.С. Указ. Соч. С. $229,230$. ние действия калмыков, озвученный послами, содержал в себе требование возвратить русских пленных и удалиться на дальние кочевья. В противном случае русская сторона обещала возобновить военные действия против калмыков. Лузан высказал свой взгляд на обострение русско-калмыцких отношений, по его мнению, этому способствовали неудачные переговоры в Самаре по вопросу о торговле. На военные угрозы русских посланцев Лузан весьма строго ответил: «чаяли они, что присланы они... для миру, а они де к ним присланы з грозами». Позже в Астрахани послы жаловались: «и бранил их Лаузан тайша всякими позорными словами и велел... драть за бороды и выслал из избы их от себя з большим позором». Вдобавок Лузан приказал конфисковать у послов все их вещи и не принимал их у себя 6 недель ${ }^{112}$.

Столь непочтительное отношение к русским посланцам могло еще более ухудшить и без того непростые русско-калмыцкие отношения, и это понимали другие тайши. Поэтому в мае Даян-Эрке обратился к Лузану с просьбой передать ему русских посланцев, что и было вскоре сделано. Молодой тайша, чувствовавший себя в это время больным, приказал предоставить посланцам отдельную кибитку, располагавшуюся рядом с кибиткой его жены Каныш. Принял он их только на десятый день. Даян-Эрке также сидя выслушал «государев лист» и на обвинения в уводе ногайцев из-под Астрахани в 1643 г. ответил, что едисаны сами пожелали присоединиться к нему, а на упреки незаконности занятия калмыками кочевий, тайша спокойно возразил: «Землю и воды бог сотворил, и те места лежат порозжи, и никакие люди на тех местах не живут. А им калмыцким людям те места угодны и покойны, и потому они на тех местах и кочуют $\rangle^{113}$.

Голятин вернулся в Астрахань вместе с калмыцкими посланцами во главе с Баимбетом, пригнавшими на продажу 600 лошадей. В число калмыцких представителей входили люди от Даян-Эрке (посланец Мамыт), Елдена (Багым-Батур) и Лузана (Чоклу). Калмыков поселили за Астраханью, в Вознесеновской слободе. В свете последних событий астраханские жители довольно настороженно отнеслись к приезду калмыцких посланцев. Как отмечали очевидцы, калмыки

112 РГАДА. Ф. 127. Оп. 1. 1644 г. Д. 1. Л. 53

${ }^{113}$ РГАДА. Ф. 127. Оп. 1. 1644 г. Д. 1. Л. 57-59. 
от постоялого двора до Съезжей избы (воеводской канцелярии) шли по дороге, вдоль которой с пищалями стояли стрельцы, посадские и торговые люди. Послы передали воеводам два письма - от Лузана и Даян-Эрке, в которых предлагалось установить мирные отношения и вести торговлю, а также содержалась просьба отправить гонцов в Царицын, Саратов и Черный Яр для предотвращения нападений на калмыцкие улусы ${ }^{114}$

Интерес представляет письмо Даян-Эрке, составленное на старописьменном татарском языке. В послании на имя царя Даян-Эрке сетовал, что после отъезда его отца Дайчина «с добрыми словами добрых послов к нам не присылали» и возмущался тем обстоятельством, что в Астрахани его посланца Ахандея Мергена «засадили и торговать ему не дали, и отпустили нечестно). По поводу последних трагических событий Даян-Эрке отмечал: «А в прошлом году ваша тысяча человек, а наших тысяча человек напрасно померли. А те люди померли оттого, что вы к нам, а мы к вам добрыми людьми не ссылались. И ныне мы послали к вам добрых своих людей и ему, государю, бьем челом...» ${ }^{115}$.

Летом 1644 г. улусы Лузана и его брата Санжина располагались в верховьях реки Иргиз, а улус Даян-Эрке с ногайцами мирзы Каспулата - около Самары и по Иргизу. Рядом с Даян-Эрке кочевали улусы Елдена, Нима-Церена и Сюнке, общая численность которых составляла более 10 тыс. человек. Чтобы предупредить возникновение эксцессов в отношениях с русскими властями, Даян-Эрке запретил своим подвластным ногайцам под страхом конфискации имущества, жен и детей совершать набеги под русские города ${ }^{116}$.

Весть о разгроме торгутов в Кабарде дошла и до чакарских калмыков. Так, приехавшие в первой половине 1644 г. из Тары в улус Кунделен-Убаши русские посланцы встретили здесь и торгутских послов. Как оказалось, инициаторами их отправки сюда были не сами торгутские тайши, а вдовы Хо-Урлюка и Кирсана. Супруга последнего приходилась дочерью Кунделен-Убаши. Именно вдовы и пред-

${ }_{114}^{11}$ РГАДА. Ф. 127. Оп. 1. 1644 г. Д. 1. Л. 45-47, 63-64, 66-67.

${ }^{115}$ РГАДА. Ф. 127. Оп. 1. 1644 г. Д. 1. Л. 125-127.

${ }^{116}$ РГАДА. Ф. 127. Оп. 1. 1644 г. Д. 1. Л. 11, 44. лагали, чтобы чакарцы их людей «от государевых воинских людей оборонили и приняли б де их под свою руку». Обратиться с такой просьбой их вынудило то, что улусные люди Хо-Урлюка и Кирсана начали разбегаться по другим торгутским улусам, а вдовы были не в силах их удержать ${ }^{117}$.

Желая довести до конца разгром торгутских тайшей, царское правительство через своих послов пыталось склонить джунгарского Батура-хунтайджи к совместному вооруженному выступлению против торгутов, но получило отказ ${ }^{118}$. В разговоре с русским посланником В. Клепиковым хунтайджи прямо заявил о своем неодобрительном отношении попыткам Москвы создать так называемую «антиторгутскую» коалицию: «Урлюк де тайша мне не недруг, дочь де ево (ЮмАгас. - B.T.) за мною [замужем], на отца дети коли войною ходят? (...) А мне де на Урлюка войною не хаживать, да иные де тайши, друзья мои, на нево, Урлюка, войною не пойдут же». Нельзя забывать и о том, что Дайчин в это время находился в Джунгарии и, по всей вероятности, с сестрой Юм-Агас имел сильное влияние на хунтайджи по данному вопросу. Ввиду того, что царские власти по этому вопросу также вели активные переговоры с чакарцами, обращая особое внимание на причастность торгутов к гибели дербетского ДайчинХошучи, Батуру-хунтайджи пришлось лично выехать на встречу с Кунделен-Убаши «на думу» для пресечения реваншистских настроений дербетских тайшей. В Тобольске Кляпиков прямо указывал на тот факт, что хунтайджи в разговоре с хошутским тайшой «велел их (дербетов. - B.T.) унять») ${ }^{119}$.

После разгрома, пережитого на Северном Кавказе, калмыцкие тайши не стали отводить свои улусы на восток, на дальние кочевья. Более того, с наступлением весны они начали перекочевку с зимних на летние пастбища, что свидетельствовало об их относительной уверенности в своих силах здесь, в степях Северного Прикаспия. Весной 1644 г. тайши двинулись со своими улусами от Нарын-песков вверх по Яику к верховьям Самары. Как отмечали очевидцы, между Лузаном и Даян-Эрке из-за улусных людей возникла напряженность в

\footnotetext{
${ }^{117}$ МИРМО. М., 1974. С. 245.

118 Златкин И.Я. История... С. 125.

${ }^{119}$ Миллер Г.Ф. История Сибири. Т. III. М., 2005. С. 296-297.
} 
отношениях, и кочевали они врозь. В это время внутри торгутского дома практически сформировались две враждебно настроенные друг другу группировки. В первой состояли Лузан, Елден и Сюнке, а во второй - Даян-Эрке и молодые тайши. Лузан и Сюнке предложили едисанским мирзам отойти от Даян-Эрке и примкнуть к ним в случае возникновения вооруженного конфликта между сторонами. Но мирзы благоразумно решили соблюдать нейтралитет, заявив, что «только б у них был бой с сторонними какими людьми и они б им помогали, а что они, калмыки, станут биться меж себя и им, едисанцам, помогать им нельзя » 120 .

Но вскоре из-за ссоры с Лузаном к молодым тайшам отошел и Сюнке. Причиной раздора между братьями стала их мачеха - младшая супруга их покойного отца. Согласно древнему обычаю, после его гибели ее взял в жены Сюнке, но женщина, невзлюбив последнего, ушла к Лузану. При этом Лузан заполучил и ее улусных людей, т. е. часть отцовского улуса. На этой почве между братьями возник конфликт, угрожавший перерасти в вооруженное столкновение, но они проявили благоразумие, и все закончилось лишь похолоданием отношений $^{121}$.

В ответ на действия калмыков зимой 1643/44 года царское правительство в Самаре, Астрахани и других поволжских городах спешно начало усиливать местные гарнизоны. Командование этими полками было возложено на самарского воеводу Л.А. Плещеева и астраханского воеводу Ф.Ф. Волконского. Нанесение удара по калмыцким улусам, видимо, планировалось одновременно с двух направлений - астраханского и самарского. Летом 1644 г. русские совершили нападение на калмыцкие улусы, пленив большое количество людей и захватив лошадей. Калмыки отступили за Яик, лишившись огромных пастбищных территорий. 28 июля Плещеев докладывал царю о своем разгроме калмыков в верховьях реки Яик и захвате в плен 480 человек. Царь Михаил Федорович отправил к воеводе государево жалованье, а также «милостивое слово и с золотыми и велел о здоровье спрашивать». Наибольшие потери понес Даян-Эрке, поскольку люди

${ }^{120}$ РГАДА. Ф. 127. Оп. 1. 1645 г. Д. 1. Л. 114-116.

${ }^{121}$ РГАДА. Ф. 119. Оп. 1. 1645 г. Д. 1. Л. 61; Ф. 127. Оп. 1. 1645 г. Д. 1. Л. 123.
Плещеева захватили калмыцкий ясырь (женщин и детей) в основном из его улуса. Когда же его улусные люди отправились к русским за своими женами и детьми, тайша по дороге их нагнал и убедил вернуться обратно, обешая признать русскую власть и таким образом вернуть в улусы калмыцких пленных ${ }^{122}$.

Подобные настроения наблюдались за молодым тайшой и ранее. Из сообщения, полученного в У фе от вышедшего из калмыцкого плена башкира Ермета Мемлибаева, было известно, что Даян-Эрке еще в 1643 г. собирался принять русское подданство. Однако Хо-Урлюк за подобный шаг угрожал внуку расправой. Уже после кабардинского поражения Лузан грозился отобрать ногайцев у Даян-Эрке за одно только намерение племянника принять русское подданство и выдать аманатов $^{123}$.

По сведениям бывшего пленника А. Серебряка в Астрахани, в июле 1644 г. тайши, опасаясь нового прихода царских войск, с улусами начали отходить за Яик, перейдя реку в ее верховьях. Улусы двигались по направлению к Бухаре, а проводниками им служили бухарские купцы. Впереди шли калмыки и джембойлуки, за ними едисаны и другие ногайцы. С тыла отход прикрывали улусы ДаянЭрке и Лузана, как отмечал очевидец, «для береженья, чтоб нагайцы и едисанцы не ушли». По наблюдениям Серебряка, всего калмыков и ногайцев насчитывалось примерно 15 тыс. кибиток. Уже осенью большинство калмыцких улусов располагалось по реке Сырь, в урочище Уракум Карагол, что в 20 днях от Яика, а Батур с немногочисленным улусом - на реке Сагиз ${ }^{124}$.

В сентябре 1644 г. на астраханскую заставу из калмыцких улусов вышли 20 татар, захваченных калмыками еще в 1632 г. в урочище Тепкире. Они сообщили, что большинство едисанских мирз изъявляют желание вернуться к Астрахани, хотя джембойлуки больше стремились уйти к Ургенчу. Ногайские мирзы Салтаналы и Каспулат оставались верными калмыкам, поскольку боялись мести астраханских едисан из-за убийства своих мирз, но их улусные люди также

${ }^{122}$ Богоявленский С.К. Указ. соч. С. 83; Кичиков М.Л. Образование Калмыцкого ханства. Элиста, 1994. С. 72.

${ }^{123}$ РГАДА. Ф. 127. Оп. 1. 1644 г. Д. 1. Л. 168-169.

${ }^{124}$ РГАДА. Ф. 127. Оп. 1. 1645 г. Д. 1. Л. 49, 64-65, 119. 
были не прочь отойти к Астрахани. Другие ногайские мирзы - Навруз, Кантемир и Салтамурат - уже вели переговоры с воеводами о своем возможном возвращении под Астрахань ${ }^{125}$. Как видим, большинство ногайских мирз из-за разногласий в калмыцких улусах всячески пыталось покинуть тайшей, но последние, будучи хорошо осведомленными об их настроениях, с помощью военных застав жестко контролировали их улусы.

По ходу движения калмыцких улусов в восточном направлении Даян-Эрке для обеспечения безопасности пытался урегулировать отношения с соседями. С этой целью он заключил мирный договор с туркменами, около трех лет притеснявшими калмыцких торговцев. Тайша отправил к южным соседям посольство из 100 человек, которое и договорилось с ними о взаимной торговле. В августе 1644 г. послы Даян-Эрке прибыли в Уфу с сообщением, что их тайша кочует в верховьях реки Илек. Тайша просил предоставить возможность беспошлинной торговли в Уфе, а также район кочевий по Яику, Сакмаре и вверх по реке Белой ${ }^{126}$.

Но Москва придерживалась прежней политики по отношению к калмыкам. Уфимскому воеводе Б.А. Репнину было направлено строгое указание: требовать от калмыков вернуться на дальние кочевья, отдать русский полон и вернуть ногайцев на прежние их кочевья под Астраханью. С этой целью в октябре 1644 г. из Уфы в улусы ДаянЭрке вместе с калмыцкими посланниками был направлен стрелецкий пятидесятник Д. Брызгалов. Но буквально за три дня до его приезда Даян-Эрке при загадочных обстоятельствах неожиданно умирает. По слухам, которые дошли до Брызгалова от ногайцев, виновником смерти молодого тайши был его дядя Лузан, якобы отравивший своего племянника с помощью некоего ламы ${ }^{127}$.

Но однозначно утверждать, что это сделал Лузан, нельзя, так как, помимо него, у Даян-Эрке из-за присоединения к себе едисан было немало недоброжелателей среди старших тайшей. Тем не менее, верЛ. 5-10.

${ }^{125}$ РГАДА. Ф. 119. Оп. 1. 1644 г. Д. 1. Л. 12-14; Ф. 127. Оп. 1. 1645 г. Д. 1. $5-10$

Л. 128.

РГАДА. Ф. 119. Оп. 1. 1644 г. Д. 1. Л. 7; Ф. 127. Оп. 1. 1644 г. Д. 1.

${ }^{127}$ РГАДА. Ф. 119. Оп. 1. 1644 г. Д. 1. Л. 16-17, 33-34. сия гибели Даян-Эрке от рук Лузана долгое время в историографии оставалось практически единственной. Однако новые сведения из архивных материалов проливают свет на тайну смерти молодого тайши.

Едисанские мирзы активно вели тайные переговоры с Астраханью о возможном возвращении на прежние свои кочевья и сознательно пытались дистанцироваться от калмыков при их перекочевке на восток. Даян-Эрке дважды к ним отправлял своих людей с приказом двигаться вслед за калмыками. В последний раз мирзы даже дали 2 рубля его посланцу, чтобы тот сообщил тайше, что следуют за ним, в то время как они двигались в обратном направлении по Эмбе к морю с намерением выйти к Астрахани. Молодой тайша срочно собрал войско и двинулся на улусы ослушавшихся его ногайцев. Мирзы сразу же поспешили отправить к Даян-Эрке 20 посланцев во главе с Сююнчой Абдуловым, но за несколько дней до их приезда молодой тайша неожиданно умер. Позже Лузан поведал Сююнче историю о том, как Даян-Эрке собрал войско и вывез боевое знамя из улусов, но Елден с супругой начали унимать племянника, напомнив, что «он человек молодой и делает все молодым умом... и за малое дело войну начинает». Даян-Эрке по пути остановился в улусе Елдена, и, почувствовав себя плохо, попросил у дяди какого-либо «зелья» от болезни. Елден дал племяннику некое «зелье» в питье, от которого молодой тайша неожиданно умер ${ }^{128}$.

Таким образом, новая версия смерти молодого тайши выглядит более правдоподобной, нежели та, которую озвучил в Астрахани Брызгалов. Даян-Эрке, приходившийся старшим сыном Дайчину, должен был стать главным претендентом на власть в торгутском доме. Конечно же, молодой и решительный владелец составлял серьезную конкуренцию братьям своего отца и, в первую очередь, Елдену и Лузану.

Даян-Эрке было всего 28 лет $^{129}$. Как отмечали его современники, простые улусные люди очень любили своего молодого тайшу, который заботился о них. Приходившим в его улус новым людям Даян-Эрке помогал, предоставляя им на первое время в качестве

${ }_{128}$ РГАДА. Ф. 127. Оп. 1. 1645 г. Д. 1. Л. 50, 116-118

${ }^{129}$ Таким образом известны годы жизни Даян-Эрке: 1616-1644 гг. 
подъемных лошадей и скот. После его смерти большинство его улусных людей затем перешло в улус Нима-Церена, младшего брата Даян-Эрке ${ }^{130}$.

Лузан не преминул воспользоваться сложившейся после смерти племянника ситуацией и в разговоре с С. Абдуловым предложил едисанским мирзам уже свое покровительство. Он указал им в ближайшую зиму кочевать за Эмбой, в урочище Каракамыш, но с запретом переходить на правобережье Яика. К едисанам и джембойлукам на Эмбу пришел и ногайский мирза Каспулат с вестью об отгоне у него астраханцами 500 лошадей. Через некоторое время он со своим улусом перешел под покровительство Лузана ${ }^{131}$. Едисанские и джембойлукские улусы после смерти Даян-Эрке сразу же откочевали к Аралу по направлению к Ургенчу ${ }^{132}$. Скорее всего, мирзы опасались возникновения раздора среди калмыков из-за ногайских улусов, который уже назревал и мог бы последовать после смерти Даян-Эрке. Один лишь мирза Султанай отправил своего посланца в Уфу с просьбой признать его вину и разрешить кочевать под Астраханью или Уфой. Но ему велели кочевать на прежних местах, а под Уфой, посчитали местные власти, ему находиться «не пристойно» ${ }^{133}$. Слишком одиозной личностью был этот мирза, царские воеводы не могли простить Салтанаю его антироссийское прошлое

Часть улусов калмыцких едисан кочевала напротив Яицкого городка. Именно к ним и прибыли отправленные из Астрахани боярский сын А. Енин и толмач А. Сафонов с предложением вернуться под «государеву руку». Но переговоры астраханцев с мирзами разбудили старые противоречия и вызвали интриги в самой ногайской среде. В ноябре 1644 г., когда Енин и Сафонов находились у мирзы Янмамета Янаева, на улус совершили нападение люди мирз Абдулы и Юсупа Тинекеевых, Сююнчи, Келмамета и Урака Абдуловых, захватив послов и стрельцов. Астраханские воеводы отправили против калмыцких ногайцев карательный отряд под командованием Ф. Оги-

${ }^{130}$ РГАДА. Ф. 127. Оп. 1. 1645 г. Д. 1. Л. 118.

${ }^{131}$ РГАДА. Ф. 127. Оп. 1. 1645 г. Д. 1. Л. 51-52, 114.

132 РГАДА. Ф. 119. Оп. 1. 1644 г. Д. 1. Л. 34.

${ }^{133}$ РГАДА. Ф. 119. Оп. 1. 1644 г. Д. 1. Л. 20-21. балова, но успеха эта затея не принесла. Схваченных русских посланцев и стрельцов ногайцы держали в улусе Абла-мирзы. Получив известие об этом, тайша Сюнке спешно отправил к ногайским мирзам 10 своих представителей, которые насильно забрали у них русских посланцев. Последние при этом оказали калмыкам сопротивление, за что подверглись физическому воздействию. Если раненого Енина тайши затем отпустили в Астрахань, то толмача Сафонова оставили в качестве заложника в улусах, и ему около года пришлось провести в калмыцком плену ${ }^{134}$.

К концу 1644 г. улусы молодых тайшей Нима-Церена, Сюнке и других зимовали в верховьях реки Уил. Тайша Батур со своим улусом (500 чел.) располагался на реке Сагиз. Старшие тайши Лузан, Елден и Санжин со своими улусами на зимовку отправились в Приаральские Каракумы, в урочище Тогалай. По договоренности с чакарцами, также прикочевавшими на Каракумы, они должны были вместе участвовать в войне против Елантуша в районе реки Сырт (Сыр-Дарья). Бухарский хан обратился к чакарским тайшам с предложением устроить битву на этой реке в отместку за прежние набеги калмыков на Бухару и Ургенч. Калмыки, видимо, вызов приняли, и торгутские тайши с 10 тыс. воинов совместно с чакарцами двинулись к месту сражения ${ }^{135}$.

К сожалению, итоги этой войны не известны, но по улусам молодых тайшей пронесся слух, будто бы на бухарской земле Лузан, Санжин и Елден потерпели поражение и были разбиты. По словам очевидцев, улусные люди Сюнке, Нима-Церена и Батура «многие плачут и говорят: будет де Лаузан... в бухарской земле побили, и им будет всем пропасть». Молодые тайши дали друг другу шерть, чтобы мирзам разрешить кочевать, где те пожелают, а самим располагаться на реке Илек. При этом тайши с мирзами также поклялись «друг на друга никакова дурна не мыслить и войной никому ни на ково не ходить $)^{136}$.

${ }^{134}$ РГАДА. Ф. 119. Оп. 1. 1646 г. Д. 1. Л. 26, 85; Ф. 127. Оп. 1. 1645 г. Д. 1. Л. 57, 64, 70-71.

${ }^{135}$ РГАДА. Ф. 119. Оп. 1. 1645 г. Д. 1. Л. 58-59, 82; Ф. 127. Оп. 1.1645 г. Д. 1. Л. 120, 123; 1646 г. Д. 2. Л. 92.

${ }^{136}$ РГАДА. Ф. 119. Оп. 1. 1645 г. Д. 1. Л. 71, 72. 
Как свидетельствуют русские документы, основная масса калмыцкого населения больше доверяла и ориентировалась на старших и опытных тайшей, нежели на молодежь. Более того, многие простые калмыки надеялись на скорое возвращение Дайчина. Тайша, действительно, дал о себе знать, прислав своих людей к Нима-Церену и Сюнке с сообщением, что находится на «Барском озере», и с ним около 20 тыс. людей. Он требовал от своих родственников срочного примирения с Астраханью и обещал скоро вернуться, но при этом запретил к нему приезжать ${ }^{137}$.

Обстановку в торгутских улусах осложняли и слухи о гибели Дайчина. Так, весной 1645 г. по улусам пронеслась молва, будто бы Дайчин во главе тысячи воинов возвращался домой, но чакарцы, подослав к нему некоего «абыза), отравили торгутского тайшу, а людей его разобрали по своим улусам ${ }^{138}$. Все эти слухи, конечно, не имели под собой никакого основания. Дайчин в это время продолжал находиться в Джунгарии, откуда пытался, в том числе и с помощью джунгарского хунтайджи, решить вопрос мирного урегулирования конфликта с дербетскими тайшами, что позволило бы ему безопасно проехать через их территорию в свои родные кочевья.

В отсутствие Дайчина его сын Нима-Церен после смерти ДаянЭрке оставался за старшего наследника в отцовском улусе. Зимой 1644/45 года к нему прибыли 20 чакарских послов с новым требованием - передать им всех ногайских едисан. Но молодой тайша проявил твердость и отказал послам, заявив, что «едисанцы пришли к ним кочевать своею волею». Тогда чакарцы потребовали, чтобы торгуты предоставили им 1 тыс. воинов и 1 тыс. калмыцкого ясыря, но и в этом Нима-Церен отказал им. Возобновление политического давления более многочисленных чакарцев вновь заставило торгутов опасаться их военного прихода ${ }^{139}$.

${ }^{137}$ РГАДА. Ф. 119. Оп. 1. 1645 г. Д. 1. Л. 79

138 РГАДА. Ф. 119. Оп. 1. 1645 г. Д. 1. Л. 101

${ }_{139}$ РГАДА. Ф. 119. Оп. 1. 1645 г. Д. 1. Л. 83.

\section{5. Русско-калмыцкие переговоры в 1645 г.}

Узнав о трагедии, постигшей родственников, Дайчин отправил в Уфу Бакши Сабанова с ходатайством разрешить ему проезд в Москву. Появившись 26 октября 1644 г. в Уфе, посланец Дайчина пояснил, что с тех пор, как Дайчин отправился «в мунгалы к Алтыному царю по своей вере молитца» пошел уже шестой год (т. е. ориентировочно он выехал в 1638-1639 гг. - B.T.). По словам посланника, Дайчин уже возвращался домой, когда узнал о разгроме царскими войсками улуса старшего сына. Поэтому он немедленно отправил его в Москву с целью скорейшего урегулирования конфликта. Вместе с Сабановым в Уфу прибыли и посланцы от Елдена - Кулачи Аздраев и другие. В качестве подарка Дайчин отправил русскому царю 8 коней и 2 иноходцев, Елден - 2 коней ${ }^{140}$.

Получив 20 марта 1645 г. официальное разрешение на выезд в Москву, калмыцкие послы 5 июня были уже в столице. На следующий день их приняли дьяки Посольского приказа - Г.В. Львов и С.Б. Кудрявцев. Послы жаловались, «что они от его государевых ратных людей разорены, многие люди побиты, а жены и дети в полон поиманы, а животы и стада пограблены и разорены без остатку». И поинтересовались у дьяков о карательном походе Плещеева против калмыков: «от ково та война учинилась, з государева ли ведома или без государева ведома?» Дьяки бросили упрек послам в том, что тайши неоднократно шертовали русскому царю, но постоянно нарушали соглашение, нападая на русских и татар. Однако те уверяли их, что калмыки сами никогда не нападали на царских подданных и не угрожали русским городам, «(только они его государеву траву едят да воду пьют, а в ыном ни в чем перед ним, великим государем, не повинны». С их стороны, как убеждали послы, могли быть только ответные действия: «и змея де по земле ползет и только кто на нее не наступит, и она никово не укусит, а кто на нее ступит, и тово де укусит, а их де [обычай] такой: только их хто не задерет, и они молчат, а будет хто их задерет, и им как не поборонитца?» ${ }^{141}$.

${ }^{140}$ РГАДА. Ф. 119. Оп. 1. 1644 г. Д. 2. Л. 1-5.

141 РГАДА. Ф. 119. Оп. 1. 1644 г. Д. 2. Л. 17-18, 44-45, 48, 51; Устюгов Н.В. Башкирское восстание 1662-1664 гг. // Исторические записки. № 24 1947. C. 50. 
Тайшей также обвинили в том, что они, учинив погром ногайцам, взяли их к себе в улусы. Но Сабанов объяснял, что ногайцы пришли к ним сами «от насильства астараханских воевод》 и кочуют с калмыками «в своей же воле», часть же из них, кто пожелал, вернулись обратно под Астрахань. Послы просили вернуть захваченные калмыцкое улусное население и скот, передать останки Хо-Урлюка, его сына и внука. Они говорили, что Хо-Урлюк перед походом на Кабарду якобы отправил в Астрахань весть, что он «праведному государю не недруг, а казыевцы и черкасы вам, государем, и нам недруги $\rangle^{142}$

Понятно, что перед калмыцкими послами стояла довольно сложная задача - смягчить острые моменты в русско-калмыцких отношениях, возникшие по вине отдельных калмыцких тайшей. Послы заявили, что все сыновья Хо-Урлюка желают быть «в вечном холопстве» у русского царя, однако дьяки еще раз подчеркнули, что верить шертям тайшей на словах нельзя и потребовали для гарантии аманатов. Тогда послы сослались на то, что тайши им об аманатах ничего не говорили, поскольку раньше такого не бывало. Окончательный ответ Москвы заключался в том, что все просьбы калмыцких тайшей будут удовлетворены русской стороной только при условии выдачи аманатов и принятия калмыками подданства ${ }^{143}$.

Как показали дальнейшие события, Дайчин задержался в Джунгарии еще на 2 года, не имея возможности безопасно проехать через кочевья чакарских калмыков. Задача послов заключалась, в первую очередь, выиграть время до приезда Дайчина в свои улусы и по возможности урегулировать отношения с Москвой, чтобы не допустить повторных карательных действий со стороны русских, как это произошло летом 1644 г. Поэтому не удивительно, что в Москве калмыцкие послы для решения поставленной задачи манипулировали вопросом о возможном принятии тайшами русского подданства.

Во многом калмыкам благоприятствовало то обстоятельство, что Московскому государству в конце 1644 г. был нанесен новый удар со стороны крымских татар. Новый крымский хан Ислам-Гирей III (1644-1654 гг.), назначенный Портой в декабре, свое правление начал

${ }_{142}$ РГАДА. Ф. 119. Оп. 1. 1644 г. Д. 2. Л. 48, 61; Кичиков 1966. С. 87

${ }_{143}$ РГАДА. Ф. 119. Оп. 1. 1644 г. Д. 2. Л. 49-52, 80-82. с организации военного набега на русские территории, таким образом вероломно нарушив мирный договор с Москвой. Братья хана, ГазиГирей и Мурад-Гирей, во главе войска вторглись в пределы южной России, но были встречены русскими отрядами и отброшены обратно за пределы государства. Москва начала подготовку к ответному удару по Крыму ${ }^{144}$. Однако русская армия остро нуждалась в дополнительной военной силе, особенно в коннице, поскольку действовать приходилось в степной местности против мобильных кочевников. Такими силами она в достаточной мере не располагала, а подвластные татары и башкиры были не совсем надежными союзниками в борьбе против их же единоверцев. Калмыки представляли вполне реальную силу на южном направлении, тем более что еще с 1630-х гг. они предлагали Москве использовать свой военный потенциал против крымских татар.

Приезд калмыцких послов в Москву оказался для этого вполне подходящим моментом. Поэтому просьбу тайшей отправить к ним русских послов для дальнейших переговоров Москва удовлетворила. В улусы был отправлен стрелецкий голова А. Кудрявцев, когда-то побывавший в калмыцком плену и потому неплохо знавший калмыцкий язык. Вместе с ним отправились стрелецкий сотник Д. Шепелев, толмач В. Киржатцкий и стрельцы. Кудрявцеву предписывалось привести тайшей к шерти и призвать их идти войной вместе с русскими ратными людьми на Крым. Правительство стягивало в Царицын войска для организации крымского похода и предложило тайшам на время военных действий прислать сюда 12 тыс. лошадей. Погибших и «худых» лошадей правительство в дальнейшем по договору предполагало компенсировать товарами «недорогой ценой». При этом аманатов от тайшей Москва требовала только на время похода, а после войны обещала предоставить калмыкам торговые привилегии в русских городах ${ }^{145}$

Выехав 22 марта 1645 г. из Уфы, посольство А. Кудрявцева, состоявшее из 50 человек, 21 апреля прибыло в калмыцкие улусы. С ними приехали и те калмыцкие послы, которые три года насильно

144 РГАДА. Ф. 119. Оп. 1. 1645 г. Д. 2. Л. 228.

${ }^{145}$ РГАДА. Ф. 119. Оп. 1. 1645 г. Д. 2. Л. 232-236. 
удерживались в Уфе. Калмыки были рады возвращению своих людей и приезду русских послов. Первоначально послы остановились в улусе Лузана, на реке Киим. На просьбу русского посла собрать калмыцкий съезд для переговоров тайша уклончиво ответил, что к нему в улус, возможно, приедут не все. 27 апреля Лузан официально принял Кудрявцева, зачитавшего ему государеву грамоту. Тайша по просьбе посла заслушал грамоту стоя и сняв шапку. На просьбу тайши оказать военную помощь против кабардинцев, русский посол ответил отказом, мотивировав это тем, что «черкасы их, калмыцких тайшей и улусных людей, не задирали и зла им никоторово не делали и воевать их отцу Урлюк тайше [было] незачто». Вполне обоснованно Кудрявцев также добавил, «чтоб наших ратных людей на наших же искони вечных холопей войною послать... немочно». Видимо, Лузан услышал не то, что хотел, а неуступчивость русского посла вывела тайшу из себя. Через неделю он приказал своим людям отобрать все вещи у послов, пригрозив Кудрявцеву отрезать бороду, а толмачу выколоть глаза ножом. Лузан сообщил послам о скором приезде Дайчина, совместно с которым угрожал совершить набег на Уфимский уезд ${ }^{146}$.

Неизвестно, чем бы закончились эти угрозы, если бы к Лузану не приехали от Нима-Церена доверенные его лица - Чокула и Замала и не забрали к себе русских послов. К Нима-Церену они прибыли 4 мая, а тайша их принял 7 мая. Молодой и неопытный тайша не знал, о чем конкретно вести переговоры с Кудрявцевым и потому отправил его к дяде Елдену. Приехав 13 июня в улус Елдена, 17 числа посол был принят тайшой. Около месяца тайши активно между собой советовались, пока 17 июля на реке Орь в урочище Одного дерева (в улусе Елдена) у них не состоялся общий съезд, на котором присутствовали практически все калмыцкие и ногайские владельцы ${ }^{147}$.

Несколько дней тайши совещались по выработке общей позиции на предстоящих русско-калмыцких переговорах. 20 июля Елден, Лузан, Санжин, Сюнке, Нима-Церен и другие тайши назначили русским послам встречу, во время которой выразили благодарность русской

${ }^{146}$ РГАДА. Ф. 119. Оп. 1. 1645 г. Д. 1. Л. 99; 1645 г. Д. 2. Л. 264-265; 1646 г. Д. 1. Л. $142,159$.

${ }^{147}$ РГАДА. Ф. 119. Оп. 1. 1645 г. Д. 2. Л. 266-267; 1646 г. Д. 1. Л. 181-182. стороне за прием в Москве калмышких послов и возможность продолжить переговоры. Кудрявцев напомнил тайшам, что Далай-Батур, Хара-Хула и Хо-Урлюк «искони» были в «повеленье и послушанье» у государя и шерть свою никогда не нарушали, на русские города и деревни не нападали. Он упрекнул тайшей в нападении на Астрахань и уводе к себе в улусы ногайцев. Посол не преминул напомнить и о том, что после поражения калмыков в Кабарде тайши «не унялися» и начали наступать на Саратов и иные «понизовые» города, за это по указанию правительства и разбил их воевода Плещеев. Кудрявцев призывал тайшей принести шерть и дать аманатов, и подчеркивал, что только в этом случае правительство разрешит им беспошлинно торговать в русских городах ${ }^{148}$.

Выслушав посла, тайши заявили, что «в прошлых годах калмыцкие тайши некоторых улусов с улусными людьми у них, у прежних государей московских, в повеленье и в послушанье бывали или нет, и чем их прежние государи тайшей жаловали или нет, того мы не упомним...». Они еще раз напомнили, что под государевой рукой «в повеленье и в послушанье не бывали». Относительно приезда калмышких послов в Москву тайши пояснили, что «не посылали, что быть нам в неволе, а посылали мы послов своих к государю бить челом о том, чтоб с ним, государем, быть в миру и войны не чинить». Точку в этом вопросе они поставили следуюшей фразой: «И отец наш, Урлюк, и мы, и иные калмыцкие тайши великому государю не служивали и шерти по своей вере не давали ${ }^{149}$.

Тайши категорически отвергли обвинения в свой адрес в нападении калмыков на Астрахань, Саратов и другие города. Они говорили, что если таковые набеги и происходили, то «приходили от нас украдкой, того мы не ведаем, потому что кочуем на новом месте», что под Астрахань в 1643 г. ходили тайши Даян-Эрке и Нима-Церен, причем не против самого города, а только навстречу едисанским мирзам, пожелавшим добровольно присоединиться к калмыкам: «они у нас не в

148 РГАДА. Ф. 119. Оп. 1. 1645 г. Д. 2. Л. 268-281, 289; Соловьев С.М. История России с древнейших времен / Отв. ред. И.Д. Ковальченко, С.С. Дмитриев. М., 1991. Кн. VI. Т. 11-12. С. 552.

${ }_{149}^{149}$ РГАДА. Ф. 119. Оп. 1. 1645 г. Д. 2. Л. 281-283, 288-289; Соловьев С.М. Указ. соч. С. 552-553. 
неволе живут, не как у вас, аманатов их у нас нет». Кавказский поход 1644 г., по словам тайшей, стал следствием нападения на крымской стороне Волги ногайских мирз на отряд Лузана, возвращавшегося из набега на Казыевский улус, подчинявшийся крымскому хану. По поводу поражения, которое калмыки потерпели в Кабарде, они вполне философски заметили, что «и то сделалось волею божьею, а мы извека на войне помираем». А насчет поражения, нанесенного им воеводой Плещеевым, сказали, что «то повелось извека на войне побивают и в полон емлют». Тайши наотрез отказались уйти на дальние кочевья, объяснив, что не кочуют непосредственно рядом с русскими городами, заметив при этом: «земля де божия, кочуем на порозжей земле; а мы люди божии, вольные, и кочуем по своей воле, не в указ, а на его государеве земле николи не кочуем». Они предложили Кудрявцеву дать клятву с целованием креста в том, что русские не направят свои войска против калмыков. Со своей стороны тайши обещали дать указание своим лучшим людям принести шерть в том, что не будут совершать нападения на русские территории ${ }^{150}$.

По вопросу об аманатах позиция тайшей была непоколебима, поскольку в этом они видели угрозу своей самостоятельности. Они еще раз твердо заявили: «Нам аманатов давать нельзя, наши деды и прадеды, и отцы наши, и мы прежним государям аманатов не давали извека ни с тайшей, ни черных людей тово у нас не повелось... Да и впредь у нас тово не будет». Возможность вести торговлю с русскими городами взамен на предоставление аманатов тайшей также не устроила: «нам и мимо государевых людей есть с кем торговать, а пошлин мы никому не даем». Кудрявцев наотрез отказался без аманатов верить на слово тайшам, поскольку калмыки «многое свое зло и грубость и измену показали», на что тайши ответили, что приходили войной на войну, и государю не изменяли по причине того, что никогда не были у него «под началом» ${ }^{151}$

Угроза военного столкновения с чакарскими калмыками стала причиной и отказа тайшей принять предложение Кудрявцева совер-

${ }^{150}$ РГАДА. Ф. 119. Оп. 1. 1645 г. Д. 2. Л. 284-284, 286-287, 290-291; Соловьев С.М. Указ. соч. С. 553.

${ }^{151}$ РГАДА. Ф. 119. Оп. 1. 1645 г. Д. 2. Л. 291-293; Кичиков М.Л. Образование... С. 75-76. шить совместный военный поход против Крымского ханства. Крым, по словам калмыков, находился далеко и «то нам место незнакомо, прежде сего мы не бывали». Основанием для отказа было и различие в военных традициях. Как говорили тайши, с государевыми людьми вместе «идти нельзя, что ваш русский поход пеший, где нам идти день, а русским людям идти неделю». Лошадей же для русской армии калмыки предлагали продать в Уфе или Астрахани ${ }^{152}$.

Переговоры, по существу, закончились провалом. Тайши достаточно резко отклонили практически все предложения Кудрявцева. Тогда русский посол, действуя согласно правительственной инструкции, перешел к прямым угрозам в адрес тайшей. Он заявил о возможном выступлении против торгутов русских войск совместно с отрядами чакарских калмыков, которые неоднократно предлагали правительству свою военную помощь. Посол опять напомнил тайшам о поражении и о потере ими значительной части своих воинов в Кабарде. Услышанное из уст Кудрявцева вызвало возмущение у калмыков, некоторые из них предлагали русских послов развезти и распродать, а другие - физически расправиться с ними. Старшие тайши говорили Кудрявцеву: «Грозить приехал, только [если] бы ты не с Москвы прислан к нам, и ты бы был за такое слово у нас в Бухарах». Единственными, кто в этой ситуации заступились за Кудрявцева и его товарищей, были калмыцкий дархан Чокула и хошут Абека, которые поспешили увезти русских послов от разгневанных тайшей в улус Нима-Церена ${ }^{153}$.

Находясь в улусах, Кудрявцев успел собрать кое-какую информацию о положении дел у калмыков. Например, ему стало известно, что в сентябре к торгутам от Дайчина прибыл человек с вестью о нахождении тайши в джунгарских улусах Батура-хунтайджи и хойтского Солтан-тайши, что Дайчин совместно с джунгарами участвовал в походе против чакарцев и казахов. В улусах многие не верили этим новостям, поскольку предводитель чакарцев Кунделен-Убаши был довольно силен, а его улус многочислен. Дайчин обещал своим людям вернуться уже следующей весной, а Елден и Нима-Церен плани-

${ }^{152}$ РГАДА. Ф. 119. Оп. 1. 1645 г. Д. 2. Л. 331-332.

${ }^{153}$ РГАДА. Ф. 119. Оп. 1. 1645 г. Д. 2. Л. 295-297; Кичиков М Л. Образование... С. 76. 
ровали встретить его на реке Сырт. Кудрявцеву также стало известно о том, что улусы Лузана, Сюнке и Батура находятся на Эмбе, где они стерегли ногайцев. В августе в улус Нима-Церена из Ургенча приезжал посол от хана Абу-л-Гази, просивший калмыков оказать ему военную помощь против туркменов. Направлявшиеся из Астрахани в Ургенч юртовские татары по секрету сообщили Кудрявцеву, что астраханские татары постоянно приезжают и докладывают тайшам о последних событиях, происходящих как в Астрахани, так и во всей России $^{154}$. Как видно, обе стороны были достаточно осведомлены друг о друге.

Здесь Кудрявцев познакомился и сблизился с вышеназванными Чокулой и Абеком, которые уговорили Нима-Церена отпустить русских послов. При отъезде посольства простые улусные люди обрашались к Кудрявцеву с просьбой посодействовать в освобождении за выкуп своих жен и детей, захваченных воеводой Плещеевым. Посол им честно признался, что сделать это будет сложно ввиду отказа тайшей выполнить требования Москвы. Многие калмыки причину своих бед видели именно в отсутствии в улусах Дайчина, который всегда, как они говорили, защищал интересы простых людей. 20 сентября посольство Кудрявцева с урочища на реке Тургай отбыло обратно в Москву. Вместе с русскими послами Чокула отправил и своих людей - Абеку и Кутагыка. В целях безопасности посольства он лично трое суток сопровождал его до границ кочевий. 5 октября 1645 г. посольство Кудрявцева благополучно вернулось в Уфу вместе с калмыцкими посланниками, просившими разрешение на проезд в Москву. Но уфимским воеводам было категорически запрещено пропускать калмыков в столицу до тех пор, пока их тайши не примут русское подданство и не предоставят аманатов. Позже выяснилось, что посланники от калмыков представляли интересы не тайши Нима-Церена, как считали воеводы, а его дархана Чокулы ${ }^{155}$.

Очевидно, что большинство тайшей, участвовавших в русскокалмыцких переговорах, находилось под влиянием Лузана, который

${ }^{154}$ РГАДА. Ф. 119. Оп. 1. 1645 г. Д. 2. Л. 338-340.

${ }_{155}$ РГАДА. Ф. 119. Оп. 1. 1645 г. Д. 2. Л. 310-313, 335; 1646 г. Д. 1. Л. 197-198; Кичиков М.Л. Образование... С. 76. не был сторонником прорусской ориентации и добивался сохранения полной независимости калмыков, хотя и не отрицал полезности сохранения добрососедских отношений с Москвой. Гибель Хо-Урлюка, смерть Даян-Эрке и продолжавшееся длительное отсутствие в улусах Дайчина фактически сделали Лузана первенствующим тайшой среди торгутов. Именно его позиция, по мнению М.Л. Кичикова, и стала определяющей в провале русско-калмыцких переговоров ${ }^{156}$. Но большинство калмыцких улусных людей желало нормализации русскокалмыцких отношений, поскольку на тот момент возвращение пленных и решение территориального вопроса для народа было жизненно важным.

\section{6. Политическое влияние буддийского духовенства}

Торгутские тайши вели сложные переговоры не только с русскими властями, но и с восточными соседями, так как еще не был урегулирован конфликт с чакарцами, пытавшимися взять реванш за 1642 г. Решающую роль в мирном разрешении данного конфликта сыграла личность некоего «кутухты» (хутугты), чей приезд к торгутам нашел отражение и в русских документах. Автор ойратского источника «Лунный свет» прямо указывает, что это был один из духовных лидеров ойратов и создатель старокалмыцкой письменности «тодо бичиг» Зая-пандита. По мнению И.Я. Златкина, «исследование обстоятельств, связанных с приглашением и пребыванием Зая-пандиты у волжских калмыков - важная задача, требующая серьезного изучения, поскольку он был известен не только как высокопоставленный религиозный деятель, но и являлся также влиятельным политиком, чья деятельность далеко не ограничивалась узким кругом интересов феодальной верхушки и пределами только ойратских кочевий»»157.

Благодаря огромному авторитету, Зая-пандите удавалось предотвращать конфликты и останавливать войны, разгоравшиеся как между отдельными тайшами, так и между крупными ойратскими

${ }^{156}$ Кичиков М.Л. Образование... С. 75.

${ }_{157}$ Златкин И.Я. Зая-Пандита... С. 22, 31. 
группировками. Проповедуя среди ойратов и монголов буддийское вероучение и занимаясь миротворческой деятельностью, хутугта преодолевал огромные расстояния, посещая их кочевья, простиравшиеся почти от Волги до Великой Китайской стены. Так, например, в 1641 г. он находился в Монголии, в 1642 г. - у хошутского тайши Очирту в Джунгарии, в 1643 г. - у дербетов Даян-Омбо и хошутов Кунделен-Убаши в степях Юго-Западной Сибири, в 1644 г. - снова в Джунгарии. На вопрос хошутского тайши Очирту, в чем же смысл таких дальних и сопряженных с трудностями поездок, Зая-пандита пояснял: «Я, во-первых, езжу для того, чтобы распространять Высшее учение; во-вторых, поскольку я обучался наукам, находясь на иждивении казначейства Далай-Ламы, а также за счет казны монастырей, то я езжу собирать для них подношения» ${ }^{158}$.

В Джунгарии, судя по всему, произошла личная встреча Зая-пандиты с Дайчином, который, видимо, и обратился к хутугте с просьбой о посредничестве в урегулировании конфликта торгутов с чакарцами, а также проведении поминального обряда по погибшим и умершим тайшам.

Приезд Зая-пандиты к калмыкам во многом являлся засекреченной информацией. Как правило, сведения в царскую администрацию попадали как через татар и ногайцев, живших или приезжавших торговать в калмыцкие улусы, так и через русских послов и выходцев из калмыцкого плена.

Итак, пребывание посольства А. Кудрявцева у калмыцких тайшей, длившееся с весны по осень 1645 г., по срокам практически совпало с приездом Зая-пандиты. И хотя они лично не виделись, русскому послу, имевшему целью, в том числе и получение информации о положении дел в улусах, удалось собрать с помощью тех же татар и ногайцев некоторые сведения о неизвестном «кутухте». Кудрявцев, не зная его имени, почти не ошибся, определив, что «кутухта» для калмыков является примерно тем же, что для русских «патриарх». Стало известно и о приезде с хутугтой чакарских послов. При посредничестве Зая-пандиты 20 июня 1645 г. прошел первый раунд переговоров между торгутами и чакарцами. Торгутскую сторону

${ }^{158}$ Норбо НI. Указ. соч. С. 43-45, 51. представляли следующие тайши: Лузан, Елден, Сюнке, Санжин и Нима-Церен. Послы выдвинули требование о материальной компенсации за ущерб, причиненный им торгутами в 1642 г., а за погибшего дербетского Дайчина-Хошучи чакарцы взамен требовали старшего сына Елдена - Бадму. Их претензии к Елдену были мотивированы, в первую очередь, тем, что он вместе с покойными отцом Хо-Урлюком и братом Кирсаном был непосредственным участником той самой битвы. За своих людей, погибших в сражении, чакарские послы дополнительно потребовали 500 калмыков, 1000 рублей, 1 тыс. лошадей и 1 тыс. куяков. Только при выполнении этих условий чакарцы обещали торгутам мир и пропуск через свою территорию их предводителю Дайчину. Но этот раунд переговоров закончился провалом, поскольку торгутские тайши отклонили все требования. В ответ они направили к чакарцам уже своих послов, попросив у хутугты содействия в их скором возвращении ${ }^{159}$.

Достаточно интересные сведения о приезде хутугты привез вернувшийся в Астрахань в декабре 1645 г. русский толмач А. Сафонов. Согласно им, неудачные попытки тайшей весной 1645 г. завязать торговлю с русскими под У фой и Самарой привели к откочевке калмыцких улусов к Яику. И именно в это время сюда к торгутам прибыл хутугта в сопровождении 60 человек и 300 воинов-телохранителей. С духовенством приехали и чакарские послы, первоначально остановившиеся в улусе Лузана. Тайша, понимая важность предстоящих переговоров, сразу же через своих людей дал знать другим тайшам о приезде важных гостей, а Сюнке и Нима-Церену предложил со своими улусами присоединиться к нему для совместной кочевки. Но брат и племянник отказались это сделать, объясняя свое решение опасением, что подвластные им ногайцы могут откочевать к Астрахани ${ }^{160}$.

Перед хутугтой стояла довольно сложная задача - во избежание кровопролития среди ойратов убедить торгутов возместить ущерб за гибель дербетского тайши Дайчина-Хошучи и его людей в 1642 г. Очевидно, что главными виновниками этого конфликта ойратское

${ }^{159}$ РГАДА. Ф. 119. Оп. 1. 1645 г. Д. 2. Л. 337.

${ }^{160}$ РГАДА. Ф. 127. ОП. 1. 1646 г. Д. 2. 74-76, 83; Кичиков М.Л. Образование... С. 77. 
сообщество считало торгутских тайшей ${ }^{161}$. Действительно, если обратиться к тексту свода монголо-ойратских законов 1640 г., то получается, что торгутские тайши нарушили сразу несколько его статей. Например, один из пунктов гласит: «...Перебежчиков безо всякого задержанья отдавать возвратно. А кто таковых перебежчиков собою не возвратит, от оного отбирать судом. И за удержанье за каждую душу брать с того штрафа по 20 лошадей и по 2 верблюда $\rangle^{162}$. Другими словами, выплата торгутами компенсации чакарцам была вполне справедливым решением, которое не позволило бы конфликтующим сторонам выяснять отношения вооруженным путем.

Но размер компенсации, на которую претендовали чакарцы, выглядел весьма внушительным. По данным Сафонова, чакарские послы требовали от торгутов выдать кочевавших совместно с Лузаном дербетский улус, едисан и джемболуков, 1 тыс. куяков, 1 тыс. верблюдов и 2 тыс. лошадей (1 тыс. хороших и 1 тыс. плохих). При этом торгуты численно значительно уступали тем же чакарцам. Сафонов в Астрахани озвучил даже вполне конкретные цифры о численном соотношении военных сил: 50 тыс. чакарцев против 10 тыс. торгутов. Если по вопросу возвращения дербетского улуса Лузан и братья ради заключения мира склонялись к принятию положительного решения, то передавать чакарцам ногайцев они категорически отказывались. По другим сведениям, чакарские послы требовали выдачи «за прежнюю недружбу и за кровь недругов их» - тайшу Батура и мирзу Султаная с джембойлуками или всех ногайцев. На требование чакарцев присоединиться к ним и кочевать совместно торгутские тайши ответили, что «им добро кочевать и на тех местах, где ныне кочуют» ${ }^{163}$.

Тем не менее, непростые переговоры к началу осени были завершены и в целом успешно. Лузану, являвшемуся главным переговорщиком с торгутской стороны, в конечном итоге удалось договориться о сокращении размеров компенсации до 500 «лучших татар» с имушеством, 500 куяков (панцирей), 500 верблюдов и 1 тыс. коней.

${ }^{161}$ Кичиков М.Л. Исторические... С. 89.

${ }_{162}$ РГАДА. Ф. 119. Оп. 1. 1640 г. Д. 2. Л. 3.

${ }_{163}$ РГАДА. Ф. 119. Оп. 1. 1645 г. Д. 1. Л. 109; Ф. 127. Оп. 1. 1646 г. Д. 2. Л. $56,83-84$.
Зая-пандита отправил к предводителю чакарцев Кунделен-Убаши послание, в котором сообщал о заключенном соглашении и на этом основании просил отменить приготовления к войне. Торгуты обещали уже следующей весной присоединиться к чакарцам и возвратить всех бежавших к ним дербетов ${ }^{164}$.

В связи с тем, что сильные морозы ударили уже осенью 1645 г., Зая-пандита принял решение перезимовать в торгутских кочевьях. Согласно «Биографии», хутугта также имел целью совершение «бесчисленного множества заупокойных служб» по скончавшемуся ДаянЭрке. Зая-пандита проповедовал среди всех сословий буддийское вероучение, убеждал людей в необходимости переписывать священные книги, читать мани, почтительно обходить вокруг храмов, молиться и т. д. Все это время каждый из тайшей посчитал за честь пригласить хутугту к себе в улус, подарить ему и его людям многочисленные подарки. Так, казне Зая-пандиты было преподнесено 10 тыс. лошадей, шанцзодбе (казначею) - 1 тыс. лошадей, старшим ламам - по 500 лошадей, грамотным послушникам-банди - по 100 лошадей, неграмотным банди - по 60 лошадей, малолетним банди - по 20 лошадей, простым прислужникам (мирянам) - по 10 лошадей. В общей сложности торгутские тайши подарили духовным лицам свыше 20 тыс. лошадей, что, по словам Елдена, значительно превышало численность подаренных скота и лошадей Индзан-хутугте, приезжавшему ранее к торгутам.

Согласно «Биографии», Зая-пандита отбыл от торгутов в Джунгарию в конце лета 1646 г. ${ }^{165}$ По калмыцкому обычаю все тайши и призванные ими ногайские мирзы отправились провожать представительство Зая-пандиты. Предполагалось также заключение мирного договора между торгутскими и чакарскими тайшами ${ }^{166}$. Возвращение хутугты оказалось своевременным, поскольку в Джунгарии ему вновь пришлось заниматься разрешением военного конфликта, теперь уже между чакарцами и джунгарами. Однако состоявшаяся зимой 1646/47

${ }^{164}$ РГАДА. Ф. 127. Оп. 1. 1646 г. Д. 2. Л. 85; Кичиков М.Л. Исторические... С. 90.

${ }^{165}$ Норбо ШІ. Указ. соч. С. 46-47.

${ }^{166}$ РГАДА. Ф. 127. Оп. 1. 1646 г. Д. 2. Л. 59. 
года при посредничестве Зая-пандиты встреча Кунделен-Убаши с Батуром-хунтайджи и Очирту не имела положительного результата ${ }^{167}$

Неурегулированные отношения с Астраханью и постоянные набеги башкир создали ситуацию, когда мелкие тайши, более подверженные риску остаться без улуса, начали откочевывать на восток. Так, летом 1646 г. такие тайши, как Цецен, Омбо и Биликту, всего 300 кибиток откочевали к хошутскому тайше Кунделен-Убаши. Немногочисленные ногайцы, жившие в их улусах, от них сбежали. Стоит отметить, что ногайцы и татары были весьма обеспокоены переговорами торгутских тайшей с чакарцами. В их улусах ходили слухи о возможном уходе калмыков на восток, на свои старые кочевья. Едисанские мирзы решили, что при таком повороте событий они, «пометав животы свои», побегут в Астрахань, невзирая на присутствие на заставе почти 400 калмыков, охранявших их. Ногайцы также надеялись на успешный исход переговоров калмыцких послов в Астрахани $^{168}$.

Одним из немногих, кто категорически был против ухода к чакарцам, был Лузан. Осенью 1646 г. он вместе с подвластными ему ногайцами перешел Яик и кочевал в междуречье, хотя большинство тайшей оставалось на прежних местах. Отсюда он пытался завязать отношения с астраханскими ногайцами, трижды отправив к ним посланцев. В ноябре терский воевода В. Оболенский сообщал о приезде неких калмыцких татар к большим ногайцам с призывом присоединиться к тайшам, в противном случае последние обещали начать против них военные действия. Параллельно Лузан просил военную помощь у астраханцев, чтоб «итти в горы и на казыевцов отмещать кровь отца своего», обещая взамен дать аманатов. В случае отказа тайша грозился поставить калмыцкую заставу за рекой Бузан, в урочище Кизыл-Бирун, и не пропускать горожан на промыслы. На требование удалиться от Астрахани он ответил, что «за Яиком кормы животинные вытравлены», да и чакарцы продвигаются на их «ближние кочевные места, и они де от них боятца) ${ }^{169}$.

167 Златкин И.Я. История... 1983. С. 132.

${ }^{168}$ РГАДА. Ф. 119. Оп. 1. 1646 Г. Д. 1. Л. 61, 77.

${ }^{169}$ РГАДА. Ф. 119. Оп. 1. 1646 г. Д. 1. Л. 80, 94-96, 106; Кичиков М.Л. Образование... С. $78-79$.

\section{7. Калмыцкие кочевья в 1645-1647 гг.}

Весной 1645 г. наблюдалась перекочевка калмыцких улусов на летние пастбища к в верховьям реки Самара, на Илек и Орь. Передвижение калмыков в уфимском направлении привело к новым столкновениям с башкирами, хотя попытки договориться с ними предпринимались. Так, в верховьях Эмбы калмыцкая разведгруппа из 40 человек во главе с Чокулой столкнулась с отрядом из 14 башкирских охотников. Стороны заключили соглашение, и калмыки вернули башкирам захваченных у них лошадей ${ }^{170}$. Примерно в маеиюне из Уфы в калмыцкие улусы приехали 50 русских и башкир с калмыцкими послами, которых местные власти насильно удерживали около трех лет. Тайши восприняли это как положительный сигнал к налаживанию отношений и в ответ с уфимцами отправили своих послов.

В августе 1645 г. в Уфимском уезде (в двух днях пути от Уфы) объявился отряд калмыков в 500 человек под командованием Чокулы. Сюда он прибыл только с одной целью - вызволить из башкирского плена свою супругу Ногану, захваченную в ходе разгрома калмыцкого улуса в 1644 г. воеводой Л. Плещеевым. Из Уфы для переговоров к нему был отправлен боярский сын П. Ураков, который вызвался помочь Чокуле обменять полон. Чокула лично дал шерть Уракову в том, что больше не будет совершать набеги со своими людьми на Уфимский уезд и башкир. Уракову помог калмыцкому дархану разыскать и вернуть его жену. В дальнейшем между ними сложились вполне доверительные отношения, и уже Чокула вызвался помочь Уракову найти в калмыцком плену его людей ${ }^{171}$

Очевидно, что у калмыков и башкир захват пленных, прежде всего, рассматривался всего лишь как средство для обмена захваченных родственников. Например, на требование воеводы представить в Уфу всех пленных калмыков башкир Конкас Давлетбаев пояснил: «... есть де у них калмацкий взятый язык, а не везут его в город Уфу, потому что ждут де оне калмыцких послов и он де его хочет им, калмыкам,

170 РГАДА. Ф. 119. Оп. 1. 1645 г. Д. 1. Л. 4, 103, 108

${ }^{171}$ РГАДА. Ф. 119. Оп. 1. 1645 г. Д. 1. Л. 126-127, 129, 131. 
отдать на откуп им свою братею на башкирцев взамен» ${ }^{172}$. Интенсивность подобных обменных операций резко возрастала после военных столкновений, когда крупные потери пленными несли обе стороны ${ }^{173}$.

Чокула был одним из приближенных людей Дайчина, человеком опытным и мудрым. Для многих молодых тайшей он был опорой, поэтому не удивительно, что Нима-Церен и вдова Даян-Эрке кочевали именно с ним. Очевидцы рассказывали, что во многом они даже слушались своего дархана, который, по сути, являлся их же подчиненным. Например, когда Нима-Церен с братьями намеревался совершить набег на Уфимский уезд и башкир, то Чокула их осадил, предупредив, что уже дал шерть русскому представителю. Молодых тайшей дархан поставил на место довольно хлесткой фразой: «и так де они завоевалися с Талаем тайшею и с кизылбашским и юргенским цари и со всеми ордами, а как они станут 3 государем ссоритца, и им де и жить будет негде». Нима-Церену и другим молодым тайшам пришлось согласиться с вескими доводами Чокулы ${ }^{174}$.

В сентябре 1645 г. в Уфу из калмыцких улусов вернулись А. Онучин, толмач Г. Люзмин и башкирский тархан Табынай. Тайши долгое время насильно их удерживали у себя, но уфимцам удалось в конечном итоге сбежать. По их словам, Лузан не раз угрожал им набегами на Уфимский и Казанский уезды ${ }^{175}$. В свою очередь бегство Онучина и его людей сорвало замыслы калмыков на очередной набег на Уфимский уезд ${ }^{176}$. Как правило, в случае бегства пленников тайши отменяли запланированный набег на соседей, поскольку это лишало их действия фактора внезапности и ставило под сомнение успешное окончание военного мероприятия.

Все это время Лузан внимательно отслеживал передвижения ногайских улусов на крымской стороне Волги. Еще в августе тайша отправил своих посланцев к казыевским мирзам с предложением при-

172 Цит. по: Азнабаев Б.А. Статус пленных в башкирских общинах XVII в. // Известия Алтайского государственного университета. Барнаул, 2012. № 4-1. C. 13.

${ }_{173}$ Азнабаев Б.А. Указ. соч. С. 13

${ }^{174}$ РГАДА. Ф. 119. Оп. 1. 1645 г. Д. 1. Л. 136-138.

${ }^{175}$ РГАДА. Ф. 119. Оп. 1. 1645 г. Д. 1. Л. 112-113, 116.

${ }^{176}$ РГАДА. Ф. 127. Оп. 1. 1646 г. Д. 2. Л. 82. соединиться к нему в обмен на возращение полона, захваченного у них в 1643 г. Такие же призывы адресовались и ногаям, кочевавших в Мочагах. В противном случае тайша обещал пойти на них войной и насильно присоединить к себе. Но мирзы, арестовав его посланцев, выдали их астраханцам. Внимание Лузана привлекала к себе и так называемая «половина» ногайского улуса Урмаметевых, отошедшая из-под Крыма и кочевавшая недалеко от Дона ${ }^{177}$.

$\mathrm{O}$ контактах тайшей с терскими ногайцами нам становится известно из материалов «Кабардинских дел». Согласно сведениям, полученным из Терского городка в Москве в декабре 1645 г., к Ямгурчею Янмаметеву, мигрировавшему ранее с улусом на Терек из-под Астрахани, прибыли татары Тюгеш и Бердымбет, представители от Лузана и Сюнкея. Оказалось, что Тюгеш был не впервые на Тереке, до этого он уже приезжал и всячески агитировал здешних мирз присоединиться к калмыкам, угрожая в противном случае силовыми действиями на них со стороны тайши Лузана. Незадолго до этого ему подобным образом удалось подговорить и увести за собой улус мирзы Солтаналея. На этот раз умелой агитации Тюгеша подверглись улусные люди мирзы Ямгурчи, но Чебан-мирза их вовремя перехватил и вернул на прежнее место кочевки. На этом основании терские власти сочли необходимым поставить в известность кумыков, кабардинцев и малых ногайцев о возможной угрозе нового калмыцкого вторжения $^{178}$.

Осенью 1645 г. ожидания тайшей оправдались, из Астрахани к ним были отправлен ранее задержанный калмыцкий посол Исенгелдей с листом. Поскольку он был человеком Сюнке, то последний срочно оповестил о прибытии своего представителя и других тайшей. Елден вместо себя отправил к брату на переговоры своего сына Бадму, Лузан - одного из своих приближенных, а Нима-Церен лично явился к дяде. На встрече Сюнке старался особо выделить свой успех на дипломатическом поприще, достигнутый, как он считал, благодаря отказу от участия во всех военных акциях против России. Бадма от имени отца дальнейшие отношения с русскими предложил начать,

177 РГАДА. Ф. 127. Оп. 1. 1646 г. Д. 2. Л. 15-17, 19, 93.

${ }^{178}$ РГАДА. Ф. 115. Оп. 1. 1646 г. Д. 1. Л. 294, 297, 309. 
что называется, с «чистого листа): «наперед сего от них, что ни бывало, и того б старого ничего не начинати, а вперед бы никому дурну не быть». Его позиция устроила практически всех собравшихся тайшей ${ }^{179}$.

По договоренности с чакарскими калмыками и Зая-пандитой торгуты должны были к ним присоединиться. Но отход от Астрахани, где оставались еще останки Хо-Урлюка, Кирсана и Церена, а также задержанные калмыцкие послы, был в принципе невозможен. Поэтому на ближайшую зиму тайши выработали общий план, предусматривавший совместный поход с отрядами к Астрахани и новой попытки договориться с воеводами о возвращении послов и останков тайшей. Если последнее не удалось бы, то калмыки планировали захватить астраханских татар и ногайцев, кочевавших по крымской стороне Волги, для дальнейшего их обмена. В том случае если бы ногайцы согласились добровольно присоединиться к калмыкам, то планировался уже совместный набег на Казыевский улус, чтобы затем казыевцев обменять на «кости» тайшей. Возвращение останков тайшей для калмыков было принципиальным вопросом: «однолично добиватца, потому что де им без Урлюковых костей к дальним калмыкам никоторыми делы идти не уметь») 180

1 декабря 1645 г. в Астрахань прибыл калмыцкий татарин Козеин с письмом от тайши Сюнке. Ниже приводится фрагмент перевода письма со старописьменного татарского языка:

Божиею милостью великого государя, царя и великого князя Михаила Федоровича Всеа Руси Самодержиа и многих государсть царя и обладателя, боярину и воеводе князю Борису Александровичу Репнину, да окольничему киязю Федору Федоровичу Волконскому, да дьякам Григорию Леонтьевичу да Дмитрию Никифоровичу Шункей майиа Урлюков с честью челом бъет.

В проилом году взят был Кересан тайчин калмыченин и с тем калмыченином прислали вы к нам с грамотою дву человек татар $A$ ная да Доюна, а с ними приказали, чтоб нам Андрея толмача (Сафонова. - В.Т.) с товарищами отдать. Да посылали мы с братею в

\footnotetext{
${ }^{179}$ РГАДА. Ф. 127. Оп. 1. 1646 г. Д. 2. Л. 87.
}

${ }^{180}$ РГАДА. Ф. 127. Оп. 1. 1646 г. Д. 2. Л. 107.
Астрахань послов своих Исенгелдея с грамотою, а в грамоте своей писали, как Урлюк тайии убили, и или с той войны назад и в то время взяли на погроме Берека туркмена да двух человек калмычат. И тово туркмена и калмыка посадили в темницу. А калмыков имен Серикеп да Барсу. Чтоб вам тово туркмена и калмыков прислать с послом наиим на Яицкий город. А мы тово толмача Андрея с товарищами привезем к тому де городу, и трех татарин вам бы разменять. И вы прислали к нам посла намего, а с ним прислали Алей мурзиных, и те татары и калмыки до нас доехали здоровыми. А с тем наиим послом прислали к нам грамоту, и мы ту грамоту к братьям своим к Елден mайше да Церен тайие, Урлюковьм детям всем, и чтоб им учинить мир и послами ссылатща. А как мы учинили договор и в Астрахань послов посылали и иертовали, после того под Астраханьто сами войной не хаживали и никово не посылали, и ни под которыми городами и в уездах не бывали, и рыболовам никоторого дурна не чинили.

И стою на своей иерти и по Волге не кочую, а кочую за Яиком. И учну зимовать и кочевать на Сагизе. А как Шереикеп к нам приехал, и мыл для государева здоровья Андрея толмача отпустили с Алей мурзиным человеком Козеем с честью. А ево было взяли не мы, отдали нам ево Андрея едисанские мурзы, а один его товарищ бежал наперед сего, а одного товарища послали с Исенгелдеем ${ }^{181}$.

Действительно, в декабре в Астрахань вернулся толмач А. Сафонов, который около года насильно удерживался в калмыцком улусе. Тайша через толмача предлагал астраханским властям обменять своих послов Барина и Байтерека, содержавшихся в тюрьме, на пленных стрельцов $^{182}$. Следует сказать, что долгое пребывание в калмыцких улусах позволяло русским посланникам собрать значительный объем информации о состоянии калмыцкого общества, и сегодня эти материалы представляют огромный интерес для исследователей.

Тяжелые погодные условия зимы 1645/46 года, повлекшие за собой массовый падеж скота и лошадей в улусах, снова подняли в калмыцком обществе вопрос о возможности компенсировать потери за счет соседей. В январе 1646 г. в урочище Белужье возле Волги неожи-

181 РГАДА. Ф. 127. ОП. 1. 1646 г. Д. 2. Л. 130-132.

${ }^{182}$ РГАДА. Ф. 127. Оп. 1. 1646 г. Д. 2. Л. 92, 99. 
данно во главе тысячного войска появился Елден с сыновьями Мергеном и Тугулом. Они выступили инициаторами набега на астраханских ногаев, призвав к участию в нем Лузана и Нима-Церена. Однако Лузану пришлось отказаться от участия в совместной акции, так как большая часть его улуса кочевала за Яиком, где в результате сильных морозов пало много лошадей. Лузан также был против похода на Казыевский улус или Крым, поскольку еще не были окончательно урегулированы отношения с Астраханью. Бедственное положение его калмыков заставило Лузана даже отпустить на Кубань двух казыевских мирз - Адиля и Шараша с сотней человек. В одну из ночей астраханцы совершили вооруженную вылазку против калмыков, отогнав у них 300 лошадей. В целях безопасности Елдену пришлось отвести свой отряд на 10 верст от города. Нима-Церен с отрядом пришел на помощь к дяде и стоял на заставе в урочище Байгонур. Отправленный им на разведку за реку Бузан отряд в 60 человек столкнулся с вооруженными астраханцами и, потеряв в бою часть людей, отступил обратно. После этого Нима-Церен, больше не испытывая судьбу, увел своих людей обратно в улусы, где у него также царил голод. В степи отсутствовали даже сайгаки. Калмыцкие тайши предусмотрительно расставили напротив Астрахани пограничные заставы в трех урочищах - Каратерезе, Кизыле и Байгонуре. 11 марта НимаЦерен откочевал со своим улусом за Яик ${ }^{183}$.

С приходом к власти царя Алексея Михайловича в 1645 г. правительственный курс по отношению к калмыкам постепенно стал меняться к лучшему. Для поддержания переговорного процесса в феврале 1646 г. из Астрахани к тайше Сюнке как ответ на его письмо были отправлены юртовские татары Чаргу и Багазыч с листом, в котором поощрялась мирная инициатива тайши, предлагались обмен пленными и возврашение калмыками ногайских кибиток ${ }^{184}$.

В мае 1646 г. в Астрахань прибыли калмыцкие посланцы Исенгелдей Тазаев и татарин Русмамбет, представлявшие интересы тайшей Сюнке и Нима-Церена. Как позже стало известно астраханцам, инициатором отправки посольства был и Дайчин, поручивший сыну

${ }^{183}$ РГАДА. Ф. 127. Оп. 1. 1646 г. Д. 2. Л. 41-45, 53-54, 62-63

${ }^{184}$ РГАДА. Ф. 127. Оп. 1. 1646 г. Д. 2. Л. 122-125.
Нима-Церену урегулировать отношения с русскими властями, признать свою вину и в дальнейшем всячески избегать столкновений. Вероятно, отец просил сына до его приезда постараться выиграть время и не втягиваться в никакие конфликты. Еще перед отьездом в Тибет Дайчин поручил свой улус старшему сыну Даян-Эрке, но после смерти последнего отцовским уделом совместно с дядей Елденом стал управлять следующий по старшинству сын - Нима-Церен ${ }^{185}$.

Для заключения мирного договора калмыцкие посланцы просили прислать к тайшам знатного дворянина и толмача. С калмыцкой стороны участвовать в переговорах выразили желание тайши Сюнке, Елден, Нима-Церен, Батур и Шарап-Омбо. Их улусы кочевали за Яиком, в урочищах рек Уил и Игирлик. Торгуты окончательно отказались от совместного кочевания с чакарцами, все еще опасаясь, что те «кровь свою им отомстят». По сообщению посланцев, по возвращении Дайчин намеревался «бить челом» перед государем и просить у него русские войска, чтобы совместно (итти на черкас (черкесов. - B.T.) отомстить кровь отца своего Урлюк тайши и брата своея, которых черкасы побили». Только на этих условиях тайша соглашался дать в аманаты сына или предоставить на государеву службу своих воинов. При этом со стороны калмыков речь шла исключительно о взаимном аманатстве и только на период военных действий. Но астраханские воеводы особо не верили обещанию тайшей принять российское подданство. Краеугольным камнем в русско-калмыцких отношениях оставался пресловутый вопрос об аманатах. Астраханцы еще раз напомнили посланцам, что без выдачи аманатов калмыкам никак не возможно будет принять русское подданство. В качестве примера они приводили ногайцев, татар, башкир, кабардинцев и другие народы, которые, дав аманатов, уже находились в орбите политического влияния Московского государства. Но калмыцкие посланцы лишь уклончиво ответили, что тайши не уполномочивали их вести переговоры по данному вопросу ${ }^{186}$.

Другой острой проблемой оставался «ногайский» вопрос. Тайши просили у русских кочевья между Яиком и Волгой, взамен обещая

${ }^{185}$ РГАДА. Ф. 119. Оп. 1. 1646 г. Д. 1. Л. 4-6.

${ }^{186}$ РГАДА. Ф. 119. Оп. 1. 1646 г. Д. 1. Л. 6-9, 10. 
вернуть едисан, но только в том случае, если они сами пожелают вернуться под Астрахань. Воеводы отказывались заключать соглашение на подобных условиях, аргументировав это тем, что едисаны и джембойлуки еще до прихода калмыков были под «государевой рукой». Посланцы также просили назначить встречу возле Яицкого городка для обмена русских пленных на останки Хо-Урлюка, Кирсана и Церена.

Летом 1646 г. тайши продолжали кочевать за Яиком. В августе посол хивинского хана Абу-л-Гази направлялся в Астрахань и, проезжая через Эмбу, на время остановился в улусе тайши Далантая, который не преминул воспользоваться выпавшим случаем и отправил вместе с ним к воеводам своего представителя с письмом. Но в районе между Яиком и Волгой посольство было ограблено астраханскими татарами. Астраханские власти, узнав об инциденте, немедленно ужесточили военное наблюдение по реке Бузан. Однако торговые караваны подвергались нападениям и со стороны отдельных калмыцких тайшей. Например, известно, что весной 1646 г. один из таких караванов, направлявшийся из Астрахани в Ургенч, был ограб́лен людьми молодого тайши Куена, приходившегося Нима-Церену племянником ${ }^{187}$

Уфимскому направлению калмыки продолжали также уделять внимание. Летом 1646 г. к Сюнке и Нима-Церену прибыли башкирские посланцы с предложением мира и взаимной торговли. Тайши, оставив их у себя в качестве заложников, отправили к башкирам большое число калмыцких торговых людей с «продажной животиной». Однако некоторые из них направлялись к соседям не только с торговой миссией. Часть калмыков, отыскав и отобрав у башкир своих плененных жен и детей, бежали обратно в свои улусы. Этот инцидент вызвал сильное недовольство у башкир, и на этом основании они задержали у себя около 60 торговых калмыков, но остальным удалось скрыться ${ }^{188}$.

В декабре 1646 г., как только замерзла Волга, ногайские мирзы Аксак Келмаметев и Каспулат Мамаев совместно с калмыками Луза-

\footnotetext{
187 РГАДА. Ф. 127. Оп. 1. 1646 г. Д. 2. Л. 198-201, 223-224, 236-237.
}

${ }^{188}$ РГАДА. Ф. 119. Оп. 1. 1646 г. Д. 1. Л. 57. на и Сюнке на крымской стороне совершили набег на ногайские улусы мирз Ямгурчея и Салтанаша. Это сразу вызвало новую волну паники среди астраханских мирз, до которых дошел слух о возможном нападении калмыков и ногайцев на татарские улусы, расположенные в морских косах и Мочагах. Для сбора разведывательной информации о калмыках и взятия языков воеводы отправили из Астрахани несколько отрядов. Вскоре они привезли в город двух калмыцких пленников, один из которых оказался татарином. Другой - калмык по имени Улжутук из улуса Лузана - под пытками дал следующие показания. В плен он попал, собирая на правобережье Волги отставший скот, который калмыки гнали из разгромленных ногайских улусов. Еще осенью тайши Лузан и Сюнке договорились о совместных военных действиях против ногайцев, кочевавших на крымской стороне Волги. Один только Лузан отправил в набег 200 своих воинов под командой своего родственника Тууша, а всего в нем участвовало около тысячи человек, включая и ногайцев, кочевавших с калмыками. В итоге у ногайцев на крымской стороне Волги нападавшая сторона захватила 200 кибиток и 2 тыс. голов скота ${ }^{189}$.

В это время у Лузана с братьями отношения были натянутыми, поскольку, по словам калмыцкого пленника, он «их ни в чем не слушает». В улусе Лузана часто и подолгу проходили съезды сторонников его «партии», на которых нередко возникали споры относительно того, как действовать дальше на астраханском направлении: продолжать силовое давление или жить в мире ${ }^{190}$.

В Астрахани казанский татарин Кармыш Тогаев сообщал, как тысячный отряд калмыцких ногайцев под командой Дойнаша на реке Тохтачю летом 1647 г. разбил казанский отряд в 500 человек. В числе пленных оказался и Кармыш. Находился он в улусе Нима-Церена, и тайша лично его расспрашивал про «Казанское государство», насколько оно велико. Известно, что в Казанском уезде проживало около 40 тыс. ясачных татар, а вместе с мордвой и черемисами их насчитывалось примерно 100 тыс. человек. Полученная от пленника информация погрузила Нима-Церена в размышления, и он, по словам

189 РГАДА. Ф. 127. ОП. 1. 1647 г. Д. 1. Л. 34, 37, 40, 66

${ }^{190}$ РГАДА. Ф. 127. Оп. 1. 1647 г. Д. 1. Л. 41, 77-78. 
Кармыша, о чем-то по-калмыцки долго советовался со своими приближенными ${ }^{191}$. Район Среднего Поволжья отдельными калмыцкими тайшами, вероятно, рассматривался как одно из возможных направлений для набегов. Но шаткое положение калмыков в Северном Прикаспии еще не позволяло им серьезно претендовать на этот регион.

В калмыцком обществе находились и те, кто давно для себя определил характер будущих отношений с русскими властями как мирное развитие на основе взаимовыгодного сотрудничества. К ним с полной уверенностью можно отнести тайшу Сюнке, чьи посланцы Эсембет и Онкай с тремя сопровождающими прибыли в Астрахань в ноябре 1647 г. С собой на продажу они пригнали 40 лошадей, 80 овец и 2 верблюдов. Посланцы передали воеводам письмо Сюнке на татарском языке, в котором тайша, в частности, жаловался на едисан, которые якобы подстрекают калмыков участвовать в набегах на русские селения, продают полон, сами же отгоняют у калмыков лошадей и продают их в Астрахани. На этом основании тайша предостерегал астраханцев особо не доверять едисанам. Посланцы также отрицали факт участия калмыков из улуса Сюнке в зимнем набеге на ногайцев, кочевавших на правом берегу Волги ${ }^{192}$.

В поиске способов урегулировании русско-калмыцких отношений находился и Лузан. Осенью 1647 г. он предлагал Нима-Церену, Елдену, Сюнке и другим тайшам собраться с отрядами недалеко от Астрахани, чтобы предложить русским заключение мирного договора, а в случае отказа начать военные действия. Но братья и племянники Лузана не одобрили этот план, поскольку в Астрахани посланцы Сюнке еще продолжали вести переговоры с воеводами. Большие надежды тайши возлагали на скорый приезд в улусы Дайчина. Братья посоветовали Лузану не предпринимать никаких активных действий хотя бы еще полгода, т. е. до лета 1648 г., и только потом попытаться снова заключить мирный договор с астраханцами. В дальнейшем тайши планировали совместный военный поход против Казыевского улуса $^{193}$. А в это время Дайчин уже возвращался в родные кочевья.

${ }^{191}$ РГАДА. Ф. 127. Оп. 1. 1648 г. Д. 1. Л. 257-258.

192 РГАДА. Ф. 127. Оп. 1. 1647 г. Д. 1. Л. 93, 96, 99, 104-105.

${ }^{193}$ РГАДА. Ф. 127. Оп. 1. 1647 г. Д. 1. Л. 148.

\section{Глава 4. \\ ПОЛИТИЧЕСКАЯ СИТУАЦИЯ В СЕВЕРНОМ ПРИКАСПИИ В 1648-1655 гГ.}

\section{1. Политическое возвышение Дайчина}

Возвращение Дайчина в родные улусы долгое время считалось не вполне определенным. При анализе сведений из архивных документов удалось выяснить, что Дайчин вернулся в свои кочевья примерно в конце 1647 г. Именно с этого времени его имя присутствует в показаниях астраханской администрации. Однако было известно, что, возвращаясь в родные кочевья, торгутский тайша примерно в сентябре 1647 г. вместе с кучумовичами был инициатором совместного военного выступления против Тюмени, Тобольска и Уфы. В частности, за поддержкой он обратился к дербетским тайшам Кешкебу и Цецену (сыновьям Дайчина-Хошучи), которые кочевали с улусами отдельно от основной массы дербетов. Об этом сообщал русский посол П. Терехов, приезжавший в улусы вышеназванных дербетских тайшей, однако результаты переговоров для него остались неизвестными. О возможном набеге калмыков указанных тайшей предупреждал сибирских воевод и хошутский Аблай. Съезд чакарских тайшей по рассмотрению инициативы Дайчина проходил непосредственно в улусе Кунделен-Убаши ${ }^{1}$. Как отмечали очевидцы, чакарцам Дайчин говорил примерно следующие слова: «не было де ево дома, как государевы люди отца его и улусных людей воевали, и он де отца своево и улусных своих людей кровь будет отомщать»². Чувства Дайчина можно объяснить его долгим отсутствием в родных кочевьях, во время которого он лишился отца, сына, брата и племянников. Во многом главными виновниками гибели своих родственников он, видимо, считал царские власти. Также очевидно, что после долгого противо-

${ }^{1}$ МИРМО. М., 1974. С. 323.

${ }^{2}$ Миллер Г.Ф. Указ. соч. Т. II. С. 606. 
стояния отмечалось потепление отношений между торгутами и чакарцами, так как в противном случае Дайчин не смог бы безопасно для себя миновать территорию, где располагались дербетские и хошутские улусы.

Как только Дайчин вернулся, другие тайши, мирзы и лучшие улусные люди приехали поприветствовать его, поздравить с долгожданным приездом и привезли многочисленные подарки. Дайчин сразу объявил им план своих действий на ближайшую зиму. С началом ледостава на Волге он планировал с войсками подойти под Астрахань, предварительно отправив своих послов к воеводам с мирным предложением, чтобы в дальнейшем двигаться уже на Северный Кавказ и отомстить кабардинцам за гибель отца. В случае непринятия астраханцами мирных условий Дайчин уже весной и летом следуюшего 1648 г. собирался открыть военные действия против русских в Поволжье и на уфимском направлении ${ }^{3}$.

По сведениям очевидцев, Дайчин по возвращении выражал недовольство и упрекал своих родственников: «для чего де они без него, Дайчина тайши, с государевыми людьми учинились в ссоре, и за то их ссору в Астрахани и послов их задерживают». Действительно, тайши уже опасались отправлять новых послов к русским, поэтому ожидали положительных вестей из Астрахани. Дайчин был крайне возмущен, когда родственники честно признались ему, что к ним из Москвы приезжал «государев посланник» (А. Кудрявцев) с письмом и «для договору», но они, отпустив его обратно, мирное соглашение так и «не учинили» ${ }^{4}$. Калмыцкий предводитель прекрасно понимал, что приезд царского посланника А. Кудряцева в 1645 г. был самым подходящим моментом для урегулирования русско-калмыцких отношений.

Астраханские воеводы, в свою очередь, также побаивались отправлять своих людей к калмыкам. Местные ногайцы небезосновательно опасались новых калмыцких набегов, они даже обратились с коллективной просьбой к астраханскому архиепископу Пахомию, чтобы тот повлиял на воевод по вопросу об отправке к тайшам по-

${ }^{3}$ РГАДА. Ф. 127. Оп. 1. 1648 г. Д. 1. Л. 33.

${ }^{4}$ РГАДА. Ф. 127. Оп. 1. 1648 г. Д. 1. Л. $34,131$. сланцев с мирным предложением. В декабре 1647 г. из Астрахани к тайшам были отправлены трое татар с письмами, в которых им указывалось отвести свои улусы на дальние кочевья, прекратить военные действия против государевых людей, а в случае невыполнения вышеуказанных условий калмыкам угрожали отправить против них царские войска ${ }^{5}$.

Как видим, язык угроз и ультиматумов, применяемый обеими сторонами, никак не способствовал разрядке напряженности в отношениях. Ситуацию осложнил и инцидент, случившийся с астраханскими посланцами, направлявшимися в калмыцкие улусы. По дороге 10 неизвестных калмыков отогнали у них лошадей. На следующее утро стало известно, что это были люди тайши Далантая, который позже лично прибыл к астраханским татарам на стан. Узнав о цели их поездки, тайша забрал у них письмо, адресованное Лузану, посмотрел его, вернул им обратно и уехал. Потом он вернулся с полсотней человек и лучным боем стал обстреливать астраханцев. Последние всячески от них отбивались и, потеряв одного убитым, успели скрыться в Яицком городке ${ }^{6}$. Этот случай еще раз свидетельствует о том, что в калмыцкой среде находились и сторонники продолжения конфронтации с русскими. Именно их агрессивные действия во многом мешали стабилизации русско-калмыцких отношений.

Одной из главных проблем, с которой пришлось столкнуться Дайчину по возвращении домой, являлось решение так называемого «ногайского» вопроса. В целях предотвращения отходнических настроений тайша своим подчиненным ногайским мирзам, как отмечали свидетели, сразу «учинился добрым и во всем им ласку и повольности дал». Если раньше калмыки могли безнаказанно обижать ногаев, отнимая у них лошадей и скот, то теперь Дайчин разрешил им («о татарскому обычаю» забирать у обидчиков свое имущество. Калмыкам же запрещалось по таким делам заниматься сыском. Ногайские мирзы были весьма довольны таким решением Дайчина и поэтому отложили свои планы по уходу от калмыков под Астрахань. Более того, созвав братьев, Дайчин устроил с ними совет, на котором

\footnotetext{
${ }^{5}$ РГАДА. Ф. 127. Оп. 1. 1648 г. Д. 1. Л. 40-41, 50.

${ }^{6}$ РГАДА. Ф. 127. Оп. 1. 1648 г. Д. 1. Л. 48-49.
} 
обсуждался вопрос о закреплении подчиненных им ногаев. В результате они приняли общее решение о заключении династических браков: например, Дайчин свою дочь выдал замуж за едисанского мирзу Салтамурата Каспулатовича Тинбаева, Лузан тоже выдал свою дочь за едисанского мирзу Сююнчу Абдулова, а другим калмыцким тайшам теперь рекомендовалось брать в жены дочерей ногайских мирз. Эта практика распространялась и на простых улусных людей. Как отмечали очевидцы, ранее ничего подобного между калмыками и ногаями не наблюдалось?

В политическом и экономическом отношении тайши пошли на определенные уступки ногайским мирзам. Дайчин назначил Аблумирзу Тинбаева князем (бием), Абдулу-мирзу Тиникеева - нуреддином, а Юсупа Тиникеева - кейкуватом. Подобного рода назначения. входили, как правило, в компетенцию крымского хана или московского царя. Это дает основание предполагать, что Дайчин после поездки в Тибет все-таки имел статус хана. Сбор пошлин с проезжавших и торговавших в калмыцких улусах купцов из Бухары, Ургенча и Туркмении также был возложен на калмыцких ногаев ${ }^{8}$. Все эти меры, конечно, были направлены на создание благоприятных условий для ногаев в составе калмыцкой орды, что, по мнению тайшей, должно было пресечь сепаратистские настроения.

В торговых связях между городами Московского государства и среднеазиатскими ханствами имелись еще трудности, особенно на сухопутных маршрутах. Так, в 1648 г. люди Дайчина захватили торговый караван, направлявшийся из Астрахани в Бухару. Если треть лучшего товара Дайчин взял себе, то остальное он купцам велел распродать у себя в улусе. Бухарец Ярам-Мамбет сообщал в Астрахани, что 20 тыс. калмыков летом 1648 г. ходили войной на казахского султана Джахангира, узнав, что тот планирует против них военный поход. С Ургенчем же калмыки находились в мире, и Дайчин ближайшую зиму намеревался провести именно под этим городом ${ }^{9}$.

РГАДА. Ф. 127. Оп. 1. 1648 г. Д. 1. Л. 27-28, 30

${ }^{8}$ РГАДА. Ф. 127. Оп. 1. 1648 г. Д. 1. Л. 372.

${ }^{9}$ РГАДА. Ф. 127. Оп. 1. 1648 г. Д. 1. Л. 433, 439.

\section{2. Крымский поход калмыков}

Долгое время Россия на крымском направлении остро нуждалась в дополнительных военных силах, особенно в коннице. Такими возможностями русская армия в достаточной мере не располагала, и калмыки, предлагавшие Москве еще с начала 1630-х гг. использовать их военный потенциал, представлялись для решения подобной задачи вполне реальной силой. Крымское направление в политике тайшей примерно с начала 1640-х годов обрело вполне четкое и зримое очертание.

Во время прошлого приезда посольства А. Кудрявцева, где решался среди прочих, как известно, и крымский вопрос, русский посол еще больше обострил интерес тайшей к данному направлению. Но только с возвращением Дайчина тайши попытались использовать в своих политических целях «крымскую проблему», одну из острых во внешней политике России, для урегулирования серьезно подорванных на тот момент русско-калмыцких отношений. Примерно около полугода ушло на подготовку крупномасштабного для того времени военного похода калмыков на Крым. Разногласия у тайшей, видимо, имелись только по одному вопросу - куда первоначально нанести удар: по Северному Кавказу или Крыму.

Поскольку калмыкам предстояло действовать на незнакомой территории, большое внимание они уделяли сбору разведывательной информации о районе предстоящих военных действий. По сообщению из Яицкого городка, уже в декабре 1647 г. Лузан и Сюнке выступили инициаторами военного похода на Кабарду и Казыевский улус. Кавказское направление для калмыцких тайшей продолжало иметь важное значение, поскольку их не покидала жажда мести за смерть Хо-Урлюка. Но военные действия в этом регионе требовали поиска союзников. Об этом свидетельствует письмо кабардинских князей А. Шеганукова и Х. Казыева русскому царю, в котором сообщалось о продолжающихся контактах эндерийского Казаналпа с калмыками и утверждалось, что они заключили между собой военный союз ${ }^{10}$.

\footnotetext{
${ }^{10}$ Нимелев А.С. Указ. соч. С. 229-230.
} 
Узнав о намерении своих братьев, Дайчин срочно отправил к ним людей с предупреждением не начинать без него каких-либо активных действий. Сам он в это время, собрав войско из калмыков и ногаев, двигался от Индерских гор к Волге. Поскольку поход намечался дальний, калмыки брали с собой продовольственный запас на 4 месяца. Лузан во главе передового отряда из 2 тыс. калмыков и 1 тыс. ногаев, уже стоял военным лагерем в урочище Нарын-песков, отправив к Волге для взятия языков 400 калмыков и 10 ногайских проводников под командованием тайши Бюракаша. В урочище Круглого острова калмыцкий разведывательный отряд захватил русского «зверовщика) и, отправив языка к Лузану, перешел на правый берег Волги в 50 верстах выше Астрахани ${ }^{11}$.

Посовещавшись, калмыцкие тайши приняли общее решение отказаться пока от похода на Кавказ и двигаться на Крым. Это направление было поддержано ими еше и потому, что были получены разведданные о нахождении Урмаметева улуса недалеко за Доном и о том, что они «государю не послушны». Исходя из этого, у тайшей возник довольно смелый и дерзкий план - захватить данный ногайский улус, овладеть его конскими табунами и уже на свежих лошадях вторгнуться непосредственно на Крымский полуостров. Именно захват ногайского конского состава, по мнению тайшей, позволил бы калмыкам достичь Крыма, поскольку на своих лошадях да еще и в зимних условиях совершить далекий марш-бросок было весьма сложно ${ }^{12}$

Передвижения крупных воинских сил калмыков в районе Волги не могли остаться не замеченными астраханскими властями. Местные мирзы были предупреждены воеводами о нависшей над ними угрозе. Несколько отрядов конных стрельцов и татар тотчас были отправлены вверх по реке для сбора разведданных о калмыках ${ }^{13}$. Весть об уходе значительного количества калмыков из своих улусов быстро распространилась по округе. Один из астраханских отрядов, сформированный из татар, разведывал передвижение калмыков на право-

${ }^{11}$ РГАДА. Ф. 119. Оп. 1. 1648 г. Д. 2. Л. 1-5.

${ }^{12}$ РГАДА. Ф. 127. Оп. 1. 1648 г. Д. 1. Л. 132, 155.

${ }^{13}$ РГАДА. Ф. 119. Оп. 1. 1648 г. Д. 2. Л. 5-13, 15. бережье Волги. Узнав примерно в каком количестве и в каком направлении двигаются калмыки, астраханские татары половину своих людей снарядили в набег на калмыцкие улусы для отгона лошадей. Более всех пострадал от них кочевавший с калмыками улус ногайского мирзы Каспулата Мамаева, который в результате нападения потерял 600 лошадей ${ }^{14}$.

29 января 1648 г. многочисленное калмыцкое войско, двигавшееся по Дону, появилось в окрестностях столицы донского казачества - Черкасского городка. По отпискам донских казаков в Москву стало известно, что во главе войска стояли 8 калмыцких тайшей: Дайчин, Лузан, Сюнке, Чукур, Нима-Церен, Шарап Кучаров, Солюнтюр, Далантай Чукурев. В состав калмыцкого войска входили и ногаи едисанских мирз Абдыли Теникеева и Теникея Абдыкова, джембойлукских мирз Шамамбета с братьями и малибашских мирз Аксака Келмамбета с братьями. По пути калмыки в степи захватили «на гульбе» (охоте) многих казаков и в знак доброй воли передали их в Черкасский городок. Тайши и мирзы сообщили атаманам об отправке своих посольств в Москву и Астрахань, предлагая и казакам заключить с ними мирный договор. Донские атаманы при столь массовом присутствии кочевников на своих землях не могли открыто ответить им отказом. Численность калмыцкого войска казаки точно не знали. По словам тайшей, всего их насчитывалось 60 тыс. человек, а по сведениям донских татар, калмыков насчитывалось не более 20-30 тысяч ${ }^{15}$. По сведениям ногайских мирз в Астрахани, участников данного военного мероприятия, всего в крымском походе приняло участие около 40 тыс. калмыков и ногаев $^{16}$. Тайши предложили казакам присоединиться к ним для участия в совместном походе против крымских татар и ногайских улусов Урмаметевых, но донские атаманы отказались. В Москве свой отказ донские представители объясняли следущим обстоятельством: «бояся твоей государевы опалы и опасаючи их (калмыков. - B.T.),

${ }^{14}$ РГАДА. Ф. 127. Оп. 1. 1648 г. Д. 1. Л. 150.

${ }_{15}$ Акты Московского государства, изданные Императорскою Академиею Наук (далее - АМГ) / Под ред. Н.А. Попова. Т. 2. Разрядный приказ. Московский стол. 1635-1639 гг. СПб., 1894. С. 196.

${ }^{16}$ РГАДА. Ф. 127. Оп. 1. 1648 г. Д. 1. Л. 155-156. 
чтоб над нами какова дурна не учинили ${ }^{17} .8$ февраля калмыки начали переправу через Дон на правый берег в районе между казачьими городками Раздорный и Бесергенево ${ }^{18}$.

В «Ногайских делах» обнаружены более подробные сведения о переговорах атаманов с тайшами. Согласно им, калмыки были в курсе отправки русских послов из Астрахани к ногайским мирзам Урмаметевым. На основании этого тайши планировали перейти в наступление на этих ногайцев только в том случае, если они откажутся принять русское подданство. Также Дайчин потребовал от атаманов передать ему для расспроса астраханского татарина Тавку Кривого, побывавшего в улусе Урмаметевых и находившегося на тот момент у казаков. Но для начала донские атаманы предложили Дайчину заключить «подлинный мир» и для принесения шерти прислать к ним «лучшего тайшу». Когда в Черкасский городок прибыл тайша БатурКашка, атаманы заявили, что «одному ему в шерти не верят» и на этом основании просили о личном присутствии Дайчина или Лузана, Сюнке или Нима-Церена. Обратно к тайшам Батур-Кашка вернулся с казаком Панкратом и татарином Тавкой, которые передали просьбу атаманов, поскольку «без того де они им не верят». Дайчин детально расспросил Тавку об улусе Урмаметевых и узнал, что эти ногайские мирзы отказались возвращаться под Астрахань и, таким образом, у царя «не учинились в холопстве». Отправленные к ним для переговоров боярский сын и 20 стрельцов Урмаметевыми были ограблены и захвачены в плен, что послужило сигналом для тайшей к продолжению намеченного похода против этого ногайского улуса. Панкрата и Тавку по приказу Дайчина задержали, но казак напомнил, что Батур-Кашка в Черкасском городке дал им шерть, что тайша «им на Дону никакие хитрости не учинит». Поэтому посланцев пришлось отпустить. Тавку калмыки хотели было взять с собой проводником к Урмаметевым, но татарин отказался, сославшись на отсутствие на то «государева указа» $)^{19}$.

В Черкасский городок на переговоры прибыли тайши Сюнке и Нима-Церен, джембойлукский мирза Шамамбет и едисанский мирза

${ }^{17}$ РГАДА. Ф. 111. Оп. 1. 1648 г. Д. 4. Л. 1.

${ }^{18}$ АМГ. СПб., 1894. С. 198.

${ }^{19}$ РГАДА. Ф. 127. Оп. 1. 1648 г. Д. 1. Л. 22-23.
Сююнча Абдулов, там они казакам дали шерть по своей вере. Тайши, мирзы и атаманы, взявшись за руки, клялись друг другу: «что им, калмыцким людем, с ними, донскими атаманы и казаками, в нынешнюю зиму быть в миру и под их казачьими городками людей в полон не имать и лошадей и животину не отгонять; а им де донским казакам над ними калмыцкими людьми под своими городками потому ж никакие хитрости не чинить и за Дон на Урмаметевых детей улусы и назад через Дон их калмыков перепустить безо всякие шкоты». Приехавшим тайшам и мирзам, а также Дайчину казаки подарили учюги (узкие кафтаны-безрукавки) из турецкого сукна, тогда как тайши, по свидетельствам очевидцев, к атаманам приехали без подарков $^{20}$. Правда, как выяснилось позже, казацкая верхушка во главе с атаманом Т. Григорьевым в своей войсковой отписке в Посольский приказ информацию о заключении мирного договора с калмыками умолчала ${ }^{21}$.

Простояв под Черкасским городком четверо суток, калмыки перешли Дон, при этом к ним присоединились около 40 донских татар. Однако продолжению похода помешали погодные условия - ударили сильные морозы, глубокий снег покрыл до этого выжженную летним зноем траву, практически лишив конский состав подножного корма. Начался массовый падеж лошадей, в пешем строю оказались многие калмыцкие воины. К тому же из передового отряда Лузана сбежал некий татарин, который успел предупредить ногайцев Урмаметева улуса о приближении калмыков, и это, конечно, лишало удар внезапности. По дороге калмыками были захвачены 6 азовских воинских людей, которых, после получения от них информации, отпустили в Азов. Дойдя до реки Миус, тайши приняли решение повернуть обратно, но к Урмаметевым они отправили четырех татарских посланцев с требованием присоединиться к калмыкам. В случае отказа калмыки угрожали прийти на них войной уже ближайшим летом, после весеннего половодья ${ }^{22}$.

\footnotetext{
${ }^{20}$ РГАДА. Ф. 127. Оп. 1. 1648 г. Д. 1. Л. 24.

${ }^{21}$ Куч О.Ю. Указ. соч. С. 317-318.

${ }_{22}^{2}$ РГАДА. Ф. 119. Оп. 1. 1648 г. Д. 2. Л. 17; Ф. 127. Оп. 1. 1648 г. Д. 1.
} Л. 25; РИБ. СПб., 1913. Т. 29. Кн. 4. С. 841-843. 
Еще в 1647 г. Крым подвергся нашествию саранчи, которая уничтожила всю растительность и хлеба, вызвав тем самым настоящий голод на полуострове. Практически все крымские татары и подвластные им ногайцы выдвинулись на север, за Перекоп, и кочевали на Конских, Молочных, Овечьих и Псонских Водах. Ногаям из Урмаметева улуса возле Крыма было довольно тесно, и они также рассматривали варианты откочевки под Астрахань, ухода к калмыкам или в Белгородскую орду. Но внезапное известие о массовом движении калмыков на Крым вызвало серьезную панику среди крымцев и ногайцев, бежавших со своими улусами к Днепру и за Перекоп. Крымский хан Ислам-Гирей III (1644-1654 гг.) в организации указанного похода открыто и незаслуженно подозревал московское правительство ${ }^{23}$.

Интересны сведения, полученные от русских посланников, находившихся в это время в Крыму. По расспросам русских полоняников им стало известно, что первая весть о движении калмыков пришла в Крым из Азова. Ногайские мирзы Урмаметевы, кочевавшие на реке Молочные Воды, присылали к хану гонцов с просьбой о военной помощи. После того, как Ислам-Гирей не отозвался на их просьбу, они уже во второй раз стали ему прямо угрожать и шантажировать, что в противном случае объединяться с калмыками и пойдут уже совместно с ними на Крым. Только после этого крымский хан объявил о всеобщей военной мобилизации, но она была практически сорвана, так как большинство татар были бесконными. Положение крымцев спасло то, что калмыки повернули обратно, поскольку татары ближе к Перекопу предварительно выжгли степь ${ }^{24}$.

Возвращаясь, калмыки на двое суток опять остановились на Дону, под Черкасским городком устроили с казаками торговый обмен. Своих новых союзников в дорогу казаки обеспечили продовольствием: мукой, просом, сухарями и рыбой. Калмыки взамен отдавали им своих лошадей. Тайши пообещали атаманам, что вновь пойдут на Крым уже ближайшей весной, как только появится трава. По достигнутой договоренности, казаки должны были осведомлять калмыков о передвижениях крымских и ногайских улусов, особенно во время

\footnotetext{
${ }^{23}$ РГАДА. Ф. 127. Оп. 1. 1648 г. Д. 1. Л. 26; АМГ. СПб., 1894. С. 216 ;
} Новосельский А.А. Указ. соч. С. 394.

${ }^{24}$ РГАДА. Ф. 123. Оп. 1. 1648 г. Д. 8. Л. 2, 3; Д. 9. Л. 21. их перехода на летние пастбища от полуострова ближе к Дону. Если крымцы не выйдут из Крыма, то зимой следующего года тайши планировали пойти на них уже совместно с казаками. По сообщению атамана Т. Григорьева, полученного от него в Москве, тайши заявили казакам, что «они за государя хотят умереть, а чтоб Урмаметевы улусы и крымские татары подвесть под государскую руку». Калмыки ушли вверх по реке Сал к Волге, которую перешли ниже Царицына, недалеко от урочища Каменный Яр ${ }^{25}$.

Татарин Айдаргул Мамбетыкулов в Астрахани сообщал о своем захвате калмыками на Дону, которым он служил проводником в походе на Урмаметев улус. Ему также не было известно о численности участников данного похода, поскольку калмыки двигались на Крым несколькими колоннами по разным дорогам. В марте 1648 г. тайши вернулись обратно в улусы, и Дайчин через татарина передал воеводам о скорой отправке своих послов в Астрахань ${ }^{26}$.

Однако часть калмыцких войск была оставлена на правобережье Волги. Еще в Черкасске тайши делились своими планами «летовать» в степи, между Волгой и Доном, чтобы «доступать де им Казыев улус $»^{27}$. Весной калмыки разгромили улусы двух ногайских мирз, направлявшихся из Азова на Кубань, в Темрюк, отогнав большое количество скота. Переправа через Волгу проходила ниже Черного Яра, и участникам похода приходилось двигаться осторожно, поскольку «лед был худ». На крымской стороне Волги калмыкам встретился астраханец Д. Юдин, отправленный с 20 стрельцами и 20 татарами в улусы Малого Ногая, там их ограбили и прогнали обратно. Некий калмыцкий тайша, встретив бредущих по степи шестерых астраханцев, дал им лошадей, шубы и свою именную стрелу, «чтобы ево воинские люди нихто их ничем не изобидил» ${ }^{28}$.

Весь 1649 г. в Крыму серьезно опасались и ждали нового прихода калмыков. Русским посланникам, Ларионову и Никитину, всерьез

${ }^{25}$ РГАДА. Ф. 127. Оп. 1. 1648 г. Д. 1. Л. 134; Ф. 119. Оп. 1. 1648 г. Д. 2. Л. 18; РИБ 1909. С. 843.

${ }^{26}$ РГАДА. Ф. 119. Оп. 1. 1648 г. Д. 2. Л. 17-18.

${ }^{27}$ РГАДА. Ф. 111. Оп. 1. 1648 г. Д. 2. Л. 6.

${ }^{28}$ РГАДА. Ф. 111. ОП. 1. 1648 г. Д. 7. Л. 3; РИБ. СПб., 1909. С. 832; РИБ. СПб., 1913. С. $3,4$. 
пришлось держать ответ на обвинения крымской стороны, что это именно московское правительство организовало калмыцкий поход. Они долго уверяли крымцев: «калмыки - люди вольные, от великого государя нашего откочевали тому многое время... ныне они кочуют самовольством, где хотят» ${ }^{29}$.

\section{3. Русско-калмыцкие переговоры и шерть 1649 г.}

После в целом неудачного крымского похода Дайчин со своим улусом кочевал за Яиком, в урочище Кайнасаргыз. Именно сюда и приехали из Яицкого городка отправленные из Астрахани татары во главе с Болсендеем, которые по дороге подверглись нападению людей тайши Далантая. Дайчин тепло встретил посланцев, обеспечил их полным содержанием и приказал найти их обидчиков. Астраханцы передали тайше лист, и, судя по их сведениям, это была первая встреча представителей Астрахани с Дайчином после его почти 8-летнего отсутствия в родных кочевьях. Дайчин сразу же упрекнул астраханцев в том, что во время похода калмыков на улус Урмаметевых, астраханские татары трижды совершили набег на слабо охранявшиеся калмыцкие улусы, отогнав в общей сложности 5 тыс. лошадей. Улус Дайчина потерял при этом убитыми двух калмыков и 100 верблюдов. При переходе через Волгу калмыки по приказу тайшей старались не трогать государевых людей ${ }^{30}$.

Дайчин понимал, что эти набеги не были санкционированы воеводами, но он ратовал за то, чтобы царские власти повсеместно строго контролировали своих подданных. Тайша сознательно не стал акцентировать внимание на этом инциденте, зная, что это может привести к дальнейшему обострению русско-калмыцких отношений. Он более чем благожелательно отнесся к астраханским посланцам, приказав «переграбить» улус Далантая и компенсировать их потери 200 лошадьми, 100 баранами и 10 верблюдами. 6 июня астраханцы были отпущены обратно, и на прощанье Дайчин передал, чтобы воеводы в

${ }^{29}$ РГАДА. Ф. 123. Оп. 1. 1649 г. Д. 3. Л. 124, 138.

${ }^{30}$ РГАДА. Ф. 127. Оп. 1. 1648 г. Д. 1. Л. 197, 365-366. знак примирения прислали к нему послов и «отгонную животину». В противном случае он обещал начать военные действия ${ }^{31}$.

Дайчин был в курсе практически всех событий, происходивших в Астрахани. Информацию из города, как правило, привозили татары, чаще всего остававшиеся жить у калмыков. В качестве подъемных Дайчин щедро предоставлял им лошадей и скот. Сохранились также сведения о том, что улусные калмыцкие и ногайские люди именовали Дайчина «ханом $\rangle^{32}$.

Сведения о возвращении Дайчина и активизация его действий против Крыма для Москвы стали своего рода сигналом к возобновлению переговорного процесса с калмыками. Из центра в Астрахань сразу же поступила инструкция о том, «чтоб Дайчин тайша был у великого государя в послушанье и с государевыми людьми в миру». В июне 1648 г. воеводы посланцами срочно отправили к Дайчину четыpex юртовских татар, а с ними и ранее задержанных калмыцких послов - Эсембета и Балдана. Дайчин в это время кочевал со своим улусом за Яиком, в урочище Курдан Элек, в 24 днях пути от Астрахани. Тайша обрадовался возвращению своих людей и приезду астраханцев, он демонстративно принял у них «государев лист» стоя и сняв шапку. В качестве широкого жеста Дайчин отпустил с послами 1,5 тыс. астраханских татар, приехавших к калмыкам торговать без разрешения администрации ${ }^{33}$.

По свидетельствам астраханских посланцев, у калмыцкого тайши было свое видение причины ухудшения русско-калмыцких отношений: «как он ездил по своей вере молиться, и без него де от братьи и от детей, и от племянников, и от улусных их людей учинился задор и ссора с государевыми людми, и он де Дайчин то все унял». Он снова предложил астраханцам мир, обмен пленными и военное сотрудничество. В результате переговоров определенная договоренность, видимо, была заключена, поскольку «лутчие родственные люди, Дуралтархан с товарищи, перед государевым посланником по своей вере шертовали $\rangle^{34}$.

${ }^{31}$ РГАДА. Ф. 127. Оп. 1.1648 г. Д. 1. Л. 368-369.
${ }^{32}$ РГАДА. Ф. 127. Оп. 1. 1648 г. Д. 1. Л. 370-371.
${ }^{33}$ РГАДА. Ф. 127. Оп. 1. 1649 г. Д. 1. Л. 1-4, 11.

${ }^{34}$ АИ. СПб., 1842. Т. 4. С. 111. 
Сообщения астраханских посланцев интересны и тем, что в них содержится информация о состоянии калмыцкого общества в рассматриваемое время. Так, летом 1648 г. калмыцкие улусы кочевали в верховьях реки Илек за Яиком, где башкиры продолжали отгонять у них лошадей. Именно в это время умирают один из младших братьев Дайчина - Сюнке и джембойлукский мирза Урак. В августе тайши начали перекочевку к Яику на зимние пастб́ища ${ }^{35}$.

В феврале 1649 г. в Астрахань прибыли уже калмыцкие посланцы - Токмак, Онкобай и Батыркей. По их словам, Дайчин кочевал за Яиком, в урочище Каракол в двух днях пути от Индерских гор. Посланцы просили вернуть им останки погибших тайшей, разрешить кочевать по ногайской стороне Волги у Астрахани, а «к государю бы посылать людей своих с ордобазарными лошадми». Но калмыки напрасно ожидали перемен в отношениях от воевод, те твердо стояли на своем, выдвигая прежние условия: выдача аманатов, возвращение ногаев, а предоставление возможности торговать - только с разрешения царя. Посланцы отказались обсуждать вопрос о выдаче калмыками аманатов, поскольку Дайчин не уполномачивал их вести переговоры на эту тему, да и ранее приезжавшие в улусы астраханские посланники не затрагивали ее. Калмыки просили прислать «доброго» боярского сына и толмача, с которыми Дайчин мог бы заключить договор и вернуть полон.

В результате калмыцкие послы дали по своей вере шерть за Дайчина, всех калмыцких тайшей и подвластных ногайских мирз: «... $\mathrm{Ha}$ том, что им у великого государя у его царского величества быти в вечном послуианье, и его царскому величеству служити и прямити и добра хотети во всем вправду, безо всякие хитрости, и никакова дурна не мыслити, и с государевыми непослуиники и с изменники ни с кем ни о чем не ссылатися; и государевых русских людей, и вечных холопей, нагайских и едисанских и юртовских татар, в улусех и на проездех и промыслов, нигде не побивати и в полон не имати и не грабити, и к себе в улусы от Астрахани и от иных городов их не nризывать и не подговаривать, а будет кто отъедет, и тех не принимати; ик Астрахани ик иным государевым городом и на уезды, на

${ }^{35}$ РГАДА. Ф. 127. Оп. 1. 1648 г. Д. 1. Л. 418. государевых людей и на нагайские и на едисанские и на тортовские улусы, и на рығоные и на соляные промысль войною самим не приходить и никого не посылати, и государевых городов, и сел и деревень, $и$ учюгов и рыбных ловель, и всяких промыслов не жечь и не грабить, $и$ никакого зла не делати и не мыслити; а где случится им, калмыцким тайшам, и братьям, и детем, и племянником их, и их улусным людем, быть на государеве службе с государевыми ратными людми, и им с государевыми изменники и с непослуиники битися до смерти, не цзадя голов своих, а великому государю его царскому величеству не изменити, и государевых людей не [на]подати и хитрости над ними никакие не чинить; и русской полон, которой у них в калмыцикх улусех, собрав им, весь отдати в его государеву отчину, Астрахань, и в иные государевы городы; и кочевати б им, калмылким людем, с улусы своими в летнее и в зимнее время за рекою Яиком, в прежнх своих дал[b]них кочевных местех, а на Нагайскую степь, через Яик и к реке Волге, и иарского величества к отчине к Астрахани в ближние места без государева указу кочевать не ходить; и посыльщиков, которых по государеву указу ныне поилют и вперед из государевы отчины из Астрахани и из иных городов бояре и воеводы учнут посылать для его государевых дел в калмыцкие улусы кнему, Дайчину тайме, ик братье его, ик детем, ик племянником, ик улусным людем, и имне грабити и тесноты и безчестья никакого не чинити, и отпуцать тех посыльщикков без задержанья ${ }^{36}$.

В правительстве все больше убеждались, что Дайчин будет придерживаться мирных отношений с Москвой. В марте 1649 г. воеводы отправили в улусы астраханца И. Суслова и толмача М. Герасимова. С ними также были отпущены калмыцкие послы Буранай и ЕмагиБатур, задержанные в Астрахани еще в 1644 г. Дайчин с радостью встретил возвращения своих людей и почтительно принял у астраханцев «государев лист». В первую очередь, стороны договорились о взаимном наказании воров, чтобы «вперед ссоры и смуты никакие не было». Правительство заверило тайшей о готовности пресекать нападения своих подданных на калмыков. Дайчин согласился выдать русский полон взамен калмыцкого, захваченного астраханцами

\footnotetext{
${ }^{36}$ РГАДА. Ф. 119. Оп. 1. 1650 г. Д. 1. Л. 6-9; АИ. СПб., 1842. С. 112-113.
} 
в 1644 г. Вопрос об аманатах продолжал оставаться одним из ключевых в переговорах. Русской стороне нужен был сам факт признания тайшами своей зависимости от Москвы. Так, Суслов просил Дайчина предоставить какого-нибудь аманата, обещая, что «им будет государево жалованье, корм и питье, и платье, и переменять их станут повольне, сколько хто похочет побыть» ${ }^{37}$.

В июне 1649 г., как сообщал в Астрахани татарин Девлет Мамет, розни между тайшами не было. Дайчин совместно с ногаями кочевал на реке Сунгурлук в двух днях пути от Индерских гор, а Лузан - в верховьях Самары, в урочище реки Сакмары ${ }^{38}$. Калмыки внимательно следили за событиями, происходившими на крымской стороне Волги. Эту территорию, как известно, они давно уже рассматривали как потенциальный район своих будущих кочевий. На переговорах Дайчин поинтересовался у Суслова, насколько послушны астраханским воеводам терские ногаи Чебан-мирзы Иштерекова и в каком районе они кочуют. Посол ответил, что они «послушны». Но у Дайчина была другая информация - он знал о набегах этих ногаев под Астрахань, как и то, что Чебан-мирза находился в ссоре с другим ногайским мирзою Ямгурчеем Тинмаметевым, который кочевал под Астраханью, что оба мирз периодически совершают друг на друга набеги ${ }^{39}$.

Еще одни важным вопросом, обсуждавшимся на переговорах, были непростые отношения калмыков с яицкими казаками, которые беспокоили своими набегами калмыцкие улусы и отгоняли лошадей. Награбленное у калмыков имущество казаки, как правило, сбывали в Самаре, а здешние воеводы, в свою очередь, снабжали их продуктами, в том числе алкоголем и оружием. Иногда самарцы совместно с казаками нападали на калмыцкие улусы. Астрахань немедленно сообщала об этих инцидентах в Москву и просила центральные власти запретить самарцам совершать подобные действия, так как они подрывали и без того непростой русско-калмыцкий переговорный процесс. Дайчин, со своей стороны, пригрозил, что, если правитель-

${ }^{37}$ РГАДА. Ф. 119. Оп. 1. 1650 г. Д. 1. Л. 13-14; Ф. 127. Оп. 1. 1649 г. Д. 1. Л. 132-133, 139; АИ. СПб., 1842. С. 114; Кичиков М.Л. Исторические... С. 94.

${ }^{38}$ РГАДА. Ф. 127. Оп. 1. 1649 г. Д. 1. Л. 155.

${ }^{39}$ РГАДА. Ф. 127. Оп. 1. 1649 г. Д. 1. Л. 142-143. ствоне урегулирует данную проблему, он начнет военные действия против яицких казаков и Самары ${ }^{40}$.

Со своим послом Салтаном Дасаковым в Астрахань Дайчин отправил письмо, в котором, помимо прочего, предлагал воеводам заключить мир на весьма длительный срок, примерно как «дети в нынешнее время породились, да как они состарятца». Калмыцкий посол присягнул за Дайчина, что он «от высокой руки отступать не будет» и наказывать будет тех калмыков, которые нарушат шерть или «учнут воровать». Но на просьбу тайши выдать ему останки отца, брата и племянника воеводы опять потребовали сначала дать им аманатов и вернуть весь русский полон. Посол ответил, что «им, не взяв костей отца Дайчинова и братьи, шертовать на том, что Дайчину аманаты дать и русской полон собрать и прислать, приказу нет». Такой ответ астраханцев не устроил, и они так и не решились первыми сделать шаг к примирению ${ }^{41}$

\section{4. Калмыцко-башкирские отношения в 1648-1649 гг.}

Взаимные набеги калмыков и башкир были распространенным явлением среди кочевников. В весьма частых подобных конфликтах правительство, как правило, принимало сторону башкир, уже почти столетие являвшихся подданными России. Если астраханское направление Дайчину удалось более или менее урегулировать, то уфимское оставалось нерешенной проблемой. В плену у башкир и уфимцев еше оставалось множество калмыцких людей, в основном это были женщины и дети, захваченные еще в 1644 г. во время карательной экспедиции воеводы Плещеева.

В 1648 г. на башкирско-калмыцкой границе возобновились вооруженные стычки. Неизвестно, кто стал зачинщиком нового конфликта, но в русских документах сохранилась версия башкирской стороны. Как сообщал астраханским татарам в калмыцких улусах ${ }^{40}$ РГАДА. Ф. 127. Оп. 1. 1649 г. Д. 1. Л. 143-144; Куи О.Ю. Указ. соч. C. 77 .

${ }^{41}$ РГАДА. Ф. 127. Оп. 1. 1649 г. Д. 1. Л. 145-148; Кичиков М.Л. Образование... С. 81 . 
башкирский тархан Илмамет Аксакалов, один из членов посольства В.К. Голубцова, первыми мир нарушили именно калмыки, совершив весной 1648 г. набег на Уфимский уезд, который башкиры успешно отразили, захватив в плен 12 человек ${ }^{42}$.

В июле Дайчин с 30-тысячным войском уже стоял в полной готовности для наступления на уфимском направлении. Однако башкирам стало известно о готовящемся нападении от бежавшего из калмыцкого плена казанского татарина Ишмамета Исаева. С его слов, Дайчин якобы отправил под Астрахань, Самару, Саратов и Царицын, Казанский и Уфимский уезды вниз по реке Белой по 5 тыс. воинов, а в Уфимский уезд вверх по реке Белой - 500 человек. Эта сообщение стало сигналом, и башкиры разных дорог и волостей срочно эвакуировали свои семьи в труднодоступные места и собрали свои военные силы. Оборону возглавил князь Акбулат Сулейманов, под началом которого собралось 560 воинов $^{43}$.

Однако за реку Белую для разведки и взятия языков Дайчин отправил отряд не из 500 калмыков, как сообщал Исаев, а из 168 человек во главе с молодыми тайшами Обогдаем и Аблаем, детьми Дюнекея, а также двумя своими доверенными людьми - Дурал-дарханом и его сыном Чокулой. В Уфимском уезде калмыки разгромили Ятаганову (мордовскую) деревню и, захватив в плен 11 ее жителей, ушли обратно. Башкиры Ногайской дороги бросились за ними в погоню. 560 башкир двигались следом, а 140 человек обходили с флангов уходящих и загруженных трофеями калмыков. В 10 верстах от Солеваренного острога, на реке Армыте, башкиры устроили калмыкам засаду, в результате чего произошел бой и захваченный полон башкирами был отбит, а калмыцкий отряд уничтожен. Спастись удалось немногим. Молодые тайши оба погибли. Чокула дважды был ранен, в бою под ним была убита лошадь, но на другой ему удалось скрыться в лесу. 28 калмыков держали круговую оборону. В результате переговоров башкиры пообещали сохранить им жизни, пленив в общей сложности 30 человек. 12 калмыков в оковах уфимские власти отправили в Москву, а остальных башкиры оставили у себя ${ }^{44}$. Пленные калмыки,

${ }^{42}$ РГАДА. Ф. 127. Оп. 1. 1649 г. Д. 1. Л. 8.

${ }^{43}$ История Башкирского народа... Т. ІІІ. С. 84.

${ }^{44}$ РГАДА. Ф. 119. Оп. 1. 1648 г. Д. 1. Л. 1-2, 7-8, 12. приведенные в Уфимскую съезжую избу и допрошенные воеводой Х.Ф. Рыльским, признавались, что «Дайчина-де тайши людей ныне в дворе з братьями и с ногаи всего с тритцать тысяч человек. А дожидается де он, Дайчин-тайша, их, калмыков, из У финского уезду с языки, и по языком де смотря, хотел идти войною» ${ }^{45}$.

Чокуле с немногими людьми удалось вернуться к своим и рассказать о случившемся. В устье реки Илек Дайчин срочно приостановил уже начавшуюся перекочевку улусов на зимние пастбища. Тайши и мирзы, собрав большое войско, двинулись в поход на башкир. Каждый воин брал собой по 2 лошади. Для охраны своих улусов они оставили только небольшой отряд во главе с тайшой Далантаем, так как угроза набега татар с астраханского направления все еще сохранялась. Участвовать в походе на башкир отказался только Лузан. Причиной этому послужило то, что незадолго до этого Дайчин отобрал у брата ногайский улус мирзы Каспулата Мамаева, и, как отмечали очевидцы, у братьев «брань меж собою и [они] не съезжаютца» ${ }^{46}$.

Неудачная разведка боем, видимо, заставила Дайчина изменить тактику по отношению к уфимцам и башкирам. Летом 1648 г. на Яике 30 башкирских охотников подверглись нападению калмыков, при этом 5 из них были убиты, 4 попали в плен, а остальных, взяв с них шерть, отпустили. Дайчин вместе со своими посланцами отправил в Уфу 7 пленных башкир, дав каждому из них по 1-2 лошади. Тайша требовал от местных воевод отпустить своих послов, заключенных в Уфе, произвести обмен пленными, запретить башкирам угонять лошадей из калмыцких улусов и прислать русского посла для продолжения переговоров. В противном случае Дайчин обещал продолжить военные действия против У фимского уезда и башкирских волостей ${ }^{47}$.

Тайши добивались от царских властей принятия жестких мер для недопущения в дальнейшем башкирских набегов на калмыков. Правительство пошло на определенные уступки калмыкам в этом вопросе, в октябре 1648 г. предписав уфимскому воеводе созвать башкир и объявить им, что калмыцкие улусы кочуют по Яику, Ори, Киилу, Сакма-

\footnotetext{
${ }^{45}$ Цит. по: История Башкирского народа... Т. III. С. 85.

${ }^{46}$ РГАДА. Ф. 127. ОП. 1. 1648 г. Д. 1. Л. 419, 434.

${ }^{47}$ РГАДА. Ф. 119. Оп. 1. 1648 г. Д. 1. Л. 22, 50-51.
} 
ре и другим рекам. Башкирам было указано на недопустимость совершения набегов на калмыцкие улусы. Власти не преминули упрекнуть их в постоянных набегах на калмыков, вследствие которых последние стали вторгаться не только в Уфимский, но и в Казанский и Самарский уезды. За нарушение этого запрета правительство пригрозило башкирам смертной казнью и отказывалось в случае попадания их в плен к калмыкам во время набегов освобождать через обмен. В свою очередь, уфимские власти предприняли меры предосторожности, выставив во всех волостях отряды стрельцов. В Уфе был издан приказ о переписи и сборе всех калмыцких пленников для их будущего обмена на русский полон ${ }^{48}$. Для изъятия калмыцких пленных и захваченного башкирами скота в Уфе был сформирован отряд служилых людей во главе с А.И. Приклонским и В.И. Киржацким, деятельность которого сопровождалась насилием и произволом. Вместо поиска калмыцких пленных и захваченного у калмыков имущества Приклонский просто обложил башкир произвольной денежной данью ${ }^{49}$.

В дальнейшем правительство предприняло более решительную попытку навести порядок в башкирско-калмыцких отношениях. В октябре 1648 г. из Уфы к Дайчину были отправлены боярский сын В. Голубцов, толмач В. Киржацкий, башкирский тархан Илмамет Аксакалов и стрелец Н. Турищев. С ними был отпущен один из калмыцких посланцев Чокулы. По дороге, уже за Яиком на реке Илек, им неожиданно встретился отряд калмыцких воинских людей, направлявшийся в набег на Уфимский уезд. Перепуганные посланцы побежали к реке, и погнавшиеся за ними калмыки ранили трех кашеваров. Затем толмач с калмыцким посланцем вышли к ним навстречу, и те, узнав о цели их поездки, отменили свой набег и вернулись обратно в улусы $^{50}$.

При встрече Голубцов напомнил Дайчину о том, что его отец Хо-Урлюк считал себя подданным Русского государства и со свои-

${ }^{48}$ РГАДА. Ф. 119. Оп. 1. 1648 г. Д. 1. Л. 56, 59, 72-73; Устюгов Н.В. Указ. соч. С. 51; Очерки... С. 107.

${ }^{49}$ Азнабаев Б.A. Статус пленных в башкирских общинах XVII в. // Известия Алтайского государственного университета. Барнаул, 2012. № 4-1. C. 15 .

${ }^{50}$ РГАДА. Ф. 119. Оп. 1. 1649 г. Д. 1. Л. 14-15. ми улусами кочевал за Эмбой, а теперь калмыки кочуют по Яику, Ори, Килу, Сакмаре и другим рекам, где расположены волости государевых ясачных людей. Из-за этого, по мнению Голубцова, и происходили между калмыками и башкирами постоянные столкновения. Посол предложил Дайчину отойти на дальние свои кочевья, взамен обещая не посылать на них ратных людей, а башкир удерживать от нападений на калмыков. Переговоры проходили в доброжелательной обстановке, и в результате стороны договорились об обмене пленными. Дайчин запретил своим улусным людям, а также другим тайшам и мирзам под угрозой смертной казни нападать на русских и башкир. «Лучшие люди» Дайчина - Дурал-дархан и Заргучи - по приказу тайши дали шерть ${ }^{51}$.

6 января 1649 г. В. Голубцов и В. Киржатцкий вернулись в Уфу, привезя из калмыцкого плена 1 русского и 7 башкир. Что касается остальных, то Дайчин обещал, что, он как только соберет весь полон, пришлет его в Уфу ближайшей весной, так как улусы других тайшей располагались на дальних кочевьях. Отойти с вотчинных башкирских земель тайша пообещал лишь после совершения обмена пленными. Принципиальным оставался также вопрос о калмыцких пленных, принявших крещение в русских городах. Правительство под разными предлогами отказывалось выдавать новокрещенных калмыков тайшам $^{52}$. Таким образом, впервые в русско-калмыцких отношениях конфликт приобрел и религиозный оттенок.

В Уфу с Голубцовым прибыли послы от Дайчина - Батур Бухин и Баста Недеев, которых тайша просил пропустить в Москву. Дайчин передал через них подарки русскому царю: 7 коней, «камка на золоте да бобров кожу». 7 мая 1649 г. послы прибыли в Москву и были приняты толмачом Посольского приказа Ф. Елчиным, а 5 июня - царем. Дайчин предлагал русскому царю мир, военное сотрудничество и взаимное наказание воров. Послы жаловались на башкирские набеги и просили разрешения на обмен пленными. Правительство, со своей стороны, призвало Дайчина во избежание конфликтов с царскими подданными отвести улусы на дальние кочевья, а между Яиком и ${ }^{51}$ РГАДА. Ф. 127. Оп. 1. 1649 г. Д. 1. Л. 9-10; Устюгов Н.В. Указ. соч. C. 51 .

${ }^{52}$ РГАДА. Ф. 119. Оп. 1. 1649 г. Д. 1. Л. 17. 
Волгой не кочевать. Царский указ, направленный в Астрахань, Уфу и другие города, запрещал нападение на калмыков и призывал произвести скорейший обмен пленными ${ }^{53}$.

Именно в 1649 г. уфимские власти попытались в Уфе взять под централизованный учет всех калмыцких пленных для последующего обмена их на российских подданных. Из Приказа Казанского дворца уфимскому воеводе предписывалось, что все без исключения жители Уфимского уезда «... тот калмыцкий полон приводили в Уфу и ты велел тот калмыцкий полон переписать и велел их держать в разменных тем же людям у себя до того, как Дайчин тайша посланцев своих и полон русский и башкирский и татарской из улусов своих на Уфу пришлет) ${ }^{54}$.

Вместе с тем уфимцы вели переговоры не только с торгутскими тайшами, но и дербетами, относящихся к сибирской группировке ойратов. В ноябре 1648 г. в Уфимский уезд прибыли трое дербетских послов. Отправленные к ним навстречу боярский сын Д. Лопатин и толмач Т. Малай с 10 стрельцами на месте выяснили, что это были люди дербетского тайши Кешкеба. Дербеты просили разрешения кочевать и торговать в Уфимском уезде. Но на реке Тобол между 20 башкирами и 100 дербетами произошла вооруженная стычка, в результате которой стороны захватили по одному пленному. Пленный калмык на допросе в Уфе сообщил, что в уезд они приходили для охоты на диких лошадей, что их тайши категорически запрещают своим людям трогать башкир. Так, незадолго до этого на реке Уя дербеты отпустили пятерых захваченных башкирских охотников ${ }^{55}$.

Летом 1649 г. в Уфу прибыло очередное посольство от группы дербетских тайшей, возглавляемых вдовой Далай-Батура - КанышАхай. Это были улусы детей покойного Дайчин-Хошучи - тайшей Кешкеба, Цагана и Цешена. Свое долгое отсутствие в Уфе дербетские послы объясняли тем, что после смерти Далай-Батура они находились в состоянии войны с торгутами, поэтому «посланников своих присылать [было] не мочно, а ныне де з Дайчином тайшею

${ }_{53}^{53}$ РГАДА. Ф. 119. Оп. 1. 1649 г. Д. 1. Л. 20; Д. 3. Л. 1-14, 53-59, 77-80, $137,161$.

${ }^{54}$ Цит. по: Азнабаев Б.А. Указ. соч. С. 13.

${ }^{55}$ РГАДА. Ф. 119. Оп. 1. 1648 г. Д. 1. Л. 128-134. помирились». Дербеты, как и торгуты, также жаловались на постоянные башкирские набеги. Например, осенью 1648 г. башкирские «зверовщики» отогнали у дербетов 131 лошадь, убили трех человек, и группу преследования следы привели в У фимский уезд. Затем весной 1649 г. на реке Тобол башкиры ограбили направлявшийся в Уфу торговый караван дербетского тайши Цагана. В списке захваченного башкирами имущества числились и подарки русскому царю (2 коня, 2 ковра и колчедан), а также товары, предназначенные для продажи (4 верблюда, 30 лошадей, пушнина и бухарские изделия). Вскоре из Москвы в Уфу пришел ответ, в котором дербетам запрещалось вести переговоры через Уфу и рекомендовалось связь с центром держать, как и прежде, через сибирские города - Тобольск и Тюмень. В целях предотвращения конфликтов с башкирами дербетским тайшам предписывалось отойти со своими улусами на дальние кочевья ${ }^{56}$.

По мнению Б.А. Азнабаева, несмотря на законодательный запрет под страхом смертной казни нападать на калмыцкие улусы, указ ввиду отсуствия какого-либо контроля над юго-восточной границей фактически не исполнялся ${ }^{57}$. Башкирские набеги на калмыков продолжались, сводя на нет всякие русско-калмыцкие договоренности.

\section{5. Миграция хошутских улусов на запад}

В 1649 г. части хошутских и дербетских улусов начали перемещаться из Юго-Западной Сибири в степи Северного Прикаспия. Вынужденная миграция чакарских калмыков на запад имела довольно сложную предысторию. Все началось с очередной ойрато-казахской войны, вспыхнувшей примерно в начале 1646 г., когда джунгарская армия под командованием Батура-хунтайджи вторглась в восточные пределы казахских кочевий. Джунгары наголову разгромили и пленили многих казахов, в том числе и брата Джахангира с семьей. На обратном пути джунгарское войско подверглось нападению уже чакарских калмыков во главе с Кунделен-Убаши. В короткой вооруженной

\footnotetext{
${ }^{56}$ РГАДА. Ф. 119. Оп. 1. 1649 г. Д. 1. Л. 52-55.

${ }^{57}$ Азнабаев Б.A. Указ. соч. С. 15.
} 
стычке стороны потеряли убитыми 250 чакарцев и 20 джунгар, «да за тем меж себя помирилися $)^{58}$.

Автор «Биографии Зая-пандиты» дает более подробные сведения о данном событии. Весной 1646 г. хошутский Кунделен-Убаши при поддержке дербетов выступил против Батура-хунтайджи и хошутского Очирту. Чакарские войска выдвинулись в район Хара-Тала, где у реки Ухарлик дали сражение возвращающимся из казахского похода джунгарам. В составе последних находился и торгутский Дайчин, чей улус пострадал в результате обходных военных маневров противников. Джунгары почти было добились успеха, но тут в конфликт с мирной инициативой вмешался хошутский Аблай, брат Очирту, во главе 4-тысячного войска. Стороны вступили в переговоры и заключили перемирие $^{59}$. Причиной вооруженного конфликта, видимо, послужили и союзнические обязательства чакарских тайшей перед казахами. Не успев прийти на помощь к ним, чакарцы бросили свои силы непосредственно в Джунгарию, где в результате так и не смогли достичь успеха.

Джунгарский Батур-хунтайджи был весьма недоволен участием в войне против него именно дербетских тайшей, так как они имели общее происхождение от ойратского Эсен-хана. В 1646-1647 гг. джунгарский хунтайджи направил против них две карательные экспедиции под командованием тайшей Кулы и Мачика, в ходе которых было захвачено большое количество людей, имущества и скота ${ }^{60}$. Дальнейшее военное давление джунгаров вызвало миграцию хошутов и дербетов в западном направлении. Начиная с этого времени, в северной группировке ойратов власть переходит в руки хошутского Аблая.

В конце 1648 г. из Юго-Западной Сибири на запад двинулись большие массы хошутов Кунделен-Убаши и дербетов Даян-Омбо, которых, по разным данным, насчитывалось от 20 до 40 тыс. улусных людей. Переселенцы расположились на восточных кочевьях торгутов в Приаральских Каракумах (в 6-8 днях пути от улуса Дайчина),

${ }^{58}$ МИРМО. М., 1974. С. 276.

${ }^{59}$ Раднабхадра. «Лунный свет»: История рабджам Зая-пандиты / Пер. с ойрат. Г.Н. Румянцева и А.Г. Сазыкина. СПб., 1999. С. 170-171.

${ }^{60}$ МИРМО. М., 1974. С. 305-306. в непосредственной близости от своего казахского союзника - султана Джахангира. Кунделен-Убаши прислал своих людей к Дайчину с предложением, чтобы тот «принел ево к себе в соединенье, а он де с ним учнет кочевать и против недругов своих станут стоять вместе заодно». Дайчин отправился «на совет» к брату Елдену, кочевавшему в двух днях пути от хошутов, в урочище на Барсучьих песках ${ }^{61}$.

Зимой 1648/49 года джунгары совершили новый поход против хошутов Кунделен-Убаши, но из-за дальности расстояния не достигли цели, удовлетворившись лишь захватом некоторых казахских улусов. Но даже этот неудачный поход джунгаров всерьез встревожил хошутов. Поэтому весной они предусмотрительно выдвинулись с Приаральских Каракумов далее на северо-запад, к реке Илек, расположившись там практически рядом с улусом Дайчина. Примерно в апреле-мае 1649 г. Кунделен-Убаши с племянником Цереном в сопровождении 1700 воинов совершили поездку в улус Дайчина для заключения договора. Как отмечали очевидцы, Дайчин приехавшим к нему гостям «честь учинил и кормы большие учал давать». Стороны предварительно условились, что по истечении 10 дней окончательно заключат договор ${ }^{62}$.

Встревоженный неожиданным поворотом событий, Дайчин срочно отправил всем своим тайшам и мирзам сообщение о приезде хошутов. Первыми откликнулись и приехали в улус старшего брата Елден и Санжин, а также едисанские и джембойлукские мирзы. Лузан был на подходе. Улусные люди, по свидетельствам очевидцев, не без оснований были взволнованы неожиданным появлением многочисленных хошутов, расположившихся в непосредственной близости от торгутских улусов ${ }^{63}$. Возникла реальная опасность - хошутские тайши могли одним ударом разгромить и подчинить себе кочевавшие на отдаленном расстоянии друг от друга торгутские улусы. Но переселенцы, видимо, были настолько вымотаны военными действиями с джунгарами и неопределенностью своего положения на новых землях, что даже и не мыслили о таком ходе развития. К сожалению,

${ }^{61}$ РГАДА. Ф. 127. Оп. 1. 1649 г. Д. 1. Л. 11-12, 141, 157.

${ }^{62}$ РГАДА. Ф. 127. Оп. 1. 1649 г. Д. 1. Л. 141, 156.

${ }^{63}$ РГАДА. Ф. 127. Оп. 1. 1649 г. Д. 1. Л. 156; Кичиков М.Л. Образование... С. 81 . 
в русских источниках нет сведений о том, чем именно закончился состоявшийся съезд.

Ситуацию осложняло и то обстоятельство, что Дайчин во время своего предыдущего пребывания в Джунгарии женил своего младшего сына Мончака (Пунцуга) на дочери Батура-хунтайджи с целью укрепления связей торгутов и джунгаров. Также этот брачный союз во многом был направлен и против чакарских калмыков, в частности против того же хошутского Кунделена-Убаши. Дайчин обязывался: «не ссылатца и в соединенье ево (Кунделена-Убаши. - В.Т.) к себе не принимать». Более того, Дайчин по древнему калмыцкому обычаю оставил своего сына на определенное время в семье у своих сватов в Джунгарии. Мончак, оказавшись невольным заложником сложившейся ситуации, весной прислал к отцу своих людей с просьбой не принимать к себе хошутов, так как в противном случае джунгарский хунтайджи мог не отпустить его домой вместе с семьей ${ }^{64}$.

Таким образом, приход хошутов поставил торгутских тайшей в трудное положение. Вытеснить за пределы своих кочевий более многочисленных переселенцев они не могли, а принять их - означало бросить вызов джунгарам. Перспектива повторить судьбу разгромленных и бежавших со своих кочевий чакарских калмыков явно не прельщала торгутов, но, с другой стороны, усиление своих позиций в Северном Прикаспии за счет новоприбывших хошутов и дербетов позволяло им действовать более решительно по отношению к другим неуступчивым соседям.

Из отписки тобольских служилых людей, составленной летом 1649 г., известно, что торгуты и джунгары находились в состоянии войны с чакарцами. Один из предводителей чакарских калмыков, хошутский Эрдени-хунтайджи, с улусами занимал восточные кочевья торгутов на Иргизе, и пытался вступить в непосредственный контакт с уфимскими властями. Но последние имели четкую инструкцию из Москвы - не вступать в отношения с «дальними» калмыцкими тайшами. Вполне мирный прием торгутами части хошутских и дербетских улусов изменил политическую расстановку сил в ойратской среде. Кунделен-Убаши и Даян-Омбо выступили теперь инициаторами

\footnotetext{
${ }^{64}$ РГАДА. Ф. 127. Оп. 1. 1649 г. Д. 1. Л. 157.
}

сближения торгутских тайшей с другими чакарскими предводителями, в частности, с Эрдени-хунтайджи. Но тот решительно отказался от примирения с торгутами ${ }^{65}$.

С приходом многочисленных хошутов у торгутов возникли проблемы и с соседями на юге. Новый для себя район кочевий Кунделен-Убаши, видимо, решил самостоятельно освоить и поправить свое материальное положение, значительно пошатнувшееся за время войны с джунгарами. При этом решение он принимал, не поставив в известность Дайчина. Зимой 1649/50 года хошуты совершили военный поход против Ургенча и Хивы, в окрестностях которых были разгромлены местные кочевники и захвачен скот. Хивинский хан Абу-л-Гази во главе войска бросился за хошутами в погоню. Настигнув калмыков на девятый день, они дали им сражение, в ходе которого хошуты были разбиты, а двое сыновей Кунделена-Убаши погибли. Потери хошутов составили около тысячи человек, а захваченные ими трофеи были отбиты ургенцами ${ }^{66}$.

Это событие нашло отражение и в исторической летописи Абу-л-Гази «История туркмен». Согласно ему, в 1649 г. калмыки «уруга Кушут» (хошуты) во главе с Дорджи-тайши совершили набег на область Кят, но на обратном пути были настигнуты ханскими войсками в местечке Йугурук-баш и наголову разбиты ${ }^{67}$. Абу-л-Гази, видимо, пытался закрепить достигнутый успех, совершив зимой 1649/50 года поход уже на дербетов Даян-Омбо, кочевавших в Приаральских Каракумах. Но последние сумели разбить хивинские войска, и Абу-л-Гази пришлось спасаться бегством ${ }^{68}$.

Об этом инциденте Дайчину сообщил брат Елден, кочевавший рядом с Кунделен-Убаши. Новость о неудачном среднеазиатском походе хошутов, к тому же не согласованном с торгутскими тайшами, привела к явному неудовольствию Дайчина. В порыве гнева он хотел даже расторгнуть заключенный недавно с Кунделен-Убаши союзный договор. Тем более, что Дайчин еще ранее «договор учинил на том, что было им, калмыцким людем, с хивинскими людми войны и задо-

${ }^{65}$ Миллер Г.Ф. Указ. соч. Т. ІІІ. С. 328-329.

${ }^{66}$ РГАДА. Ф. 127. Оп. 1. 1650 г. Д. 1. Л. 94-95.

${ }^{67}$ Родословная туркмен... С. 18.

${ }^{68}$ РГАДА. Ф. 127. Оп. 1. 1651 г. Д. 1. Л. 140 
ру не чинить» ${ }^{69}$. Установившееся к этому времени взаимовыгодное экономическое и политическое сотрудничество торгутов со среднеазиатскими городами несогласованными действиями хошутов теперь было поставлено под угрозу. Дайчин никак не мог этого допустить и стал прилагать все усилия к тому, чтобы предотвратить эскалацию конфликта.

Когда весной 1650 г. к нему прибыли джунгарские послы, тайша вместе с ними выехал в Джунгарию, чтобы совместно с Батуром-хунтайджи лично обсудить 《хошутский» вопрос. По пути Дайчин заехал в улус Кунделен-Убаши, и в урочище Аманкарагае они еще раз договорились, («что им вперед войны не чинить и быть в миру, и в совете, а кому де куды случитца итти войною, и им де ходить вместе» ${ }^{70}$. Осенью Дайчин отправил двух своих братьев - Елдена и Санжина, а также сына Нима-Церена с улусами кочевать в непосредственной близости с хошутами, видимо, для обеспечения безопасности последних от ургенцев. Зимой предполагался совместный поход торгутов с хошутами под Ургенч. Дайчин приказал братьям и сыну взять в предстоящий поход только 2 тыс. воинов, а остальных для охраны оставить в улусах ${ }^{11}$.

\section{6. Конфликт под Астраханью и русско-калмыцкие преговоры}

В то время как Дайчин пытался урегулировать проблемы на уфимском направлении, его брат Лузан переместился со своими улусами ближе к астраханской стороне. В апреле 1649 г. Лузан отправил в Астрахань своих посланцев Илгуная и Ургечея в сопровождении 200 торговых калмыков, пригнавших 3 тыс. лошадей на продажу. Тайша вновь предложил воеводам военное сотрудничество, взаимную торговлю и обмен пленными. В результате его посланцы дали в Астрахани шерть:

${ }^{69}$ РГАДА. Ф. 127. Оп. 1. 1650 г. Д. 1. Л. 94-95.

${ }^{70}$ РГАДА. Ф. 127. Оп. 1. 1650 г. Д. 1. Л. 93.

${ }^{71}$ РГАДА. Ф. 119. Оп. 1. 1650 г. Д. 1. Л. 318; Ф. 127. Оп. 1. 1650 г. Д. 1 Л. 95.
Лузану тайме, з братею своею и з детьми, и с племянники ис улусньли своими людьми быть у тебя, великого государя, царя и великого князя Алексея Михайловича Всея Русии, под твоею царского величества высокою рукою в вечном послуианье. И служити, и прямити, и добра тебе, великому государю, и твоим государевым людем хотети во всем в правду безо всякие хитрости и никакова дурна не мыслити. И с твоими государевыми непослушники и с ызменники ни с кем, ни о чем не ссылатися. И твоих государевых русских людей и вечных холопей, нагайских и едисанских и юртовских татар, в улусех и на проездех и у промыслов нигде не побивати и в полон не имати и не грабити. И к себе в улусы от твоей государевой отчины, от Aстарахани и от иных твоих государевых городов, их не призывать и не подговаривать, а будет хто отъедет, и тех не принимать. Ик твоей государеве отчине, к Aстарахани, и киным твоим государевым городам и на уезды, на твоих государевых людей и на нагайские, и на едисанские, и на юртовские улусы, и на рыбные, и на соляные промысльы войною самим не приходити и никово не посылати. И твоих государевых городов, и сел, и деревень, и учюгов, и рыбных ловель, и всяких промыслов не жечь и не грабити, и никакова зла не делати и не мыслити.

$A$ где, государь, случитча их калмыцким тайшам, и их улусным людем, и братем, и детем, и племянником их на твоей государеве службе с твоими государевыми ратными людми и им с твоими государевыми изменники и с непослуиники битися до смерти, не щадя голов своих. А тебе, великому государю, твоему изарскому величеству, не изменити и твоих государевых людей не подать и хитрости над ними никакие не чинити.

И русской полон, которой у них в калмыицих улусех, собрав, им весь отдать в твою государеву отчину, в Астарахань и в ыные твои государевы городы.

И кочевать бы им, калмыцким людем, с улусы своими в летнее и зимнее время за рекою Яиком в прежних своих дальних кочевных местех. А на Нагайскую степь через Яик и к реке Волге, и к твоей государеве отчине, к Астарахани в ближние места без твоего государева указа кочевать не ходить ${ }^{72}$.

${ }^{72}$ РГАДА. Ф. 127. Оп. 1. 1649 г. Д. 1. Л. 111-113. 
Воеводы с калмыцкими послами в улусы Лузана отправили И. Шумникова и толмача В. Михайлова. Тайша к моменту их приезда кочевал в урочище Щучья Узень, где и произошла встреча. Когда Лузан намеревался принять «государев лист» сидя, Шумников ему напомнил, что «лист прислан к нему [от] царского величества боярин и воевод». Только после этого тайша встал и с поклоном принял лист от астраханского воеводы Ф.С. Куракина. Содержание письма особо не отличалось от предыдущих, в нем выдвигались все те же требования: о предоставлении аманатов, отводе калмыцких улусов на дальние кочевья и т.Д. Лузан выразил желание оставаться с русскими в мире, но только без выдачи аманатов. При этом тайша, подчеркивая главенство своего брата Дайчина, заявил: что «будет де брат ево Дайчин тайша учинит государю шерть и аманатов в государеву отчину в Астрахань учнет давать, и он де, Лаузан тайша, также станет делать, как и брат ево». Как отмечали очевидцы, к этому времени отношения у братьев улучшились, хотя они «пересылаютца улусными своими людми, а сами не съезжаютца ${ }^{73}$.

По вопросу откочевки калмыков на дальние кочевья Лузан, видимо, решил наглядно продемонстрировать Шумникову ситуацию на востоке и, взяв с собой русского посланника, отправился в верховья рек Самары и Яика. Действительно, за Яиком они обнаружили улусы Кунделен-Убаши и Даян-Омбо. Здесь торгутский тайша с дербетами и хошутами «в прежних своих ссорах помирились и договор учинили». Лузану пришлось снова возвращаться к Волге. При переходе люди тайши неоднократно угрожали Шумникову и требовали, чтобы тот способствовал переходу их улуса на правый берег Волги, поскольку Лузан собирался в поход на Крым и Казыевский улус. Но посол без царского указа отказался выполнить их требование ${ }^{74}$.

По наблюдениям Шумникова, калмыки имели достаточно оживленные торговые отношения с яицкими казаками. Отправленный им в Яицкий городок стрелец привез довольно интересные сведения об условиях, на которых велась торговля. На время торга калмыки

${ }^{73}$ РГАДА. Ф. 127. Оп. 1. 1649 г. Д. 1. Л. 114, 275, 278; Ф. 119. Оп. 1. 1650 г. Д. 1. Л. $161,165$.

${ }^{74}$ РГАДА. Ф. 127. Оп. 1. 1649 г. Д. 1. Л. 276; Ф. 119. Оп. 1. 1650 г. Д. 1. Л. $148-149,166$. предоставляли казакам аманатов из числа знати. Например, в городке в качестве аманата сидел племянник Лузана - тайша Далантай. Как только торг заканчивался без эксцессов, то казаки отпускали тайшу ${ }^{75}$.

Получается, что яицким казакам удалось добиться от калмыков примерно то, что долгое время не получалось у астраханских воевод. Отношения калмыков с яицкими казаками были довольно сложными и переменчивыми. В архивных документах сохранились сведения не только о вооруженных конфликтах между ними, но и о взаимопомощи. Например, к Дайчину прибыл отряд яицких казаков из 150 человек во главе с атаманом И. Кондыревым. В это время они находились в царской опале из-за того, что ходили в морской поход на Каспий для «воровства» в окрестностях персидских городов. Возвращаться в русские города, а также на Яик и Дон, они опасались, поэтому дорога этих «воровских» казаков привела к калмыкам. Дайчин в качестве подъемных выделил им коров, лошадей и овец, разрешив им жить у себя в улусе ${ }^{76}$. По другим сведениям, в 1650 г. Кондырев жил в улусе Лузана, откуда донские казаки по указу из Москвы призвали его к себе на Дон ${ }^{77}$.

Лузан просил русских посланцев по возвращении в Астрахань передать воеводам, чтобы они разрешили «торг повольный, то бы де государевых людей к нам была и правда». Тайша выразил желание лично шертовать воеводам на реке Бузан. По «ногайскому» вопросу Лузан высказал Шумникову такое мнение: «государевы люди верят нагайским татарам китайского да кипчацкого родства, а лутче бы де их разорили, и сколько де их государевым людям у себя ни держать, а не удержать будет ${ }^{78}$. Улус Лузана кочевал в районе между Царицыном и Черным Яром, рядом с ним находился улус ногайского мирзы Салтаналы ${ }^{79}$.

Начало 1650 г. ознаменовалось резким ухудшением русско-калмыцких отношений на астраханском направлении, вызванным оче-

${ }^{75}$ РГАДА. Ф. 119. Оп. 1. 1650 г. Д. 1. Л. 170.

${ }^{76}$ РГАДА. Ф. 119. Оп. 1. 1650 г. Д. 1. Л. 185; Куц О.Ю. Указ. соч. С. 402.

${ }^{77}$ РИБ. СПб., 1913. С. 354, 495-496; Куц О.Ю. Указ. соч. С. 402.

${ }^{78}$ РГАДА. Ф. 119. ОП. 1. 1650 г. Д. 1. Л. 168-169.

${ }^{79}$ РГАДА. Ф. 127. Оп. 1. 1649 г. Д. 1. Л. 277. 
редным набегом калмыков на ногайские улусы под Астраханью. Ситуацию предопределили несколько причин.

Во-первых, зима 1649/50 года выдалась чрезвычайно холодной, это привело к массовому падежу скота в калмыцких улусах. В такой ситуации кочевники пытались решить свои проблемы, как правило, за счет соседей. Астраханские едисаны, кочевавшие со скотом на морских косах и Мочагах, практически не подверглись ударам природной стихии, благодаря мягкой зиме в этих местах ${ }^{80}$.

Во-вторых, калмыцкими тайшами на эту зиму уже был запланирован поход на Кабарду. Желание отомстить за гибель своих родственников в 1644 г. все еще не покидало калмыков. Но разведка, проведенная на крымской стороне Волги, выяснила, что «снеги велики и в горах в зборе ратные многие люди ${ }^{81}$. Другими словами, калмыков уже ждали в Кабарде, и фактору внезапности уже не было места. Ошибку, допущенную в 1644 г., тайши не хотели повторять.

В-третьих, посланцы Лузана - Энгей-дархан и Каим Дургеев, отправленные в октябре 1649 г. в Астрахань, были задержаны воеводами. В ответ к тайше был отправлен толмач Г. Михайлов с одним лишь калмыцким послом Ургечеем для разбирательства случившегося вооруженного конфликта. Незадолго до этого люди Лузана были замечены в нападениях на «государевых людей» возле Волги. Позже выяснилось, что это были дербеты владелицы Сувундай, которая кочевала совместно с братом Лузаном. Именно ее люди и совершили нападение на группу астраханцев, направлявшихся из Саратова в Астрахань, захватив 6 человек в плен ${ }^{82}$.

В-четвертых, часть астраханских едисан мирзы Сююнчи Абдулова выразила желание присоединиться к калмыкам. Первым, кто из тайшей отозвался и пришел под Астрахань, был именно Лузан ${ }^{83}$.

Согласно сведениям из различных источников, изначально у тайшей не было намерения нападать на астраханских ногаев. Одним из основных их требований была выдача астраханцами останков ХоУрлюка, Кирсана и Церена. Но когда из Астрахани пришел отрицательный ответ, калмыки перешли к наступательным действиям. При

${ }^{80}$ РГАДА. Ф. 119. Оп. 1. 1650 г. Д. 1. Л. 192.

${ }^{81}$ РГАДА. Ф. 119. Оп. 1. 1650 г. Д. 1. Л. 109.

${ }^{82}$ РГАДА. Ф. 119. Оп. 1. 1650 г. Д. 1. Л. 18-20, 30

${ }^{83}$ РГАДА. Ф. 119. Оп. 1. 1650 г. Д. 1. Л. 99. этом инициатива исходила именно от Лузана, а Дайчин со своими воинами двинулся к нему, чтобы «им бы де быть вместе, а не врозни, и чтоб де иво, Лаузана, одного государевы ратные люди, пришед меж Волги и Яика, безвестно не повоевали» ${ }^{84}$. В ноябре 1649 г. на военный сбор на заставе у реки Ахтуба собралось в общей сложности около 20 тыс. калмыцких воинов ${ }^{85}$.

На крымскую сторону Волги Дайчин и Лузан отправили военную разведку из 300 воинов, собиравших информацию и одновременно действовавших под Азовом и Темрюком. В этих местах калмыкам удалось отогнать лошадей, но за ними была организована погоня. В результате азовские ногаи на реке Сал настигли калмыков, не имевших возможности уйти далеко из-за очень глубокого снега, и отбили своих лошадей. В ходе завязавшегося боя оборонявшиеся калмыки большей частью погибли, и лишь немногим удалось вернуться обратно ${ }^{86}$.

Пока ждали возвращения разведки, тайши отправили посольство к терским ногаям мирзы Чебана Иштерекова с предложением присоединиться к калмыкам. Послов сопровождал военный отряд из 200 калмыков и 300 ногаев под руководством безулусного тайши АкынКошучея, племянника Дайчина, и ногайского мирзы Каспулата Мамаева $^{87}$. К сожалению, в документах не находят отражения результаты, достигнутые этим посольством.

На заставе Дайчин отговаривал Лузана от агрессивных действий против астраханцев. Но улусные люди Дайчина втайне от своего тайши отогнали скот у астраханских едисан. Когда об этом узнал Лузан, он прямо обвинил старшего брата в обмане, на что Дайчин ответил, что весь отогнанный скот у своих людей отыщет и обязательно вернет в Астрахань. Но это уже не могло удержать Лузана. Он приказал отправить около 2 тыс. своих людей под началом племянников, безулусных тайшей Шура и Омбо, на морские косы и Мочаги для отгона скота у астраханских едисан ${ }^{88}$.

${ }^{84}$ РГАДА. Ф. 119. Оп. 1. 1650 г. Д. 1. Л. 239, 243.

${ }^{85}$ РГАДА. Ф. 119. Оп. 1. 1650 г. Д. 1. Л. 102.

${ }^{86}$ РГАДА. Ф. 119. Оп. 1. 1650 г. Д. 1. Л. 400.

${ }^{87}$ РГАДА. Ф. 119. Оп. 1. 1650 г. Д. 1. Л. 105, 225-226.

${ }^{88}$ РГАДА. Ф. 119. Оп. 1. 1650 г. Д. 1. Л. 106, 110, 277. 
С проблемой неподчинения Лузана Дайчин столкнулся практически сразу по приезде в свои улусы в 1647 г. Очевидцы сообщали в Астрахани, что «брата де своего Дайчин тайши во всяких делах Лаузан не слушает, делает все по своему». Вдобавок ко всему отдельные калмыцкие тайши находились под влиянием ногайских мирз. Как отмечали многие русские посланцы, побывавшие в калмыцких улусах, «а на всякое де дурно калмыков приводы научают мурзы и татаровя нагайские и едисанские, которые с калмыки кочюют» ${ }^{89}$.

Астраханская администрация сразу же отреагировала на приход к Волге большого количества вооруженных калмыков. К Дайчину был отправлен астраханец И. Остриков, а к Лузану - толмач М. Герасимов. В дальнейшем Остриков сумел выехать от калмыков в Астрахань только на третий день, поскольку Дайчин опасался за его безопасность, «чтоб де на дороге на встрече над ними Лаузановы люди дурна никакова не учинили». Лузан же принял «государев лист» от толмача Герасимова демонстративно сидя и даже не прочитал его, что являлось выражением крайнего неуважения. Затем с заставы он отправил его к себе в улусы. На попытки Дайчина заступиться за Герасимова, Лузан «осердился» на старшего брата, выговаривая, что «де к нему (к Дайчину. - B.T.) из Астарахани присылают присыльщиков добрых (знатных. - B.T.), а к нему де Лаузану присылают присыльщиков худых, да и иво ж людей из Астарахани ис тюрмы к нему не отпустили, да и послов де иво в Астарахани долго держали». В улусе Лузана Герасимов стал очевидцем приезда к тайше около 20 послов от чакарцев, каракалпаков и джунгар. Прибытие к нему русского посланца Лузан использовал как дипломатическое прикрытие на переговорах с приехавшими послами, чтобы у тех сложилось впечатление о том, что он состоит в серьезных отношениях с царскими властями. Герасимов вернулся в Астрахань только в апреле 1650 г. Лузан предлагал астраханским воеводам обменять русский полон на кости отца и на своих людей, находившихся в городской тюрьме. В противном случае он обещал возобновить военные действия ${ }^{90}$.

Воеводы немедленно приняли ответные меры на нападения калмыков на астраханских едисан. В помощь им из Астрахани были от-

${ }^{89}$ РГАДА. Ф. 119. Оп. 1. 1650 г. Д. 1. Л. 244.

${ }^{90}$ РГАДА. Ф. 119. ОП. 1. 1650 г. Д. 1. Л. 102-103, 107, 111, 433-434, $437-438,444$. правлены несколько отрядов стрельцов и служилых татар, которые местами вступали в бой с калмыками ${ }^{91}$. Несколько калмыков в ходе вооруженных стычек были захвачены в плен и привезены в Астрахань, где под пытками дали весьма интересные показания. Один из пленных калмыков по имени Нондук из улуса Дайчина сообщил, что тайши со своими людьми пошли к Волге на заставу «для договору об миру» с астраханцами. Но Лузан, у которого насчитывалось примерно 4 тыс. воинов, направил своих людей в «загон» на астраханских татар в Мочаги и морские косы ${ }^{92}$.

Другой калмыцкий пленник, дербет из улуса владелицы Сувундай, сообщил, что отряды Лузана возглавляли его приближенные люди - дархан Кошучи и безулусный тайша Тепшиген. Из улусных людей Дайчина примерно 50-100 человек также участвовали в набеге, но втайне от своего тайши ${ }^{93}$. Калмыцкий пленник «кереитского родства) из улуса Дайчина по имени Лабан сообщил о наличии на заставе 10 тыс. воинов Дайчина и 2 тыс. воинов Лузана ${ }^{94}$.

В ходе допроса пленных астраханские воеводы задавали им вопрос: «Какое в их калмыцкой вере в шертованье крепко, чтоб крепче того не было?» Ответ калмыков состоял в следующем: «у них в вере крепче того нет сабака ссечь да пищаль лизать с клятвою, да послед-

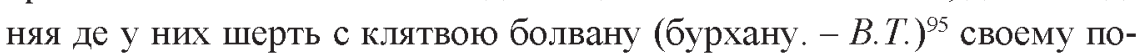
клонитца, а больше де того в их вере шертованья нет $)^{96}$. Подобная ин-

${ }^{91}$ РГАДА. Ф. 119. ОП. 1. 1650 г. Д. 1. Л. 44-46.

92 РГАДА. Ф. 119. Оп. 1. 1650 г. Д. 1. Л. 98-99.

${ }_{93}$ РГАДА. Ф. 119. Оп. 1. 1650 г. Д. 1. Л. 101-102, 106.

${ }^{94}$ РГАДА. Ф. 119. Оп. 1. 1650 г. Д. 1. Л. 109.

95 Здесь, видимо, речь идет о знаменитой статуе ламы Цзонкапы, основателя буддийской школы Гелугпа, хранящаяся ныне в Монголии, в храме Гандан. К торгутам она была привезена либо хутугтой Зая-пандитой в 1645 г., либо Дайчином в 1647 г. Есть свидетельства того, что по заданию буддийского проповедника в Восточной Монголии Нейджи-тойна (сына торгутского тайши Мергена-Темене, 1557-1653 гг.) было отлито 108 золотых статуэток богдо Цзонкапы, каждая высотой с локоть. Воплотив в них тарни и совершив обряд освящения, примерно в 40-х гг. XVII в. они были розданы монгольским и ойратским феодалам (Пурбуева Ц.П. Указ. соч. С. 80). По всей вероятности, одна из этих статуэток оказалась у волжских калмыков.

${ }^{96}$ РГАДА. Ф. 119. Оп. 1. 1650 г. Д. 1. Л. 113. 
формация воеводам нужна была для определения условий будущих договоров с тайшами.

Наибольшие потери в ходе последнего набега понесли улусные люди Лузана. Только из числа «ближних добрых (знатных. - В.T.) людей〉 его улуса четверо были захвачены в плен, не говоря уже о простых калмыках. Но большинство погибло не в вооруженных стычках с астраханцами, а на реках, около учугов, видимо, переправляя отогнанный скот. Очевидцы из татар сообщали в Астрахани, что в калмыцких улусах «о взятых и побитых людех плачь был во многие дни, и тужат де калмыки об них гораздо». Скот, отогнанный у едисан, не принес счастья калмыкам, ибо “(та животина с перегону многая померла)" ${ }^{97}$.

Но отгоном скота занимались не только калмыки. Позже тайши жаловались царским представителям: «сколько де они калмыки сее зимы у астраханских татар лошадей и животины отогнали было, и астраханские татаровя у них сее зимы отогнали их калмыцких лошадей болши того в десятеро ${ }^{98}$. Суровые реалии жизни кочевников, как правило, вынуждали их прибегать к подобному способу выживания - за счет соседей.

Улус Дайчина понес значительно меньшие потери. В связи с наступлением холодной зимы тайша сначала планировал провести зимовку возле Волги и Бузана, так как в здешних местах выпадало меньше снега, чем в глубокой степи. Но в связи с последними событиями ему пришлось, не дожидаясь весны, уйти к Яику. Поэтому Дайчин был очень зол на тех своих улусных людей, которые без его разрешения участвовали в набеге с людьми Лузана 99.

Лузан осознавал, что являлся инициатором неудачного набега, и решил выместить свое неудовольствие на своих же улусных людях, приказав конфисковать имущество у тех, кто по его приказу не явился на заставу. С улусом тайша зимовал в урочище на реке Еруслан, а затем откочевал на летние пастбища по рекам Иргиз и Камыш-Сама$\mathrm{pa}^{100}$. В это время люди Лузана начали активно совершать набеги на русские поселения на Волге. Так, зимой они захватили государевых

${ }^{97}$ РГАДА. Ф. 119. Оп. 1. 1650 г. Д. 1. Л. 216, 249.

${ }^{98}$ РГАДА. Ф. 119. Оп. 1. 1650 г. Д. 1. Л. 245.

${ }^{99}$ РГАДА. Ф. 119. Оп. 1. 1650 г. Д. 1. Л. $218,281$.

${ }^{100}$ РГАДА. Ф. 119. Оп. 1. 1650 г. Д. 1. Л. 295, 296. служилых людей, ехавших из Москвы в Астрахань с царскими грамотами. Под Черным Яром его отряды по 50-100 человек грабили и убивали на промыслах местных жителей ${ }^{101}$. Все эти действия можно рассматривать как попытку использовать русский полон для будущего обмена на калмыцких пленников, захваченных астраханцами в ходе зимнего набега.

Астраханские воеводы в свете последних событий сразу же прислали к Дайчину своими представителями татар для обмена и выкупа полона. Тайша был рад приезду астраханцев и заверил их в своем мирном отношении к Астрахани. Он приказал собрать со всех улусов захваченный на Тереке русский и ногайский полон. Тайша даже отправил своих людей к брату Лузану с требованием отпустить удерживаемого им толмача Герасимова и весь русский полон. Около 50 стрельцов удерживались в плену у ногаев, подчинявшихся Лузану ${ }^{102}$.

Если Дайчин приказал своим людям безвозмездно отпустить астраханских едисан, то Лузан отдавал жен и детей только тем приезжим татарам и ногаям, которые соглашались оставаться жить у него в улусе. Герасимов в улусе тайши насчитал примерно 150 русских пленников, часть из которых была продана в Хиву и Бухару. На требование Дайчина собрать и прислать к нему весь русский полон для обмена с астраханцами Лузан ответил отказом, заявив, что сам вернет его в Астрахань ${ }^{103}$.

Действительно, уже в апреле 1650 г. в Астрахань прибыли послы Лузана - Балдан и Темир. Тайша через них передал воеводам, что признает свою вину в недавнем набеге и на этом основании предлагал обменяться пленными. В этом же месяце Лузан со своими людьми охотился на крымской стороне Волги, был на Сарпе и Дону. Встречавшихся государевых людей калмыки не трогали, подчеркивая в разговоре, что они с ними находятся «в миру». Как отмечали очевидцы, часть улуса Лузана располагалась уже на правом берегу Волги ${ }^{104}$.

В июле 1650 г. Дайчин отправил в Астрахань письмо, адресованное воеводе И.Ф. Голицыну: «От нас к вам никоторые войны нет, 3

${ }^{101}$ РГАДА. Ф. 119. Оп. 1. 1650 г. Д. 1. Л. 18-20, 348, 349, 361.

${ }^{102}$ РГАДА. Ф. 119. Оп. 1. 1650 г. Д. 1. Л. 232, 233, 271, 272.

${ }^{103}$ РГАДА. Ф. 119. Оп. 1. 1650 г. Д. 1. Л. 212, 315, 444, 446.

${ }^{104}$ РГАДА. Ф. 119. Оп. 1. 1650 г. Д. 1. Л. 288-289, 321. 
Белым Князем были мы мирны, а ныне учинилося дурно от нас или от вас про то не ведомо. И за что вы Лаузанова посла засадили? И вам бы Лаузанова посла прислать, а что Лаузан взял, и мы то вам отдадим. Лаузанова посла пришлете, и мы примем, а не пришлете, и мы учнем воевать. В мире быть добро или воеватца добро сами ведаете. И о том бы вам прислать к нам весть» ${ }^{105}$.

Как видно из содержания письма, всю ответственность за последние события Дайчин переложил на астраханскую сторону. Он всячески оправдывает своего брата, хотя отношения с ним складывались в это время у него весьма не просто.

К осени 1650 г., когда из Астрахани были отпущены послы Лузана, русско-калмыцкие отношения еще не были окончательно урегулированы. Летом люди Лузана на Иргизе захватили 25-26 казаков, направлявшихся из Москвы через Самару на Яик. Трое из них были проданы хивинцам, а остальным удалось бежать. Осенью выходцы из калмыцкого плена сообщали властям о прикочевке улусов Дайчина и Лузана в район между Царицыном и Саратовым. На зиму тайши запланировали нападение на Кабарду и Казыевский улус, а свои улусы перевести на крымскую сторону, в район междуречья Сарпы и Дона. В октябре черноярские стрельцы наблюдали возле Волги калмыцкие отряды по 50-100 человек, совершавшие нападение на промыслы и рыбные ловли ${ }^{106}$

В ноябре из Астрахани к тайшам были отправлены Д. Ефимонов и толмач А. Герасимов. В районе Нарын-песков их встретил Утешдархан, который и отвез астраханцев к Дайчину и Санжину, охотившимся в это время на сайгаков. Их встреча состоялась 18 декабря ${ }^{107}$.

На просьбу посланцев отправить в составе посольства в Астрахань кого-нибудь из ближайших родственников Дайчин ответил категорическим отказом, что так «у нас не повелось». При обсуждении обмена полона Дайчин сделал строгое внушение русским по поводу того, что в Уфу он отпустил 10 человек, в Астрахань отдал 10 русских пленников, освободил 20-30 астраханских татар с семьями, а с русской стороны еше не поступил ни один пленный калмык. Дайчин

${ }^{105}$ РГАДА. Ф. 119. Оп. 1. 1650 г. Д. 1. Л. 466.

${ }^{106}$ РГАДА. Ф. 119. ОП. 1. 1650 г. Д. 1. Л. 184-185, 188

${ }^{107}$ РГАДА. Ф. 119. Оп. 1. 1650 г. Д. 3. Л. 1, 6. соглашался дать аманатов в Астрахань только при условии, если Москва разрешит ему организовать военный поход против Крыма или Казыевского улуса ${ }^{108}$.

Из Астрахани к Лузану в то же время был отправлен Т. Селезнев, которому тайша объяснил, что активизация действий калмыков под Астраханью является ничем иным, как реакцией на следующие обстоятельства.

Во-первых, еще зимой 1649/50 года люди Лузана перехватили гонца, направлявшегося из Москвы в Астрахань с государевой грамотой, в которой якобы указывалось собирать войска со всех городов и направлять против калмыков.

Во-вторых, той же зимой посланцев Лузана арестовали в Астрахани, а скот, пригнанный ими на продажу, был конфискован.

B-третьих, астраханские татары, приезжавшие в калмыцкие улусы для торговли или к своим родственникам, при отъезде угоняли у калмыков лошадей, и, по словам тайши, «в том де промеж нами чинитца ссора большая» ${ }^{109}$.

Вопрос об обмене пленными в этот период стоял довольно остро в русско-калмыцких отношениях. Данная проблема рассматривалась калмыками не только на астраханском направлении, но и на уфимском. По царскому указу от 9 сентября 1649 г. в калмыцкие улусы для выработки условий обмена пленными был направлен уфимец И.И. Онучин в сопровождении толмача В. Киржатцкого, стрельца Ф. Федорова и башкирского тархана Аккуса Кусябердеева. Сведения о поездке в калмыцкие улусы русского посла Онучина, впервые опубликованные в «Материалах по истории русско-монгольских отношений», для исследователей представляют огромный интерес. Запись разговора с Дайчином, сделанные русским посланником, дает возможность более полно представить политические взгляды калмыцкого тайши на события того периода.

Выехав из Уфы 21 сентября, посольство 4 ноября благополучно прибыло в калмыцкие улусы. 8 ноября послы были приняты Дайчином, которому они передали прежнее государево требование - отход

${ }^{108}$ РГАДА. Ф. 119. Оп. 1. 1650 г. Д. 3. Л. 8-11.

${ }^{109}$ РГАДА. Ф. 119. Оп. 1. 1650 г. Д. 3. Л. 24-25. 
калмыков на дальние кочевья и обмен пленными. Только при выполнении этих условий правительство обещало калмыкам мир, отказаться от посылки против них русских войск и запретить башкирам нападать на калмыцкие улусы. Дайчин также выразил свою готовность к сотрудничеству. Но, немного подумав, тайша сформулировал уже свои претензии к московскому правительству. Он напомнил, что приезжавший год назад в калмыцкие улусы В.К. Голубцов предъявлял аналогичные требования и давал тайшам те же обещания, что и Онучин. Но после отъезда Голубцова башкиры уже четырежды совершали набеги под калмыцкие улусы, отгоняли лошадей и убили пятерых калмыков. Дайчин потребовал немедленного расследования по этим делам, наказания виновных и возвращения отогнанных лошадей. В случае невыполнения его требований он пригрозил, что и сам справится с башкирами. На том и закончилась их первая встреча ${ }^{110}$.

Через неделю Дайчин, посоветовавшись с братом Лузаном, сыном Нима-Цереном и другими тайшами, отправился на заставу на реке Ахтуба. В декабре он уже вернулся в свой улус. Онучин сразу же отправился на встречу с тайшой, чтобы выразить протест по поводу последнего набега под Астрахань ${ }^{111}$. Дайчин объяснил ему ситуацию: «Я под Астраханью не бывал, а стоял на Волге с воинскими людьми, а под Астраханью повоевал с воинскими своими людьми брат мой, Лаузан, а ведаете вы и сами, что брат мой кочует о себе и меня ни в чем не слушает. Ходили с братом моим, с Лаузаном, под Астрахань воевать мои, Дайчиновы люди калмыки, без моего ведома, а те, которые кочевали с ним, Лаузаном, вместе и которые мои, Дайчиновы люди, з братом моим, с Лаузаном, ходили под государеву отчину под Астрахань войною без моего ведома, и я их по своей вере велю переграбить, а инова наказанья никакова у нас не бывает» ${ }^{112}$.

Онучин напомнил Дайчину о шерти 1648 г., которую дали калмыцкие представители В. Голубцову и В. Киржацкому, в частности, где упоминалось об отказе калмыков нападать на государевы земли. Русский посланник вопрошал, в чем состоит «правда» Дайчина, если

\footnotetext{
110 Устюгов Н.В. Указ. соч. С. 52

${ }^{111}$ МИРМО. М., 1974. С. 354.

${ }^{112}$ МИРМО. М., 1974. С. 356.
}

он с калмыками все же ходил в набег на русские земли и захватил полон. Также он поставил в известность тайшу о событиях начала XVII в., когда (прежние Батыр-тайша (Далай-Батур. - В.T.) и Каракола-тайша и отец ваш, Урлюк-тайша, з братьею и с вами, 3 детьми своими и с племянники, и все калмыцкие тайши с своими улусными людьми были под его царскою величества высокою рукою в повеленье и в послушанье, и послов своих к нему, великому государю, присылали почасту, и ему, великому государю, служили во всем правдою». Но Дайчин сразу же отверг все претензии и обвинил Онучина во лжи: «И вы то солгали: отцы наши и деды и прадеды отвеку в холопстве ни у кого не бывали. Да и в книгах у нас того не написано, чтоб мы у ково были в холопстве, а живем мы о себе, владеем сами собою и улусными своими людьми. Да и ныне мы, окроме бога, никово не боимся, а послами мы ссылались наперед сего и ныне ссылаемся ж о миру и о совете». Онучина не устроил такой ответ тайши, и он пригрозил ему, что, если это будет ведомо государю, «тебе за то чаю от царского величества не прибудет».

В дальнейшем в ходе разбирательств о причине вооруженного конфликта под Астраханью выяснилось, что выступление калмыков произошло из-за ареста астраханскими властями посланцев Лузана. Но Онучин владел информацией о недавнем разгроме калмыками русско-татарского отряда, направлявшегося из Москвы в Астрахань, что в конечном итоге и стало причиной ареста калмыцких послов. Как оказалось, виновником нападения был дербетский владелец Субалтай, кочевавший совместно с Лузаном и который, по словам Дайчина, «своровал без нашего ведома». На предложение Онучина наказать владельца смертной казнью, чтоб «иным неповадно было воровать», Дайчин отказался это делать: «У нас того не повелось, што смертью казнить, и никакова наказанья не чинят, окроме тово, что животы грабят». Но такой ответ не устроил русского посланника: «И ваша то какая правда, что через шерть свою велите людям своим воровать, а сказываете, што воруют без вашего ведома, а казни и наказанья им никакова не учините»> ${ }^{13}$.

Дайчину нечем было парировать на вполне резонные доводы Онучина. Набеги продолжались и не только на астраханском направ-

\footnotetext{
${ }^{113}$ МИРМО. М., 1974. С. 356.
} 
лении. Весной к Онучину часто с жалобой обращались калмыцкие ногаи, что «Дайчин-тайша поволил под государевы городы и на уезды войною ходить» ${ }^{114}$. Действительно, летом 1650 г. четверо едисанских мирз с отрядом в 1100 человек совершили набег на Казанский уезд, где башкиры их полностью разгромили. Вернулись только двое мирз с 300 человек. Под Самару же ходили 90 калмыцких едисан, и их самарцы также разбили. Как отмечали очевидцы, «плачь в едисанских улусех по побитых татарех был многой». Недовольство едисан Дайчин всячески пресекал, а едисанского мирзу Сююнчу Абдулова в качестве заложника держал у себя в улусе, чтобы его подвластные не ушли к Астрахани 115 .

На следующей встрече с Дайчином Онучин поднял вопрос и о продолжающихся набегах. По сведениям, полученным им от кочевавших с калмыками ногайских мирз, Дайчин посылал войной ногаев на приграничные русские города и уезды. Тайша не отрицал этот факт, но уточнил, что посылает их в набег не в Уфимский уезд, с населением которого он находился в мирных отношениях, а Казанский: «та чуваша и черемиса Казанского уезду со мною не в миру». Подобный ответ не устроил Онучина: «Шертовали за тебя улусные твои люди на том, что было тебе не ходить и улусных своих людей не посылать ни под которые государевы городы и в уезды... И Казань, и У фа - царского величества городы, и люди в тех городех и в уездех одного государя, а не самовластные: живут под государевою высокою рукою».

Дайчин был высокого мнения о военном потенциале башкир и относительно их будущего не скрывал своих планов: «А чаю, што и добром башкирцы будут у меня, а только башкирцы учнут кочевать со мною, и нам де, окроме бога, кому что зделать». На воинственные заявления Онучину пришлось лишь константировать: «Чево у тебя слушать и какова от тебя вперед постоянства чаять: на чем ты ни шертовал, и ты в том во всем солгал. А што ты говоришь про башкир, что они будут у тебя, и башкирцы - исконные холопы царского величества, а в измене николи не бывали и не будут».

Как видно, конструктивного диалога между Онучиным и Дайчином не получилось. Каждый из них остался при своем мнении. При

\footnotetext{
${ }^{114}$ МИРМО. М., 1974. С. 356; Устюгов Н.В. Указ. соч. С. 52-53

${ }^{115}$ РГАДА. Ф. 127. Оп. 1. 1650 г. Д. 1. Л. 37-38, 109.
}

отъезде из улусов Онучин еще раз пришел к тайше и на прощание ему еще раз напомнил о прежних договоренностях калмыков с В. Голубцовым и Д. Долгоруковым, где они обязывались сойти с башкирских вотчин и отйти в дальние свои прежние кочевья на реке Иргиз и Каракумах: «а меж Яика и Волги, где преж сего калмыцкого кочевья не бывало, на государеве ясачных людей земле не кочевали». Но у Дайчина было свое видение по территориальному вопросу, которое он весьма подробно объяснил: «Земля и воды божьи, а прежде сево та земля, на которых мы и ногайцы ныне кочуем, была ногайская, а не государева, и башкирских вотчин в тех местах не бывало. И мы, на те места пришед, и ногайцев с того места сбили. И ногайцы после того кочевали под Астраханью, а мы, калмыки, после ногайцев кочуем на той земле и по се число. А как мы под Астраханью ногайских, едисанских и ембулутцких мурз и улусных их татар за саблею взяли, и мы по тем рекам и по урочищам с теми ногайцы посполу и кочуем вместе по-прежнему, потому что они, ногайцы ныне стали наши холопы. А наперед сего по тем местам и по рекам кочевали они и нам де в тех местах и ныне зачто не кочевать. Да и кочевать нам, окроме тех мест, негде. А на той земле и по тем рекам государевых городов нет».

На основе вышеизложенного разговора М.Л. Кичиков сделал ряд существенных выводов: во-первых, в 1649 г. Дайчин в русско-калмыцких переговорах выступает в качестве главного лица от калмыцкой стороны, хотя он еще не имел полной власти над братом Лузаном; во-вторых, Дайчин все еще пытался найти какое-либо обоснование правам на земли, по которым кочевали его подвластные; в-третьих, Дайчин доказывал необходимость кочевки калмыков в междуречье, так как кочевать им было больше негде ${ }^{116}$. Территориальный вопрос в русско-калмыцких отношениях занимал ключевое место. В.В. Трепалов отмечает, что, несмотря на притязания царского правительства на обладание заволжскими степями в первой половине XVII в., настоящего административного «освоения» региона не происходило, а, следовательно, эта территория не воспринималась местными народами как российская ${ }^{117}$.

\footnotetext{
${ }^{116}$ Кичиков М.Л. Образование... С. 83.

${ }^{117}$ Трепавлов B.B. «Белый царь»... С. 156-157.
} 
14 июня 1650 г. Онучин вернулся в Уфу вместе с калмыцкими послами от Дайчина - Чегланом Кесеповым и Таганом Чентуевым. Калмыки привезли с собой 14 пленных для обмена и выкупа. Уфимский воевода Ф.Я. Милославский 17 июня принял послов, которые дали шерть за Дайчина, его братьев, племянников и за всех улусных людей, кроме Лузана, который, как отмечали сами калмыки, «з братом своим, с Дайчином, не в совете и ни в чем ево не слушает». Тайши обешали сойти с государевой земли, не нападать на башкир и других русских подданных, совершить обмен пленными, а также предлагали военно-политическое сотрудничество 118

Текст шерти 1650 г.: Дайчину maйuе и братье ево, и племянником, и всем улусным их людем, окроме Лаузана тайии, на государевы городь войною не ходить, городов и уездов не воевать, и людей не побивать и в полон не имать. А которой полон взят преж сево в калмыцкие улусы, и тот полон отпустить в государевы городы весь безо всякие зацепки. И з государевы земли, з баикирских вотчин, сойти в дальние свои прежние кочевья и впредь на те места для кочевья Дайчину и братье ево, и племянником, и улусным их людем не приходить и на промыслех ясаиных людей не побивать и не грабить. Быть с государевыми людми в дружбе и в совете вовеки непременно. И Лаузану тайше и иным тайшам, и всяким владетелем людми и казною на государевых людей не вспомогать. А где будет ему, Дайчину, вмоч Лаузана или иньхх каких владетелей, и их людей унять и ему унимать. А кто государевым людем друг, тот и ему Дайчину будет друг, а кто государевым людем недруг, тот и Дайчину недруг.

Послы дали шерть и совершили клятвенный обряд: «секли собаку», прошли между пищалями и целовали носимые при себе нательные золотые червонцы, священные книжки и бурханы ${ }^{119}$.

Миссия Онучина в калмыцких улусах еще раз подтверждает мнение, что в те годы тайши искали скорее союза с Россией, чем принятия подданства. Слова Дайчина, видимо, отражали взгляд на русскокалмыцкие отношения большинства калмыцких владельцев. Шерти, заключенные в начале XVII в. и в настоящее время известные как

${ }^{118}$ РГАДА. Ф. 119. Оп. 1. 1650 г. Д. 2. Л. 1-2, 10; Устюгов Н.В. Указ. соч. С. 53-54; Очерки... М., 1967. Т. 1. С. 108.

${ }^{119}$ РГАДА. Ф. 119. Оп. 1. 1650 г. Д. 2. Л. 10-11. договора о принятии калмыками русского подданства, требуют дополнительного исследования и более точной трактовки. Калмыцкая интерпретация шертей начала XVII в., как видно из слов Дайчина, существенно отличалась от русской. Сохранившиеся и опубликованные калмыцкие источники также не дают однозначного ответа на данный вопрос. «Калмыцкие книги», на которые ссылается Дайчин, к сожалению, так и остаются для нас неизвестными. Подобные диалоги, записанные русскими дипломатами, и письма калмыцких тайшей на сегодня являются ценнейшими источниками.

\section{7. Укрепление политической власти Дайчина}

После неудачного зимнего набега калмыков на астраханских ногаев, спровоцированного во многом своевольством Лузана, Дайчин пришел к необходимости окончательно решить вопрос о главенстве в торгутском доме, призвав для этого всех тайшей. С этой целью он отправил посланцев к братьям Санжину, Елдену и его сыновьям, кочевавшим в верховьях Эмбы и на Барсучьих песках, в 25 днях пути от Яика. Тайши должны были собраться на съезд “для совету», который был вызван тем, как отмечали очевидцы, что прежде «царем (ханом. - B.T.) был он, Дайчин тайша, и владал один, а ныне де Лаузан тайша ево, Дайчина, не слушает и ставитца другим царем; и с какими де людми он, Дайчин тайша, хочет быть в миру, а Лаузан де тайша с теми людми чинит ссору и иво, Дайчина, ни в чем не слушает; а у одного де юрта по два царя не бывает». Братья должны были окончательно разрешить давно назревший в калмыцком обществе вопрос: «Дайчину впредь быть царем (ханом. - B.T.) или Лаузану»» ${ }^{120}$.

К окончательному разрешению спорной ситуации подтолкнул и случившийся инцидент между братьями. Поскольку угроза ответных действий русских войск на последний набег калмыков под Астраханью была реальной, возникла необходимость объединения всех имеющихся калмыцких сил. Дайчин отправил к Лузану и другим братьям своих посланцев с призывом присоединиться к нему для организации

\footnotetext{
${ }^{120}$ РГАДА. Ф. 119. Оп. 1. 1650 г. Д. 1. Л. 284.
} 
общей обороны. Но Лузан категорически отказал в этом старшему брату. Тогда посланцы потребовали от него передать Дайчину улус ногайского мирзы Каспулата Мамаева, являвшийся объектом давнего спора между братьями. Но и в этом вопросе Лузан оказался неуступчив, заявив им недвусмысленно: «и хто де будет силен, и у тово де Каспулат мурза и станет жить». Более того посланцы Дайчина в улусе Лузана были избиты, лошади у них отобраны, а сами они, как передавали очевидцы, спаслись бегством ${ }^{121}$. Несмотря на открытое неподчинение Лузана, Дайчин не стал форсировать события с позиции силы, поскольку у него, видимо, такой возможности еще не было. В русских документах, к сожалению, нет сведений о калмыцком съезде, так что неизвестно, состоялся ли он вообще, если Лузан отказался принять в нем участие.

Переломным моментом в отношениях братьев стали события, последовавшие весной 1650 г. Как сообщал в Астрахани ногаец Бедяш, в это время к Дайчину прибыло совместное посольство от хунтайджи и хутугты с предложением приехать в Джунгарию для заключения нового договора об объединении. В случае отказа джунгары угрожали торгутам войной. Дайчину пришлось согласиться, и он с послами отправился в Джунгарию. С собой он взял 500 калмыков, 100 ногаев, а также едисанского мирзу Сююнчу Абдулова, ногайского мирзу Салтамурата Каспулатова и двух джембойлукских мирз, что давало гарантию в том, что за время его отсутствия улусы указанных мирз не уйдут от калмыков. Но отъезд Дайчина в Джунгарию и стал катализатором выяснения отношений между двумя его братьями - Елденом и Лузаном. Провоцировал конфликт Елден - из братьев второй по старшинству после Дайчина, затаивший давнюю обиду на младшего брата и ждавший удобного случая, чтобы свести с ним счеты. Как отмечали очевидцы, Елдена очень раздрожало и то, что Лузан «большово брата своего, Дайчина тайшу, и ево, Елдена, не почитает и не слушает». Елден решил отобрать у Лузана ногаев и три торгутских рода, которые, как он считал, принадлежали ему по праву и насильно удерживались в улусе младшего брата ${ }^{122}$. По всей видимости, своими неудачными действиями зимой под Астраханью Лузан заметно уро-

${ }^{121}$ РГАДА. Ф. 119. Оп. 1. 1650 г. Д. 1. Л. 442.

${ }^{122}$ РГАДА. Ф. 127. Оп. 1. 1650 г. Д. 1. Л. 92. нил себя в глазах братьев, и некоторые из них попытались провести передел кибиток

Неизвестно, чем бы все закончилось, если бы об этом не узнал сын Дайчина, Нима-Церен, отправивший гонцов с вестью о возникшей усобице вдогонку за отцом, который уже около двух недель находился в пути в Джунгарию. Дайчину пришлось срочно вернуться в улусы, и он, судя по документам, «унял» брата Елдена и на Лузана «войною ходить не велел». Таким образом, назревавший между братьями конфликт был исчерпан. Лузан оценил посреднические действия старшего брата и, как отмечали свидетели, решил окончательно ему «покоритца». Братья долгое время не виделись и общцались через посредников. Тем не менее, Лузан, решив лично встретиться с Дайчином, перед поездкой лично отобрал у себя в улусе лучших 50 лошадей и 1 тыс. овец в подарок старшему брату ${ }^{123}$.

В январе 1651 г. в Астрахани калмыцкие посланцы Кулеген Демчи, Утеш Тархан и Чирядай сообщали воеводам, что Дайчин над всеми братьями «учинился начальным человеком». Посланцы Лузана - Барчю и Батур - также подтвердили, что «ныне де у них у всех калмыцких тайшей во владенье учинился большой брат его, Дайчин тайша, и де Лаузана тайшу во всем договор учинил он, брат иво Дайчин; и на чем де он в правде своей договор учинит, и он де, Лаузан тайша, ис того Дайчинова договору не выступит и ево договор не нарушит» ${ }^{124}$. Централизация властных полномочий в калмыцких улусах теперь позволяла царской администрации иметь отношения с одним общим правителем. Но, как показали дальнейшие события, эти шаги окончательно не предотвратили раскола в торгутском доме.

На среднеазиатском направлении калмыки продолжали поддерживать союзнические отношения с Хивой. Хан Абу-л-Гази, считая туркмен своими главными врагами, предпринял против них ряд походов в 1646 и 1648 гг. В 1651 г. он разбил непокорное туркменское племя байрач, обитавшее на берегах рек Атрек и Гюрген ${ }^{125}$. Согласно русским источникам, туркмены отказались платить подать хивинскому хану, и последний обратился за военной помощью к Дайчину и

\footnotetext{
${ }^{123}$ РГАДА. Ф. 119. Оп. 1. 1650 г. Д. 1. Л. 36, 94.

${ }^{124}$ РГАДА. Ф. 119. Оп. 1. 1651 г. Д. 1. Л. 55-56, 71-72.

${ }^{125}$ Родословная туркмен... С. $17-18$.
} 
Лузану. Зимой 1650/51 года Дайчин, остававшийся верным союзу с Абу-л-Гази, отправил против туркменов сына Нима-Церена во главе отряда из 700 воинов. Но в горах калмыцкий отряд был разбит, и Нима-Церен бесславно вернулся в свои улусы ${ }^{126}$.

Перекочевка калмыков в междуречье Яика и Волги подтолкнула Астрахань снова активизировать переговорный процесс с тайшами. В октябре 1650 г. воеводы отправили к Дайчину астраханца Д. Ефимонова и толмача А. Герасимова, а к Лузану - Т. Селезнева и толмача А. Борисова. В январе астраханцы вместе с калмыцкими посланцами вернулись в Астрахань ${ }^{127}$. Послы Дайчина - Кулеген Демчи и Утеш Тархан - передали представителям местной администрации письмо тайши, написанное на старописьменном татарском языке, в котором Дайчин впервые именует себя и покойного своего отца ханскими титулами. Воеводы сразу же обратили внимание на то обстоятельство, что «государево имя не попригожу написано», а ханский титул Дайчина «наперед сего в листах своих к государевым боярам и воеводам не писывали» ${ }^{128}$.

Русский перевод XVII в. письма Дайчина на старописьменном татарском языке приводим ниже

Божиею милостию великий государь, Дайчин хан, Урлюк ханов сын, Ево Величества калмыциой и татарской самодержеи и многих людей государь и обладатель от нас, великого хана Дайчина, великому государю Белому Царю с молитвою челобитье астраханским воеводам после челобитья слово то, что они к нам присылали послов, чтоб наме нам отдать, а свое б себе взять. А наме проиение: отца намего Урлюково да братнее тела, да Карамеима, да что есть в Астрахани всех калмылкв нам отдать, и Сачан Дайчина и взятых татар, которые пойманы, от вас нам отдать. Да проилого году 7-8 человек русских людей я отдал... А против того мне ни единого калмыченина не отдадут, и нам своем слове не стоять. А ныне послал послов своих Кулегена Демчина да толмача Утеи Тархана... А лист писал Силман Дайчи ${ }^{129}$.

${ }^{126}$ РГАДА. Ф. 127. Оп. 1. 1651 г. Д. 1. Л. 77, 140.

${ }^{127}$ РГАДА. Ф. 127. Оп. 1. 1650 г. Д. 1. Л. 88; 1651 г. Д. 1. Л. 55.

${ }^{128}$ РГАДА. Ф. 119. Оп. 1. 1651 г. Д. 3. Л. 1-2.

${ }^{129}$ РГАДА. Ф. 119. Оп. 1. 1651 г. Д. 3. Л. 6-7.
Представленное письмо - иллюстрация того, как Дайчин рассматривал последние события, произошедшие под Астраханью. Зачастую агрессивное поведение калмыков по отношению к царским подданным объяснялось невыполнением взятых на себя обязательств противоположной стороной. На следующей встрече, во время приезда в улусы Я. Ушакова, русский посланник напомнил Дайчину о его письме, отправленном в Астрахань, где он «себя написал не так, как писывался отец ево Урлюк». Замечание Ушакова очень удивило тайшу, и он, немного подумав, дал довольно любопытный ответ: «велел де я писать в листах так, как прежде сего писывали, а что меня написали над калмыки и над татары самодержцем и обладателем, и то я писался над своими людьми, а не над чужими - и то обычное дело» ${ }^{130}$.

Вопрос о времени образования Калмыцкого ханства является до сих пор дискуссионным в историографии. В калмыцких источниках, в частности, у Габан Шараба, упоминается факт получения Дайчином от Богдо-гегена грамоты и печати на ханское достоинство. Но тайша отправил их обратно, заявив, что «подобных ему много имеется, и потому ему ханом быть не можно», что заслужило одобрения многих ойратских владельцев ${ }^{131}$. А согласно исторической версии Батур-Убаши Тюменя, ойратские тайши все-таки уговорили Дайчина принять ханский титул $^{132}$. Однако ни в одном из калмыцких источников эти события не датируются. Вероятно, они происходили в период с 1640 по 1647 гг., т. е. во время первой паломнической поездки Дайчина в Тибет. По мнению А.А. Курапова, сообщения об отказе Дайчина принять ханский титул от буддийских иерархов, являются не более чем «исторической легендой», так как получение титула хана было итогом его централизаторской политики в активной борьбе с политическими конкурентами ${ }^{133}$. Основываясь на свидельствах, зафиксированных в русских источниках, можно считать, что Калмыцкое ханство ведет свое начало от времени, когда впервые упоминается ханский титул Дайчина.

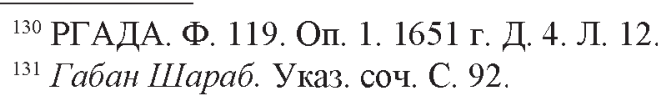

132 Батур Убаии Тюмень. Сказание о дербен ойратах // Лунный свет: Калмыцкие историко-литературные памятники / сост., ред., предисл., коммент. А.В. Бадмаева. Элиста, 2003. С. 142.

${ }^{133}$ Курапов A.A. Указ. соч. С. 90. 


\section{8. Крымский поход калмыков в 1651 г.}

В конце 1649 г. донские казаки оказались в очень сложной ситуации. Крымский хан Ислам-Гирей III начал собирать силы для военного похода против Черкасского городка. При этом он обратился за военной помощью к своим на тот момент союзникам - запорожским казакам в лице гетмана Богдана Хмельницкого. Ислам-Гирей III всерьез опасался нового нападения калмыков зимой и поэтому попытался заручиться поддержкой Хмельницкого, прислав ему богатые подарки. Гетман подарки не принял и войск своих крымцам не дал, но при этом пригрозил донцам, чтобы те не ссорились с ханом $^{134}$. Однако 10 апреля 1650 г. в Москве была получена войсковая отписка об ожидаемом походе крымцев и турок на Дон. В ноябре казаки узнали, что азовский паша Мустафа-бей с крымскими татарами, ногаями, черкесами и запорожцами общей численностью в 12 тыс. воинов планирует идти войной на Черкасский городок и далее вверх по Дону вплоть до Воронежа с целью окончательного изгнания казаков ${ }^{135}$.

Достаточных для отражения неприятеля сил на Дону не было. Здесь имелось всего 300 государевых солдат, и столь малое их количество объяснялось массовым дезертирством. Всего казаков и солдат на Дону насчитывалось около 2 тыс. человек ${ }^{136}$. Поэтому донские казаки обратились за военной помощью к астраханским воеводам, поскольку Царицын не мог оказать таковой ввиду малочисленности своего гарнизона.

Поскольку московское правительство не имело возможности выделить на Дон дополнительные военные силы, то оно разрешило казакам «посылать от себя к калмыцким тайшам нарочных своих посыльщиков, призывать калмыцких людей войною на Крым», часть из которых еще осенью 1649 г. перешла Волгу и кочевала около Цари-

\footnotetext{
C. 444

${ }^{134}$ РГАДА. Ф. 119. Оп. 1. 1651 г. Д. 1. Л. 358, 359; РИБ. СПб., Т. 29

${ }^{135}$ Смирнов Н.А. Борьба русского и украинского народов против агрессии су лтанской Турции в XVII-XVIII вв. // Воссоединение Украины с Россией. 1654-1954. М., 1954. С. 107.

${ }^{136}$ РИБ. СПб., 1913. С. 455.
}

цына, ближе к донским городкам, Чиру и Сарпе ${ }^{137}$. Первыми на контакт вышли именно калмыки, прислав к атаманам посланцев с предложением мира и заверением, «чтоб они, казаки, от них, калмыцких людей, дурна никакова не опасалися, и жили б с ними в миру и в совете» ${ }^{138}$. Вспомнив о заключенном с калмыцкими тайшами союзном договоре 1648 г., донцы отправили атамана Чирского городка К. Федосеева с двумя донскими татарами в близлежащий калмыцкий улус Лузана. Но тайши в улусе не оказалось, в это время он находился на заставе против Астрахани. Улусные люди Лузана в его отсутствие не решились принять письмо от донцов, и тем пришлось ни с чем вернуться обратно ${ }^{139}$.

Царский указ, разрешающий казакам призывать на помощь калмыков, ставил в двусмысленное положение уже астраханских воевод. С одной стороны, они всячески стремились не допустить перехода калмыков на правый берег Волги, с другой - Москва поощряла участие калмыков в союзе с донскими казаками в крымской кампании. Подобная несогласованность политики центра и местных администраций по отношению к калмыкам мешала нормальному развитию русско-калмыцких отношений.

Но попытка через казаков привлечь калмыков для обороны против Крыма, по всей видимости, носила все-таки секретный характер, и правительство в ходе русско-крымских переговоров старалось особо не афишировать какие-либо свои связи с тайшами, указывая, что те самовольно кочуют по обоим берегам Волги. Например, когда в начале 1650 г. в Москву от хана Ислам-Гирея прибыл посол Джанмирза Улан, то он прямо обратился к русскому царю с требованием немедленно оттеснить калмыков от Волги, «чтоб от них крымским кочевным людем убытку не было». В то же время в своем письме на имя царя крымский хан писал: «безверные калмыки - люди степные и не под однем началом не уметь им государством владеть и городы имать». Ислам-Гирей серьезно опасался, что, если калмыки все-таки с разрешения царских властей начнут кочевать по Волге, то их на445 .

${ }^{137}$ РГАДА. Ф. 119. Оп. 1. 1650 г. Д. 1. Л. 362; РИБ. СПб., 1913. С. 444.

${ }^{138}$ РИБ. СПб., 1913. С. 454, 455

${ }^{139}$ РГАДА. Ф. 119. Оп. 1. 1650 г. Д. 1. Л. 351-352, 362. 
падению могут подвергнуться ногайцы, кочевавшие у Перекопа и по Днепру. При этом крымский хан пытался уверить русскую сторону, что не боится калмыков: «мы от них не страшны, потому что они безверные воры, подобны ветру ${ }^{140}$.

Со своей стороны калмыцкие тайши также не собирались отходить от заключенных договоренностей с казаками. Более того, в отношении Крыма у них имелись свои планы, которые во многом не отвечали интересам московского правительства, так как оно в это время вступило в переговоры с крымской стороной. Урегулировав в течение 1650 г. отношения с Астраханью, тайши все свое внимание устремили на крымское направление. В начале 1651 г. Лузан перешел Волгу в районе между Царицыном и Черным Яром по направлению к реке Сарпа. В дальнейшем он намеревался совершить набег под Крым, чтобы отогнать у местных ногаев и татар лошадей. По сведениям русских послов, находившихся в это время в улусе Лузана, с ним находилось около 4 тыс. калмыков и ногайцев мирзы Салтаналы Аксакельмаметева. При этом не все в калмыцких улусах точно знали, чем был вызван этот переход на правобережье Волги. Одни говорили, что Лузан пошел будто бы по призыву донских казаков, другие - что тайша хочет идти в горы, «отмеща кровь отца своего Урлюкая и братьи своей» ${ }^{141}$

Весной 1651 г. тайши прислали к донским атаманам своих посланцев, которые заверили их в том, чтобы «они от них, калмыцких людей, дурна никакова не опасалися, и жили б с ними в миру и в совете». В ответ атаманы с послами вновь отправили к тайшам К. Федосеева с товарищами. В результате стороны договорились, что в случае прихода на Дон крымцев и запорожцев калмыки окажут казакам военную помощь, а если крымцы и черкесы пойдут против калмыков, то уже донские казаки обязаны были им всячески помогать. С целью укрепления отношений калмыки и казаки совершили торговый обмен ${ }^{142}$.

${ }^{140}$ РГАДА. Ф. 123. Оп. 1. 1650 г. Д. 2. Л. 14, 16, 17, 37, 39

${ }^{141}$ РГАДА. Ф. 127. ОП. 1. 1651 г. Д. 1. Л. 72-75; Новосельский А.А. Исследования по истории эпохи феодализма (научное наследие). М., 1994. С. 52.

${ }^{142}$ РИБ. СПб., 1913. С. 454-455.
О численности калмыцкого войска разные источники называют разные цифры. Так, по донесению русских посланников П. Коптева и Я. Ушакова, прибывших в конце 1651 г. в Крым, изначально Волгу и Дон перешли 20 тыс. калмыков. Если 10 тыс. воинов направились в причерноморские степи с целью захватить ногайские улусы, то другая половина войска направилась в набег на Кабарду, где она понесла большие потери. Местом сбора отрядов после проведенных набегов было назначено устье реки Донец. Калмыкам удалось взять в плен ногайского Мухаммеда-мирзу У ракова ${ }^{143}$.

Для сбора сведений о действиях калмыков на правобережье Волги астраханские воеводы отправили к донским казакам стрелецкого сотника П. Балакирева. Вернувшись 2 мая в Астрахань, он сообщил, что в войске, возглавляемом Лузаном, насчитывалось примерно 15 тыс. воинов. Под Азовом он разгромил небольшие ногайские улусы, взял в плен 13 казаков, а под верховыми городками учинил «большую шкоту». Перейдя на правый берег Дона, калмыки уже громили крымских людей ${ }^{144}$. По словам других очевидцев, в октябре 1651 г. Лузан с войском перешел Дон между казачьими городками Сиротиным и Кременным, в окрестностях которых калмыки действительно захватили в плен трех казаков. Но затем они прислали их к атаманам вместе с двумя калмыками в качестве аманатов на время похода против Крыма. Это было своего рода залогом того, чтобы казаки их беспрепятственно пропустили на обратном пути через Дон на Северный Кавказ ${ }^{145}$

Калмыки знали, что в степях между Доном и Крымом располагались ногайские улусы У раковых и Урмаметевых, находившиеся друг с другом в конфронтации. Чтобы примирить их, крымский хан направил к ним двух царевичей. Как и во время предыдущего калмыцкого похода на Крым в 1648 г., из улуса Лузана сбежал татарин, который предупредил крымских ногайцев о готовящемся приходе на них калмыков. Это позволило ногайцам и крымцам вовремя уйти и скрыться

${ }^{143}$ РГАДА. Ф. 123. Оп. 1. 1652 г. Д. 1. Л. 15, 20.

${ }^{144}$ Новосельский А.А. Исследования... С. 53; Куц О.Ю. Указ. соч. С. 317.

${ }^{145}$ РГАДА. Ф. 127. Оп. 1. 1651 г. Д. 1. Л. 232, 237; Куц О.Ю. Указ. соч. C. 317 . 
за Перекопом. Лузан не терял надежды настичь их и организовал погоню ${ }^{146}$

Подойдя к Крыму в конце 1651 г., калмыки в ходе вооруженной стычки на крымской заставе убили двух мирз Мансуровых и всех их людей, а также отогнали 40 тыс. лошадей. Поскольку некоторые преследуемые ими ногайские улусы успели скрыться на полуострове, большую часть своих людей Лузан направил за Перекоп, где они вступили в бой с ногайцами Урмаметевых и Ураковых, в то время как крымские татары со своими царевичами выступили против Лузана и Салтаналы. Вторгшиеся на полуостров калмыки и ногаи были «все побиты», о чем сообщил Лузану вырвавшийся оттуда с 30 ногаями мирза Аллачуват Акимбетев (племянник Салтаналы). Сам Салтаналы погиб в сражении ${ }^{147}$

По показаниям толмача Г. Гостева, прибывшего из Крыма в Москву в марте 1652 г., «от того калмыцкого приходу в Крыму страхованье было и всполох большой». Бой с калмыками возглавил Батырша-мирза Сулешев. Ему удалось отбить только 30 лошадей, при этом ранены были 7 татар. Ногайцам удалось захватить в плен двух калмыков, одного из которого повесили, а другого «держали в крепи». Крымский хан лично привел все имеющиеся военные силы к Перекопу, а калга Гази-Гирей отозвал войско, отправленное в черкесский поход ${ }^{148}$.

Лузан сутки простоял у Перекопа и, собрав всех своих людей из «загонов», пошел к себе в улусы. С ним находились сын Дайчина, Нима-Церен, и примерно 10 тыс. воинов. На четвертый день к Перекопу с войском подошел крымский царевич (нуреддин), а на восьмой день прибыл и сам крымский хан, но преследовать калмыков они так и не решились. Улусы Мансыровых, Ураковых и Урмаметевых, находившиеся в «крепких местах» у моря, были загнаны в Крым и расписаны все порознь по «табунам». Всерьез опасаясь нового нападения калмыков, крымский хан отказался выполнить указ турецкого султана направиться в поход на волохов ${ }^{149}$.

\footnotetext{
${ }^{146}$ РГАДА. Ф. 127. ОП. 1. 1651 г. Д. 1. Л. 76

${ }^{147}$ РГАДА. Ф. 127. Оп. 1. 1651 г. Д. 1. Л. 77.

${ }^{148}$ РГАДА. Ф. 123. Оп. 1. 1652 г. Д. 3. Л. 3-5.

${ }^{149}$ Новосельский А.А. Исследования... С. 53, 55.
}

Как и в 1648 г., крымцы всерьез считали организаторами калмыцкого похода именно московское правительство. Толмач Г. Гостев в Москве делился своими впечатлениями о крымских настроениях: «а в Крыму о том калмыцком приходе татаровя говорят от мала и до велика, будто де те калмыки приходили з государева ведома», якобы через Волгу их перевозили астраханские люди ${ }^{150}$. Но из документов ясно видно, что царское правительство не имело никакого отношения к военной акции калмыков. Приезд русского посольства в Крым в конце 1651 г., т.е. накануне калмыцкого вторжения на территорию ханства, прямо свидетельствует о незаннтересованности Москвы в силовых действиях во время русско-крымских переговоров. Негласное разрешение донским казакам призывать калмыков на помощь касалось только совместных оборонительных действий, но не наступательных.

В русских документах сохранилась и калмыцкая интерпретация результатов крымского похода. В феврале 1652 г. Лузан прислал в Астрахань своего посланца Илгоная с письменным сообщением, в котором говорилось, что калмыки «Крым погромили, а крымские люди государевым и им, калмыцким людям, были недруги, а они, калмыцкие люди, государевым людям друзья». Лузан предлагал в дальнейшем действовать уже совместно против Крымского ханства. В Астрахани вполне благосклонно отнеслись к инициативе калмыков и на этом основании разрешили людям Лузана вести торговлю под городом, тайше выплатили жалованье. По словам посланца, поход против Крыма оказался вполне успешным, однако, по другим сведениям, калмыки все же потеряли много людей ${ }^{151}$. В любом случае калмыцкие тайши сумели впервые провести активные военные действия на крымском направлении, а степи Северного Причерноморье в дальнейшем стали регионом постоянного калмыцкого присутствия.

${ }^{150}$ РГАДА. Ф. 123. Оп. 1. 1652 г. Д. 3. Л. 5.

${ }^{151}$ РГАДА. Ф. 127. Оп. 1. 1652 г. Д. 1. Л. 16, 24. 


\section{9. Русско-калмыцкие переговоры 1651-1654 гг.}

Одновременно с вышеописанными событиями началось движение и в калмыцких улусах. В январе 1651 г. в Астрахань из калмыцких улусов возвратились Д. Ефимонов и толмач А. Герасимов. С ними Дайчин и Санжин прислали своих посланцев, которые заявили о готовности калмыков быть с русскими в «мире и в совете и старого не вспоминать». Тайши сообщали о своей готовности выступить войной против «(государевых ослушников). Всех русских пленных они обещали вернуть только после того, как будут возвращены их люди. Но астраханский воевода выдвинул ряд встречных условий (отход за Яик, возвращение полона и т.п.), требуя подтвердить их шертью. Посланцы лишь ответили, что без согласия Дайчина тайши дать шерть на подобных условиях не смогут. В этом же месяце в калмыцкие улусы из Астрахани были отправлены Я. Ушаков и толмач Д. Аксентьев. Дайчин был весьма недоволен тем, как идет процесс обмена пленными, поэтому на встрече с астраханцами заявил, что он уже отпустил из улусов несколько десятков русских пленников в Астрахань, Уфу, Самару, а оттуда не прислали ни одного калмыцкого пленника. Ушаков объяснял это тем, что русские взяли пленных в бою, а калмыки захватили мирных жителей ${ }^{152}$.

Продолжал оставаться открытым и вопрос о передаче Дайчину останков его родственников. Тайша просил передать ему людей, которые везли останки и находились в астраханской тюрьме. Но Ушаков указал на невозможность такого шага, так как Шаим-мирза, везший эти останки, - «природной холоп государев». Далее Дайчин пригрозил посланнику сойтись с крымским ханом в случае, если царские власти надумают поставить городки по Яику и Камыш-Самаре. Тайша также указал на недопустимость требования правительством выдачи калмыцкой стороной аманатов: «А об аманатах послам своим шертовать не приказывал, что мне аманаты в Астрахань дать. Шертовали они в чем я им приказывал моею волею, а о чем им не приказано и то их силою шертовать заставили. И вольно и мне над тобою также силу учинить велеть крест целовать поневоле. И на Москве у меня

${ }^{152}$ РГАДА. Ф. 119. Оп. 1. 1651 г. Д. 4. Л. 1, 9. государь аманатов просить не велел» ${ }^{153}$.

Ушаков предложил Дайчину лично шертовать и дать аманатов «для веры и утверженья», а взамен при обмене полона получить останки отца и брата. Посланник также напомнил о приезде в улусы М. Щукина, через которого Дайчин якобы будто бы передавал, что желает дать аманатов в Астрахань. Но Дайчин ответил: «С Мишкою Щукиным таких слов не приказывал и от нево ничего не слыхал. Был у меня Мишка заездом, а сказал мне, что он послан к брату моему Лузану тайше. И он сам к Лузану ехать не посмел, а послал к брату ево татарина, а сам назад поехал. И тому не бывать, что мне в Астрахань аманаты дать. Как свет стал, и калмыки никому аманатов не давали. да и впредь того не будет. О том и говорить полно») ${ }^{154}$.

Как видно из этого диалога, далеко не все русские посланники четко следовали инструкциям и наказам отправлявшей их стороны Дайчин также отказался шертовать по вопросам о совместных военных действиях с русскими и ненападении сторон, поскольку по этим пунктам его послы уже не раз за него шертовали. Тайша поручился и за брата Лузана, отмечая, что он у него «в послушанье». На замечание Ушакова по поводу того, что в письме Дайчина в Астрахань государево имя «не попригожу написано» было, тайша вполне спокойно отметил, что «ко мне пишут от государя царя и великого князя Алексея Михайловича всея Руси, чтоб мне быть в холопстве, и я на то не пеняю, тем я в холопстве не учинился〉 ${ }^{155}$. Дайчин готов был дать аманатов только на время военного похода против «государевых недругов». Чтобы предотвратить любые эксцессы, тайша отправил к Волге 100 воинов для оберегания государевых людей от своих же калмыков ${ }^{156}$.

Уже в феврале посольство Ушакова вернулось в Астрахань с весьма неутешительными вестями: Дайчин так и не шертовал, пленных и аманатов не выдал, но прислал очередного своего посланца Укора Даулата. По словам Дайчина, никто из калмыков не пожелал быть в качестве аманата, поскольку «они наперед сего в аманатах в

${ }^{153}$ РГАДА. Ф. 119. Оп. 1. 1651 г. Д. 4. Л. 10.

${ }^{154}$ РГАДА. Ф. 119. Оп. 1. 1651 г. Д. 4. Л. 11

155 РГАДА. Ф. 119. Оп. 1. 1651 г. Д. 4. Л. 11-12.

${ }^{156}$ РГАДА. Ф. 119. Оп. 1. 1651 г. Д. 4. Л. 12-13. 
Астрахани не бывали). Выдав жалованье для Дайчина (однорядки и шапки), воеводы вскоре отпустили калмыцкого посланца обратно в улусы ${ }^{157}$

Нормальному развитию русско-калмыцких отношений продолжали препятствовать несанкционированные набеги и отгоны лошадей. Если тайшам удавалось как-то контролировать своих улусных людей, запрещая им ходить в набег на государевых людей под страхом конфискации имущества, то у царской администрации на местах это выходило не всегда. Так, во время крымского похода Лузана астраханские татары отогнали из его улуса 212 лошадей. Тайша через своих посланцев в Астрахани требовал вернуть захваченных лошадей, при этом в своих письмах Лузан также именовал себя (ханом». Воеводы, как и в случае с Дайчином, довольно болезненно отреагировали на это и указывали, чтобы он «себя б писал так же, как и отец ево, Урлюк тайша, а сверх чести отца своего на себя не накладывал» ${ }^{158}$.

Летом 1651 г. яицкие казаки совершили набег на дербетский улус, кочевавший с Лузаном, и, перебив охрану, отогнали большое количество лошадей. Когда же казаки погнали калмыцких лошадей в Самару на продажу, то дербеты на «самарской дороге» устроили им засаду и, разбив казаков, отбили своих лошадей ${ }^{159}$.

Тем же летом башкиры из улуса Дайчина отогнали 3 тыс. лошадей. Возмущенные этим набегом, Дайчин и Лузан отправили 7-тысячный отряд под Уфу. Очевидцы отмечали, что калмыки готовят к походу своих лошадей, «никуды на них не ездят» ${ }^{160}$. Таким образом, нельзя согласиться с утверждением Н.В. Устюгова о том, что с лета 1650 г. по 1657 г. между калмыками и башкирами установился мир ${ }^{161}$.

В феврале 1652 г. улус Дайчина располагался за Индерскими горами, в урочище Алмалы-ата, в 12 днях пути от Астрахани, где не раз подвергался набегам соседей. Во время приезда к нему астраханских посланцев Аллаберды и Байтерека тайша выговаривал им, что вслед за астраханскими посланцами приходят астраханские же татары и со-

\footnotetext{
${ }^{157}$ РГАДА. Ф. 119. Оп. 1. 1651 г. Д. 4. Л. 1-5.

${ }^{158}$ РГАДА. Ф. 127. Оп. 1. 1652 г. Д. 1. Л. 16-18.

${ }^{159}$ РГАДА. Ф. 127. Оп. 1. 1651 г. Д. 1. Л. 206; Куц О.Ю. Указ. соч. С. 77.

${ }^{160}$ РГАДА. Ф. 127. Оп. 1. 1651 г. Д. 1. Л. 206, 208-209.

161 Устюогов Н.В. Указ. соч. С. 54.
}

вершают у калмыков отгоны лошадей. Например, в бытность в улусах Я. Ушакова те же татары отогнали из улуса Дайчина 500 лошадей, но астраханские власти впоследствии вернули не всех лошадей.

Сохранявшаяся напряженность в русско-калмыцких отношениях имела и другую причину. Калмыкам было известно, что в Яицкий городок свозится большое количество лесоматериалов и кирпичей. Дайчин через их посланцев передал астраханским воеводам, что в случае постройки русскими властями крепости в Индерских горах на Яике и невозвращения всех отогнанных лошадей, он будет с ними «в недружбе». Посланцы предъявили ответные претензии, заявив в невозврате калмыками всего русского полона и продолжающихся случаях нападений на государевых людей ${ }^{162}$.

В это время у людей Дайчина неизвестные отогнали 160 лошадей, за которыми была организована погоня. В качестве улики к тайше была приведена загнанная лошадь одного из воров, по седлу которой калмыцкие ногаи определили, что она принадлежала некоему астраханскому татарину. Это дало Дайчину повод обвинить прибывших астраханских посланцев во лжи, хотя те пытались оправдаться, говоря, что это могли быть башкиры или яицкие казаки. В порыве гнева тайша приказал отобрать у них все вещи и не кормить, а сам перестал с ними общаться. Астраханская администрация, не желая дальнейшего осложнения отношений с калмыками, пыталась жестко контролировать подвластных татар и прекратить их набеги на калмыцкие улусы ${ }^{163}$.

Отгоны лошадей у калмыков продолжались не только с астраханского, но и с уфимского направления. Когда башкиры отогнали у Дайчина 400 лошадей, 60 калмыцких едисан пустились за ними в погоню, но в верховьях реки Самара башкиры их разбили, 10 человек захватив в плен. После этого в ответный набег на башкир отправилась уже сотня калмыков под командованием Дурал-дархана, но они, не достигнув цели, вернулись обратно, привезя в улус только двух пленных черемисов, а 20 калмыцких едисан под Самарой захватили в плен 6 русских людей ${ }^{164}$.

\footnotetext{
${ }^{162}$ РГАДА. Ф. 127. Оп. 1. 1652 г. Д. 1. Л. 27,29.

${ }^{163}$ РГАДА. Ф. 127. Оп. 1. 1652 г. Д. 1. Л. 30-32.

${ }^{164}$ РГАДА. Ф. 127. Оп. 1. 1652 г. Д. 1. Л. 31-32.
} 
В декабре 1652 г. тайши Нима-Церен и Мончак прислали в Астрахань двух посланцев - Телебердея и Темира, которые сообщили воеводам об отъезде Дайчина в дальние калмыцкие улусы. Отбывал, тайша наказывал своим людям жить мирно с государевыми людьми и отправить в Астрахань послов. Поводом для приезда калмыцких посланцев послужил отгон астраханскими татарами 270 лошадей у калмыков. Воеводы уверяли посланцев, что они уже вернули 200 лошадей Лузану, а остальных пообещали возвратить позже, как только их отыщут. В свою очередь, астраханские власти имели свои претензии к тайшам, в частности, продолжительное удерживание в калмыцких улусах Михаила Щукина ${ }^{165}$.

Начиная с этого времени имя Мончака упоминается в русских документах, что говорит о его возвращении из Джунгарии в родные улусы. Отъезд Дайчина в (верхние» калмыцкие улусы, по-видимому. был сопряжен как раз с тем периодом, когда он совершил вторую поездку в Джунгарию. Несомненно, что возвращение Мончака и отьезд Дайчина были как-то между собой связаны и относились к их взаимоотношениям с джунгарским Батуром-хунтайджи.

В дальнейшем отношения между калмыками и русскими стали обостряться еще больше. В ответ на действия группы молодых тайшей - Серешкепа (сына Сюнке), Солом-Церена и Мончака, которые совместно с дядей Лузаном стояли во главе войска на заставах по обоим берегам Волги, калмыцкие посланцы были задержаны в Астрахани. Фактически с суши на расстоянии 10 верст калмыки заблокировали все подходы к Астрахани. В окрестностях города, а точнее в районе учуга Басаргу, у астраханцев произошел ночной бой с калмыками, отогнавшими у местных татар лошадей и скот. В районе Черного Яра калмыки захватили 7 местных жителей и одного убили. Воеводы срочно отправили к тайшам задержанного калмыцкого посла Телебердея, а также М. Щукина и туркмена Аклаша ${ }^{166}$.

13 января 1653 г. Лузан и Мончак с заставы прислали в Астрахань Щукина с калмыцким послом Батыром-Демчи. Тайши передали, что пришли под город для заключения договора о возврашении кал-

${ }^{165}$ РГАДА. Ф. 119. Оп. 1. 1653 г. Д. 1. Л. 1-4.

${ }^{166}$ РГАДА. Ф. 119. Оп. 1. 1653 г. Д. 1. Л. 8-10 мыцких отогнанных лошадей и возобновлении торговли. Взамен они были готовы вернуть астраханцам весь захваченный полон и скот. Инцидент под Басаргу калмыки обьясняли тем, что это были люди Лузана, ходившие в набег без ведома своего тайши. В Астрахани Батур-Демчи дал шерть и 16 января был отпущен обратно в улусы. Вместе с ним к тайшам отправились стрелецкий голова М. Волков, толмач В. Михайлов и М. Щукин в сопровождении 14 стрельцов. На этот раз калмыкам вернули 134 лошади и 2 верблюдов ${ }^{167}$.

Мончак заявил русским представителям, что уже после последней шерти, которую дал калмыцкий посол в Астрахани, из его улуса астраханские татары отогнали 400 лошадей. Но окончательный мир калмыцкая сторона обещала только после выдачи астраханцами останков тайшей, а также удерживаемого в городе с 1644 г. казыевского мирзы Карашеима. Волков упрекнул тайшей в том, «что де посол их в Астрахани шертовал, и они де то ставят ни во что». В ответ русские посланцы были калмыками задержаны ${ }^{168}$.

Мончак снова отправил к астраханским воеводам Телебердея с Щукиным. В письме, привезенном послом от него, тайша просил предоставить ему возможность беспошлинно торговать под городом и требовал возвращения всех угнанных лошадей. При этом в письме Мончак именовал себя «великого царя сыном» (т.е. ханским сыном), что вызывало явное раздражение у воевод. В своих ответных письмах они требовали от Мончака писать свое имя соответсвенно прежнему титульному обозначению - (тайша). Астрахань обещала удовлетворить требование тайши о возврате лошадей, но, задержав Телебердея, выдвинула Мончаку ультиматум - в течение трех дней вернуть всех удерживаемых в калмыцких улусах русских посланцев ${ }^{169}$. Как видим, ультиматумы и угрозы продолжали сыпаться с обеих сторон, что, конечно, не способствовало налаживанию мира, подрывало переговорный процесс.

Переговоры с Волковым вел лично Мончак, поскольку Лузан в это время был болен. В улусе русскому посланцу пришлось пережить

\footnotetext{
${ }^{167}$ РГАДА. Ф. 119. Оп. 1. 1653 г. Д. 1. Л. 11-12, 15-16.

${ }^{168}$ РГАДА. Ф. 119. Оп. 1. 1653 г. Д. 1. Л. 18-19.

${ }^{169}$ РГАДА. Ф. 119. Оп. 1. 1653 г. Д. 1. Л. 6-7, 19-20.
} 
немало неприятных моментов, так как его пребывание там происходило на фоне следующих событий. В урочище Алгарах произошел ночной бой между калмыками и отрядом стрельцов. Астраханцы под натиском превосходящих сил калмыков отступили к Красному Яру, но 31 стрелец и 1 боярский сын попали в плен. Калмыцкие войска полностью блокировали Красноярский городок. Практически все калмыцкие тайши, а с ними и ногайские мирзы участвовали в этой военной операции, за исключением едисанского С. Абдулова, который со своими людьми оставался охранять улусы. Воеводы поспешили отправить к тайшам разъяснение, что отряд стрельцов направлялся не против калмыков, как те посчитали, а для охраны Красного Яра, и на этом основании требовали вернуть всех захваченных во время боя пленных ${ }^{170}$

1 февраля в 3 часа дня калмыки вновь появились под Астраханью, блокировав город с обоих берегов Волги. Улусы астраханских мирз Салтанаша, Аксака Келмаметева и Ямгурчея кейкувата Янмаметева оказались блокированными. Часть калмыков, перейдя реку Кутум, подошла вплотную к улусу Иштерековых, засевшему в укрепленном Ногайском городке. Ногаи из вышеуказанных улусов совместно с астраханцами вышли из укреплений и в ходе боя смогли оттеснить калмыков. В вооруженной стычке погибли боярский сын В. Есипов и трое калмыков. Следует отметить, что непосредственно в самом городе гарнизон был малочисленным, ввиду того, что был рассредоточен по окрестным заставам и учугам. Вечером того же дня калмыки отошли в степь. Многие астраханцы в окрестностях города были ранены или захвачены в плен ${ }^{171}$.

3 февраля Волков, толмач и стрелец вернулись в Астрахань, но остальных продолжали удерживать калмыки. С Волковым в посланцах от тайшей приехал татарин Отей. 10 февраля вернулся и Щукин с новым предложением от тайшей обменять в Красном Яру останки Хо-Урлюка на пленных стрельцов. Он же вернулся к калмыкам с ответом от воевод: только обмен тех, кто был захвачен в бою, на калмыцких пленных и отогнанных лошадей. В случае невозвращения русских представителей Астрахань обещала больше не присылать к

${ }^{170}$ РГАДА. Ф. 119. Оп. 1. 1653 г. Д. 1. Л. 22-24.

${ }^{171}$ РГАДА. Ф. 119. Оп. 1. 1653 г. Д. 1. Л. 24-26. тайшам своих посланцев и не предоставлять калмыкам возможность торговать. По-видимому, это условие подействовало на тайшей, и 21 февраля Мончак отпустил еще семерых человек. 27 февраля Щукин вернулся с двумя выкупленными им стрельцами. Мончак со своим войском возвратился в улусы на Яике. Воеводы попросили стрелецкого голову И. Горяинова, который находился в Яицком городке, чтобы тот обратился к Нима-Церену, не участвовавшему в последних событиях, за содействием в освобождении остальных пленных стрельцов $^{172}$.

Как видим, силовая акция калмыцких тайшей под Астраханью не принесла им ожидаемых результатов, усложнив и до того непростые русско-калмыцкие отношения. Причина столь агрессивной позиции тайшей становится известной из доклада в Астрахани русского посланца Волкова. Когда после переговоров Мончак и Лузан уже хотели было отправить с ним своего посла, из города приехал некий татарин с сообщением, что астраханские стрельцы идут войной на калмыцкие улусы. После этого по приказу тайшей всех русских послов связали и ограбили. На попытки Волкова объяснить, что тот татарин сознательно их ссорит, а указанный отряд стрельцов направлялся всего лишь на заставу, Мончак обвинил посла во лжи и отправил 7 тыс. калмыков и ногаев под Астрахань, которые впоследствии вернулись ни с чем. Тайши угрожали Волкову, что, если Астрахань не выполнит их требования, то послов продадут в Крым, Бухару или Ургенч. При этои почти как угроза из уст тайшей прозвучало заявление о том, что они с крымским ханом учинили мир, на что Волков ответил: «хотя меня отдадите в Крым или куды и продадите, и я человек последней, а вам впредь меж Яика и Волгою не кочевать». После этого калмыки послов морили голодом, кормя «скверной кобылятиной», которую сами русские не ели ${ }^{173}$.

Примерно в это время калмыки попали в поле зрения правительства Речи Посполитой. В июне 1652 г. поляки потерпели сокрушительное поражение в битве у Батога, на Украине, от действовавших совместно войск Б. Хмельницкого и крымских татар. Для борьбы с ними польский двор короля Яна Казимира попытался привлечь на

172 РГАДА. Ф. 119. Оп. 1. 1653 г. Д. 1. Л. 26-29.

${ }^{173}$ РГАДА. Ф. 119. Оп. 1. 1653 г. Д. 1. Л. 41-44, 50. 
свою сторону калмыков. В конце апреля 1653 г. король и канцлер Штефан Корицинский приняли решение послать со столь важной миссией на Нижнюю Волгу Каспера Шаманского, уважаемого городского дворянина, бывшего посла в Крыму, знавшего татарский и турецкий языки. В Главном архиве древних актов в г. Варшаве сохранилась копия секретной правительственной инструкции, выданной послу К. Шаманскому, направлявшемуся в Калмыцкую орду с целью склонить ее выступить против крымского хана. За оказанную помощь калмыкам обещали заплатить 50 тыс. талеров. Польша также предлагала тайшам подчинить себе Крымское государство, «которое издавна служило калмыцкому народу». В случае захвата калмыками Крыма польское правительство обещало им «вечный союз) и всевозможную военную помощь для удержания за калмыками этой территории ${ }^{174}$. Правда, среди польских историков нет единого мнения по поводу того, достигло посольство конечной цели или нет. Стоит отметить, что калмыцкое направление во внешней политике польского двора присутствовало и в последующие годы.

На среднеазиатском направлении калмыки продолжали играть заметную роль. Летом 1653 г. хивинский хан Абу-л-Гази планировал поход против туркменов, плативших подать калмыцким тайшам. Нима-Церен отправил своих послов к хану с требованием не трогать туркменов $^{175}$. Это свидетельствует о том, что мангышлакские туркмены находились под покровительством именно Нима-Церена. В этом же году калмыки во главе с Мергеном, Огжодбой и Тугулом (сыновьями Елдена) совершили набег на окрестности Хазараспа, а затем двинулись на Седур и Даруган. Хан Абу-л-Гази, получив известие о нападении калмыков, устроил за ними погоню, в ходе которой часть калмыков была перебита, а часть во главе с Огжодбой и Тугулом вынуждена была сдаться, заключив мир ${ }^{176}$.

Как видим, примерно в это время происходит отход улусов Елдена и его сыновей от основной массы торгутов - из Северного Прикаспия в район Северного Приаралья. Позже Елден направился к

${ }^{174}$ Трызярки Э. Сообщения поляков о калмыках с 1870 года / Пер. Д. Романова // http://www.m-m.sotcom.ru/8-10/prushins.htm.

${ }^{175}$ РГАДА. Ф. 119. Оп. 1. 1654 г. Д. 1. Л. 11-12.

${ }^{176}$ Родословная туркмен... С. 18-19. своему тестю Гуши-хану в Тибет, который еще ранее предсказывал ему разорение улуса по вине старшего брата Дайчина ${ }^{177}$. Сыновья Елдена оставались кочевать со своими улусами в Приаралье до 60-х гг. XVII в., пока их здесь окончательно не разгромил Мончак.

Из донесения астраханского воеводы в сентябре 1653 г. стало известно, что улус Лузана кочевал между Волгой и Яиком. Тайша на осень планировал вооруженный поход с 8-тысячным отрядом, правда, о направлении удара никто не знал. Под Царицыном, Саратовом и Черным Яром уже действовали калмыцкие разведывательные отряды по 200-400 человек, которые отгоняли скот и лошадей у местных жителей. Видимо, в этом регионе калмыки чувствовали себя настолько уверенно, что улус Мончака планировал провести зимовку в урочище Карадуван, в 2-3 днях пути от Астрахани. Воеводы поволжских городов постоянно запрашивали у Москвы военное подкрепление, указывая на большое скопление калмыков между Царицыном и Саратовом.

В связи с этим ситуация в регионе накалялась, и в октябре уже самарский воевода сообщал в Астрахань о намерениях Лузана и Мончака совершить набег под Уфу, Царицын, а также в Казанский и Самарский уезды. Мончак кочевал недалеко от Яицкого городка, а Лузан из-за Яика направился к Волге с целью совершить набег на ногаев, кочевавших по крымской стороне ${ }^{178}$. В ноябре калмыцкие улусы появились возле Черного Яра, где калмыками были захвачены четверо местных рыбаков, а сам городок с суши был полностью блокирован. Часть калмыцких улусов перешла на крымскую сторону Волги. Астраханские татары и ногаи, жители Яицкого городка властями были срочно предупреждены об угрозе нападения калмыков ${ }^{179}$. Несмотря на эскалацию событий, тайши не исключали возможного приезда астраханских посланцев для заключения мирного договора, в противном случае они планировали снова прийти на заставу под Астрахань ${ }^{18 n}$.

Судя по дальнейшим событиям, возвращение Дайчина из Джунгарии в улусы было своевременным, что не позволило вооруженным

\footnotetext{
${ }^{177}$ Габан Шараб. Указ. соч. С. 93.

${ }^{178}$ АИ. СПб., 1842. С. 195.

179 РГАДА. Ф. 119. Оп. 1. 1654 г. Д. 1. Л. 1-5.

${ }^{180}$ РГАДА. Ф. 119. Оп. 1. 1654 г. Д. 1. Л. 9-10
} 
стычкам между калмыками и русскими перерасти в полномасштабную войну. Позже калмыцкие пленники из Царицына были переданы Дайчину с просьбой «унять» брата Лузана, который, видимо, и являлся главным зачинщиком конфликта. Уже на тот момент начал действовать особый царский указ, строго запрещавший воеводам нападать на калмыцкие улусы ${ }^{181}$.

\subsection{0. Второй приезд Зая-пандиты}

Второй приезд Зая-пандиты в калмыцкие улусы фактически не находит отражения в историографии и русских документах. Единственным источником, в котором освещается визит хутугты, до сих пор остается жизнеописание Зая-пандиты, написанное его учеником Раднабхадрой. Правда, оставляет желать лучшего существующие комментарии к ним, поскольку они изобилуют ошибками в определении исторических личностей, датировки и местностей. Использование последних данных из русских архивных документов и комментарии специалистов по топонимике к «Биографии» дает возможность построить хронологию событий, происходивших во время второго визита Зая-пандиты к волжским калмыкам в 1655-1656 гг.

Когда в конце 1653 г. умер джунгарский правитель Батур-хунтайджи, по приглашению его сыновей для участия в похоронах прибыл Зая-пандита, который выполнил положенные погребальные обряды. Тело покойного предали огню, а прах сложили в урну. Одна из супруг покойного хунтайджи, Юм-Агас, на 49-й день приняла от хутугты посвящение в духовный сан ${ }^{182}$. На похороны свояка и свата Батура-хунтайджи не мог не приехать и торгутский Дайчин. Слишком многим он был обязан хунтайджи, особенно его поддержке и посреднической миссии в торгуто-дербетском конфликте. Зиму 1653/54 года Дайчин провел в Джунгарии, а летом 1654 г. находился уже в гостях у своего племянника - хошутского тайши Аблая. Поприветствовать дядю по материнской линии приехали и другие хошутские тайши -

${ }^{181}$ РГАДА. Ф. 119. Оп. 1. 1655 г. Д. 2. Л. 16-17, 54-55, 57-58.

${ }_{182}$ Раднабхадра. Указ. соч. С. 188
Галдамба, Соном и Сутай. Во время пира, устроенного Аблаем, Дайчин пригласил присутствовавшего здесь Зая-пандиту приехать еще раз в калмыцкие улусы.

Спустя некоторое время хутугта отправился на Яик и зиму 1654/55 года провел в дороге, проезжая через владения дербетских тайшей Кешкеба, Цагана и Цецена, чья ставка находилась в местности Усун Монцог ${ }^{183}$. Здесь он совершил обряды по случаю праздника Цаган Сар, а дербеты преподнесли ему в качестве подношения 30 верблюдов, 300 коней и другие подарки. Весной 1655 г. хутугта совершил поминальное богослужение по умершему к тому времени дербетскому Гумбо (сыну Далай-Батура). По пути следования Заяпандита побывал в гостях и у других дербетских тайшей - Даян-Омбо и Аюши (сыновей Далай-Батура), которые также преподнесли ему большое количество даров. А тайша Алдар (сын Чуу и внук ДалайБатура) даже выпросил для себя полное одеяние хутугты, преподнеся ему в дар 300 лошадей и 30 верблюдов ${ }^{184}$.

До приезда непосредственно в улус Дайчина Зая-пандиту поочередно приглашали к себе в гости торгутские Огджодба и Мерген (сыновья Елдена), Санжин, Урджин, Нима-Церен и другие старшие тайши, а также младшие тайши Шарап-Омбо и дербетский СоломЦерен. Все тайши обеспечивали многочисленную свиту хутугты в дороге продовольствием, делали им подношения. Прибыв в улус Дайчина на Яике, Зая-пандита провел здесь зиму 1655/56 года, проведя новогодние богослужения по случаю праздника Цаган Сар, много проповедовал, (сея семена добрых дел). При отъезде из торгутских улусов в августе 1656 г. Дайчин сделал хутугте подношение 3 тыс. лошадей и множество других подарков ${ }^{185}$.

Именно тогда, в 1656 г., произошел окончательный разрыв между Дайчином и Лузаном. Поводом послужило желание Дайчина полностью прекратить со стороны калмыков насильственные действия в

183 По мнению казахского исследователя Ж.О. Артыкбаева, данная местность находилась на реке Ишим. См.: Аpmылкбаее Ж.О. Среднее Прииртышье в контексте проблем истории Евразийских степей (этноисторический и этноархеологический опыт исследований). Т. 1. Павлодар, 2007.

${ }^{184}$ Раднабхадра. Указ. соч. С. 190-191.

${ }^{185}$ Pаднабхадра. Указ. соч. С. 191 
отношении царских подданных. С этой целью он приказал младшему брату кочевать рядом с собой и для убедительности захватил принадлежавший ему ногайский улус. Но Лузан не подчинился требованию старшего брата и в знак протеста откочевал со своим улусом за верховья Яика, на дальние кочевья, где присоединился к своим племянникам, сыновьям Елдена - Огджодбе и Тугулу ${ }^{186}$.

Указанные события в своем сочинении подтверждает и биограф Зая-пандиты. Правда, в отдельных комментариях к переводу указывается о конфликте, возникшем из-за ногаев, между Лузаном и Мергеном ${ }^{187}$, что в корне неверно. К этому времени из-за ссоры с Дайчином сыновья Елдена и Лузан практически окончательно отошли от основной массы торгутов. В анонимной «Истории калмыцких ханов) находится подтверждение тому, что Дайчин действительно отобрал у братьев - Елдена и Лузана - принадлежавшие им ногайские улусы. Елден с небольшой частью своих людей впоследствии откочевал в Тибет к тестю - хошутскому Гуши-хану ${ }^{188}$. Но дети Елдена не последовали вслед за своим отцом, а присоединились к чакарским калмыкам, кочевавшим в Приаралье. Лузан, прибыв сюда, принял участие в конфликте между детьми Елдена, поддержав Огджодбу и Тугула против Мергена, взяв последнего в осаду на озере Агсагал ${ }^{189}$. Зая-пандита срочно направился к ним и примирил конфликтующие стороны ${ }^{190}$.

Зиму 1656/57 года Зая-пандита провел в улусе дербетского тайши Даян-Омбо, в Приаральских Каракумах. Здесь он провел богослужения по случаю праздника Цаган Сар, а тайше дал много наставлений в вере. Даян-Омбо, Лузан и Огджодба преподнесли хутугте каждый по тысяче лошадей и другие дары, Тугул подарил 500 лошадей. По

\footnotetext{
${ }^{186}$ РГАДА. Ф. 119. Оп. 1. 1657 г. Д. 1. Л. 149.

${ }^{187}$ Норбо ШІ. Указ. соч. С. 76.

${ }^{188}$ История калмыщких ханов... С. 114.
}

${ }^{189}$ По мнению Ж. Артыкбаева, крупное озеро Агсагал (Аксакал), существовавшее в XVII в., сегодня на современных картах отсутствует. Он предполагает, что озеро высохло, а на его месте остался лишь солончак под названием Шалкар тениз к западу от гор Улытау (Артылбаев Ж.О. Указ. соч. C. 147-149)

${ }^{190}$ Раднабхадра. Указ. соч. С. 191. пути следования хутугты со свитой от Каракумов до Аблай-кита на Иртыше Зая-пандиту приглашали к себе и другие ойратские тайши: Убаши-хунтайджи, Дорджи, Эрке-Дайчин, Менке и другие ${ }^{191}$.

К сожалению, кроме религиозной составляющей, о целях второго приезда Зая-пандиты к волжским калмыкам ничего не известно. Но по странной случайности именно в это время происходит отход улуса Лузана к чакарцам, а захват у него Дайчином ногайского улуca, скорее всего, послужило только поводом. Зая-пандита, видимо, продолжал проводить политику консолидации ойратов, стараясь объединить все их группировки. Особенную озабоченность в этом плане вызывали, наверное, торгуты, чьи улусы оторвались далеко на запад от центров ойратского сообщества и буддийского мира.

${ }^{191}$ Норбо НI. Указ. соч. С. 76-77. 
Глава 5.

ПОЛИТИЧЕСКАЯ СИТУАЦИЯ В СЕВЕРНОМ ПРИКАСПИИ В 1655-1661 гГ.

\section{1. Русско-калмыцкие переговоры и шерти 1655,1656 и 1657 гг.}

К 1653 г. в России улучшилась экономическая ситуация, поутихли сотрясавшие страну волнения и мятежи, обновленный при молодом и энергичном царе Алексее Михайловиче состав правительства усиленно занимался подготовкой к войне с Речью Посполитой и формированием новых армий. 1 октября 1653 г. Земский собор принял решение о принятии Войска Запорожского (Гетманщины) в российское подданство. А 23 октября государь Алексей Михайлович объявил в Успенском соборе о начале войны с Речью Посполитой. Наступление трех основных русских армий в Литве должны были поддержать Б. Хмельницкий и воевода А.В. Бутурлин с полком (4000 чел.), сковав на Украине польские войска. С юга, со стороны Крымского ханства, прикрывал воевода В.Б. Шереметьев с Белгородским полком (свыше 7000 чел.) $)^{1}$. Как видим, в предстоящей войне южное направление оставалось недостаточно защищенным участком в случае крымского вторжения, как это произошло во время предыдущей Смоленской войны.

В связи с этим на повестке дня в царском правительстве встал настоятельно вопрос об окончательном урегулировании русскокалмыцких отношений. С весны 1654 г. в дипломатических кругах России активно стала обсуждаться возможность использования калмыков в борьбе против Крымского ханства. Поводом для этого послужили события на Украине. 8 января 1654 г. решение о воссоединении Украины с Россией было единогласно принято участниками Переяславской рады. Именно тогда в доверительной беседе москов-

\footnotetext{
${ }^{1}$ Малов А.B. Указ. соч. С. 15-16.
}

ского боярина В.В. Бутурлина с войсковым писарем И. Выговским была озвучена идея привлечения калмыков против Крыма. В письме от 21 марта 1654 г. Б.М. Хмельницкий сообщал боярину В.Б. Шереметьеву, что «калмыки с донскими казаками живут советно» и только ожидают царского указа, чтобы двинуться на Крым, что в походе под Терки калмыки захватили 28 мирз Большого Ногая, намеревавшихся идти на помощь полякам. Он предлагал направить калмыков степью, а донцов морем на Крым, тогда, по его мнению, татары оберегали бы свои города и не имели бы возможности прийти на помощь польскому королю Яну Казимируㄹ. Сведения о попытке Б. Хмельницкого вступить в непосредственный контакт с калмыцкими тайшами мы находим в его письме на имя царя, где он жалуется на донских казаков, задержавших на Дону его посланцев, направлявшихся к калмыкам ${ }^{3}$. Правительство указала донцам пропустить их в калмыцкие улусы, но, к сожалению, нам не известны результаты этих переговоров.

В конце 1654 г. донские казаки, в том числе и с подачи правительства, отправили к калмыкам посланцев с предложением участвовать в совместном военном походе против Крыма. Момент для этого был избран подходящий, поскольку большинство крымцев ушли в польские и литовские города, ослабив тем самым защиту своего ханства. Тайши согласились и уже на весну 1655 г. планировали совместное с казаками выступление на Крым. Правительство, всячески поощряя такие связи, предоставило калмыкам возможность вести вольную и беспошлинную торговлю в русских городах ${ }^{4}$. Мирное соглашение с калмыками давало возможность передислоцировать значительную часть стрельцов, размещенных в волжских городах на границе с восточными кочевниками, на польско-литовское направление ${ }^{5}$.

До заключения шерти 1655 г. целый год велись сложные переговоры между астраханской администрацией и тайшами. 8 января 1654 г. в Астрахань прибыли 4 татарских посланца от Мончака во главе с Тлевбердеем. Тайша предлагал заключить мирный договор при

${ }^{2}$ Санин Г.А. Отношения России и Украины с Крымским ханством в середине XVII века. М., 1987. С. 124, 125-126.

${ }^{3}$ РГАДА. Ф. 111. ОП. 1. 1654 Г. Д. 3. Л. 73

${ }^{4}$ РГАДА. Ф. 119. Оп. 1. 1655 г. Д. 2. Л. 19-20, 70-71.

${ }^{5}$ Khodarkovsky $M$. Where Two Worlds Met... P. 80. 
условии возвращения калмыцких пленных и отогнанных лошадей. Воеводы не признали наличия у них калмыцких лошадей, а мирный договор согласились заключить только при условии, если тайши пришлют к ним для переговоров более знатных представителей и вернут русский полон, к тому же сама личность калмыцкого татарина Тлевбердея не внушала им доверия. Тогда же, в январе, выходец из калмыцкого плена Степан Григорьев предупреждал администрацию, что калмыки откармливают лошадей для похода, а тайшам будто ведомо, что из Астрахани в Москву ушла большая партия стрельцов. Поэтому, принимая меры предосторожности, астраханцы дополнительно разместили 500 стрельцов по окрестным учугам в дельте Волги 6 .

12 января 1654 г. от тайшей вновь прибыл Тлевбердей, но уже с уфимцем В. Киржатцким. Требования оставались прежними, в частности, о возвращении 300 лошадей, отогнанных астраханскими татарами с калмыцких застав. Еще летом 1653 г. к Мончаку из Уфы приезжали русские и башкирские посланцы с предложением обменять полон. Мончак, собрав в улусе весь русский полон, часть его отправил в Уфу с одним из уфимских посланцев, остальных же оставил у себя в качестве заложников до возвращения калмыцкого полона7 Так Киржатцкий волею обстоятельств оказался в калмыцких улусах и принял деятельное участие в переговорном процессе с Астраханью. Перед тем как заключить договор, астраханские власти требовали от тайшей прислать к ним знатных аманатов и только в этом случае обещали заключение мира, предоставление возможности торговать и отправку своих посланцев к тайшам. 19 января в Астрахань от Мончака прибыл калмык Конкодай с тем же Киржатцким и новым предложением о мире.

Активизация калмыцкой стороны в переговорном процессе объяснялась тем, что Дайчин прислал к Мончаку 30 своих людей со строгим указанием «быть в миру» с астраханцами. 27 января в Астрахань также прибыли послы Лузана - Батур и Ургечи, которых тайша прислал с правого берега Волги, где «зверовал» уже 10 дней. Лузан тоже предлагал воеводам жить в мире и обоюдно наказывать смертной

\footnotetext{
${ }^{6}$ РГАДА. Ф. 119. Оп. 1. 1654 г. Д. 1. Л. 12-15
}

${ }^{7}$ РГАДА. Ф. 119. Оп. 1. 1654 г. Д. 1. Л. 11, 16. казнью тех, кто занимается отгонами лошадей. Но астраханская администрация приехавшим калмыцкими посланцам выдвинула те же требования, что и ранее предьявляла Тлевбердею ${ }^{8}$.

5 февраля в Астрахань из калмыцких улусов вернулись толмач А. Борисов и В. Киржатцкий вместе с калмыцкими посланцами Беркулой и Досалеем. Борисов рассказал о своей встрече с Мончаком в урочище за рекой Алгара, в двух днях пути от города. Когда он прибыл в улусы, там царила довольно напряженная обстановка. Калмыки жаловались Мончаку о захвате и грабеже под Астраханью Янмаметмирзою многих калмыцких людей, что стало основанием для недоверия тайши к русским посланцам. Мончак, не желая прекращать переговорный процесс, все-таки отправил к воеводам своих людей «для проведывания) о захваченных калмыках. Длительную задержку Борисова в улусах калмыцкие посланцы обьясняли согласованием Мончаком и Лузаном общей позиции по отношению к Астрахани. Но Лузан без предварительного возвращения астраханцами калмыцких пленных наотрез отказался заключать договор. Борисов пытался обьяснить тайшам, что в астраханской тюрьме нет калмыков, кроме двух ранее захваченных. По словам калмыцких посланцев, Лузан не желал слушать ни Мончака, ни отца его 9

Когда попытки договориться мирным путем не имели успеха, калмыцкая сторона перешла к более активным действиям. 10 февраля Мончак с войском подошел к Астрахани и остановился напротив Долгого острова, в 12 верстах от города. К тайше воеводы отправили татарина, который, прибыв обратно 13 февраля, сообщил, что Мончак предлагает мир на основе заключения шерти и требует отпустить захваченных калмыков из Астрахани и Яицкого городка. Калмыцкие отряды заняли практически все городские окрестности. Астраханские мирзы обратились к воеводам с просьбой отпустить из тюрьмы двух калмыков, и те пошли им навстречу. Но 14 февраля был отпущен только Когулда, его отправили к тайшам с татарином, который 19 февраля возвратился в Астрахань. Мончак требовал вернуть и второго калмыка, обещая после заключения мирного договора от-

${ }^{8}$ РГАДА. Ф. 119. Оп. 1. 1654 г. Д. 1. Л. 16-24.

${ }^{9}$ РГАДА. Ф. 119. Оп. 1. 1654 г. Д. 1. Л. 31-33. 
пустить весь русский полон. В этот же день от тайши прибыли двое калмыков, Шен-Темир и Элбузар, с требованием вернуть из Яицкого городка уже 4 захваченных калмыков и отогнанных лошадей, а также прислать посланцев для заключения мирного договора. Лузан тоже участвовал в этом событии, поскольку астраханские татары отогнали у него с заставы тысячу лошадей, он со своим войском находился по соседству с Мончаком ${ }^{10}$.

22 февраля калмыцких послов отпустили, а с ними к тайшам из Астрахани был направлен толмач Борисов. Лузан и Мончак находились на правом берегу Волги, в урочище Коровья Лука, на расстоянии дневного перехода от Астрахани. Борисов отправился к тайшам с прежними требованиями: возвращение ногаев, выдача калмыцких аманатов в подтверждение шерти, обмен пленными и откочевка калмыков за Яик. Толмач порекомендовал тайшам «быть под государевою рукою в подданстве и в послушанье), так как раньше «миру не бывало, опроче обману». Лузан и Мончак на это лишь ответили, «что де у них бывает договор, и послов своих они в Астрахань посылают на правде, и в том де они стоят, и идут они договариваться к Астрахани сами». В результате тайши своих посланцев к воеводам не отправили, а Борисова задержали, сломав при этом ему правую руку и заявив, «что де он к ним прислан для обману в лазутчиках, а не с правдою». Отправленный к калмыкам 25 февраля из Астрахани татарин Сеит также был задержан тайшами ${ }^{11}$.

Обстановка накалялась. Лузан и Мончак в это время отправили часть своих людей к Балчиклынскому и Вертлюжному городкам. Здесь в зимнее время обитали астраханские ногаи, и тайши под угрозой войны требовали разрешения вести с ними торговлю на правом берегу Волги. Тайши планировали отправить 5 тыс. воинов под рыбные учуги, но разведка доложила, что на морских косах слишком тонкий лед. Только после этого тайши увели свои войска обратно в улусы: Лузан отправился в свои кочевья вверх по Волге по направлению к Самаре, а Мончак - в верховья Яика, в урочище Кашаун ${ }^{12}$.

\footnotetext{
${ }^{10}$ РГАДА. Ф. 119. Оп. 1. 1654 г. Д. 1. Л. 37-44.

11 ДАИ. СПб., 1848. С. 531-533, 536-537.

12 ДАИ. СПб., 1848. С. 537.
}

Но приход калмыков в окрестности Астрахани, видимо, был всего лишь попыткой разузнать, насколько эффективно астраханская администрация контролирует обстановку в Нижнем Поволжье, чтобы затем перейти к более активным действиям на правобережье Волги. И, действительно, 27 февраля Лузан совместно с ногайским мирзой Солтанаем Аксак-Келмаметевым во главе отряда примерно в 600-700 человек направился в набег на Казыевский улус. Мончак 28 февраля тоже отправился со своими людьми к Волге, и часть из них отправил в набег на Терек и под Астрахань. 20 марта калмыцко-ногайский отряд атаковал терских ногаев в районе между Кизляром и Терским городком. Здесь они сумели захватить 440 ногаев, отогнать скот и 150 лошадей у кабардинского князя Муцала Черкасского. Из-за отсутствия лошадей преследовать калмыков князь так и не решился ${ }^{13}$.

Конфликтная ситуация у калмыков сохранялась не только на Волге, но и на Яике. В то время, когда Лузан и Мончак находились за рекой Бузан, к ним в урочище Берекете от тайши Церена Чоктуева, кочевавшего со своим улусом возле Яицкого городка, прибыли двое тайшей в сопровождении 30 человек. Они сообщили о захвате в плен яицкими казаками тайши Кайкулака с сыном и зятем. Лузан и Мончак отдали им задержанного Борисова с расчетом обменять его на тех пленных, но стрелецкий голова Яицкого городка Т. Селезнев отказался совершить обмен, не имея на то государева указа ${ }^{14}$.

Как выяснилось позже, Кайкулак со своими людьми 1 февраля прибыл к Яицкому городку. Здесь калмыки в ходе торговли что-то не поделили с местными казаками и «служилым людем учали чинить дурно», в частности, тот же Кайкулак «наезжал бить плетьми, и ружье и товары отымать, и борошни от поясов обрывать и обрезывать». Стрелецкий голова срочно отправил туда команду стрельцов под командой В. Колзакова, которые и схватили тайшу Кайкулака, а также его сына Михулу, зятя Здария Шадаева и трех улусных людей. Официально захват в плен тайшей обьяснялся тем, что Кайкулак не вернул русской стороне пленных стрельцов, за которых уже был отдан выкуп ${ }^{15}$.

\footnotetext{
${ }^{13}$ РГАДА. Ф. 119. Оп. 1. 1654 г. Д. 1. Л. 55, 58, 61.

${ }^{14}$ РГАДА. Ф. 119. ОП. 1. 1655 г. Д. 2. Л. 27; ДАИ. СПб., 1848. С. 534, 537.

${ }^{15}$ РГАДА. Ф. 119. Оп. 1. 1654 г. Д. 1. Л. 35.
} 
Это был тот редкий случай, когда русским удалось захватить в плен калмыцких тайшей. Позже Кайкулак пытался договориться с Селезневым, за свою свободу предлагая ему содействие в том, что Мончак и Нима-Церен отдадут всех русских пленных, захваченное оружие и лошадей. В крайнем случае, он обещал отдать лично Селезневу всех своих лошадей. В это время улусные люди Кайкулака окружили Яицкий городок, полностью блокировав его с суши. Астрахань срочно отправила в помощь туда стрелецкий отряд с запасами свинца и пороха, но калмыки сумели по дороге его перехватить, взяв в плен трех стрельцов и захватив 5 пудов свинца. Другой отряд из сотни стрельцов под командой Т. Ерофьева был также атакован калмыками, но уже под самим городком. В результате сотник и 59 стрельцов были убиты, 13 ранены, а все оружие досталось калмыкам. Вышедшие из городка на помощь им стрельцы спасли своих раненых сослуживцев. Калмыки, также потеряв часть своих людей, смогли взять в плен только четырех конных стрельцов. Вокруг Яицкого городка повсюду стояли калмыцкие заставы ${ }^{16}$.

В мае из осажденного калмыками городка Селезнев сумел передать в Астрахань, что Кайкулак 1 апреля умер от неизвестной болезни, а его сын и зять больны. 23 мая 1654 г. из Москвы пришел особый указ о переводе захваченных калмыцких тайшей из Яицкого городка в Астрахань, на Аманатный двор, с целью дальнейшего их обмена на государевых людей. Пленных калмыков удалось перевезти в Астрахань под усиленной охраной на судне по морю ${ }^{17}$. Дальнейшая судьба этих людей в русских документах не прослеживается.

После несостоявшегося обмена Борисова перевезли в улус Мончака, а затем передали на поруки едисанскому мирзе С. Аб̆дулову. Здесь астраханец смог получить от ногаев много интересной информации о положении дел в калмыцких улусах. В начале 1654 г. около 500 башкир совершили набег на калмыцкие кочевья, в результате которого наибольший ущерб был нанесен ногайскому улусу мирзы Каспулата Мамаева: 20 человек погибли, около 200 попали в плен. Примерно 2 тыс. калмыков и ногаев бросились за башкирами в пого-

${ }^{16}$ РГАДА. Ф. 119. Оп. 1. 1654 г. Д. 1. Л. 36, 56-57, 59.

${ }^{17}$ РГАДА. Ф. 127. ОП. 1. 1654 г. Д. 1. Л. 19; ДАИ. СПб., 1848. С. 532-533. ню, дважды они вступали в бой, но в результате смогли отбить только 20 человек. Позже Борисов рассказывал в администрации, что «над калмыцкими людьми и над татары башкиры поиск чинят почасту» ${ }^{18}$. Действия башкир вызвали ответные набеги калмыцких ногаев на Уфимский уезд. Так, осенью 1653 г. сотня едисан совершила набег на Уфимский уезд и привела в улусы русский полон из 150 человек, который в дальнейшем был продан в Хиву. По наблюдениям Борисова, в набегах в основном участвовали ногаи, «а калмыцкие люди с ними не ходят, а татар не унимают» ${ }^{19}$.

В доверительной беседе едисанский мирза С. Абдулов поделился с Борисовым, что калмыки на зиму 1654/55 года планируют военный поход. При этом мирза через Борисова советовал астраханским воеводам, как можно скорее оттеснить калмыков на дальние рубежи. В частности, он предлагал построить 4 крепости на важных и ключевых участках: первую - по Яику в Индерских горах; вторую - в Яблонном урочище, «где их татарский молебщик лежит»; третью - на реке Ахтубе, в урочище Укреме, где калмыки постоянно переходят Волгу; и четвертую - на реке Илек за Яиком, в которую можно было бы поселить уфимских людей и башкир. Тогда, по мнению мирзы, «калмыцкие люди вдали от Астрахани и будут». С. Абдулов также просил передать воеводам, что он желает отойти со своим улусом от калмыков и кочевать где-нибудь под Астраханью, но этому мешает находившаяся в урочище Тепкире (в двух днях пути от города) калмыцкая застава под командованием Дурал-дархана. Едисанские улусы кочевали врозь в 3-4 днях пути от Астрахани, при этом астраханские татары постоянно приезжали в калмыцкие улусы с последними новостями о положении дел в городе ${ }^{2 n}$.

В марте 1654 г. астраханский татарин Исенегеп сообщал в администрации, что в улусе Мончака слышал о намечавшемся приезде весной Дайчина с джунгарским хунтайджи и большим войском, правда, неизвестно с какой целью ${ }^{21}$ В 1654 г. Дайчин, правда, без

18 ДАИ. СПб., 1848. С. 538.

19 ДАИ. СПб., 1848. С. 538.

20 ДАИ. СПб., 1848. С. 538-539.

${ }^{21}$ РГАДА. Ф. 119. Оп. 1. 1654 г. Д. 1. Л. 54; Златкин И.Я. История... C. 133. 
хунтайджи, действительно вернулся из Джунгарии в родные кочевья, находившиеся за Яиком в Индерских горах ${ }^{22}$.

С возвращением калмыцкого предводителя переговорный процесс калмыков с астраханской администрацией сразу же возобновился. 1 декабря 1654 г. в Астрахань вернулись Борисов, татарин Сеит Мамбеткулов и стрелец Ф. Дунайка. С ними приехали отправленные Дайчином и Мончаком «калмыцкие природные люди» - Сартугар, Ангай и Басу. Тайши снова предлагали астраханцам заключение мира и обмен пленными. Ухудшение русско-калмыцких отношений, по мнению калмыцких посланцев, было вызвано временным отьездом их предводителя: «как он, Дайчин тайша, кочевал в улусех своих, и при нем де государевым людем нигде от них калмыцких людей дурна никакого и задору не бывало, а как де он, Дайчин тайша, из улусов своих ездил по своей вере к молбищу молиться, и без него де твоим государевым людем под Астраханью и под иными твоими государевыми городами, и на промыслах от калмыцких их людей и от татар дурно всякое было, а на всякое де дурно их калмыцких людей наводят татаровя, которые с ними калмыцкими людьми вместе кочюют». Теперь Дайчин обещал астраханцам, что впредь с калмыцкой стороны «никакого дурна не будет». Тайша сознательно не включил в состав посольства ногайских представителей, так как, по его мнению, «от татар всякая ссора чинится). Дайчин через своих людей передал воеводам, что готов дать шерть, обменять пленных и вернуть захваченное в бою оружие. 10 декабря калмыцкие посланцы вместе с Сеитом Мамбеткуловым были отпущены из Астрахани в улусы к Дайчину 23 .

В течение января 1655 г. стороны еще несколько раз обменялись посланцами, и в ходе этого процесса астраханские воеводы неоднократно требовали от тайшей аманатов, шерти и обмена пленными, обещая взамен предоставить возможность торговать под Астраханью и возвратить «кости» Хо-Урлюка. Если на обмен пленными Дайчин еще соглашался, то первые два требования он решительно отверг. Лично шертовать Дайчин отказывался, впоследствии его представитель Дурал-дархан обьяснял это тем, что тайша, будучи на богомо-

22 ДАИ. СПб., 1848. С. 538.

${ }^{23}$ РГАДА. Ф. 119. ОП. 1. 1655 г. Д. 1. Л. 14; ДАИ. СПб., 1848. С. 533-534; Преображенская П.С. Из истории... С. 62-63. лье в Тибете, дал обет, что ни он, ни его дети, ни при каких обстоятельствах шертовать не будут. Конечно, такая позиция не устраивала царских представителей и внушала еще больше недоверия к калмыкам. Но в условиях, когда Москва требовала решительных шагов в нормализации русско-калмыцких отношений, астраханские воеводы были вынуждены пойти на определенные уступки и согласиться с тем, что шерть дадут доверенные люди Дайчина - Дурал-дархан, у которого тайша «на руках вскормлен», его сын Чокула и тайша Церен Чоктуев ${ }^{24}$.

Но уступки в данной ситуации предполагались отнюдь не в одностороннем порядке. Дайчину также пришлось в определенной степени изменить своим принципам. Форма клятвы, по сведениям астраханского воеводы И.П. Пронского, у калмыков была наиболее уважаемой. Поэтому накануне принятия шерти астраханских воевод интересовал вопрос процедуры клятвенного обряда у калмыков. Калмыцкая культура (с элементами буддийской), в отличие от относительно известной им мусульманской, была совершенно неизвестна русским людям. Поэтому воеводы расспросили у астраханских мирз, ранее живших у калмыков, «какая в калмыцкой вере прямая и крепкая шерть». Ответ их был довольно любопытным: калмыки «веруют и поклоняютца куклам, а по их калмыцкие - бурхан, да книги и чотки, что они на шеях у себя носят, а по их калмыцкие - бичик; и будет де тое шерти они учинят, то де их прямая шерть и тому де и верить мочно». По требованию воевод Дайчин после долгих препирательств всетаки согласился привезти (бурхана» к месту предполагаемой встречи русских и калмыцких представителей ${ }^{25}$.

В подтверждение договоренности уже 3 февраля 1655 г. Дайчин прислал в Астрахань 5 русских пленников, а взамен от воевод получил 10 калмыцких. Так начался активный процесс обмена полоном, и стороны от угроз и ультиматумов перешли к конкретным действиям. Дайчин предложил отныне строить русско-калмыцкие отношения с «чистого листа): (и что де в прежних летах к твоим государевым людем от их калмыцких людей было утесненье, и на нем бы де впредь

${ }^{24}$ Преображенская П.С. Из истории... С. 62-63.

${ }_{25}^{25}$ РГАДА. Ф. 119. Оп. 1. 1655 г. Д. 1. Л. 63-65; Преображенская П.С. Из истории... С. 62. 
того не спрашивать, а он де своих прежних и улусных людей всяких обид и убытков спрашивать не станет» ${ }^{26}$.

Калмыцкие представители - тайша Церен Чоктуев, Дурал-дархан и его сын Чокула в сопровождении 200 человек - 4 февраля 1655 г. прибыли на заранее оговоренное место - у протоки Балчиклы. Русскую сторону на съезде представляли прибывшие из Астрахани Я. Ушаков, К. Козлов, подьячие, толмачи и стрелецкий голова ${ }^{27}$. С coбой русские представители привезли заранее подготовленный текст «шертной записи», на которой посланцы тайшей должны были расписаться. В ходе последовавших переговоров стороны обсудили и уточнили отдельные моменты, что также нашло отражение в шерти ${ }^{28}$. Текст шерти, впервые опубликованный в Полном собрании законов Российской империи в 1830 г., приводится ниже.

Яз Дурал Тархан, Яз Серень Таииа, яз Чокула, иертуем Великому Государю, Царю и Великому Князю Алексею Михайловичу, всея Великия и Малья России Самодержсиу, и многих Государсть Государю и Обладателю, и его Государеву сыну Государю Царевичу Князю Алексею Алексеевичу, и иным его Государским детям, которых впредь ему Государю Бог даст, за Дайчина Тайцу, и за Лаузана Таииу, и за Санжсина Тайшу, и за Мончака, и за Мамсреня Тайшей, и за братью их и за детей и за племянников, и за всех улусных людей, по их Дайчинову и Мончакову веленью, иертуем на том, что Дайчину и Лаузану и Санжсиу и Мончаку Таимам, с детьми своими, и с братьею, и с племянники, и нам всем их улусным людям быть у Великаго Государя Царя и Великаго Князя Алексея Михайловича, всея Великая и Малья России Самодержиа в вечном послуианьи, и добра ему Великому Государю и его Государевым людям хотети, во всем в правду безо всякия хитрости, и с его Государевыми непослуиники и с изменники, ни с кем ни о чем не ссылатись и за них не стояти, и Государевых Русских людей и вечных холопей Нагайских и Едисанских и Юртовских Татар в улусах и на проездех, и на промыслех нигде не побивать и в полон не имать, и не грабить, и от прежних от всех своих неправд отстать, и Государеве отчине к Астарахани и на иные Государевы Украйные

${ }^{26}$ РГАДА. Ф. 119. Оп. 1. 1655 г. Д. 1. Л. 37, 51.

${ }^{27}$ РГАДА. Ф. 119. Оп. 1. 1655 г. Д. 1. Л. 81-82.

${ }^{28}$ Преображенская П.С. Из истории... С. 64. городы и на уезды на Государевых людей, которые бывают в посылках и на промыслех и в проездех, и на Нагайские и на Юртовские улусы, и на конские и животинные стада, войною Дайчину, и Лаузану, и Санжину, и Мончаку, и Мамсреню самим Таимам не приходить, $и$ братьи своей, и детей, и племяников и улусных людей, и Государевых изменников Мурз и Татар не посылать, и Государевых городов, и сел, и деревень и учугов не жечь, илюдей не побивать, и в полон не имать, и не грабить, и ни какаго зла не делать и не мыслить, по сей иерти и утвержденью. А где Государь укажет быть наиим Калмыиким Таииам и нам улусным людям на своей Государеве службе, с своими Государевыми ратными людьми вместе: и Таймам нашим и нам с Государевыми изменники и с непослуиники битись до смерти, нещадл голов своих, а Великому Государю Царю и Великому Князю Алексию Михаиловичу, всея Великия и Малья России Самодержуу, его Царскому Величеству не изменить, его Государевых людей не подать, и хитрости над ними никакия не чинить. А Государевых людей Русской и Татарской и Черкаской полон и их животы, которых в проильхх годех и в нынеинем во 163 году взяли мы Калмыцкие люди и изменники Нагайские и Едисанские и Енбулуцкие Татарове, под Астараханью и под Темнякам и под иными Государевыми городами, собрав всех отдать в Государеву отчину в Астарахань; и Государевых изменников, Нагайских и Едисанских и Енбулуиких мурз и татар, которые в проилльх годех изменя Государю, из под его Государевы отчины из под Астарахани отошли к Ташиам нашим в Калмылькие улусы, которые из них похотят собою идти в Астарахань, и Таииам наиим и нам улусным людям в неволю их у себя не держать и не грабить, и отпущать их в Астарахань совсем, безо всякаго задержанья, и впредь к себе в улусы Государевых вечных холопей Нагайских и Едисанских и Юртовских мурз и татар от Государевы отчины от Астарахани, и от иных его Государевых городов не призывать; а будет кто собою придет, и их не принимать, и отсылать их в Астарахань, и Государевых людей Русскихъ и Татар и Черкас полоняников, прислати им Таииам из улусов своих всех в Астарахань. А которых посыльщиков, по Государеву указу, из Государевы отчины из Астарахани посылають, и впредь из Астарахани и из иных Государевых городов Бояре $и$ Воеводы учнут присылать, для Государевых всяких дел в Калмыцкие 
улусы, к ним Дайчину Тайце, ик Лаузану, и к Санжсну, ик Мончаку Таишам, ик их детям, ик братье, ик племяиникам, ик улуснылм людям: и Дайчину Тайше, и детям его, и братье, я племяиникам, и улусным людям, тем присыльщикам безчестья ни какаго не делать, $и$ не бить их и не грабить, и тесноты им у себя не чинить, и отпуиать их безо всякаго задержания».

Яз Дурал Тархан, язъ Серень Тайша, язъ Чокула, шертуем Великому Государю, Царю и Великому Князю Алексию Михайловичу, всея Великия и Малья России Самодержиу, и многих Государств Государю и Обладателю, Его Царскому Величеству, и сыну Его Государеву, Государто Царевичу, Князю Алексию Алексеевичу, и иным Его Государевым детям, которых Ему Государю впредь Бог даст, за Дайчина и за Лаузана и за Санжина и за Мончака и за Мамсреня Таймей, и за братью их и детей и племянников, и за себл, и за всех улусных людей на том на всем, как в сей иертовальной записи написано. А будет Тайщи наши и мы улусные люди не учнемь так делать, как в сей иертовальной записи написано, и иерть свою и утвержденье чем наруиим: ина Тапиах наших, и на нас, Дурал Тархане, и на Серень Тайше, и на Чокулае, и на всех улусных людех, буди Божий гнев и огненный меч, и будем мы прокляты в сем веце и в будуцем ${ }^{29}$.

Калмыки в присутствии русских представителей провели клятвенный обряд: «бурхан свой и книги и чотки, что на шеях у себя носят, положа на шапки свои, подымали на головы свои, и, прикладываясь, целовали и поклонялись по своей вере и шертной записи». Затем тайша Церен приказал одному из сопровождающих его лиц по имени Батур «в шертной записи вместо их руки приложить калмыцким письмом». При отъезде калмыцких представителей астраханцы Церену Чоктуеву, Дурал-дархану и Чокуле подарили по 4 аршина английского красного сукна, а Батуру и Тлевбердею - по 3 аршина литовского сукна. По 4 аршина английского сукна в качестве жалованья было отправлено Дайчину, Мончаку и Манжи-Ялбо ${ }^{30}$. По прось-

${ }^{29}$ РГАДА. Ф. 119. Оп. 1. 1655 г. Д. 1. Л. 76-80; Полное собрание законов Российской империи, повелением Государя Императора Николая Павловича составленное (далее - ПСЗРИ). Собрание Первое. Т. 1. С 1649 по 1675. СПб., 1830. С. 356-357.

${ }^{30}$ РГАДА. Ф. 119. Оп. 1. 1655 г. Д. 1. Л. 66-68. бе Дайчина ему было также передано 5 ведер вина. Всех калмыков, присутствовавших при подписании шерти, русские щедро угостили вином и медом. Стоимость подарков была весьма скромной и составляла всего 24 рубля 30 копеек ${ }^{31}$.

По мнению П.С. Преображенской, самым ранним письменным текстом шерти, из дошедших до нас, является шерть от 1655 г., а до этого времени записей калмыцкой шерти, собственно, не было ${ }^{32}$. Однако с подобным утверждением нельзя согласиться. Подробное изучение русских документов первой половины XVII в. показывает, что имеются и более ранние письменные тексты шертей, например, шерть от 12 сентября 1631 г., которую дал Хар-Мерген за Хо-Урлюка, Дайчина и других торгутских тайшей, а также 2 шерти (февральская и апрельская) от 1649 г. Единственным их отличием от шерти 1655 г. является то, что они не имели большого политического значения в русско-калмыцких отношениях, которые могли бы кардинально повлиять на положение калмыков в Северном Прикаспии.

Письменная шерть 1655 г. походила больше на присягу в верности калмыков своим обязательствам по отношению к русской стороне. В документе не оговаривались сроки его действия, а Москва со своей стороны не требовала аманатов и ясака. Документ, подписанный под Астраханью калмыцкими представителями, в сущности, был соглашением между союзниками о мире и военном сотрудничестве. Именно так калмыцкая сторона рассматривала это соглашение, ожидая получения определенных обязательств от другой стороны ${ }^{33}$. Также шерть 1655 г. не проливает свет и на решение территориального вопроса. Фактическое пребывание калмыков на левобережье Волги де-юре не было закреплено в шерти. Формально теперь калмыцкие улусы могли не опасаться карательных действий со стороны царских войск за нахождение на данной территории. Большое значение имело предоставление калмыкам возможности относительно безопасно торговать в поволжских городах. Торговля выступала своего рода орудием в руках правительства для достижения политического соглашения

${ }^{31}$ Преображенская П.С. Из истории... С. 64

${ }^{32}$ Преображенская П.С. Из истории... С. 61.

${ }^{33}$ Khodarkovsky M. Where Two Worlds Met... P. 90-91; Преображенская II.С. Из истории... С. 61. 
с тайшами. Калмыцкой стороне пришлось отказаться от языка военных угроз, чтобы обеспечить прочные торговые связи с русскими городами. В любом случае шерть 1655 г. имела для калмыков положительное значение, в первую очередь, как серьезное основание для решения в дальнейшем территориального вопроса, а также вопросов безопасности и торговли. Именно с этого времени отмечается потепление русско-калмыцких отношений, которое, в первую очередь, было связано с началом русско-польской войны.

Но заключение соглашения требовало и конкретных шагов, подкрепленных материальным стимулированием. Для этой цели уже в феврале 1655 г. из Москвы с жалованьем были отправлены: к Дайчину - 3. Волков, а к Лузану - И. Горохов. Им предписывалось склонить тайшей к совместному военному выступлению на Крым и участию в польской кампании. Но дорогой послы были отозваны обратно ${ }^{34}$. Основанием для этого стало получение царской ставкой под Смоленском отписки астраханского воеводы И.П. Пронского, сообщавшего уже о заключенной калмыками шерти под Астраханью. Правительство строго запретило своим подданным нападать на калмыцкие кочевья, фактически признав право калмыков кочевать по берегам Волги. В царской грамоте от 6 апреля 1655 г. на имя Г.С. Куракина, заведовавшего делами в Москве, прямо указывалось: предоставить тайшам кочевья на левобережье Волги, по рекам Ахтубе и Белой, или «под городами, где они (калмыки. - B.T.) кочевать похотят». Отныне местные воеводы должны были всячески защищать калмыков от внешних угроз. В противном случае, «если же воевода... такое воровство сам учинит... или кого пощадит... и ему самому потому ж быть казнену, а бояром нашим за то быть в опале и разоренье ${ }^{35}$. Подобные распоряжения были отправлены в Астрахань, Самару, Саратов, Царицын, Черный Яр, а уфимскому воеводе А. Грановскому, например, прямо указывалось наказывать смертной казнью через повешение тех русских людей и башкир, кто в нарушенье начнет с калмыками ссориться $^{36}$. Как видим, только с выходом в свет царского указа от

${ }^{34}$ РГАДА. Ф. 119. Оп. 1. 1655 г. Д. 2. Л. 1; Преображенская П.С. Из истории... С. 65.

${ }^{35}$ Санин Г.А. Указ. соч. С. 126.

${ }^{36}$ Преображенская П.С. Из истории... С. 58.
6 апреля 1655 г. уже «де-юре» положительно решается вопрос пребывания калмыков на левобережье Волги, начиная от Астрахани и до Самары.

Донские казаки совместно с запорожцами с 4 февраля по 17 сентября 1655 г. совершили морской поход на крымские владения. Еще до возвращения казаков в Черкасск, в июле к Дайчину и Лузану от атаманов были отправлены новые посланцы с повторным предложением о совместном выступлении на Крым и ногайские улусы ${ }^{37}$. Подробности это поездки нам становятся известны из сообщения в Москве станичного атамана П. Шевырева - одного из непосредственных участников этой поездки. Дорога в калмыцкие улусы у них заняла 9 недель, а остановились они в улусе Дайчина, к которому затем прибыли Лузан и Сюнкей. Тайши еще раз заверили, что готовы по царскому указу идти на Крым, как только Волга покроется льдом, но самостоятельно, без поддержки казаков. Донским представителям тайши выразили прямое недоверие: «чают тово, что они призывают их обманом, а хотят, вызвав их, и сложась с крымским ханом, побить» ${ }^{38}$.

Крымский хан был в курсе о заключении русско-калмыцкого соглашения: эту информацию он получил от пленного казака, захваченного под Азовом. По сообщению пленных крымцев, летом этого года хан отказался от отправки военной помощи полякам, так как ждал совместного выступления против него казаков и калмыков ${ }^{39}$. Однако, по вышеизложенным причинам военные действия калмыков не носили совместный с казаками характер. Примерно в конце ноября - начале декабря 1655 г. калмыки под началом Лузана начали переправляться на правый берег Волги, весьма встревожив этим крымско-татарские дозоры на границе. Дон переходили в районе Раздорского городка, не заходя в само Войско и не вступая в контакт с атаманами ${ }^{40}$.

Из донесений волуйского воеводы Ф. Зарубина известно, что в начале 1656 г. калмыцкий отряд в 1,5 тыс. человек за Молочными Водами под Крымом овладел улусом Армамет-мирзы, захватив свыше тысячи человек и около 15 тыс. лошадей. Позже, 17 февраля, этим же

${ }^{37}$ РГАДА. Ф. 111. Оп. 1. 1655 г. Д. 5. Л. 8.

${ }^{38}$ РГАДА. Ф. 111. Оп. 1. 1656 г. Д. 1. Л. 6, 7.

${ }^{39}$ РГАДА. Ф. 111. Оп. 1. 1655 г. Д. 5. Л. 14, 16

${ }^{40}$ РГАДА. Ф. 111. Оп. 1. 1656 г. Д. 1. Л. 4, 7. 
маршрутом на Крым двинулся другой калмыцкий отряд в 500 человек. На этот раз удар был нанесен уже по татарским улусам на азовском взморье, южнее крепости Азов. В этот же день 4 тыс. азовских татар совершили ответное нападение на Черкасский городок, видимо, с целью предотвратить объединение калмыков и казаков ${ }^{41}$. Отсюда можно сделать вывод, что военная служба калмыков России началась именно с 1656 г., хотя первоначально она не включала в себя совместные с русской армией действия.

В 1655 г. воеводой в Астрахани был назначен боярин В. Г. Ромодановский, который продолжил переговорный процесс с тайшами с целью подписания ими новой шерти. Можно предположить, что в Москве не совсем были удовлетворены результатами работы команды предыдущего воеводы И. Пронского и заключенной с калмыками шерти 1655 г., поскольку в течение всего этого года калмыки так и не выставили значительные свои силы против крымских татар. Это обстоятельство, видимо, и повлекло за собой полную смену руководства Астрахани, отвечавшего за калмыцкое направление во внешней политике Москвы. Воеводе Ромодановскому и его команде ${ }^{42}$ ставилась задача - заключить новое русско-калмыцкое соглашение.

В марте 1656 г. при дьяке И. Горохове калмыцкие посланцы шертовали за Дайчина, Лузана, Мончака, Нима-Церена и Санжина. П.С. Преображенская, изучив сохранившиеся фрагменты текста шерти 1656 г., пришла к выводу, что в основном она соответствует предыдущей шерти 1655 г. Известно, что по ее заключении Дайчину, двум его сыновьям и 55 улусным людям было выдано жалованье, о чем свидетельствуют сохранившиеся росписи «шертовавших) лиц и размеры выданного им жалованья ${ }^{43}$.

Судя по русским источникам, после взятия на себя определенных политических обязательств в 1655 и 1656 гг. калмыки так и не приняли должного участия в военной кампании России против Крыма и Речи Посполитой. Причиной этому могли стать продолжающиеся

${ }^{41}$ Санин Г.А. Указ. соч. С. 126-127.

${ }^{42}$ В ее состав входили Иван Никитич Колтовский (до 1656 г.), стольник кн. Иван Семенович Гагарин (1656-1657 гг.), дьяки Иван Горохов и Исай Нефедьев.

${ }^{43}$ Преображенская П.С. Из истории... С. 65. совместные набеги башкир и саратовцев на пограничные калмыцкие улусы $^{44}$. Но основанием для возобновления новых русско-калмыцких переговоров послужили известия о прибытии в калмыцкие улусы персидских и крымских послов с письменными посланиями от своих правителей. Например, осенью 1656 г. из Крыма к тайшам прибыли четверо послов ${ }^{45}$.

Но более всего царское правительство было обеспокоено сведениями о калмыцко-крымских переговорах. Так, в начале мае 1656 г. русские посланники в Крыму узнали о приезде к хану калмыцкого представительства из 30 человек, пригнавших на продажу 6 тыс. лошадей. Вглубь полуострова пропустили только трех человек - двух послов и толмача, остальных людей крымцы оставили за Перекопом. Калмыков расположили на постой недалеко от Бахчисарая, в деревне Бунганак, что находилась в 5 верстах от русского посольского стана. Толмач И. Свиридов с татарским переводчиком сразу же вошли с ними в контакт и узнали о цели их приезда. Как оказалось, калмыцкие послы прибыли к крымскому хану от некоего тайши, по их словам, «потому, что николи в Крым, от их, калмыков, послов не бывало». В подарок хану и его приближенным людям они пригнали тысячу лошадей, что подтверждало, со слов русских посланников, уже устоявшееся мнение: «в Крыму без прибыли слов не бывает». Но крымский хан не спешил их принимать, в это время он готовился к походу против волохов и мадьяр. Принять калмыков он собирался уже после похода, так как относительно них у него имелись большие подозрения: «опасаетца их, калмыков, впрямь ли они пришли пословать или дороги проведывать в Крым». Однако послы уже в июне покинули территорию ханства ${ }^{46}$.

Под личностью неизвестного калмыцкого владельца, от которого и приехали послы, возможно, скрывался некий тайша Бисурман, чье имя больше не упоминается в русских документах. Известно, что осенью 1656 г. именно этот тайша вместе с четырьмя крымскими послами возвращается из Крыма в калмыцкие улусы. Причем, как передают очевидцы, ездил он туда молиться («по своей вере» ${ }^{47}$. Москва

${ }^{44}$ РГАДА. Ф. 119. Оп. 1. 1657 г. Д. 1. Л. 147

${ }^{45}$ РГАДА. Ф. 119. Оп. 1. 1657 Г. Д. 1. Л. 141, 143, 152, 153

${ }^{46}$ РГАДА. Ф. 123. ОП. 1. 1656 г. Д. 11. Л. 86, 87, 93, 94, 115.

${ }^{47}$ РГАДА. Ф. 119. Оп. 1. 1657 г. Д. 1. Л. 153. 
требовала от тайшей прекратить все сношения с Крымом и извещать ее о калмыцко-крымской переписке.

В ходе переговоров по подготовке подписания шерти воевода Ромодановский предъявил тайшам два главных требования: выдача аманатов в Астрахань и принесение шерти лично тайшами. В этом случае калмыкам были обещаны безопасность кочевий и свободная торговля. Ромодановский делал упор на те условия договора, которых так и не удалось добиться от калмыков прежним астраханским воеводам. В подобной ситуации, когда одна жесткая позиция наталкивается на другую, большую роль играет посредническая деятельность лиц, способных сгладить острые противоречия договаривающихся сторон. В данном переговорном процессе в роли посредника выступил едисанский мирза Сююнча Абдулов, пользовавшийся доверием Дайчина. Именно он по просьбе Ромодановского «наговорил) приближенным людям Дайчина оказать давление на тайшу, чтобы тот согласился с требованиями воеводы. После достаточно сложных предварительных обсуждений тайши согласились дать шерть на условиях, выдвинутых Ромодановским. При этом о своем окончательном согласии дать аманатов Дайчин обьявил через посланца в Астрахани буквально за день до шертования, т.е. 29 марта. Все это стало результатом настойчивости, проявленного воеводой. 30 марта в устье реки Кутум под Астраханью состоялся русско-калмыцкий съезд. С астраханской стороны приняли участие стрелецкий голова А. Дернов и участвовавший в подготовительной работе татарин Эшей Кашкарин. С калмыцкой стороны прибыли в сопровождении 1,5 тыс. человек тайши Мончак и Манжи-Ялббо, лично подписавшиеся под шертью ${ }^{48}$.

При сравнении текста шерти ${ }^{49}$ с предыдущими устными и письменными шертями обнаруживается несколько существенных отличий. Во-первых, в отличие от предыдущих договоренностей, например, от шерти 1655 г., где имела место не совсем определенная формулировка отношений «быть в вечном послушании», базировавшаяся на принципах вассалитета, новая шертная запись конкретно определила «быть в вечном подданстве и послушании».

${ }^{48}$ РГАДА. Ф. 119. Оп. 1. 1657 г. Д. 2. Л. 28; Преображенская 1960: 66-67.

${ }^{49}$ РГАДА. Ф. 119. Оп. 1. 1657 г. Д. 1. Л. 12-18.
Во-вторых, новым пунктом стало обязательство предоставлять аманатов из числа родственников, ближайших к правящей семье Дайчина и Мончака.

В-третьих, впервые калмыки обязывались не иметь никаких отношений с враждебными России государствами - Османской империей и Крымским ханством. Последнее обязательство, как считает П.С. Преображенская, нельзя рассматривать как попытку правительства ограничить свободу внешних сношений калмыков ${ }^{50}$. Договор только фиксировал принцип: «враг моего союзника - мой враг», и это никак не распространялось на другие государства, находившиеся в мирных отношениях с Россией и калмыками.

Вместе с тем, как свидетельствуют русские документы, в калмыцкие улусы все же продолжали беспрепятственно приезжать многочисленные крымские посольства, что не мешало тайшам оставаться верными русско-калмыцким договоренностям.

Содержание русско-калмыцких переговоров, предшествовавших подписанию шерти 1657 г., свидетельствует о том, что калмыки эту присягу рассматривали как соглашение между двумя военными союзниками ${ }^{51}$. В.В. Трепавлов приходит к выводу о том, что подобный вид документа можно рассматривать и как форму межгосударственных, а не внутригосударственных отношений, на период действия которого младший партнер как бы переходил под покровительство российского монарха, но не включался в число его подданных ${ }^{52}$

В качестве аманата Мончак и Манжи-Ялбо отправили тайшу Кулачи, а с ним и двух его родственников «кереитского родства» Булата Когуржанова и Эргеля Мубулова. В Астрахань их привезли А. Чернов и толмач П. Иванов, с которыми тайши также передали пленных. Калмыцким аманатам была устроена торжественная встреча, вдоль их шествия стояли служилые люди, и все было устроено «по посольскому обычаю». Воеводы поселили калмыков не на Аманатном дворе, где содержались другие мирзы-заложники, а в отдель-

${ }^{50}$ Преображсенская П.С. Указ. соч. С. 69.

${ }^{51}$ Khodarkovsky $M$. Where Two Worlds Met... P. 92.

${ }_{52}$ Tрепаелов B.B. «Белый царь»: образ монарха и представление о подданстве у народов России XV-XVIII вв. М., 2007. С. 137. 
ном дворе, тем самым, подчеркивая особенность данного события ${ }^{53}$. 1 апреля Кулачи был принят астраханскими воеводами в Приказной палате. Астраханцы расспросили тайшу о его здоровье, а затем привели его к шерти. В знак особого к нему расположения воеводы угостили Кулачи и его людей медом, вином, подарили однорядки и шапки. По сравнению с другими аманатами калмыков обеспечили питанием «с прибавкой». Приехавших в Астрахань калмыцких послов затем отправили в Москву ${ }^{54}$.

Калмыцкой стороне были переданы удерживавшийся в Астрахани калмыцкий ясырь и жалованье для тайшей. Дайчину отправили соболью шубу, украшенную серебром и жемчугами стоимостью 60 руб., а таюже меховую шапку из горностая (20 руб.). Мончаку достались соболья шуба (55 руб.) и шапка (21 руб.). Московские власти перешли к более весомому размеру материального стимулирования калмыков. Как известно, после подписания шерти 1655 г. тайши получили весьма скромные по стоимости подарки. Двумя годами позже правительство поняло, что подарки и жалованье тайшам должны ничуть не меньше соответствовать подаркам, которые они получают из Крыма. Теперь калмыцкие тайши стали получать ежегодное жалованье в размере 810 рублей ${ }^{5}$. В марте этого же года в районе Красного Яра по просьбе Дайчина дали шерть его родственники и приближенные люди ${ }^{56}$.

Дайчин остался доволен заключенным соглашением и отправил в Москву своих послов - Кучюка Нарушаева, Элакая Эшбердеева и ногайца Бекбаши (представителя С. Абдулова). 16 июня калмыцкие послы прибыли в Москву. 23 июня они были приняты царем. Дайчин через послов сообщил царю о шерти, заключенной его сыном и внуком под Астраханью, и на этом основании просил разрешения для калмыцких улусов кочевать летом по берегам Волги и предоставить возможность свободной торговли в приволжских городах. Тайши выразили готовность совместно участвовать с русскими в войне против Крыма ${ }^{57}$.

${ }^{53}$ РГАДА. Ф. 119. Оп. 1. 1657 г. Д. 1. Л. 5-7, 20; Очерки... С. 118

${ }^{54}$ РГАДА. Ф. 119. Оп. 1. 1657 г. Д. 1. Л. 9-10.

${ }^{55}$ РГАДА. Ф. 119. Оп. 1. 1657 г. Д. 1. Л. 7, 8, 21.

${ }^{56}$ РГАДА. Ф. 119. Оп. 1. 1657 г. Д. 1. Л. 90, 94.

${ }^{57}$ РГАДА. Ф. 119. Оп. 1. 1657 г. Д. 2. Л. 13, 42-44, 61, 103.
В июле 1657 г. состоялось заседание Боярской Думы, на котором обсуждался вопрос о принятии калмыцкими тайшами новой шерти ${ }^{58}$. Послам в Москве оказали радушный прием, и этим же летом по царскому указу тайшам отправили жалованье: шубы, однорядки, меховые шапки и сукно. Царь также приказал вернуть калмыкам хранившиеся в Астрахани останки Хо-Урлюка и других тайшей. Из Москвы к местным воеводам пришел строгий указ: казнить всех, кто нападает на калмыков без государева указа ${ }^{59}$.

П.С. Преображенская обращает внимание на тот факт, что в письме к царю за 1657 г. Дайчин именует себя (ххолопом», чего ранее за ним не наблюдалось. Основываясь на этом, исследователь делает вывод, что именно с этого года можно рассматривать завершение процесса добровольного вхождения калмыков в состав Российского государства $^{60}$. По мнению К.Н. Максимова, принцип «государь - холоп» характеризовал саму суть самодержавной политики, и с появлением подобной официальной формулировки определился новый рубеж в отношениях России с калмыками - добровольное государственное подданство без приобретения населением, так сказать, гражданства ${ }^{61}$. Можно предположить, что произошло принятие калмыками российского подданства, но без вступления в состав государства.

Формулировки «холопство» и «подданство» в некоторой степени нуждаются в уточнении. Мы не знаем, насколько точен был русский перевод письма Дайчина 1657 г., на который ссылаются П.С. Преображенская и М.Л. Кичиков ${ }^{62}$, но в нашем распоряжении имеются полные тексты русского перевода аналогичных писем Дайчина за 1658 и 1661 гг. (в т.ч. подлинники на старописьменном монгольском и татарском языках), где отсутствуют такие термины, как («хлоп» или «холопство» ${ }^{63}$. Более того, в самом тексте шерти 1657 г. отсутствуют подобные формулировки.

${ }^{58}$ Санин Г.А. Указ. соч. С. 212.

${ }^{59}$ РГАДА. Ф. 119. Оп. 1. 1657 г. Д. 2. Л. 65-66, 83-84, 116.

${ }^{60}$ Очерки истории Калмыцкой АССР... С. 119.

${ }^{61}$ Максимов К.Н. Калмыкия в национальной политике, системе власти и управления России (XVII-XX). М., 2002.C. 62, 63

${ }^{62}$ Очерки истории Калмыцкой АССР... С. 119; Кичиков 1966. С. 102.

${ }_{63}^{6}$ Tепкеев В.T. Калмыки в Северном Прикаспии. Элиста, 2012. С. 268 , $270,292-297$ 
Как отмечает М.М. Батмаев, в дальнейшем царские власти и калмыцкие правители не могли предвидеть объективный ход событий, поэтому у первых оставались большие подозрения об истинных намерениях тайшей, а последние преследовали свои интересы, не всегда совпадавшие с желаниями правительства ${ }^{64}$. Новое соглашение, однако, оказалось непрочным, поскольку правительство не сумело до конца выполнить свои обещания. В последующие годы выплаты жалованья временно приостановились, а набеги башкир и казаков на калмыцкие улусы продолжились. Все это не могло не разочаровывать тайшей в политике российских союзников, в то время как крымские посольства делали все более заманчивые предложения ${ }^{65}$. Но продолжение курса на укрепление союза с Россией для калмыков было более перспективным, нежели предложения крымского хана. Положительное решение территориального вопроса оказалось для калмыков наиболее насущным и необходимым, поскольку определилась более или менее постоянная территория калмыцких кочевий в Северном Прикаспии, что, в свою очередь, отражало процесс становления Калмыцкого государства ${ }^{66}$.

\section{2. Калмыцко-крымские и калмыцко-башкирские отношения в 1658-1661 гг.}

Крымский хан Мухаммед-Гирей IV внимательно и настороженно следил за укреплением связей калмыков с Россией. Крымская дипломатия предприняла ряд конкретных шагов по привлечению калмыков на свою сторону, а крымские послы стали частыми гостями в улусах тайшей ${ }^{67}$. Как упоминалось выше, примерно во второй половине 1656 г. в калмыцкие улусы прибыло крымское посольство с письменным посланием от хана. Внимательно следивший за ситуацией в калмыцких улусах астраханский воевода Ромодановский был

${ }^{64}$ Батмаев M.M. Социально-политический строй и хозяйство калмыков в XVII-XVIII вв. Элиста, 2002. С. 80.

${ }^{65}$ Khodarkovsky M. Where Two Worlds Met... P. 94.

${ }^{66}$ Кичиков М.Л. Исторические... С. 37.

${ }^{67}$ Очерки... С. 104. осведомлен об этих событиях, он немедленно потребовал от калмыков выдачи этого письма. После долгого упорства тайши в феврале 1657 г. все-таки передали астраханским властям «лист» крымского хана ${ }^{68}$.

Позже письмо было переправлено из Астрахани в Посольский приказ. Оригинал данного письма в архивных фондах, к сожалению, не обнаружен, но в нашем распоряжении оказался его русский перевод XVII в.

Обращает на себя тот факт, что крымский хан именует Дайчина своим «братом и другом» и пытается найти родство, называя себя и тайшу «потомками Чингисхана). Мухаммед-Гирей разъяснил Дайчину подробности своих отношений с Москвой и Польшей: «каждый год с Руси и от короля (польского. - В.T.) казну емлем, а в те годы, когда казну не дают, и мы их воюем и разоряем, и животы их емлем». Поэтому хан был явно недоволен всяческими контактами калмыков с казаками и их набегами на территорию Крыма: «А братья ваши приходят со степи и несколько кобыл отогнали и тем чают такому великому государству убыток учинили. И тем никакое дело не совершится, чем такое непристойное дело делать». С целью совместного выступления против Москвы Мухаммед-Гирей предлагал Дайчину: «А как мы с сей стороны учнем Русь воевать, а вам бы [со] своей стороны Русское государство воевать, многие животы и казну возьмете». Для поддержания отношений хан настаивал на обмен послами, «чтоб меж нами дружба добрая совершалася, чтоб с нашей стороны к вам никакова дурна не будет $)^{69}$.

В Посольском приказе внимательно рассмотрели данный «лист» и пришли к выводу, что он не имеет никакого отношения к крымскому хану. Такое умозаключение основывалось на нескольких обстоятельствах: во-первых, письмо было написано на кумыцком языке; во-вторых, почерк не являлся характерным для крымских писцов; в-третьих, имя крымского хана не было выведено, как и положено, золотыми буквами; в-четвертых, размер «листа) не соответствовал настоящим крымским письмам ${ }^{70}$. Таким образом, можно предполо-

\footnotetext{
${ }^{68}$ Преображенская П.С. Из истории... С. 65-66.

${ }^{69}$ РГАДА. Ф. 119. Оп. 1. 1657 г. Д. 2. Л. 32-33.

${ }^{70}$ РГАДА. Ф. 119. Оп. 1. 1657 г. Д. 2. Л. 34.
} 
жить, что оригинал крымского письма все-таки остался у тайшей, а русским властям была передана неточно воспроизведенная копия.

Летом 1657 г. из Астрахани к Дайчину прибыли татарские посланцы с письмом. Его улус в это время кочевал в урочище реки Иргиз, но самого тайши и его братьев, а также Мончака и Манжи-Ялбо в улусах не оказалось. Как выяснилось, они отправились на дальние кочевья для «призыва) Лузана, отошедшего от них в прошлом году. Посланцам пришлось передать «лист» супруге Дайчина - КанышАхай. От нее они узнали, что прошлой весной башкиры совершили очередной набег на калмыков, захватили 200 кибиток, скот и лошадей. При этом в разговоре с посланцами Каныш подчеркнула, что это уже «учинилося после шертованья и аманатов» ${ }^{71}$.

Как видно, новый виток напряженности в русско-калмыцких отношениях был снова спровоцирован третьей стороной. Посланцы решили дождаться возвращения тайшей, и именно в это время произошел очередной башкирский набег. 40 башкир на реке Узени отогнали у калмыцких джембойлуков 200 лошадей, но в ходе организованной погони ногаи сумели их отбить. От преследователей удалось уйти только 10 башкирам. Астраханские посланцы, так и не дождавшись возвращения Дайчина, уехали обратно. Каныш через них передала воеводам заверение, что калмыки, несмотря на последние события, будут и дальше придерживаться своей шерти, но просила астраханские власти все-таки решать проблему башкирских набегов ${ }^{72}$.

Продолжавшиеся нападения башкир на калмыцкие улусы не могли не вызвать недовольство у Дайчина после его возвращения с дальних кочевий. Действительно, уже в сентябре 1657 г. в Уфу вместе с торговым караваном из Ургенча прибыл его посланник - ногаец Янибек Идилбаев, который сообщил о готовности Дайчина совершить обмен полоном. По его сведениям, в Яицком городке находились 53 калмыка, захваченных во время совместного набега казаков и башкир на калмыцкие улусы. Однако в Яицком городке прибывшим калмыцким посланцам казаки сообщили, что все пленные калмыки находятся в Уфе. Уфимские власти не подтвердили наличие у себя калмыцкого полона, напомнив, что башкирам официально запрешено

\footnotetext{
${ }^{71}$ РГАДА. Ф. 119. Оп. 1. 1657 г. Д. 1. Л. 209-210.

${ }^{72}$ РГАДА. Ф. 119. Оп. 1. 1657 г. Д. 1. Л. 211-212.
}

нападать на калмыков, а яицкие казаки находятся далеко. Уфимский воевода А.И. Головин отверг причастность башкир к последним набегам на калмыцкие улусы, в то же самое время доложив о них в своем сообщении в Москву ${ }^{73}$.

По мнению М. Ходарковского, правительство, занятое решением проблем на западе, оказалось неспособным выполнить свои обещания перед тайшами и не смогло в достаточной мере использовать власть по отношению к «непослушным» подданным, поскольку указы жить мирно с калмыками часто ими игнорировались ${ }^{74}$.

Всерьез опасаясь ответных военных действий со стороны калмыков, в октябре 1657 г. уфимский воевода Головин в ответ на просьбу Дайчина прислать посланцев спешно отправил к нему стрельца И. Кузнецова. Воевода наказывал ему категорически отрицать причастность башкир в последнем набеге, но в то же время поинтересоваться условиями обмена пленными. Головин пообещал посланцу Дайчина произвести соответствующий розыск калмыцких пленных среди башкир ${ }^{75}$.

При встрече Дайчин, несмотря на последние события, заверил Кузнецова, что он «великого государя людьми хочет быть в миру до смерти своей». На уверение Кузнецова о действующем в Уфе государевом указе, запрешающим «под смертной казнью» башкирам нападать на калмыков, Дайчин заметил, что он и раньше не раз подобное слышал от уфимских представителей, но это не мешало башкирам продолжать совершать свои набеги на калмыков. Как выяснилось позже, калмыцкий полон, захваченный башкирами и яицкими казаками, был затем отправлен в Москву, шесть человек были переданы впоследствии калмыцким послам ${ }^{76}$.

19 декабря 1657 г. от Дайчина и Манжи-Ялбо в Уфу прибыли четверо калмыцких посланцев во главе с Боком Коргушевым. Послов сопровождал ранее отправленный в улусы стрелец Кузнецов. На жалобы калмыков по поводу башкирских набегов воеводы ответили, что

${ }^{73}$ РГАДА. Ф. 119. Оп. 1. 1658 г. Д. 1. Л. 5-6, 12-13, 17; Устюгов Н.В. Указ. соч. С. 54-55.

${ }^{74}$ Khodarkovsky $M$. Where Two Worlds Met... P. 94.

${ }^{75}$ Устюгов Н.В. Указ. соч. С. 55.

${ }^{76}$ РГАДА. Ф. 119. ОП. 1. 1658 г. Д. 1. Л. 48-49, 52, 58-60. 
об этом ничего не знают, а если и случалось такое, то, возможно, так башкиры ответили за причинение им обид калмыками на «зверовье». По словам посланцев, Манжи-Ялбо был активным сторонником того, чтобы произвести ответный набег на Уфимский уезд, но неожиданный приезд к тайшам из Уфы Кузнецова заставил Манжи распустить войско и отменить набег.

В конце 1657 г. калмыцкие улусы кочевали по Яику, на зимних пастбищах ниже Яицкого городка. Дайчин в это время все свое внимание переключил на астраханское направление. В Астрахани воеводы настойчиво продолжали требовать от тайшей заменить калмыцких аманатов на более знатных лиц, а также на сына или племянника едисанского мирзы С. Абдулова ${ }^{77}$. Недоверие воевод к тайшам сохранялось, и это заметно раздражало последних, а невыполнение русской стороной взятых на себя обязательств, особенно по вопросу о башкирских набегах, только усиливало их недовольство.

Весть о заключении русско-калмыцкого договора быстро разлетелась по соседним регионам. Народы Северного Кавказа эта новость сильно встревожила, так как они опасались, что теперь это развяжет калмыкам руки по отношению к тем, кто еще не принял русское подданство или действовал против интересов Москвы. Например, кумыцкий шевкал и Казаналп-мирза обратились к терскому воеводе с просьбой об оказании им военной помощи в случае калмыцкого вторжения на их территорию. Взамен они обещали предоставить в Терский городок аманатов, вернуть имеющийся у них русский полон и отправить своих послов в Москву ${ }^{78}$.

В действительности это была умело организованная дезинформация. Когда в начале 1658 г. в Терском городке были получены сведения о готовящемся нападении кумыков и ногаев Большой Орды, астраханские воеводы немедленно предписали своему терскому коллеге распустить в городке и его окрестностях слух о намечающемся походе калмыков на территорию кумыков в Северном Дагестане, чтобы тем самым устрашить последних и «обнадежить» терских жителей. Результат не заставил себя ждать. Когда Казаналп и шевкал

\footnotetext{
${ }^{77}$ РГАДА. Ф. 119. Оп. 1. 1658 г. Д. 1. Л. 63, 91.

${ }^{78}$ РГАДА. Ф. 119. Оп. 1. 1658 г. Д. 1. Л. 96.
}

Сурхай узнали о прибытии подкрепления в Терскую крепость и об угрозе нападения калмыков, они трижды прислали гонцов к терскому воеводе с просьбой не вести против них войны, в том числе и с помощью калмыков. Астраханские воеводы по царскому указу отправили к Дайчину двух гонцов с грамотой, в которой ему предписывалось отправить письменное предупреждение шевкалу и Казаналпу о возможности нанесения ими ударов по их территории в случае неподчинения Москве. Если бы это не возымело действия, то Дайчин должен был быть готовым послать в этот регион свои войска совместно с русскими ${ }^{79}$.

Но Дайчин не торопился включиться в борьбу с «недругами» России. На востоке у него еще оставался опасный враг - брат Лузан, ждавший удобного момента, чтобы ему навредить. С Крымом он тоже продолжал еще вести диалог и политический торг о возможном своем участии в войне. В архивных данных имеются сведения, что крымским послам тайша все-таки продал тысячу лошадей ${ }^{80}$.

В январе 1658 г. к Дайчину в улус от крымского хана МухаммедГирея IV прибыло внушительное по численности посольство (4 посла и 300 торговых людей) во главе с Зал-агой с подарками, «литовским ясырем〉 и товаром для обмена на калмыцких лошадей. Перед крымскими послами стояла вполне конкретная задача - склонить тайшей к совместному выступлению против России. Поскольку у азовцев и больших ногаев Урмаметева улуса зимой от бескормицы случился массовый падеж лошадей, крымцы остро нуждались и в калмыцких лошадях. Также они хотели выкупить своих крымских людей, находившихся в калмыцком плену.

Сохранился перечень даров, привезенных Дайчину от крымского хана: 40 тыс. золотых, 40 собольих шуб, «золотое древо с корольками〉, 40 хорьковых шуб, 40 куньих шуб, 40 беличьих шуб, 40 атласов, 40 учюг (кафтанов) золотых, 40 камок тканей и множество других подарков. Послы привезли от крымского хана заверение в том, в случае победы над Россией он отдаст калмыкам такие города, как Казань и Астрахань, и будет выплачивать ежегодное жалованье в размере

${ }^{79}$ Шиелев А.С. Указ. соч. С. 230-231.

${ }^{80}$ РГАДА. Ф. 119. Оп. 1. 1658 г. Д. 1. Л. 109. 
40 тыс. рублей. Однако калмыцкие тайши, не польстившись на эти подарки и обещания, отказали крымскому послу, заявив, что они «у великого государя учинились в вечном подданстве и по своей вере шерть учинили и аманат в Астрахань дали, и они де шерти своей нарушать не хотят ${ }^{81}$.

В Астрахани с беспокойством следили за развитием калмыцкокрымских переговоров, подтверждением тому стала срочная отправка к тайшам стрелецкого головы Г. Есипова и толмача И. Романова с целью отговорить калмыков от сотрудничества с крымцами и убедить их следовать заключенной шерти. Чтобы экономически заинтересовать калмыков, им предлагалось продать большую партию лошадей не крымцам, а русским под Астраханью. Но требование астраханцев выдать крымских послов Дайчин категорически отверг, ссылаясь на древнюю традицию: «нигде не повелось, чтоб послов отдавать, а крымские послы приехали к нему з большою почестию, и ему, Дайчину, их оскорбить нельзя ${ }^{82}$.

В феврале 1658 г. Дайчин со своим улусом начал перекочевку с Волги на Яик. Именно в этот период у астраханских посланцев, находившихся в калмыцких улусах, возник тайный замысел - заполучить «лист» крымского хана, который хранился у Эсен-дархана, доверенного лица Дайчина. Информацию об этом астраханцам по секрету сообщил едисанский мирза С. Абдулов, приходившийся приятелем Эсен-дархану. Посланцы предложили хранителю крымского «листа» взятку в размере 50 рублей, но тот отказался, заявив, что это в принципе невозможно ${ }^{83}$.

Дайчин вместе с крымскими послами отправил к хану уже своего представителя - татарина Калдыкеря. Но Мончак вдогонку за крымцами отправил отряд в 400 человек под командованием Чокулы с целью ограбить их по дороге. Потом сын уговорил отца срочно отправить калмыцкое посольство в Москву ${ }^{84}$. Очевидно, что в правящей

${ }^{81}$ РГАДА. Ф. 119. Оп. 1. 1658 г. Д. 1. Л. 66, 80; Пальмов Н.Н. Очерк истории калмыцкого народа за время его пребывания в пределах России. 2-е изд. Элиста, 1992. С. 43-44.

${ }^{82}$ РГАДА. Ф. 119. Оп. 1. 1658 г. Д. 1. Л. 66-67, 69; Д. 2. Л. 12-13.

${ }^{83}$ РГАДА. Ф. 119. Оп. 1. 1658 г. Д. 1. Л. 73-74.

${ }^{84}$ РГАДА. Ф. 119. Оп. 1. 1658 г. Д. 1. Л. 74. верхушке калмыцкого обшества находились активные сторонники укрепления отношений с Россией, и таковым, в первую очередь, являлся именно Мончак, который к этому времени имел уже четкую политическую ориентацию.

В Москву калмыцкое посольство прибыло в мае 1658 г. В его состав входили представители Дайчина, Мончака и едисанского мирзы C. Абдулова, а калмыцкую делегацию из 6 человек возглавлял Кушучи-дархан. В Посольском приказе послы сообщили о неоднократных попытках крымского хана, персидского шаха и хивинского хана склонить калмыков к союзу и подчеркнули, что тайши и мирзы настроены на дальнейшее укрепление русско-калмыцких отношений ${ }^{85}$. Единственное, что, по мнению послов, омрачало эти самые отношения, были постоянные набеги башкир и яицких казаков, о чем в своем письме, адресованном царю Алексею Михайловичу, сообщали Дайчин и Мончак: «Да после договору астяки (башкиры. - B.T.) и яицкие казаки калмыцких наших улусов громили, многой ясырь взяли и многие лошади, и животину отогнали» ${ }^{86}$.

В письме от тайшей излагалась жалоба на одного из астраханских воевод, И. Колтовского, который ранее докладывал в Москву, будто бы Мончак и Манжи-Ялбо в 1657 г. под Астраханью великому государю лично не шертовали, а в аманаты дали, «назвав тайшою, самово худово и старово и увечного человека, а другово и тово хуже». На основании полученной информации из Москвы в Астрахань пришел указ, чтобы временно придержали уже отправленное тайшам жалованье ${ }^{87}$. Подобные подозрения и недоверие со стороны местной администрации оскорбляли тайшей, и они, в свою очередь, пытались добиться справедливости в Москве.

25 июня 1658 г. прошла аудиенция калмыцких послов у царя Алексея Михайловича. Имеется довольно любопытное описание церемониала представления государю калмыков. На постоялый двор из царской конюшни послам присылали лошадей. Их доставляли в Кремль, непосредственно в Посольскую палату. Здесь послы ждали указа, а затем их проводили через Архангельскую площадь, отсюда

\footnotetext{
${ }^{85}$ РГАДА. Ф. 119. Оп. 1. 1658 г. Д. 2. Л. 23-24, 27-28.

${ }^{86}$ РГАДА. Ф. 119. Оп. 1. 1658 г. Д. 2. Л. 38.

${ }^{87}$ РГАДА. Ф. 119. Оп. 1. 1658 г. Д. 2. Л. 63.
} 
они поднимались по Средней лестнице и входили в палату к государю, где «били ему челом» ${ }^{88}$. В царский дворец Московского Кремля иностранные послы входили двумя путями: представители христианских государей - по лестнице (уу Благовещения) на соборную паперть и далее по переходам у Красного крыльца; иноверцы - по Средней лестнице сразу на Красное крыльцо, так как «бусурманским» дипломатам негоже было проходить соборной папертью ${ }^{89}$.

Тронное возвышение русского царя находилось в Золотой палате, в юго-восточном углу ${ }^{90}$. Думный дьяк Л. Лопухин официально представил калмыцких послов государю. Алексей Михайлович велел провести расследование по “делу» Колтовского и вынести решение вплоть до его возможного наказания. Что же касалось набегов на калмыцкие улусы башкир и яицких казаков, то царь приказал вернуть калмыкам все захваченное у них имущество, пленных и обменять аманатов $^{91}$

Калмыцким послам, как и членам других посольств, прибывавших в Москву, предоставлялось отдельное подворье, а Посольский приказ обеспечивал стрелецкой охраной. В XVII в. калмыков обычно селили на Ордынской улице или в Ордынской слободе. При этом никто, кроме приставов и охраны, не имел права входить к послам. Чтобы не допустить возможности калмыкам собирать информацию, царская администрация старалась не допустить их контактов с местными жителями.

В итоге в Москве калмыцким послам удалось донести до царя пожелания и просьбы тайшей и получить положительный ответ. Но на местном уровне инертность, субьективизм и недоверие к калмыкам большинства царских представителей тормозили дальнейшее развитие русско-калмыцких отношений, что в условиях продолжавшейся войны не отвечало интересам и царских властей.

В Москве внимательно отслеживали ход калмыцко-крымских переговоров, при этом информация поступала к ним не только из Астрахани. В начале 1658 г. на Дону стало известно об отъезде из Крыма

${ }^{88}$ РГАДА. Ф. 119. Оп. 1. 1658 г. Д. 2. Л. 52-53.

${ }^{89}$ Рогожин Н.M. У государевых дел быть указано ... М., 2002. С. 55

${ }^{90}$ Рогожин H.M. Указ. соч. С. 55.

${ }^{91}$ РГАДА. Ф. 119. Оп. 1. 1658 г. Д. 2. Л. 88, 91. очередного посольства к калмыкам. Донским казакам было приказано по «шляхам и перевозам» организовать засады с целью перехвата послов. 2 апреля им удалось разгромить одно из таких крымских посольств и взять языков. На допросе один из пленников, татарин Яныпай, сообщал, что к крымскому хану приезжал калмыцкий посол с конкретной просьбой, «чтоб крымской хан помог калмыцкому тайше и етисанцам Царство Астараханское заодно войною взять... [А] как де возьмем, а будем де жить заодно в вековом миру и в совете, а с Московского де Царя Белова буду дань имать». В Азове, по словам Яныпая, находилось большое количество калмыцких и едисанских людей. Насколько правдоподобны были эти сведения, неизвестно, поскольку вскоре Яныпай по дороге в Москву сбежал из плена ${ }^{92}$.

В калмыцких улусах астраханским татарам удалось проведать о приезде весной 1658 г. к калмыкам персидского посольства, состоявшего из трех купцов и 30 сопровождающих лиц. Персидский шах Аббас II (1632-1667 гг.) прислал Дайчину письмо и подарки: 5 «индейских» аргамаков, 10 одногорбых верблюдов и 30 «азямов» (долгополых кафтанов). Мончак и Манжи-Ялбо также не остались без подарков. С послами из Персии приехал и ранее отправленный туда калмыцкий посол Алыбай-дархан. Персидские послы пробыли в улусе Дайчина 3 месяца, в обратный путь они отправились по хивинской дороге вместе с калмыцким послом и 30 сопровождавшими его лицами. В ответ персидскому шаху Дайчин также отправил подарки: 100 лошадей, сокола, кречета и ястреба. Письмо тайша не стал посылать, но передал шаху устное послание через своего посла ${ }^{93}$.

В Астрахани внимательно отслеживали ситуацию в калмыцких улусах, и летом 1658 г. к Дайчину прибыли астраханские посланцы, татары Чювак Сары и Кучей Ажимбетев. Астраханцы еще раз напомнили тайшам о заключенной шерти 1657 г. и пожаловались на подчиненных тайшам татар-келечинцев, отогнавших у астраханских татар лошадей, и едисан, которые под Самарой отогнали 2 тыс. коров, а под Саратовом - 300 лошадей. Дайчину вновь пришлось заверить воевод от имени своих тайшей и мирз в том, что они выполняют взятые на

92 Русская историческая библиотека Министерства Народного Просвещения. Т. 34. Донские дела. Кн. 5. Петроград, 1917. С. 316, 317.

${ }^{93}$ РГАДА. Ф. 119. Оп. 1. 1658 г. Д. 2. Л. 4-5. 
себя обязательства: «ничево в нарушенье не ставит и ничево не лживит». Но в ответ Дайчин предьявил русской стороне и свои претензии. Еще в 1657 г. башкиры и саратовцы отогнали из калмыцких улусов 500 лошадей, а в Астрахани задержали жалованье, отправленное тайшам из Москвы ${ }^{94}$. Как видим, несанкционированные взаимные отгоны скота и лошадей продолжались, хотя и не носили уже масштабного характера, и это позволяло сторонам не накалять обстановку во время переговорного процесса.

В августе 1658 г. из Астрахани к тайшам с жалованьем был отправлен стрелецкий голова П. Шибанов, который 22 сентября прибыл в улус Дайчина ${ }^{95}$. Попытки русских властей взять под контроль внешнеполитические связи калмыков (в первую очередь это касалось их отношений с Крымом) не имели успеха. Слухи о приездах к тайшам все новых посольств из соседних государств обрастали свежими подробностями. Поэтому главной задачей, стоявшей перед русским посланцем, был получение любыми средствами писем крымского хана. На требование Шибанова о выдаче царским властям крымского письма Дайчин ответил достаточно кратко и сухо: как отыщем, так и пришлем. Понятно, что письма существовали, и об их содержании русские могли только догадываться. Подобное поведение калмыцких владельцев, конечно, не устраивало царскую администрацию, но и у тайшей имелись свои резоны. Когда Шибанов посоветовал Дайчину, чтобы тайши «обновили» свои шерти, тот ответил: когда в Астрахани сменится боярин, то и «шерти обновим и аманатов переменим» ${ }^{96}$.

Частая ротация воевод в Астрахани также была одной из причин, затруднявших достижение сторонами взаимопонимания. Не успевали тайши наладить отношения с одним воеводой, как на смену ему приходил другой. Действительно, в 1658 г. Москва полностью сменила руководство в Астрахани. На воеводство вместо Ромодановского и его людей прибыли кн. Д.П. Львов, Н.М. Беклемишев, дьяки М. Шишкин и С. Калинин. Возможно, это было сделано в ответ на многочисленные жалобы калмыцких тайшей на действия отдельных астраханских

${ }_{94}^{94}$ Архив Санкт-Петербургского института истории РАН. Ф. 178 (Астраханская приказная изба). Д. 3221. Л. 1-4, 8-9.

${ }^{95}$ РГАДА. Ф. 119. Оп. 1. 1659 г. Д. 1. Л. 23, 28.

${ }^{96}$ РГАДА. Ф. 119. Оп. 1. 1659 г. Д. 1. Л. 29. воевод, которые, как считали они, незаслуженно обвиняли калмыков в «политических махинациях» при заключении договора. В нашем распоряжении, к сожалению, нет документальных свидетельств, которые могли бы пролить свет на эти события, но, судя по реакции центральных властей, в условиях продолжавшейся войны с Польшей и Крымом Москва решила не обострять русско-калмыцкие отношения.

Упрек Шибанова о продолжавшихся нападениях калмыков на государевых людей Дайчин парировал тем, что это была всего лишь ответная реакция его людей на набеги башкир и яицких казаков. Несмотря на имевшиеся разногласия, Дайчин согласился вернуть русский полон, но при условии выдачи ему калмыцких пленников. Нападения калмыков на Яицкий городок тайша оправдывал тем, что в шерти 1657 г. казацкие городки по Яику не упоминались ${ }^{97}$.

10 октября 1658 г. Шибанов вернулся в Астрахань вместе с калмыцким представительством, куда входили следующие лица: Дайдархан и Келделе (от Дайчина), Янги-Батур (от Мончака), Начин (от Мергена), Эрке-Батур, внук тайши Даря, и Чавук (от едисанского Абла-мирзы Тинбаева) ${ }^{98}$.

Послы привезли с собой составленное на ногайском языке письмо Дайчина, где тайша обращается на имя русского царя и нового астраханского воеводы. В нем он перечисляет вещи (однорядки, шубы и шапки), привезенные Шибановым в качестве жалованья, и имена калмыцких тайшей, между которыми он их поделил. Однако калмыцкий правитель был недоволен отсутствием денежного жалованья, которое якобы словесно было ранее обещано его послу из расчета 200 руб. Дайчину и по 100 руб. - Манчику и Манжи-Ялббо. Дайчин также напомнил новым воеводам и о прошлых ложных обвинениях в адрес калмыков: «Архиепископ писал государю ложно, и в той лжи меж нами много остуды было. А только буде вы, новые воеводы, учнете верить лживым словам, и ныне меж нами будет многая ссора. И вам бы лживым словам не верит». В заключение тайша еще раз заверил воевод в незыблемости прежних договоренностей: «И прежняя шерть наша была верна и нынешней бы шерти нашей верить» ${ }^{99}$.

\footnotetext{
${ }^{97}$ РГАДА. Ф. 119. Оп. 1. 1659 г. Д. 1. Л. 30-31.

${ }^{98}$ РГАДА. Ф. 119. ОП. 1. 1659 г. Д. 1. Л. 25.

${ }^{99}$ РГАДА. Ф. 119. Оп. 1. 1659 г. Д. 1. Л. 38-40.
} 
О возросшей роли калмыков во внешней политике России, особенно на крымском направлении, говорят многочисленные факты. Например, в сентябре 1658 г. из Москвы астраханскому воеводе Д.П. Львову пришел указ склонить Дайчина, Мончака и МанжиЯлбо к тому, чтобы они отправили совместное письмо крымскому хану Мухаммед-Гирею с предупреждением не ходить войной под русские города, в противном случае угрожая выступить против Крыма $^{100}$

Опасения не были беспочвенны. В начале 1659 г. царские власти обеспокоило то обстоятельство, что Дайчин не приехал к Астрахани для заключения нового договора. 9 февраля в калмыцкие улусы был направлен боярский сын К. Кереитов, и 18 февраля он уже был на месте. Сначала Кереитов остановился в улусе едисанского С. Абдулова, где обнаружил присутствие двух крымских послов, одного из которых звали Карашу-бий. Крымцы, как и прежде, упорно добивались своей цели: привезли Дайчину новые подарки и просили у него военной помощи ${ }^{101}$. Кереитову также стало известно, что калмыцкие татары, ездившие торговать в Крым, привезли довольно интересные сведения. В Крыму прошел слух, будто в Москве был насильно крещен касимовский царевич, а другой царевич, отказавшийся креститься, был сослан на каторгу в Сибирь. В свою очередь, казанские татары, опасаясь насильственной христианизации, просили крымского хана прийти со своим войском под Казань и Астрахань, и якобы только в этом случае они обещали поднять антирусское восстание ${ }^{102}$

Дайчин в это время охотился на сайгаков, после чего остановился недалеко от вышеуказанного улуса. С. Абдулов, взяв с собой крымских послов с подарками, отправился к Дайчину. Калмыцкий тайша принял подарки, но отказал крымским послам в военной помощи. Объяснял он свой отказ тем, что с востока на его пограничные улусы напал Лузан и часть их захватил. Поэтому тайша собирался в ответный поход на брата, чтобы (выручать улусы свои». Дайчин со своими людьми затем двинулся на Яик и приказал всем подвластным

\footnotetext{
${ }^{100}$ РГАДА. Ф. 123. Оп. 1. 1658 г. Д. 17. Л. 1-4

101 РГАДА. Ф. 119. Оп. 1. 1659 г. Д. 2. Л. 2-3.

${ }^{102}$ РГАДА. Ф. 119. Оп. 1. 1659 г. Д. 2. Л. 3.
}

ногайским мирзам следовать за ним, чтобы вместе пойти войной на Лузана ${ }^{103}$

В документах за 1658 г. встречаются сведения о Лузане и Елдене, которые кочевали со своими улусами на дальних кочевьях - за Яиком, в урочище Улуктав, в 8 неделях пути от Яицкого городка. Например, известно, что в это время между Елденом и Лузаном вспыхнула ссора из-за нежелания последнего возвращаться к Дайчину. Елден начал было подумывать о возвращении к старшему брату и уже отправился со своим улусом на запад, но по неизвестной причине вернулся назад и, как отмечали очевидцы, «меж ими де за то стала война») ${ }^{104}$. Возможно, Елден хотел со своим улусом вернуться к Дайчину, но только вместе с Лузаном, так как возвращение двух улусов гарантировало бы им обоим относительную безопасность. Однако агрессивные действия Лузана против старшего брата свели на нет планы Елдена.

Подтвердить шерть перед новыми астраханскими воеводами и переменить аманатов Дайчин соглашался только при условии выплаты ему окончательного жалования в 800 рублей. В противном случае он грозился Кереитову оказать военную помощь Крыму ${ }^{105}$. Дайчин, высказав в открытой форме все свои претензии, предупреждал о возможных последствиях в случае невыполнения русской стороной его требований.

В 1659 г. русско-калмыцкие отношения подверглись новому испытанию, на этот раз на уфимском направлении. Военная активизация калмыков была вызвана очередным набегом башкир летом, в результате которого пострадал кочевавший с калмыками ногайский улус ((лутчево) человека Дайчина - мирзы Казарчи Бекимбета. Погибли сам Казарчи, трое его сыновей и сын ногайского мирзы Аслана. Башкиры в ходе набега отогнали 600 лошадей.

Со стороны уфимских властей последовали определенные шаги по нормализации отношений с калмыками. Осенью 1659 г. из Уфы к тайшам было отправлено представительство в сопровождении ранее прибывших туда калмыцких посланцев. В мае 1660 г. уфимцы вернулись в Уфу вместе с большим калмыцким посольством, воз-

${ }^{103}$ РГАДА. Ф. 119. Оп. 1. 1659 г. Д. 2. Л. 4-6.

${ }^{104}$ РГАДА. Ф. 119. Оп. 1. 1658 г. Д. 2. Л. 6.

${ }^{105}$ РГАДА. Ф. 119. Оп. 1. 1659 г. Д. 2. Л. 6. 
главляемым Маметом. В состав калмыцкой делегации входили представители от Дайчина, Санжина, Манжи-Ялбо и дербетских тайшей Аючея и Аюкея (младших сыновей Далай-Батура). В Уфу на продажу калмыки пригнали 870 лошадей, а также привели для обмена полон, состоящий из русских, башкир и чувашей. Дербетский представитель передал воеводе, что их тайши живут в мире с Дайчином, а братья Аюкей и Аючей приходятся ему «вместо детей». Аючей к тому же доводился Дайчину зятем. Калмыки жаловались воеводам на продолжающиеся набеги башкир, угнавших в прошлом году у вышеуказанных дербетских тайшей 400 лошадей ${ }^{106}$.

Первое упоминание в русских документах об этих двух владельцах свидетельствует о второй после 1642 г. волне миграции дербетских улусов к торгутам в степи Северного Прикаспия. Тогда, как известно, здесь впервые появился улус владелицы Сувундай, матери Солом-Церена. Но уфимский воевода А.Т. Измайлов отказался вести переговоры с представителем дербетских тайшей, поскольку на тот момент еще продолжал действовать указ о запрете дербетам приезжать в Уфу, а отношения с царскими властями поддерживать только через сибирские города Тюмень или Тобольск.

Воевода был осведомлен, что весной 1659 г. тайши Санжин и Аючей с 2 тыс. калмыков ходили в набег на Уфимский уезд и башкирские волости, но из-за снежных заносов не смогли осуществить свой замысел и вернулись обратно в улусы. Калмыцкие посланцы отрицали данное утверждение, указывая, что башкиры «затевают на них напрасно» и не возвращают лошадей, отогнанных у дербетов. По вопросу о законности присутствия дербетского представителя в Уфе другие калмыцкие посланцы пояснили, что дербеты кочуют с торгутами «многие годы». Пожурив посланцев за то, что они разогнали по дороге башкирских «зверовщиков», уфимский воевода все-таки разрешил им, за исключением дербетов, обменять полон и торговать под городом, но только после весеннего паводка ${ }^{107}$.

С калмыцкими послами из Уфы в улусы были отправлены стрельцы С. Писарев и П. Лутохин. По дороге Писарев заболел и вернулся

${ }^{106}$ РГАДА. Ф. 119. Оп. 1. 1659 г. Д. 1. Л. 6, 7, 17, 19

${ }^{107}$ РГАДА. Ф. 119. Оп. 1. 1660 г. Д. 1. Л. 18-19, 21-23, 31, 41-42. обратно, а Лутохин стал свидетелем башкирского нападения на калмыцких посланцев на реке Чеган, в результате которого у них отогнали 21 лошадь. Стрелец отправил в Уфу находившегося при нем тархана Ахманая с уведомлением об инциденте и призвал уфимские власти срочно отыскать у башкир отогнанных калмыцких лошадей ${ }^{108}$.

Улус Дайчина в это время кочевал на реке Берги-Чеган. Старшая супруга Дайчина, Батыр, отправила прибывшего уфимского посланника к мужу, находившемуся с войсками на реке Иргиз. Здесь тайша формировал военные отряды для набега на русские территории: 2-тысячный отряд под командой Чокулы направлялся на Казанский уезд, другой отряд в 3 тыс. человек шел на Уфимский уезд, 5 тыс. калмыков во главе с Аючеем и Аюкеем направлялись непосредственно под Уфу.

Как говорил Дайчин, башкирские набеги совершались постоянно, а уфимский воевода про «башкирский задор как не ведает». Лутохин пытался оправдать уфимские власти и предлагал калмыцким представителям лично приехать в Уфу и убедиться, что «башкирские воры в тюрьме и в железе сидят». Однако подобные заверения не удержали калмыков от ответных силовых действий. Так, дербеты из набега на Уфимский уезд привели полон в 40 человек, пленили башкирского тархана Кипчатцкой волости Табыная Аксакалова и захватили большое количество скота и лошадей. Отпуская уфимского посланника, Дайчин передал через него воеводе, что прерывает всякие отношения с Уфой, а с башкирами отныне находится в состоянии войны. Лутохина Дайчин так и не принял. Тайша отправил его в улус своего внука Манжи-Ялбо, поскольку в Уфу приезжал и его представитель. Однако молодой тайша, который кочевал с улусом на реке Черной, не принимал уфимского посланца до тех пор, пока уфимские власти не пригнали отогнанных калмыцких лошадей. Только после этого Лутохин отправился в Уфу вместе с калмыцким послом ${ }^{109}$.

Ухудшение русско-калмыцких отношений развивались на фоне продолжавшихся переговоров с крымским Мухаммед-Гиреем, который, несмотря на неудачи своих первых посольств, упрямо продол-

108 РГАДА. Ф. 119. Оп. 1. 1660 г. Д. 1. Л. 108.

${ }^{109}$ РГАДА. Ф. 119. Оп. 1. 1660 г. Д. 1. Л. 109-114, 123, 129. 
жал предлагать тайшам заключение антимосковского союза. В 1659 г. к тайшам из Крыма вновь прибыло посольство во главе с Караш-мирзой Аталыком, который около года прожил в калмыцких улусах и весной 1660 г. вернулся в Крым с калмыцкими посланниками ${ }^{110}$. Не добившись положительного результата, крымский посол был весьма недоволен этим обстоятельством и, чтобы досадить калмыкам, подговорил и увел с собой в Крым 100 кибиток калмыцких ногайцев ${ }^{111}$. Только после его отъезда об этом стало известно Дайчину, а также и то, что Караш-мирза агитировал калмыцких ногайцев нынешней зимой уходить на территорию Крымского ханства, в урочище у Можарского городища. В этой местности весной 1660 г. хан планировал построить укрепленный каменный городок и усилить гарнизон из черкесов и кубанских ногаев ${ }^{112}$.

Поступок крымского посла крайне возмутил калмыцких тайшей, и, как отмечали очевидцы, «у крымцев учинилась ложь, и впредь де им [калмыки] никоторого добра делать не хотят». Дайчин принял решение об организации похода против подвластных крымскому хану ногайцев. Чтобы усыпить бдительность крымцев и вернуть ранее посланных в Крым калмыцкого татарина Баракчина с сыном, к ним отправили калмыцкого посла Алыбай-дархана. По мнению Н.Н. Пальмова, обмен послами должен был гарантировать мирное отношение крымцев к калмыкам, но это не препятствовало самим калмыкам совершать нападения на крымцев в доказательство своей верности российскому правительству ${ }^{113}$.

В архивных документах есть свидетельства об успешных военных действиях калмыцких отрядов под началом Мончака против азовцев и кубанских ногайцев, завершившихся захватом свыше тысячи пленников и около 18 тыс. голов скота ${ }^{114}$. По другим сведениям, в начале 1660 г. калмыки разгромили три ногайских улуса Шейдяковых, убили трех мирз и захватили большое количество их улусных людей. Из-под Азова ими были также отогнаны конские табуны. По-

${ }^{110}$ РГАДА. Ф. 123. Оп. 1. 1660 г. Д. 4. Л. 6.

${ }^{111}$ Пальмов Н.Н. Очерк... С. 44.

${ }^{112}$ РГАДА. Ф. 112. Оп. 1. 1661 г. Д. 1. Л. 16

${ }^{113}$ Пальмов Н.Н. Очерк... С. 44

${ }^{114}$ Очерки... С. 122-123. сле этого тайши отправили в Крым своих послов, правда, неизвестно с какой целью, а крымский хан задержал их. Летом калмыки совершили набег на улус Малого Ногая мирзы Арсланбека, дважды отогнав у него табуны. Очевидцы в это время отмечали, что «с калмыками де у крымского хана ссылки ныне нет, потому что меж ими война» ${ }^{115}$.

В течение 1650-х гг. астраханские воеводы настойчиво и зачастую безрезультатно добивались принесения присяги в верности русскому царю от мирз Малого Ногая. Но последние калмыцкие вторжения на Куб̆ань все-таки заставили казыевских мирз Арсланбека, Навруза и других присягнуть Москве. Воеводы безуспешно добивались привлечения военных сил подвластных им ногаев для участия в войне против Польши и Крыма, по крайней мере, удержанию их от войны против России. С началом русско-польской войны началось движение всех ногайских орд, включая даже улусы темрюцких и горских татар. Слишком был велик соблазн участия на стороне Крыма в большой войне и захвата богатых трофеев ${ }^{116}$. Поэтому ничего удивительного нет в том, что у калмыцких тайшей и московского правительства был общий интерес - нейтрализация кубанских ногаев.

Как подтверждение этому можно считать приезд 20 июля 1660 г. в Москву калмыцкого посольства от Дайчина, возглавляли которое Батур и Урусамба. Послы сообщили, что Дайчин учинился «под высокою рукою со всеми своими калмыцкими людьми в подданстве и, служа... великому государю, ходил воевать... царского величества недругов, крымских людей и изменников наших нагаев». В ответной царской грамоте, отправленной в сентябре, правительство благодарило калмыцкого тайшу за верную службу ${ }^{117}$.

В ноябре 1660 г. Дайчин и Мончак были готовы совершить очередной большой военный поход на Северный Кавказ и в Северное Причерноморье. Практически все калмыцкие тайши участвовали в нем, за исключением дербетского Солом-Церена, оставленного со своими людьми для охраны улусов. Предварительно в районы будущих вторжений были направлены разведывательные отряды, а имен-

\footnotetext{
${ }^{115}$ РИБ. Петроград, 1917. С. 674, 715, 767.

${ }^{116}$ Новосельский А.А. Исследования... С. 90.

${ }^{117}$ Очерки... С. 123.
} 
но - под Крым, Азов, Казыевский улус и Северный Дагестан. Как сообщали посланцы Дайчина и Мончака в Астрахани, сами тайши находились «на стану для вестей»), в то время как основные силы калмыков располагались на одном из урочищ у реки Кума. В результате набегов разведывательных отрядов у казыевцев было убито 40 человек и отогнано 2 тыс. лошадей, крымцы потеряли 200 человек, у кемардеевских и бесленеевских владельцев отогнали 2 тыс. овец, у большеногайских мирз Султанаша, Ямгурчея и Каракасала, кочевавших под Тарками и у Эндери, отогнали 2 тыс. лошадей ${ }^{118}$.

Только после получения развединформации о положении дел в этих районах тайши повели свои основные силы в разных направлениях. Дайчин и Мончак с войском двинулись на Казыевский улус, под Темрюк, Крым, Азов, на Тамань, Кемурдей и Бесленей - области, владельцы которых отправили своих людей на помощь крымскому хану. Манжи-Ялбо направился против ногайских улусов, кочевавших под Кабардой и по соседству с кумыками ${ }^{119}$.

Крымский хан Мухаммед-Гирей, узнав о приближении крупных воинских сил калмыков к территории Малого Ногая, отправил навстречу Дайчину своего посла - ширинского мирзу Касима в сопровождении 30 человек. Не доезжая до Кубани, у тайшей состоялась встреча с указанными крымскими послами, которые настойчиво отговаривали калмыков от продолжения похода и предлагали присоединиться к ним для войны с Россией. Мухаммед-Гирей ради заключения соглашения готов был даже отдать в жены Дайчину и Мончаку своих дочерей. Но, если Дайчин отправил Касима с двумя послами обратно в Крым с сообщением, что он и его люди «с ханом за его неправды в миру не будут и на битву де с ним готовы», то остальных крымцев он отослал в калмыцкие улусы, кочевавшие на реке Узень, под присмотр С. Абдулова до его возвращения из похода ${ }^{12 n}$.

В декабре 1660 г. Мончак со своим войском перешел реку Лаба и в урочище Бичигиз разгромил казыевские улусы Навруза Шейдякова и других пяти мирз. Дайчин ходил войной на темрюкских, та-

${ }^{118}$ РГАДА. Ф. 112. Оп. 1. 1661 г. Д. 1. Л. 28, 29.

${ }^{119}$ РГАДА. Ф. 112. Оп. 1. 1661 г. Д. 1. Л. 29.

${ }^{120}$ РГАДА. Ф. 112. Оп. 1. 1661 г. Д. 1. Л. 16; Ф. 119. Оп. 1. 1660 г. Д. 5. Л. 16-19, 29; 1661 г. Д. 1. Л. 111. банских, кимирдинских, бесленеевских людей, а также ногайских мирз «Ураковой половины» - Девея-мирзу, Чебан-мирзу Ищерекова и Навруз-мирзу. Разгрому подвергся и Казыевский улус Кантемирамирзы Аблина и Урак-мирзы Каспулатова. Калмыки захватили большое количество пленных, лошадей и скота. Раньше всех в улусы вернулся Манжи-Ялбо, захвативший в ходе военного похода ногайский улус мирзы Навруза Касаева и 3 тыс. пленных. Затем, в начале марта 1661 г., домой вернулся Мончак, Дайчин двигался следом. Общая численность ясыря, захваченная этими двумя тайшами, насчитывала до 4 тыс. человек. От Маныча калмыки шли «тихим ходом», поскольку их лошади сильно ослабли от дальних походов ${ }^{121}$.

К этому времени улус Мончака расположился на волжских островах и в займищах ниже Енотаевского Яра, в 80 верстах от Черного Яра. Рядом кочевал дербетский улус Солом-Церена. Сразу по приезду Мончака домой Г.С. Черкасский направил к нему для переговоров И. Исакова. Для нас представляет большой интерес подробный отчет Исакова о его поездке в калмыцкие улусы. В день его приезда в улус встретиться ему с тайшой так и не удалось, так как у Мончака был болен сын. На второй день тайша передал Исакову, «что у них, у калмык, тот день черной и отуда де нибудь хто к ним ни приедет, и они де в тот день не видятца и не говорят ничего». Встреча состоялась только на третий день ${ }^{122}$.

В обязанности Исакова было предложить Мончаку лично приехать под Астрахань и встретиться с воеводой Г.С. Черкасским. Однако тайша не спешил самостоятельно вступить в переговоры с властями и ждал возвращения из похода отца. Вскоре Исаков получил неожиданное предложение от Мончака самому выехать навстречу возвращавшемуся в улусы Дайчину, и на пятый день он выехал в сопровождении калмыков Батура и Чегана, а также кабардинского узденя Хапыха Жуватова. Мончак велел передать отцу, чтобы тот ехал прямо к нему в улус, чтобы затем вместе направиться под Астрахань. В это время калмыцкий тайша желал засватать за себя сестру К. Черкасского, и по этому поводу он с отцом планировал провести пере-

${ }^{121}$ РГАДА. Ф. 112. Оп. 1. 1661 г. Д. 1. Л. 19, 20, 30, 33; Ф. 119. Оп. 1. 1661 г. Д. 1. Л. 3-4; Новосельский А.А. Указ. соч. С. 92.

${ }^{122}$ РГАДА. Ф. 112. Оп. 1. 1661 г. Д. 1. Л. 135. 
говоры с Г.С. Черкасским, доводившимся родным дядей будущей невесты $^{123}$

Только на шестой день пути, 10 марта, Исаков с провожатыми встретили возвращавшегося Дайчина у Маныча: «едет к себе в улусы тихо, что де у него и у калмык лошади выбиты и люди многие томны». Но при первой встрече разговор у них не получился, так как на предложение посланца Дайчин ничего не ответил и отпустил его от себя. На второй день он уже предложил Исакову ехать рядом с собой, но затем велел отправляться вперед к Мончаку и дожидаться его там. Дайчин передал сыну, чтобы тот к его приезду собрал на сьезд всех владельцев. Через четыре дня они уже были в улусе Мончака, который к этому времени уже перешел на левый берег Волги, в урочище Баскунчакской соли, и именно сюда сьезжались на сьезд другие калмыцкие владельцы. На третий день к сыну от отца прибыл нарочный с сообщением, что тот уже близко, и все владельцы во главе с Мончаком отправились навстречу к Дайчину ${ }^{124}$.

На следующий день тайши вернулись и сообщили Исакову, что дадут ответ только после проведенного между собой совета, который длился два дня. Дайчин поставил в известность астраханского представителя об успешном окончании военного похода калмыков на Северном Кавказе и в Причерноморье, в ходе которого было взято большое количество пленных, а также скота и других трофеев. К встрече с воеводой Г.С. Черкасским тайши были готовы, но сам Дайчин от нее отказался, сославшись на сильную усталость после похода, и попросил 15 дней для восстановления сил: «лошади свои и платья с себя переменят» ${ }^{125}$. На правах правителя все трофеи Дайчин взял себе и поделил между тайшами по мере их вклада в общее дело ${ }^{126}$.

Помощь, оказанная калмыками в ходе зимней военной кампании 1660/61 года, русским правительством была признана весьма ощутимой. Но, по всей видимости, тайши не довольствовались раз-

\footnotetext{
${ }^{123}$ РГАДА. Ф. 112. Оп. 1. 1661 г. Д. 1. Л. 136, 137.

${ }^{124}$ РГАДА. Ф. 112. Оп. 1. 1661 г. Д. 1. Л. 138-141.

${ }^{125}$ РГАДА. Ф. 112. Оп. 1. 1661 г. Д. 1. Л. 142, 145.

${ }^{126}$ Позднеев A.M. Астраханские калмыки и их отношения к России до начала нынешнего столетия // Журнал Министерства народного просвеще-
} ния. Ч. CCXLIV. Отд. 2. 1886. С. 148. громом Казыевского улуса, поскольку после зимнего похода в двух днях пути от этого улуса, в урочище Морская протока, ими был оставлен отряд в 500 калмыков с приказом - громить остатки казыевцев. Как докладывал Мончак в своем письме к Г.С. Черкасскому, у Дона, под Азовом и Темрюком он оставил в общей сложности до 2 тыс. калмыков ${ }^{127}$

Северный Дагестан также оказался в зоне военных ударов калмыков. В конце 1660 г. улусы терских ногаев мирз Султанаша (Султан-Ахмеда) Аксак-Кельмаметева, Ямгурчея и Каракасая, кочевавших под Тарками и Эндери, в результате калмыцких набегов потеряли 2 тыс. лошадей. Есть сведения о том, что калмыки захватили в плен сына Султанаша - Ябагу. По мнению А.С. Шмелева, удар был предпринят с одной целью - вернуть ногайцев под Астрахань, поскольку еще в декабре 1660 г. посланец Дайчина и Мончака сообщал в Астрахани о планах тайшей относительно присоединения ногайского улуса Султанаша ${ }^{128}$. После кавказского похода Мончак просил Г.С. Черкасского не предпринимать против Султанаша и Ислама Чубармаметева силовых акций, поскольку те «по своей мусульманской вере им, тайшам, душу дали, что им кочевать с ними, тайшами». А в апреле 1661 г. в Астрахани стало известно, что тайши направили мирз Ислама и Ябагу агитировать Султанаша и Каракасая идти кочевать на Волгу ${ }^{129}$. По донесению терских воевод, указанные ногайские мирзы обсуждали с эндерийским Казаналпом возможность их ухода из северной части Дагестана и присоединения к Дайчину и Мончаку, так как те всерьез угрожали им карательными акциями ${ }^{130}$.

Несомненно, наиболее всего от ударов калмыцких войск пострадал Казыевский улус. Как сообщали калмыцкие посланцы в Астрахани, вскоре после возвращения Дайчина из кавказского похода к нему прибыли 40 человек от казыевских мирз Арсланбека и Навруза «для сыску ясырей своих». Виновником своих бед казыевцы считали К. Черкасского, который, по их мнению, посредством заключения

${ }^{127}$ РГАДА. Ф. 112. Оп. 1. 1661 г. Д. 1. Л. 20, 93.

${ }^{128}$ ИІмелев А.С. Указ. соч. С. 230-231.

${ }^{129}$ РГАДА. Ф. 112. Оп. 1. 1661 г. Д. 1. Л. 75-77, 147.

${ }^{130}$ Шимелев А.С. Указ. соч. С. 231. 
династического брака с тайшами сознательно направил калмыков войной против Малого Ногая ${ }^{131}$

Боевые столкновения на Северном Кавказе и Причерноморье показали военное превосходство калмыков над крымскими и ногайскими отрядами. Это подтверждает и современник тех событий, османский путешественник Эвлия Челеби, который отмечал, что «калмыки всегда возвращаются, побивая крымчаков, и они превосходят крымский народ храбростью) ${ }^{132}$.

Прибывшие в начале 1661 г. в калмыцкие улусы крымские послы известили тайшей о разгроме крымско-польскими войсками 40-тысячной русской армии под Чудновым в октябре 1660 г. Вдохновленные военным успехом, крымцы агитировали Дайчина и других тайшей присоединиться к ним для войны с Россией, обещая в случае победы отдать такие города, как Казань и Астрахань. Но Дайчин, не польстившись на столь громкие обещания, заявил послам следующее: «он с ними в войне, а в миру де он учинился великого государя с русскими людьми, и всякое де повеленье исполняет он царскому величеству, и на том де он стоит». Крымцы, находившись под присмотром Эсен-дархана, родственника Дайчина, в урочище Яшкуль, испытывали крайнюю нужду в продовольствии, так как «корму де им ничего не дают, а покупают на свое». Когда послы на одной из аудиенций лично обратились к Дайчину с просьбой отпустить их в Крым, то тайша демонстративно их проигнорировал: «в то время чол свою калмыцкую книгу». Мончак крымцев еще более не жаловал, а на попытку едисанского мирзы С. Абдулова выяснить относительно их будущего ответил буквально следующее: «Мне де они не надобны, а буде де похотите, и вы де тех крымских послов убейте или де отдайте в Астарахань русским людем». Однако на просьбу крымцев передать их все-таки в Астрахань, тайша также ответил отказом ${ }^{133}$.

Задержка крымцев обьяснялась еще и тем, что в это время в Крыму находился калмыцкий посол Алыбай-дархан, который вел переговоры по вопросу бежавших туда в 1659 г. улусных людей. В марте

${ }^{131}$ РГАДА. Ф. 112. Оп. 1. 1661 г. Д. 1. Л. 157, 158

132 Эвлия Челеби. Книга путешествия. Вып.1. Земли Молдавии и Украины. М., 1961. С. 246.

${ }^{133}$ РГАДА. Ф. 112. Оп. 1. 1661 г. Д. 1. Л. 21, 33, 114, 115.
1661 г. он вернулся в калмыцкие улусы и докладывал Мончаку о всех тамошних вестях и событиях. Например, ему было известно, что Азов недавно получил подкрепление, или что в «турецкой земле» зимой 1659/60 года был сильный пожар, и Стамбул горел семь дней и ночей, погибло большое количество его жителей, также пожар был в Крыму ${ }^{134}$.

По мнению М.Л. Кичикова, усилия крымского хана, рассчитывавшего своей провокационной деятельностью посеять раздор и недоверие между калмыками и русскими властями, потерпели неудачу ${ }^{135}$. Калмыцко-крымские переговоры в целом не изменили политического курса большинства представителей калмыцкой знати, ориентированного на укрепление связей с Москвой, несмотря даже на продолжавшиеся инциденты на границе между царскими подданными и калмыками.

\section{3. Русско-калмыцкие переговоры и шерти 1661 г.}

Крупные сражения, произошедшие в 1659-1661 гг. в ходе русскопольской войны, привели к значительному истощению сил с обеих сторон. Русская армия потерпела поражения под Конотопом (1659 г.), где погибла элитная дворянская конница князей С.Р. Пожарского и С.П. Львова, и под Чудновым (1660 г.), приведшая к пленению полководца и боярина В.Б. Шереметьева. Участие в войне на стороне Речи Посполитой значительной массы крымских татар заставило царское правительство вновь вернуться к (калмыцкому вопросу».

Сохранение относительного спокойствия на степных границах на южном направлении было одной из главных задач внешнеполитического курса правительства царя Алексея Михайловича. Во многом это зависело от урегулирования взаимоотношения с калмыцкими тайшами. Поэтому в планы царского правительства, естественно, входило привлечение калмыков в качестве дополнительной военной силы в виде конницы. Как посчитали в Москве, использование калмыцких отрядов в войне с Крымом позволило бы правительству существен-

${ }^{134}$ РГАДА. Ф. 112. Оп. 1. 1661 г. Д. 1. Л. 106, 107.

${ }^{135}$ Кичиков М.Л. Образование... С. 104. 
ным образом улучшить положение дел на южном театре. В 1660 г. как одно из отделений Посольского приказа был создан особый Калмыцкий приказ под управлением боярина В. Ромодановского и дьяка И. Горохова ${ }^{136}$. Серьезность намерений царя и его правительства выразилась и в выборе главой русского посольства к тайшам опытного переговорщика И. Горохова. Как отмечал современник тех лет Г. Котошихин, к крымскому хану и калмыцким тайшам отправляли посланников из числа представителей средних дворянских родов ${ }^{137}$.

Среди русских посольских миссий, отправленных к калмыкам в XVII в., посольство Горохова 1661 г. занимает особое место. Это важное событие всецело отражено в путевых заметках русского посла, изложенных им в «Статейном списке дьяка Ивана Горохова, посыланного к калмыцким тайшам для приведения их к присяге в верности к государю» ${ }^{138}$. Назначение Горохова дьяком Калмыцкого приказа было отнюдь не случайным. Правительство царя Алексея Михайловича обращало серьезное внимание на подбор кадров, осуществлявших сношения с калмыками. За короткое время Горохов сделал блестящую карьеру. Хорошее знакомство с жизнью кочевников, находчивость, смекалка и другие способности содействовали его выдвижению. Первые упоминания о нем относятся к 1642 г., когда ему было поручено отправиться в Москву с отписками из Астрахани. В 1655 г. он уже выступал послом царя к тайшам Дайчину и Лузану. В 1656 г. Горохов принимал шерти (договора) от 50 калмыцких тайшей. Присутствует он и при подписании шерти в 1657 г.

Правительство ставило перед Гороховым главную задачу - заручиться согласием тайшей на отправку своих войск против Крыма. Москва связывала большие надежды с положительным решением этого вопроса, поэтому посольство было тщательно подготовлено, подарки для тайшей оценивались на общую сумму в 1074 руб. В «наказной памяти», составленной для Горохова в Посольском приказе, предусматривались приблизительные ответы на возможные вопросы калмыцких тайшей. Схожие цели и задачи были поставлены и

${ }^{136}$ Преображенская П.С. Из истории... С. 69, 70.

${ }_{137}$ О России в царствование Алексея Михайловича. Современное сочинение Григория Котошихина. Изд. 3. СПб., 1884. С. 47.

${ }^{138}$ РГАДА. Ф. 119. Оп. 1. 1660 г. Д. 5. перед назначенным 6 июня 1660 г. новым астраханским воеводой кн. Г.С. Черкасским ${ }^{139}$.

Большой интерес для исследователей представляют подробные путевые заметки Горохова. Так, в конце декабря 1660 г. он выехал из Москвы, и путь его пролегал через Коломну, Переяславль-Рязанский, Ряжск, Тамбов, Черный Яр. От Черного Яра до Астрахани он проезжал уже непосредственно через калмыцкие улусы. В дороге к проезжавшему русскому послу подходили простые улусные люди с женами и детьми, выражали искренние дружеские чувства, «что де они великого государя милости ради и с русскими людьми мирны». Горохов щедро угощал встречавших его калмыков вином, дарил подарки. До своего прибытия в Астрахань 9 февраля 1961 г. Горохов проезжал по территории, где располагались улусы калмыцкого тайши Солом-Церена и супруги Мончака - Уралмы, дочери джунгарского Батура-хунтайджи. На приглашение посетить их ставку Горохов ответил отказом, ограничившись отправкой к ним с извинениями царицынского стрельца Т. Степанова, которого указанные калмыцкие владельцы довольно хорошо встретили. Но к приезду Горохова главные калмыцкие правители, тайши Дайчин и Мончак, отсутствовали в улусах. Дьяк зря времени не терял и провел довольно активные предварительные переговоры с ближайшим окружением Дайчина. В частности, он провел совещательную встречу с дарханом Чокулой, пообешавшим Горохову привлечь на его сторону супругу Дайчина и калмыцких «законников» - Эрке-ламу и Алдар-Кечика, к мнению которых тайши прислушивались ${ }^{140}$

В марте Дайчин вернулся из тяжелого 4-месячного кавказского похода и попросил Горохова подождать 15 дней, так как хотел отдохнуть перед началом официальных переговоров. Уже 26 апреля выехавший из Астрахани Горохов ждал тайшей на левобережье Волги, за рекой Берекети. Именно сюда 4 мая также прибыли К. Черкасский с донскими представителями. Приезд посланцев от донского казачества не был случайным. Еще 20 февраля Дайчин прислал к войсковому атаману К. Яковлеву посольство во главе с Батуром Аянгеевым,

${ }^{139}$ Преображенская П.С. Из историн... С. 69-71.

${ }^{140}$ РГАДА. Ф. 119. Оп. 1. 1660 г. Д. 5. Л. 39; Преображенская П.С. Из истории... С. $70-71$. 
чтобы «они, Донское Войско, были с ними в миру и на крымского хана стояли заодно». В результате переговоров стороны заключили мир, а калмыки в качестве гарантии дали двух аманатов и шертовали (на своей правде и по своей калмыцкой вере) за всех своих владельцев. Атаманы в свою очередь отправили к тайшам уже своих представителей - Ф. Будана и С. Разина, которые должны были окончательно решить вопрос об условиях участия калмыков в предстоящем крымском походе ${ }^{141}$. По-видимому, у Дайчина сложились весьма доверительные отношения с казаками, поскольку, судя по сведениям с Дона, тайша включил своих детей и внуков в состав посольства из 9 человек. Дайчин кочевал под Астраханью и готовил к крымскому походу войско из 6 тыс. калмыков и 2 тыс. ногаев под командой Чокулы ${ }^{142}$.

Большую помощь посольской миссии Горохова в калмыцкие улусы оказали назначенный царским указом в Астрахань главным воеводой боярин Г.С. Черкасский, а также окольничий С.В. Волынский и стольник А.Я. Дашков. Одновременно Г.С. Черкасский возглавил недавно созданный Калмыцкий приказ, сменив на этом посту В.Г. Ромодановского. Главным порученцем воеводы по связям с калмыками был его племянник К.М. Черкасский.

В апреле 1661 г. из Астрахани в калмыцкие улусы были отправлены К. Черкасский и стрелецкий сотник М. Сурин. Первоначально они прибыли в улус Дайчина, кочевавший на реке Узень, где пробыли 9 недель, затем, отправившись вверх по реке, достигли улуса Мончака, где прожили еще 5 недель. Есть интересные сведения, насколько калмыцкие тайши с большим уважением относились к К. Черкасскому. Например, при встрече Дайчин говорил Каспулату примерно следующие слова признания: «любит сына своего, Мончака тайшу, а ево де, Каспулата, ноипаче ево любит, и чтоб де он, Каспулат, у нево, Дайчина, был большой сын, выше Мончака). Очевидцы отмечали, что «и честь де ему, Каспулату, Дайчин тайша учинил великую»)

В результате переговоров с тайшами был заключен договор, по которому калмыки обязались выделить для совместного с русскими

${ }^{141}$ РГАДА. Ф. 111. Оп. 1. 1661 г. Д. 1. Л. 4, 5, 13.

${ }^{142}$ РГАДА. Ф. 119. Оп. 1. 1660 г. Д. 5. Л. 13; РИБ. СПб., 1917. С. 847-847, $850,885,923$.

${ }^{143}$ РГАДА. Ф. 112. Оп. 1. 1661 г. Д. 1. Л. 99. похода на Крым 500 воинов под началом 30 командиров. Военный сбор калмыцких отрядов из разных улусов состоялся на реке Еруслан, и общую команду из 472 воинов возглавил Зан-Кашка. Для переправки калмыков через Волгу царицынский воевода выделил 2 струга и 20 лодок. Уже на Дону калмыки соединились с русским войском под командой воеводы И. Хитрово и атамана К. Яковлева, состоявшим из 200 конных казаков, 3 тыс. казаков на судах и 6 тыс. пехотных солдат $^{144}$.

16 мая Горохов остановился в улусе Нима-Церена, где местные татары по секрету ему сообщили, что Мончак принял к себе 30 ceмей башкирских повстанцев, которых Дайчин принять отказался. В апреле 1661 г. башкиры совместно с яицкими казаками отогнали из улуса дербетского тайши Аючея 300 лошадей. Поскольку из-за этого инцидента под угрозой оказались предстоящие важные переговоры, Горохову для разрешения конфликта пришлось отправить своего порученца в Яицкий городок ${ }^{145} .22$ мая к Горохову прибыл Чокула с объявлением о готовности Дайчина принять его. Вместе с К.М. Черкасским русский посол прибыл к тайше, привезя ему царскую грамоту и жалованье.

При первом же знакомстве у Дайчина с Гороховым произошла словесная дуэль по поводу разного понимания церемониальных традиций. На предложение дьяка встать и снять головной убор «против царского величества имени» тайша ответил отказом, сославшись на отсутствие у калмыков подобного этикета перед иностранными послами. Когда же Горохов привел в пример имена других монархов, по его словам, не гнушающихся встать перед именем русского царя, Дайчин ответил, что поступает так не из гордости, и приказал своему переводчику Эсен-дархану встать и снять шапку. Таким образом, выход из ситуации был найден. Русский посол после обмена приветствиями и любезностями вручил калмыцкому правителю царскую грамоту и сообщил о положительном решении московскими властями ходатайства тайшей о возвращении калмыцких пленных, захваченных башкирами. Далее последовала процедура вручения тайшам государевых подарков и жалованья.

${ }^{144}$ РГАДА. Ф. 119. Оп. 1. 1661 г. Д. 1. Л. 29-33, 54

${ }^{145}$ РГАДА. Ф. 119. Оп. 1. 1660 г. Д. 5. Л. 42, 45. 
В течение последующих четырех дней Горохов вел переговоры не только с Дайчином, но и его ближайшим окружением, в ходе которых обсуждались различные вопросы: о задержке в Москве калмыцкого посла Урусамба, недостаточном размере выдаваемого тайшам царского жалованья, об укрывательстве в калмыцких улусах башкирских повстанцев и условиях взаимного ненападения ${ }^{146}$.

Дайчин рассказал Горохову о недавних походах калмыков на Кубань и под Азов, а также о дальнейшем намерении выдвинуться на Крым. Всем своим улусным людям тайша велел «заказ учинить крепкий»), чтобы «никаких ссор и задоров с людьми великого государя не чинили, только чтоб и от русских людей калмыкам лиха не было». Но до сих пор нерешенным оставался башкирский вопрос: «всегда всякое зло калмыкам от башкирцев». Горохов поставил в известность Дайчина о конкретных шагах правительства в решении этого вопроса: «по этой жалобе послан на Уфу стольник Сомов, велено ему про башкирцев сыскать накрепко, взятое ими отослать к вам в улусы, а башкирцев, пущих воров, велено казнить смертию, а других наказать торговою казнию». Но при этом дьяк указал на присутствие в калмыцких улусах башкирских повстанцев: «Башкирцы, пущие воры и ваших улусов разорители, Гаурко Ахбулатов с товарищами, 30 человек, избывая смертной казни, бежали и живут теперь у сына твоего Мончак-тайши, и сын твой, позабыв их обиды, сделал им большой привет и ласку, дал им на приезде по две лошади да по верблюду человеку, коров и овец дал немало». По мнению русского посланника, подобные действия тайшей были прямым нарушением заключенной шерти. В случае невыдачи повстанцев в Астрахань, то «вперед башкирцев от калмыцкого разоренья унимать нельзя»).

Дайчин, немного помолчав, сослался на незнание этой информации и посоветовал по этому вопросу переговорить лично с сыном: «Мончак сам владелец, а я стар, и улусные люди прочат Мончака, а я к нему с ближними своими людьми прикажу». На прощанье тайша пожелал Горохову скорой отправки в Москву: «службу нашу и послушанье великому государю объяви, и если вперед государю надобно будет наше калмыцкое дело, то государь указал бы ведать это дело в

${ }^{146}$ Преображенская П.С. Из истории... 72-73.
Астрахани Казбулату-мурзе Черкасскому, потому что ему калмыцкое наше дело за обычай>>147.

26 мая Дайчин отправил Горохова к Мончаку в сопровождении двух своих приближенных - Зоргучи-кашки и Эсен-дархана. Первым же делом Горохов отправил уфимцев к беглым башкирам, живущим у калмыков, чтобы выяснить, «для чего они великому государю изменили, с У фы бежали и какого себе добра ждут в калмыцких улусах» ${ }^{148}$. Как видно, царское правительство всячески старалось предотвратить любые контакты калмыков с башкирами.

29 мая состоялась первая встреча Горохова с Мончаком, и носила она во многом закрытый характер, поскольку тайша велел своим людям никого не впускать в кибитку. Мончак сразу же выразил Горохову свою готовность отправить калмыцкие отряды против Крыма. Переговоры не омрачил и факт присутствия в улусе крымского посла в лице азовского аги, поскольку тайша успокоил Горохова, заверив его в том, что у калмыков намерения мирные ${ }^{149}$. Можно предположить, что сознательно была устроена утечка информации о приезде крымского посольства через едисанского мирзу С. Абдулова, чтобы тем самым оказать определенное давление на русского посла во время переговоров.

При следующей встрече, но уже с участием едисанских мирз во главе с С. Абдуловым, последние, выразив недовольство отсутствием выплаты им из Москвы жалованья, открыто стали шантажировать Горохова: «если нам государева жалованья дано будет столько же, сколько давалось крымскому хану, по 40000, то мы на службу пойдем, а если жалованья не будет, то на службу не пойдем, а станем воевать по Волге города великого государя и его людей». При этом едисанские мирзы ставили себе в заслугу привлечение калмыков «к послушанью великого государя ${ }^{150}$. Мончак подтвердил Горохову, что его подвластные ногайские мирзы весьма недовольны тем, что не получают от государя никакого жалованья, хотя, по словам тай-

147 Соловьев С.М. История России с древнейших времен / Отв. ред. И.Д. Ковальченко, С.С. Дмитриев. Кн. VI. Т. 11-12. М., 1991. С. 555, 556.

${ }_{148}$ Соловьев С.М. Указ. соч. С. 556.

${ }^{149}$ Преображенская П.С. Из истории... С. 73-74.

${ }^{150}$ Соловьев С.М. Указ. соч. С. 556. 
ши, «можно было их обрадовать». Но Горохов, как опытный дипломат, ему возразил: «В Калмыцкой орде над калмыками и татарами владельцы вы, тайши, великий государь присылает вам жалованье, с вами о своих делах переговоры ведет, а мурзам в равенстве с вами быть непристойно; да и то вам знать можно, что мурзы и все татары калмыкам не доброхоты, послушны вам только из страха, по своей басурманской вере желают всякого добра крымцам, а калмыкам ищут всякого разоренья и хотят вас от милости великого государя отлучить».

Относительно крымского направления, то, по сведениям дьяка, «абызы их татарские по закону своему говорят, что татарам и Крыму быть от калмыков в разоренье». Поэтому Горохов предлагал калмыкам окончательно завладеть «крымскими юртами». На это предложение тайша ответил откровенно: «И в нашем калмыцком письме написано, что калмыки будут владеть крымскими юртами. Есть на Крымском острове гора, слывет Чайка-бурун, про ту гору написано у нас, что в нем много золота и владеть тем золотом калмыкам. Что татары нам не доброхоты, это мы и сами знаем, только и на русских людей надеяться нам нельзя... А крымский хан каждый год присылает послов к нам, сулит большую казну, хочет брать государевы города калмыцкими людьми и отдавать их совсем калмыкам. Но мы не слушаемся и крымскому хану не помогаем, но и войной нам идти на Крым с чего? Нам казны не прислано, а крымскому хану ежегодно из Москвы присылают по сороку тысяч золотых, однако же крымцы на Русь войною ходят, а калмыки чем хуже крымцев?» ${ }^{151}$.

Из приведенного разговора видно, что калмыцкие тайши были весьма недовольны малым размером жалованья, выплачиваемого Москвой за военную службу, особенно заметным на фоне крупных денежных «поминок», ежегодно отправляемых из Москвы к крымскому хану, что, по существу, выглядело политикой «задабривания врага». Такое положение, по всей видимости, не устраивало тайшей, а царское правительство считало, что компенсацией калмыкам могли бы послужить богатые трофеи, захваченные у крымских и ногайских улусов. Также очевидно и искусное умение Горохова вести перего-

\footnotetext{
${ }^{151}$ РГАДА. Ф. 119. Оп. 1. 1660 г. Д. 5. Л. 127, 128
}

ворный процесс, на все возражения и претензии калмыцкой стороны у него находились веские контрдоводы. В русле царской дипломатии русский посланник умело использовал наличие противоречий у соседствующих кочевых народов, в том числе и на религиозной основе.

Но в дальнейшем переговоры приостановились из-за очередного башкирского набега, в результате которого калмыки потеряли 2 тыс. лошадей. Этот случай круто изменил тональность переговоров: стороны перешли к взаимным обвинениям и угрозам по «башкирскому» и «ногайскому» вопросам. Однако Мончак, решив не обострять ситуацию и посоветовавшись с приближенными людьми, вернул разговор к основной теме - организации совместного крымского похода. В результате стороны договорились, что Мончак и Дайчин пришлют к Горохову своих доверенных лиц для подтверждения своих прежних обязательств. При этом Мончак недвусмысленно предупредил русского посла: в случае повторного башкирского набега он немедленно вернет калмыцкие войска с крымского направления и отправит их уже против башкир. Горохов заверил тайшей, что со своей стороны царское правительство предпримет все меры по недопущению в дальнейшем набегов на калмыцкие улусы и пришлет тайшам жалованье. Находившиеся в свите Горохова представители донского казачества также дали обязательство, что примут совместно с калмыками участие в предстоящем крымском походе ${ }^{152}$.

Предложение Горохова о возможности находиться в улусах представителям волжских городов для охраны калмыков от башкир не получило одобрения со стороны Мончака. Решение этого вопроса тайша видел, прежде всего, в организации совместной карательной экспедиции против башкир. Но Горохов и К. Черкасский все-таки уговорили Мончака воздержаться от ответных силовых действий, заверив, что необходимые меры правительством обязательно будут предприняты. Переговоры в целом закончились успешно, и стороны пришли к единому положительному решению ${ }^{153}$.

8 июня 1661 г. к Горохову прибыла калмыцкая делегация из 30ти человек, состоявшая из ближайшего окружения Дайчина и Мончака. Главными лицами здесь выступали Зоргучи-дархан, Дазан-каш-

152 Там же. Л. 135-137.

${ }^{153}$ Преображенская П.С. Из истории... С. 75. 
ка, Байскулан, Малай, Дай-дархан, Батур и другие. Зоргучи-дархан и Дазан-кашка, помолившись, «дали веру» в шертной записи за всех тайшей по калмыцкому обычаю, чтобы «идти войною ратным нашим людям нынешнего 169 году июня с 1 на 10 число на крымские улусы, и с крымским ханом в миру и в соединении нам не быть, а великого государя с людьми быть в вечном миру и в соединении и вспоможение русским людям везде чинить не оплошно. А что за помощью божьею поиск какой учиним над крымскими людьми и над их улусы, и нам, тайшам, и всем нашим калмыцким людям взятых крымских языков присылать к великому государю к Москве; а полон крымских улусов и отгонные лошади и всякую добычу назад крымским людям на выкуп ничего не отдавать, а продавать ту свою добычу великого государя в городах всяких чинов русским людям. А русских людей полоняников, что в крымских улусах добудем, и тех русских людей обьявлять и отдавать великого государя отчине в Астрахани, или в которые города ближе» ${ }^{154}$.

14 июня состоялась очередная встреча Горохова и К. Черкасского с Мончаком, на которой обсуждались уже детали предстоящего крымского похода. Мончак заявил о готовности тайшей отправить на войну около 10 тыс. калмыков. На следующий день к русскому послу пришли представители Мончака и Солом-Церена и поименно назвали командный состав калмыцкого войска. 16 июня Мончак собственноручно подписал подготовленную Гороховым «шертную запись» и список ратных людей. Процедуру подписания шерти Мончак закончил словами: «Как де бумага склеена, так бы де калмыцким людем с русскими людьми вместе быть вечно» ${ }^{155}$.

Вызывает интерес сам список командного состава и численности калмыцкого войска. Согласно договоренности, Дайчин выделял на крымскую кампанию 5 тыс. воинов под командой Чокулы и Эсендархана, Мончак - тысячный отряд под командой Усмана Батыртайши, Манжи-Ялбо - тысячный отряд под командой Куден Ясана, Дари-тайша - 1 тыс. воинов под командой Мергена. Солом-Церен выделил 500 человек под началом Эрдене-кошучи, не считая 400 вои-

${ }^{154}$ Полное собрание законов Российской империи: Собрание 1-е. Т. І. С. $531,532$.

${ }^{155}$ РГАДА. Ф. 119. Оп. 1. 1660 г. Д. 5. Л. 154. нов, которые ранее были оставлены на Дону для набегов. Дугар также выделил 500 воинов под командой Дурачи-кашки. Братья Аючей и Аюкей выставили 500 воинов под началом Макаис-тархана. Всего численность калмыцкого войска составила 9900 человек ${ }^{156}$.

Подробно изложив в свосй работе миссию Горохова в калмыцкие улусы, П.С. Преображенская сделала ряд существенных замечаний. Во-первых, посольские заметки отражают характерные черты калмыцкого подданства: определенную свободу внешних сношений и полную самостоятельность во внутренних делах; во-вторых, шерть от 8 июня 1661 г. носила характер военного договора, реально указывая на вассальные отношения калмыцких тайшей с московским царем ${ }^{157}$. Обращает на себя внимание и тот факт, что аманатство как рычаг воздействия на соблюдение договора уже не упоминается.

В августе 1661 г. в Москву прибыло калмыцкое посольство во главе с Зайсан-дарханом, Нанзаем, Зоргучи и Эрденом, а также 35 сопровождающими лицами ${ }^{158} .5$ августа калмыцких послов в Посольской палате принял царь Алексей Михайлович. Посланцы привезли от тайшей три письма. Поскольку в Посольском приказе на то время отсутствовали знатоки калмыцкого языка, то зачастую послы при помощи царских толмачей сами выступали в роли переводчиков письменных посланий тайшей. Первое письмо, написанное от лица Дайчина, Мончака и Манжи-Ялбо, было изложено на старописьменном татарском языке.

Божсию милостию великому государю, царю и великому князю Алексею Михайловичу всеа Великия и Мальл и Белыл России самодержиу, Дайчин да Мончак, да Манжик тайии с братьями и детьми, и с улусными людыми челом быют.

А что ты, великий государь, прислал в Астрахань боярина своего князя Григория Сунчалеевича, и он, князь Григорий Сунчалеевич, приехав в Астрахань, прислал к нам с твоим царским повеленьем узденя своего, чтоб в Крым идти войной. Н мы до Крылму не доили, а воевали Меньиой Нагай. Да по твоему великого государя указу прислал

${ }^{156}$ РГАДА. Ф. 112. Оп. 1. 1661 г. Д. 1. Л. 190-192.

${ }^{157}$ Преображенская П.С. Из истории... С. 77-78.

${ }^{158}$ РГАДА. Ф. 119. Оп. 1. 1661 г. Д. 2. Л. 1-2, 12; Д. 3. Л. 4. 
к нам племянника своего Каспулата просить ратных людей идти в Крым, и Каспулат нам ваи великого государя указ сказал.

И мы после приезду Каспулатова по киязю Григорьеву слову ратных людей Каспулату в руки дали и на недруга вамего, на Крым послали. И впредь на недруга вамего готовы для правды своей с Каспулатом и с Иваном (Гороховым - В.Т.) дуиами своими верилися, буде похочешь меня у себя в близости видеть. И вы московское мое дело прикажсте дьяку Ивану, а астраханское и терское дело прикажите князю Григорию да Каспулату.

А что я тебя чинился в близости, и то не любя, того недруг учнет говорить, и тебе б на его слова не смотреть. А сю свою грамоту послали к тебе, великому государю, с Зайсаном с товарицами. А для правды к сей грамоте приписал калмыцким письмом. И совериив посольские дела, послов наиих отпусти вскоре. Потом челом бью ${ }^{159}$.

Следующее письмо, изложенное уже на старописьменном монгольском языке

Небесный царь, а по намей вере святой бурхан, тебя, великого государя, Белого Царя, а меня, Дайчина тайшу, и Мончака помиловал. А потому вы, великий государь, были здоровы на много лет. А изволииь про нас ведать, и мы долго живы. И про ведомости меж обоими государствами послали грамоты да слово наме то.

Прежде крымскийхан был с нами неприятелем, как и вы, великий государь. А после вы, великий государь, и крымский хан стали жсть с нами дружно. Казбулат мурза киязь Муцалович да дьяк Иван Савельевич по твоему великого государя указу твое повеленье сказали. И по их сказке обо всем указ исполнили. А впредь что учинитца, и про то нам будет ведомо, то слово наме вам, великому государю. А послов наиих, не задержав, изволите к нам отпустить ${ }^{160}$.

Третье письмо, написанное уже от имени дербетского Солом-Церена, было изложено уже на старописьменном калмыцком языке и переведено совместно калмыцким послом и русским толмачом. На сегодня письмо дербетского тайши является наиболее ранним документом, составленным на старокалмыцком письме. Текст русского перевода XVII в. сохранился не полностью.

159 РГАДА. Ф. 119. Оп. 1. 1661 г. Д. 2. Л. 38-39.

${ }^{160}$ РГАДА. Ф. 119. Оп. 1. 1661 г. Д. 2. Л. 40, 41.ф
Великому государю и многих государств обладателю, Белому Царю, Вашего Царского Величества, калмыцкий Солом-Церен тайиа челом бьет. А после поздравленья. А мы по ваией милости живы.

Преж сего отеи наи, Далай-тайша, со многими улусными людьми был царем владетельным, и тот отеу наи, Далай-тайиа, к вам, великому государю, послал своего калмыка Бучия (в 1630 г. - В.Т.).

А ныле мы, сын его Солом-Церен тайща, против вашего государского неприятеля, крымского хана, преж сего 13 походов их улусы воевали и 7 их начальных мурз до смерти, да взяли в полон 4 мурз.

И в то время от вас, великого государя, послов не бывали. А ныне вы, великий государь, изволили ко мне нарочно посла своего прислать. А Казбулат мурза да дьяк Иван Горохов по ваиему великого государя указу говорили, и мы по вашему указу на Крым войною ратных людей послали.

Да о том у тебл, великого государя милости просим, чтоб великий государь пожаловал нам добрый иатер больиой, чтоб людям было что показать, да добрых 5 иуб собольих просим еще.

А мы вам, великому государю, служить рады... А даст бог ежели на Крым войною [идти], прося у бога милости, а бог надо мной отеч, и меня иметь [ввиду] с сыном. А чтоб меж нами было добро, а дурна бне было... ${ }^{161}$.

В нашем распоряжении есть выдержки и современного перевода этого письма ${ }^{162}$.

Ом а хум ${ }^{163}$. Здоров ли Великий бельй хан, проживающий в дальных местах и ведаюший многими улусами? Мы здесь пребываем во здравии.

Раньие отеи мой, Далай тайии, был ханом четырех ойратов. [Человека] по имени Буучи отправлял [отправлял к вам] послом. Ныне, я-сын его, Баатур тайши, отправил послами двух - Дайчи заргучи и Эркебани бакии.

Не твой ли враг - сын султана [из] Крыма? Тринадиать раз нападал я [на него]. Убил семерых нойонов (мирз). Пятерых княжен пленил. Четырех нойонов поймал.

${ }^{161}$ РГАДА. Ф. 119. Оп. 1. 1661 г. Д. 2. Л. 35-37.

162 Перевод выполнил Нацагдордж Цонгоол Батцэнгэлийн.

163 Буддийская мантра. 
В то время мой посол не ходил [к тебе], а твой посол не приходил сюда. Великий хан, отправь мне посла отдельно. Пожалуй мне отдельное жалованье

Отправил это войско по случаю заключения союза с Иваном, сыном Саввы. У хана проиу кольчугу, не пробиваемую ружьем, десять с лииним иатров для показа многим людям, десять беличьих икур ..., сто золотых [рублей] и десять тысяч тенге [монет], пать собольих иуб, десять добрых $[\ldots]$ шелка...

Ты стань моим отцом-ханом. Я стану сыном твоим... За то, что завериил хороио твои дела, подружил я с Иваном, сыном Саввы. Заключаем мир до тех пор, пока дети, которые сейчас родились, не станут седовласыми.

В Посольском приказе калмыцкие послы снова жаловались на башкирские набеги, которые произошли уже после заключения русско-калмыцкого договора. В результате у калмыков было отогнано 100 лошадей и убито 15 человек, а башкиры сумели скрыться в Самаре. Дайчин в приступе гнева стал готовить ответные действия против башкирских волостей, но от такого шага его отговорил К. Черкасский. По словам калмыцких послов, «от тех де башкирцов и иштяков исстари многие ссоры и задоры чинятца $)^{164}$.

После подписания июньской шерти военная служба калмыков стала носить более упорядоченный характер ${ }^{165}$. 5 августа Дайчин, Мончак и Солом-Церен через своего посланца Зайсан-дархана официально уведомили казаков о заключении шерти с И. Гороховым и К. Черкасским ${ }^{166}$. Данное событие весьма сильно встревожило жителей причерноморских степей. По сведениям пленных азовцев, крымские ногайцы настолько серьезно опасались прихода калмыков, что даже отказались от самой идеи набега на южнорусские земли ${ }^{167}$.

В июне 1661 г. донские казаки в Москве сообщали о подготовке тайшами к походу 6 тыс. калмыков и 2 тыс. ногайцев, которые предполагались быть вскоре на Дону ${ }^{168}$. Но в архивных документах нет

${ }^{164}$ РГАДА. Ф. 119. Оп. 1. 1661 г. Д. 1. Л. 86-87.

${ }^{165}$ Преображенская П.С. Из истории... С. 81.

${ }^{166}$ РГАДА. Ф. 111. Оп. 1. 1661 г. Д. 4. Л. 32, 39.

${ }^{167}$ РГАДА. Ф. 111. Оп. 1. 1661 г. Д. 4. Л. 39

${ }^{168}$ РГАДА. Ф. 111. Оп. 1. 1661 г. Д. 3. Л. 7. прямых свидетельств об отправке столь многочисленного «соединения». Причина, скорее всего, кроется в продолжавшихся башкирских набегах, которые русская сторона в ходе переговоров обещала пресечь, но не выполнила это условие.

21 июня Мончак по этому вопросу приезжал на стан к К. Черкасскому, сообщив, что 60 башкир совершили набег на подвластный ему ногайский улус, отогнав большое количество лошадей. Ногайцы ходили за ними в погоню, но в стычках с башкирами потеряли 13 человек убитыми, а последние успели скрыться в Самаре. Ввиду возникшей угрозы К. Черкасский немедленно отправил письмо к самарскому воеводе И. Языкову, чтобы тот задержал «воровских» башкир. Это в конечном итоге возымело действие, и уже в июле к Мончаку на Иргиз прибыли башкирские и уфимские посланцы с уведомлением, что готовы вернуть калмыкам захваченное ранее имущество, если на то будет соответствующий царский указ ${ }^{169}$.

По всей видимости, эти переговоры закончились ничем, так как в сентябре Г. Черкасский получил сообщение от И. Онучина, находившегося в это время в калмыцких улусах, что калмыки и ногайцы двинулись в ответный набег на Уфимский уезд ${ }^{170}$, где они разорили. захватив полон, Усолинский городок, чувашские и черемисские деревни ${ }^{171}$. Когда 27 сентября 1661 г. к тайшам приехали с жалованьем М. Греков и уздень И. Каржанов, чтобы забрать из улусов весь русский полон, то Мончак отказался выдать пленников только из Уфимского уезда. При этом он заверил, что никуда его не раздаст, пока не приедет из Москвы царский посланник, уполномоченный вести переговоры по «уфимскому делу» ${ }^{172}$.

В целом так и не решив калмыцко-башкирский конфликт, в крымском направлении стали выдвигаться лишь небольшие по численности калмыцкие отряды. Так, царицынский воевода сообщал в Москву о встрече казака А. Нормацкого и астраханца К. Кереитова с калмыцким отрядом в 500 человек во главе с Зан-кашкой. Именно этот отряд совместно с русским отрядом, состоявшим из 3 тыс. каза-

${ }^{169}$ РГАДА. Ф. 112. Оп. 1. 1661 г. Д. 1. Л. 289.

${ }^{170}$ РГАДА. Ф. 112. Оп. 1. 1661 г. Д. 1. Л. 327.

${ }^{171}$ РГАДА. Ф. 119. Оп. 1. 1661 г. Д. 2. Л. 64-67.

${ }^{172}$ РГАДА. Ф. 112. Оп. 1. 1661 г. Д. 1. Л. 342-344. 
ков и 6 тыс. солдат, 1 августа, ближе к вечеру, вступил в бой с неприятелем под Азовом. В результате азовцы потеряли убитыми 104 человека, а большая часть трофеев и 134 пленника достались калмыкам. При этом они отказались передать русской стороне пленных, не дав возможности их переписать и допросить, как того требовал атаман Корнила Яковлев. Захваченный калмыками у азовцев русский полон Зан-кашка по просьбе казаков передал атаманам, одного азовского языка отправили в Москву. В бою калмыки потеряли убитыми всего лишь трех человек ${ }^{173}$.

Сославшись на конский падеж, часть калмыков с захваченными трофеями вернулась обратно в улусы, а другая часть под командой Эсен-дархана совместно с К. Черкасским двинулась на Терек против ногайских улусов мирз Султанаша, Каракасая и Ислама, намеревавшихся откочевать из-под «государевой руки») к крымскому хану. 8 августа 1661 г. в Астрахань прибыл кабардинский князь К. Черкасский с тысячным калмыцким отрядом. В разговоре с астраханскими воеводами он сообщил, что тайши Дайчин, Мончак и Манжи-Ялбо предоставили ему калмыцкий отряд, чтобы идти к Тереку и заставить находившихся там ногайских мирз кочевать под («осударевой рукою» у Терского городка или под Астраханью. У терских ногайцев была альтернатива - присоединиться к калмыкам. 13 августа К. Черкасский с калмыцким отрядом выступил из Астрахани к Терской крепости. Вдогонку тайши отправили дополнительно 500 татар-келечинцев под командой Мамедимина и 400 калмыков из улуса Манжи-Ялбо под началом Мангыш-кашки. 28 августа в Астрахань от Дайчина прибыл Кенжей Катлешев, один из участников терского похода, с сообщением, что ногайские мирзы Султанаш и Каракасай со своими улусами (5 тыс. человек) направляются с Терека, чтобы совместно кочевать с калмыками, а мирзе Исламу со своим улусом удалось укрыться у кумыков в горах ${ }^{174}$.

После Терского похода К. Черкасский с калмыками направился уже в западную часть Кавказа - под Бесленей, Кимирдей (Темиргой)

${ }_{173}$ РГАДА. Ф. 112. Оп. 1. 1661 г. Д. 1. Л. 312; Ф. 119. Оп. 1. 1661 г. Д. 1. Л. 28.

${ }^{174}$ РГАДА. Ф. 112. Оп. 1. 1661 г. Д. 1. Л. 220, 224, 278, 315; Ф. 119. Оп. 1 1661 г. Д. 1. Л. 28, 34-35, 42, 46-47, 54; Шмелев А.С. Указ. соч. С. 230-231; Очерки... С. 124. и Темрюки, где им в качестве трофеев достались 8 тыс. овец и 1200 лошадей. Командиры калмыцких отрядов, Янтой Чокула и Эрке-кашка, приняли решение об отправке 300 человек во главе с Карантушем обратно в улусы с захваченным скотом, в то время как с остальными людьми продолжали оставаться на Кавказе 175 .

В сентябре 1661 г. Дайчин и Мончак отправили в поход на Крым отряд из 1100 человек во главе с Зан-кашкой ${ }^{176}$, который, по всей видимости, действовал и в южной части Украины. В ноябре гетман Левобережной Украины И. Брюховецкий, московский подданный, просил донских атаманов передать тайшам сведения о неких калмыках, которые, действуя одновременно против Крыма, «заходят к ним на Запорожье и их в полон емлют и разоряют». Гетман предлагал, чтобы калмыки, перед тем как идти на Крым, «с ними, с Войском Запорожским, ссылались и над крымскими улусы промысл чинили заодно» ${ }^{177}$.

По всей видимости, в новом для себя регионе калмыки плохо ориентировались в политической расстановке украинского общества, разделенного на противоборствующие стороны. Известно, например, как некий донской казак с группой запорожцев попал в плен к калмыкам. Если донца последние отпустили, то запорожцев убили, мотивируя это тем, «что они (калмыки. - B.T.) с ними, черкасы, не в миру, что де они царскому величеству изменники, и впредь де их они воевать учнут» ${ }^{178}$. Запорожцев, видимо, калмыки посчитали противниками России, имея в виду предательство гетмана Ю. Хмельницкого осенью 1660 г., в результате которого стало возможным поражение русской армии под командованием В. Шереметьева.

В октябре Сефер Гази-ага, один из приближенных к крымскому хану Мухаммед-Гирею, в разговоре с русским послом в Крыму Ф. Байбаковым обвинил царские власти в том, что они прислали к тайшам посольство с казною и призывали калмыков идти войной на крымские земли. По сведениям крымцев, «калмыки приходили и улусным людем на степи шкоду учинили, стада отогнали, а Крымом не завладели». Только благодаря усилиям нуреддина Мурат-Гирея,

\footnotetext{
${ }^{175}$ РГАДА. Ф. 112. Оп. 1. 1661 г. Д. 1. Л. 431, 432

${ }^{176}$ Преображенская П.С. Из истории... С. 82.

177 РГАДА. ОП. 1. Ф. 111. 1661 г. Д. 6. Л. 3.

${ }^{178}$ РИБ. СПб., 1917. С. 930-931.
} 
лично руководившего обороной ханства, удалось в конечном итоге отбить набеги калмыцких отрядов. Со своей стороны русский посол всячески отрицал причастность своего правительства в организации какого-либо военного мероприятия против Крыма с привлечением калмыков, указывая лишь на то, что царь «посылал калмыкам жалованье за то, чтоб они государевым понизовым городам шкоды не чинили, а не на Крым итти» ${ }^{179}$.

В ноябре 1661 г. калмыцкий отряд в 200 всадников из улуса тайши Дугара отогнал с прилегающих к Крыму земель 2 тыс. лошадей, захватив 100 человек «ясыря». Той же осенью конный отряд в тысячу воинов двинулся на Крым и уже за Днепром отогнал многочисленный табун. Захваченные в плен пастухи сообщили, что крымские улусы остались без защиты. Это стало сигналом: отряд из 800 калмыков отправился в повторный набег, а 200 воинов погнали захваченных лошадей к себе в улусы ${ }^{180}$.

Мончак по приказу князя Г. Черкасского осенью отправил на Крым конный отряд в 800 воинов под командованием Умар-кошучи. В декабре из-под Крыма вернулись 350 человек, которые пригнали тысячу лошадей. Другая половина отряда продолжала действовать в степях, прилегающих к Крыму. Эти набеги приносили калмыкам богатые трофеи, и Мончак дополнительно отправил на Крым еще 700 воинов, которые привели 150 крымских «ясырей». Наибольших успехов достиг один из отрядов Мончака под командованием Будан-Церена: в боях они убили большое количество крымцев (включая знаменитого Сары-мирзу, неоднократно совершавшего набеги на русские земли) и захватили много «ясыря», лошадей и скота ${ }^{181}$.

4 декабря к воеводе Г. Черкасскому от Мончака прибыл посланец Чеган-кашка, из сообщения которого стало известно, что отряд в 300 калмыков ходил под Крым и отогнал 1500 лошадей. На обратном пути калмыки разбили одно из крымских подразделений, шедшее на соединение к хану для дальнейшего набега на южные русские города. Если одного пленного крымца в качестве «языка) и в сопровождении

${ }^{179}$ РГАДА. Ф. 123. Оп. 1. 1659 г. Д. 3. Л. 111, 112.

${ }^{180}$ РГАДА. Ф. 112. Оп. 1. Д. 1661 г. Д. 1. Л. 469; Ф. 119. Оп. 1.1662 г. Д. 1. Л. 7, 10.

${ }^{181}$ РГАДА. Ф. 119. Оп. 1. 1662 г. Д. 1. Л. 13-14, 24. отряда из 50 человек под командой Умар-дархана отправили к Мончаку, то остальные калмыки под началом Будачири-кашки и Церена остались в причерноморских степях для разведывания за перемещением крымских войск. Только после получения от них разведывательной информации о положении дел в Крыму, Мончак планировал отправить в этот регион дополнительные отряды ${ }^{182}$.

Новый импульс русско-калмыцким отношениям, особенно в вопросе организации нового крупного наступления калмыков в крымском направлении, был задан благодаря усилиям астраханского воеводы Г. Черкасского. Многие калмыцкие владельцы высоко отзывались о деятельности князя. Например, когда в сентябре в Астрахань прибыл посланец Манжи-Ялбо, Зоргул-Далай Башаев, он передавал воеводе весьма лестные о нем отзывы: «калмыцким людям дурна и никакой худобы нет, опричь всяких добрых дел», «а прежде сего так не бывало, и за то де иво, боярина и воеводу князя Григория Сунчалеевича Черкасского, калмыцкие тайши похваляют ${ }^{183}$.

6 ноября 1661 г. в урочище Берекети (в 60 верстах от Астрахани) начался сьезд с участием калмыцких, едисанских, джемболукских и малибашских правителей и военачальников. На нем присутствовали практически все калмыцкие тайши, кроме Манжи-Ялбо. В результате переговоров было принято решение: как установится лед на Волге, отправить калмыцкие отряды на Крым. Мончак, как глава всех калмыцких владельцев, дал клятву астраханскому воеводе за отца, сыновей, племянников и других тайшей и мирз в том, что будут «в вечном послушании и на государевой службе) ${ }^{184}$.

Организация такой встречи русскими властями стала шагом своевременным, поскольку незадолго до этого к тайшам, которые кочевали в районе между Черным Яром и Астраханью, прибыло очередное крымское посольство во главе с Текей-агой. Крымцы снова предлагали мир и призывали калмыков к участию в совместной войне против России. Но им было вновь отказано: «в миру де калмыкам с крымцы никому не бывать». Крымских послов тайши просто по-

${ }^{182}$ РГАДА. Ф. 112. Оп. 1. 1661 г. Д. 1. Л. 453, 454.

${ }^{183}$ РГАДА. Ф. 112. Оп. 1. 1661 г. Д. 1. Л. 408.

${ }^{184}$ РГАДА. Ф. 119. ОП. 1. 1662 г. Д. 1. Л. 52-53; Кичиков М.Л. Указ. соч. 
ставили перед фактом, что они идут на Крым «большим собраньем войною». По приказу Мончака крымских послов какое-то время насильно удерживали в его улусе во избежание утечки сведений о готовящемся нападении на Крым. Очевидцы отмечали и отнюдь не гостеприимное отношение калмыков к прибывшим крымцам: «чести им и корму нет». Но на предложение Г. Черкасского о передаче крымцев в Астрахань, тайши ответили отказом ${ }^{185}$. Вскоре Текей-аге удалось добиться разрешения вернуться в Крым, и «Дайчин де им сказал: как де они приехали, так бы и поехали». Ранее обещанных 100 лошадей и 30 «ясырей» он им так и не дал и к хану в подарках ничего не отправил $^{186}$

В ноябре стрелецкий сотник Г. Голочолов в пяти верстах выше Царицына наблюдал улус Мазан-Батура, с которым он лично познакомился. По словам тайши, он также участвовал в русско-калмыцком съезде, на котором произошло знаменательное событие - сватовство племянницы князя Г. Черкасского - Обелханы (Абуханы) Муцаловны и сына Мончака - Аюки. Стороны договорились, что свадьбу сыграют после зимнего похода на Крым. Тогда же водным путем по Волге возвратились из Москвы калмыцкие послы с жалованьем для тайшей и высадились возле Черного Яра ${ }^{187}$

В результате русско-калмыцких переговоров 9 декабря 1661 г. Мончак подписал новый текст шерти, более конкретный по содержанию в сравнении с июньским договором. Отчетливо были сформулированы внешнеполитические обязательства тайшей: «с турским султаном и с кызылбашским ханом, и с крымским ханом, и с азовским беем, и с Темрюки, и с Табаны, и с Бесленейцы, и с Кумыки нам, тайшам, ... в ссылке и в соединенье, и в миру не быть». Тайши также обязывались не помогать им оружием и лошадьми, не посылать им в помощь людей. Такие же обязательства давались и по отношению к другим «иноземцам», которые «великому государю не послушны») ${ }^{188}$.

${ }^{185}$ РГАДА. Ф. 119. Оп. 1. 1662 г. Д. 1. Л. 6, 44; Акты Московского государства, изданные Императорскою Академиею Наук. Т. 3. Разрядный приказ. Московский стол. 1660-1664 гг. СПб., 1901. С. 460-461.

${ }^{186}$ РГАДА. Ф. 112. Оп. 1. 1661 г. Д. 1. Л. 467.

187 АМГ. СПб., 1901. С. 460-461.

188 ПСЗРИ. СПб., 1830. Т. 1. С. 540-541.
По мнению В.И. Колесника, таким способом Мончак единолично замыкал на себе все контакты на высшем уровне с северным соседом, оттесняя отца и племянника от очень важного направления во внешней политике ${ }^{189}$. После шертей 1661 г. правительство целых 12 лет не требовало от калмыцких тайшей их подтверждения, что свидетельствует о достаточно твердой уверенности в военной службе калмыков $^{190}$.

Упоминание в декабрьской шерти народов Северного Кавказа отнюдь не было случайным, поскольку тайши имели виды и на этот регион. В декабре 1661 г. Дайчин, Мончак, Солом-Церен, Дугар, Лобачи, Даря, Доржи, Батур и Бок отправили сводный отряд в 300 калмыков под командованием Зоргул Зоритуева и Уваш-кашки Тулуева к шевкалу и другим кумыцким владельцам. Тайши потребовали от них «учиниться» в подданстве у русского царя, в противном случае они грозились начать против них военные действия. В результате кумыки согласились и пообещали калмыкам прислать своих представителей в Астрахань. Известно также, что Манжи-Ялбо рассчитывал связать династические узы с кумыцкой аристократией, взяв в жены дочь таркинского шевкала ${ }^{191}$. Как стало известно позже, главным переговорщиком с калмыцкой стороны был Алыбай-дархан ${ }^{192}$.

Дайчин и Мончак отправили своих людей в Кабарду для сбора ясака с местных владельцев - Алегуки, Котогожуки и Арсланбека. При этом строго их предупредили, «чтоб они были у них в послушанье, а ясаку крымскому хану не давали» ${ }^{193}$. Все эти факты свидетельствуют о серьезном влиянии калмыцких тайшей на Северном Кавказе.

Заключение русско-калмыцкого договора о военно-политическом сотрудничестве имело большой резонанс не только в северокавказском регионе, но и далеко за его пределами. Астраханские татары, побывавшие на Кавказе, Г. Черкасскому сообщали: «Да и то де в кумыцкой земле говорят, не умолкая, и удивляютца большим удивле-

\footnotetext{
${ }^{189}$ Колесник В.И. Указ. соч. С. 87.

${ }^{190}$ Преображсенкая П.С. Из истории... С. 79; Очерки... С. 122.

${ }^{191}$ РГАДА. Ф. 119. Оп. 1. 1662 г. Д. 1. Л. 6, 20-23.

192 РГАДА. Ф. 112. Оп. 1. 1661 г. Д. 1. Л. 483.

${ }^{193}$ РГАДА. Ф. 112. Оп. 1. 1661 г. Д. 1. Л. 469.
} 
ньем, как де так доброе дело зделалось, чтоб боярин и воевода, да князь Григорий Сунчалеевич Черкасской... с калмыцким с Мончаком тайшею и о всем договорился, и с калмыками соединился, чево де извеку не бывало». Сведения об этом союзе дошли и до Османской империи, традиционно внимательно следившей за ситуацией в регионе: «Да и турскому де солтану про то ж калмыцкое дело ведомо учинилось, и он де тому не доверивает, и говорит де как де так калмыки доброе соединенье учинилось; только де подлинно так, и то де великое дело великому государю учинилось». Для подтверждения этой информации султан даже отправил письменный запрос крымскому хану, и тот подтвердил ${ }^{194}$.

Ситуация на Кубани также была весьма сложной. Малые ногайцы понесли серьезные потери в ходе совместной с крымцами неудачного зимнего набега на южные территории Московского государства, потеряв практически половину своих людей. Как сообщал бежавший из кубанского плена калмык Манжи, по погибшим ногайцам в улусах «у них де плач был таков же, как де в прошлых годах в горех побили Урлюка тайшу». В свете последних событий казыевцы отказали крымцам в военной помощи, так как «от их калмыцкого разоренья и так их, казыевцов, стало мало ${ }^{195}$

Отправка относительно небольших по численности калмыцких отрядов на Северный Кавказ и крымский театр военных действий обьяснялось еще и тем, что для волжских калмыков сохранялась угроза со стороны восточных соседей. Так, 18 декабря 1661 г. посланцы Солом-Церена, Обак и Бежук, в Астрахани ставили в известность Г. Черкасского, что Дайчин и Мончак собираются идти войной на «дальних» калмыков, и только после этого принять личное участие в крымском походе ${ }^{196}$

Напряженность в отношениях с восточными калмыками, повидимому, была вызвана событием, произошедшим в 1660 г., и связана с личностью торгутского тайши Лузана. Летом этого года хошутский Аблай разгромил улус Лузана, убив самого тайшу и двух

${ }^{194}$ РГАДА. Ф. 112. Оп. 1. 1661 г. Д. 1. Л. 573, 574.

${ }^{195}$ РГАДА. Ф. 112. Оп. 1. 1661 г. Д. 1. Л. 564, 569.

${ }^{196}$ РГАДА. Ф. 112. Оп. 1. 1661 г. Д. 1. Л. 461, 462; Ф. 119. Оп. 1. 1662 г. Д. 1. Л. 16-18. его сыновей - Доржи и Галдаму ${ }^{197}$. Причиной этому стали несанкционированные набеги торгутов Лузана и дербетов Кешкепа совместно с кучумовичами на сибирские города. Неоднократные предупреждения в их адрес от Аблая, стремившегося поддерживать мирные отношения с русскими, закончились в конечном итоге полным разгромом улусов «непослушных» тайшей ${ }^{198}$. Как сообщал джемболукский мирза Шамамет Г. Черкасскому, примерно в августе 1661 г. от хошутского Доржи к Дайчину прибыли двое посланцев с известием о разгроме Аблаем его и улуса торгутского тайши Орджана, сына Кирсана. Незадолго до этого Аблай потребовал от них бежавших после погрома улусных людей погибшего Лузана. Получив отказ, Аблай организовал против двух тайшей карательный поход и «многих де их людей побил». Дорджи и Орджан с оставшимися после разгрома улусными людьми скрывались в урочище Намет Тургай и оттуда решили откочевать к Дайчину ${ }^{199}$. Когда в сентябре к Дайчину прибыли посланцы из улуса Лузана, то тайша намеревался отправить к ним для встречи отряд, но Мончак отменил приказ отца, посоветовав для начала заключить договор с воеводой Г. Черкасским и дождаться возвращения многих воинских людей, разосланных в разные направления ${ }^{200}$. И только в октябре на Волгу прибыли остатки разгромленного улуса Лузана (100 человек) во главе с его вдовой Цецен-Каныш. Дойдя до Яика, она отправила посланцев к Дайчину и Мончаку с просьбой принять их обратно, и к ним срочно был отправлен военный отряд для встречи беженцев ${ }^{201}$. В дальнейшем потомки Лузана, находясь в числе мелких владельцев, уже не претендовали на власть и не имели влияния среди волжских калмыков.

${ }^{197}$ РГАДА. Ф. 119. Оп. 1. 1661 г. Д. 1. Л. 56

${ }^{198}$ РГАДА. Ф. 119. Оп. 1. 1661 г. Д. 1. Л. 89.

${ }^{199}$ РГАДА. Ф. 112. Оп. 1. 1661 г. Д. 1. Л. 394, 395.

${ }^{200}$ РГАДА. Ф. 112. Оп. 1. 1661 г. Д. 1. Л. 369.

${ }^{201}$ РГАДА. Ф. 119. Оп. 1. 1662 г. Д. 1. Л. 7. 


\section{Глава 6. \\ ПОЛИТИЧЕСКАЯ СИТУАЦИЯ В СЕВЕРНОМ ПРИКАСПИИ В 1662-1672 ГГ.}

\section{1. Укрепление власти Мончака}

В феврале 1662 г. в Астрахань прибыла группа казацких представителей: донские казаки В. Гладков и С. Разин, запорожский казак Е. Тимофеев и другие. Перед ними стояла конкретная задача агитировать калмышких тайшей за продолжение совместной борьбы против Крыма. Но в это время Дайчин, как оказалось, со своими войсками уже двинулся за Яик против чакарцев, а Мончак следовал за отцом. На этом основании тайши объяснили властям, что лично не смогут участвовать в крымской кампании. Но Мончак, следуя договоренностям, все-таки выделил в крымский поход отряд в 500 калмыков под командованием Каракучи ${ }^{1}$

Еще одним условием своего личного участия в крымской кампании Мончак выдвигал обязательное участие в ней и астраханского воеводы Г. Черкасского. Но в Москве были против подобного предложения и власти указали прибыть из Астрахани в Царицын - центр командования войсками на южном направлении - К. Черкасскому, думному дворянину 3. Левонтьеву и дьяку А. Ташлыкову. Г. Черкасскому указывалось оставаться на прежнем месте, поскольку «отчина Астарахань - место великое и пограничное»?

4 марта 1662 г. к астраханскому воеводе Г. Черкасскому прибыл от тайши Дайчина посланец Алыбай-дархан. Выяснилось, что этот ногайский подданный калмыцкого тайши, «ведавший» посольскими связями калмыков с мусульманскими государствами, осенью 1661 г. побывал с визитом в Крыму. По словам посланца, хан Мухаммед-Ги-

${ }^{1}$ РГАДА. Ф. 119. Оп. 1. 1662 г. Д. 1. Л. 51, 52, 89, 90.

${ }^{2}$ РГАДА. Ф. 112. Оп. 1.1661 г. Д. 1. Л. 585, 586. рей в разговоре с ним обвинил калмыков в том, что они «ему, крымскому хану, делают многую неправду и иво разоряют». В случае отказа калмыцких тайшей от участия в войне на стороне Москвы, хан обещал им в награду города Казань, Астрахань, Касимов, Симбирск, Нижний Новгород, Тамбов и Шацк. По словам Алыбая, он резонно возразил хану, «что те городы великого государя, а не ево, крымского хана, и как он смеет чюжие городы давать, и как ему их дать, а тайшам де и самим те городы не надобны, что они, тайши, у великого государя в подданстве». Посольская миссия Алыбай-дархана в Крым состояла лишь в том, чтобы официально объявить войну крымскому хану, а угроза калмыцкого посланца полностью разорить владения хана вызвала у того бурю негодования. Алыбай был арестован. Мухаммед-Гирей пригрозил калмыкам направить против них 40-тысячную армию, и что им «из Волги воды пить не дадут». Однако после очередного набега калмышкой конницы на крымские владения, хан поспешил отправить калмыцкого посла вместе со своим человеком, Касим-мирзою, к тайшам с предложением мира, а также жалобой на дерзкое поведение Алыбай-дархана: «к нему, крымскому хану, приезжает 3 большим невежеством и з грозами». Но при встрече с крымским посланшем Дайчин и Мончак еще раз подтвердили, что находятся с крымцами в состоянии войны, потому что «от него, крымского хана, правды и постоянства нет, а они де тайши иво, крымского хана, не боятца не в чем $)^{3}$.

Несмотря на столь воинственные заявления, тайши продолжали поддерживать посольские отношения с крымским ханом, так как все еще оставался ряд неурегулированных вопросов, в частности ногайский. Об этих переговорах было известно русскому представителю в Крыму Ф. Байбакову. Согласно его сведениям, в апреле 1662 г. к хану прибыло очередное калмыцкое посольство с требованием - вернуть тех ногайцев, которые откочевали от калмыков «по наговору» Караш-аги. В случае невыполнения этого требования тайши угрожали, что «с московским войском пойдут на Крым войною» ${ }^{4}$.

Отъезд Дайчина и Мончака в восточном направлении был напрямую связан с приходом к торгутам в конце 1661 г. дербетских и

${ }^{3}$ РГАДА. Ф. 112. Оп. 1. 1661 г. Д. 1. Л. 482-485.

${ }^{4}$ РГАДА. Ф. 123. Оп. 1. 1659 г. Д. 3. Л. 126, 127. 
хошутских улусов. В частности, это были улусы хошутских тайшей Кунделен-Убаши и его старшего сына Доржи, а также дербетских тайшей Малая, сына Даян-Омбо, и Алдара, сына Чуу. Не вполне уверенный в своих силах, Мончак просил русские власти оказать ему военную помощь в случае возможной военной агрессии со стороны восточных соседей. Следует отметить, что на ноябрьском русско-калмыцком сьезде 1661 г. под Астраханью присутствовали и представители хошутских тайшей - Цецен, Эрген и Джовба 5 .

Причин очередного прихода части дербетов и хошутов к торгутам было несколько. Во-первых, внутри “хошутского дома» произошел новый виток борьбы между сводными братьями - сыновьями покойного Байбагаса, тайшами Аблаем и Очирту. Это событие подробно освещено в «Биографии Зая-пандиты». Попытки Зая-пандиты примирить братьев успеха не имели. Зимой 1660/61 года Очирту во главе 30-тысячного войска выступил против брата, находившегося в долине реки Аягуз. На стороне Аблая выступили его дядя КунделенУбаши и дербетские тайши, сторону Очирту приняли джунгарские тайши (цоросский Сенге и хойтский Солтан). Летом 1661 г. сторонники Аблая потерпели от джунгаров сокрушительное поражение в двух сражениях. Оказавшись заблокированным в своем монастыре Аблайин-кит на Иртыше, Аблай вынужден был сдаться на милость победителям ${ }^{6}$. Кунделен-Убаши, решив не испытывать судьбу, со своим улусом перекочевал в степи северо-восточного Прикаспия. Это был уже второй по счету его приход к торгутам, и Дайчин, как и в 1649 г., принял хошутов, предоставив им свои восточные кочевья.

Во-вторых, из письма едисанских мирз к Г. Черкасскому от 12 октября 1661 г. становится известно о прибытии к Дайчину какого-то количества дербетов, которые кочевали по Тургаю. Приход их был связан с тем, что у них «учинилась война с Аблай тайшою»?

В-третьих, желание закрепиться на торгутских кочевьях по Яику y части чакарских тайшей было вызвано и военным давлением на них со стороны каракалпаков Шабана, особенно усилившееся во второй половине 1662 г.

${ }^{5}$ РГАДА. Ф. 119. Оп. 1. 1662 г. Д. 1. Л. 11-12.

${ }^{6}$ Раднабхадра. Указ. соч. С. 76-79.

${ }^{7}$ РГАДА. Ф. 112. Оп. 1. 1661 г. Д. 1. Л. 416.
Но большинство улусов чакарских тайшей продолжало оставаться на прежних кочевьях, в районе Тургайской ложбины и Северного Приаралья, поэтому переход к торгутам не носил массового характеpa. В феврале 1663 г. к Дайчину прибыли двое послов от дербетского Даян-Омбо с требованием вернуть тех дербетов, которые примкнули к торгутам осенью 1662 г., угрожая в случае отказа начать войну ${ }^{8}$. Здесь, по-видимому, имеется в виду откочевавший к торгутам дербетский улус старшего сына Даян-Омбо - Малай-Батура, предка малодербетовских князей Тундутовых.

В марте 1663 г. Уралма, супруга Мончака, сообщала в Царицын воеводе Г. Черкасскому, что за прибывшими осенью 1662 г. хошутами и дербетами движутся джунгарские войска ее брата Сенге и Галдамбы (ее зятя и сына Очирту), которые требуют от торгутских тайшей, чтобы те не принимали беглецов ${ }^{9}$. Но, по всей видимости, Уралма преувеличила опасность, поскольку в указанные годы в русских и ойратских источниках нет никаких сведений о крупных перемещениях джунгарских войск в западном направлении.

Временное отсутствие Дайчина и Мончака в кочевьях, связанное с приходом большого количества ойратов с востока, подтолкнуло к дестабилизации политической ситуации в Северном Прикаспии. Главным зачинщиком здесь выступил Манжи-Ялбо ${ }^{10}$, который, как известно, был старшим сыном покойного Даян-Эрке. Несомненно, если бы Даян-Эрке был жив, то он на правах старшего сына попытался бы взять власть в свои руки и передать ее уже своему старшему сыну. Можно с уверенностью сказать, что на рубеже 1650-1660-х гг. в торгутском правящем доме сложился своего рода триумвират - Дайчин, Мончак и Манжи-Ялбо. Однако, если в шерти 1657 г. имя Манжи-Ялбо стояло в одном ряду с именем дяди Мончака, то в июньской

${ }^{8}$ РГАДА. Ф. 119. Оп. 1. 1662 г. Д. 1. Л. 110, 119, 120.

${ }^{9}$ РГАДА. Ф. 119. Оп. 1. 1663 г. Д. 1. Л. 153.

${ }^{10} \mathrm{~B}$ документах этот тайша фигурирует под двумя именами - Манжи и Ялбо (Джалбо). Вот какое объяснение этому дает в своих записках Витсен: «Его имя - Йалба, а Доис - имя его отца. Прежде он имел другое имя (Манжи. - B.T.), но он все время болел и, считая, что причиной болезни является имя, переменил его» (Витсен Н. Путешествие в Московию. СПб., 1996. C. 200.). 
шерти 1661 г. упоминаются имена только Мончака и Дайчина как главных гарантов с калмыцкой стороны. Это свидетельствует о том, что внутриполитическая обстановка в торгутском доме изменилась, и в расстановке сил большую роль уже играли поддержка большинства представителей правящей калмыцкой элиты и позиция русского правительства.

Декабрьскую шерть 1661 г. Мончак уже единолично давал за весь калмыцкий народ. Такое положение ему обеспечивало настроение большинства народных масс и калмыцкой элиты. Это подтверждают и сообщения татар в Астрахани осенью 1661 г. о том, что улусные люди Дайчина и Манжи-Ялбо «ни в чем не почитают и не слушают, а во всем де почитают и слушают Мончака тайшу... и калмыки де и татары владеет он, Мончак) ${ }^{11}$.

Первое упоминание о конфликте между дядей и племянником мы находим из сообщения Мончака к воеводе Г.С. Черкасскому еще в мае 1661 г., т.е. уже после возвращения из кавказского похода. Накануне важных русско-калмыцких переговоров тайша отказывался приезжать под Астрахань или Красный Яр, так как опасался оставить без присмотра свой улус. Мончак прямо указывал, что существовала для него угроза со стороны Манжи-Ялбо, как он сам отмечал: «учинилась ссора за улусных людей и отцу иво, Дайчину, и ему, Мончаку, ныне он недруг». Также в своем письме Мончак высказывал подозрение о намерении племянника откочевать с улусом на дальние кочевья, под покровительство Елдена ${ }^{12}$.

В этой ситуации интересно проследить за поведением самого Манжи-Ялбо. Единственным из тайшей, кто отказался участвовать в дальнейшей войне против Крыма на стороне России, был именно он. Но его антирусские настроения не ограничивались только этим. Утром 29 декабря 1661 г. под Терским городком появились калмыки из улуса Манжи-Ялбо под командованием Мангуш-кашки. Здесь они захватили ногайские улусы кейкувата Ямгурчи-мирзы Янмаметева и его брата Сеит-Мамбета. Ввиду того что указанные ногайские мирзы на тот момент являлись царскими подданными, астраханский воевода

${ }^{11}$ РГАДА. Ф. 119. Оп. 1. 1661 г. Д. 1. Л. 56.

${ }^{12}$ РГАДА. Ф. 112. Оп. 1. 1661 г. Д. 1. Л. 111.
Г.С. Черкасский срочно сообщил об этом инциденте старшим тайшам $^{13}$.

11 января 1662 г. к воеводе Г. Черкасскому от Манжи-Ялбо прибыли посланцы с обьяснением, что Мангуш-кашка с пятью сотнями калмыков якобы кочует сам по себе и нападение на терских ногайцев совершил без «ведома) своего тайши. Со слов посланца, Манжи-Ялбо «за то на них шумел, что де в их воровстве и в ссоре ему, Ялбе, от тебя, великого государя, быть не в милости, и за то хочет он тех своих людей розграбить». В качестве демонстрации серьезности своих намерений он предлагал приехать астраханскому представителю к нему в улус, чтобы тот стал свидетелем расправы над виновниками. Все захваченное имущество у ногайцев тайша обязался вернуть ${ }^{14}$.

Правящая калмыцкая верхушка была в полном недоумении, некоторые из них даже пытались оправдать молодого тайшу. 18 января 1662 г. в Астрахань прибыл Каши, посланец Уралмы. Она сообщила, что люди Манжи-Ялбо действительно захватили ногайских мирз на Тереке якобы без ведома своего тайши, а Дайчин «такова дела не хвалит... и на Ялбу тайшу в том добре досадует». После того, как Дайчин отправил трех своих родственников с выговором к внуку, тому пришлось отдать всех захваченных ногайцев деду, которых затем вернули в Астрахань и на Терек ${ }^{15}$.

Но дальнейшие действия показали, что Манжи-Ялбо все-таки имел самое непосредственное отношение к последним событиям. 23 января 1662 г. келечинские татары, находившиеся в подчинении у Манжи-Ялбо, внезапно атаковали астраханских стрельцов. 25 января келечинцы отогнали у юртовских татар из-под Астрахани 500 лошадей. А на следующий день уже сам Манжи-Ялбо во главе 3-тысячного отряда из подвластных калмыков и татар подошел к окрестностям Астрахани, отправив под город и учуги 500 людей для отгона скота и лошадей у местных жителей. Воеводе Г. Черкасскому пришлось вывести навстречу им практически весь гарнизон города. Но МанжиЯлбо так не решился вступить в бой и увел войска обратно в улусы.

${ }^{13}$ РГАДА. Ф. 119. Оп. 1. 1662 г. Д. 1. Л. 36, 37.

${ }^{14}$ РГАДА. Ф. 112. Оп. 1. 1661 г. Д. 1. Л. 488.

${ }^{15}$ РГАДА. Ф. 112. Оп. 1. 1661 г. Д. 1. Л. 450, 451; Ф. 119. Оп. 1. 1662 г. Д. 1. Л. $48,49$. 
Вооруженные мелкие стычки произошли только в окрестностях города, и в большинстве случаев они закончились в пользу астраханцев. Агрессивные выходки Манжи-Ялбо объяснялись его отношением к тому, что «от великого государя жалованье и честь менши Мончака тайши, а он, Ялба, таков же, что Мончак тайши». Его дед Дайчин и другие тайши и мирзы до этих событий всячески «унимали» молодого тайшу от конфликта с русскими, но он не послушался и все сделал по-своему. Стоит заметить, что время для демарша Манжи-Ялбо выбрал подходящее, поскольку Мончак в это время в улусах отсутствовал, он отправился на охоту в дальние кочевья ${ }^{16}$.

Узнав истинную причину агрессивных действий Манжи-Ялбо, воевода Г. Черкасский вскоре отправил ему дополнительное жалованье: 2 панциря, 2 собольи шубы, саблю, пищаль, жемчуг. Но еще в конце прошлого года князь отправил своего племянника К. Черкасского в улус Мончака с сообщением о событиях, произошедших на Тереке. 9 января 1662 г. Каспулат прибыл в улус Мончака и до 26 января ждал возвращения того с охоты. А уже 4 февраля вместе с ним в Астрахань прибыли посланцы Мончака - Малай и Доржи. Тайша был весьма недоволен поступком своего племянника, и передал воеводе признание в том, что Манжи-Ялбо тем самым «зло учинил над ними (калмыками. - B.T.)», а не над русскими. Мончак пообещал астраханскому воеводе, что после возвращения 500 своих воинов из крымского похода обязательно предпримет должные меры воздействия на своего племянника ${ }^{17}$.

В документах нам удалось найти и главного виновника, которого тайши подозревали в развязывании конфликта путем «закулисных интриг». Например, во время нахождения К. Черкасского в калмыцких улусах, он был свидетелем того, как Мончак выговаривал едисанскому С. Абдулову «з большою бранью, что такое воровство чинитца ево сююнчеевым воровским наговором». Присутствовавшие при этом разговоре джемболукский мирза Шамамет и «владетельные ближние люди» Мончака (Тюпчин, Кайряту, Баян и Малай) также подтвержда-

${ }^{16}$ РГАДА. Ф. 112. Оп. 1. 1661 г. Д. 1. Л. 489, 490, 495; Ф. 119. Оп. 1. 1662 г. Д. 1. Л. $60-66$

${ }^{17}$ РГАДА. Ф. 119. Оп. 1. 1662 г. Д. 1. Л. 36, 37, 69, 70, 78. ли причастность Сююнчи к разжиганию интриг внутри «торгутского дома», несмотря на то, что последний всячески отпирался. Относительно этого едисанского мирзы у астраханских властей давно были подозрения в его деятельности как «агента влияния). Воевода Г. Черкассский докладывал в Москву, что Абдулов всячески подговаривает тайшей к измене в пользу крымского хана, а несколько лет назад он выдал свою дочь замуж за крымского посла Караш-бия. На Берекетинский съезд мирза приезжал «утайкою и стоял с улусными своими людьми особе), несмотря на то, что Мончак его туда не приглашал. В калмыцких улусах он сеял всяческие слухи, например, будто бы крымский хан с запорожцами осадил Москву ${ }^{18}$.

В исторической литературе нет подробностей разбирательств между дядей и племянником, только известно, что в 1662 г. Мончак захватил Манжи-Ялбо, а его улус присоединил к себе ${ }^{19}$. Последние сведения из архивных материалов дают нам вполне конкретную картину и время этих событий.

9 апреля 1662 г. в Астрахани появились калмыцкие посланцы Чагантей и Бахчи с пятью сопровождающими. Прислали их с Нарынпесков «владетельные люди» Мончака (Бунчука) - Тюпчин и Малай, просившие сообщить, что они везут Манжи-Ялбо на урочище Берекети или Красный Яр с одной целью - передать астраханским властям арестованного молодого тайшу. Для безопасности мероприятия калмыки просили воеводу встретить их с «ратными людьми», «чтоб у них, собрався, воровские люди ево, Ялбы, не отбили». Г. Черкасский немедленно отреагировал и с крупным отрядом выехал навстречу на реку Болда, отправив вперед стрельцов и узденей во главе с Каспулатом, стрелецким головой А. Нормацким и Ф. Пущиным. На следующий день в 2-3 верстах от Красного Яра состоялась их встреча, а 11 апреля Тюпчин и Малай и сопровождавшие их 67 калмыков официально передали астраханскому воеводе Г. Черкасскому арестованного Манжи-Ялбо. Стало известно, что Мончак захватил и жену молодого тайши, а также всех улусных его людей ${ }^{2 n}$.

${ }^{18}$ РГАДА. Ф. 112. Оп. 1. 1661 г. Д. 1. Л. 473, 474, 477, 478.

${ }^{19}$ Бакунин В.M. Описание калмыцких народов, а особливо из них торгоутского, и поступков их ханов и владельцев. 2-е изд. Элиста, 1995. С. 23.

${ }^{20}$ РГАДА. Ф. 112. Оп. 1. 1661 г. Д. 1. Л. 546, 547, 549. 
Момент ареста Манжи-Ялбо и передача его астраханским властям Мончаком был выбран вполне подходящий. Дайчин в это время с войском находился в дальнем походе против чакарских калмыков и ничем на тот момент не мог помочь своему внуку. Передавая своего племянника в Астрахань, Мончак договорился с воеводой Г. Черкасским, «чтоб ево, Ялбу, без ево Мончакова ведома никому не отдавать». Своим людям Мончак приказал не распространяться о местонахождении Манжи-Ялбо, давая им понять, что «тужить об нем не станет, хотя де он вечно пропадет». Г. Черкасский со своей стороны позаботился об обеспечении молодого тайши надежной охраной в Астрахани и приказал своим людям, чтобы по отношению к знатному калмыцкому пленнику они (держали честь и ласку, и привет, и береженье большое) ${ }^{21}$.

Но весть о том, что Манжи-Ялбо находится под арестом в Астрахани, быстро распространилась по калмыцким улусам. Первой же реакцией Дайчина была незамедлительно освободить внука. Но он не обладал для этого достаточными военными силами, поэтому в январе 1663 г. Дайчин попытался уговорить хошутского Кунделен-Убаши и дербетских тайшей совершить совместный поход под Астрахань для вызволения из плена внука. Очевидцы отмечали, что престарелый Дайчин в решении этого вопроса находился под сильным влиянием своей старшей жены Батыр-Каныш, которая была матерью покойного Даян-Эрке. У ралма, супруга Мончака, сообщала Г. Черкасскому о влиянии, оказываемом на Дайчина группой людей, которые сильно ненавидели ее мужа 22 .

У Дайчина было несколько жен, но Батыр-Каныш, считавшаяся его старшей женой и соответственно доводившаяся Мончаку мачехой, при поддержке своих сторонников активно выступала за передачу Дайчином власти внуку Манжи-Ялбо. Но эта идея не находила поддержки у большинства калмыцкой элиты и народных масс. Отсюда можно сделать вывод, что антирусские выступления Манжи-Ялбо были инспирированы не Дайчином, как утверждает в своей работе В.И. Колесник ${ }^{23}$, а группой влиятельных лиц из окружения его старшей супруги Батыр-Каныш.

\footnotetext{
${ }^{21}$ РГАДА. Ф. 119. Оп. 1. 1665 г. Д. 2. Л. 93; 1663 г. Д. 1. Л. 7, 59, 81.

${ }^{22}$ РГАДА. Ф. 119. Оп. 1. 1663 г. Д. 1. Л. 52, 154.

${ }^{23}$ Колесник В.И. Указ. соч. С. 91.
}

Стремясь не допустить эскалации событий, Мончак пресек все попытки отца привлечь прибывших дербетов и хошутов к разрешению раздора внутри торгутского дома. Не последнюю роль в этом сыграла и поддержка Мончака его зятем - хошутским Доржи, старшим сыном Кунделен-Убаши, имевшем сильное влияние на своего отца. Для убедительности Мончак недвусмысленно пригрозил новоприбывшим дербетским и хошутским тайшам, что если они поддержат его отца в деле с Манжи-Ялбо, он «надо всеми над ними учинит то ж, что учинил над племянником своим». Хошутские тайши даже дали шерть Мончаку в том, «что им отца ево, Дайчина, к дурной мысли никакой не пристать $\rangle^{24}$. Согласованные действия Мончака и Доржи являются ярким свидетельством прихода к власти в ойратском обществе нового поколения политиков, фактически контролировавших положение дел в своих собственных кочевьях, в отличие от своих отцов, которые всего лишь формально владели ими.

Мончак полностью контролировал ситуацию, а его люди жили в улусе Дайчина и «тайным обычаем» следили за каждым шагом престарелого тайши. Большинство улусных людей Дайчина были на стороне его сына: «прочат его, Мончака, себе на отцово место», поэтому в любом случае не выполнили бы приказ его отца. В своих письмах Г. Черкасскому тайша отмечал, что «отец ево, Дайчин, в древних летах, хотя ему и впрямь идти, и у него подьем тяжелый». Также он обешал, что если со стороны отца последуют «неадекватные» действия против Астрахани, он собственными силами возьмет в окружение отцовский улус и будет отговаривать его от недобрых намерений. Но если бы ситуация вышла из-под контроля, то Мончак рассчитывал уже на военную помощь астраханского гарнизона ${ }^{25}$.

Из сообщения Солом-Церена, поступившего Г. Черкасскому, стало известно о попытке Дайчина в начале января 1663 г. организовать наступление против Астрахани и Мончака. Однако, узнав о свадьбе своего внука Аюки, он отменил поход, сказав, что «непошто ему одною бессильною головою идти к сильным» ${ }^{26}$. Очевидно, что этот брак выдавал особый характер отношений Мончака с

\footnotetext{
${ }^{24}$ РГАДА. Ф. 119. Оп. 1. 1663 г. Д. 1. Л. 53, 69, 207

${ }^{25}$ РГАДА. Ф. 119. Оп. 1. 1663 г. Д. 1. Л. 67, 207.

${ }^{26}$ РГАДА. Ф. 119. Оп. 1. 1663 г. Д. 1. Л. 76
} 
Москвой, и отныне борьба против усиления его позиций без всякого сомнения расценивалась как противодействие внешнеполитическому курсу, ориентированному на партнерство с Московским государством ${ }^{27}$.

Русские источники довольно подробно освещают свадебную церемонию. 6 января 1663 г. в Астрахань за невестой для Аюки - Обелханой Муцаловной Черкасской прибыли родственники Мончака «кереитского родства) - Эмчи, Топчи, Доржи и Малай. Из Астрахани в калмыцкие улусы невесту провожали кабардинские уздени Чепал с 20 товарищами ${ }^{28}$.

Начиная с января 1663 г. Дайчин беспрестанно отправлял своих посланцев в Астрахань с просьбой вернуть ему внука. В случае удовлетворения его просьбы он обещал возвратить всех живущих у него башкирских повстанцев, принять лично русское подданство и пойти с Манжи-Ялбо на войну против Крыма, в противном случае - сойтись с крымским ханом и совместно с башкирскими повстанцами напасть на русские города. Только немногие продолжали поддерживать престарелого тайшу, среди них были дербетские тайши - братья Аючей (зять Дайчина) и Аюкей. 13 февраля Дайчин собирался двинуться со своими людьми под Астрахань, но, узнав о приближении к его улусу крупных военных сил неких двух тайшей, сразу же отменил свой поход. Буддийское духовенство в лице его главы Эрке-ламы пыталось отговорить Дайчина от применения силы в решении данного вопроса: «лутче ему ныне беречь своих людей». В марте Эрке-лама выступил в роли посредника между отцом и сыном и организовал им встречу, на которой Дайчин попытался договориться с Мончаком и просил его содействия в освобождении Манжи-Ялбо ${ }^{29}$.

Из отписки, отправленной 15 февраля 1663 г. Ф. Омачиным из Красного Яра астраханскому воеводе А. Дашкову, стало известно о намерении сторонников Манжи-Ялбо захватить в плен астраханского архиепископа Иосифа во время его поездки в Москву с целью дальнейшего обмена ${ }^{30}$.

${ }^{27}$ Колесиик В.И. Указ. соч. С. 87.

${ }^{28}$ РГАДА. Ф. 119. Оп. 1. 1663 г. Д. 1. Л. 93-94.

${ }^{29}$ РГАДА. Ф. 119. Оп. 1. 1663 г. Д. 1. Л. 82-84, 119, 206

${ }^{30}$ АСПбИИ РАН. Ф. 178. Д. 4538. Л. 1.
Действия Мончака против Манжи-Ялбо можно рассматривать не только как ревностное соблюдение им заключенных русско-калмыцких договоров, но и как желание в будущем привести к власти своего старшего сына Аюку. Брак его сына и племянницы князя Черкасского был еще одним дополнительным козырем в укреплении власти Мончака в калмыцком обществе, поскольку поддержка Москвы имела также ключевое значение

Летом 1663 г. в Сарпинских песках состоялась очередная встреча воеводы Г. Черкасского с Мончаком. На ней также присутствовали представители хошутского Кунделен-Убаши и его сына Доржи, которые пожелали, как и Мончак, принять русское подданство и отправить свои военные отряды на Крым. По мнению М.Л. Кичикова, так дербето-хошутская группировка Кунделен-Убаши вошла в состав Калмыцкого ханства, признав над собой верховную власть Мончака и Москвы $^{31}$. В действительности прибывшие хошуты и дербеты не входили в состав торгутского владения, а располагались рядом, на предоставленных торгутами восточных кочевьях. Более того, они так и не приняли участия в крымской кампании. По сведениям В.М. Бакунина, у Кунделен-Убаши и четырех его сыновей по прибытии к торгутам в общей сложности насчитывалось 4 тыс. улусных людей ${ }^{32}$.

Дальнейшую судьбу Манжи-Ялбо в русских документах обнаружить не удалось. Но из путевых записок одного из представителей голландского посольства, Н. Витсена, сделанных в начале 1665 г., становится известно, что молодого тайшу из Астрахани перевезли в Москву. Под видом купца Витсен проник в охраняемый стрелецкой стражей двор Манжи-Ялбо, которого голландец называл Тайчжи Йалба Доис. Он довольно интересно описал внешний вид молодого тайши: «Тайчжи - человек очень некрасивый, коричневато-желтый, с плоским широким лицом, лоб у него высокий, черные волосы, сзади коса). Далее Витсен рассказывает краткую историю его появления в Москве и незавидное будущее: «Этот правитель, который у себя на родине может привести на поле боя 30 тысяч человек, теперь был предан своим дядей и с его коварной помощью вывезен русскими из своей

${ }^{31}$ Кичиков М.Л. Исторические... С. 129-130.

${ }^{32}$ Бакунин B.M. Указ. соч. С. 22. 
страны во время боя. Здесь его держат как пленного; он же, говорят, предлагает царю все, что у него есть, за что будет пожалован титулом князя-царевича. Может быть, он примет русскую веру, иконы уже висят в его комнате, он уже умеет креститься, и тогда он станет русским придворным, подобно другим крещеным татарским князьям $\rangle^{33}$. Витсен был свидетелем того, как царский врач-иностранец вылечил молодого тайшу, которого царские приставы уверяли, будто его болезнь случилась от тоски по родине, и если он хочет вылечиться, то не должен так сильно тосковать. Приходя к Манжи-Ялбо, доктор часто заставал его за молитвой: сидя на полу, он читал какие-то листки, похожие на игральные карты, и щелкал пальцами «назло дьяволу) ${ }^{34}$. По всей вероятности, Манжи-Ялбо, находясь в московской ссылке, в конечном итоге вынужден был закончить свою жизнь на чужбине.

В результате кратковременной борьбы власть в правящей семье относительно бескровно перешла от династической линии Даян-Эрке в лице Манжи-Ялбо к линии Мончака, который был только третьим по старшинству сыном Дайчина. Но благодаря умелым политическим действиям он сумел закрепить за собой первенствующее положение в торгутском доме и обеспечить условия для прихода к власти в будущем старшего сына Аюки. Обстановка, сложившаяся в начале 1660-х гг. в калмыцком обществе, отчетливо показала смену политических лидеров и расклад сил, определявших выбор центральной фигуры, а значит, и дальнейшую историю волжских калмыков.

\section{2. Калмыки и Башкирское восстание 1662-1664 гг.}

В начале 1660-х гг. Московское государство переживало серьезный экономический кризис. Для ведения войн с Польшей и Швецией на содержание армии требовались огромные средства. Отток из страны большого количества золота и серебра, главным образом вследствие особых льгот, предоставлявшихся Россией иностранным купцам, неудачная денежная реформа (введение в оборот медных денег)

\footnotetext{
${ }^{33}$ Витсен Н. Путешествие в Московию. СПб., 1996. С. 200.

${ }^{34}$ Bumceн H. Указ. соч. С. 167
}

и неурожкаи 1660 и 1661 гг. привели к высокому уровню инфляции. Стремясь всеми доступными средствами увеличить доходы государства, правительство попыталось расширить и ужесточить сбор податей с ясачных народов, что, конечно, вызвало их недовольство. Башкиры также выражали недовольство захватами земель многочисленными русскими крестьянами со Средней Волги и Нижнего Прикамья, бежавшими от крепостнических порядков. Массовое насильственное изъятие пленных калмыков, сопровождавшееся притеснениями со стороны местных чиновников, также было главной причиной восстания.

В «Крымских делах» удалось найти и другую причину восстания, озвученную башкирскими посланцами на аудиенции у крымского хана Мухаммед-Гирея в январе 1664 г. Когда с Москвы в Башкирию прибыли «переписчики» и в результате переписи насчитали 80700 человек. По царскому указу башкирам было велено выдвигаться на войну против Польши и Крыма. Башкиры проигнорировали этот указ, и тогда власти взяли у них в заложники 50 «лучших людей», посадив их под арест в Казани. Только после этого, по словам посланцев, и вспыхнуло восстание ${ }^{35}$.

Волнения начались в 1662 г. среди татар, проживавших по реке Кама, вблизи Закамской линии, затем они быстро распространились по всем башкирским волостям, и в конечном итоге охватили множество других народов ${ }^{36}$. Башкиры искали поддержки у кучумовичей, обращались за помощью в Крым. Так, по сведениям С. Абдулова, крымские послы, приехавшие в начале 1661 г. в калмыцкие улусы, говорили ему о прибытии в Крым 10 башкирских посланцев, представлявших группу башкир, которые должны были указу из Москвы направиться на русско-польскую войну. Решив саботировать царский указ, башкиры рассматривали возможность ухода в крымские владения или к калмыкам, но склонялись все-таки присоединению к единоверцам ${ }^{37}$.

${ }_{35}^{35}$ РГАДА. Ф. 123. Оп. 1. 1663 г. Д. 2. Л. 59, 60.

${ }^{36}$ Материалы по истории Башкирской АССР. Ч. 1: Башкирские восстания в XVII и первой половине XVIII в. М.-Л., 1936. С. 178; Устюгов Н.В. Указ. соч. С. 105.

${ }^{37}$ РГАДА. Ф. 112. Оп. 1. 1661 г. Д. 1. Л. 25. 
Потерпев поражение, часть башкирских повстанцев с семьями бежала с насиженных мест и в южных степях примкнула к калмыкам Например, один из организаторов неудавшегося восстания - Гаур Ахбулатов в 1661 г. со своими людьми присоединился к Мончаку. В улусе тайши у него состоялась встреча с русским послом И. Гороховым, результатом которой стало «шертование» в верной службе и обещание башкирских повстанцев вернуться на свои прежние кочевья. Но вернулись они не все, Гаур остался с калмыками. В конце 1662 г. он с четырьмя посланцами Дайчина приезжал к восставшим башкирам Ногайской дороги, чтобы уговорить их откочевать к калмыкам, но был схвачен и по приказу князей Волконских повешен ${ }^{38}$.

Осенью 1662 г. к дербетскому тайше Аючею пришли «на житье» 30 башкирских повстанцев. Это побудило тайшу привлечь в свой улус новые группы башкир. С отрядом в 1700 воинов Аючей направился вверх по Яику и привел к себе в улус еще 200 башкирских кибиток. Аючей также призывал к себе в улус 1,5 тыс. кибиток башкир, кочевавших в верховьях реки Самара. Башкир Тлеумбет Рысаев с сотней своих родственников пришел к Дайчину и в знак подчинения преподнес ему соболью шубу. Во владении тайши уже находился башкир Карабаш со своими людьми, который кочевал с ним по Волге. Башкиры тархана Эшимбета кочевали совместно с Аючеем в верховье Яика ${ }^{39}$. Именно этот дербетский тайша, которого большинство исследователей путали с Аюкой, сыном Мончака, стал первым калмыцким владельцем, вступившим в тесный контакт с башкирскими повстанцами.

Другие калмыцкие тайши, используя сложную обстановку в Приуралье, также пытались привлечь башкир в свои улусы. В частности, хошутский тайша Доржи, прибывший к торгутам с востока и не знавший хорошо этот регион, расспрашивал башкир в улусе Аючея о протоках, реках, деревнях и дорогах в Уфимском уезде. Он также был не прочь привести к себе в улус башкирских повстанцев. Другой новоприбывший дербетский тайша Малай-Батур участвовал совмест-

${ }^{38}$ Материалы по истории Башкирской АССР... Ч. 1. С. 164-165; Устюгов Н.В. Указ. соч. С. 70-71.

${ }^{39}$ РГАДА. Ф. 119. Оп. 1. 1663 г. Д. 1. Л. 114-115, 122; Устюгов Н.В. Указ. соч. С. 70 . но с башкирами в набегах на русские селения. Подобные свои действия отдельные тайши обьясняли, по словам того же Аючея, тем, что «идет великого государя жалованье всяким дар, а мне не идет ничево, и шерть де я не шертовал». В общей сложности около 8 тыс. башкир таким образом присоединились к калмыкам. Но большинство из них не переселялось непосредственно в калмыцкие улусы, а продолжало оставаться на своих прежних кочевьях ${ }^{40}$.

Участие Дайчина в башкирском восстании определить сложно. С одной стороны, неуступчивость русских властей в вопросе о выдаче Манжи-Ялбо подталкивала его к ответным агрессивным действиям, и башкиры в этом плане могли ему помочь. С другой - решительный разрыв отношений с Москвой окончательно лишал его поддержки основной массой калмыцкого народа. По всей видимости, тайша не желал открыто проявлять свое участие в башкирском восстании, хотя сочувствовал повстанцам и тайно им покровительствовал. Об этом свидетельствует сообщение побывавшего в калмыцком плену чуваша Токмамета Байзыгитова, полученное от него в 1663 г.: «Дайчин де тайша сам к ним (башкирам. - B.T.) не бывал, а прислал к ним калмыков 4000 да нагайских людей, и иные люди к ним сьезжаются). От Аючея к башкирским повстанцам приезжали 6 человек для ведения переговоров о совместном нападении на г. Мензелинск. Башкиры Ногайской дороги во главе с тарханом Иш-Мухаммедом (Эшимбетем) Девлетбаевым, соединившись с калмыками и ногайцами, двинулись под Уфу. Отступив от Мензелинска, калмыки отправили сюда посланца, требуя возвращения внука Дайчина - Манжи-Ялбо, находившегося под арестом в Астрахани. В случае выполнения этого условия Дайчин обещал отказать башкирским повстанцам в поддержке и выдать беглецов. Однако его условие не было принято, и люди Дайчина продолжали поддерживать участников башкирского восстания ${ }^{41}$.

Очевидно, что калмыцкие тайши не имели единой линии поведения в отношении башкирского восстания. Большинство из них продолжало придерживаться курса на сближение с Россией и сообщало властям о действиях враждебно настроенной к правительству группы

${ }^{40}$ РГАДА. Ф. 119. Оп. 1. 1663 г. Д. 1. Л. 122-124; 1664 г. Д. 4. Л. 3; Устюгов Н.В. Указ. соч. С. 90.

${ }^{41}$ АИ. СПб., 1842. Т. 4. С. 336; Устюогов Н.В. Указ. соч. С. 94. 
тайшей. Так, в январе 1663 г. Солом-Церен жаловался Г. Черкасскому в Царицын на своего сводного брата Аючея, называя его своим «недругом», который принимал к себе башкирских повстанцев. Более того, дербетский тайша предлагал князю организовать совместный карательный поход против брата ${ }^{42}$.

Солом-Церен и Аючей были сыновьями покойного дербетского правителя Далай-Батура, правда, рождены они были от разных матерей. Солом-Церен, видимо, рассчитывал на то, что родственники по матери (торгуты) окажут ему безоговорочное содействие в переходе всех новоприбывших дербетов в его улус. Но образование отдельных дербетских улусов в составе волжских калмыков под покровительством Дайчина привело к тому, что отношения племянника и дяди были натянутыми. Так Солом-Церен стал одним из активных сторонников Мончака.

Крупные башкирские владельцы также искали связи с калмыками. Например, влиятельнейший из тарханов Ногайской дороги ИшМухаммед Девлетбаев признал над собой власть тайши Аючея и получил от него район кочевий вверх по Яику. Приток новых людей в улус побудил Аючея распространить свои притязания и на других его соседей. Тайша вступил в конфликт с Яицким городком, где на тот момент проживало около 300 казаков. Аючей с башкирами начали вынашивать план по вытеснению казаков с Яика, чтобы затем поставить там свой городок, «хлеб пахать и жить житьем». Но Дайчин пресек эти попытки своего зятя, поскольку на тот момент находился в мире с яицким казачеством ${ }^{43}$.

В начале 1663 г. Сары Мергень, один из предводителей восстания, отправил своих посланников к Дайчину с просьбой оказать ему военную помощь против правительственных войск. Но выступление калмыков в уфимском направлении не было ответом на просьбу Сары Мергеня, поводом послужила вновь вспыхнувшая давняя вражда. В мае 1663 г. башкиры Ногайской дороги, разорвавшие зимой всякие отношения с калмыками и примирившиеся с правительством, отогнали у Дайчина множество лошадей. В отместку разгневанный тайша

${ }^{42}$ РГАДА. Ф. 119. Оп. 1. 1663 г. Д. 1. Л. 1.

${ }^{43}$ РГАДА. Ф. 119. ОП. 1. 1663 г. Д. 1. Л. 121-122; Устюгов Н.В. Указ. СОч. С. 90 . организовал ответный набег на Уфимский уезд. В результате пострадали не только башкиры, но и небольшие городки возле Уфы, где преимущественно проживали чуваши и черемисы. Дайчин также понес серьезные потери - погибли несколько его командиров. Калмыцкий поход, правда, не задел башкир под предводительством Кучука, которые продолжали участвовать в восстанин ${ }^{44}$.

С весны 1664 г. у калмыков вновь обострились отношения с яицкими казаками. Именно в это время башкиры совместно с казаками в ходе трех набегов отогнали из улуса Мончака 3 тыс. лошадей. Тайша потребовал от русских властей немедленно наказать виновных и возвратить лошадей. В противном же случае он обещал самостоятельно провести карательный поход против зачинщиков ${ }^{45}$. В сентябре калмыки Дайчина совместно с ногаями и башкирами совершили нападение на Яицкий городок, отогнали скот и лошадей, побили многих казаков, взяв их в осаду ${ }^{46}$. Осенью этого же года самарский воевода С. Шеховской сообщал в Москву о намерении крупного отряда калмыков блокировать дорогу с Яика на Самару, чтобы не пропустить самарских жителей на Яик для рыбного промысла, а яицким казакам не дать пройти в Самару ${ }^{47}$.

В дополнение к мерам военного режима, введенного в Башкирии, правительство попыталось устранить и причины беспорядков. Были приняты меры по облегчению бремени повинностей для местного населения, ограничению захватов земель и наведению порядка в хозяйственной деятельности местных чиновников. Даже среди тех, кто примкнул к восставшим, существовали значительные расхождения во взглядах. Многие повстанцы на собраниях башкирского народа неоднократно высказывались за установление мира с правительством ${ }^{48}$. Башкиры также официально добились от властей отмены указа о возврате пленных калмыков ${ }^{49}$. Таким образом, несмотря на малочисленность находящихся здесь войск, царское правительство, умело играя

${ }^{44}$ РГАДА. Ф. 119. ОП. 1. 1663 г. Д. 1. Л. 242; Устюгов Н.В. Указ. соч. С. 89.

${ }^{45}$ РГАДА. Ф. 119. Оп. 1.1664 г. Д. 9. Л. 25.

${ }^{46}$ РГАДА. Ф. 119. Оп. 1. 1665 г. Д. 1. Л. 3, 4.

${ }^{47}$ Куч О.Ю. Указ. соч. С. 77-78.

${ }^{48}$ Материалы по истории Башкирской АССР... Ч. 1. С. 159-161,162,164$166,175,176,177-179$

${ }^{49}$ Азнабаев Б.А. Указ. соч. С. 16. 
на межнациональной неприязни и используя внутренние раздоры в повстанческом руководстве, смогло в 1664 г. окончательно подавить башкирское восстание.

Известно, что в январе 1664 г. в Крым прибыли трое башкирских посланцев - Жолмамет, Мулла Гази и Адильбек в сопровождении семерых астраханских юртовских татар. Они обратились за помощью к крымскому хану, чтобы тот прислал к ним войска и способствовал переводу их в крымские владения. Кочевали эти башкиры в устье реки Самара и по Яику ${ }^{50}$. Самостоятельно им это сделать было сложно, поскольку основная масса калмыков располагалась на их пути по левому берегу Волги. Крымский хан по указу турецкого султана в это время находился в венгерском походе, но имеются сведения об отправке им трех султанов с войсками для встречи башкир ${ }^{51}$. Результат этой военной операции неизвестен. Но идея сменить подданство в пользу Крыма поддерживалась далеко не всеми башкирами, а многие из них даже участвовали в подавлении восстания вместе с правительственными войсками ${ }^{52}$.

Отношение калмыков к башкирскому восстанию 1662-1664 гг. было довольно противоречивым. Одни из них приняли сторону башкир, другие продолжали оставаться союзниками правительства. В Москве полагали, что эти два народа вряд ли когда смогут договориться между собой о совместных действиях, если вспомнить историю их непростых взаимоотношений. Однако неудачное развитие восстания заставило часть башкир рассматривать уход к калмыкам как один из возможных вариантов развития ситуации, и они не раз обращались к тайшам за помощью. Калмыки не принимали непосредственного участия в башкирском восстании, но отдельные тайши пытались использовать ситуацию в своих личных целях - присоединить себе новых подданных или поставить перед правительством ряд политических условий. Как видим, в указанный период основная масса калмыцкого народа, включая и национальную элиту, оставалась практически нейтральной к национальным движениям в России.

${ }^{50}$ РГАДА. Ф. 123. Оп. 1. 1663 г. Д. 2. Л. 59, 60; АИЮЗР. СПб., 1867. С. 208

${ }^{51}$ РГАДА. Ф. 119. Оп. 1. 1664 г. Д. 10. Л. 3.

${ }^{52}$ Материалы по истории Башкирской АССР... Ч. 1. С. 159-161,164$166,175-179$.

\section{3. Участие калмыков в русско-польской войне}

Как упоминалось выше, сражения 1658-1661 гг. в ходе продолжающейся русско-польской войны крайне истощили ресурсы обеих сторон. В 1662 г. Россия и Польша накапливали силы, ожидая благоприятного момента, чтобы переломить военно-политическую ситуацию в свою пользу. На южном направлении война калмыков с Крымом превратилась в череду мелких набегов.

В сентябре сын крымского хана, Мухаммед-Гирей, с войском возвращался из Украины в Крым, и по дороге его головной и замыкающий отряды были внезапно атакованы калмыками. Одновременно калмыки набегом отбили скот и лошадей у ногайцев, кочевавших у Азова и Перекопа ${ }^{53}$.

В целях укрепления прежних договоренностей, 27 октября 1662 г. под Царицыном состоялся очередной русско-калмыцкий съезд, где князь Г. Черкасский с племянником Каспулатом лично встретился с тайшами. С калмыцкой стороны в мероприятии участвовали только сторонники Мончака, среди которых были такие тайши, как Солом-Церен, Дугар, Лобачи, Батур и Бок. Стороны договорились об отправке новых калмыцких отрядов на Крым. Поскольку намечался совместный поход, то Мончак поставил условие, чтобы все стрельцы были конными, объясняя это тем, что у калмыков «поход скорой и лошадей у них много», и чтобы русские «на степи не отставали) (4. $^{2}$

Осенью этого года Мончак, Дугар, Солом-Церен и другие тайши отправили свои отряды на Крым. Так, Мончак выделил 4 тыс. воинов под командой Маникар-Дачи и Унидей-кашки. На реке Сал был организован сборный пункт, куда из различных улусов стекались отряды, которые затем отправлялись на Крым. Не дождавшись на Дону подхода отряда К.М. Черкасского, Маникар-Дачи со своими людьми направился в набег на Казыевский улус Малого Ногая, где захватил 5 тыс. лошадей и 30 ясырей ${ }^{55}$.

Другая часть калмыков направилась на Крым. В октябре к северу от Перекопа крымцы снова наблюдали передвижения большого чис-

\footnotetext{
${ }^{53}$ РГАДА. Ф. 123. Оп. 1. 1659 г. Д. 3. Л. 146-148

${ }^{54}$ РГАДА. Ф. 119. Оп. 1. 1663 г. Д. 1. Л. 11, 15

${ }_{55}^{5}$ РГАДА. Ф. 119. Оп. 1. 1662 г. Д. 1. Л. 101.
} 
ла калмыцких всадников, не решаясь вступить с ними в бой. Чтобы выманить татар из укреплений, небольшие калмыцкие отряды появлялись у самого Перекопа - и татары часто устремлялись в погоню. Однажды, в ноябре, перекопский бий лично возглавил преследование одного из калмыцких отрядов. В результате, как стало известно из донесения русских посланцев в Крыму, (навели калмыки татар на больших людей и татар побили». Самому бию удалось чудом избежать плена ${ }^{56}$

Тайши отказались от практики использования крупных воинских соединений, как это было в прошлых годах, а ограничились немногочисленными отрядами, которые действовали по всей степной части Северного Причерноморья. Возможно, такую тактику действий против крымцев калмыкам порекомендовал воевода Г. Черкасский. Еще в августе 1662 г. к нему через своего сына Сары-мирзы обратился казыевский мирза Урак, который советовал: «А с Царицына де под Крым для поиску великого государя ратных больших людей не посылать, а посылать бы де небольших людей почасту, потому что де небольшими людми и частыми посылками крымцов всех разорят, да и крымцом де от малых людей будет оплошно $)^{57}$.

Так, тайше Эрке во главе отряда силой в 260 конников в районе Перекопа удалось захватить 300 лошадей и четырех человек. 200 калмыков под началом Тогуш-Батура ворвались вглубь полуострова на 15 верст и, захватив трофеи, вернулись без потерь. Отряд под началом Колчюгаша ночью под Перекопом перехватил крымцев, возвращавшихся с русским «ясырем» из набега. Половина из 60-ти татар была убита, остальные разбежались, русских пленников освободили. 10 калмыков из этого отряда остались на Молочных Водах, где они устроили «перевалочный пункт», дожидаясь там прихода следующего отряда под командой Шогаш-Мергена ${ }^{58}$.

Яркие детали своего участия в одном из крымских набегов оставил в своем донесении в Царицын калмык Болкаш из улуса Мончака. Отряд в составе 100 воинов, в котором он состоял, осенью 1662 г, из-под Перекопа отогнал 100 лошадей и 30 коров. В урочище Ушон-

${ }^{56}$ РГАДА. Ф. 123. Оп. 1. 1659 г. Д. 3. Л. 149, 151.

${ }^{57}$ РГАДА. Ф. 127. ОП. 1. 1662 г. Д. 1. Л. 20, 21.

${ }^{58}$ РГАДА. Ф. 119. Оп. 1. 1662 г. Д. 1. Л. 102; 1663 г. Д. 1. Л. 106, 107, 160. кар калмыки вступили в бой с крымской заставой в 400 человек под командой Казы-мирзы. В разгар боя Болкашу удалось поразить копьем крымского мирзу в спину. Калмыки захватили два крымских знамени, убили 40 крымцев, многих ранили. Отогнанная ими тысяча лошадей и взятые четыре «языка» были отправлены в улус Мончака, кочевавший возле Черного Яра. В этом бою калмыки потеряли убитым только одного человека ${ }^{59}$.

В декабре того же года черноярский толмач К. Степанов на Волге повстречался с калмыцким отрядом из 25-ти всадников под командой Доржи Янырдаева, возвращавшимся из крымского похода. На двух верблюдах калмыки везли захваченные в бою два крымских знамени и 17 пищалей, вели крымских «языков». Они сообщили Степанову, что их отряд из 200 калмыков в бою на подступах к Крыму уничтожил 200 крымцев, отогнал 500 лошадей, 300 коров и 14 тыс. овец ${ }^{60}$.

Отряд из 150-ти калмыков из улуса Дугара также ходил под Перекоп и захватил 400 лошадей и 100 коров, отбил 16 русских пленников. С крымской заставы за ними пустились в погоню 300 татар. В ходе боя калмыки, не понеся значительных потерь, уничтожили 100 татар. захватив их знамя. 25 февраля 1663 г. представители Дугара и СоломЦерена привезли в Царицын это знамя и в торжественной обстановке передали его князю Г. Черкасскому. Знамя захватил калмык по имени Кичик Дарашаев ${ }^{61}$.

От тайши Батура в крымских походах принимал участие отряд из 500 человек под началом Доржи. С урочища Еничигей они отогнали 150 лошадей, с урочища Шункар - 730, а с урочища Бербоин - 1000 лошадей, однако крымцам удалось отбить их ${ }^{62}$.

В марте 1663 г. уже Солом-Церен сообщал в Царицын Г. Черкасскому о военных успехах своих людей. Дербетский тайша осенью 1662 г. направил на Крым 600 своих воинов. Отряд в 50 человек под началом Шогаш-Мергена и Батур-бакши соединился на Молочных Водах с пятью сотнями донских и запорожских казаков под командой С. Разина и Сар-Манжи. Совершив совместный поход на Крым, они

${ }^{59}$ РГАДА. Ф. 119. ОП. 1. 1663 г. Д. 1. Л. 35-37.

${ }^{60}$ РГАДА. Ф. 119. Оп. 1. 1662 г. Д. 1. Л. 104, 110.

${ }^{61}$ РГАДА. Ф. 119. Оп. 1. 1663 г. Д. 1. Л. 96, 190.

${ }^{62}$ РГАДА. Ф. 119. Оп. 1. 1663 г. Д. 1. Л. 224. 
под Перекопом захватили 2 тыс. лошадей, 600 овец и 350 «ясырей»). С крымской заставы за ними погнались 600 татар во главе с СафарКазы-агой. В завязавшемся бою казаки проявили смекалку: на татарском языке стали кричать крымцам, что на Молочных Водах находятся еще 1,5 тыс. калмыков. Услышанное сразу же обратило татар в паническое бегство. Казаки и калмыки разделили трофеи. После чего казаки с добычей вернулись домой, а калмыки, оставив захваченное имущество под охраной на Молочных Водах, снова отправились в набег под Крым. В урочище Чюкар-Ауз калмыки захватили еще тысячу лошадей, но в ходе стычки с преследовавшими их крымцами потеряли их.

Захваченный скот и лошадей калмыки приводили на свой временный «перевалочный пункт» на Молочных Водах, там же отдыхали и снова шли в набег под Крым. Часто сюда выходили бежавшие из крымского плена русские люди, и калмыки по возможности помогали им продуктами, выделяли лошадей, чтобы они могли добраться до русской территории. В общей сложности калмыки провели здесь около двух месяцев.

В январе 1663 г. перекопский Мустафа-бий докладывал хану, что калмыки уже с начала года в два набега отогнали тысячу лошадей. Из-за глубоко выпавшего снега преследовать их никто из татар не решился ${ }^{63}$. Судя по крымским источникам, в феврале по приказу хана Мухаммед-Гирея отряд из 1100 воинов под командой ногайского Ислам-мирзы (сына Бекмирзы) сумел выследить три калмыцких стана в причерноморских степях и полностью их уничтожить. Девять калмыков были взяты в плен, а захваченные ими под Перекопом лошади отбиты. Всех пленных калмыков по приказу хана отправили в Стамбул ${ }^{64}$.

В марте 1663 г. в Царицын прибыли люди Мончака и представили князю Г. Черкасскому своего рода отчет о «зимней кампании» под Перекопом. Всего они захватили у крымцев: в первом походе 200 лошадей, 60 коров, 3 тыс. баранов и 10 «ясырей»; во втором 200 лошадей и 6 польских «ясырей»; в третьем - 300 лошадей и 20

${ }^{63}$ РГАДА. Ф. 123. ОП. 1. 1663 г. Д. 2. Л. 2

${ }^{64}$ РГАДА. Ф. 123. Оп. 1. 1663 г. Д. 2. Л. 5-7. «ясырей〉. Были также убиты 100 крымцев и несколько мирз, среди которых был Казымбек. Польские пленники, захваченные у татар, поведали о настроениях, воцарившихся среди крымских татар: «От калмыцкого разоренья их (крымцев. - B.T.) стало мало, лутче б де им смерть, а не явное разоренье; николи де ниотково такова разоренья не бывало, какое разоренье им ныне чинитца» ${ }^{65}$.

Активные действия калмыков и запорожцев под Крымом вызвали у крымского хана стремление как можно быстрее укрепить днепровские границы новыми оборонительными пунктами и построить сплошной вал до Азовского моря. Также он приказал перевести ногайцев из Белгородской орды под Крым. Со всех крымских деревень сгоняли жителей на Перекоп. Крымский хан поручил горским черкесам изготовить 4500 копий, так как «биться им с копьи против калмыков, а перекопский де Мустафа-бей копий сделал немало» ${ }^{66}$.

1663 г. прошел под знаком активных действий калмыцких отрядов на крымском направлении. В январе азовский паша сообщал крымскому хану о намерении калмыков кочевать в степях Причерноморья и просил дополнительно прислать в Азов военную помощь для его защиты. Хан Мухаммед-Гирей «для спасенья от калмыков» распорядился переписать и мобилизовать во всех крымских городах греков, армян и евреев и обязать их иметь при себе пищали. Сам хан, царевичи, карачеи, мирзы и уланы готовили лошадей, «блюдяся калмыцкого прихода». Хан задумал провести большие работы по укреплению Перекопского перешейка, решив в мае начать строительство каменной стены по старому валу. Для этого на строительные работы было привлечено почти все население Крыма. Но все эти оборонительные меры не создавали серьезных препятствий для калмыков. Тогда же, в январе, перекопский Мустафа-паша сообщил о нападении калмыков на полуостров Чонгар, делящий Сиваш на две ветви, и отгоне ими 1 тыс. лошадей. Однако преследованию калмыков помешал глубокий снег ${ }^{67}$.

Калмыки продолжали действовать и на кубанском направлении. В районе озера Маныч находилась военная база калмыков, действовавших на этом театре военных действий. Когда команда дербетов

\footnotetext{
${ }^{65}$ РГАДА. Ф. 119. Оп. 1. 1663 г. Д. 1. Л. 127-129.

${ }^{66}$ Цит. по: Новосельский А.А. Указ. соч. С. 94.

${ }^{67}$ РГАДА. Ф. 119. Оп. 1. 1663 г. Д. 1. Л. 3.
} 
под началом Умар-Эрке у Казыевского улуса отогнала 1300 лошадей, мирза Навруз пытался их догнать, но безуспешно. В декабре 1662 г. Солом-Церена сообщал в Царицыне о походе сотни дербетов с Маныча под Темрюк, где они разбили отряд из 50 человек, направлявшийся в Азов. Уже в январе 1663 г. из Казыевского улуса от мирзы Арсланбека к Мончаку прибыли послы с просьбой прекратить калмыцкие набеги на их территорию, изъявив при этом готовность платить тайшам ежегодный ясак ${ }^{68}$. Вероятно, казыевские мирзы сочли это за лучшее, чем переживать постоянные набеги калмыков, наносившие им существенный материальный ущерб.

С началом весны 1663 г. князь Г. Черкасский отдал приказ Мончаку, Солом-Церену, Дугару и другим тайшам об отправке дополнительных отрядов на Крым. Мончак вскоре действительно отправил отряды под командой База-Батура, Усман-Батура и Сахан-Кашки. Солом-Церен также отрядил команды под началом Зан-Кашки, Басу, Мерген-Кошучи. Активное участие калмыков в новой крымской кампании было вызвано еще и тем обстоятельством, что зима 1662/63 года выдалась чрезвычайно холодной. Начался массовый падеж скота и лошадей, что привело к голоду в калмыцких улусах ${ }^{69}$. Поэтому калмыки остро нуждались как в военных трофеях, так и в дополнительном царском жаловании за службу

Возобновившиеся калмыцкие набеги на территорию Крыма привели к тому, что крымский хан отказал польскому королю в помощи против «непослушных» украинских гетманов. Турецкий султан, не считаясь с трудным положением Крыма, таюже требовал от Мухаммед-Гирея помощи в войне против Венгрии. Опасаясь новых нападений со стороны восточных соседей, крымский хан пытался уклониться от своих обязательств перед сюзереном, но все-таки нашел выход, отправив в поход против венгров своего сына Ахмед-Гирея с небольшим количеством людей ${ }^{70}$. Хан отправил в разведку 100 чело-

${ }^{68}$ РГАДА. Ф. 119. Оп. 1. 1662 г. Д. 1. Л. 107; 1663 г. Д. 1. Л. 60, 227.

${ }^{69}$ РГАДА. Ф. 119. Оп. 1. 1663 г. Д. 1. Л. 3, 139.

${ }^{70}$ Калга, или калга-султан, - первый наследник в Крымском ханстве, второе после хана лицо в государстве. Нуреддин, или нуредди султан, - второй наследник в Крымском ханстве, третье после хана и калга-султана лицо в ханстве. век «для проведыванья калмыков», а сам с войсками вышел в степь за Перекоп, «чтоб с ними учинить бой». При этом крымцы были осведомлены, что между калмыками и запорожцами установились «совет и дружба большая) ${ }^{71}$.

Уже в апреле 1663 г. под Перекопом у калмыков с крымцами состоялся бой, в результате чего многие татары были побиты и захвачено большое количество лошадей и «ясыря». Часть калмыков вернулось с добычей обратно на свою перевалочную базу на Дону, а другая отборная тысяча направилась в Запорожье на помощь казакам, прибыв 19 апреля к кошевому атаману С. Туровцу. После них на Крым пришел уже другой калмыцкий отряд, учинив под Перекопом крупный бой с татарами. Калмыки полностью разгромили крымцев, и, как отмечали очевидцы, «топтали их до самой Перекопи» ${ }^{72}$.

По сообщению калмыцких пленных в Крыму, около 10 тыс. калмыков пришли кочевать на Молочные Воды. Получив эти сведения, Мухаммед-Гирей все свои силы привел к Перекопу. Один из украинских перебежчиков сообщил крымцам, что атаман И. Серко с казаками, калмыками и обозом стоит у Каменного затона на Днепре и намерен двигаться к Перекопу ${ }^{73}$.

Однако удар калмыков и запорожцев был нанесен в район Цибульника, где у них произошел ночной бой с 10-тысячным крымским войском. Перед атакой они окружили татарский лагерь, предварительно договорившись «в добычю ни на какую не падатца и языков не имать, чтоб всех побивать». В результате боя они захватили вражеский обоз и перебили татар, кроме одного султана, который через три дня умер от ран. Спаслись из крымцев лишь немногие, «разве кто в болоте оттопился $\rangle^{74}$. Разгром татар под Цибульником подтверждал в своем сообщении к Мухаммед-Гирею и гетман Правобережной Украины П. Тетеря, который просил от хана нового подкрепления ${ }^{75}$. Затем калмыки с запорожцами двинулись за Днепр и Буг, узнав о нахождении здесь крымских улусов, но по дороге пришло сообщение,

\footnotetext{
${ }^{71}$ АИЮЗР. СПб., 1867. С. 136, 140.

${ }^{72}$ АИЮЗР. СПб., 1867. С. 171, 172.

${ }^{73}$ РГАДА. Ф. 123. Оп. 1. 1663 г. Д. 2. Л. 8, 9.

${ }^{74}$ АИЮЗР. СПб., 1867. С. 172.

${ }^{75}$ РГАДА. Ф. 123. Оп. 1. 1663 г. Д. 2. Л. 11.
} 
что татары исчезли. Крымский хан, узнав о совместных действиях калмыков с казаками, весной трижды посылал в Запорожское войско послов с предложением мира, но получил отказ ${ }^{76}$.

Калмыки просили у гетмана И. Брюховецкого разрешение проехать в Москву, чтобы известить о военных успехах, достигнутых ими на Украине и под Крымом. Весьма любопытны личные впечатления гетмана о калмыках, изложенные им в письме к государю в мае 1663 г.: «хотя люди некрешеные и в поступках своих с христяны не сообщники, но желательством своим к вашему царскому пресветлому величеству лутчие от изменников поставляютца; а нам таковых и потребно лихого недобрым казнити, пусть нечистый с поганым бьетца, дабы чистым и законным пространство от безбожных было, а отчина вашего царского пресветлого величества Русская земля в покое и в целости пребывала» ${ }^{77}$.

В мае Мухаммед-Гирей назначил нуреддина Мурат-Гирея руководить обороной Крыма на Перекопе вместо Мустафы-бия, который в свою очередь должен был заниматься строительством каменной стены по старому валу. Со всего полуострова на Перекоп свозили камни, а также сгоняли различную рабочую силу. Это сооружение пролегало по перешейку между морскими косами, как отмечали очевидцы, «для береженья крымского юрта от калмыцкого приходу $\rangle^{78}$

Наибольших успехов в столкновениях с калмыками в 1663 г. сумели достичь крымский военачальник Батырша Сулешев и ногайский Ислам-мирза. В мае они обнаружили в верховьях реки Тор лагерь калмыков из 200 〈кош» и полностью его разгромили. 80 калмыцких пленников были доставлены к хану в Перекоп, который их затем отправил к турецкому султану на каторгу ${ }^{79}$.

В начале лета 1663 г. ногайский улус Шейдяковых, располагавшиеся под Азовом, подверглись новому нападению калмыков ${ }^{80}$. Крымский хан, опасаясь повторного прихода калмыков и запорожцев, большие силы продолжал держать непосредственно в Крыму.

\footnotetext{
${ }^{76}$ АИЮЗР. СПб., 1867. С. $172,173$.

${ }^{77}$ АИЮЗР. СПб., 1867. С. 169-170.

${ }^{78}$ РГАДА. Ф. 123. Оп. 1. 1663 г. Д. 2. Л. 12.

${ }^{79}$ РГАДА. Ф. 123. Оп. 1. 1663 г. Д. 2. Л. 9.

${ }^{80}$ РГАДА. Ф. 123. Оп. 1. 1663 г. Д. 2. Л. 13.
}

Но под давлением турецкого султана часть своих войск он вынужден был отправить на войну против венгров и персов, а также для защиты Азова. Выполняя союзнические обязательства перед Речью Посполитой, часть крымских отрядов направил и на помощь королю ${ }^{81}$.

В июне 600 калмыков прибыли в Запорожье, «где мир и веру соопча приняв, ходили под Чигирин, и под Крыловым кош татарской взяли». Использование различных военных уловок, особенно при численном превосходстве противника, взаимно обогащало арсенал тактических приемов казаков и калмыков. Сохранилось описание одного такого военного приема, использованного казаками и калмыками, когда крымцы организовали за ними погоню. После того как татары переправились через речку Омельничек, они, внезапно развернувшись, по ним ударили «и мало не всех снесли, едва которой где мог утечь $)^{82}$.

Действуя против крымских татар, калмыки проявляли отчаянную смелость. Так, в июле 1663 г. 400 калмыков, подойдя к Перекопу, сбили ханские шатры, захватили в бою мирзу, побили многих татар и едва не пленили самого Мухаммед-Гирея и нуреддина, но тех выручил вовремя подоспевший турецкий отряд. В Перекоп с подкреплением был вызван калга. Однако в августе калмыки вновь напали на Крым и, прорвавшись за Перекоп, пожгли хлеб в копнах и сено. В сентябре уже атаман И. Серко при поддержке калмыков из-под Перекопа отогнал большие стада скота, а позже напал на татарские улусы под Аккерманом, освободил русских пленников и выжег селения, «учинив большое разоренье». В ходе повторного нападения на татар под Перекопом И. Серко с калмыками разгромил и сжег посад, захватил богатую добычу ${ }^{83}$.

В сентябре в Крым пришло известие, что казачий отряд И. Серко с калмыками обманным путем овладели Белгородской ордой, войдя туда беспрепятственно со стороны волошской границы под ногайскими знаменами. На расстоянии от самой орды и до сторожевых башен ими были сожжены все селения, захвачены скот и лошади, а также

\footnotetext{
${ }^{81}$ Новосельский А.А. Указ. соч. С. 75.

${ }^{82}$ АИЮЗР. СПб., 1867. С. 169.
}

${ }^{83}$ РГАДА. Ф. 123. Оп. 1. 1663 г. Д. 2. Л. 13; Новосельский А.А. Указ. соч. 
«ногайский ясырь) и имевшийся у них (русский полон». По словам очевидцев, «такое большое разоренье Белгородом учинилось по тому приходу их, черкасского и калмыцкого, [ранее] не бывали ${ }^{84}$.

1 декабря 1663 г. в Запорожское войско от Мончака прибыл отряд в 100 калмыков под командой Эркета Атуркая. И. Серко с казаками и Г. Косагов с калмыками 6 декабря направились в набег под Перекоп, чтобы не допустить соединения крымского хана с польскими войсками, а также для взятия «языков». Они беспрепятственно жгли татарские села и отбили около сотни русских и украинских пленных, пока 11 декабря начальник перекопского войска Карачбей не вывел своих воинов с ними на бой. Соотношение сил было на стороне крымцев: 1000 татар против 90 запорожцев, 30 донцов и 60-ти калмыков. Казаки и калмыки применили против татар тактику ложного отступления, а затем, предоставив возможность противнику переправиться через реку Колончак, (устроя коньми кош», пошли в атаку и «побили и рубили татар до Перекопи». Среди убитых оказались Карачбей, его брат и племянник. По свидетельствам казаков, «живых калмыки брать не дали, в руках кололи», кроме одного знатного турка ${ }^{85}$. По другим данным, в отряде преследования Карачбея находилось до 500 татар. Самому ему после боя с калмыками и казаками все-таки удалось спастись бегством, но 400 его воинов пропали без вести ${ }^{86}$

По сведениям пленных, турецкий султан приказал крымскому хану двигаться на помощь польскому королю, чтобы противостоять основным силам русско-украинского войска, но хан из-за боязни нового прихода калмыков и казаков его ослушался. Калмыцкие конные отряды своими активными действиями в Северном Причерноморье и на Кубани в целом выполнили задачу, поставленную перед ними русским командованием, так как они значительно облегчили положение русско-украинского войска в войне против Речи Посполитой. Москва всячески поощряла совместные выступления казаков с калмыками против Крыма. В феврале 1664 г. пограничным воеводам указывалось: «калмыков наговаривать и нашею великого государя

\footnotetext{
${ }^{84}$ РГАДА. Ф. 123. Оп. 1. 1663 г. Д. 2. Л. 52.

${ }^{85}$ АИЮЗР. СПб., 1867. С. 148-149.

${ }^{86}$ РГАДА. Ф. 123. Оп. 1. 1663 г. Д. 2. Л. 58.
}

милостию обнадеживать, чтоб они нам, великому государю, служили и против неприятелей стояли твердо и непоколебимо и ни на какие неприятельские прелести и подсылки не склонялись; а служба их от нас, великого государя, никогда забвенна не будет» ${ }^{87}$.

Весной 1664 г. практически вся крымская орда вышла за Перекоп в степь для охраны полуострова от набегов калмыков, перекрывших полностью единственную сухопутную дорогу из Крыма в Азов, по которой доставлялись в турецкую крепость подкрепление и казна. Действия калмыков привели к тому, что среди крымских подданных воцарилось мнение о том, что напрасно хан развязал войну против России в союзе с поляками. Мухаммед-Гирей, поддавшись этим умонастроениям, отправил в Москву посольство с предложением мира, а при отправке наказывал своим послам ехать только ночью, останавливаясь днем в «крепких местах в чернях и в камышах, чтоб их было не видно», так как «ведомо де в Крыму, что калмыцкие многие люди на крымской степи». Однако послы до Москвы не доехали, и хан предположил, что «их калмыки побили в степи». Действительно, той весной И. Серко и Г. Косагов с калмыками разгромили крымский обоз (850 человек), шедший из Крыма в Черкасский городок ${ }^{88}$.

Угроза, возникшая для донских городков, и нехватка вооруженных сил побудили полковника Г. Косагова отправить своих людей к калмыцким тайшам с очередной просьбой об оказании военной помощи. В июне 1664 г. по приказу гетмана И. Брюховецкого объединенный отряд Серко, Косагова и калмыков выдвинулся из Канева на правобережную Украину. В 25-ти верстах от Корсуни они разбили крымское войско, шедшее на соединение к С. Чарнецкому. Затем они двинулись на Умань, на помощь поднестровским городкам, перешедшим на сторону России. За Уманью разбили еще один крымский отряд, идущий также к Чарнецкому, и «салтанова сына взяли». Еще один бой произошел в Сарачинском лесу, где были убиты 100 татар и поляков ${ }^{89}$.

В августе 1664 г. калмыки покидали Украину и возвращались в свои улусы, обещая, что «они и впредь великому государю служить с

\footnotetext{
${ }^{87}$ АИЮЗР. СПб., 1867. С. 149.

${ }^{88}$ АИЮЗР. СПб., 1867. С. 201-202, 209.

${ }^{89}$ АИЮЗР. СПб., 1867. С. 154, 157, 202-203, 210.
} 
Серком ради» и вернуться следующим летом ${ }^{90}$. К Мончаку от Г. Черкасского были отправлены за военной помощью стрелецкие сотники М. Сурин и Г. Голочелов. В этом же году тайша Мончак выделил для русской армии 3 тыс. воинов под командованием Маничар-Дайчи. Причем одна половина отправилась в новый крымский поход с Г. Черкасским, а другая ушла к гетману Брюховецкому ${ }^{91}$.

Но уже осенью 1664 г. 2-тысячное калмыцкое войско под командой Ишкепа и Батура прибыло на Бузулук. Тайши сообщали в Москву, что во главе этого войска отправились самые лучшие командиры, поэтому в ноябре к гетману Брюховецкому поступило указание «тех калмыцких людей покоить, чтоб им ни в каких запасах скудости не было» и всячески стремиться к тому, чтобы их оставить зимовать на Украине. Об этом свидетельствуют и отчеты гетмана, по государеву указу калмыков обеспечивали «добрым товаром, овечками, хлебом, медом, пивом, тютюном... и [они] в иных вещах выгоду имеют доброю» ${ }^{92}$.

Зиму 1664/65 года Дайчин провел у моря, возле Яика, а Мончак кочевал возле Астрахани, в Нарын-песках ${ }^{93}$. С началом 1665 г. среди калмыцких ногайцев наметилось стремление откочевать в пределы Крымского ханства. Так, в феврале такую попытку предприняли мирзы Султанаш и Адиль, которые перевели через Волгу свои улусы общей численностью в 8 тыс. человек. Но вовремя отправленный за ними 3-тысячный калмыцкий отряд преследования сумел по дороге их нагнать и вернуть обратно на левый берег. Половина из этого отряда выдвинулась дальше в западном направлении и совершила набег на ногайский улус Шейдяковых, подвергнув его полному разгрому. Пятеро мирз вместе с их улусными людьми были взяты в плен, а их имущество досталось калмыкам ${ }^{94}$.

В начале 1665 г. Брюховецкий отправил к Мончаку двух посланцев - С. Остренского и М. Кимбарова. Мончак радушно принял украинцев и на просьбу гетмана об оказании военной помощи ответил согласием. Тайша предупредил посланцев об откочевке в Крым

\footnotetext{
${ }_{90}^{90}$ АМГ. СПб., 1901. С. 580.

${ }^{91}$ РГАДА. Ф. 119. Оп. 1. 1664 г. Д. 9. Л. 22-24, 26

${ }_{92}$ АИЮЗР. СПб., 1867. С. 210, 220-223, 282.

${ }^{93}$ РГАДА. Ф. 119. Оп. 1. 1664 г. Д. 8. Л. 2.

${ }^{94}$ РГАДА. Ф. 123. Оп. 1. 1663 г. Д. 2. Л. 88, 89, 93.
}

200 калмыцких кибиток и, по словам украинцев, «сте нас с крымцами караулили, и Мончак велел нам их беречься». Мончак изъявил желание вместе с гетманом участвовать в походе против Крыма. В то же время украинцы были свидетелями отказа тайши в помощи донским посланцам от воеводы Я.Т. Хитрово, как они сами отмечали, «и с стыдом их (донских казаков. - B.T.) отпустил $)^{95}$.

Видимо, отношения с донскими казаками у калмыков в то время складывались не совсем гладко. Однако уже в мае калмыки с донцами действовали совместно, когда они сумели перехватить один из крымских отрядов, направлявшийся с запасами из Крыма к хану «в полки». Перекопский Караш-бий предпринял за ними погоню, но потерпел поражение. После с более многочисленным войском преследование организовал уже калга и в районе Черных колодцев сумел их настичь и отбить имущество. Калмыки и казаки по Конским водам отступили к Дону ${ }^{96}$.

Результаты службы калмыцких воинов на Украине не заставили долго себя ждать. 21 мая 1665 г. в 10 верстах от г. Белая Церковь калмыки, предварительно окружив лагерь поляков и немцев-наемников, полностью его разбили, уничтожив около тысячи человек. Как отмечали свидетели, 80 сдавшихся в плен поляков после боя «с запалу воинского всех калмыки кололи». Победителям досталось немало трофеев: кони, одежда, панцири, сбруи, копья гусарские и другие вещи ${ }^{97}$. Польский военачальник Яблонский, потеряв множество своих людей, в страхе перед калмыками ушел в Польшу. Анонимный автор «Летописи Самовидца» описывая эти события, высоко отзывался о боевых качествах калмыцких воинов: «Вправді, люд военній, с копием всідает на коня, а нікоторіе и сагайдаки и стріли великіе с площиками широкими. Тилко найболше до потреби копій заживают кожен, бо справне уміют вбити копіем, в пікоторих и панціри, а инпіе и наго идут до потреби. Люд отважній, а на взгляд чорній, пікчемній, страшній, чарами бавятся, бо балвохвалці...»>

\footnotetext{
${ }_{95}$ АИЮЗР. СПб., 1869. Т. 6. С. 52.

${ }^{96}$ РГАДА. Ф. 123. Оп. 1. 1663 г. Д. 2. Л. 94.

${ }^{97}$ АИЮЗР. СПб., 1867. С. С. $274,282-283$.

98 Літопис Самовидця / видання підготував Я.1. Дзира. Київ, 1971. С. 98-
} 
Это была первая крупная победа калмыков над регулярной польской армией, которую по достоинству оценили многие военные специалисты в России. Белая Церковь - важнейший стратегический пункт в центре Правобережной Украины. Крепость стояла на пересечении торговых путей, а обладание ею давало возможность контролировать положение во всем междуречье Днепра и Южного Буга ${ }^{99}$. После таких громких побед спрос на военную службу калмыков в русской армии резко возрос. По одним данным, у гетмана Брюховецкого насчитывалось 7 тыс. калмыков, а всего на Украине сражались около 10 тыс. калмыцких воинов. Именно они и совершили новый поход под Перекоп, разбили 10 тыс. татар и «добычю себе многую учинили» ${ }^{100}$.

Чрезмерно жестокое отношение калмыков к своему противнику в условиях войны можно обьяснить только традициями военного ремесла, желанием психологически подавить не только прямого врага, но и потенциального. Это можно осуждать, но такая практика оправдывала себя в войнах XVII в., когда при одном упоминании о калмыках крымские татары, турки и ногаи бежали с поля боя. Османы и крымцы по отношению к калмыкам употребляли слово «злонравный,

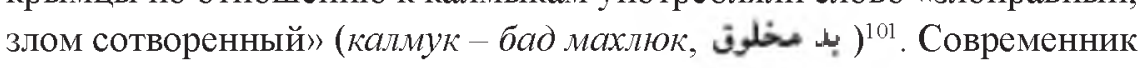
тех событий османский путешественник Эвлия Челеби дал довольно любопытную оценку калмыкам: «Калмыки всегда возвращаются, побивая крымчаков, и они превосходят крымский народ храбростью ${ }^{102}$. По наблюдению О.Ю. Куца, жестокость, безусловно, носила характер самозащиты, а страх перед жестоким врагом обычно парализовывал волю противника к сопротивлению ${ }^{103}$.

Активное участие калмыков в крымской кампании Москва оценила по достоинству. Выражением доверия и признанием заслуг в военной службе Русскому государству явилась отправка в июне 1664 г. казанца А. Нармацкого к тайшам с жалованьем. Тайше Мончаку он

${ }^{99}$ Санин Г.А. Указ. соч. С. 136.

${ }^{100}$ АИЮЗР. СПб., 1867. С. 283.

${ }^{101}$ Hadzy Mehmed Senai z Krymu. Histjoria Chana Islam Gereja III / Tekst turecki wydal, przelożyl i opracowal Z. Abrahamowicz. Warszawa, 1971. C. 62

102 Челеби Э. Указ. соч. С. 246

${ }^{103}$ Куц О.Ю. Указ. соч. С. 390. привез военное знамя. По мнению П.С. Преображенской, это свидетельствует о том, что Москва теперь считала калмыцкое войско неотьемлемой составной частью русской армии ${ }^{104}$.

В поступившем в Посольский приказ царском указе о новом оформлении грамот, направляемых к тайшам, имена Дайчина и Мончака предписывалось обозначать золотыми буквами ${ }^{105}$. Это подтверждают и сведения Г. Котошихина, отмечавшего еще в середине XVII в., что в царских письмах имена и титулы калмыцких тайшей пишутся «... золотом все, на меншой Александрийской бумаге, Татарским же письмом, без трав» ${ }^{106}$. Такой чести, как правило, удостаивались правители иностранных государств, например, крымский хан. Контакты с калмыцкими правителями мало чем отличались от дипломатических сношений с зарубежными государствами, а на посольских приемах и других мероприятиях дипломатического характера калмыцкие правители приравнивались к крымским ханам ${ }^{107}$.

\section{4. Мончак и русско-калмыцкие переговоры}

Летом 1664 г. российское правительство официально признало Мончака верховным правителем волжских калмыков, наделив соответствующими символами власти - булавой и знаменем. Именно в этом году отмечался всплеск активности дипломатических контактов между Москвой и калмыцкими тайшами. Например, 13 августа в Москву прибывает посольство Кулачи-дархана и Путарыка (кабардинский уздень К. Черкасского) ${ }^{108}$. В сентябре сюда же прибыло очередное калмыцкое посольство во главе с Айдарукой Мурзаевым, который привез довольно интересные сведения.

В это время Мончак совершил военный поход против детей Елдена, его старший сын Мерген был убит, а улус захвачен. Двум другим братьям Мергена удалось уйти с немногими людьми. Как отме-

${ }^{104}$ Преображенская П.С. Из истории... С. 83.

${ }^{105}$ РГАДА. Ф. 119. Оп. 1. 1664 г. Д. 3. Л. 144.

${ }^{106}$ О Россин... С. 42.

${ }^{107}$ О России... С. $41,42,76,77,82$

${ }^{108}$ РГАДА. Ф. 119. Оп. 1. 1664 г. Д. 6. Л. 1. 
чал посол, Мончак со своими людьми вернулись «томны и лошеди у них выбиты» ${ }^{109}$. В калмыцкой летописи Габан Шараба также есть сведения об убийстве Мергена его двоюродным братом Мончаком, хотя некий тайша Буян (возможно, это внук торгутского тайши Манхана) предупреждал Мергена об опасности соединения с родственниками, говоря, что «живота лишен будет» ${ }^{110}$. Таким образом Мончак ликвидировал одного из своих конкурентов внутри торгутского дома.

Но с вышеизложенной историей связано и другое громкое событие - уход тайши Дугара в крымские владения. Стоит отметить, что подробности перехода Дугара под турецкую протекцию остаются так и не выясненными до конца, в том числе не известно и время. Большинство исследователей склонны считать, что это произошло в конце 1660-х гг. Во многом свет на это событие проливают материалы немецкого исследователя П.С. Палласа. Согласно ему, тайша Мерген поссорился со своими братьями, чем не преминули воспользоваться Мончак и Дугар, совершив совместный поход на восток против двоюродного брата. В результате Мерген был убит, а его улус насильно захвачен. Однако Мончак принял единоличное решение - улус Мергена присоединил к себе, не выделив никакой доли Дугару. Это и стало основной причиной произошедшего между ними конфликта. Но в дальнейшем Дугар, бросив значительную часть своего улуса, поспешно бежал в крымские владения ${ }^{111}$. Во многом это подтверждают и русские документы. Например, в 1673 г. дербетский тайша Дондук (сын Кашак-Батыма и внук Далай-Батура) сообщал в Тобольске местным властям подробности этого конфликта. С его слов известно, что торгутский Дугар отъехал в крымские владения в результате ссоры с Мончаком, а причиной тому послужили их совместные военные действия против торгутского Цамбы (сына Мергена), улус этого владельца был разгромлен, а Мончак (погромом всем один завладел». Дугар, не согласный с подобным решением, но серьезно опасавшийся повторить судьбу Цамбы, поспешил со своим улусом откочевать от Мончака под Азов ${ }^{112}$.

${ }^{109}$ РГАДА. Ф. 119. Оп. 1. 1664 г. Д. 4. Л. 2

${ }^{110}$ Габан ІІараб. Указ. соч. С. 94.

${ }^{111}$ Pallas P.S. Sammlungen... S. 61.

112 ДАИ. СПб., 1857. С. 282.
Первые случаи бегства калмыков на территорию Крымского ханства нам становятся известны из материалов «Крымских дел» за 1664 г. Как сообщали русские посланцы, в ноябре в Крыму объявились 18 калмыцких перебежчиков, просивших хана предоставить им возможность остаться на постоянное жительство, так как «ушли от тайшей〉. Первоначально их насчитывалось 300 человек, не считая женщин и детей, и, когда они двигались в сторону Крыма, калмыцкий отряд преследования, организованный тайшами, по дороге их настиг и практически полностью перебил. Спастись удалось только этим 18 человекам: пятеро из них были с женами и детьми и 13 бессемейных. Крымский хан их принял и указал жить на полуострове, в устье реки Альма ${ }^{113}$. По всей видимости, это были именно те люди, о которых еще летом этого года Мончак предупреждал о возможной опасности со стороны откочевавших в Крым 200 калмыцких кибиток прибывших к нему гетманских посланцев ${ }^{114}$. Возможно, они же и участвовали в нападении на казацкие городки в верховьях Дона в октябре 1664 г., и атаманы по этому поводу жаловались на калмыков в Москву ${ }^{115}$.

Осенью 1664 г. наблюдалась активизация калмыков и на Северном Кавказе. В октябре Мончаку и К. Черкасскому из Москвы поступил указ предотвратить попытки крымцев и малых ногаев построить крепость в междуречье Кубани и Инжика ${ }^{116}$. Укрепление крымцев в этом регионе не входило в планы не только русского командования, но и тайшей, поскольку, как говорили калмыцкие послы, «калмыкам де тот городок гораздо грубен». Мончак через К. Черкасского просил об оказании военной помощи у астраханских воевод, в частности, о предоставление артиллерии, так как «без огненного бою города не взять». Воевода Я.Н. Одоевский выразил готовность помочь калмыкам. Желание принять участие в этом походе изъявил и Дайчин, у

${ }^{113}$ РГАДА. Ф. 123. Оп. 1. 1663 г. Д. 2. Л. 85, 86.

${ }^{114}$ АИЮЗР. СПб., 1869. С. 52.

${ }^{115}$ РГАДА. Ф. 119. Оп. 1. 1664 г. Д. 9. Л. 10-11.

116 Здесь, скорее всего, речь идет о крепости Шад-керман, расположенной у слияния рек Зеленчук и Кубань. Как сообщает Эвлия Челеби, крепость была построена кабардинским князем Мисост-беем для защиты от калмыков, и взята под управление крымским ханом Мухаммед-Гиреем. 
которого отношения с Мончаком в это время стали налаживаться. Отряды калмыцких тайшей, а также К. Черкасского подошли к в верховьям Кумы, где ожидали подхода астраханцев с артиллерией. Прождав их более месяца, но, так и не дождавшись, калмыки отправили в Астрахань гонца с запросом. Однако местные воеводы отказались от совместного участия в походе. Ранняя оттепель и начавшееся половодье вынудили тайшей отменить военный поход и вернуться в улусы $^{117}$.

Нерешительность, интриги или предательство побудили астраханских воевод так действовать, неизвестно. Однако очевидно, что уход с воеводства в Астрахани и Царицыне Г. Черкасского повлек за собой ослабление активности русско-калмыцких отношений. Единственным, кто продолжал поддерживать с калмыцкими тайшами тесные отношения, оставался терский воевода К. Черкасский. Мончак через своих послов в Москве сообщил о преступном бездействии и инертности астраханских воевод, и 20 марта 1665 г. воеводам в Астрахань поступило строгое указание о немедленной отправке отряда с пушками во главе с С. Беклемишевым совместно с донскими казаками и терцами против крымского городка ${ }^{118}$. В апреле Мончак сообщал в Царицын, что ближайшим летом начнет новую военную кампанию, при этом на Кубань против Малого Ногая им уже было отправлено 3 тыс. воинов, в Запорожье - 500, на Дон - 300 и на Терек к К. Черкасскому - 150 воинов ${ }^{119}$

12 февраля 1665 г. в Москву от Мончака прибыло посольство во главе с Каичю ${ }^{120}$. В архивных материалах до наших дней сохранилось калмыцкое письмо тайши, доставленное послами (Приложение). Ниже дается современный перевод письма ${ }^{121}$ :

Здоров ли там бельй хан? Здесь мы все пребываем во здравии.

Не Вы ль прислали Михайли и Манаг чухула двоих? Через них Bbl передали сказать [нам]: "Крым [иы]] построили город. Разруиьте его». Товарищей моих тех казаков мало осталось. Мы вступили в по-

${ }_{117}$ РГАДА. Ф. 119. Оп. 1. 1664 г. Д. 7. Л. 53-54, 69; 1665 г. Д. 1. Л. 11-12.

${ }^{118}$ РГАДА. Ф. 119. ОП. 1. 1665 г. Д. 1. Л. 14.

${ }^{119}$ РГАДА. Ф. 119. ОП. 1. 1665 г. Д. 1. Л. 35.

${ }^{120}$ РГАДА. Ф. 119. Оп. 1. 1665 г. Д. 2. Л. 41, 44, 186, 187.

${ }^{121}$ Перевод выполнил Нацагдордж Цонгоол Батцэнгэлийн. ход. Если прибудет больиая подмога, мы отправимся. Если не прибудут мы сами решим. Летом через Айдар духа и Манаг чухула двоих передали Вы [нам] выступить в поход. Отправил я двоих - Никепа и Баатур тайджи (Солом-Церена). Шесть человек во главе с Михайли, иедиие с ними для товарищества, пусть хоромо следят за ними в noxode.

Отправленными стода вещами я распорядился. Отправил я человекак Аюии с увещеванием: "Не враждовать». Если примет мои слова, то примет. Если не примет мои слова, то отправлю я человека с оповещением [о том, что он] не принял мои слова.

Не вылаю ли я холопов белого хана? Говорят, у белого хана находятся много моих холопов. Отправляйте их сюда для выдачи.

Ас дархан (Астрахань) не выдал нам за два года ежегодного жалованья. Не выдали нам по указанию или без указания белого хана?

[Наиим] людям, которые идут по делам белого хана, не выдают лодки [для переправы] в городах. Укажите им. Только один князь Ахами (Царицьна) переправляет.

Мои младиие братья сами ли просили выдать им отдельное жалованье [или] вы сами своевольно вылали? Вы не жалованье им выдали, а беду. [Раньие] когда я выдавал, брали, когда не выдавал, то не требовали. А теперь они стали [получать] наравне со мной жалованье? Я думал, это я их определяю к службе и отправляю. Получается, что они сами едут [на службу]. Нынче тогда пользуйтесь их службами. Самым правильным является вылача жалованья мне на руки и было бы хорочо, если бы я определял им [жалованье].

Князь крепости Самары поймал двух моих людей и связал руки и ноги. Три раза обрачался - не выдал. Спросите [его], какие преступления совериили те люди? Нужсно [знать] и вам и нам.

Поскорее отправьте [назад] наиих послов ${ }^{122}$.

В Москве калмыцкие послы представили довольно смелый план действий в новой крымской кампании, запланированной на ближайшие весну и лето. Проект заключался в наступлении крупных русско-калмыцких воинских сил на Кубань, уничтожении в этом регионе крымской крепости с целью переселения сюда калмыцких

\footnotetext{
${ }^{122}$ РГАДА. Ф. 119. Оп. 1. 1665 г. Д. 2. Л. 25, 26.
} 
улусов. В дальнейшем предполагалось уже совместное с новоприбывшими дербетами и хошутами, а также казаками и русскими, движение войск на Крым, «чтоб крымские улусы разорить и на тех местах быть им самим калмыкам» ${ }^{123}$. Другими словами, тайши вынашивали планы по уничтожению или подчинению Крымского ханства, занятию татарских земель в Причерноморье. А свои кочевья в Северном Прикаспии освободить для новоприбывших хошутов и дербетов. Действительно, это был очень смелый план, который мог существенно изменить политическую карту Северного Причерноморья и Северного Кавказа. Ранее в Москве рассматривалась возможность перемещения калмыцких улусов в Причерноморье, на земли Крымского ханства. Мончак предлагал русскому царю строить отношения «по чести», что должно было, как считал тайша, устрашить крымского хана - единственного врага калмыков. Мончак заверил правительство, «что не разобив крымсково хану и ево улусов, войны не покинет» ${ }^{124}$.

Но осуществлению этого плана мешал ряд неурегулированных вопросов в русско-калмыцких отношениях.

Во-первых, калмыцкие послы в Москве жаловались на астраханских, черноярских и саратовских воевод, отказывавшихся перевозить через Волгу калмыцких воинов, возвращающихся из крымских походов. К тому же Астрахань, Черный Яр и других волжские города не возвращали калмыкам захваченный ими под Крымом, но бежавший из калмыцких улусов ясырь (поляков, литовцев, мадьяров и др.), не обеспечивали должным питанием людей Мончака приезжавших по делам тайши к воеводам ${ }^{125}$. Еще в 1663 г. Г. Черкасский жаловался в Москву об обидах, нанесенных калмыцким торговцам в Саратове и Самаре, об игнорировании местными воеводами приказов самого князя ${ }^{126}$. Москва немедленно отреагировала, строго указав всем волжским воеводам возвращать калмыкам беглый их ясырь и всячески оказывать им всемерное содействие ${ }^{127}$.

${ }^{123}$ РГАДА. Ф. 119. Оп. 1. 1665 г. Д. 2. Л. 96.

${ }^{124}$ РГАДА. Ф. 119. Оп. 1. 1665 г. Д. 2. Л. 110-111.

${ }^{125}$ РГАДА. Ф. 119. Оп. 1. 1665 г. Д. 2. Л. 97-98.

${ }^{126}$ РГАДА. Ф. 119. Оп. 1. 1663 г. Д. 1. Л. 194-195.

${ }^{127}$ Преображенская П.С. Из истории... С. 56-57.
Во-вторых, для очередного похода на Крым послы просили в помощь 2 тыс. русских конных воинов, запасы и жалованье. При этом Мончак указывал, что царского жалованье присылать нужно не всем тайшам и не в одинаковом размере, поскольку в крымской кампании они участвовали не все. В 1664 г. Мончак сетовал, что царские власти жалованье его братьям посылают «мимо» него. На этом основании Мончак предлагал жалованье присылать только ему, а он бы уже распределял его среди тайшей соответственно их заслугам. В Москве приняли его предложение ${ }^{128}$.

В-третьих, Мончак всячески пытался дистанцировать своих калмыков от башкирского восстания. Вместе с К. Черкасским они отправили к дербетскому тайше Аючею гонца с приказом немедленно выслать из улуса всех башкирских повстанцев и присоединиться к Мончаку. Правительство также поддержало эту инициативу ${ }^{129}$.

В-четвертых, послы ходатайствовали о том, чтобы ведал «Калмыцкими делами» боярин Г. Черкасский. Но, как оказалось, на этой должности уже находился другой «ближний» боярин - Ю.А. Долгорукий. Послам пришлось только констатировать: «кому он, великий государь, укажет их калмыцкие дела ведать, то де добро, только Долгорукий им незнаком» ${ }^{130}$. У дивительно, но ведать калмыцким направлением поручили человеку, ничего не знавшему о калмыках, равно как и они о нем. По всей видимости, решение кадрового вопроса при царе зависело от степени приближенности к нему того или иного боярина. Очевидно, что князь Г. Черкасский в это время оказался в царской немилости и, отойдя на второй план, лишился своих ключевых постов в Астрахани и Царицыне. Возможно, это было следствием провальной операции по освобождению в 1664 г. из крымского плена боярина В.Б. Шереметева, инициированной Алексеем Михайловичем и руководимой Г. Черкасским.

Еще одним неурегулированным вопросом в русско-калмыцких отношениях оставался обмен пленными. Несмотря на то, что царь приказал взять у послов поименный список калмыцких пленников,

${ }^{128}$ РГАДА. Ф. 119. Оп. 1. 1665 г. Д. 1. Л. 13; Д. 2. Л. 105, 108-109; Очерки... С. 100 .

${ }^{129}$ РГАДА. Ф. 119. Оп. 1. 1665 г. Д. 2. Л. 91, 93.

${ }^{130}$ РГАДА. Ф. 119. Оп. 1. 1665 г. Д. 2. Л. 122. 
находившихся в русских городах и, срочно разыскав, вернуть, сделать это было весьма сложно. Например, большинство пленных калмыков, проживавших в Москве, были уже обращены в православную веру. На тот момент существовал особый царский указ о запрете передавать православных калмыков их же собратьям. Послы знали о существовании подобного указа и поэтому просили от царских властей личной встречи с каждым из новокрещеных калмыков, чтобы убедиться в добровольности принятия ими новой веры.

Именно все вышеперечисленные обстоятельства мешали полноценному развитию русско-калмыцких отношений, особенно в условиях продолжавшейся войны, когда требовалась консолидация общих усилий. Как видим, противники сближения были как с русской, так и с калмыцкой стороны. Все эти факты были им на руку, и они всячески использовали их во внутриполитической борьбе.

Довольно интересные сведения о калмыцком посольстве в Москве сохранились и в европейских источниках. Например, 4 марта 1665 г., в столице калмыцких послов с любопытством наблюдали представители голландского посольства. Вот как описал калмыков в своем путевом дневнике Н. Витсен: «... на прием к великому царю пришли калмыки..., у них самостоятельный князь. Говорят, они приезжают сюда, чтобы предложить свои услуги царю от имени их князя Тайчжи Мончака. Этот Тайчжи женат на черкесской татарке, племяннице Григория Синсилевича, царевича черкесов, теперь он князь ${ }^{131}$; через этот брак черкесский князь пытается добиться тесной связи с Россией $\rangle^{132}$.

В документах за 1665-1666 гг. нет никаких существенных сведений о нападениях крымских татар на Московское государство, поскольку в это время они были вовлечены в междоусобную войну в Северном Причерноморье. Несмотря на спад их активности, калмыцкие набеги на Крым продолжились. В мае 1665 г. калмыки совместно с донскими казаками совершили набег на крымскую территорию, где им удалось перехватить один из отрядов, двигавшихся с запасами в полки к хану. Попытка перекопского военачальника Карачбея их

131 Здесь, скорее всего, речь идет о браке Аюки и Обелханы.

${ }_{132}$ Витсен Н. Указ. соч. С. 197. преследовать закончилась для него поражением. Более успешными оказались действия крымского калги, которому при поддержке многочисленного войска в районе урочища Черный колодец удалось всетаки отбить захваченные калмыками и донцами трофеи и заставить их отступить к Дону ${ }^{133}$.

В том же году калмыцкие тайши перенесли свои основные боевые действия на территорию Северного Кавказа и в район Азова. Например, в июле на Кубани калмыками был разгромлен отряд из 450 татар, направленный по приказу крымского хана из Керчи в Черкессию для захвата «языков». Только 250 татарам удалось уйти, а 200 были побиты или взяты в плен ${ }^{134}$. Тем же летом в одной из вооруженных стычек с калмыками был убит азовский паша Мустафа. Турецкий султан, которому погибший паша приходился зятем, обрушился с обвинениями в адрес крымского хана Мухаммед-Гирея, в чью обязанность входило обеспечение безопасности турецкой крепости со стороны степи ${ }^{135}$. По всей видимости, именно это и стало причиной смены прежнего крымского хана на нового - Адиль-Гирея.

Отчасти это подтверждают и показания пленного азовского армянина Сеина, захваченного калмыками и доставленного затем в Москву в ноябре 1664 г. С его слов, летом под Азов приходили калмыцкие отряды по 40-50 человек и в одной из вооруженных стычек убили зятя турецкого султана Мустафу-пашу ${ }^{136}$ и Бахмех-агу, отогнали из-под крепости большое количество скота и лошадей. В Азове

${ }^{133}$ РГАДА. Ф. 123. Оп. 1. 1663 г. Д. 2. Л. 94.

${ }^{134}$ РГАДА. Ф. 123. Оп. 1. 1665 г. Д. 3. Л. 3.

${ }^{135}$ РГАДА. Ф. 111. Оп. 1. 1666 г. Д. 1. Л. 7, 8.

${ }_{136}$ Об убийстве калмыками в бою азовского Мустафы-паши свидетельствует в своем сочинении и османский путешественник Эвлия Челеби: «Впоследствии они [калмыки] устроили великое сражение с Гюрджу Мустафа-пашой, который пребывал в Азове для обороны [крепости]. Не обращаясь к чьей-либо помощи, всего лишь с семьюдесятью копьями Мончак-шах из [племени] калмыков напал на Азов, и азовский везир Мустафа-паша был убит копьем, [направленным] руками калмыков. Затем неверные-калмыки перешли близ Азова реки Дон, Миус и Дрынь. Разгромив племена ногайцев Адиля, Урмамета и Шейдяка, которые находились за пределами Крыма, они захватили безграничное и ни с чем несравнимое по обилию количество скота (Челеби. Указ. соч. С. 195). 
находилось примерно 700-800 воинов (в том числе 300 конных). По свидетельству Сеина, если под крепость приходят даже 50 калмыков, то, как правило, азовцы на бой с ними не выходят, «потому что калмыцкие люди, как емлют их на боях в полон, и они де их рубят, а живых не держат) ${ }^{137}$.

Нахождение калмыков в причерноморских степях было серьезной опасностью не только для крымцев. Так, 15 октября 1665 г. недалеко от Перекопа, в урочище Косаева Клюка, отрядом из 20 калмыков было разгромлено направлявшееся в Крым русское посольство. Жертвами калмыков стали посол И. Богданов, два толмача, остальные разбежались. Спасти удалось и Г. Прокопову, который смог добраться до Крыма и сообщить о случившемся. Калмыкам достались государевы грамоты на имя хана, казна, а также посылка для томившегося в крымском плену боярина В.Б. Шереметева ${ }^{138}$.

В Крыму в это время под арестом находились и калмыцкие послы. Об обстоятельствах их освобождения мы находим в донесениях в Москву русских посланцев. В октябре того же года к хану приехал черкесский владелец Тохтарал, который построил укрепленный городок на Кубани для защиты ногайского улуса Шейдяковых от калмыков. В нем попеременно несли службу 500 ногайцев. Незадолго до этого к Тохтаралу прибыли посланцы от Дайчина с предложением, что, если тот желает с калмыками «быть в миру», то должен посодействовать в освобождении калмыцких послов, а именно - выпросить их у хана. Адиль-Гирей пошел навстречу просьбе Тохтарала и отпустил с ним калмыков. По сообщению побывавшего в Бахчисарае русского толмача П. Кучумова, калмыцкие послы во главе Манзичюлукаем действительно выехали из Крыма с Тохтаралом ${ }^{139}$.

Однако уже в феврале 1666 г. из Азова в Крым пришла весть, что тот самый городок на Кубани калмыками разорен, а его ногайский гарнизон «порублен» ${ }^{140}$. Сведения о разгроме кубанского городка нам известны сразу из нескольких источников, но, возможно, здесь речь

${ }^{137}$ РГАДА. Ф. 119. Оп. 1. 1664 г. Д. 10. Л. 1-2, 4; Куц О.Ю. Указ. соч. C. 390 .

${ }^{138}$ РГАДА. Ф. 123. Оп. 1. 1665 г. Д. 10. Л. 2, 3.

${ }^{139}$ РГАДА. Ф. 123. Оп. 1. 1665 г. Д. 3. Л. 9.

${ }^{140}$ РГАДА. Ф. 123. Оп. 1. 1665 г. Д. 3. Л. 13. идет о разных укреплениях. Например, в донесении в Москву донских казаков в январе 1666 г. говорится, что городок был земляным, и стоял он на правом берегу Кубани. В строительстве его участвовали турки, так как гарнизон состоял из 200 азовцев, но Мончак «тот городок разорил» ${ }^{141}$. По показаниям неизвестного русского пленника, городок был каменным и стоял в верховьях Кубани. Причиной его разгрома калмыками стала месть за гибель «начального человека» Мончака, Малай-кашки. Незадолго до этого он совершил нападение на окрестности этого самого городка, отогнал “живность», но в ходе преследования был убит. После этого Мончак, собрав все имеющиеся силы, пошел войною и подверг разгрому городок и ногайские улусы, кочевавшие на Кубани ${ }^{142}$.

О расстановке калмыцких улусов в этот период нам становится известно из сообщения в Москве атамана Р. Осипова в декабре 1665 г. Осенью улус Дайчина кочевал за Волгой, а улус Мончака расположился по Дону и Манычу, в непосредственной близости от Черкасского городка. Ввиду столь массового присутствия калмыков на этой территории, общую численность его владения казакам сосчитать было сложно. Однако Осипов отмечал, что калмыки «с Войском до ныне живут в совете, а от Войску чинят им честь и посланцы на [обе] стороны ходят беспрестанно». Отряд из 80 калмыков, отправленный в ноябре Мончаком на помощь войсковому атаману М. Самаренину и воеводе И. Хвостову, участвовал в бою под Азовом. Несмотря на численное превосходство, азовский паша потерпел поражение. С началом весны следующего года Мончак планировал направиться войною на крымского хана ${ }^{143}$.

С началом года улус Мончака откочевал в район реки Кума. У Дона, в районе «верховых» городков, продолжали оставаться двое неизвестных калмыцких тайшей с тысячью калмыков, не считая женщин и детей. Как отмечали про эту группу калмыков сами донцы, «с казаками они ж в миру и задоров от них никаких нет», вели взаимную торговлю ${ }^{144}$.

${ }^{141}$ РГАДА. Ф. 111. ОП. 1. 1666 г. Д. 1. Л. 5.

${ }^{142}$ РГАДА. Ф. 111. Оп. 1. 1666 г. Д. 1. Л. 9, 10.

${ }^{143}$ РГАДА. Ф. 111. Оп. 1. 1665 г. Д. 4. Л. 1-3.

${ }^{144}$ РГАДА. Ф. 111. Оп. 1. 1666 г. Д. 1. Л. 6. 
В последующих своих донесениях в Москву Мончак отношения с донскими казаками оценивал не так безоблачно. Калмыцкий посол Казик, прибывший в российскую столицу весной 1666 г., жаловался на донцов, что те («инят шкоду большую): «ясырь у них подговаривают и лошадей отгоняют». Под «ясырем» здесь имелись ввиду захваченные в ходе набегов у крымцев пленные поляки и черкасы. На неоднократные требования Мончака выдать пленных беглецов и захваченных лошадей атаманы всячески отрицали свою причастность $^{145}$, указывая, что виновниками этого были беглые донские казаки, живущие на Куме ${ }^{146}$.

Со стороны калмыков все же последовали ответные действия, и уже в сентябре донские атаманы жаловались на убийство калмыками семерых казаков на реке Бузулук, а также отгоне ими лошадей и скота $^{147}$. Однако к концу года калмыцко-донские отношения были в целом улажены, о чем свидетельствовали в Москве донские посланцы. Зимой 1666/67 года улус Солом-Церена кочевал отдельно от основной массы калмыков между Доном и Донцом, откуда под Перекоп он продолжал отправлять отряды в набег. Так, осенью 1666 г. калмыки пришли из-под Крыма на Дон с богатыми трофеями, обменивали у казаков захваченных лошадей на «киндяки») и «зипуны» ${ }^{148}$

В 1666 г. набеги калмыков на Крым возобновились, чему также способствовала вспыхнувшая в ханстве междоусобица. В начале года отряд из 77 калмыков совершил нападение на крымские улусы, отогнав 8 тыс. лошадей, и без потерь вернулся домой ${ }^{149}$. В октябре калмыки на Чонгаре отогнали конские табуны и скот. Уже в конце года объединенный отряд, состоящий из 300 калмыков и 500 запорожцев, объявился под Перекопом, но местный комендант ничего не мог против них предпринять и жаловался хану на малочисленность своего гарнизона ${ }^{150}$.

Политика Турции была направлена на то, чтобы русская армия в войне с Польшей не имела какого-либо значительного преимущества,

\footnotetext{
${ }^{145}$ РГАДА. Ф. 111. ОП. 1. 1666 г. Д. 1. Л. 24, 30.

146 РГАДА. Ф. 111. ОП. 1. 1666 г. Д. 3. Л. 3.

${ }^{147}$ РГАДА. Ф. 111. ОП. 1. 1666 г. Д. 3. Л. 3.

${ }^{148}$ РГАДА. Ф. 111. Оп. 1. 1666 г. Д. 6. Л. 8

149 АИЮЗР. СПб., 1869. С. 86.

${ }^{150}$ РГАДА. Ф. 123. Оп. 1. 1665 г. Д. 3. Л. 16, 18.
}

и военные силы Крымского ханства должны были предпринять для этого все возможные меры. Нейтрализация отрядов крымских татар требовала привлечения значительной массы конницы, и в этом надежда русско-украинского командования были только на поддержку калмыков.

Летом гетман Брюховецкий отправил к Мончаку посланцев С. Петрова и полковника Ф. Донца с очередной просьбой об оказании военной помощи. Мончак снова пошел навстречу Брюховецкому и отправил к нему 5 тыс. воинов. Перейдя Дон, часть калмыцкого войска с Ф. Донцом степью направилась на Тор и далее на Полтаву, а другая часть, сопровождая подводы, отправилась к гетману в Гадяч. Но недостаточное обеспечение продовольствием и кормами, а также затишье на фронтах вынудили калмыков вернуться в свои улусы. Например, уже в июле 300 калмыков самовольно покинули Брюховецкого ${ }^{151}$.

С наступлением осенних холодов немногочисленные калмыцкие отряды вновь появляются в причерноморских степях. В течение октября-декабря месяцев 1666 г. отмечаются совместные их с запорожцами нападения на Чонгар и Перекоп, откуда они смогли отогнать большое количество лошадей и скота. Вынужденный заниматься оборонительными действиями, перекопский комендант просил хана о подкреплении, указывая на малочисленность своего гарнизона ${ }^{152}$.

C началом 1667 г. набеги калмыков ненадолго прекратились. Как сообщали вернувшиеся из-под Азова в Крым татары, калмыцкие улусы ушли с Дона на зимние кочевья ${ }^{153}$. Но уже в мае отряды запорожцев и калмыков перешли Днепр под Шах-Керменом и угрожали Перекопу. В июле из Азова снова пришла весть о намерении тайшей кочевать в азовской степи ${ }^{154}$. Все эти действия заставили хана Адиль-Гирея срочно туда выдвинуться с войском. В районе Перекопа нападавшими калмыками и запорожцами был разгромлен крымский отряд в 300 человек, направлявшийся под Чигирин на соединение с гетманом Правобережной Украины П. Дорошенко, выступавшим за союз с Турцией и Крымом ${ }^{155}$.

${ }^{151}$ АИЮЗР. СПб., 1869. С. 130, 138

${ }^{152}$ РГАДА. Ф. 123. Оп. 1. 1665 г. Д. 3. Л. 16, 18, 19.

${ }^{153}$ РГАДА. Ф. 123. Оп. 1. 1665 г. Д. 3. Л. 27.

${ }^{154}$ РГАДА. Ф. 123. Оп. 1. 1667 г. Д. 1. Л. 10, 21

${ }^{155}$ РГАДА. Ф. 123. Оп. 1. 1665 г. Д. 3. Л. 109. 
В заслугу за военную службу денежное жалованье из Москвы к тайшам теперь поступало регулярно. Например, перед заключением Андрусовского перемирия поляки запросили у российской стороны огромную контрибуцию. Однако главный российский переговорщик А.Л. Ордин-Нащокин ответил отказом, сославшись на будто бы большие расходы, вызванные отправкой правительством денег калмыкам, «чтоб они теснили Крымский юрт и не пускали хана на Польшу» ${ }^{156}$. На самом деле это была дипломатическая уловка с целью отказать полякам в выплате контрибуции: размеры годового денежного жалования тайшам, как показывают документы, отнюдь не были большими. Но условия политического соглашения с Москвой вполне устраивали калмыцкую правящую верхушку, которая небольшое по размеру жалованье во многом компенсировала за счет беспошлинной торговли с русскими городами, обеспечения относительной безопасности калмыцких кочевий и получения трофеев в ходе военных набегов на территории Северного Кавказа и Крымского ханства.

В результате Андрусовского перемирия 1667 г. между Россией и Польшей произошло разделение Украины по Днепру - на Левобережную и Правобережную. Общественные настроения украинского населения носили как антироссийский, так и антипольский характер. В 1668 г. атаман Серко перешел на сторону Дорошенко, «воевал» украинские города, идя (против бояр и воевод), в то же время не переставал тревожить своими набегами и крымцев. В октябре крымский пленник Криштоф Турач сообщал в Киеве, что Серко с донцами, запорожцами и калмыками четырежды приходил на Крым. Во время третьего похода они разбили 3 тыс. и пленили 500 крымцев, а в четвертом - дошли до Бахчисарая ${ }^{157}$

В 1669 г. калмыцкие набеги на Крым продолжились. По сведениям русского посланца Г. Михайлова, в апреле калмыки отогнали из-под Перекопа 200 лошадей, и ширинский Мин-Гирей отправлял за ними отряд преследования. А в июне уже до тысячи калмыков под Перекопом совершили внезапное нападение и разгромили лагерь нуреддина, захватив шатер, едва не пленив его самого. Выручил нуред-

${ }_{156}$ Соловьев С.М. История России с древнейших времен. Т. 11, 12. М., 1991. C. 175.

${ }^{157}$ АИЮЗР. СПб., 1872. Т. 7. С. 101. дина вовремя подоспевший с отрядом перекопский бий. Татары потеряли в бою около 600 человек, а также большое количество лошадей и скота. Нападению калмыков подверглось и мунтянское посольство, направлявшееся к крымскому хану с подарками и «окупными деньгами». Из 50 членов посольства спаслись только 8 человек ${ }^{158}$.

Уже с весны правительство ожидало новые набеги татар на пограничные уезды. С целью обезопасить рубежи границ по ряду городов были поставлены калмыцкие отряды. Стоит отметить, что жители приграничных городов часто сами выступали инициаторами в письменных прошениях к государю о присылке к ним именно калмыков, так как татары и ногайцы старались обходить те населенные пункты, где стояли калмыцкие отряды. Так, нам известно, что в августе под Белгородом стоял отряд в 400 калмыков, под Царевым Борисовым - 300 калмыков. Часто они срывались с мест своих дислокаций и направлялись в Запорожье, чтобы затем участвовать совместно с казаками в набегах под Перекоп ${ }^{159}$.

15 августа 1669 г. в Москву прибыло посольство от Мончака. Посол Манхадан жаловался царю на донских казаков, которые «имали на перевозах [через Дон] наем большой» с калмыков, направлявшихся или возвращавшихся из крымских походов. Также он требовал вернуть захваченных казаками у калмыков в устье Хопра трофейных 40 отборных лошадей, саадаки, сабли, шубы и «всякую рухлядь». Донской атаман Я. Веневитинов в Москве объяснял властям, что уполномоченные люди уже отправлены в «верхние» городки «для сыску» тех калмыцких лошадей и вещей, а также наказания виновных ${ }^{160}$. Калмыцкие тайши обращались в Москву с предложением совершить поход на левобережье Днепра против изменника гетмана И. Брюховецкого, но получили строгое указание без приказа с войсками не выдвигаться на Украину. Правительство беспокоилось за целостность православных храмов и безопасность людей в этом регионе ${ }^{161}$.

${ }^{158}$ РГАДА. Ф. 123. Оп. 1. 1669 г. Д. 1. Л. 4, 5, 12, 13.

${ }^{159}$ РГАДА. Ф. 123. Оп. 1. 1669 г. Д. 1. Л. 16, 19.

${ }^{160}$ РГАДА. Ф. 111. Оп. 1. 1669 г. Д. 9. Л. 24-26.

${ }^{161}$ РГАДА. Ф. 111. Оп. 1. 1669 г. Д. 9. Л. 24, 26; АИЮЗР. СПб., 1875. Т. 8. C. 247. 
С атаманом Я. Веневитиновым, есаулом П. Жуковым и 9 казаками прибыли и трое калмыцких посланцев (Алдай, Иджигер и Ламач) от дербетского Солом-Церена, которые привезли пленного азовского татарина. Калмыки приехали с определенной целью, «чтоб служба их великому государю была ведома». Летом тайша Даши (старший сын Солом-Церена) отправил в помощь казакам с левого берега Волги на Дон отряд в 200 калмыков под командой Тупшина. В это время 150 азовских татар совершили нападение на Казацкий Караул у реки Махина, но неожиданное появление сотни казаков и калмыков обратило их в бегство. При погоне казаки захватили в плен 12 , а калмыки - 8 татар. Одного пленного азовца отправили для допроса в Москву, а остальных повесили, поскольку азовцы поступали таким же образом с пленными казаками, захваченными при набегах. 5 августа азовцы, собрав все силы, подошли к Черкасску, но снова были разбиты объединенным войском казаков и калмыков ${ }^{162}$.

\section{5. Калмыцко-донские отношения в период Разинского восстания}

В 1667 г. в России разгорелся пожар очередной крестьянской воны. На Дону появился новый вожак, способный начать восстание, - Степан Тимофеевич Разин. Разин принадлежал к состоятельной, «домовитой» казачьей семье. Правительство Войска Донского часто доверяло ему дипломатические и военные миссии. Известно, что в 1660 г. Разин входил в донскую делегацию царского посольства к калмыкам. Два года спустя он вместе с другим представителем снова вел переговоры с калмыками о военном сотрудничестве против крымских татар. В 1663 г. Разин командовал отрядом донских казаков, который при поддержке калмыков и запорожцев воевал с татарами.

Морские экспедиции («поход за зипунами»), привлекавшие своими богатыми добычами, для их организаторов являлись едва ли не лучшим способом завоевать авторитет среди казаков разных слоев. Ранней весной 1667 г. Разин расположил свой штаб на островах в излучине Дона напротив излучины Волги. На его призыв собралось

\footnotetext{
${ }^{162}$ РГАДА. Ф. 111. Оп. 1. 1669 г. Д. 9. Л. 2-5, 10-12.
}

около тысячи бедных казаков и беглых крестьян. Яицкие казаки предложили Разину использовать район Яика в качестве опорного пункта, с которого удобно было отправляться в захватнические походы по нижнему течению Волги и в окрестности Каспийского моря ${ }^{163}$. Спустившись вниз по Волге, разинские суда, проплыв вдоль северного побережья Каспия, дошли до Яика и захватили Яицкий городок. Однако стрельцы гарнизона отказались вступить в армию Разина и большую их часть казаки убили, спастись удалось лишь немногим. Зиму 1667/68 года Разин провел в Яицком городке.

Что же касается калмыков, то документы свидетельствуют, что они остались верны договоренностям с правительством и даже попытались подавить выступление казаков на начальном его этапе. Еще в июне 1667 г. Дайчину из Москвы пришла грамота, в которой ему указывалось принять все меры предосторожности и противодействия повстанцам. Уже в августе Солом-Церен с отрядом в 600 человек вместе с сотней царицынских стрельцов преградил путь 800 донским казакам под командой атаманов П. Перевощикова и Н. Чертка (дяди С. Разина), которые шли на соединение с Разиным. В результате боя с калмыками казаки отступили. В начале 1668 г. 10-тысячное калмыцкое войско под началом Дайчина и Мончака с суши блокировало Яицкий городок. В ходе приступов калмыки пробили крепостную стену на полторы сажени, а устье Яика попытались «заметать хрящем» ${ }^{164}$. Казакам удалось отбить все калмыцкие атаки, но в результате они оказались в осадном положении ${ }^{165}$.

С весенним половодьем 23 марта 1668 г. Разину со своими сторонниками все же удалось покинуть осажденный калмыками городок и уйти вниз по Яику в Каспийское море. Флотилия Разина, состоявшая из 24 судов и 1600 человек, была вооружена захваченными в крепости пушками $^{166}$. В дальнейшем повстанцы разграбили мусульман-

${ }^{163}$ АИ. СПб., 1842. С. 376.

${ }^{164}$ Хрящ - крупный песок, образовавшийся из обломков твердых горных пород.

165 Крестьянская война под предводительством Степана Разина. Сборник документов / сост. Е.А. Швецова. Т. 4. М., 1976. С. 5, 7-8; АИ. СПб., 1842. С. $380-381$

166 Крестьянская война под предводительством Степана Разина. Сборник документов / сост. Е.А. Швецова. Т. 1. М., 1954. С. 73-104. 
ские города на западном побережье Каспия - от Дербента до Баку. Достигнув персидского города Решт, что на южном берегу, Разин предложил шаху свои военные услуги в обмен на земли для расселения своих казаков в Персии. Когда переговоры по этому вопросу уже начались, жители Решта напали на казаков. Потеряв 400 человек, казаки отправились в другой прибрежный персидский город Ферахабад, который безжалостно был ими разграблен. Весной 1669 г. Разин разорил туркменские владения на восточном побережье Каспия, а затем разбил шахский флот под командованием персидского адмирала Манади-хана. Поскитавшись по чужбине, казаки решили, что пора им возвращаться домой. Разин отправил гонцов к астраханскому воеводе И.С. Прозоровскому с выражением готовности просить у царя прощения и впредь верно ему служить. 4 сентября казаки отплыли из Астрахани вверх по Волге к Царицыну, откуда возвратились на Дон. На родину Разин вернулся победителем и со сказочной добычей. К его штабу у Кагальника потянулись толпы бедных казаков с Дона и северных территорий, и даже из Запорожья. Донское казачество в результате разделилось на две группы: «разинскую армию» и регулярное Войско Донское во главе с атаманом К. Яковлевым. Весной 1670 г. Разин с соратниками появился в Черкасске, где несколько дней правил единовластно. Оттуда он отправился вверх по Дону в Паншин городок, где к нему присоединился В. Ус со своими людьми. Под командованием Разина уже находилось примерно 7 тыс. казаков.

Стратегический план Разина предусматривал превращение Волги в основную линию его военных операций. Захватив Царицын, он перекрыл связь между Москвой и Астраханью. Московское правительство отправило к Царицыну отряд в тысячу стрельцов, в то же время воевода С.И. Львов вышел к Царицыну из Астрахани с отрядом в 2500 стрельцов. На соединение с ним с севера вдоль Волги двигались калмыки Аюки. Но как только лодки Разина 4 июня 1670 г. подошли к Черному Яру, где стояло войско князя Львова, астраханские стрельцы перешли на сторону повстанцев. Казаки жестоко расправились со стрелецкими командирами, а рядовых приняли в свою «армию). Воевода Астрахани, князь Прозоровский готовился к обороне города от приближавшихся повстанцев, но не надеялся удержать его, так как верность стрельцов не внушала доверия, а вспомогательные отряды калмыков и черкесов были малочисленны. Мятежники 24 июня подошли к Астрахани, и уже после двух дней осады стрельцы и посадские люди перешли на сторону Разина. Некоторых сторонников Прозоровского убили, а его самого казаки сбросили с крепостного вала. После этого в городе начался всеобщий грабеж. Разин установил казацкую форму правления, а Аманатный двор распустил. Группа калмыков, кочевавшая возле Астрахани, предпочла отойти от города ${ }^{167}$

15 июля 1670 г. в Саратов от дербетского Солом-Церена в прибыли посланцы Чекулат и Кажамгур. Они сообщили, что по государеву указу Аюка и Батур с 20-тысячным войском двинулись на повстанцев Разина. Солом-Церен отрядил с ними 1,5 тыс. своих людей под командованием старшего сына Даши. Последний отправил 400 человек под мятежный Царицын для отгона скота и лошадей. Дербеты практически полностью блокировали город, захваченный повстанцами, отогнав у его жителей большое количество скота и лошадей. По другим данным, у Даши было 2 тыс. человек, и он стоял со своими людьми на заставе между Царицыным и Паншиным городком с целью не пропустить казаков, направлявшихся с Дона на Волгу на соединение c Разиным. С этой задачей (видимо, поставленной Аюкой) дербеты успешно справились. Но они действовали до тех пор, пока 7 июля здесь не появилось 4-тысячное войско мятежных тайшей Дугара и Бока (совместно с азовцами и крымцами), направлявшееся по левобережью Дона в набег на южные окраины России. В результате неравного боя в районе между Царицыным и Пятиизбенской дербетская застава была полностью разбита, погибли Даши и полторы тысячи его людей. Остальные смогли уйти через Волгу к реке Камышинка и вернуться к Солом-Церену ${ }^{168}$.

Дугар и Бок, видимо, тоже понесли серьезные потери, так как им пришлось отменить свой дальнейший набег и вернуться под Азов. По сведениям воронежского воеводы Бориса Бухвостова, люди этих тайшей полностью перекрыли дорогу с Дона на Царицын, убивали казаков и угоняли у них скот и лошадей. Калмыки и ногаи мятежных тайшей совершили нападение на казачьи селения по Хопру, Чиру и

${ }^{167}$ Крестьянская... Т. 1. С. 252.

${ }^{168}$ Крестьянская... Т. 1. С. 185, 213-214, 232, 234. 
Медведице в отместку за недавний разгром их же улусов людьми Разина. Атаманы отправляли посланцев к Дугару и Боку с предложением мира, но получили отказ, мотивированный тем, «что они воры и своему государю изменили, а им от них тово ж ждать» ${ }^{169}$.

В июле 1670 г. Аюка со своим войском находился на левобережье Волги, в 60 верстах ниже Черного Яра. Здесь состоялась его встреча со стрелецким сотником Г. Ломакиным. Аюка сообщил ему об измене астраханского отряда, на соединение с которым шли калмыки, чтобы вместе ударить по повстанцам. Переход астраханских стрельцов на сторону Разина фактически оставил калмыков один на один с повстанцами. Аюка просил Ломакина передать в Москву просьбу о присылке новых войсковых подкреплений, место общего сбора определив урочище Ураков Караул в 20 верстах выше реки Камышинка. Тайша еще раз заверил, что «вопче с твоими великого государя ратными людьми служить и радеть и над богоотступным вором, над Стенькою Разиным, всякими промыслы промышлять рад» ${ }^{170}$.

Пробыв в Астрахани примерно четыре недели, 20 июля 1670 г. Разин отправился вверх по Волге. По дороге от Астрахани до Царицына 10-тысячное войско Разина приняло участие в грабеже населения калмыцких и едисанских улусов ${ }^{171}$. Разин, без труда овладев Саратовом и Самарой, подошел к Симбирску. Последовавшая битва с правительственными войсками не принесла весомых результатов, но посадские люди Симбирска впустили повстанцев в город. Получив подкрепление в конце сентября 1670 г., князь Барятинский 1 октября нанес сокрушительное поражение Разину под Симбирском. Повстанцы планировали закрепиться в Самаре, однако горожане в город их уже не впустили. Разин пытался призвать на помощь калмыков, чтобы в дальнейшем с ними двинуться степью вверх по Волге, но тайши ему отказали ${ }^{172}$. Разин предпринял безуспешную попытку захватить Черкасск и отступил к Кагальнику. 14 апреля верные атаману Яков-

${ }^{169}$ Крестьянская... Т. 1. С. 224-225, 239; Крестьянская война под предводительством Степана Разина. Сборник документов / Сост. Е.А. Швецова. T. 2. М., 1957. С. 16.

${ }^{170}$ Крестьянская... Т. 1. С. 225-226.
${ }^{171}$ Крестьянская... Т. 1. С. 177, 180-181.
${ }^{172}$ Крестьянская... Т. 2. С. $184-185$. леву казаки штурмом взяли Кагальник. Разина арестовали и выдали Москве, где 6 июня он был казнен.

Разинское восстание произвело сильное впечатление не только на казаков и крестьянство юга России, но и на калмыцкое население. С одной стороны, харизма Разина, его личная храбрость, которую калмыки не раз наблюдали в совместных походах на Крым, привлекали кочевников. С другой - договоренности с правительством обязывали тайшей действовать против повстанцев. Антиразинские настроения калмыков окончательно сформировались после погрома повстанцами калмыцких и едисанских улусов в 1669-1670 гг. Попытки Разина после этого договориться с тайшами и привлечь их на свою сторону уже не имели успеха. Действия Дугара и Бока летом 1670 г. на Дону, в ходе которых была уничтожена дербетская застава Даши, невольно помогли повстанцам расширить район своих действий и пополнить свои ряды донскими казаками. Внутренние усобицы, имевшие место в калмыцком обществе, по времени совпали с этим восстанием и невольно способствовали активизации антиправительственных действий Разина.

\section{6. Политический кризис в калмыцком обществе. Приход к власти Аюки}

Калмыцкое общество, как и в целом Российским государство, на рубеже 1660-х-1670-х гг. переживало внутренний политический кризис. Русские и калмыцкие источники весьма скупо освещают события того периода, которые заметно повлияли на дальнейшую расстановку сил в ойратском обществе.

Начало этого политического кризиса зародилось далеко на востоке. Потерпев поражение в борьбе за верховенство в хошутском доме, Аблай со своим улусом откочевал вслед за дядей Кунделен-Убаши со Среднего Прииртышья в западном направлении. В историографии устоялось ошибочное мнение о том, что хошутский тайша имел целью возвращение торгутов на их старые кочевья в Юго-Западной Сибири. Мы уже не раз наблюдали, что в среде ойратской знати в случае возникновения семейных ссор тайши часто со своими улусами 
уходили к материнским родственникам. Мать Аблая, Сайханчжунхатун, была дочерью Хо-Урлюка, соответственно, ее сын приходился Дайчину племянником, а Аюке - двоюродным дядей. Более того, Аблай был женат на дочери Дайчина ${ }^{173}$. Но в его случае имеет место настоящая экспансия хошутов на позиции торгутов в Северном Прикаспии. Перед Аблаем, видимо, стояла определенная задача - захватить кочевья и подчинить волжских калмыков. Чакарских калмыков. как известно, еще с 1630-х гг. привлекали прикаспийские степи, а также многочисленные ногайские улусы, подчинявшиеся торгутским тайшам. Сведения о вспыхнувшем на юге России восстании С. Разина, вероятно, дали Аблаю основание считать, что российское правительство, занятое своими внутренними проблемами, не будет активно вмешиваться в калмыцкие дела.

Примерно во второй половине 1669 г. происходит объединение двух групп чакарских калмыков: улусов хошутского Кунделена-Убаши с дербетами, откочевавшими из Юго-Западной Сибири в степи Северного Прикаспия еще в начале 1660-х гг., и новоприбывшим со своим улусом хошутским Аблаем. Первой жертвой их совместного нападения стал улус дербетского тайши Даян-Омбо, видимо, отказавшегося от участия в коалиции. Затем объединенные силы чакарцев нанесли удар уже непосредственно по торгутским улусам на Яике ${ }^{174}$.

Смерть Мончака, по всей вероятности, произошла в результате именно этих событий, но подробных сведений о том, при каких обстоятельствах это случилось, к сожалению, ни в русских, ни в калмыцких источниках нет. По сведениям П.С. Палласа, Аблай захватил в плен Мончака в районе яицких степей ${ }^{175}$. Погиб ли Мончак в бою или уже в плену и имел ли к этому отношение Аблай - неизвестно. Но очевидно одно - при живом предводителе волжских калмыков хошутскому правителю не удалось бы прийти к власти.

Вышеизложенные события в какой-то мере дополняют недавно выявленные сведения из русских архивных документов. Примерно на рубеже 1670 и 1671 гг. от Аюки и Солом-Церена в Москву прибыл

173 Материалы по истории русско-монгольских отношений (далее PMO). 1654-1685: Сб. документов / Сост. Г.И. Слесарчук. М., 1996. С. 205

${ }^{174}$ Раднабхадра. Указ. соч. С. 92; Норбо ШІ. Указ. соч. С. 107.

${ }^{175}$ P.allas P.S. Указ. соч. C. 28. посланец Юмай-дархан. Именно из его показаний стало известно, что на момент вторжения Аблая на территорию торгутских кочевий Дайчин совместно с внуком Назар-Мамутом (сыном покойного Нима-Церена) кочевал на Яике, выше Индерских гор. Ориентировочно зимой 1670/71 года собственно в этот район и вторгся Аблай, «а с ним кошоуцкие и дербенские тайши». Общая численность объединенного их войска, по сведениям Юмай-дархана, составляла 40 тыс. человек. Поскольку в это время основные силы волжских калмыков под командованием Аюки и Солом-Церена находились в военном походе против ногайского Ямгурчи-мирзы, который незадолго до этого увел к себе на Кубань значительное число калмыцких ногаев, создалась ситуация, при которой вторгшиеся на территорию волжских калмыков хошуты и дербеты «Дайчина со всеми улусы загнали к себе без бою». Узнав о приходе войска Аблая, Аюка срочно привел все свои военные силы к Волге, где ожидал прихода хошутского войска, видимо, для решающего сражения. Но там Аблай так и не появился, Аюке и Солом-Церену пришлось увести свои улусы в степи Придонья, в район рек Иловля и Юла. Юмай-дархан от имени Аюки просил правительство оказать военную помощь против Аблая, а также жалованье, («что давано было отцу иво (Аюки - B.T.), давать матери иво» ${ }^{176}$.

Аблай со своей стороны также предпринял энергичные дипломатические шаги, когда прислал в Москву уже своего посла с письменным извещением о том, что он с сыном Цаганом и Эрке-ламой захватил улусы Дайчина и Назар-Мамута, а Аюка якобы «с малыми людьми» бежал на правый берег Волги. С позиции победителя хошутский тайша требовал жалованье, ранее выдаваемое Дайчину и Мончаку, теперь присылать из Москвы только ему, поскольку отныне он стал кочевать на торгутских землях ${ }^{177}$. Стоит отметить, что послы Аюки и Аблая одновременно находились в Москве и вели друг против друга закулисную борьбу за право заручиться поддержкой царского правительства в пользу своих владельцев. О примирении сторон, на чем настаивала Москва, не могло быть и речи, поскольку в Северном Прикаспии происходила постепенный переход власти от торгутского правящего дома к хошутскому.

${ }^{176}$ РГАДА. Ф. 119. Оп. 1. 1673 г. Д. 1. Л. 56-58.

${ }^{177}$ РГАДА. Ф. 119. Оп. 1. 1673 г. Д. 1. Л. 59. 
Указанные события повлекли за собой новый всплеск вынужденных миграций, внутренних усобиц, и, как отмечали многочисленные очевидцы, у калмыков происходили «межусобье и бои великие и сеча большая ${ }^{178}$. Кризис в торгутском доме, последовавший после смерти Мончака и пленения Аблаем Дайчина, поднял вопрос о преемственности власти. Кандидатура молодого и амбициозного Аюки, видимо, устраивала не всех старших тайшей. По мнению В.И. Колесника, далеко не все тайши были согласны с автоматическим наследованием по прямой нисходящей линии от Мончака к Аюке ${ }^{179}$.

Габан Шараб в своей летописи, правда, без подробностей и указания на дату, упоминает о враждебных действиях против Аюки соратников его отца - Солом-Церена и Батура ${ }^{180}$. Более поздние по времени русские документы раскрывают некоторые моменты из взаимоотношений Аюки с дербетским Солом-Цереном в указанный период. В 1699 г. Мунко-Темир, второй сын Солом-Церена, в своем письме в Москву сообщал о том времени, когда хошутский Аблай «Мунчака тайшу разорил». Именно после этого события Аюка и Солом-Церен со своими улусами ушли кочевать на Дон, где между ними, видимо, и произошел тот самый конфликт, на который в своей летописи указывает Габан Шараб. Суть его заключалась в том, что Аюка после погрома Аблаем торгутских улусов надумал уйти в крымские владения, по всей видимости, к уже находившемуся там с 1664 г. двоюродному дяде Дугару. Но Солом-Церен всячески его отговаривал от такой затеи, предлагая и дальше верно служить московскому государю. По сведениям Мунко-Темира, именно за это Аюка «сложась с сыном иво Солом Сереневым, ево Солом Сереня разорил» ${ }^{181}$. Под сыном СоломЦерена здесь подразумевается его старший сын Даши. Как видим, Аюка и Даши, будучи людьми одного поколения, воспользовались сложившимся политическим кризисом и попытались отодвинуть на второй план представителей старшего поколения, захватив власть в собственных владениях. Однако Даши не довелось окончательно за-

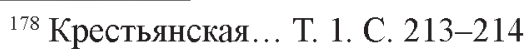

${ }^{179}$ Колесник В.И. Указ. соч. С. 96.

${ }^{180}$ Габан Шараб. Указ. соч. С. 103; Крестьянская... Т. 1. С. 220.

${ }^{181}$ РГАДА. Ф. 119. Оп. 1. 1699 г. Д. 6. Л. 8-9. хватить власть в дербетском улусе, так как вскоре, летом 1670 г., он погиб на Дону в одном из сражений с крымско-калмыцким отрядом Дугара.

Ранней весной 1670 г. к Дугару под Азов откочевал его брат, тайша Бок. Причиной его ухода, как сообщали донские атаманы, стало убийство им некоего «свойственника» Мончака. Казаки были свидетелями перехода 4 тыс. калмыков и ногаев Бока через реку Донец в районе Хороших гор по направлению к Азову. В апреле-мае 1670 г. люди этого тайши совершили нападение на казачий городок Сиротин и отогнали скот. В дальнейшем Дугар и Бок совместно с азовцами планировали напасть на Валуйки и другие пограничные русские города. Общая численность войска двух тайшей под Азовом составляла около 10 тыс. калмыков и ногаев. 11 мая перемирие, действовавшее на тот момент между казаками и азовцами, закончилось, но конфликт у них во многом возник из-за действий вышеуказанных тайшей. Объединенные силы мятежных калмыков, азовцев и крымцев в мае отправились в набег вверх по Дону на южное порубежье России, по дороге разоряя казачьи городки ${ }^{182}$.

Об отношениях Дугара и Бока с крымским двором нам становятся известны из донесений в Москву от русских посланцев в Крыму. Так, толмач Г. Михайлов докладывал о кочевке весной 1670 г. на реке Миус двух тайшей, откуда они обратились к хану с просьбой о подданстве. Столь неожиданная просьба и массовое присутствие калмыков на территорию ханства вызвали серьезное опасение среди крымцев. Адиль-Гирей не доверял тайшам и держал большое количество войск за Перекопом ${ }^{183}$. Однако переговоры последовали, и в июне в Крым вернулся посланец Ежиеш-бей, который по указанию хана ездил в улусы вышеуказанных тайшей, кочевавших уже под Азовом. Всего в подчинении этих владельцев находилось до двух тысяч кибиток. В знак признательности перед принявшим их ханом Адиль-Гиреем они обещали не ходить войной под Крым и вместе с подчиненными ногайскими мирзами принять подданство ${ }^{184}$.

${ }^{182}$ РГАДА. Ф. 111. Оп. 1. 1669 г. Д. 12. Л. 72; Новосельский А.А. Указ. соч. С. 104 ; Крестьянская... Т. 1. С. 206.

183 РГАДА. Ф. 123. ОП. 1. 1669 г. Д. 1. Л. 79.

${ }^{184}$ РГАДА. Ф. 123. Оп. 1. 1670 г. Д. 1. Л. 19, 21, 22. 
Обращает на себя и ситуация в ногайских улусах. По сведениям В.М. Бакунина, в 1670 г. междоусобие разгорелось среди калмыцких ногайцев. Пользуясь неразберихой среди калмыков, Ямгурчей-мирза захватил астраханских юртовских татар мирзы Бека Оллашева и насильно увел их на Терек ${ }^{185}$. В то же время наметилась и обратная тенденция, а именно, переход части ногайцев из-под власти крымского хана к тайшам. Так, известно, что летом 1670 г. к Аюке присоединились выходцы из Казыевского улуса - дети Касая-мирзы: Навруз, Росланбек и Девой. Ставя в известность донских атаманов, Аюка не без удовлетворения отмечал, «что все ногайские мурзы с ним, Аюкою, в миру и хотят против крымского хана стоять заодно ${ }^{186}$. Подобные действия не могли не остаться без последствий и не повлиять серьезно на калмыцко-крымские отношения.

После подавления правительственными войсками восстания Разина калмыцкие тайши попытались урегулировать свои сильно подорванные отношения с донскими казаками. Весной 1671 г. Аюка с улусами кочевал в районе казачьего городка Курман Яр, откуда дважды присылал к атаманам своих представителей. В результате последовавших переговоров стороны заключили шерть, подтвердив прежние договоренности и предопределив возможные последующие действия: «А которые их калмыцкие люди, прикочевав, похотят у них жить на Дону, и за тех людей не стоять и у них, казаков, назад не просить. И живучи, им меж собою никаких обид не чинить, а если кому какая обида учинитца, и им про то на обе стороны разыскивать вправду» ${ }^{187}$. Данное соглашение свидетельствует о появлении в это время первых калмыцких поселенцев в составе донского казачества.

Уже с начала лета отмечаются совместные действия казаков и калмыков. Так, в июне азовские люди были свидетелями о движении в сторону Крыма отряда из 300 казаков и 300 калмыков. В причерноморских степях, на реке Молочные воды, ими был перехвачен возвращавшийся из набега с русским «ясырем» крымский отряд Шевкалаги и полностью уничтожен ${ }^{188}$.

${ }^{185}$ Бакунин В.М. Указ. соч. С. 23.

${ }^{186}$ РГАДА. Ф. 111. Оп. 1. 1670 г. Д. 2. Л. 7, 10.

${ }^{187}$ Цит. по: ИІовунов К.П. Калмыки в составе российского казачества (вторая половина XVII - XIX вв.). Элиста, 1992. С. 33

${ }^{188}$ РГАДА. Ф. 123. Оп. 1. 1671 г. Д. 1. Л. 23, 24.
В среде так называемой “калмыцкой оппозиции» в лице Дугара и Бока вскоре произошли изменения в политической ориентации. Они отошли из-под Азова и кочевали со своими улусами в междуречье Кагальника и Маныча, откуда прислали посланцев к Аюке и Батуру с просьбой, что «хотят великому государю служить же с ними вместе». Смена их настроений была вызвана возникшим недоверием к ним со стороны турецких властей, подозревавших их в постоянных сношениях с другими тайшами и на этом основании не пускавших калмыков в Азов. По сведениям донских казаков, ранее турецкий султан приказал казнить путем отсечения головы азовского пашу Сулеймана только на том основании, что тот «призвал без салтанова ведома к себе Дувара и Бока ${ }^{189}$.

В ноябре 1670 г. крымский хан с войском, по оценкам казаков, насчитывавшим до 100 тыс. человек, пытался догнать беглецов, перейдя Дон в районе Азова. Как сообщал в Москве атаман Л. Семенов, прежде Дугар и Бок «наперед сего бывали ево, хановы (крымского. - B.T.), а ныне де они... служат великому государю». В преследовании калмыков принимал участие и союзник крымцев - правобережный гетман П. Дорошенко с двухтысячным отрядом. Однако тайши со своими улусами успели скрыться на Тереке, под защиту Аюки ${ }^{190}$.

В любом случае объединение тайшей (как показали дальнейшие события, только временное) имело целью, в первую очередь, возврашение 40 тыс. малибашских и джемболукских ногайцев, ушедших от калмыков на Кубань после погрома разинцами калмыцких улусов на Дону. Неоднократные обращения Аюки, Солом-Церена, Батура к донским атаманам за военной помощью в итоге получили поддержку, и 300 казаков совместно с калмыками отправились в поход на Кубань. В результате летом 1671 г. ногайские улусы с пятью мирзами были возвращены в калмыцкие кочевья, а казаки и калмыки, как отмечали свидетели, «пришли все в целости». Калмыцкие улусы, чьи тайши, как отмечали очевидцы, находились между собой «все в дружбе», располагались кочевьями по рекам Маныч, Егорлык и Калаус ${ }^{191}$.

${ }^{189}$ РГАДА. Ф. 111. Оп. 1. 1670 г. Д. 2. Л. 9.

${ }^{190}$ РГАДА. Ф. 111. Оп. 1. 1670 г. Д. 2. Л. 6, 7

${ }^{191}$ РГАДА. Ф. 111. Оп. 1. 1671 г. Д. 9. Л. 4, 13-15. 
Но последние совместные действия казаков и калмыков, направленные против ногайцев, только недавно вышедших из-под власти тайшей и принявших крымское подданство, всерьез встревожили крымского хана. Около трех тысяч ногайцев успели после погрома скрыться в Азове и уже оттуда обратились к хану за помощью ${ }^{192}$. В августе 1671 г. к хану Селим-Гирею с просьбой о военной помощи прибыли 5 большеногайских мирз во главе с Ямгурчеем. Как стало известно, в нападении на их улусы совместно с калмыками и казаками приняли участие и Юсуп Ураков с мирзами из клана Арсланбековых и Шейдяковых ${ }^{193}$.

Собрав большое войско, крымцы подошли к Азову и перешли на левый берег Дона. 6 декабря 1671 г. донские атаманы, следившие за передвижениями татар, срочно отправили сообщение в Москву о выступлении крымцев на калмыцкие улусы, в это время кочевавших уже на Тереке. Предупреждение о крымской угрозе казаки также отправили в Астрахань и дважды - тайшам ${ }^{194}$. По сведениям харьковского полковника Г. Захаревича, всю зиму 1671/72 года крымский хан находился в Кабарде, где у него произошел бой с черкесами и калмыками ${ }^{195}$.

Указанные события, видимо, были связаны, в том числе и со сменой власти в Крыму, когда в мае 1671 г. из Стамбула на место Адиль-Гирея на ханство был прислан новый ставленник - Селим-Гирей. Тогда же из донесений в Москву стало известно, что в 1671 г. Адиль-Гирей, несогласный с политикой Порты, «подняв калмыков и черкес, идет войною на хана нового » ${ }^{196}$. Другой причиной крымского вторжения, скорее всего, могла стать ссора с крымцами и бегство из крымских владений в Кабарду ногайских улусов мирз Дивея и Юсуфа Ураковых. Новый крымский хан Селим-Гирей принял решение вернуть беглецов и вторгся непосредственно в кабардинские пределы ${ }^{197}$.

${ }^{192}$ РГАДА. Ф. 111. Оп. 1. 1670 г. Д. 2. Л. 8.

${ }^{193}$ РГАДА. Ф. 123. Оп. 1. 1671 г. Д. 1. Л. 66.

${ }^{194}$ РГАДА. Ф. 111. Оп. 1. 1671 г. Д. 1. Л. 67; Крестьянская война под предводительством Степана Разина. Сборник документов / Сост. Е.А. Швецова. Т. 3. М., 1962. С. 122-123, 138-139, 144, 168

${ }^{195}$ Новосельский А.А. Указ. соч. С. 104.

${ }^{196}$ АИЮЗР. СПб., 1877. С. 576

${ }^{197}$ АИ. СПб., 1842. С. 506.
Царское правительство, занятое подавлением последних очагов восстания на юге России, не могло в полной мере вмешаться во внутрикалмыцкие дела. В русских документах удалось обнаружить подробные сведения об официальной реакции царских властей на последние события у калмыков, последовавшей уже после подавления разинского выступления. Они, несомненно, представляют огромный интерес.

В январе 1672 г. из Москвы через Эрке-ламу тайше Аблаю и его сыну Цагану был прислан письменный ответ, в котором, в частности, сообщалось: «Ведомо великому государю его царскому величеству учинилось, что Аблая тайши сын, Чаган, идет войною на подданных его царского величества на калмыцких на Аюкая, и на Солом Сереня, и на иных тайшей, а те тайши великому государю его царскому величеству служат и во всем его государское повеленье исполняют и кочюют под его государскою самодержавною рукою. И они б, Аблай и сын ево Чаган тайши, на подданных царского величества на калмыцких Аюкая и на Солом Сереня, и на иных тайшей войною не ходили и жили б с ними в миру и в совете».

Далее хошутским тайшам предлагалось со своими войсками совместно с Аюкой отправиться на войну против крымского хана, который, по сведениям царского правительства, вышел с полуострова и находился с армией на Кубани. Примерно такой же царский ответ был доставлен и Аюке. О реакции послов Аюки на подобное предложение ничего известно, но посол Аблая согласился с мирной инициативой Москвы, и, как он ответил, хошуты «на крымского хана войною итти ради» ${ }^{198}$.

В отдельной инструкции, отправленной на имя только что назначенного в Астрахань воеводой князя Я.Н. Одоевского указывалось, что если Аблай и дальше будет упорствовать и выдвигать требования по территориальному вопросу, то всячески его убеждать, чтобы кочевал он на дальних кочевьях между Яиком и Тоболом, поскольку в районе Астрахани у его улусных людей могли бы возникнуть ссоры с русским населением ${ }^{199}$. Из вышеизложенного видим, что Москва не стремилась однозначно принять сторону своих подданных Аюки и

198 РГАДА. Ф. 119. Оп. 1. 1673 г. Д. 5. Л. 63-65.

199 РГАДА. Ф. 119. Оп. 1. 1673 г. Д. 5. Л. 68. 
Солом-Церена в их конфликте с хошутскими тайшами, пытаясь использовать в своих интересах военный потенциал обеих сторон. Данное обстоятельство толкало Аюку к принятию собственного решения, не рассчитывая особенно на помощь царского правительства.

Ситуация, сложившаяся между двумя калмыцкими группировками в Волго-Яицком междуречье зимой 1671/72 года, обострялась, о чем не преминул сообщить в своем донесении боярин И.Б. Милославский. Цаган, сын Аблая, с целью окончательно разгромить силы Аюки с 30-тысячным войском подошел к реке Ахтубе, в местность, что была в трех днях пути от Астрахани. Аюка также вышел из улусов с войском и находился в районе Нарын-песков ${ }^{200}$. Собрав воедино оставшиеся после разгрома улусы и помирившись с Дугаром, Аюка решил взять реванш у Аблая.

Решить эту задачу во многом ему облегчило то обстоятельство, что недавние союзники Аблая от него отошли и вернулись на свои старые кочевья на востоке. В «Биографии Зая-пандиты» прямо указывается, что во время зимовки на Яике у Аблая произошел конфликт с сыновьями Кунделен-Убаши и дербетскими тайшами, которые были недовольны несправедливым разделом имущества, захваченного у торгутов. В это время другой противник Аблая, хошутский Очирту, воспользовался ситуацией и из Джунгарии совершил молниеносный рейд на север, разгромив и подчинив себе улусы Кунделен-Убаши, Доржи и дербетских тайшей. В числе захваченных улусов оказалось и владение его родного дяди по матери - торгутского Дайчина. После одержанной им громкой победы Очирту провозгласил себя Цещен-ханом, поскольку ему удалось вернуть в Джунгарию значительную массу ойратов, откочевавших в свое время на запад ${ }^{201}$. Новым титулом он именовал себя и в письме на имя русского царя уже в сентябре 1673 года ${ }^{202}$

Однако часть торгутов, кочевавшая совместно с Дайчином, вернулась обратно на Волгу. Улус Назар-Мамута был освобожден Очирту Цецен-ханом, и, как сообщал посол Аюки в Москве в 1672 г., «все пришли к ним в улусы, а Дайчин после Аблаева разоренья ушел ко-

${ }^{200}$ РГАДА. Ф. 119. Оп. 1. 1673 г. Д. 5. Л. 62.

${ }^{201}$ Раднабхадра. Указ. соч. С. 92; Норбо ШІ. Указ. соч. С. 107.

${ }^{202}$ РГАДА. Ф. 119. Оп. 1. 1674 г. Д. 2. Л.7. чевать на Яике ${ }^{203}$. К сожалению, дальнейшая судьба Дайчина в русских документах не прослеживается. Биограф Зая-пандиты сообщает о нахождении в 1675 г. Дайчина на территории Джунгарии ${ }^{204}$. Отсюда можно сделать вывод, что престарелый тайша остаток своей жизни провел именно там, откуда в свое время с отцом Хо-Урлюком откочевал в степи Северного Прикаспия.

В начале 1672 г., в месяц Цаган Сар, Аюка со своим войском и союзниками, в числе которых был и его свояк Каспулат Черкасский с кабардинцами, совершил поход на Яик, полностью разгромив владение Аблая. Хошутский тайша с семьей был пленен и первое время содержался под арестом на Тереке под присмотром кабардинских родственников Аюки. В 1672 г. пленники были переданы в Астрахань. Дальнейшая судьба Аблая находит противоречивое отражение в русских источниках. Г.Ф. Миллер сообщает, что тайша умер в Астрахани, («сидя в тюрьме городовой стене в башне» ${ }^{205}$. П.С. Паллас утверждает, что Аблай скончался в плену на р. Сал, одном из притоков Дона, а до того как попасть в плен, он находился на горе Чир-Тумер-ула, которая, по его мнению, возможно являлась частью Мугоджарских гор $^{206}$. В августе 1672 г. послы Очирту Цецен-хана официально обратились к властям в Тобольске с требованием выдать хошутскому правителю его брата Аблая, взамен обещая обеспечить безопасность русским людям, добывающим соль на Ямыш-озере ${ }^{207}$. В официальном ответе центральных властей, переданном Цецен-хану в 1674 г., прямо указывалось: «Аблай тайша за ево измены и за неправды взят был в полон и привезен к Москве и на Москве умре» ${ }^{208}$. В любом случае Аблай в исторической памяти калмыков остался как тайша, потерявший свой улус «за умножившуюся в нем зависть» ${ }^{209}$.

Относительно сына Аблая, Цагана, то из новых сведений стало известно, что ему удалось уйти со своим людьми к Очирту Цецен-ха-

${ }^{203}$ РГАДА. Ф. 119. Оп. 1. 1673 г. Д. 5. Л. 60.

${ }^{204}$ Норбо III. Указ. соч. С. 108

${ }^{205}$ PMO. M., 1996. C. 245.

${ }^{206}$ P.allas P.S. Указ. соч. С. 28.

${ }^{207}$ PMO. M., 1996. C. $245,445$.

${ }^{208}$ РГАДА. Ф. 113. Оп. 1. 1674 г. Д. 1. Л. 2об

${ }^{209}$ Габан ШІараб. Указ. соч. С. 96. 
ну. В 1673 г. дербетский тайша Дондук сообщал в Тобольске о ссоре Цагана с Цецен-ханом и об уходе его к хану Тевке (Тауке) в Казахскую орду, где он вскоре скончался. Улусные люди Цагана были задержаны и стали служить казахскому хану, так и не получив возможности соединиться со своими соплеменниками ${ }^{210}$.

После победы над Аблаем среди торгутских тайшей по неизвестным причинам вспыхнул новый конфликт. Весной 1672 г. Аюка сообщал царицынскому воеводе Дмитрию Свищову, что Дугар «великому государю изменил» и направляется к крымскому хану. На этом основании он просил казаков не пропускать ушедших калмыков через Дон. У Дугара в это время в подчинении находилось примерно 15 тыс. улусных людей, в том числе и подвластные умершего к тому времени его брата Бока. Прикочевав летом на Дон, он дважды отправлял своих послов к атаманам с предложением «быть у великого государя под рукою» и пойти войной на Крым и Азов. В ответ на эту просьбу к нему был отправлен с царской грамотой Леонтий Копнин. Однако когда донские казаки предложили Дугару отправиться в совместный поход под Азов, тайша отказался. Выяснилось, что ногайские мирзы отговорили его от сотрудничества с донцами. Позже Дугар с подвластными калмыками и ногаями ушел в горы ${ }^{211}$.

В июне 1672 г. Аюка с другими тайшами кочевал на левобережье Волги, в районе Саратова, где его люди активно торговали с местным населением. Но под Черным Яром у его калмыков произошел конфликт с местными жителями, о чем он сообщил на Дон. Несмотря на возникшие внутрикалмыцкие неурядицы, Аюка продолжал придерживаться договоренностей с правительством, заключенных его покойным отцом. Еще весной тайша отправил к Перекопу 260 калмыков для взятия «языков». Захватив в плен трех татар, на обратном пути они натолкнулись на лагерь азовцев, отбили у них русский полон, взятый под Валуйками и Рыбным. 20 мая калмыки «все в целости» пришли на Дон. 2 июня они же совместно с казаками совершили еще один поход под Калачинские башни для захвата ногайских малибашей, ранее находившихся в подчинении у покойного тайши Бока

210 ДАИ. СПб., 1857. С. 282

${ }^{211}$ РГАДА. Ф. 111. Оп. 1. 1671 г. Д. 1. Л. 115-116; 1672 г. Д. 9. Л. 15, 17 ; Д. 11. Л. $4-5$. и направлявшихся к крымскому хану. 29 октября на Дон от Аюки пришел отряд в 200 человек под командой Будачери. Совместно с казаками атамана К. Яковлева они совершили поход под Азов, побив множество азовцев и захватив в плен 48 человек ${ }^{212}$.

Осенью 1672 г. в Астрахань от Аюки прибыли послы - Юмайдархан и Эшбердей Авжиев с 4 товарищами. По их словам, калмыцкие улусы в это время кочевали под Царицыном, в верховьях реки Сарпа, у озера Цаган-Нур. Аюка еще раз подтверждал свое желание и дальше верно служить государю, как его дед Дайчин и отец Мончак. Но, по мнению тайши, развиваться русско-калмыцким отношениям должным образом мешали продолжавшиеся инциденты. Например, ехавший из Астрахани с отрядом боярин и воевода И. Милославский между Черным Яром и Царицыным разгромил один из калмыцких улусов, захватив 15 человек и 50 голов скота. Аюка не без основания интересовался «по государеву указу это сделано» или нет, поскольку «никакова дурна с калмыцкими своими людьми не учинил». Тайша просил правительство выслать ему годовое жалованье. Отправленные из Астрахани вместе с послами в калмыцкие улусы казанец М. Бараков и М. Протопопов должны были призвать Аюку, Солом-Церена и других тайшей собраться на съезд под Астраханью для подтверждения прежних шертей. Задержка правительством жалованья тайшам, видимо, не совсем устраивала Аюку, и он до ноября оставил посланцев у себя в улусе, а сам с войском двинулся к Куме ${ }^{213}$.

В это время калмыки совершили крупный военный поход на $\mathrm{Ce}-$ верный Кавказ с целью укрепить здесь свои позиции, пошатнувшиеся в связи с недавними событиями и возвращением ушедших сюда калмыцких ногаев. Предварительно к князьям Большой Кабарды, мирзе Большого Ногая Каракасаю Яштерекову и другим казыевским мирзам были отправлены посланцы с жестким требованием, чтобы они со своими улусами «от крымского хана и от худых дел отстали», учинили шерть и дали «добрых» аманатов. В противном случае Аюка обещал «разорить их до конца». В результате переговоров ногайские мирзы обязались кочевать совместно с калмыками, не иметь отноше-

${ }^{212}$ РГАДА. Ф. 111. Оп. 1. 1671 г. Д. 1. Л. 113-115; 1672 г. Д. 1. Л. 13; Д. 11. Л. 5, Л. 7-8.

${ }^{213}$ РГАДА. Ф. 119. Оп. 1. 1672 г. Д. 1. Л. 1-4, 8. 
ний с крымским ханом, в чем они и дали шерть. Казыевские мирзы Арсланбек и другие отдали калмыкам в аманаты пятерых своих детей. С Кавказа Аюка по просьбе донских казаков планировал совершить военный поход под Крым и Азов, затем вернуться к Астрахани для участия в предстоящем русско-калмыцком съезде, на котором, как он решил, «прежнюю шерть отца своего Мончака тайши подкрепит» 214.

Бежавший в крымские владения Дугар вернулся обратно к калмыкам, но, как считал Аюка, «для проведыванья вестей и для обману и воровства). При попытке к бегству мятежный тайша был арестован и вместе с Аблаем и крымским послом находился под арестом на Тереке. В ноябре 1672 г. в Астрахань прибыл калмыцкий посол Банши с 6 товарищами и письмом, в котором Аюка еще раз подтвердил прежние, заключенные его отцом шерти ${ }^{215}$.

Таким образом, молодому Аюке удалось преодолеть все препятствия, мешавшие разрешению политического кризиса в калмыцком обществе. Успешное подавление внутренней оппозиции и внешних врагов помогло ему завоевать симпатии простого калмыцкого народа и особенно старших тайшей, поначалу относившихся к нему с недоверием. Укрепление русско-калмыцких отношений свидетельствовало о продолжении политики Дайчина и Мончака, видевших в этом главную гарантию обеспечения безопасности калмыцких кочевий. 1671 год можно считать и датой окончательного падения некогда могущественной северной группировки ойратов - чакарских калмыков. Большая их часть была подчинена джунгарами, и лишь немногочисленные группы влились в состав волжских калмыков.

${ }^{214}$ РГАДА. Ф. 119. Оп. 1. 1672 г. Д. 1. Л. 12-14.

${ }^{215}$ РГАДА. Ф. 119. Оп. 1. 1672 г. Д. 1. Л. 15. 
ки ойратских улусов: волжская в Северном Прикаспии, сибирская в Юго-Западной Сибири, джунгарская в Центральной Азии и кукунорская в Тибете. Численность и состав каждой из этих группировок менялись в зависимости от военно-политической ситуации. Если проследить хронологию данного исторического процесса, то в результате откочевки из Джунгарии к началу XVII в. в Юго-Западной Сибири сформировался самый крупный союз ойратских улусов, включавший в себя преимущественно дербетов, торгутов и хошутов. Постепенно от них отделилась часть торгутов (1630 г.) и дербетов (1642 г.), образовав волжскую группировку, а также часть хошутов и торгутов (1636-1642 гг.), которые в Тибете основали кукунорскую группировку. Значительное сокращение численности северных ойратов (чакарских калмыков) привело к окончательному их падению в борьбе с джунгарами. Небольшая часть дербетов и хошутов мигрировала к торгутам в степи Северного Прикаспия, где приняла участие в формировании уже Калмыцкого ханства, но большинство было присоединено джунгарами в состав своего формировавшегося ханства.

Появление калмыков в Северном Прикаспии в первой половине XVII в. явилось следствием как сложных социально-экономических и политических процессов, происходивших внутри ойратского общества, так и тяжелой международной ситуации в Центральной Азии. Вместе с тем русские источники свидетельствуют, что первое появление калмыков в этом регионе можно рассматривать и как борьбу калмыцких тайшей с Московским государством за влияние на тюркские народы в Восточной Европе. Однако попытки калмыцких тайшей в течение 20-30-х гг. XVII в. объединить под своим началом все ногайские племена к успеху не привели.

В историографии утвердился ряд ошибочных взглядов относительно отдельных страниц истории калмыков в первой половины XVII в., которые, как видится, не состоятельны в свете появления новых фактических данных.

Во-первых, на самом начальном этапе в авангарде ойратской миграции в прикаспийские степи находились не торгуты Хо-Урлюка, а хошутские улусы под началом Чокура и его соратников. Борьба, возникшая внутри хошутского дома, переросла в общеойратскую во- йну 1625-1630 гг., которая и создала предпосылки первых поселений калмыков в степях Северного Прикаспия. Таким образом, переселение торгутов на Волгу было не бегством из-за внутренних раздоров джунгаров, а следствием междоусобной войны хошутов, в которую, в конечном счете, были вовлечены все ойраты ${ }^{1}$.

Во-вторых, район северо-восточного Прикаспия в качестве поселения серьезно рассматривал и дербетский тайша Далай-Батур, чьи послы вели довольно интенсивные, но безуспешные переговоры по этому вопросу с московским правительством в 1629-1630 гг. После разгрома группировки Чокура на Яике перед многими тайшами открылись явные преимущества нового для них региона: пересечение торговых магистралей, близость крупных рынков, слабость соседних тюркских племен, отдаленность от враждебных сил Алтын-хана, благоприятные климатические условия, богатые биоресурсы и т.д.

В-третьих, только после откочевки дербетов и хошутов на старые кочевья в Юго-Западной Сибири в конце 1630 г. в Северном Прикаспии появляются торгутские улусы Хо-Урлюка и Дайчина. Но идейным вдохновителем переселения торгутов в степи Северного Прикаспия выступал не Хо-Урлюк, а его старший сын Дайчин, формально признававший отца главой торгутских родов. Успешные военные действия в регионе, харизматичность, массовый приток тюркских племен и калмыцких родов в его улусы позволили ему фактически претендовать на главенство в торгутском доме, поскольку он стал владельцем наиболее многочисленного улуса и войска. Хо-Урлюк старался держаться поближе к ойратскому сообществу, но после конфликта с Далай-Батуром в 1635 г. вынужден был откочевать из ЮгоЗападной Сибири к старшему сыну в степи Северного Прикаспия.

В-четвертых, калмыки, как повествуют калмыцкие источники, не могли прийти на Волгу с целью поселения в 1630 или 1632 гг. Более того, в течение 30-х гг. XVII в. они так и не смогли окончательно закрепиться в волжском регионе. Кратковременные набеги, совершенные калмыками на астраханских ногайцев и татар в 1630, 1633, 1635 гг., можно рассматривать не как их приход на Волгу, а как эпизодические

${ }^{1}$ Мияваки-Окада Дж. Джунгарское ханство, которое не было ханством / Пер. с англ. Е. Бойковой // Altaica IV. М., 2000. С. 65. 
появления, имевшие место и ранее. Основной ареал кочевок торгутских улусов в это время находился между Яиком и Приаральскими Каракумами - по рекам Эмба, Илек, Иргиз, Орь, хотя некоторые из них пытались обосноваться и в Волго-Яицком междуречье - на Узени и в верховьях Самары. Попытки калмыков подойти к Астрахани и перейти Волгу в 30-е гг. XVII в. не имели положительного результата. Иногда калмыки переходили на «ккрымскую сторону» Волги, но главным образом эти переходы носили военно-разведывательный характер. Появление калмыков западнее Яика царским правительством рассматривалось как нарушение границы, и на переговорах власти неоднократно требовали откочевки их улусов именно за Яик 2 .

В течение 30-х гг. XVII в. на торгутских тайшей, пытавшихся самостоятельно закрепиться в степях Северного Прикаспия, со стороны ойратского сообщества оказывалось мощное политическое и военное давление. Главным проводником такой политики выступал один из предводителей так называемых «чакарских калмыков» - Далай-Батур, пользовавшийся в этом вопросе поддержкой буддийского духовенства. Именно дербетский предводитель при поддержке хошутских тайшей требовал от торгутов отказа идеи поселения в Северном Прикаспии, немедленного возвращения на старые кочевья, выдачи Чокура и его сторонников. Если Хо-Урлюк под давлением более сильных соседей склонялся к принятию компромиссного решения по данному вопросу, то Дайчин решительно отказывал им. Только смерть ДалайБатура и поражение чакарцев в столкновениях с отрядами сибирских городов во второй половине $30-\mathrm{x}$ гг. XVII в. снизили накал в отношениях. Постепенное сближение недавних противников подвигло торгутских тайшей к принятию решения о переходе части улусов в ЮгоЗападную Сибирь, а другую половину улусов оставить на прежних кочевьях в Северном Прикаспии.

Для выработки общеполитической доктрины в сентябре 1640 г. в Джунгарии состоялся крупнейший съезд монгольских ханов и ойратских тайшей, на котором присутствовали Хо-Урлюк и его старшие сыновья. Буддийскому духовенству во главе с Индзан-хутугтой к концу 1630-х гг. удалось примирить враждующие ойратские группи-

\footnotetext{
${ }^{2}$ Преображенская П.С. Калмыки в первой половине XVII века... С. 13.
}

ровки и в целом наладить отношения между ойратами и восточными монголами. Объединению способствовали идеологические установки, утвержденные на монголо-ойратском съезде 1640 г., выразившиеся в едином законодательном кодексе. Также было принято решение о продолжении совместного участия ойратов в религиозной войне в Тибете. Примирение и консолидация ойратских группировок с восточномонгольскими княжествами были приоритетными в политике тайшей и буддийского духовенства.

Консолидация ойратского сообщества, отмечавшаяся после съезда 1640 г., не мешала торгутским тайшам, чьи улусы были разделены на две группы, одновременно участвовать в политических событиях как в Северном Прикаспии, так и в Юго-Западной Сибири и Центральной Азии. Однако такое положение было прервано дербето-торгутским конфликтом 1642 г. Именно это событие ускорило разрушение системы безопасности, выработанной и принятой на съезде 1640 г. В условиях затяжного внутреннего конфликта буддийское духовенство пыталось его урегулировать при помощи разработанного ими же кодекса законов. Однако за период вооруженного противостояния в течение нескольких лет погибло большое количество ойратских тайшей, в том числе и двое непосредственных участников съезда - торгутский Хо-Урлюк и дербетский Дайчин-Хошучи.

Очевидно, что попытки консолидации ойратов сталкивались со старыми проблемами. История конфликтов в ойратской среде показывает, что коренились они во внутрисемейных противоречиях. Зачастую старшие владельцы, обладавшие наибольшими людскими и материальными ресурсами, а также многочисленными семьями, невольно создавали потенциальные конфликтные условия для борьбы за наследство между рожденными от разных матерей сыновьями. Это видно на примере дербетского дома, когда семейный конфликт привел к вооруженному столкновению в 1642 г., затем переросшему в настоящую войну между северной (чакарскими калмыками) и западной (торгутской) группировками. В результате этих событий в составе торгутских кочевий впервые появился дербетский улус Солом-Церена.

Перемещение торгутских улусов в Волго-Яицкое междуречье активизировало русско-калмыцкие отношения и одновременно обо- 
стрило территориальный вопрос. Но камнем преткновения стал так называемый «ногайский» вопрос, спровоцированный своевольством отдельных молодых калмыцких тайшей, пытавшихся самоутвердиться. Именно в 1643 г. часть ногайских улусов впервые добровольно вливается в состав Калмыцкой орды, в то время как в 1630-е гг. такое присоединение в основном носило насильственный характер. «Ногайский» вопрос не только создал конфликтную ситуацию внутри калмыцкого обшества, но и серьезно осложнял русско-калмыцкие отношения

Необходимость продажи скота и лошадей и приобретения товаров подталкивала калмыцких тайшей к установлению прочных торговых связей с российскими городами. Но когда царское правительство по разным причинам отказывало калмыкам в такой возможности, они начинали оказывать силовое давление. Подобные действия, однако, не способствовали развитию добрососедских отношений. Попытка силового решения сложившейся ситуации привела к разгрому калмыков на Северном Кавказе и ответным военным ударам русских войск на Волге в 1644 г., что резко ухудшило и без того непростые русско-калмыцкие отношения и в целом положение калмыцких улусов в Северном Прикаспии.

Однако стремление торгутских тайшей к политической самостоятельности удерживало их от ухода из этого региона. Большое значение имело и выгодное геополитическое расположение кочевий здесь проходили торговые пути, связывавшие южные государства с Россией и Европой. Уход отсюда привел бы к потере торгутами не только политической независимости, но и благоприятных условий для хозяйственной деятельности. Дайчин и другие старшие тайши стремились к скорейшему установлению стабильных отношений с соседями и, в первую очередь, с Московским государством.

Длительное отсутствие Дайчина в родных кочевьях объяснялось тем, что он в составе общеойратской военной кампании под командованием Гуши принимал непосредственное участие в религиозной войне в Тибете. Но, даже находясь в Джунгарии, Дайчин продолжал активно влиять на политическую ситуацию в Северном Прикаспии. Именно он выступил с важными инициативами - привлечь в качестве посредников хутугту Зая-пандиту и джунгарского Батура-хунтайджи для урегулирования торгуто-дербетского конфликта, а также отправить посольство в Москву, чтобы наладить взаимоотношения с русскими властями.

К середине XVII в. территориальный вопрос все чаще стал подниматься калмыцкой стороной в переговорах с представителями русских властей. Стесненность торгутских кочевий еще более усугубил приход в 1649 г. хошутских и дербетских улусов. Теснимые джунгарами, хошутские улусы Кунделена-Убаши продвинулись на запад, в район реки Эмбы. Появление здесь новых крупных ойратских улусов заставило торгутских тайшей отойти в западном направлении, т.е. в сторону Волги. Здесь обращает на себя внимание тот факт, что торгутские и хошутские тайши пытались решить территориальный вопрос не вооруженным путем, а посредством переговоров, что в целом отвечало духу законов, принятых в 1640 г.

Дальнейшее перемещение торгутских улусов в западном направлении встречала на первых порах неодобрительное отношение со стороны царского правительства. Из Москвы неоднократно поступали в Астрахань указы, запрещающие калмыкам кочевать в Волго-Яицком междуречье, а ходатайства тайшей о разрешении кочевать по Волге неизменно отклоняются царскими властями. Конечно, тайши не всегда считались с этим запретом и с улусами переходили установленные для них рубежи, зачастую приближаясь к самой Астрахани и другим поволжским городам. Но правительство твердо стояло на своем, указывая калмыкам отойти на дальние кочевья.

Самостоятельный выход калмыков на Волгу и Дон в то время не отвечал интересам царского правительства, но, с другой стороны, это давало возможность использовать калмыцкую конницу для охраны слабо укрепленных южных и юго-восточных границ России. Географическая близость, взаимовыгодная торговля и общность интересов в борьбе против кубанских ногаев и крымских татар определяли необходимость установления широких контактов между калмыками и донскими казаками. Царское правительство, понимая, что в лице калмыков может получить внушительную военную силу в борьбе против Крымского ханства, в дальнейшем всячески поощряло данный 
процесс, хотя и стремилось взять его под свой контроль. При этом стоит отметить, что заключение калмыцко-донского военного союза в 1648 г. состоялось раньше, чем окончательно было достигнуто русско-калмыцкое соглашение, принятое во второй половине 1650-х гг., и послужило своего рода толчком к дальнейшей интеграции кочевого народа в политическую орбиту России. С калмыцкой стороны также преследовались определенные цели, заключавшиеся в расширении территории своих кочевий в Нижнем Поволжье, а значит, в возможности совершать военные походы с целью захвата ногайских улусов и трофеев на территории Северного Кавказа и Причерноморья.

Русско-калмыцкие переговоры 1640-х-1650-х гг. выявили всю палитру политических взглядов, дипломатических традиций, мировоззрений, культуры и т. д. Правительство убедилось в своеобразном понимании тайшами шерти - они рассматривали эту присягу как союзный договор, а не как признание подданства с вытекающими из этого обязательствами. Поэтому оно избрало более жесткий курс по отношению к калмыкам: ограничение торговли в русских городах и организация военных экспедиций в ответ на калмыцкие набеги. Но ультиматумы и угрозы, сыпавшиеся с обеих сторон, не способствовали укреплению отношений.

Решающее значение в изменении политики России по отношению к калмыкам имела начавшаяся в 1654 г. русско-польская война. Выступление Крымского ханства на стороне Польши привело к активизации русско-калмыцких переговоров на качественно ином уровне. Теперь стороны от языка ультиматумов и угроз перешли к поискам взаимоприемлемых решений, шли на определенные уступки друг другу. Царское правительство кардинальным образом пересматривает свое отношение к вопросу о районе калмыцких кочевий. Калмыцкие тайши со своей стороны все больше склоняются к мысли о необходимости принять на себя определенные политические обязательства, а правительство согласилось предоставить калмыкам свои рынки в Поволжье.

В 1655 г. в документах впервые встречается упоминание о том, что калмыкам может быть предоставлено право кочевать по Волге. Понятно, что это разрешение было обусловлено обязательством тайшей принять непосредственное участие в войне против Крыма и Польши. Но только после шерти 1657 г. тайшам было официально разрешено кочевать по обоим берегам Нижней Волги. Спустя год уход калмыков из-под Астрахани царское правительство рассматривало уже как нарушение договоренностей. Русско-калмыцкие отношения оформлялись письменными актами - шертями. В течение 1655-1657 г. калмыцкие тайши дали 3 шерти, каждая из которых подтверждала и конкретизировала содержание предыдущей. Затягивание переговорного процесса в указанные годы во многом объяснялось невыполнением обеими сторонами в полной мере взятых на себя обязательств.

Сложность ситуации, в которой оказалось калмыцкое общество к началу 1650-х гг., вынуждало его правителей искать надежного и сильного союзника. В эти годы наиболее приоритетными для калмыцкой внешней политики были два направления - московское и крымское. Калмыцко-крымские контакты с середины 1650-х гг. приобретают характер постоянных. Но «прокрымской» ориентации придерживалось меньшинство из представителей правящей калмыцкой верхушки, так как решение территориального вопроса во многом зависело от позиции Москвы и для калмыков имело первостепенное значение. Скорее всего, «крымский фактор» калмыцкие тайши использовали для оказания определенного политического давления на Москву, чтобы таким образом обратить внимание на свои проблемы. В то же время решающую роль в принятии Москвой решения о заключении русско-калмыцких договоров, как например, шертей 1657 и 1661 гг., сыграла дипломатическая активность Крымского ханства в отношении калмыков. Именно активизация калмыцко-крымских связей, особенно в условиях войны России с Польшей, вынудила царское правительство прервать чрезвычайно затянувшееся обдумывание и оживить переговорный процесс по «калмыцкому вопросу».

Нельзя не заметить, что и после окончательного оформления отношений с Россией, калмыцкие тайши еще долго сохраняли политическую самостоятельность. Это выражалось в сохранении тайшами независимости в решении вопросов внутренней жизни калмыцкого общества и в признании за калмыками свободы внешних сношений 
с зарубежными государствами. Такая форма отношений сохранялась до середины XVIII в. Соглашение с Россией создавало калмыкам более благоприятные социально-экономические условия и обеспечивало относительную безопасность их кочевий от нападений соседей, хотя отчетливо видится, что царское правительство в полной мере не контролировало действий своих подданных. Развитие торговых связей во многом компенсировало потери, понесенными калмыками в результате природных катаклизмов и набегов соседних народов, и одновременно создавало условия для постепенной их интеграции в российское общество. Несмотря на многие препятствия, осложнявшие процесс русско-калмыцких переговоров (взаимные набеги, самовольное занятие калмыками кочевий, споры по процедурным вопросам и т.п.), в целом они завершились успешно.

Шерти 1661 г. большей частью носили характер военных договоров, и вспомогательное калмыцкое войско уже было задействовано совместно с русскими и украинскими вооруженными силами против Крыма и Польши. Правительство назначило тайшам денежные годовые жалованья и, начиная с 1658 г., регулярно их выплачивало.

Следует признать, что ключевую роль в форсировании русскокалмыцких переговоров сыграл боярин Г.С. Черкасский. Именно ему и его команде, в которую входил и племянник К.М. Черкасский. удалось добиться положительного результата в урегулировании отношений с калмыками и привлечь их к военной службе России. Г.С. Черкасский, учитывая неудачный опыт предыдущих переговоров с калмыками, стал выстраивать свои отношения с тайшами на абсолютно новой основе - в отказе от практики аманатства и установлении личных связей. Заключение династического брака между сыном Мончака, Аюки, и племянницей Г.С. Черкасского, Обелханы, стало поворотным моментом в русско-калмыцких отношениях, событием, закрепившим политический договор.

После заключения шертей позиции калмыков в регионе еще более укрепились. Кроме волжских степей для них теперь были открыты и степи Придонья. Наряду с Астраханью и Уфой заметную роль в отношениях с кочевниками стали теперь играть Царицын и Чер- касск. Но было бы неправильно полагать, что царское правительство в решении территориального вопроса для калмыков занимало столь бескорыстную позицию. Из Волго-Донского междуречья более всего удобно было организовывать походы калмыцких отрядов в Причерноморье и на Северный Кавказ, а присутствие здесь калмыков служило своего рода заградительным барьером от набегов крымских татар на южные русские города ${ }^{3}$.

В 1664 г. Мончак получил от правительства знамя и другие атрибуты, символизировавшие признание его заслуг. Военная служба, по существу, становится формой вассальных обязательств калмыков перед Россией. Организация военных походов для калмыцких тайшей оставалась главным способом обогащения - за счет отгона скота, захвата пленных и имущества у противника.

Но не следует и переоценивать обязательства калмыков о военной службе, поскольку отношения с Россией часто менялись в результате различных внешних и внутренних обстоятельств. Ярким примером этому является конфликт между Дайчином и Мончаком по вопросу о Манжи-Ялбо. По существу, он расколол калмыцкую элиту на два лагеря, в том числе и по отношению к правительству, принявшего сторону Мончака. Но этот конфликт четко показал политический расклад в калмыцком обществе и его политические предпочтения, поскольку основная часть народных масс, духовенства и знати поддержала Мончака, выступая, таким образом, за дальнейшее укрепление русско-калмыцких отношений.

Рассмотрение русских архивных источников позволяет сделать вывод, что калмыцкие тайши, участвуя в русско-польской войне на стороне Москвы, планировали если не ликвидировать, то значительно ослабить позиции Крымского ханства в северокавказском и причерноморском регионах. Но запланированному продвижению калмыков в причерноморские степи помешала очередная волна ойратской миграции с востока. Многочисленные улусы хошутских и дербетских тайшей, не желая подчиняться джунгарам, двинулись на занятые торгутами земли в Северном Прикаспии. Новоприбывших тайшей во главе с Аблаем, видимо, не устраивала второстепенная роль в отно-

\footnotetext{
${ }^{3}$ Преображенская П.С. Калмыки... С. 14.
} 
шениях с Москвой, тем более что последний в Западной Сибири был главным союзником русских. Прочные позиции торгутских тайшей в регионе, многочисленность их подданных, удачные военные походы с захватом богатых трофеев притягивали в степи Северного Прикаспия и других ойратских тайшей.

После неудачных вооруженных столкновений с хошутами, торгутские улусы откатываются к Дону. В свою очередь, эти события провоцируют борьбу за власть непосредственно в торгутском правящем доме. Преемнику Дайчина и Мончака, Аюке, в условиях сложной международной обстановки и противостояния внутренней оппозиции удалось достойно выйти из трудного положения. Следующий виток междоусобной войны среди ойратов относится ко второй половине 1670-х гг., в результате которого власть в Джунгарском ханстве перешла окончательно к цоросскому дому. На западе, на берегах Волги отмечалось становление его политического противовеса - Калмыцкого ханства, которое достигло своего расцвета именно в период правления Аюки. Эти два основных ойратских «полюса», помимо Хошутского ханства на Кукуноре, оставались главными политическими ориентирами для большей части ойратского мира в XVII в. вплоть до их окончательного падения в XVIII в.

По вопросу об образовании Калмыцкого ханства в историографии существует несколько точек зрения. Так, некоторые исследователи относят это событие к периоду правления Дайчина и Мончака ${ }^{4}$. Другие полагают, что существование ханства нужно отсчитывать с момента признания Россией ханского титула Аюки 5 . Особое мнение было высказано М.М. Батмаевым, считающего, что начало образования государственности и утверждения ханской власти относится к периоду правления Дайчина и Мончака, а окончательное становление

${ }^{4}$ Позднеев А.М. Указ. соч. С. 16; Пальмов Н.Н. Очерк... С. 42; Кичиков М.Л. Исторические... С. 113; Максимов К.Н. Указ. соч. С. 74-75; Цюрюмов А.В. Указ. соч. С. 75.

${ }^{5}$ Костенков К.И. Исторические и статистические сведения о калмыках. кочующих в Астраханской губернии. СПб., 1870. С. 6; Преображенская П.С. М. Л. Кичиков. Исторические корни дружбы русского и калмыцкого народов. Образование Калмыщкого государства в составе России // Вопросы истории. М., 1968. № 8. С. 167-168. ханства произошло к концу XVII в. и было связано с деятельностью Аюки ${ }^{6}$.

Подобный разброс мнений говорит о том, что этот вопрос требует все-таки более обстоятельного разбора. Процесс образования Калмыцкого ханства можно условно разделить на несколько этапов:

- образование отдельной группировки в Северном Прикаспии;

- консолидация власти в руках первенствующего тайши;

- провозглашение Калмыцкого ханства;

- признание Калмыцкого ханства Россией.

Точкой отсчета провозглашения Калмыцкого ханства можно считать 1647 г., т. е. с момента возвращения Дайчина в родные кочевья в Северном Прикаспии из Джунгарии и Тибета, где он был признан ханом большинством представителей верхушки ойратского сообщества и буддийского духовенства, но без наделения соответствующими атрибутами. Но ханский статус Дайчина не был признан московским правительством.

Признание Россией Калмыцкого ханства можно отсчитывать с момента подписания «Договорных статей, учиненных на реке Камышенка, между Калмыцким ханом Аюкой и боярином кн. Борисом Голицыным» от 17 июля 1697 г. ${ }^{7}$, когда царские власти впервые официально признали ханский титул калмыцкого правителя. При этом стоит учитывать и тот факт, что еще до этого времени, а именно во второй половине XVII в., многие соседние государства уже признали калмыцкого хана.

Термин «кочевое государство» весьма расплывчат. По мнению А.М. Хазанова, кочевыми государствами должны именоваться лишь те независимые образования, которые достигли соответствующего эволюционного уровня и обладали соответствующей политической организацией, где большинство населения составляли номады, разделенные на господствующие и подчиненные классы ${ }^{8}$. М.М. Батмаев же считает, что государственность кочевых народов Евразии должна

${ }^{6}$ Батмаев М.М Калмыки... С. 101-104.

${ }^{7}$ ПСЗРИ. СПб., 1830. Т. 3. С. 331.

${ }^{8}$ Хазанов А.M Кочевники и внешний мир. Изд. 3-е, доп. Алматы 2002. 
рассматриваться не с точки зрения того, соответствует ли она параметрам государственности земледельческих народов периода феодализма, а с точки зрения того, справлялась ли она с функциями регулирования всего комплекса общественных отношений, присущим кочевым обществам на определенном этапе их развития ${ }^{9}$. Понятно, что кочевое государство обязано иметь элементы государственной структуры, территорию с четкими границами, обладать юрисдикцией и эффективным аппаратом управления, что вкупе позволяет хану использовать власть над подданными. Дайчин, а затем и Мончак обладали лишь некоторыми из перечисленных компонентов. По мнению М. Ходарковского, титул хана в их случае являлся всего лишь показателем политического престижа, который не всегда предполагал наличие власти с огромными полномочиями ${ }^{10}$.

Некоторые исследователи полагают, что калмыки пришли в степи Северного Прикаспия с уже сложившимися общественными и государственными традициями ${ }^{11}$. Но в данном случае речь идет об образовании государства именно торгутами, которые как раз и не имели собственного опыта государственного строительства и, по крайней мере, в XV-XVI вв. находились в подчинении у ойратских ханов. Возможно, идея создать собственное ханство отчасти появилась в ответ на жесткую централизаторскую политику дербетского предводителя Далай-Батура, стремившегося собрать большинство улусов вокруг «сибирского ядра» ойратов. Таким образом, продвижение торгутов в западном направлении и образование собственного государственного объединения не происходили в русле общей политики ойратского сообщества. Напротив, это больше выглядело как противопоставление себя основному политическому центру ойратов, находившемуся на востоке. А уже со второй половины XVII в. Калмыцкое и Джунгарское ханства выступали главными «центрами притяжения» для курсировавших между ними различных ойратских улусов.

Известно, что в большинстве случаев кочевые государства возникали в результате внешнего завоевания или экспансии. Исторические

\footnotetext{
${ }^{9}$ Батмаев М.M. Социально-политический строй... С. 326.

${ }^{10}$ Khodarkovsky $M$. Where Two Worlds Met... P. 15.

${ }^{11}$ Кичиков М Л. Указ. соч. С. 122; Батмаев М.М. Указ. соч. С. 100-101.
}

параллели между монгольским нашествием в Восточную Европу в XIII в. и калмыцким продвижением в западном направлении в XVII в. проводили многие исследователи. Например, экспансионистский характер продвижения калмыков в степи Северного Прикаспия отмечало большинство дореволюционных авторов, особенно такие из них, как Н.Я. Бичурин, А.М. Позднеев, Н.И. Веселовский, Гурий и др. Движение калмыков на запад рассматривалось ими как «хорошо задуманный план для завоевания новых земель и восстановления империи Чингис-хана» ${ }^{12}$. А утверждение некоторых западных авторов о том, что экспансия носила религиозный оттенок, что-то вроде буддийского «крестового похода» ${ }^{13}$, не выдерживает никакой критики.

Новые архивные материалы позволяют показать более объективную историческую картину в указанный период. Будет справедливым считать, что процесс продвижения калмыков в степи Северного Прикаспия носил все-таки характер силовых действий по отношению к обитателям этого и соседних регионов. Вместе с тем продвижение и расселение на этой территории не были направлены на захват русских городов, поскольку калмыки не обладали для этого ни политическими, ни военно-техническими возможностями.

В рамках концепции добровольного вхождения калмыцкого народа в состав Российского государства в качестве исходной даты берется прибытие одного из первых посольств в Москву в начале XVII в. Данное событие имело важное политическое значение для России и калмыков как субъектов международных отношений. Сегодня в историографии происходит пересмотр множества проблем и аспектов, одним из которых является трактовка присоединения на-

${ }_{12}$ Например, архимандрит Гурий это процесс описывал следующим образом: «Историческое прошлое калмыков ясно показывает, что они шли в Россию не с целью мирной жизни возле русских границ, а с целью господства и завоевания русских городов, быть может, в надежде восстановить свое владычество там, где некогда сидели юртом потомки Чингис-хана, его внуки Батый (от сына Джучи) и др.» (Гурий. Очерки по истории распространения христианства среди монгольских племен. Казань, 1915. Т. 1. Ч. ІІ. С. 12).

${ }^{13}$ Lemercier-Quelquejay $C h$. Les Kalmuks de la Volga entre l'empire Russe et l'empire Ottoman sous le règne de Pierre le Grand // Cahiers du Monde Russe et Soviètique. 1966. Vol. VII. № 1. P. 64. 
родов и территорий к России. В прошлом историки объявляли тот или иной народ добровольно вступившим в российское подданство на основании первого договора, заключенного национальной знатью с Москвой или местными царскими властями. По мнению В.В. Трепавлова, отношение подчинения и подданства русская сторона и ее партнеры зачастую воспринимали совершенно по-разному ${ }^{14}$

С самого начала царское правительство пыталось поставить калмыков в подчиненное положение, что вызывало естественное отторжение со стороны последних. Тайши предлагали правительству мир, торговлю и военное сотрудничество на основе взаимных обязательств. Но правительство твердило о подданстве как необходимом условии для дальнейших сдвигов в решении вопросов о торговле и кочевьях. Правительство усиленно добивалось, чтобы шерти калмыков не носили формального характера, а гарантировались выдачей аманатов. Другими словами, Москва не желала видеть калмыцких тайшей в качестве равноправных партнеров международных отношений. В любом случае этот вопрос требует дальнейшего и более детального изучения на основе широкого круга архивных материалов, позволяющих объективно рассмотреть русско-калмыцкие отношения в XVII-XVIII вв.

В завершении автор хотел бы отметить, что данная работа, при всей многочисленности привлеченных источников, не раскрывает весь комплекс вопросов и проблем политической истории калмыков XVII в. Для раскрытия всех страниц калмыцкой истории исследователь, к сожалению, ограничен имеющейся источниковой базой. Это обстоятельство наложило отпечаток на некоторые моменты нашей работы, поэтому она открыта для критических замечаний, уточнений или корректировки. Однако основные проблемы политической истории калмыков второй трети XVII в. в настоящей книге затронуты в полной мере. Это обязательно даст новый толчок дальнейшему исследованию истории калмыков XVII столетия.

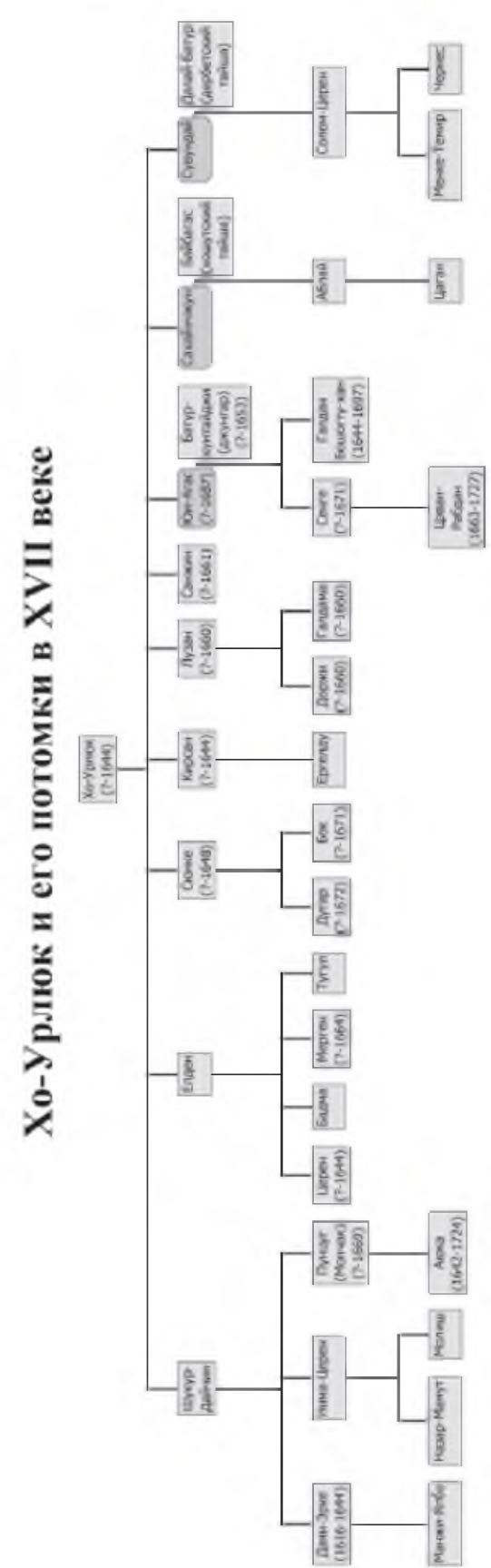

${ }^{14}$ Трепавлов В.В. «Белый царь»... С. 6-7. 


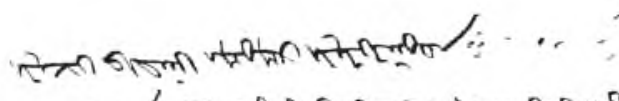

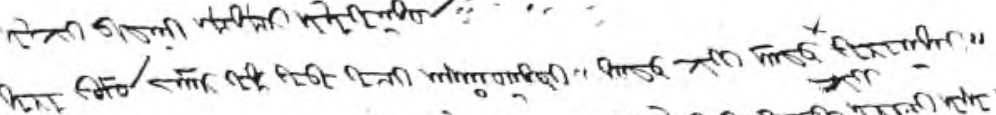

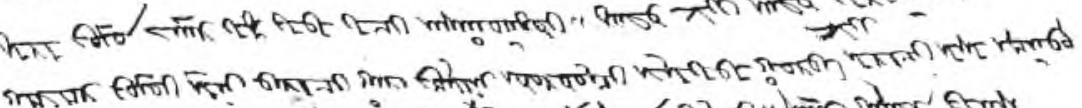

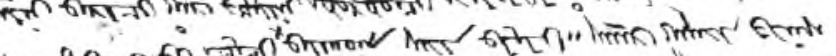

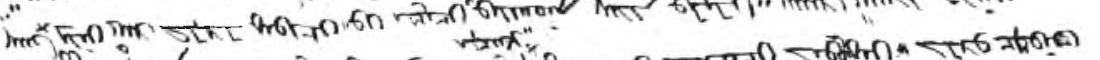

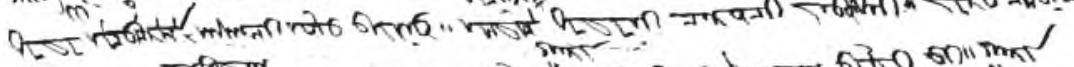

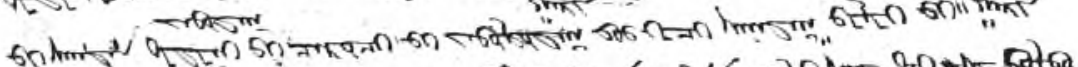

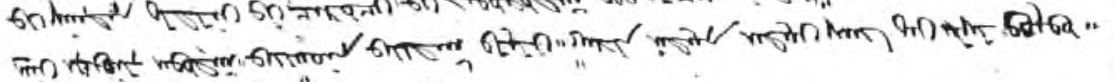

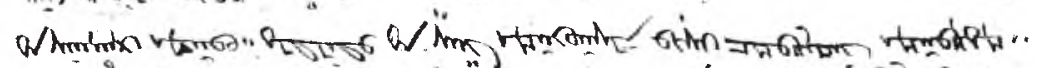
Qti

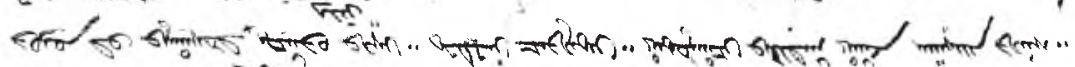

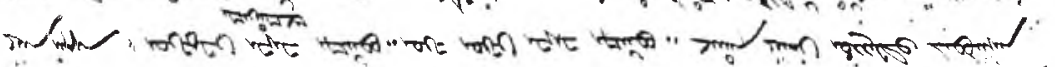

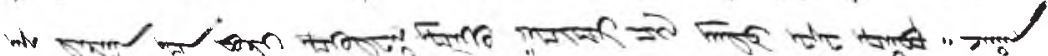

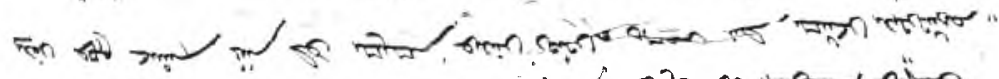

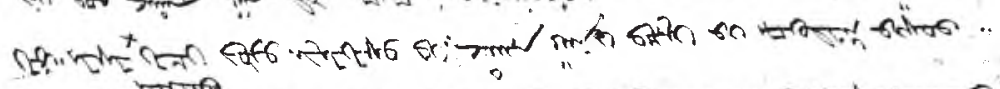

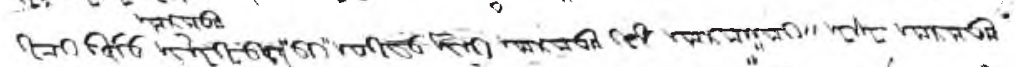

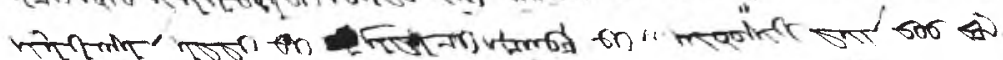

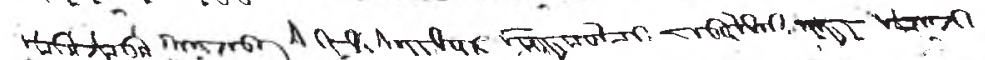

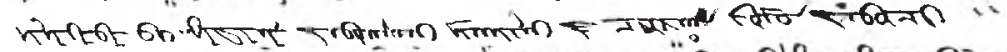

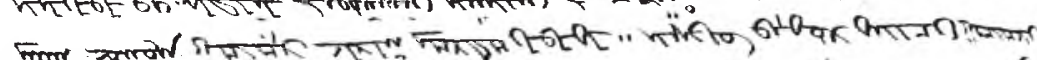

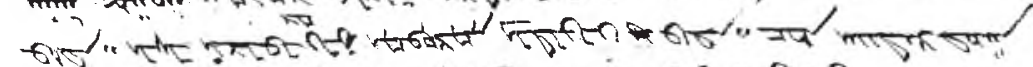

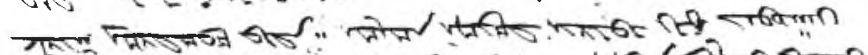

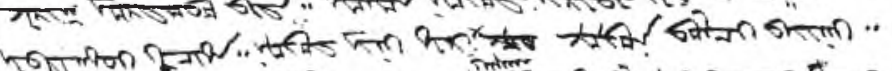

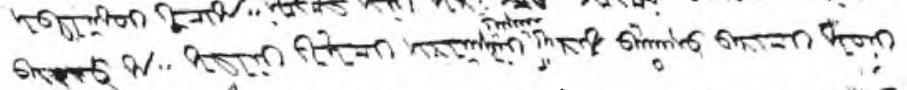

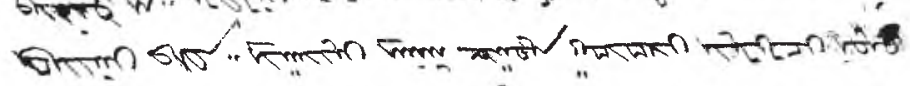

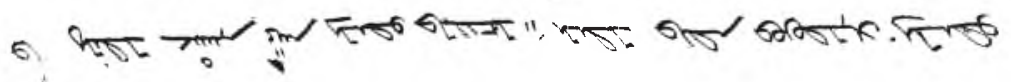

9

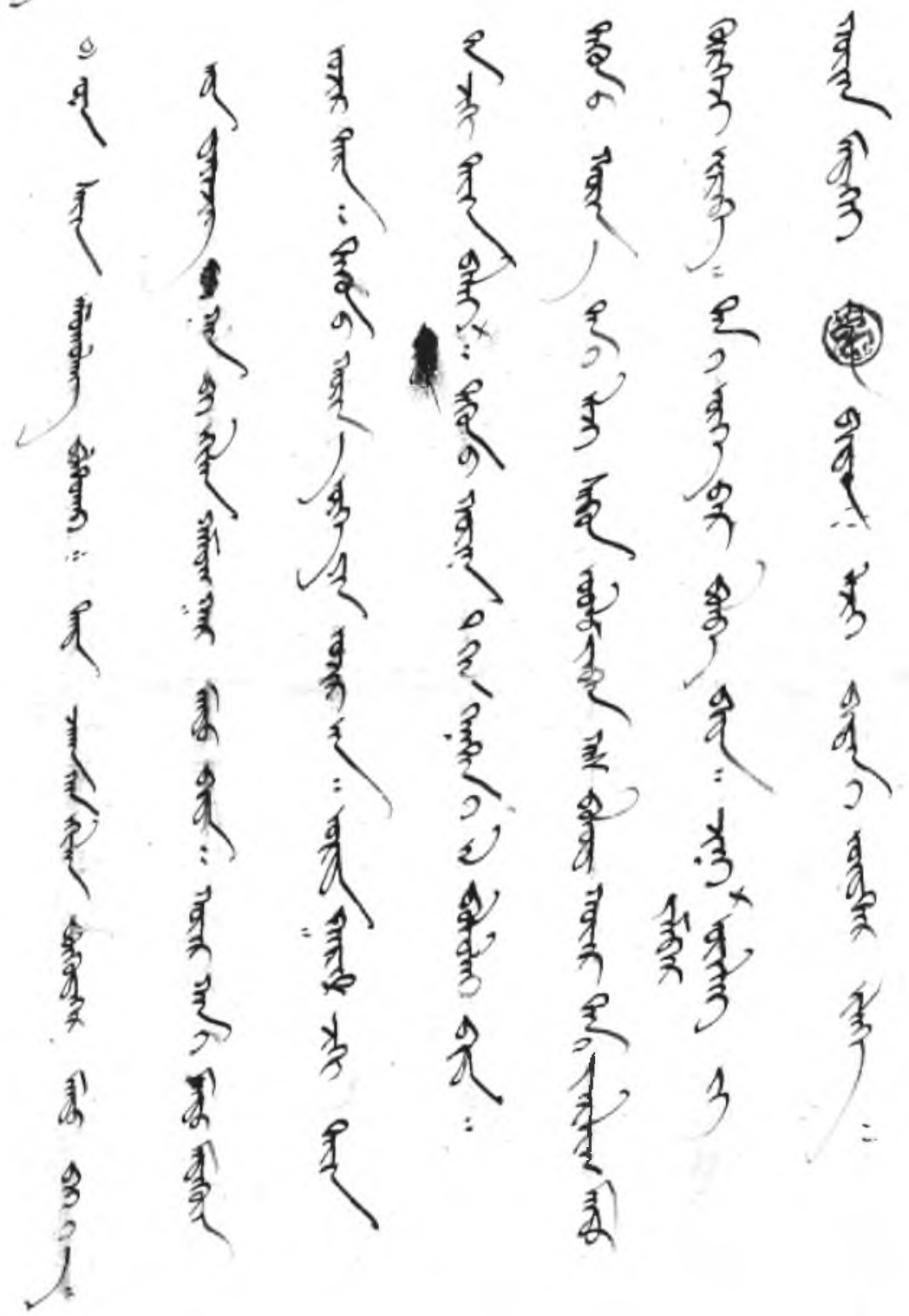

Письмо царю Алексею Михайловичу от тайшей Дайчина и Мончака на старописьменном монгольском языке. 1661 г. 


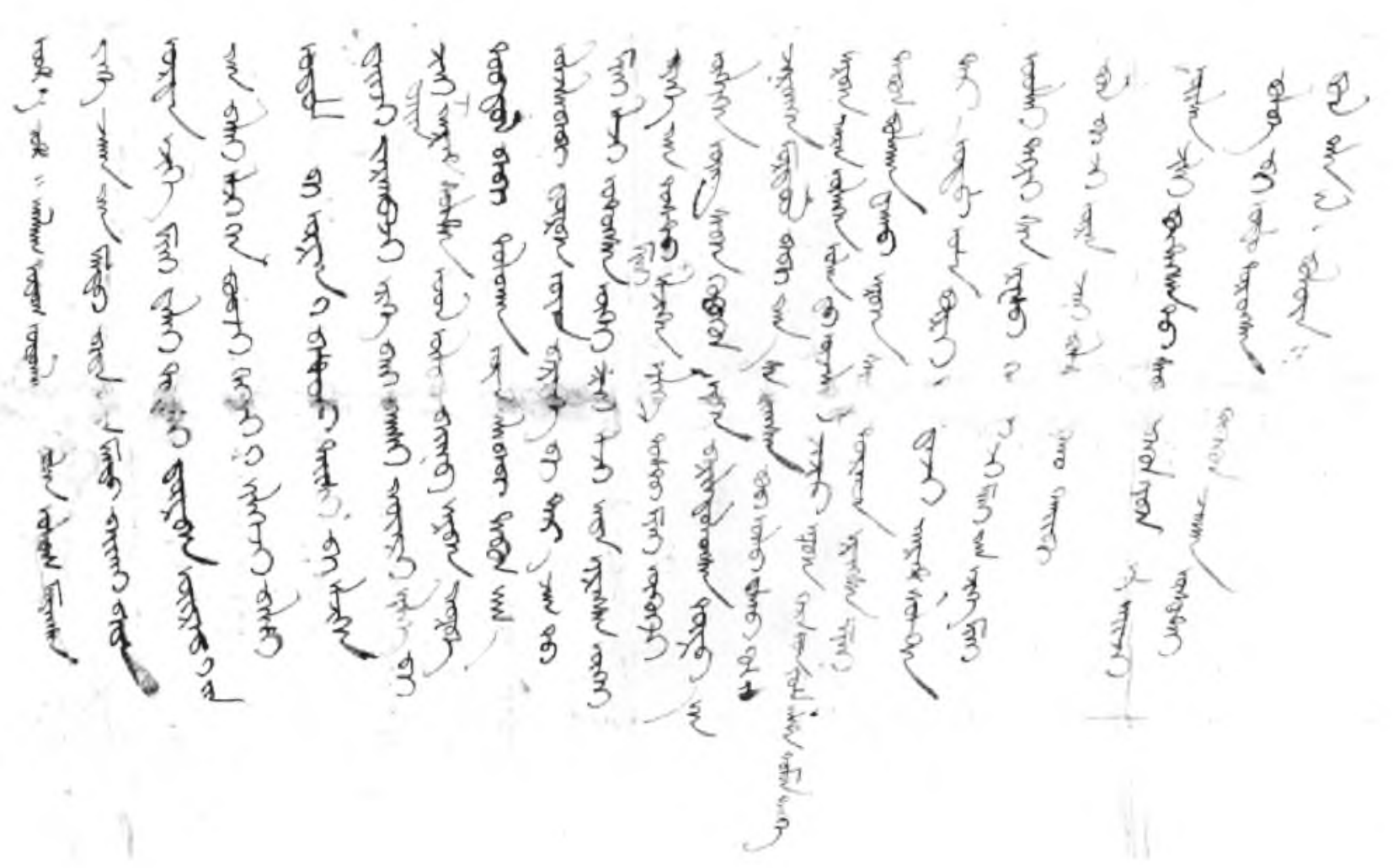

Письмо царю Алексею Михайловичу от дербетского тайши Солом-Церена на старописьменном калмыцком языке. 1661 г.

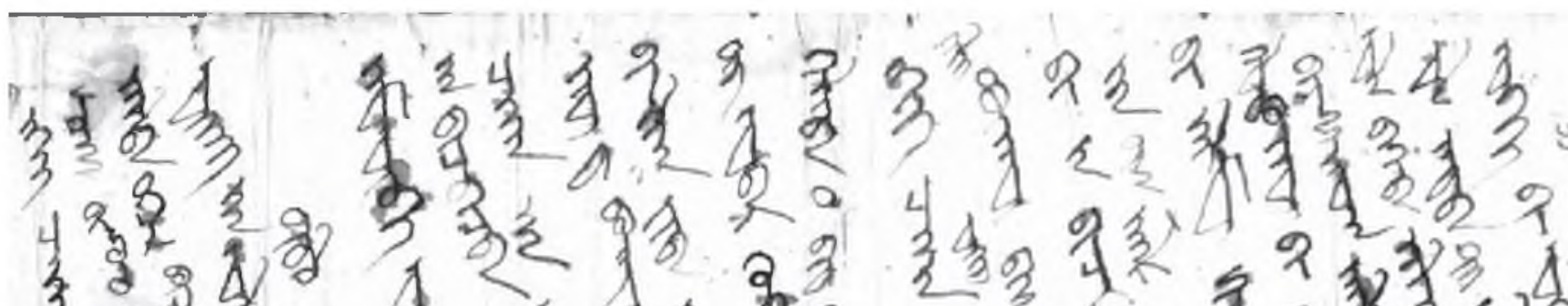

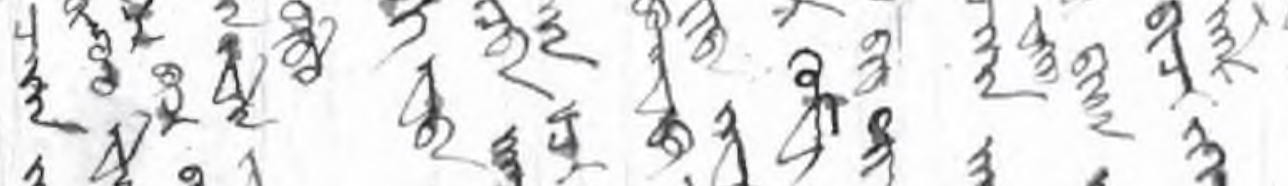
然是2

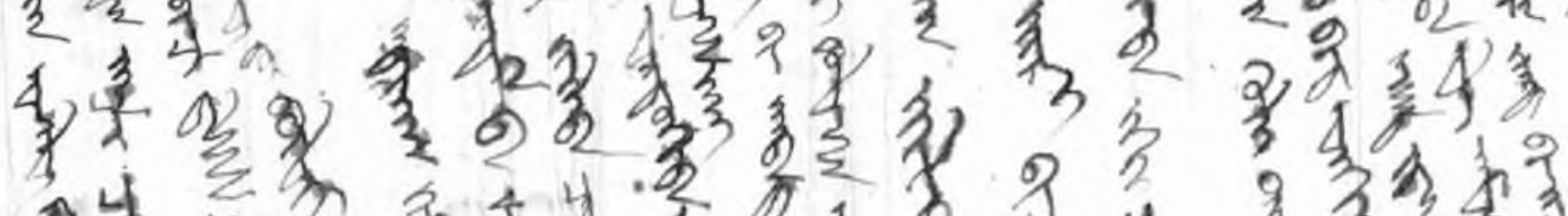

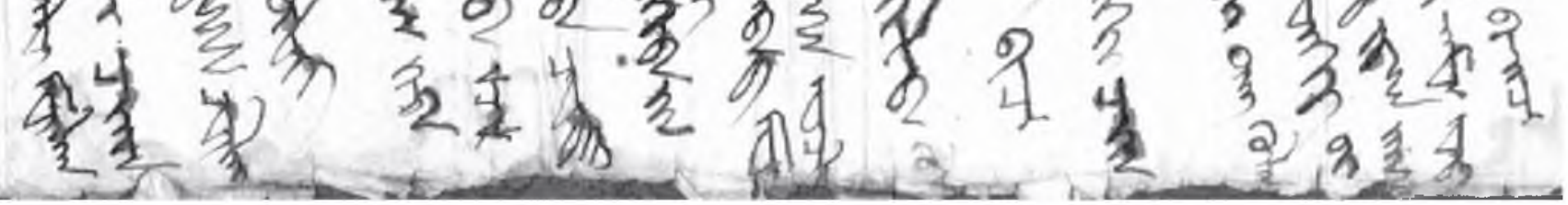


-

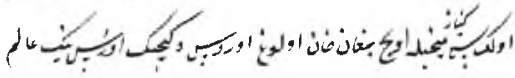

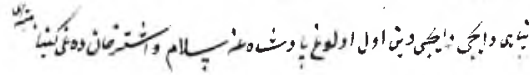

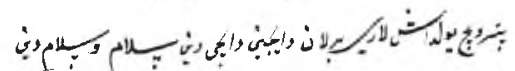
بإبكا:

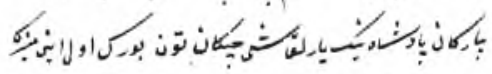

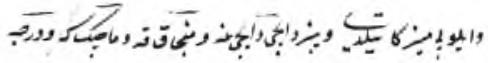
"

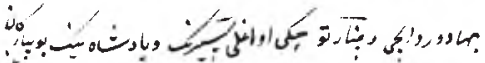

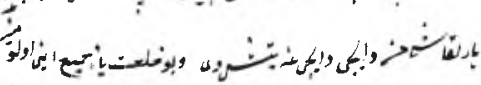

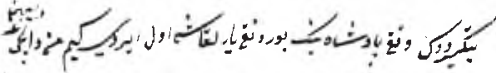

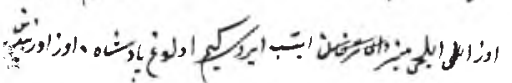

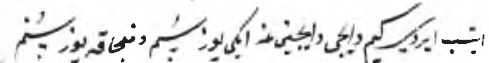

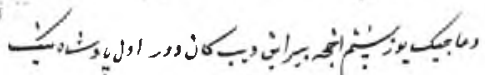

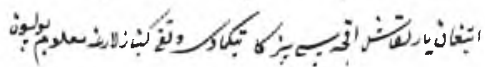

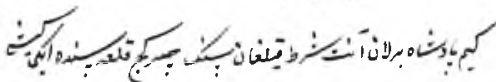

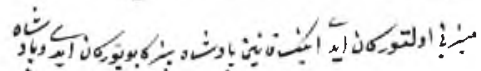

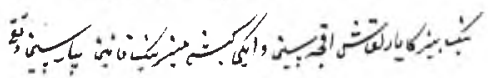

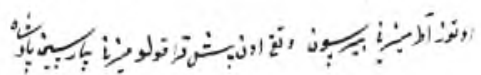

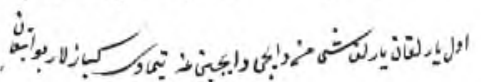

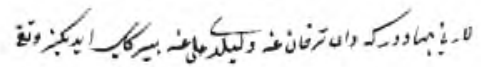

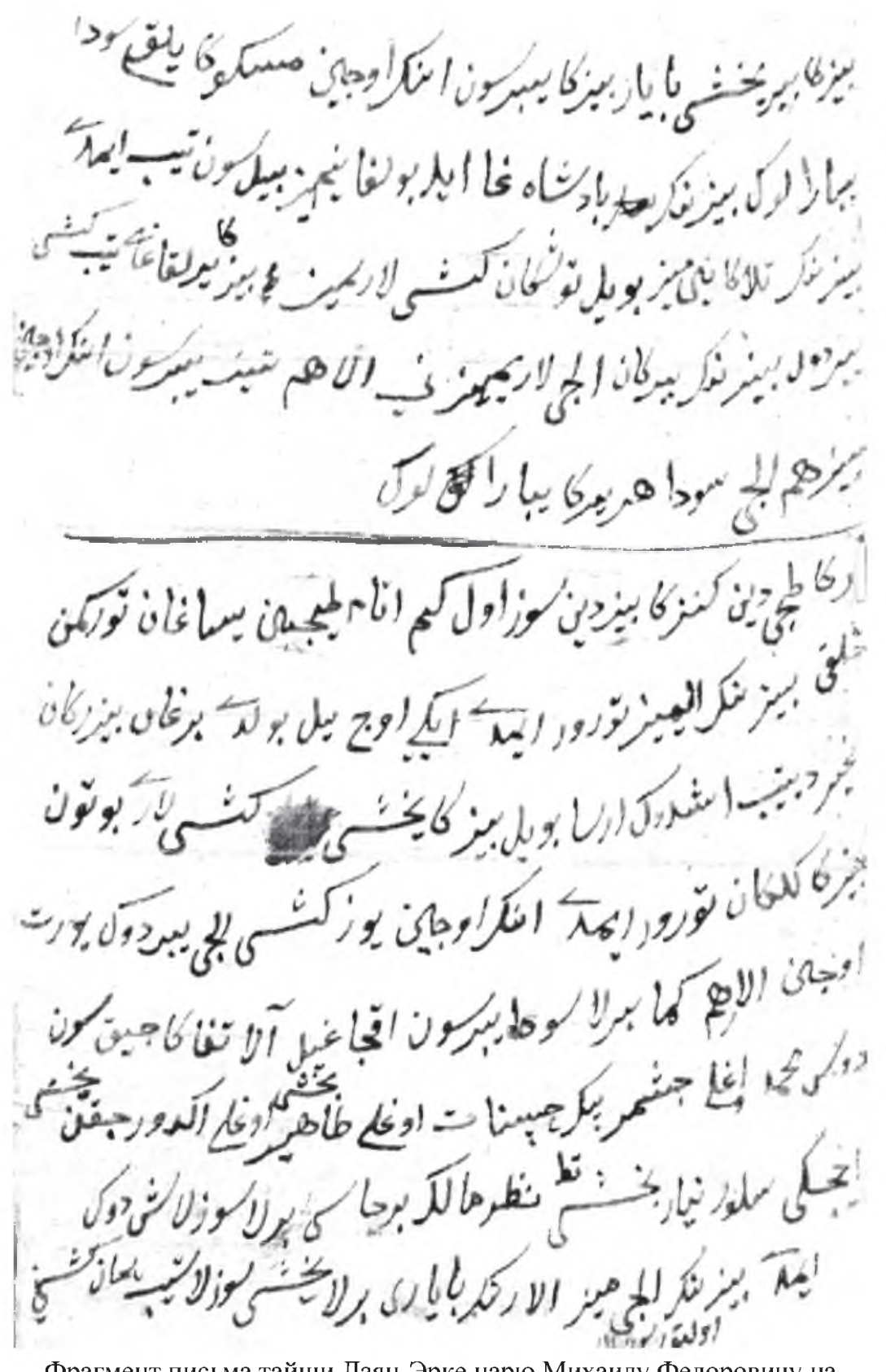

Фрагмент письма тайши Даян-Эрке царю Михаилу Федоровичу на старописьменном татарском языке. 1644 г. 


\section{УКАЗАТЕЛЬ ИМЕН}

Абека, калмык 173, 174

Абай, супруга тайши Изенея 43

Абакай, тайша 41

Абахай, хан 114

Аббас II, шах 49, 291

Абдула Тинекеев, мирза 164, 194.

197

Абла Тинбаев, мирза 194, 293

Аблай, тайша 74, 129, 133, 191 ,

$214,256,257,326,327,330,381$.

$382,383,384,389-392,394$

Аблай Ишимов 81, 112

Абугу, тайша 116

Абу-л-Гази, хан 76, 120-122, 124,

$174,188,217,237,238,254$

Адиль, мирза 186

Адиль-Гирей, хан 369, 370, 373 ,

385,388

Адильбек, посол 346

Азнабаев Б.А., историк 213

Айдарук Мурзаев, посол 361

Айдемир-шамхал 156,

Айтек, мирза 121

Акбулат Сулейманов, кн. 208

Ак-мирза Байтереков 88

Аккус Кусябердеев, тархан 229

Аксак Келмаметев, мирза 188

197, 252

Аксенов Д., толмач 109

Аксентьев Д., толмач 246

Акшоби Манджушири 115

Акын-Кошшучи, тайша 223

Алатай, посол 55

Алгамышев Я., сотник 135

Алдай, посол 376

Алдар, тайша 257, 330

Алдар-Кечик 307

Алегуко Шегануков, кн. 151, $154-$

156. 195.325
Алей Урмаметев, мирза 54, 62, 77, 88,185 ,

Алексей Михайлович, царь 186 , $218,247,260,270-272,289,290$

$305,306,315,367$

Аллаберды, посол 248

Аллачуват Акимбетев, мирза 244

Алтын-хан 35, 36, 41, 43-46.

50-54, 56, 60, 71, 81, 133

Алыбай-дархан, посол 291, 298 ,

304, 325, 328, 329

Амуга-шиди 115

Ангай, посол 267

Аристов И., голова 82, 89, 90

Арлай Алаков, посол 41

Армамет, мирза 275

Арслан, мирза 108, 135

Арсланбек, мирза 150, 151, 152.

$299,303,325,352,394$

Арсланбековы, клан 388

Артемьев К., толмач 80, 97-100

Архули, тайша 150

Аршинский Б., посол 103

Асаналей, татарин 94

Аслан, 295

Ахай-хатун 57

Ахай, супруга Далай-Батура 131

Ахандей Мерген, посол 158

Ахманай, тархан 297

Ахмед-Гирей 352

Аюка, тайша 118, 324, 337-339.

$340,342,378-380,382-384,386$

387, 390-394

Аюкей, тайша 296, 297, 315, 338

Аючей, тайша 296, 297, 309, 315 ,

$338,342-344,365,367$

Аюши, тайша 257
Багазыч, посол 186

Багилдинский И, казак 145

Багым-Батур, посол 157

Бадма, тайша 137, 138, 150, 177

183

База-Батур, калмык 352

Базрек (Берек), посол 154, 185

Баимбет, посол 134, 157

Байбагас, тайша 46, 47, 51, 52 ,

$54,56-59,62-65,67,68,70,74$

$127-129,330$

Байбаков Ф., посол 321, 329

Байзыгитов Токмамет, чуваш 343

Байскулан, калмык 314

Байтерек, посол 185, 248

Бакунин В.М. 386

Бакши Сабанов, посол 167, 168

Балакирев П., сотник 243

Балдан, посол 203, 227

Балту, посол 71, 72

Банши, посол 394

Бараков М., посол 393

Баракчин, посол 298

Барсу, калмык 185

Барчю, посол 237

Барын, посол 154, 185

Барятинский, князь 380

Баста Недеев, посол 211

Басу, калмык 268, 352

Батмаев М.М., историк 144, 282

Батур, тайша 54, 55, 59, 61, 62, 63 ,

$123,135,161,165,174,178,187$

Батур Аянгеев, посол 307

Батур Бухин, посол 211, 237, 262

Батур-бакши, калмык 349

Батур-Демчи, посол 250, 25

Батур-Кашка, тайша 198

Батур-хунтайджи 47, 75, 76, 81 ,

$91,112,114-118,129,130,132$,

$133,153,158,173,180,213,214$

$216,218,250,256,307$
Батур-Убаши Тюмень, нойон 239 Батыр-Каныш, супруга Дайчина 297, 336

Батыркей, посол 204

Батырша Сулешев, мирза 244

Баучин, посол 41, 71, 72, 317

Бахмех-ага 369

Бахтый, посол 133

Бахчи, посол 335

Баян, калмык 334

Бежук, посол 326

Бекбаши, посол 280

Бек Оллашев, мирза 386

Беклемишев Н.М., воевода 292

Беклемишев С., голова 364

Бердембет (Бердымбет), посол

140,183

Бердыш, посол 125

Беркула, посол 263

Беш, посол 68

Биликту, тайша 180

Би-мирза Урмаметев 95

Бисурман, тайша 277

Бияра, посол 119

Бо-Елден, тайша 117

Богданов И., посол 370

Богдо-геген 239

Богоявленский С.К., историк 40 $47,50,56,60,63,71,76,81,83,84$. $86,92,94,105,135,138,144,153$

Бойма, посол 74

Бок, тайша $325,347,379-381,385$.

387, 392

Бок Коргушев, посол 285

Бокей, посол 104

Болда, посол 74

Болкаш, калмык 348,349

Болсендей, посол 202

Болтин И., голова 77

Борис Янарасланов, мирза 83,84 88 
Борисов А., толмач 94, 95, 238 . 263-268

Брызгалов Д., стрелец 162, 163 Брюховецкий И., гетман 321, 354 , $357,358,373,375$

Буга, посол 45

Будан $\Phi$., казак 308

Будан-Церен, калмык 322

Будачей, кн. 156

Будачери-кашка, калмык 323

Булат Когуржанов, аманат 279

Бура, тайша 116

Буранай, посол 205

Бурвей, тайша 123

Бутак, тайша 43,45

Бутурлин А.В., воевода 260

Бутурлин В.В., боярин 261

Бухаров Я., посол 61,82

Бухаров Л., посол 134

Бухвостов Б., воевода 379

Буян, тайша 362

Буяран Улчиев, тайша 42 ,

Бюракаш, тайша 196

Бюрчи, посол 124

Васильев А., толмач 156

Веневитинов Я., атаман 375,376

Вернадский Г.В., историк 39-41

Вершинин Е., казак 130

Витсен Н., посол 339, 340, 368

Внуков Б., командир 66

Волков В., посол 54

Волков 3., посол 274

Волков М., голова 251-253

Волконский Ф.Ф., воевода 160 .

184

Волынский А.П., воевода 152

Волынский М., воевода 148

Волынский С.В., окольничий 308

Выговский И., писарь 261

Выходцев П., посол 105, 106
Габан Шараб, летописец 47, 75 , 103, 239, 362, 384

Гагарин С.И., воевода 38,39

Гази-Гирей, калга 169, 244

Галдамба, тайша 257, 331

Гаур Ахбу латотв, башкир 310, 342

Герасимов А., толмач 228, 238 ,

246

Герасимов М., толмач 205, 224.

227

Гладков В., казак 328

Гладышев А., посол 68

Голицын И.Ф., воевода 227

Головин А.И., воевода 285

Голочелов Г., сотник 324,358

Голубин П., посол 43

Голубцов В.К., посол 208, 210.

$211,230,233$

Голугень, тайша 73

Голятин Б., посол 156, 157

Горохов И.С., дьяк 274, 276.

306-318

Горохов С., голова 89, 90

Горяинов И., голова 253

Гостев Г., толмач 244,245

Грановский А., воевода 274

Греков М., посол 319

Григорьев Т., атаман 199, 201

Гумбо, тайша 104, 131, 257

Гуши, тайша, хан $67,68,70,71$,

$74,81,87,91,103,105,106,108$.

$109,112,117,123,129,255,258$

Дазан-кашка, посол 313, 314

Дай-дархан, посол 293, 314

Дайчи, тайша 113

Дайчи-заргучи, посол 317

Дайчин, тайша 46, 63, 64, 75, 78 ,

79, 81, 83-102, 104-113, 117-119,

$121,123,125,128-133,136,156$,

$158,159,163,166-168,170,173-$
$177,182,186,187,190-198,201-$ $212,214-218,220,221,223-239$. $244,246-250,255,256,257,258$, $259,262,267-276,278-281,283-$ 289, 291-304, 306-311, 313-316. $318,320,321,324-334,336-338$, $340,342-345,358,361,363,370$. $371,377,382-384,390,391,393$, 394

Дайчин-Хошучи, тайша 71, 103. $104,106,117,123,131,132,159$, $177,191,212,214,215$

Далай-Батур, тайша 36, 39-47, 52-54, 58-60, 68-76, 81, 87, 91-93, $98,100-104,106,108,117,128-$ $131,133,171,182,212,231,257$, $296,317,344,362$

Далай-Лама V 100, 117, 129, 176 Далай-Хунг, монг. кн. 116

Далантай, тайша 188, 193, 197 202, 209, 221

Данашир, тайша 63

Дара-Эке, супруга ДайчинХошучи 131

Дарашаев Кичик, калмык 349

Дарын, посол 125

Даря, тайша 293, 314, 325

Даши, тайша 376, 379, 381, 384

Дашков А.Я., стольник 308,338

Даян-Омбо (Тенгерийн-Тойн), тайша $71,104,117,128,131,176$ $214,216,217,220,257,258,330$, 331,382

Даян-Эрке, тайша $113,132,134-$ 141, 147-150, 153, 157-164, 166. $171,175,179,182,187,336,340$ Девлет Тахабакшеев, посол 41, 74 Девлет-Гирей Ишимов 112 Девлетбаев Эшимбет (ИшМухаммед), тархан 342-344 Девой, мирза 301, 386
Дернов А., стрелец 278

Джан-мирза Улан, посол 241

Джахангир, султан 91, 92, 194. 213, 215

Дженкисон, посол 37

Джовба, калмык 330

Джонсон Р., посол 37

Дзасагту-хан 114-117

Дин-Мухаммед (Тинмамет), мирза 51

Дойнаш, командир 189

Долгорукий Ю.А., боярин 367 Долгоруков Д., посол 233

Дондук, тайша 362, 392

Донец Ф., полковник 373

Доржи, сын Чокура 63-65, 70

Доржи, сын Далай-Батура 71-73

Доржи, сын Кунделен-Убаши 217,

$325,327,330,337,339,342,390$

Доржи, посланец 334,338

Дорошенко П., гетман 373, 387

Досалей, посол 263

Дубеней, тайша 42

Дугар, тайша 315, 322, 325, 347.

349, 352, 362, 379-381, 384-386. 390,394

Дурал-дархан 98, 106, 203, 208

$211,249,267-270,272$

Дурачи-кашка, калмык 315

Дунайка $Ф .$, стрелец 268

Дюнекей, тайша 208

Ежиеш-бей, посол 385

Елай-ага, башкир 123

Елантуш (Ялантуш), султан 123

133, 165

Елден, тайша 95, 96, 105, 113, 117.

$129,132,135-137,147,150,153$,

$157,158,160,163,165,167,170$.

$173,177,179,183,185-187,190$,

$215,217,218,235-237,254,255$.

$257,258,332,361$ 
Елчин Ф., толмач 211

Емаги-Батур, посол 205

Енин А., посол 164, 165

Ергелды, тайша 147, 150, 153

Ермомет Шагалаков, бухарец 130

Ерофьев Т., стрелец 266

Есипов В., боярский сын 252

Есипов Г., стрелец 288

Ефимонов Д., посол 228, 238, 246

Жапьг Жуватов, уздень 301 Желябоовский И., воевода 68

Жолмамет, посол 346

Жуков Б., голова 97

Жуков П., есаул 376

Зайсан-Дархан, посол 315, 316.

318

Зал-ага, посол 287

Замала, калмык 170

Зан-Кашка, калмык 309, 319, 320.

321,352

Заргучи-кашка, посол 211, 311 ,

313-315

Зарубин Ф., воевода 275

Заруцкий И., атаман 49

Захаревич Г., полковник 388

Зая-пандита, хутугта 100, 115

$117,128,132,175,176,180,184$,

$214,256-259,330,390,391$

Здарий Шадаев, тайша 265

Зиновьев В., толмач 125

Златкин И.Я., историк $36,47,56$,

$114,115,175$

Зоргул Зоритуев, калмык 325

Зоргул-Далай Башаев, посол 323

Зоройкту, калмык 70

Иванов П., толмач 279

Игнатьев Д., казак 145

Иджигер, посол 376
Идиль, мирза 147

Изеней (Эзене-тайджи), тайша

40-43,

Измайлов А.Т., воевода 296

Илгунай, посол 218

Илмамет Аксакалов, тархан 208, 210

Имам-кули, хан 60, 100, 111

Индзан-хутугта 100, 102, 109, 115 , 179

Иосиф, архиепископ 338

Исаков И., посол 301

Исенгелдей Тазаев, посол 185, 186

Исенгул, тайша 54

Исентур, тайша 44

Ислам-Гирей III, хан 153, 168.

200, 240, 241

Ислам Чубармаметев, мирза 303 , 320,354

Исфендияр, хан 55, 85, 100, 110 ,

120-122, 126

Ишбердей, посол 52

Ишим (Есим), хан 60-62, 91

Ишим, царевич 45, 52

Ишкеп, калмык 358, 365

Иштерек, князь 49, 50, 51

Иштерековы, клан 252

Кажамгур, посол 379

Кайку лак, тайша 265, 266

Кайряту, калмык 334

Казаналп, мирза 148, 156, 195.

$286,287,303$

Казанцев А., посол 119-124

Казарчи Бекимбет, мирза 295

Казик, посол 372

Казы Казыев, посол 85

Казый Мударов, мирза 156

Казый Пшеапшоков, кн. 151

Казы-мирза 349

Казымбек, мирза 351
Каим Дургеев, посол 223

Калашников В., посол 45

Калдыкерь, посол 288

Калинин С., дьяк 292

Калкын-Сарый 106

Канай Тинбаев, бий 52, 54, 55, 67,

77, 78, 82-88, 120

Кантемир, мирза 162, 301

Каныш, супруга Даян-Эрке 157

Каныш-Ахай, супруга Далай-

Батура 212

Каныш-Ахай, супруга Дайчина 284

Кара Кель-Мухаммед, мирза 64

Карабаш, башкир 342

Каракасай Яштереков, мирза 303,

320,393

Каракасал, мирза 300

Каракучи, калмык 328

Карантуш, калмык 321

Карасашев Л., голова 97

Карачбей, комендант 368

Караш-ага, посол 294

Карчитай, посол 95, 97

Кары Богатырь, посол 50

Карасаин Иштереков, мирза 149

Караш-мирза Атальк, посол 298.

329,335

Карашеим (Шагин, Шаим), мирза $140,147,155,238,246,251$

Каржанов И., уздень 319

Кармыш Тогаев, татарин 189, 190

Касай-мирза 150, 386

Касим-мирза, посол 300, 329

Каспулат Касаев, мирза 150

Каспу лат Мамаев, мирза 147, 148 ,

$158,161,164,188,197,209,223$

236, 266

Катачей Бурундуев, посол 38

Кашак-Батым, тайша 362

Каши, посол 333

Кейкуват, мирза 149

Келделе, посол 293
Келимбет Абдулов, мирза 147

Кель-Мухаммед (Келмамет), мирза $50,77,164$

Кельмамет Ибаков, мирза 156

Кенжей Катлешев, посол 320

Кесенчак Чиганов, посол 41

Кереитов К., посол 294, 295, 319

Кешкеб, тайша 191, 212, 257, 327

Кимбаров М., посол 358

Киржатцкий В., толмач 169, 210 , $211,229,230,262,263$

Кирсан, тайша $39,40,85,113,132$

$136,144,147,150,152,153,155$,

$158,159,177,184,188,222,327$

Кичиков М.Л., историк 132, 175 , $233,281,305,339$

Клепиков В., посол 159

Клубков-Мосальский С.В., воевода 130

Козеин, посол 184,185

Козлов К., посол 270

Кокун, тайша 71

Колесник В.И., историк 144, 325 ,

336,384

Колзаков В., голова 26

Колтовский И., воевода 289, 290

Колчюгаш, калмык 348

Кондратьев Ф., толмач 65

Кондырев И., атаман 221

Конкас Давлетбаев, башкир 181

Константинов Б., казак 41

Коомдан, посол 45

Коптев П., посол 243

Косагов Г., полковник 356,357

Котвич В.Л. 37

Котошихин Г. 306, 361

Кошевчей, тайша 43

Кошучи, дархан 225, 289

Кугонай Тубеев, посол 39, 41

Куден Ясан, калмык 314

Ку денет, мирза 149 
Кудрявцев А., посол 169-174, 176 192, 195

Кудрявцев С.Б., дьяк 167

Куен, тайша 65, 188

Кузнецов И., стрелец 285, 286

Кула, тайша 214

Кулай, мирза 62 ,

Кулачи-дархан Аздраев, посол 167, 279, 280, 361

Кулеген-Демчи, посол 237, 238

Кулук, посол 55

Кунделен-Убаши (Дургучи), тайша 67, 71, 74, 108, 109, 112, 117, 132.

$133,153,158,159,173,176,179$,

$180,191,213-218,220,330,336$

$337,339,381,382,390$

Кунищын И., посол 43, 46

Куракин Г.С., боярин 274

Куракин И.С., воевода 44, 47

Куракин Ф.С., воевода 78, 220

Курапов А.А., историк 239

Кутагык, посол 174

Куц О.Ю., историк 360

Кучей Ажимбетев, посол 291

Кучук, башкир 345

Кучук Салтан, хан 67

Кучум, хан 45, 52, 112

Кучумов П., толмач 370

Кучюк Нарушаев, посол 280

Куян, тайша 58

Ламач, посол 376

Левонтьев 3., думный дворянин 328 Лигдан, хан 100, 114

Лихачев $\Phi$., дьяк 74

Лобачи, тайша 325,347

Локтев Е., толмач 119.

Ломакин $Г$, , сотник 380

Лопатин Д., посол 212

Лопухин Л., дьяк 290

Лузан, тайша $75,85,96,112,113$,

$119,123,125-128,132,136-139$.
$147,148,156-165,170,172,174$. $175,177,178,180,182,183,186$ 188-190, 194-199, 206, 209, 215. 218-231, 234-238, 241-245, 248. $250,251,253,255-259,262-265$. 270-272, 274-276, 284, 287, 294, $295,305,326,327$

Лутохин П., стрелец 296, 297

Львов Г.В., дьяк 167

Львов Д.П., воевода 292, 294

Львов И., воевода 103, 109

Львов С.И., воевода 378

Львов С.П., кн. 305

Лыткин Ю. 116

Люзмин Г., толмач 182

Майдар, тайша 71

Мазан-Батур, тайша 324

Мазика, супруга тайши Чокура, 63 70

Макаис, дархан 315

Максимов К.Н., историк $38,48,281$

Малай Т., толмач 212

Малай, посланец $314,334,335,338$

Малай-Батур, тайша $330,331,342$

Малай-кашка, калмык 371

Малдышери, тайша 43, 45

Мамай, мирза 65

Мамбет-Сеин, мирза 64

Мамет, посол 296

Мамут, посол 109

Мамыт, посол 157

Манади-хан, адмирал 378

Мангуш-Кашка, калмык 320, 332

Мангыт, тайша 54, 59

Мандраш, посол 74

Манжи-Ялбо, тайша 278, 279

284-286, 289, 291, 294, 296, 297,

$300,301,314,315,320,323,325$.

$331-340,343,364$

Маникар-Дачи, калмык 347,358

Манзичюлюкай, посол 370
Мансуровы, клан 244

Манхадан, посол 375

Манхан, тайша 362

Матюшкин М., дьяк 74

Мачик, тайша 214

Мейдала, посол 78

Менке, тайша 259

Мерген, тайша 186, 254, 257, 258. $293,361,362$

Мерген-Дайчин, тайша 117

Мерген-Кошучи, калмык 314, 352

Мерген-нойон 116

Мерген-Темене, тайша 54, 58-62, $65,67,68,70$

Миллер Г.Ф., историк 391

Милославский И.Б., боярин 390 393

Милославский Ф.Я., воевода 234 Мин-Гирей, мирза 374

Михаил Федорович, царь 44,49 , $72,79,85,127,142,146,160,184$ Михайлов В., толмач 220, 251

Михайлов Г., толмач 222, 374, 385 Михула, тайша 265

Мияваки Дж., историк 47, 116

Моков Б.М., историк 151

Молчанов Н., командир 66

Мончак (Пунцуг), тайша 118, 216 $250,251,253,255,261-268,270-$

272, 276, 278-280, 284, 288, 289 .

$291,293,294,298-305,307-311$.

$313-316,318-332,334-340,342$.

$344,345,347-350,352,358-363$,

$366-368,371-373,375,377,382$

$385,393,394$

Мулла Гази, посол 346

Мунко-Темир, тайша 384

Мурат-Гирей, нуреддин 169, 321 ,

354

Мурзей, посол 73, 74

Мустафа Наим, летописец 151
Мустафа-бий, паша 240, 350, 351. 354,369

Мухаммед Ураков, мирза 243

Мухаммад-Баки-калмок, эмир 111

Мухаммед-Гирей IV, хан 146,

151, 282, 283, 287, 294, 297, 300 .

$321,328,329,341,350-355,369$

Навруз, мирза 147, 162, 299, 301

Навруз Шейдяков, мирза 300

Навруз Касаев, мирза 301, 352. 386

Назар-Мамут, тайша 383

Нанзай, посол 315

Начин, посол 293

Нима-Демчин, посол 126

Нима-Церен, тайша 135, 148, 149.

158, 164-166, 170, 171, 173, 174,

$177,182,183,186-190,197,198$,

$218,230,237,238,244,250,253$.

$254,257,266,270-272,276,309$,

383

Ногмов Ш.Б. 150, 152, 154

Норбо Ш., историк 100, 116

Нормацкий А., стрелец 319,335 . 360

Нурхаци, хан 114

Обак, посол 326

Обелхана Черкасская, супруга

Аюки 324, 338

Обогдай, тайша 208

Оболенский В., воевода 180

Огибалов Ф., голова 164

Огжодба, тайша 254, 257, 258

Одоевский Н.И., воевода 119

Одоевский Я.Н., воевода 363,389

Омачин Ф., воевода 338

Омбо, тайша 180,223

Омбо-Эрдени, тайша 133

Онкай, посол 190 
Онкобай, посол 204

Онученов Д., посол 109, 110

Онучин А., посол 182

Онучин И.И., посол 229-234, 319

Ордин-Нащокин А.Л. 374

Орджан, тайша 327

Осипов Р., атаман 371

Осичков С., голова 64

Остренский С., посол 358

Остриков И., посол 224

Очирту Цецен-хан, 74, 115, 117

$129,133,176,180,214,330,331$,

391,392

Паллас П.С., историк 131, 362.

382,391

Пальмов Н.Н., историк 90, 121 .

144, 298

Пахомий, архиепископ 192

Перевощиков П., атаман 377

Петров С., посланец 373

Петров Т., посол 43, 46

Писарев С., стрелец 296

Плещеев Л.А., воевода 142, 160

172, 174, 181, 207

Пожарский С.Р., кн. 305

Поппе Н.Н. 117

Преображенская П.С., историк

$273,276,279,281,315,361$

Приклонский А.И., голова 210

Прозоровский И.С., воевода 378 , 379

Прокопов Г., посол 370

Пронский И.П., воевода 269, 274.

276

Протопопов М., посол 393

Пунцок Намджал, правитель 100

Путарык, уздень 361

Путилов А., подьячий 97

Пушкин П., воевода 66

Пущин Ф., стрелец 335

Пшагин Д., посол 125, 126
Раднабхадра, биограф 256

Разин С., атаман 308, 328, 349.

376-382, 386

Ремезов М., посол 116

Репнин Б.А., воевода 162, 184

Романов И., толмач 288

Романовы, династия 44

Романчуков С, дьяк 45

Ромодановский В.Г., боярин 276 ,

278, 282, 306, 308

Росланбек, мирза 386

Русаков Г., боярский сын 80

Русмамбет, посол 186

Рыльский Х.Ф., воевода 209

Рысаев Тлеумбет, башкир 342

Савельев И., посол 44, 45

Садашкир, посол 154

Салтамурат Каспулатов, мирза 236

Салтамурат Тинбаев, мирза 162 ,

194

Салтан Дасаков, посол 207

Салтаналы, мирза 161, 221, 242.

244

Салтыков Б., воевода 69

Салтыков И., воевода 85

Самаренин М., атаман 371

Самарин Е., воевода 148

Санжин, тайша 113, 125, 128 ,

$132,134,135,147,158,165,170$.

177, 215, 218, 228, 235, 246, 257.

270-272, 276, 296

Санчиров В.П., историк 77,114 .

\section{5,118}

Сарбашов Я., казак 57

Сар-Манжи, казак 349

Сартугар, посол 268

Сары-мирза 322, 348

Сары Мергень, башкир 344

Сафонов А., толмач $164,165,177$,

$178,184,185$
Сахайчжун-хатун 382

Сахан-Кашка, калмык 352

Свищов Д., воевода 392

Сеин, армянин 369

Сеит Мамбеткулов, посол 268

Сеит-Мамбет, мирза 332

Селезнев Т., голова 229, 238, 265 ,

266

Селим-Гирей, хан 388

Семенов Л., атаман 387

Сенге, тайша 330

Сенгерчин, посол 125

Серешкеп, тайша 250

Серко И., атаман $355,356,357$,

358,374

Сершкеп (Шерешкеп), калмык 185

Сефер Гази-ага 321, 350

Скарятин С., посол 138, 139

Созоруко Анзоров, мирза 156

Солдат Я., казак 145

Солом-Церен, тайша 131, 132

250, 257, 296, 299, 301, 307, 314 .

$316-318,325,326,337,344,347$

$349,352,372,376,377,379,382$

$384,389,390$

Солтан, тайша 133, 173, 330

Солтанай Келмаметев, мирза 147 265

Солтанай Рохмангулов, мирза 147

Солюнтюр, тайша 197

Сомов Ф.И., воевода 310

Соном, тайша 257

Степанов К., толмач 349

Степанов Л., толмач 96, 97, 107

Степанов Т., стрелец 307

Сувундай (Субундай), супруга

Далай-Батура 132, 222, 225, 296

Сулейман-паша 387

Сулешев Батырша, мирза 354

Султанай (Салтанай), мирза 52 ,

$59,61-63,65,70,77,85,93,101$,

$108,113,123,135,164,178$
Султанаш (Салтанаш), мирза 189 ,

$252,300,303,320$

Сунгул, тайша 69

Сурин М., сотник 308,358

Сурхай, шевкал 287

Суслов И., посол 205, 206

Сутай, тайша 257

Сюнке, тайша 74, 76, 113, 119

$126,128,132,149,153,158,160$.

$165,166,170,174,177,183,184$.

186-189, 190, 195, 197, 198, 204.

250,275

Сююнча Абдулов, мирза 119, 147.

$163,164,194,199,222,236,252$,

$266,267,278,280,286,288,289$,

$294,300,304,311,334,335,341$

Сыргенчек, посол 126

Табутай, тайша $45,58,60$

Табынай Аксакалов, тархан 182.

297

Тавка Кривой, татарин 198

Таган Чентуев, посол 234

Тарбеев А., голова 89, 90, 97

Ташлыков А., дьяк 328

Тевке (Тауке), хан 392

Тевке, внук хана Кучума 112

Текей-ага, посол 323, 324

Тлевбердей (Телебердей), посол

250, 251, 261-263, 272

Телепнев Е., дьяк 72

Телятевский Ф., воевода 138

Темир, посол 227, 250

Темкин-Ростовский М., воевода

109, 112

Теникей Абдыков, мирза 197

Тепшиген, тайша 225

Терехов П., воевода 191

Тетеря П., гетман 353

Тимофеев Е., казак 328

Тинмаметевы, клан 51, 55, 56, 95

Товарыщев А., командир 82 
Тогачи Тохтараев, тайша 42

Тогон, тайша 36

Тогуш-Батур, калмык 348

Токмак, посол 204

Токчу, тайша 71

Топчи, калмык 338

Тордагул, ногаец 55

Тохтарал, владелец 370

Траханиотов И.Н., воевода 135

Трепавлов В.В., историк 48,87 ,

$88,144,233,279$

ТрубецкойА.Н., воевода 88

Тугул, тайша 150, 186, 254, 258

Туменгийн Сайн-нойон 116

Тундутовы, князья 331

Тупшин, калмык 376

Турач Криштоф, поляк 374

Тургай, посол 74

Тургень, тайша 43, 45

Турищев Н., стрелец 210

Туровец С., атаман 353

Турсун, хан 60

Тууш, командир 189

Тушэту-хан 114-116

Тюгеш, посол 183

Тюпчин (Топчи), калмык 334, 335

Убаши-хунтайджи, тайша 259

Уваш-кашка Тулуев, калмык 325

Ужен Конаев, посол 39

Укор Даулат, посол 247

Улчечи (Илю-Цензе), тайша 42

Умар, дархан 323

Умар-кошучи, калмык 322

Умар-Эрке, калмык 352

Унидей-кашка, калмык 347

Урак, мирза 65, 147, 164, 204, 301, 348

Ураков П., посол 181

Ураковы, клан 243, 244, 301, 388

Уралма, супруга Мончака 307 ,

$331,333,336$
Ургечей, посол 218, 222, 262,

Урджин, тайша 257

Урмаметевы, клан 51, 95, 183 .

196-202, 243, 244, 287

Урусамб, посол 299, 310

Урусовы, клан 82

Ус В., атаман 378

Усман-Батур, тайша 314,352

Устюгов Н.В., историк 248

Утеш-дархан, толмач 228, 237 , 238

Ухандыр, тайша 63

Ушаков Я., посол 239, 243, 246, $247,249,270$

Федоров Е., толмач 97,98

Федоров Ф., стрелец 229

Федосеев К., атаман 241, 242

Фишер И.Е., историк 129

Хабуту-Хасар, брат Чингис-хана 116

Халду, тайша 150

Хан-мирза Тинмаметев 55

Ханмирза Арсланов 148

Ханай-нойон Хонгор 57

Хандер, тайша 70

Хара-Мерген, посол 78-80, 273

Хара-Хула, тайша $36,45,47,58$,

$59,128,171,231$

Хвостов И., воевода 371

Хитрово Я.Т., воевода 359

Хмельницкий Б., гетман 240, 253. 260,261

Хмельницкий Ю., гетман 321

Ходарковский М., историк 42, 285

Ходождуко Казыев, кн. 154-156.

195,325

Хо-Урлюк, тайша 38-40, 42, 43.

$46,50-52,54,56,59,60,63,68$

$74-79,81,84,85,87,91-93,95,96$,

104-106, 108, 109, 112, 113, 117 ,
$125,128-134,136,137,142,144$.

$147,148,150,152-156,158-161$.

$168,170,171,175,177,184,185$.

$187,188,195,210,222,231,238$,

$239,242,248,252,268,273,281$.

382,391

Хунг-нойон 116

Цаган, дерб. тайша 212, 213, 257

Цаган, хошут. тайша 383, 389-392

Цамба, тайша 362

Церен, тайша $135,150,153,155$,

$184,185,188,222$

Церен Чоктуев, тайша 265, 269. 270, 272

Цецен, тайша $117,180,191,257$

Цецен, калмык 330

Цецен-Каныш, супруга Лузана 327

Цецен-нойон 116

Цэцэн-хан 114

Цин, династия 114

Цогту, тайша 100, 117, 129

Цюрюмов А.В., историк 145

Чагантей, посол 335

Чаргу, посол 186

Чарнецкий С., полковник 357

Чебан Иштереков, мирза 148, 183.

206, 223, 301

Чеган-кашка 322

Чеглан Кесепов, посол 234

Чекулат, посол 379

Челеби Эвлия, 150, 152, 154, 304.

360

Чепал, уздень 338

Черкасский Г.С., воевода 301-303

$307,308,315,316,319,322-328$,

$330-337,344,347-350,352,358$,

$364,366-368$

Черкасский Каспулат, кн. 301 ,

$303,307-309,311,313,314,316$
$320,328,334,347,361,363,364$, 367,391

Черкасский Муцал, кн. 148, 265

Чернов А., посол 279

Черток Н., атаман 377

Чин, тайша 56-58

Чингил, посол 74

Чингис-хан 96, 98, 99, 116, 121. 283

Чирядай, посол 237

Чово-Мерген, тайша 71

Чоклу, посол 157

Чокту, тайша 150

Чокула, дархан 170, 173, 174, 181.

182, 208-210, 269, 270, 272, 288 ,

$297,308,309,314$

Чокур, тайша 46, 47, 52, 54, 56-65. $67-71,73,75,77,93,101,106,129$

Чокур-Убаши, тайша 117, 128

Чораш, мирза 147

Чубармамет (Джаббар-

Мухаммед), мирза 88

Чукур, тайша 197,

Чулошников А., историк 53

Чуу, тайша 257, 330

Чювак Сары, посол 291, 293

Шабан, каракалпак 330

Шабликин М., сотник 64

Шайнек, мирза 59, 60

Шамамет (Шейх-Мухаммед), мирза 61, 62, 65, 112, 135, 197. $198,327,334$

Шаманский Каспер, посол 254

Шапкула Татугуев, посол 42

Шарап Кучаров, тайша 197

Шарап-Омбо, тайша 187, 257

Шараш, мирза 186

Шевкал-ага 386

Шевырев П., атаман 275

Шейдяк, мирза 77 
Шейдяковы, клан 298, 354, 358 ,

370,388

Шен-Темир, посол 264

Шепелев Д., сотник 169

Шереметьев В.Б., боярин 260, 261. $305,321,367,370$

Шеховской С., воевода 345

Шибанов П., стрелец 292, 293

Шишкин М., дьяк 292

Шмелев А.С., историк 303

Шогаш-Мерген, калмык 348, 349

Шолой Убаши-хунтайджи 35, 54

Шолой Цецен-хан 116

Штефан Корицинский, канцлер 254

Шуйский В.И., царь $39,41,44,48$

Шумников И., посол 83, 220, 221

Шура, тайша 223

Шушерин А., командир 82, 83

Шушерин Т., воевода 142

Щукин М., посол 247, 250-253

Элакай Эшбердеев, посол 280

Элбузар, посол 265

Эмчн, калмык 338

Энгей-дархан, посол 222

Эргель Мубулов, аманат 279

Эрген, калмык 330

Эрдени-кошучи, посол 314, 315

Эрдени хун-тайша, монг. кн. 116

Эрдени-хунтайджи, тайша 216 ,

217

Эрке, тайша 348

Эрке-Батур, посол 293

Эрке-Дайчин, тайша 259

Эрке-Елден, тайша 58

Эрке-кашка, калмык 321

Эрке-лама, 307, 338, 383, 389
Эркебани-бакши, посол 317

Эркет Атуркай, калмык 356

Эсембет, посол 190, 203

Эсен, тайша 36, 214

Эсен, дархан 288, 304, 309, 311 . 314, 320

Эшбердей Авжиев, посол 393

Эшей Кашкарин, татарин 278

Юдин Д., посол 201

Юм-Агас, супруга Батура-

хунтайджи 133, 159, 256

Юмай-дархан, посол 383

Юрикты Конаев, посол 39, 41

Юсуп Тиникеев, мирза 135, 164

194

Юсуп Ураков, мирза 65, 388

Ябагу, мирза 303

Яблонский, генерал 359

Языков И., воевода 319

Яковлев К., атаман 307, 309, 320 378, 380, 393

Яковлев М., стрелец 64

Ямгурчи Тинмаметев, мирза 206

Ямгурчи-мирза Янмаметев, 183

$189,252,300,303,332,383,386$, 388

Ян Казимир, король 253, 261

Янги-Батур, посол 293

Янибек Идилбаев, посол 284

Янмамет Рамазанов, голова 97

Янмамет Янаев, мирза 78, 82, 89 ,

$149,164,263$

Янтой Чокула, калмык 321

Янчевский Н.Л., историк 145

Янырдаев Доржи, калмык 349

Ярам-Мамбет, бухарец 194

Ярмечен Полеван, посол 140

\section{УКАЗАТЕЛЬ ГЕОГРАФИЧЕСКИХ НАЗВАНИЙ}

Аблайин-кит 259, 330

Агсагал 03. 258

Азов 82, 139, 145, 199-201, 223 ,

$243,275,276,291,298,300,303$.

$305,310,320,347,351,352,354$,

$355,357,362,369-371,385,387$.

388, 392-394

Азовское море 351

Аккерман 355

Аксай р. 149

Алгара р. 263

Алгару, ур. 107, 252

Алмалы-ата, ур. 248

Алтай 35

Алтайские горы 36

Альма, p. 363

Аманкарагай, ур. 218

Аму-Дарья, р. 122

Арал 49, 113, 164

Армыт р. 208

Астрахань 51-55, 59-62, 64 ,

66-68, 77-80, 82-99, 101, 106-112

$119,120,122-126,128,134-141$,

$144,147-150,152,153,155-158$

$160,162-166,168,171,173,174$.

$177,178,180,183-186,188-190$

192-194, 196-198, 200-208, 212.

218-233, 235-239, 241-243, 245-

$248,250-253,255,261-271,274-$

276, 278-281, 283, 284, 286-294.

$300,301,303,304,306-308,310$

$311,314,315,320,323-326,328$

$330,332-339,343,358,364-367$.

378-380, 388-391, 393, 394

Атрек, р. 237

Ахтуба, p. 223, 230, 267, 274, 390

Ачилы-Тогай, ур. 94

Аягуз, p. 330
Байгонур, ур. 186

Баку 378

Балхан (Балх), обл. 120, 122, 123

Балчиклы, прот. 270

Балчиклынский городок 264

Барабинская волость 102

Барагуны, обл. 149

Баркуль, о3. 35

Барсучьи Копани, ур. 70

Барсучьи пески, пуст. 60, 215, 235

Баскунчакская соль, ур. 302

Бахчисарай 277, 370, 374

Башкирия 341,345

Белая, p. 162, 208, 274

Белая Церковь 359, 360

Белгород 375

Белгородская орда 200, 355, 356

Белужье, ур. 185

Бербоин, ур. 349

Берги-Чеган, p. 297

Берекети, p. 95, 97, 265, 307, 323 ,

335

Бесергенево 198

Бесленей, обл. 300, 320

Бичигиз, ур. 300

Болда, p. 108, 135, 335

Большая Ногайская орда 49, 69 , $80,95,146,261,286,393$

Бузан, p. 89, 95-98, 106, 107, 120

136, 180, 186, 188, 221, 226, 265

Бузулук, р. 358, 372

Буланай, p. 115

Бунганак, дер. 277

Бухара $53,60,78,105,111-113$

$119,126,139,161,165,173,194$.

227,253

Бухарское ханство 130 


\section{Валуйки 385, 392}

Великая Китайская стена 176

\section{Венгрия 352}

Вертлюжный городок 264

Войско Донское 275, 308, 371.

376, 378

Волга, p. 48, 55, 69, 75, 77, 78,

80, 86-88, 91, 94-99, 106, 107.

$113,118,124,126,134,138-143$,

$145,147,149,150,155,172,176$

$182,184,185,187-190,196,197$.

201, 202, 204-206, 212, 219, 220

$222-228,233,238,240-243,245$,

$247,250,252,253,255,262,264$

$265,267,273-275,280,288,303$,

$309,311,323,327,329,342,346$,

$349,358,366,371,376-380,383$.

390,392

Воронеж 240

Восточный Туркестан 36, 37

Волго-Яицкое междуречье 51, 52 , $66,94,145,390$

Восточный Алтай 36

Гадяч 373

Гетманщина 260

Гюрген, p. 237

Дагестан 143, 286, 300, 303

Даруган 254

Дербент 378

Джунгария $34,36,46,49,76,115$.

$118,128-130,154,166,168,176$,

$179,214,216,218,236,237,250$,

$255,256,268,390,391$

Джунгарское ханство 36

Днепр, p. 200, 242, 322, 353, 360

$373,374,375$

Долгий остров 263

Дон, р. 69, 106, 183, 198-201, 221.

$227,240,242,261,275,290,303$.
$308,309,315,318,347,353,359$. $363,364,369,371-373,375,376$. $378,379,381,384-388,391-393$ Донец, р. 243, 372, 385

Дурун 120

\section{Егорлык, p. 387}

Елек, ур. 124

Еничигей, ур. 349

Енотаевский о-в, 134, 150

Енотаевский Яр 301

Еруслан, p. 113, 226, 309

Зайсан, о3. 36, 116

Закамская линия 341

Западная Монголия $34,35,38,49$

Западная Сибирь 38, 50, 74

Запорожское войско 261, 321, 354 , 356

Запорожье 321, 353, 355, 364, 375. 378

\section{Игирлик, p. 187}

Ик, р. 66

Илек, p. 162, 165, 181, 204, 209.

$210,215,267$

Иловля, p. 383

Индерские горы 196, 204, 206

$248,249,267,268,383$

Индия 86

Инжик, p. 363

Иргиз, р. 104, 158, 216, 226, 228

233, 284, 297, 319

Иргиз, ур. 55, 139

Иртыш, p. 38-42, 48, 54, 58-60, 63 .

$67,68,103,116,259,330$

Исфаган, обл. 120

Ичик-боре, ур. 147, 150

Ишим, p. 38, 48, 51, 64, 68, 81.

104,105

\section{Йугурук-баш, ур. 217}

Кабарда $144,148,150,151,153$. $154,156,158,168,171-173,195$. $222,228,243,300,325,388,393$

Кагальник, р. 378, 380, 381, 387

Казань 42, 232, 287, 294, 304, 329. 341

Казанский уезд 182, 189, 208, 210 , 232, 255, 297

Казахская орда $37,46,55,79,130$ 392

Казацкий Караул 376

Казыевский улус 79, 97, 140, 146,

$147,155,184,186,190,195,201$,

$220,228,229,265,300,301,303$.

$347,352,386$

Кайнар Сагызу, ур. 52

Калаус, р. 387

Калачинские башни 392

Калмыцкое ханство 239, 282, 339

Кама, p. 140, 341

Каменный затон 353

Каменный Яр, ур. 201

Камызяк, учуг 89

Камыш-Самара, p. 51, 82, 84, 226 246

Камышинка, р. 379, 380

Камышлов, p. 38, 41, 42

Канев 357

Караганская пристань 111

Карадуван, ур. 70, 255

Карадуванские пески 89

Каракамыш, ур. 164

Каракул, ур. 65, 204

Каратабынская волость 68

Каратерезе, ур. 186

Карачав, ур. 65

Касимов 329

Каспийское море 50, 221, 377, 378

Кашаун, ур. 264
Каш-Катау, г. 151

Кемурдей, обл. 300, 320

Керчь 369

Кигач, ур. 89

Киев 374

Кизляр 265

Кизлярский перевоз 149

Кизыл-Бирун, ур. 180

Кизыл-илгын, ур. 150

Киил, p. 170, 209, 211

Кипчатцкая волость 297

Китай 34

Коломна 307

Колончак, p. 356

Кондаки, ур. 66, 99

Конотоп 305

Конские воды, p. 200

Коровья Лука, ур. 264

Корсунь 357

Косаева Клюка, ур. 370

Кошкарагай, ур. 104

Красный Яр 252, 280, 332, 335

338

Кременной 243

Круглый остров, ур. 196

Крылов 355

Крым 79, 88, 93, 106, 110, 145

146, 169, 173, 183, 186, 195, 196. $200,201,203,220,229,240-245$. $253,254,261,274-278,280,283$. $287,290,292-295,298-300,304-$ 306, 309-312, 315-317, 322-324.

$328,329,332,338,339,346-359$. $363,366,368,370,372-374,381$. $385,388,392,394$

Крымское ханство 80, 143, 173. 254, 260, 279, 298, 358, 363, 366, 373,374

Кубань, p. 147, 186, 201, 300, 310 $326,356,363,364,365,369-371$, $383,387,389$ 
Кукунор, оз. 129

Кулебинская волость 102

Кума, р. 153, 300, 364, 371, 372 , 393

Курдан Элек, ур. 203

Курман Яр 386

Кутум, р. 135, 144, 252, 278

Кят, обл. 217

Лаба, р. 300

Литва 260

\section{Мангышлакский п-ов 111}

Малый Ногай $80,82,86,97,99$, $140,143,144,146,154,201,299$. $300,304,315,347,364$

Маниту-гатулган, ур. 116

Маныч, p. 301, 302, 351, 352, 371 . 387

Махина, р. 376

Медведица, p. 380

Мензелинск 343

Миус, p. 199, 385

Можарское городище 298

Молочные Воды, р. 200, 275, 348 $349,350,353,386$

Монголия 114, 115, 118, 176

Морская протока, ур. 303

Москва 39-42, 44, 45, 47, 49-53. $66,69,71-74,80,85,88,90,94,97$ $126,138,148,153,162,167-169$. 171, 173-175, 183, 192, 195, 197. $201,203,205,206,208,211,213$. $216,221,227-229,231,241,244$. $245,246,255,262,266,269,273$. $274,275,276,277,280,281,283$. 285-294, 299, 305-307, 310-312. $314,315,318-320,324,328,329$. $335,338,339,341,343,345,346$, $354,356-358,360,361,363-372$. 374-378, 380-383, 387-391

Московское государство 37,38 ,
$40-44,47,48,52,53,55,56,63$, $73,90,101,139,143,168,187,194$. $326,338,340,368$

Мочаги, ур. 139, 147, 183, 189.

222, 223, 225

Мугоджарские горы 391

Намет Тургай, ур. 327

Нарын-пески 95, 134, 150, 196

$228,335,358,390$

Насыр Хабырге, ур. 52

Нижнее Поволжье 144, 265

Нижнее Прикамье 341

Нижний Новгород 329

Ниса 120

Ногайская дорога 208, 342, 343 , 344

Обь, p. 38

Овечьи воды, p. 200

Оил, р. 67,69

Оилкарагол, ур. 119

Омельничек, p. 355

Омь, p. 38, 42

Ордынская слобода 290

Орын ганц модон, ур. 75

Орь, p. 53, 102, 104, 170, 181, 209.

211

Османская империя 139, 143, 279 . 326

\section{Паншин городок 379}

Перекоп 200, 242, 244, 277, 347 . $348,349,350,351,353-357,350$. $370,372-374,385,392$

Переяславль-Рязанский 307 Пермь 42

Персия 86, 120, 121, 143, 291, 378 Полтава 373

Польша 283, 293, 299, 340, 341 $347,359,372,374$

\section{Предкавказье 144}

Приаралье 342

Приаральские Каракумы, 48, 59 , $60,65,70,71,77,104,105,113$,

$119,165,214,215,217,233,258$ 259

Придонье 383

Прикаспий 73, 92, 112

Приуралье 73

Псонские воды, р. 200

Пятиизбенская 379

Раздорный городок 145,198

Речь Посполитая 80, 93, 253, 260. $305,355,356$

Решт 378

Россия 37, 48, 86, 93, 128, 169.

$195,207,234,260,270-272,276$, $279,281-283,287,289,294,300$ $304,321,323,332,340,343,346$. $347,360,376,379,381,382,385$. 389

Рыбный 392

Ряжск 307

Савран 53, 85

Сагиз, p. 161, 165, 185

Сал, p. 145, 201, 223, 347, 391

Сакмapa, p. 162, 206, 209, 211

Самара 65, 69, 70, 139-142, 157.

$158,160,177,207,208,228,246$, $248,249,264,274,275,291,318$. $319,342,345,346,365,366,380$ Самара, p. 159, 181, 206, 220, 232 Самарканд 130

Самарская Лука, p. 49

Самарский уезд 210, 255

Саразман, ур. 77

Сарайчик 52

Саратов 138, 139, 141, 158, 171.

$208,222,228,255,274,291,366$
$379,380,392$

Сарачинский лес 357

Сарпа, p. 147, 227, 241, 242, 393

Сарпинские пески 339

Сауке, ур. 55

Северное Приаралье 331

Северное Причерноморье 245 ,

299, 302, 304, 348, 356, 366, 368

Северный Прикаспий 49, 52, 68 ,

$70,72,74-76,82,84,86,90,92,93$, $96,105,109,111,113,119,123$, $125,130,138,154,159,190,191$. $213,216,254,273,282,296,331$. $366,382,383$

Северный Кавказ 143, 144, 146. $150,156,159,192,195,196,243$. 286, 299, 302, 304, 320, 321, 325.

$326,363,366,369,374,391,393$

Седур 254

Семиречье 36,37

Сибирь 43, 44, 46, 48, 65, 67, 76 .

104, 106, 294

Сиваш, о3. 351

Симбирск 381

Синин 130

Синьцзян-Уйгурский автономный район 34,130

Сиротин городок 243, 385

Смоленск 274

Солеваренный острог 208

Соленые озера $38,39,41$

Соленый городок 69

Сорока, p. 142

Средняя Азия 53, 63, 86, 91, 111.

120,121 .

Средняя Волга 341

Стамбул 305, 350, 388

Сунгурлук, p. 206

Сырт (Сырдарья), p. 61, 63, 85,

$111,165,174$

Сырь, p. 161 
Табарек 120

Тамань 300

Тамбов 307,329

Tара $38-43,45,59,60,102,105$. 158

Тарбагатай 36,116

Тарковское шамхальство (Тарки)

143, 303

Тарский уезд $38,43,103$

Ташкент 60, 130

Темир, p. 123

Темрюк 201, 223, 300, 303, 321.

324,352

Тепкире, ур. 96, 97, 161, 267

Терек, р. 138, 147, 148, 149, 183 , $227,265,320,333,364,386-388$. 391

Терский городок $144,148,149$, $156,183,265,286,287,321,332$

Тибет 100, 118, 129, 187, 194, 239. 255, 258, 269

Тобол, р. 48, 64, 66, 81, 113, 212. 213, 389

Тобольск 42, 44, 47, 57, 102, 104 , $105,133,159,191,213,296,391$. 392

\section{Тобольский уезд 38}

Тогалай, ур. 165

Томск 41,130

Томский уезд 38,130

Top, p. 373

Торгул, р. 113

Тохтачю, р. 189

Тургай, p. 81, 129, 174, 330

Тургайская ложбина $48,60,76,81$,

$113,132,331$

Туркестан 60, 61, 65, 121

Туркмения 194

Турция 372,373

Тюмень 42, 53, 64, 66, 85, 87, 102.

$105,132,191,213,296$
Тюменский уезд 81

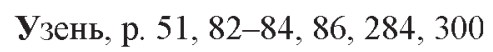
Уил, р. 165,187

Украина 253, 260, 321, 347, 353 , $354,357-360,374,375$

Укреме, ур. 267

Улен Кабала, ур. 56, 64

Ураков Караул, ур. 380

Уракум Карагол, ур. 161

Ургенч 49, 55, 60, 61, 70, 79, 91,

$95,104,111,112,121,122,161$

$164,165,174,188,194,217,218$. 253

Усолинский городок 319

Усун Монцог, ур. 257

Усун-Хаджир, ур. 115

Уфа 42, 50, 52-56, 65, 66, 68, 69, $71-73,90,103,139,161,162,164$ $167,169,170,173,174,177,181$ $182,191,209-213,228,229,232$. $234,246,248,255,262,284-286$, 295-297, 310, 311, 343, 345

Уфимский уезд 63, 68, 72, 112 ,

$126,128,170,181,182,208-210$.

$212,213,232,267,286,296,297$.

$319,342,345$

Ухарлик, р. 214

Ушонкар, ур. 348

Уя р. 212

Хазарасп 254

Халха 114-116, 118

Хара-Тала 214

Хива 91, 110, 217, 227, 237, 267

Хивинское ханство 120, 122

Хобог-Сайир 130

Хопер, p. 375, 379

Хорошие горы 385

Хубсугул, 03. 35
Цаган-Нур, оз. 393

Царев Борисов 375

Царев брод 149

Царицын 138, 147, 158, 169, 201

$208,221,228,240,242,255,256$,

$274,324,328,331,344,347,348$

$349,350,352,364,365,367,378$

$379,380,393$

Центральная Азия 35, 37

Цзан, обл. 100

Цибульник 353

Цинская империя 118

Чеган, р. 297

Чегат, ур. 136, 140

Черкасский городок 198-201, 240, $275,357,376,378,380$

Черкессия 369

Черная, р. 297

Черные колодцы, ур. 369

Черный Иртыш, p. 36

Черный Яр 158, 201, 221, 227, 242.

$250,255,274,301,307,323,324$

$349,366,378,380,392,393$

Чигирин 355,373

Чир, р. 241, 379

Чирский городок 241

Чир-Тумер-ула, г. 391

Чонгар 351, 372, 373

Чудново 304,305

Чюдете, ур. 56, 64

Чюкар-Ауз, ур. 350

Шад-Керман 373

Шам, ур. 67

Шацк 329

Швеция 340
Шибегийн Улан Бура, ур. 116

Шункар, ур. 349

Щучья Узень, ур. 220

Эмюба, p. 48, 49, 53, 56, 59-65, 67-71, 77-79, 85, 91, 92, 95, 107 . $112,119,120,163,164,174,181$. $188,211,235$

Эмель, оз. 130

Эндери, обл. 148, 149, 156, 303

Юго-Западная Сибирь 36-38, 73 $101,102,108,134,176,213,214$, 381,382

Южный Буг, p. 360

Юла, p. 383

Яблонное, ур. 267

Яик, p. 48-52, 65, 67, 69, 70, 72, $73,75,77-79,81,85,87,92,93,96$, 98-100, 102, 107, 112, 119, 120 .

$124,134,135,138,141,142,145$.

159-162, 164, 177, 180, 185-188, 202-205, 209-211, 219-221, 223.

$226,228,233,235,238,246,249$,

253, 255, 257, 258, 264, 265, 267 ,

$268,286,288,293-295,328,330$

$342,344-346,358,377,382,383$, 389-391

Яицкий городок $137,138,164$, 185, 188, 193, 195, 202, 220, 249. 253, 255, 263-266, 284, 286, 293, $295,309,344,345,377$

Ямыш, 03. 58, 391

Ятаганова деревня 208 Яшкуль, ур. 304 


\section{СПИСОК СОКРАЩЕНИЙ}

АИ - Акты исторические, собранные и изданные Археографическою коммиссиею.

АИЮЗР - Акты, относящиеся к истории Южной и Западной России, собранные и изданные Археографической комиссией.

АМГ - Акты Московского государства, изданные Императорскою Академиею Наук.

АСПбИИ РАН - Архив Санкт-Петербургского института истории РАН

ДАИ - Дополнения к Актам историческим, собранные и изданные Археографическою коммиссиею.

ИКРИ - История Казахстана в русских источниках.

КРО - Кабардино-русские отношения в XVI-XVIII вв.

МИРМО - Материалы по истории русско-монгольских отношений.

ПСЗРИ - Полное собрание законов Российской империи.

РГАДА - Российский государственный архив древних актов.

РИБ - Русская историческая библиотека, издаваемая Императорскою Археографическою коммиссиею.

РМО - Русско-монгольские отношения

\section{АРХИВНЫЕ МАТЕРИАЛЫ}

Российский государственный архив древних актов.

Фонд 111. Донские дела. Опись 1: 1661 г. Д. 1, 3, 4, 6; 1669 г. Д. 9, 12 1671 г. Д. 1; 1672 г. Д. 1, 9, 11.

Фонд 112. Дела едисанских, ембулуиких, буджаиких и едичкульских mamap. Опись 1: 1661 г. Д. 1.

Фонд 113. Зюнгарские дела. Опись 1. 1674 г. Д. 1.

Фонд 115. Кабардинские, черкесские и другие дела. Опись 1: 1644 г. Д. 1; 1645 г. Д. 1; 1646 г. Д. 1.

Фонд 119. Калмыцкие дела. Опись 1: 1616 г. Д. 1; 1618 г. Д. 1; 1621 г. Д. 1 , $2 ; 1630$ г. Д. 1; 1632 г. Д. 1; 1633 г. Д. 1; 1635 г. Д. 1; 1636 г. Д. 1; 1640 г. Д. $1,2,3 ; 1641$ г. Д. $1 ; 1643$ г. Д. $1 ; 1644$ г. Д. 1,$2 ; 1645$ г. Д. 1, 2; 1646 г. Д. 1 ; 1648 г. Д. 1, 2; 1649 г. Д. 1, 3; 1650 г. Д. 1, 2, 3; 1651 г. Д. 1, 3, 4; 1653 г. Д. 1; 1654 г. Д. 1; 1655 г. Д. 1, 2; 1657 г. Д. 1, 2; 1658 г. Д. 1, 2; 1661 г. Д. 1, 2; 1662 г. Д. $1 ; 1663$ г. Д. 1, 2; 1664 г. Д. 3, 4, 6, 7, 8, 9, 10;1665 г. Д. 1, 2, 3; 1673 г. Д. 1 , 5; 1674 г. Д. 2; 1699 г. Д. 6.

Фонд 123. Сношения России с Крымом. Опись 1: 1644 г. Д. 3; 1648 г. Д. 8 , 9; 1649 г. Д. 3; 1650 г. Д. 2; 1652 г. Д. 1, 3; 1656 г. Д. 11; 1657 г. Д. 14; 1658 г Д. $17 ; 1659$ г. Д. 3; 1660 г. Д. 4; 1663 г. Д. 2; 1665 г. Д. 3; 1667 г. Д. 1; 1669 г. Д. 1; 1670 г. Д. 1; 1671 г. Д. 1.

Фонд 127. Сномения России с ногайскими татарами. Опись 1: 1613 г. Д. 1; 1614 г. Д. 2; 1622 г. Д. 1; 1625 г. Д. 1; 1626 г. Д. 1; 1627 г. Д. 1; 1628 г.; Д. 1,$2 ; 1629$ г. Д. $1 ; 1631$ г. Д. 1; 1633 г. Д. 1; 1635 г. Д. 1; 1636 г. Д. 1; 1637 г. Д. $1 ; 1638$ г. Д. 1; 1639 г. Д. 1; 1641 г. Д. 1; 1642 г. Д. 1; 1643 г. Д. 1; 1644 г. Д. 1; 1645 г. Д. 1; 1646 г. Д. 2; 1647 г. Д. 1; 1648 г. Д. 1; 1649 г. Д. 1; 1650 г. Д. 1; 1651 г. Д. 1;1652 г. Д. 1;1654 г. Д. 1;1662 г. Д. 1.

Фонд 214. Сибирские дела. Опись 4: 1628 г. Д. 8; 1660 г. Д. 53.

Архив Санкт-Петербургского института истории РАН. Фонд 178. Астраханская приказная изба. Д. 3231, 4538. 


\section{ОПУБЛИКОВАННЫЕ МАТЕРИАЛЫ}

Абуль-Гази. История монголов и татар / Пер. с перс. Г.С. Саблукова // Известия Казанского университета. Казань, 1905. Т. 21.

Акты исторические, собранные и изданные Археографическою коммиссиею. Т. 3. 1613-1645. СПб., 1841.

Акты исторические, собранные и изданные Археографическою коммиссиею. Т. 4. 1645-1676. СПб., 1842.

Акты Московского государства, изданные Императорскою Академиею Наук / Под ред. Н.А. Попова. Т. 2. Разрядный приказ. Московский стол. 1635 1639 гг. СПб., 1894.

Акты Московского государства, изданные Императорскою Академиею Наук / Под ред. Н.А. Попова. Т. 3. Разрядный приказ. Московский стол. 1660 1664 гг. СПб., 1901

Акты, относящиеся к истории Южной и Западной России, собранные и изданные Археографической комиссией. Т. 5. 1659-1665. СПб., 1867.

Акты, относящиеся к истории Южной и Западной России, собранные и изданные Археографической комиссией. Т. 6. 1665-1668. СПб., 1869.

Акты, относящиеся к истории Южной и Западной России, собранные и изданные Археографической комиссией. Т. 7. 1659-1665. СПб., 1872.

Акты, относящиеся к истории Южной и Западной России, собранные и изданные Археографической комиссией. Т. 8. 1668-1669. СПб., 1875.

Акты, относящиеся к истории Южной и Западной России, собранные и изданные Археографической комиссией. Т. 9. 1668-1672. СПб., 1877.

Батур Убаии Ттомень. Сказание о дербен ойратах // Лунный свет: Калмыцкие историко-литературные памятники / сост., ред., предисл., коммент. А.В. Бадмаева. Элиста, 2003. С. 125-154.

Габан Шараб. Сказание об ойратах (Калмыщкая летопись) // Лунный свет: Калмыцкие историко-литературные памятники / сост., ред., предисл. коммент. А.В. Бадмаева. Элиста, 2003. С. 84-107.

Голстунский К.Ф. Монголо-ойратские законы 1640 г., дополнительные указы Галдан-хун-тайджия и законы, составленные для волжских калмыков при калмыцком хане Дондук-Даши. СПб., 1880.

Дополнения к Актамисторическим, собранныеи изданные Археографическою коммиссиею. Т. 2. СПб., 1846.

Дополненияк Актамисторическим, собранныеиизданные Археографическою коммиссиею. Т. 3. СПб., 1848.

Дополнения кАктамисторическим, собранныеиизданные Археографическою коммиссиею. Т. 6. СПб., 1857

История Казахстана в русских источниках. Т. 1. Алматы, 2005.
История калмыцких ханов // Лунный свет: Калмыцкие историколитературные памятники / сост., ред., предисл., коммент. А.В. Бадмаева. Элиста, 2003. С. 113-119.

Кабардино-русские отношения в XVI-XVIII вв. Документы и материалы. М., 1957. T. 2

Крестьянская война под предводительством Степана Разина. Сборник документов. Т. 1. 1666 - июнь 1670 гг. / Сост. Е.А. Швецова. М., 1954.

Крестьянская война под предводительством Степана Разина. Сборник документов. Т. 2. М., 1957.

Крестьянская война под предводительством Степана Разина. Сб́орник документов. Т. 3. М., 1962.

Крестьянская война под предводительством Степана Разина. Сборник документов. Т. 4. М., 1976.

Леонтович Ф.И. К истории права русских инородщев. Древний монголокалмыцкий или ойратский устав взысканий. Одесса, 1879.

Літопис Самовидця / видання підготував Я.1. Дзира. Київ, 1971.

Материалы по истории Башкирской АССР. Ч. 1: Башкирские восстания в XVII и первой половине XVIII в. М.-Л., 1936.

Материалы по истории русско-монгольских отношений. 1607-1636: Сб. документов / Сост. Л.М. Гатауллина, М.И. Гольман, Г.И. Слесарчук; отв. ред. И.Я. Златкин, Н.В. Устюгов. М., 1959.

Материалы по истории русско-монгольских отношений. 1636-1654: Сб́ документов / Сост. М.И. Гольман, Г.И. Слесарчук; отв. ред. И.Я Златкин, Н.В. Устюгов. М., 1974.

Материалы по истории русско-монгольских отношений. 1654-1685: Сб. документов / Сост. Г.И. Слесарчук. М., 1996.

Материалы по истории туркмен и Туркмении. Том. II. XVI-XIX вв. Иранские, бухарские и хивинские источники / Под ред. В.В. Струве, А.К. Боровкова, А.А. Ромаскевича и П.П. Иванова. М.-Л., 1938

Материалы по истории Узбекской, Таджикской и Туркменской ССР. Вып.3. Ч. 1. Л., 1933.

О России в царствование Алексея Михайловича. Современное сочинение Григория Котошихина. Изд. 3. СПб., 1884.

Памятники дипломатических и торговых сношений Московской Руси с Персией. Т. 2. СПб., 1892.

Полное собрание законов Российской империи, повелением Государя Императора Николая Павловича составленное. Собрание Первое. Т. 1, 5. С 1649 по 1675. СПб., 1830.

Путешествия русских послов XVI-XVII вв. Статейные списки. М.-Л., 1954.

Раднабхадра. «Лунный свет»: История рабджам Зая-пандиты / Пер. с ойрат. Г.Н. Румынцева и А.Г. Сазыкина. СПб., 1999. 
Родословная туркмен. Сочинение Абу-л-гази, хана хивинского. М.: АН ССCP, 1958.

Посольские книги по связям России с Калмыцким ханством. 1672-1675 гг. / Сост. Н.М. Рогожин, М.М. Батмаев. Элиста, 2003.

Русская историческая библиотека, издаваемая Императорскою Археографическою коммиссиею. Т. 2. СПб., 1875.

Русская историческая библиотека, издаваемая Императорскою Археографическою коммиссиею. Т. 26. Донские дела. Кн. 3. СПб., 1909.

Русская историческая библиотека, издаваемая Императорскою Археографическою коммиссиею. Т. 29. Донские дела. Кн. 4. СПб., 1913. Русская историческая библиотека Министерства Народного Просвещения. Т. 34. Донские дела. Кн. 5. Петроград, 1917.

Эвлия Челеби. Книга путешествия. Вып.1. Земли Молдавии и Украины. М., 1961.

Эвлия Челеби. Книга путешествий (Извлечения из сочинения турецкого путешественника XVII века). Перевод и комментарии. Вып.2. Земли Северного Кавказа, Поволжья и Подонья. М., 1979.

\section{ЛИТЕРАТУРА}

Азнабаев Б.А. Статус пленных в башкирских общинах XVII в. // Известия Алтайского государственного университета. Барнаул, 2012. № 4-1. C. $12-16$.

Английские путешественники в Московском государстве в XVI веке. М., 1937.

Артькбаев Ж.О. Среднее Прииртышье в контексте проблем истории Евразийских степей (этноисторический и этноархеологический опыт исследований). Т. 1. Павлодар, 2007.

Aхмедов Б.А. История Балха (XVI - первая половина XVIII в.). Ташкент, 1982.

Бакунин B.M. Описание калмыцких народов, а особливо из них торгоутского, и поступков их ханов и владельцев. 2-е изд. Элиста, 1995.

Батмаев M.M. Калмыки в XVII-XVIII веках. События, люди, быт. В 2-х кн. Элиста, 1993.

Батмаев M.M. Социально-политический строй и хозяйство калмыков в XVII-XVIII вв. Элиста, 2002.

Бембеев B.III. Ойраты и калмыки на евразийском пространстве (XIII 60-е гг. XVII века). Элиста, 2007.

Бичурин Н.Я. (Иакинф). Историческое обозрение ойратов, или калмыков, с $\mathrm{XV}$ столетия до настоящего времени. 2-е изд. Элиста, 1991

Бобров Л.А., Худяков ЮО.С. Вооружение и тактика кочевников Центральной Азии и Южной Сибири в эпоху позднего Средневековья и Нового Времени (XV - первая половина XVIII вв.). СПб., 2008.

Богоявленский С.К. Материалы по истории калмыков в первой половине XVII века // Исторические записки. М., 1939. № 5. С. 48-102.

Бюлер Ф.A. Кочующие и оседло-живущие в Астраханской губернии инородцы. Их история и настоящий быт // Отечественные записки. 1846. Т. 47. № 7. С. 1-28.

Вернадский Г.В. Историческая основа русско-калмыцких отношений // Калмыцко-ойратский сборник / Под ред. А.Э. Борманжинова, И. Крюгера. Филадельфия, 1966. С. 11-50.

Веселовский Н.И. Передовые калмыки на пути к Волге // Записки Восточного отделения Императорского Русского археологического общества. Т. 3. СПб., 1888. С. 365-370.

Bитсен Н. Путешествие в Московию. СПб., 1996.

Джсалаева А.М. Политика России в отношении донских казаков и калмыков в XVII в. // Калмыки в многонациональной России: опыт четырех столетий. Элиста, 2008. С. 125-136.

Джалаева А.М. Предисловие / Пальмов Н.Н. Материалы по истории калмыцкого народа за период пребывания в пределах России. Элиста, 2007. C. $3-25$. 
Дробышев Ю.И. Человек и природа в кочевых обществах Центральной Азии (III в. до н.э. - XVI в. н.э.). М., 2014. 608 с.

Златкин И.Я. Зая-Пандита - как политический деятель // 320 лет старокалмыцкой письменности. Материалы научной сессии. Элиста, 1970. C. 21-39.

Златкин И.Я. История Джунгарского ханства. 1635-1758. 2-е изд. М., 1964. История Калмыкии с древнейших времен до наших дней: в $3-x$ т. Т. 1. Элиста, 2009.

История Башкирского народа: в 7 т. / гл. ред. М.М. Кульшарипов. Уфа, 2011. T. III.

Их Цааз («Великое уложение»). Памятник монгольского феодального права XVII в. M., 1981.

Каррыев А., Мошкова В.Г., Насонов А.Н., Якубовский А.Ю. Очерки из истории туркменского народа и Туркменистана в VIII-XIX вв. Ашхабад, 1954.

Каиин В.Н. Крестьянская железоделательная промышленность Кузнецкого края XVII-XVIII вв. // Проблемы истории докапиталистических обществ. № 7-8. М., 1934.

Китинов Б.У. Священный Тибет и воннственная степь: буддизм у ойратов (XIII-XVII вв.). М., 2004.

Кичиков М.Л. Исторические корни дружбы русского и калмыцкого народов Элиста, 1966.

Кичиков М.Л. Образование Калмыцкого ханства в составе России (16071664): автореф. дис. ... канд. ист. наук / АН СССР, Ин-т народов Азии, КНИИЯЛИ. М.-Элиста, 1963.

Кичиков М Л. Образование Калмыцкого ханства. Элиста, 1994

Колесиик В.Н. Последнее великое кочевье:Переход калмыков изЦентральной Азии в Восточную Европу и обратно в XVII и XVIII веках. М., 2003.

Котвич В.Л. Русские архивные документы по сношениям с ойратами в XVII-XVIII веках // Известия Российской академии наук. № 12-15. 1919. C. 791-822.

Кусаинова E.B. Русско-ногайские отношения и казачество в конще XV-XVII веке. Волгоград, 2005.

Кундакбаева Ж.Б. «Знаком милости Е.И.В. ...». Россия и народы Северного Прикаспия в XVIII веке. М.-СПб., 2005.

Кундакбаева Ж.Б. «Прислал де их Аюкай тайша бить челом великому государю царю... » (приезд в Москву калмыцких посланников во второй половине XVII в.) // Иноземцы в России в XV-XVII веках. M., 2006. C. 520-532.

Kурапов A.A. Буддизм и власть в Калмыцком ханстве XVII-XVIII вв. Элиста, 2007.

Куч О.Ю. Донское казачество в период от взятия Азова до выступления С. Разина (1637-1667). СПб., 2009.
Льтткин Ю.С. Материалы для истории ойратов // Лунный свет: Калмыцкие историко-литературные памятники / Сост., ред., предисл., коммент. А.В. Бадмаева. Элиста, 2003. С. 390-468.

Любимов Ю.В. Миграция западных ойратов в Поволжье и русскокалмыцкие отношения // Восток. Афро-азиатские общества: история и современность. № 2. М., 2008. С. 46-55.

Максимов К.Н. Калмыки в геостратегических планах России XVII века // Вестник Калмыцкого института гуманитарных исследований РАН. Элиста, 2013. С. 5-10

Максимов К.Н. Калмыкия в национальной политике, системе власти и управления России (XVII-XX). М., 2002.

Максимов К.Н. Роль шерти в правовой инкорпорации калмыков в российское подданство // Калмыки в многонациональной России: опыт четырех столетий. Элиста, 2008. С. 71-90.

Малов А.B. Русско-польская война 1654-1667 гг. М., 2006.

Миллер Г.Ф. История Сибири. Т. ІІ. М., 2000.

миллер Г.Ф. История Сибири. Т. ІІІ. М., 2005.

Мияваки-Окада Дж. Джунгарское ханство, которое не было ханством / Пер. с англ. Е. Бойковой // Altaika IV. M., 2000. С. 58-72.

Мияваки-Окада Дж. Калмыцкие тайши в начале XVII века / Пер. с англ. В Санчирова // Altaika IV. M., 2000. С. 70-77.

Моков Б.M Кабарда второй половины XVI-XVII вв. Нальчик, 2001

Новолетов М.Г. Калмыки. Исторический очерк. СПб., 1834.

Новосельский А.А. Борьба Московского государства с татарами в первой половине XVII века. М.-Л., 1948.

Новосельский A.A. Исследования по истории эпохи феодализма (научное наследие). М., 1994.

Ногмов ШШ.Б. История адыхейского народа, составленная по преданиям кабардинцев. Нальчик, 1958.

Норбо ШІ. Зая-Пандита (Материалы к биографии) / Пер. со старомонг. Д.Н Музраевой, К.В. Орловой, В.П. Санчирова. Элиста, 1999.

Onapuнa T.A. Полковник Александр Лесли и православие // Иноземцы в России в XV-XVIII веках / Под общей ред. А.К. Левыкина. М., 2006.

Очерки истории Калмыцкой АССР: Дооктябрьский период / Под ред. Н.В. Устюгова. М., 1967.

Пальмов Н.Н. Материалы по истории калмыцкого народа за период пребывания в пределах России / Сост. А.М. Джалаева. Элиста, 2007.

Пальмов Н.Н. Очерк истории калмыцкого народа за время его пребывания в пределах России. 2-е изд. Элиста, 1992.

Пальмов Н.Н. Этюды по истории волжских калмыков XVII и XVIII века Ч. І. Астрахань, 1926; Ч. 5. Астрахань, 1932

Перетяткович Г.И. Поволжье в XVII и начале XVIII века (Очерки из истории колонизации края). Одесса, 1882 
Позднеев A.M. Астраханские калмыки и их отношения к России до начала нынешнего столетия // Журнал Министерства народного просвещения. Ч. CCXLIV. Отд. 2. 1886. С. 140-170.

Попов A. Краткие замечания о приволжских калмыках // Журнал Министерства народного просвещения. СПб., 1886. Ч. ХXII. Отд. 2. С. 17-46.

Попnе Н.Н. Роль Зая-пандиты в культурной истории монгольских народов // Калмыцко-ойратский сборник / Под ред. А.Э. Борманжинова, И. Крюгера. Филадельфия, 1966. С. 52-72.

Преображснская П.С. Из истории русско-калмыцких отношений в 50-60-х годах XVII в. // Записки Калмыцкого НИИЯЛИ. Элиста, 1960. Вып.1. C. 49-83.

Преображсенская П.С. Калмыки в первой половине XVII века. Принятие калмыками (торгоутами и дербетами) русского подданства. Автореф. канд. дис. М., 1963.

Пузанов В.Д. Военные факторы русской колонизации Западной Сибири (конец XVI-XVII в.). СПб., 2010.

Пурбуева ЦЦ.П. «Биография Нейджи-тойна» - источник по истории буддизма в Монголии. Новосибирск, 1984.

Рогожин H.M. У государевых дел быть указано... М., 2002.

Санин Г.А. Отношения России и Украины с Крымским ханством в середине XVII века. М., 1987

Санчиров В.П. «Илэтхэл шастир» как источник по истории ойратов. М., 1990. Санчиров В.П. Историческое значение Джунгарского съезда монгольских и ойратских князей 1640 года // Вестник Калмыцкого института гуманитарных исследований РАН. Элиста, 2009. № 2. С. 14-18.

Санчиров В.П. К изучению топонимики ойратов и калмыков (XVII-XVII вв.) // Новый исторический вестник. М., 2011. № 29. С. 67-73.

Санчиров В.П. На пути к Волге: ойратские этнополитические объединения 20-30-х гг. XVII в. // Вестник Калмыцкого института гуманитарных исследований РАН. Элиста, 2008. № 2. С. 2-23.

Смирнов В.Д. Крымское ханство под верховенством Отоманской Порты до начала XVIII века. СПб., 1887.

Смирнов Н.A. Борьба русского и украинского народов против агрессии султанской Турции в XVII-XVIII вв. // Воссоединение Украины с Россией. 1654-1954. М., 1954.

Соловьев С.М. История России с древнейших времен / Отв. ред. И.Д. Ковальченко, С.С. Дмитриев. Кн. VI. Т. 11-12. М., 1991.

Сусеева Д.А. Письма хана Аюки и его современников (1714-1724 гг.): опыт лингвосоциологического исследования. Элиста, 2003

Tрепавлов B.B. Алтыулы: остатки Ногайской орды в казахских степях // Вестник Евразии. М., 2001. № 2. С. 33-53.

Трепавлов B. B. «Белый царь»: образ монарха и представление о подданстве у народов России XV-XVIII вв. М., 2007.
Трепавлов В.В. История Ногайской Орды. М., 2002.

Tрепавлов B.B. Калмыки и Россия в XVII-XVIII вв.: подданные, вассалы или союзники? // Калмыки в многонациональной России: опыт четьрех столетий. Элиста, 2008. С. 58-70.

Трыярски Э. Сообщения поляков о калмыках с 1870 года / Пер. Дениса Романова // http://www.m-m.sotcom.ru/8-10/prushins.htm.

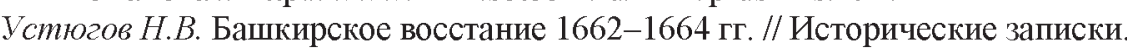
№ 24. 1947. C. 30-110.

Фирсов Н.А. Положение инородцев северо-восточной России в Московском государстве. Казань, 1866

Фuщер И.Е. Сибирская история с самого открытия Сибири до завоевания сей земли российским оружием. СПб., 1774.

Цюрюмов А.В. Калмыцкое ханство в составе России: проблемы политических взаимоотношений. Элиста, 2007.

Чулошников А. Торговля Московского государства со Средней Азии в XVI-XVII вв. // Материалы по истории Узбекской, Таджикской и Туркменской ССР. Вып.3. Ч. 1. Л., 1933. С. 61-88.

IIмелев A.C. Русско-дагестанско-калмыцкие отношения в XVII в. (по материалам кумыкско-калмыцких контактов) // Кавказ. Балканы. Передняя Азия. Вып. 2(9). Махачкала, 2004. С. 228-235.

Шовунов К.П. Калмыки в составе российского казачества (вторая половина XVII-XIX вв.). Элиста, 1992.

Янчевский Н.Л. Колониальная политика на Дону торгового капитала Московского государства в XV-XVII вв. Ростов-на-Дону, 1930.

Далай Ч. Ойрад Монголын тууўх. Тэргўўн боть. Хоёрдахь хэвлэл. Улаанбаатар, 2006.

Hadży Mehmed Senai z Krymu. Histjoria Chana Islam Gereja III / Tekst turecki wydal, przelożyl i opracowal Z. Abrahamowicz. Warszawa, 1971.

Khodarkovsky M. Where Two Worlds Met: The Russian State and The Kalmyk Nomad, 1600-1771. Ythaka, N.Y., 1992.

Khodarkovsky $M$. Russia's Steppe Frontier. The Making of a Colonian Empire. 1500-1800. Bloomington, 2002.

Lemercier-Quelquejay Ch. Les Kalmuks de la Volga entre l'empire Russe et l'empire Ottoman sous le règne de Pierre le Grand / Cahiers du Monde Russe et Soviètique. 1966, vol. VII, № 1. P. 63-76.

Miyawaki, Junko. A Volga-Kalmyk family tree in the Ramstedt collection // Journal de la Societe Finno-Ougrienne. Helsinki, 1991. Vol. 83.

Miyawaki, Junko. Internal Rivalries in the Four Oyirad Tribal Federation // Ethnohistorische Wege und Lehrjahre eines Philosophen: Festschrift für Lawrence Krader zum 75. Geburtstag. Frankfurt am Main u.a.: Lang, 1995. P. 228-260

Pallas P.S. Sammlungen historischer Nachrichten uber die mangolischen Volkerschaften. T. 1. SPb., 1776. 


\section{Научное издание}

Тепкеев Владимир Толтаевич

\section{КАЛМЫКИ В СЕВЕРНОМ ПРИКАСПИИ}

ВО ВТОРОЙ ТРЕТИ ХVI ВЕКА:

ПРОБЛЕМЫ ПОЛИТИЧЕСКИХ

ВЗАИМООТНОШЕНИЙ

Редактор Т. А. Михалева

Компьютерная верстка Д. В. Татнинов

Художник Д. А. Санджинов

Подписано в печать 15.12.2014. Формат 60x90 11/16

Гарнитура Times. Бумага офсетная

Печать офсетная. Усл.-печ.л. 28,0

Тираж 500 экз. Заказ № 2057-12.

Отпечатано в 3АOp «НПII «Джангар»

358000 , Республика Калмыкия, г. Элиста, ул. Ленина, 245 